\title{
3 An Edition of Cambridge Ms. Add. 1326
}

This substantial and carefully designed manuscript is the earliest known dated witness of the South Asian Dhäranīsamgraha tradition written on paper. ${ }^{1}$ The history of this Nepalese piece from 1719 CE (NS 839) can be traced down remarkably well thanks primarily to the comprehensive colophon on the last two folios. ${ }^{2}$ It informs the reader that in the reign of king Jayamahendrasimha Malla (1714-1722 CE) a certain Śākyabhikșu householder-monk named Trailokara who belonged to the Pārāvata Mahāvihāra ${ }^{3}$ commissioned along with his first wife, Pūrnāvatīi, a scribe called Patideva of the Tarumūla Mahāvihāra ${ }^{4}$ to produce this compendium for him and his family members, namely two wives, three sons, two daughters, a grandson and a daughter-in-law. As it is stated, the family hoped to gain merit, protection, health and welfare from the compilation of this manuscript because such an object is considered to embody auspicious and apotropaic qualities. This bundle of 225 paper leaves with six lines was put between two illuminated wooden covers and meant to be kept at the donor's home. It is evident from traces of ritual substances on the top binding board that the whole book was venerated as a cultic object and it may also have been opened occasionally and read out aloud. Note that on folios $84 \mathrm{v}, 91 \mathrm{r}$ and $94 \mathrm{v}$ there is a female donor's name inserted in the text: Lìlādevikā, which shows that this section with the Mahāsāhasrapramardanī-nāma-vidyā-dhāraṇī was copied from a source sponsored by another person. ${ }^{5}$

This exquisite manuscript, a high-end market product for a prosperous Buddhist family, ${ }^{6}$ is more than a repository of texts: it is a piece of art as well perhaps the most beautiful volume among the Dhäranisamgraha collections. Its yellow coloured paper leaves have been marked by a balanced hand in black

1 Those undated paper manuscripts available to me and listed in the appendices appear to be later ones palaeographically. It requires further research to find out which period the unstudied manuscripts listed in Chapter $1 \mathrm{fn} .29$ and 31 can be dated to.

2 For the first detailed description see Bendall 1883: 49-50. A brief account of this manuscript appeared in Cuneo 2014 and Hidas 2015a provided a longer study. An online description and complete digital reproduction is available at https://cudl.lib.cam.ac.uk/view/MS-ADD-01326 (accessed March 2020).

3 Modern day Ituṃ Bāhā. See Locke 1985: 284-293.

4 Modern day Sikhamu Bāhā. See Locke 1985: 258-269. Note that Cambridge Ms. Add. 1343, a shorter collection of dhāraṇis, was also produced in the Tarumūla Mahāvihāra in 1663 CE (NS 783). 5 Cf. the copied donor's name in the edition of Add. 1680.8.3, too: a certain Śrāvīryaśrīkșuna appears on folio $1 \mathrm{r}$.

6 Cf. Kim 2013: 220.

2 Open Access. (C) 2021 Gergely Hidas, published by De Gruyter. (c))BY-NC-ND This work is licensed under the Creative Commons Attribution-NonCommercial-NoDerivatives 4.0 International License. https://doi.org/10.1515/9783110713367-003 
ink. ${ }^{7}$ The titles are neatly highlighted in red colour and the different texts are separated from each other mostly by flower-like puspikā ornaments. ${ }^{8}$ Two of the folios contain fine miniature paintings: folio $1 \mathrm{v}$ appears to depict Mahākṣobhya Buddha, ${ }^{9}$ and folio 223v the donor's family with Mañjuśrī Bodhisattva in the middle. ${ }^{10}$ The inner sides of the two wooden covers are also decorated in colour: twice three Pāramitā goddesses are painted in delicate fashion.

This manuscript contains 180 texts altogether and some of these are grouped under five sub-chapters ${ }^{11}$ referring to the Buddha, ${ }^{12}$ the Dharma, ${ }^{13}$ the Samgha, ${ }^{14}$ the Seven Buddhas ${ }^{15}$ and the Five Protections. ${ }^{16}$ While it is not always straightforward how to categorize each text, ${ }^{17}$ there are approximately 128 spells (dhārañi) ${ }^{18}$ 26 worship manuals (sädhana), 7 praises (stotra, stava or stuti), 4 texts with both spells and praises (dhāraṇi and stotra) ${ }^{19}$ and 15 other texts ${ }^{20}$ included. Twelve of these all are complete and extensive pieces, ${ }^{21}$ the longest being the Saptaśatik $\bar{a}$ -

7 Note the somewhat obscure wording in the colophon: pitakāgatapatre karjarākșareṇa likhitam.

8 On this topic see Bhattarai 2020.

9 Cf. Nișpannayogāvalī 21 (Mallmann 1975: 92-93).

10 There are other volumes which depict a donor and his family in fine paintings. Zwalf 1985: 131-132 (nos. 180-181) shows two Pañcarakșā manuscripts kept at the British Library, Or. 13852 from 1659 CE and Or. 13946 from 1676 CE, with family portraits made in a comparable style to Add. 1326 at the same Tarumūla Vihāra in Kathmandu.

11 See the list after the table of contents below.

12 Folio 3r. The Vairocana-, Akșobhya-, Ratnasambhava-, Amitābha- and Amoghasiddhi-tathāgatadhāranīs.

13 Folio 13v. The Prajñāpāramitā-, Gaṇdavyūha-, Daśabhūmīśvara-, Samādhirāja-, Lañkāvatāra-, Saddharmapuṇdarīka-, Tathāgataguhyaka-, Lalitavistara- and Suvarnaprabhāsa-dhāraṇīs.

14 Folio 14v. The Padmahasta-, Maitreya-, Gaganagañja-, Samantabhadra-, Vajrapāṇi-, Mañjughoșa-, Sarvanivaraṇanișkambhinī-, Kșitigarbha- and Khagarbha-dhāraṇīs.

15 Folio 15v. The Vipaśyi-, Śikhi-, Viśvabhuvo-, Krakucchanda-, Kanakamuni-, Kāśyapa- and Śākyamuni-dhäraṇis.

16 Folio 160v. The Mahāpratisarā-, Mahāmāyūrū-, Mahāsāhasrapramardan̄̄-, Mahāmantrānusāraṇī- and Mahāśîtavatī-sādhanas.

17 E. g. nos. 92, 94, 153-162, 165, 167, 170, 171 and 173-175 are titled dhäraṇi while these are actually sādhana texts.

18 No. 110 is titled rakșāmantra.

19 Nos. 76, 78, 80, 81.

20 E.g. vidhi, upadeśa, praises of names, sūtra, praṇidhāna.

21 The Aparimitāyur-mahāyānasūtra (No. 47), Vasudhārā-dhāraṇi (No. 62), Amoghapāśa-hrrdayamahāyānasūtra (No. 63), Sarvatathāgatoṣnị̄ṣasitātapatrā-nāmāparājitā-pratyañgirā (No. 83), Dhvajāgrakeyūra-dhāraṇī (No. 90), Vajravidāraṇa-hṛdayamantra-dhāraṇī (No. 98), Gaṇapatihṛdaya (No. 99), Uș̣ị̄ṣavijayā-dhāraṇī (No. 100), Pañcaviṃśatikā-prajñāpāramitā (No. 101), Mārīci-dhāraṇī (No. 102), Saptaśatikā-prajñāpāramitā (No. 163) and the Grahamātṛkā-dhāraṇi (No. 177). Note that these include all texts of the Saptavāra collection (Bühnemann 2014). 
Prajñāpāramitāa, “The Perfection of Wisdom in Seven Hundred Verses," stretching to 30 folios. ${ }^{22}$ A few texts are incorporated twice in the bundle at different places. ${ }^{23}$ There are also texts that bear the same title but have different contents. ${ }^{24}$ The most recurring tradition is that of the Vasudhārā, "Flow of Wealth," which appears five times in total in separate versions. ${ }^{25}$ It is worth noting that towards the end of the manuscript there are a handful of non-Buddhist works as well: the Pithāstavastotra, ${ }^{26}$ "Praises of Sacred Places," the Bhimasenadhyānasvalpastuti,, "Short Praise with Meditation on Bhìmasena" and the Śanaiścarastavastotra, ${ }^{28}$ "Praise Hymn of Saturn." Note similarly the Ādityadvādaśa-nāma and the Niśākaranāma. ${ }^{29}$

\subsection{Contents}

1. Mūlavidyā-dhāraṇi $\bar{i}^{30} 2 \mathrm{r}$

[The first section of the Trisamayarāja-sādhana]

2. Śatākṣara-sarvatathāgata-hṛdaya-dhāraṇi ${ }^{31} 2 \mathrm{r}$

[A further section of the Trisamayarāja-sādhana]

3. Vairocanatathāgata-dhāraṇi $2 \mathrm{v}$

[A brief text with an invocation and a spell]

4. Akṣobhyatathāgata-dhāraṇī $2 \mathrm{v}$

[A brief text with an invocation and a spell]

5. Ratnasambhavatathāgata-dhāraṇī $2 \mathrm{v}$

[A brief text with an invocation and a spell]

22 Folios 171v-201v.

23 The Siddhinikā- (Nos. 65,116), Buddhabhațțārakasya- (Nos. 34,119), Pìtavarnaprajñāpāramitā(Nos. 55,162) and Prajñāpāramitā-dhāran̄is (Nos. 8,56) are quite similar while the Cintāmani(Nos. 33,109), Mahābhairavasya- (Nos. 108,133), Punyavardhanī- (Nos. 52,138), Grahamātṛā(Nos. 103,177) and Saddharmapāța-dhārañis (Nos. 51,125) are close to each other.

24 Maitreya-dhāraṇi (Nos. 18,124), Mārīcī-dhāraṇi (Nos. 92,102) Șaḍakṣarī-(mahāvidyā)-dhāraṇī (Nos. 69,139) and Vasudhārā-dhāraṇi (Nos. 62, 82, 165).

25 Nos. 62 (complete dhāraṇi-sūtra), 82 (parts of the dhäraṇi), 97 (stotra), 137 (vidhi), 165 (sādhana).

26 No. 178.

27 No. 179. On Bhīmasena see Bühnemann 2013.

28 No. 180.

29 Nos. 111 and 112.

30 Editions known to me are indicated in the footnotes. Cf. Sādhanamālā No. 1. (Bhattacharyya 1925-1928: 1-2).

31 Cf. Sādhanamālā No. 1. (Bhattacharyya 1925-1928: 2). 
6. Amitābhatathāgata-dhāraṇī 3r

[A brief text with an invocation and a spell]

7. Amoghasiddhitathāgata-dhāraṇī $3 \mathrm{r}$

[A brief text with an invocation and a spell. Four mantras of goddesses appended after the colophon.]

8. Prajñāpāramitā-dhāraṇī 3v

[Invocation, a spell and its benefits. Similar to No. 56 except for the description of benefits]

9. Gaṇḍavyūha-nāma-dhāraṇī 3v

[Invocation and a brief spell]

10. Bodhisattvacaryāprasthāna-daśabhūmīśvara-nāma-mahāyānasūtra-

ratnarāja ${ }^{32} 7 \mathrm{r}$

[The complete text]

11. Samādhirāja-nāma-dhāraṇī $7 \mathrm{r}$

[A brief text with invocation, a spell and its benefits]

12. Lan̉kāvatāra-nāma-dhāraṇi $\overline{1}^{33} 8 \mathrm{v}$

[Chapter 9 (Dhāraṇīparivarta) of the Laṅkāvatārasūtra]

13. Saddharmapuṇḍarīkāyā dhāraṇī-mantra ${ }^{34}$ 9r

[Spells from chapters 21 (Dhāraṇīparivarta) and 26

(Samantabhadrotsāhanaparivarta) of the Saddharmapuṇḍarīkasūtra]

14. Tathāgataguhyakā-nāma-dhāraṇī 10v

[The Buddha requests Vajrapāṇi Guhyakādhipati to utter a spell. The Māras promise to support the reciter of this spell. The Buddha teaches further incantations. Concluding verses]

15. Lalitavistare trapuṣabhallikaparivartane datta-kalyāṇavākya ${ }^{35} 13 \mathrm{r}$

[Verses from chapter 24 of the Lalitavistara with an introduction]

16. Suvarṇaprabhāsottamasūtrendrarāje sarvabuddhabodhisattvānāṃ-nāmadhāraṇi $\bar{i}^{36} 13 \mathrm{v}$

[Chapter 9 of the Suvarṇaprabhāsottamasūtra with the beginning of chapter 1]

17. Padmahasta-dhāraṇī $13 \mathrm{v}$

[A brief text with invocations, a spell, ritual instructions and benefits]

18. Maitreya-dhāraṇī 14r

[Invocation and a spell. Different from No. 124]

32 Cf. Vaidya 1967: 103-109 and No. 26 in Pandey 1994.

33 Cf. Vaidya 1963: 1, 106.

34 Cf. Vaidya 1960b: 233, 235, 265.

35 Cf. Vaidya 1958: 282-85.

36 Cf. Skjaervø 2004: 10, 201-204. 
19. Gaganagañja-dhāraṇī $14 \mathrm{r}$ [Invocation and a spell]

20. Samantabhadra-dhāraṇī $14 \mathrm{r}$ [Invocation and a spell]

21. Vajrapāṇi-dhāraṇī 14r [Invocation and a spell]

22. Mañjughoșa-dhāraṇī 14r [Invocation and a spell]

23. Sarvanivaraṇavișkambhinī-dhāraṇī 14r [Invocation and a spell]

24. Kṣitigarbha-dhāraṇī 14v [Invocation and a spell]

25. Khagarbha-dhāraṇī $14 \mathrm{~V}$ [Invocation and a spell]

26. Vipaśyi-dhāraṇī 14v [Invocation and a spell]

27. Śikhi-dhāraṇī 15r

[Invocation and a spell]

28. Viśvabhuvo-dhāraṇī 15r [Invocation and a spell]

29. Krakucchanda-dhāraṇī 15r [Invocation and a spell]

30. Kanakamuni-dhāraṇī 15r [Invocation and a spell]

31. Kāśyapa-dhāraṇī 15v [Invocation and a spell]

32. Śākyamuni-dhāraṇī 15v [Invocation and a spell]

33. Cintāmaṇi-nāma-dhāraṇī 16v [Invocation and a spell followed by the Vimaloṣṇīṣa-dhāraṇī. ${ }^{37}$ Different from No. 109]

34. Buddhabhațtāarakasya-nāma-dhāraṇi 16v [Invocation and a spell. Similar to No. 119]

35. Śākyamunīnāṃ viśeșamantra-dhāraṇī 17r [Invocation and a string of mantras for rituals]

36. Jātismara-nāma-dhāraṇī 17v

[Invocation, two spells, ritual instructions and benefits]

37 Cf. Schopen 1985. 
37. Hutāśanatejorāja-nāma-dhāraṇī 17v

[Invocation, a spell, ritual instructions and benefits]

38. Bhaișajyarāja-nāma-dhāraṇī 18r

[Invocation and a spell]

39. Sarvaman்gala-nāma-dhāraṇī 18r

[Invocation and a spell]

40. Karṇajāpa-nāma-dhāraṇī 18r

[Invocation and a spell]

41. Sarvapāpadahanī-nāma-dhāraṇī 18r

[Invocation and a spell]

42. Guhyendrasamādhivajra-nāma-dhārạ̣ī 18v

[Invocation, the eight names of Guhyendrasamādhivajra, ritual instructions and benefits]

43. Gāthādvaya-nāma-dhāraṇī 19r

[Invocation, verses, a spell and benefits]

44. Sạ̣mukhī-nāma-dhāraṇi $\bar{i}^{38}$ 20r

[The complete text]

45. Sarvadurgatipariśodhana-nāma-dhāraṇ $\bar{i}^{39} 23 \mathrm{v}$

[The beginning of the Sarvadurgatipariśodhanatantra]

46. Vajramaṇḍālaṃkāra-nāma-dhārạ̣ī 23v

[Invocation and a spell]

47. Aparimitāyur-nāma-mahāyānasūtra-dhāraṇī $\overline{10}^{40} 31 \mathrm{v}$

[The complete text]

48. Sarvadurgatipariśodhanavinirgata-anantakalparāja-nāma-dhāraṇi ${ }^{41} 32 \mathrm{v}$

[A section of the Sarvadurgatipariśodhanatantra]

49. Vajrapāṇi-mahārakșā-nāma-dhāraṇī 32v

[Invocation and a spell]

50. Ușṇīṣacakravartī-nāma-dhāraṇī 33r

[Invocation and a spell]

51. Saddharmapāṭhe ghaṇțāvādana-nāma-dhāraṇī 33r

[Invocation, a spell and ritual instructions. Close to No. 125]

52. Punyavardhanī-nāma-dhāraṇī 33v

[Invocations, a spell, ritual instructions and benefits. Close to No. 138]

38 Cf. Mimaki 1977.

39 Cf. Skorupski 1983: 120-132.

40 Cf. Konow 1916.

41 Cf. Skorupski 1983: 180, 156, 188-190. 
53. Sarvajñatākāra-dhāraṇīmukhapraveśa $\mathrm{a}^{42} 38 \mathrm{v}$

[Text from the Dhāraṇimukhaparivarta of the Karuṇāpuṇdarīkasūtra]

54. Ardhaśatikā-prajñāpāramitā ${ }^{43} 41 \mathrm{r}$

[The complete text]

55. Pītavarṇa-prajñāpāramitā-dhāraṇi $\bar{i}^{44} 41 \mathrm{v}$

[The complete text. Cf. No. 162]

56. Prajñāpāramitā-dhāraṇī 42r

[Close to No. 8]

57. Māyājālaṣoḍaśasāhasrikān mahāyogatantrāntaḥpātisamādhijālapaṭalād bhagavattathāgataśākyamunibhāṣitā bhagavato mañjuśrījñānasattvasya paramārthā-nāmasaṃīiti ${ }^{45} 42 \mathrm{v}$

[Sections from the Mañjuśrīnāmasamgīit]

58. Mañjuśrībhațtāarakasya pratijñā-nāma-dhāraṇī 43r

[Invocations, a spell, ritual instructions and benefits]

59. Șaṭpāramitā-hṛdaya-nāma-dhāraṇī 43v

[Invocation, six spells dedicated to the various pāramitās and a seventh devoted to all of them]

60. Yakṣāșțaka-samyaksambuddhabhāṣita 44r

[An introductory verse followed by an invocation and praises with benefits]

61. Jambhalajalendrasya-nāma-dhāraṇī 44v

[The Buddha in Śrāvastī where Māṇibhadra offers a spell for prosperity]

62. Vasudhārā-nāma-dhāraṇī ${ }^{46} 58 \mathrm{v}$

[Introductory verses followed by the complete text]

63. Amoghapāśa-nāma-hṛdaya-mahāyānasūtra ${ }^{47} 66 \mathrm{r}$

[The complete text]

64. Siṃhanādalokeśvarasya vyādhipraśamanī-nāma-dhāraṇi $\overline{1}^{48} 66 \mathrm{v}$

[The last part of the text]

65. Āryāvalokiteśvarasya mukhodgīrṇa-siddhinikā-nāma-dhāraṇi 66v

[A short text with invocation, a spell, ritual instructions and benefits. Similar to No. 116]

42 Cf. Isshi 1968: 21-30, 41-47.

43 Cf. Conze 1978: 66-67.

44 Cf. Sādhanamālā No. 152. (Bhattacharyya 1925-1928: 312).

45 Cf. Davidson 1981.

46 Cf. Jaini 1968, Dhīh 2007.

47 Cf. Meisezahl 1962.

48 Cf. Sādhanamālā No. 17. (Bhattacharyya 1925-1928: 47-48). 
66. Sahasrabhujalokeśvara-nāma-dhāraṇị ${ }^{49} 67 \mathrm{r}$

[Invocations and a spell]

67. Avalokiteśvarasya-nāma-dhāraṇī 68r

[Invocations and spells]

68. Sahasrāvartā-nāma-dhāraṇī 68v

[Invocation, spells, ritual instructions and benefits]

69. Șaḍakṣarī-mahāvidyā-nāma-dhāraṇī 69v

[The Buddha dwells in Śrāvastī and teaches this spell and its benefits to Ānanda. Different from No. 139]

70. Bhadracari-mahāpraṇidhānarāja ${ }^{50} 73 \mathrm{v}$

[The verses from chapter 56 (Samantabhadracaryāpraṇidhāna) of the Gaṇdavyūhasūtra]

71. Mokșapada-nāma-dhāraṇī 73v

[A short text with an invocation and a spell]

72. Abhayaṃkarī-nāma-dhāraṇī 74r

[A short text with an invocation and a spell]

73. Māṇibhadra-nāma-dhārạ̣ī $74 \mathrm{v}$

[The Buddha dwells in Śrāvastī where Mānibhadra offers a spell followed by ritual instructions]

74. Durgatipariśodhanī-nāma-dhāraṇị ${ }^{51} 74 \mathrm{~V}$

[An invocation and a short spell from the Sarvadurgatipariśodhanatantra]

75. Cundābhagavatī-dhāraṇī 75r

[A short spell and ritual instructions followed by an invocation, a spell and ritual instructions]

76. Mahāpratisarā-mahāvidyā-dhāraṇī $\overline{1}^{52} 80 \mathrm{v}$

[The complete text printed in Shashani 1999 plus an abridged version of the nidāna]

77. Pratisarāyā kalpa-dhāraṇīī3 $83 r$

[A text somewhat longer than the one printed in Shashani 1999]

78. Mahāsāhasrapramardanī-nāma-vidyā-dhāraṇī ${ }^{54} 95 \mathrm{v}$

[Parts of this scripture sometimes paraphrased]

49 Cf. Dutt 1939: 39 (Ekādaśamukha).

50 Cf. Vaidya 1960a: 428-36.

51 Cf. Skorupski 1983: 162, 172.

52 Cf. Shashani 1999, Hidas 2012.

53 Cf. Shashani 1999, Hidas 2012.

54 Cf. Iwamoto 1937a. 
79. Mahāmāyūrī-vidyārājñī-nāma-dhāraṇīin ${ }^{55} 110 \mathrm{r}$

[Parts of this scripture sometimes paraphrased]

80. Mahās̄îtavatī-nāma-vidyā-dhāraṇị ${ }^{56} 112 \mathrm{r}$

[Parts of this scripture often paraphrased]

81. Mahāmantrānusāriṇī-mahāvidyā-nāma-dhāraṇīin $114 \mathrm{~V}$

[Parts of this scripture sometimes paraphrased]

82. Vasudhārā-nāma-dhāraṇi ${ }^{58} 115 \mathrm{v}$

[Parts of the spell itself]

83. Sarvatathāgatoṣṇiṣasitātapatrā-nāmāparājitā-pratyañgirā-mahāvidyārājñ̄ī ${ }^{59}$

$124 \mathrm{r}$

[The complete text]

84. Sapane-vidyā-dhāraṇi $\bar{i}^{60} 124 \mathrm{r}$

[The last part of section [6.7] of the Vajratuṇ̣asamayakalparāja ${ }^{61}$ ]

85. Parṇaśavarī-mahāmārīpraśamanī-nāma-dhāraṇī ${ }^{62} 125 \mathrm{r}$

[The complete text]

86. Hemāñgā-nāma-dhāraṇī 125v

[Invocations, a spell, ritual instructions and benefits]

87. Maitreyapratijñā-nāma-dhāraṇī 126r

[Invocations, a spell, ritual instructions and benefits]

88. Mañjughoṣakṛti-praṇidhānarāja 126v

[Seven verses with vows]

89. Tārāpratijñā-nāma-dhāraṇī 127r

[Invocations and a spell]

90. Dhvajāgrakeyūrā-nāma-dhāraṇīi ${ }^{63} 128 \mathrm{v}$

[The complete text]

91. Mahāmāyāvijayavāhinī-nāma-dhāraṇī ${ }^{64} 130 \mathrm{v}$

[The first part of the text with the spell]

55 Cf. Takubo 1972.

56 Cf. Hidas 2017.

57 Cf. Skilling 1994.

58 Cf. Jaini 1968, Dhīḥ 2007.

59 Cf. Dhīh 2002.

60 Cf. Hidas 2019: 128.

61 Note that in the Vajratundasamayakalparāja this spell is called nāgaśapatha or "Nāgacurse." Note the variant Sarpan[=ṇ?] eya-vidyā-dhāraṇi in Matsunami 1965: 331 and in the Dhāranīsaṃgraha ms. in Appendix 5.X.

62 Cf. Sādhanamālā No. 150. (Bhattacharyya 1925-1928: 308-310).

63 Cf. Giunta 2008.

64 Cf. Banerjee 1941. 
92. Mārīcī-nāma-dhāraṇī ${ }^{65} 131 \mathrm{r}$

[The Jāngulī-dhāraṇī, followed by the complete sādhana text. Different from No. 102]

93. Vajrasarasvatī-sādhana ${ }^{66} 131 \mathrm{v}$

[The complete text]

94. Mahāsarasvatī-dhāraṇi ${ }^{67} 132 \mathrm{v}$

[The complete text]

95. Kurukullā-nāma-dhāraṇī 132v

[Invocation and a spell]

96. Vajravairocanī-stava $133 r$

[Invocation and four verses dedicated to Vajravairocanī]

97. Vasudhārā-nāmāṣțottaraśata-nāma-buddhabhāṣita ${ }^{68} 134 \mathrm{r}$

[The complete text]

98. Vajravidāraṇa-hṛdaya-mantra-nāma-dhāraṇī ${ }^{69} 135 \mathrm{v}$

[The complete text]

99. Gaṇapati-hṛdaya-nāma-dhāraṇi $\bar{i}^{70} 136 \mathrm{v}$

[The complete text]

100. Ușṇișavijayā-nāma-dhāraṇī $\bar{i}^{71} 138 \mathrm{r}$

[The complete dhāraṇī-sūtra]

101. Pañcaviṃśatikā-prajñāpāramitā-nāma-dhāraṇị $\overline{12}^{72} 139 \mathrm{r}$

[The complete text]

102. Mārīcī-nāma-dhāraṇī ${ }^{73} 140 \mathrm{r}$

[The complete text. Different from No. 92]

103. Grahamātṛkā-nāma-dhāraṇi $\overline{1}^{74} 141 \mathrm{r}$

[The latter part of the text with the spell]

104. Hayagrīvakalpe vajragandhārī-nāma-dhāraṇī 141v

[Invocations, spells, ritual instructions and benefits. Shares parts with No. 141]

65 Cf. Sādhanamālā No. 147. (Bhattacharyya 1925-1928: 305-306).

66 Cf. Sādhanamālā No. 168. (Bhattacharyya 1925-1928: 340).

67 Cf. Sādhanamālā No. 162. (Bhattacharyya 1925-1928: 329-330).

68 Cf. No. 105 in Pandey 1994.

69 Cf. Iwamoto 1937b.

70 Cf. Iwamoto 1937b.

71 Cf. Müller and Nanjio 1884, Yuyama 2000, Hidas 2020.

72 This is the longer Prajñāpāramitā-hṛdayasūtra. Cf. Vaidya 1961: 98-99. For details see Zacchetti 2015: 194-197.

73 Cf. Dhìh 2006.

74 Cf. Dhīh 2005. 
105. Mahāmāyāvajravārāhī-nāma-dhāraṇī ${ }^{75} 143 \mathrm{r}$

[Invocations, introductory verses, invocations, a spell, ritual instructions and benefits]

106. Mahāmāyādevyāh śmaśāna ${ }^{76} 143 \mathrm{v}$

[The complete text]

107. Vidyādhari-svalpa-stuti $143 \mathrm{v}$

[Three verses of praise]

108. Mahābhairavasya-nāma-dhāraṇī 143v

[Invocation and a spell. Somewhat shorter than No. 133]

109. Cintāmaṇi-nāma-dhāraṇī 144r

[The Vimaloṣnịșa-dhāraṇī. ${ }^{77}$ Different from No. 33]

110. Cundābhațtāinikāyā rakṣāmantra 144v

[Invocation and a spell]

111. Ādityadvādaśa-nāma $144 \mathrm{v}$

[Five verses with the twelve names of the Sun and the benefits of their recitation]

112. Niśākara-nāma $144 \mathrm{~V}$

[Two verses dedicated to the Moon]

113. Ekajațā-nāma-dhāraṇi $147 \mathrm{v}$

[Invocations and a lengthy spell]

114. Daśakrodhamahābhairavāṇāmenāma-dhāraṇī 147v

[A brief text with an invocation and a spell]

115. Nāmasaṃīti-dhārạ̣ī 148r

[Invocations, spells, ritual instructions and benefits]

116. Avalokiteśvarasya mukhodgīrnāa siddhinikā-nāma-dhāraṇī 148v

[Similar to No. 65]

117. Amṛtabhakṣā-nāma-dhāraṇī 148v

[Invocations, a spell, ritual instructions and benefits]

118. Așțamahābhayaharaṇatārā-nāma-dhārạ̣ī 149r

[Invocations and a spell]

119. Buddhabhațțārakasya dhāraṇī 149r

[Similar to No. 34]

120. Yogāmbarasya karmarāja-nāma-dhāraṇī 149v

[Invocation and a spell]

75 Cf. Sādhanamālā Nos. 221-222. (Bhattacharyya 1925-1928: 434-436).

76 Cf. Sādhanamālā No. 223. (Bhattacharyya 1925-1928: 437).

77 Cf. Schopen 1985. 
121. Sarvalokeśvara-dhāraṇī 149v

[Invocation and a spell]

122. Khasarpaṇa-nāma-dhāraṇī 149v

[Invocation and a spell]

123. Arapacanamañjuśrī-nāma-dhāraṇī 149v

[Invocation and a spell]

124. Maitreya-nāma-dhāraṇī 150r

[Invocation and a spell. Different from No. 18]

125. Saddharmapāṭha-dhāraṇī 150r

[Close to No. 51]

126. Vajratārā-nāma-dhāraṇī 150r

[Invocation and a spell]

127. Ugratārā-nāma-dhāraṇī 150v

[Invocation and a spell]

128. Daśakrodhānām dhāraṇī 150v

[Invocation and a spell]

129. Lokapālasya nāmānām dhāraṇi 151r

[Invocation and a spell]

130. Gaganākṣepavajrayogīnī-nāma-dhāraṇī 151r

[Invocation and a spell]

131. Raktayamāri-nāma-dhāraṇī 151v

[Invocation and a spell]

132. Prasannatārā-nāma-dhāraṇī 151v

[Invocation and a spell]

133. Mahābhairavasya dhāraṇī 151v

[Invocation and a spell. Longer than No. 108]

134. Siddhivighneśvara-dhāraṇī 152r

[Invocation and a spell]

135. Mahākālasya dhāraṇī 152r

[Invocation and a spell]

136. Gaṇeśasya șoḍaśanāma ${ }^{78} 152 \mathrm{r}$

[The sixteen names of Ganeśa with the benefits of their recitation]

137. Vasudhārā-dhāraṇy-upadeśa ${ }^{79} 152 \mathrm{v}$

[The complete text]

138. Punyyavivardhana-nāma-dhāraṇī 153r

[Close to No. 52]

78 Cf. the last part of No. 30 in Pandey 1994.

79 Cf. Sādhanamālā No. 216. (Bhattacharyya 1925-1928: 423). 
139. Sạạakṣarī-dhāraṇi $\bar{i}^{80} 154 \mathrm{r}$

[A section of the Śārdūlakarṇāvadāna. Different from No. 69]

140. Sarvajñajinadhāturatnakaraṇḍaka-nāma bhagavata āryāvalokiteśvarastotra $156 \mathrm{r}$

[The Buddha dwells on Mount Potalaka where the gods praise

Avalokiteśvara. The text concludes with ritual instructions and benefits]

141. Vajragāndhārī-nāma-dhāraṇi $\overline{1}^{81} 156 \mathrm{v}$

[The complete text. Shares parts with No. 104]

142. Kālacakranibaddha-dhāraṇī 157r

[Invocation, an abecedarian spell and instructions for recitation]

143. Hevajradhāraṇapūjā-vidhi-samgraha ${ }^{82} 158 \mathrm{r}$

[Invocation, opening verse, ritual instructions with various mantras]

144. Herukasya-nāma-dhāraṇī 158v

[A spell against diseases]

145. Mahāpratisarāyā dhāraṇi $\bar{i}^{83} 159 \mathrm{r}$

[The complete text]

146. Mahāpratisarāyā-sādhana ${ }^{84} 159 \mathrm{v}$

[The complete text without the final, seemingly extra mantra section given in the Sādhanamālā edition]

147. Mahāmāyūrī-dhāraṇi $\overline{1}^{85} 160 \mathrm{r}$

[The complete text]

148. Mahāsāhasrapramardanī-sādhana ${ }^{86} 160 \mathrm{r}$

[The complete text]

149. Mahāmantrānusāraṇī-sādhana ${ }^{87}$ 160r

[The complete text]

150. Mahās̄îtavatī-sādhana-nāma-dhāraṇī ${ }^{88} 160 \mathrm{v}$

[The complete text]

151. Pañcarakṣā-mahādevyā sādhana ${ }^{89} 165 r$

[The complete text]

80 Cf. Mukhopadhyaya 1954.

81 Cf. Sādhanamālā No. 205. (Bhattacharyya 1925-1928: 403-404).

82 Cf. Isaacson 2009: 115-116 (no. 22).

83 Cf. Sādhanamālā No. 194. (Bhattacharyya 1925-1928: 396).

84 Cf. Sādhanamālā No. 195. (Bhattacharyya 1925-1928: 397-398).

85 Cf. Sādhanamālā No. 197. (Bhattacharyya 1925-1928: 400).

86 Cf. Sādhanamālā No. 198. (Bhattacharyya 1925-1928: 400).

87 Cf. Sādhanamālā No. 199. (Bhattacharyya 1925-1928: 401).

88 Cf. Sādhanamālā No. 200. (Bhattacharyya 1925-1928: 401).

89 Cf. Sādhanamālā No. 206. (Bhattacharyya 1925-1928: 405-413). 
152. Hastapūjā-vidhāna ${ }^{90} 165 \mathrm{v}$

[The complete text]

153. Nairātmā-sādhana-dhāraṇi ${ }^{91} 166 \mathrm{r}$

[The complete text]

154. Vajrahūṃkārabhairavasya dhāraṇi $\overline{1}^{92} 166 \mathrm{v}$

[The complete text]

155. Hayagrīva-dhāraṇi ${ }^{93} 166 \mathrm{v}$

[The complete text]

156. Hayagrīvabhairavasya dhāraṇi $\bar{i}^{94} 167 \mathrm{v}$

[The complete text]

157. Bhūtaḍāmara-saṃkṣipta-dhāraṇi $\overline{1}^{95} 168 \mathrm{v}$

[The complete text]

158. Gaganātmajaśuklavarṇavajravārāhī-nāma-dhāraṇī 169v

[Ritual instructions for a sādhana and homa]

159. Vajrayoginī-nāma-dhāraṇī ${ }^{96} 170 \mathrm{r}$

[The complete text]

160. Vajrașṛnkhalā-dhāraṇi $\overline{1}^{97} 170 \mathrm{v}$

[The complete text]

161. Saṃkṣipta-dvibhujaherukasya-nāma-dhāraṇīis $171 \mathrm{r}$

[The complete text]

162. Pītavarṇa-prajñāpāramitā-nāma-dhāraṇi ${ }^{99} 171 \mathrm{v}$

[The complete text. Cf. No. 55]

163. Saptaśatikā-prajñāpāramitā ${ }^{100} 201 v$

[The complete text]

164. Svalpākṣarā-prajñāpāramitā̄101 $203 v$

[The complete text]

90 Cf. Sādhanamālā No. 253. (Bhattacharyya 1925-1928: 498-500) and Dhīh 1992.

91 Cf. Sādhanamālā No. 230. (Bhattacharyya 1925-1928: 451).

92 Cf. Sādhanamālā No. 257. (Bhattacharyya 1925-1928: 506-507).

93 Cf. Sādhanamālā No. 259. (Bhattacharyya 1925-1928: 508).

94 Cf. Sādhanamālā No. 260. (Bhattacharyya 1925-1928: 508-510).

95 Cf. Sādhanamālā No. 264. (Bhattacharyya 1925-1928: 512-514).

96 Cf. Sādhanamālā Nos. 236. (Bhattacharyya 1925-1928: 456-457).

97 Cf. Sādhanamālā Nos. 207-208. (Bhattacharyya 1925-1928: 413-414).

98 Cf. Sādhanamālā Nos. 243-244. (Bhattacharyya 1925-1928: 472-473).

99 Cf. Sādhanamālā No. 152. (Bhattacharyya 1925-1928: 312).

100 Cf. Tucci 1923. For details see Zacchetti 2015: 197-198.

101 Cf. Vaidya 1961: 93-94. For details see Zacchetti 2015: 202-203. 
165. Vasudhārā-dhāraṇīi ${ }^{102} 204 \mathrm{~V}$

[The complete text followed by an extra section]

166. Sitātapatrāparājitā-nāma-dhāraṇị ${ }^{103} 204 \mathrm{~V}$

[The complete text]

167. Vajracarcikā-nāma-dhāraṇi ${ }^{104} 205 r$

[Ritual instructions for a sādhana]

168. Dhvajāgrakeyūrā-sādhana-dhāraṇī ${ }^{105} 206 r$

[The complete text]

169. Uṣṇiṣavijayā-sādhana-dhāraṇi ${ }^{106} 207 r$

[The complete text]

170. Mahāmāyā-nāma-dhāraṇi ${ }^{107} 208 \mathrm{r}$

[The last section of the text]

171. Vajrajvālānalārka-dhāraṇī ${ }^{108} 208 v$

[Ritual instructions for a sādhana]

172. Caṇḍamahāroṣaṇa-dhāraṇī 209r

[Invocation and two spells]

173. Mahāsaṃvarasya karmarājaviśuddhi-nāma-dhāraṇī 210r

[Ritual instructions for a sādhana]

174. Hevajra-nāma-dhāraṇi 210v

[Ritual instructions for a sādhana]

175. Trailokyavijayā-nāma-dhāraṇīi ${ }^{109} 211 \mathrm{r}$

[The complete text]

176. Lokātīta-stava ${ }^{110} 212 \mathrm{r}$

[The complete text]

177. Grahamātṛkā-nāma-dhāraṇīin $217 r$

[The complete text]

102 Cf. Sādhanamālā No. 213, 216. (Bhattacharyya 1925-1928: 421-423).

103 Cf. Sādhanamālā No. 192. (Bhattacharyya 1925-1928: 395).

104 Cf. Sādhanamālā No. 193. (Bhattacharyya 1925-1928: 395-396).

105 Cf. Sādhanamālā No. 210. (Bhattacharyya 1925-1928: 415-417).

106 Cf. Sādhanamālā No. 211. (Bhattacharyya 1925-1928: 417-418).

107 Cf. Sādhanamālā No. 239. (Bhattacharyya 1925-1928: 458-465).

108 Cf. Sādhanamālā No. 263. (Bhattacharyya 1925-1928: 512).

109 Cf. Sādhanamālā No. 262. (Bhattacharyya 1925-1928: 511).

110 Cf. Lindtner 1987[1982]: 128-138. Cf. also no. 38 in Pandey 1994 and Seyfort-Ruegg 1981: 31-32.

111 Dhīḥ 2005. 
178. Pīthā-stava-stotra ${ }^{112} 220 v$

[The complete text]

179. Bhīmasena-dhyāna-svalpa-stuti 221r

[A conversation between Skanda and Mahādeva with praises and ritual instructions]

180. Skandapurāṇe śanaiścara-stava-stotra ${ }^{113} 224 \mathrm{r}$

[A conversation among Vasișțha, Śanaiścara, Daśaratha and Śani with a praise. Shares parts with the electronic text available]

\section{Sub-colophons:}

Buddhamaṇḍala-dhāraṇīsaṃraha-saṃkṣipta 3r

Dharmamaṇḍalasya dhāraṇīsamgraha-saṃkṣipta 13v

Saṃghamaṇḍalasya saṃkṣipta-dhāraṇīsaṃraha 14v

Saṃkṣipta-saptabuddha-dhāraṇīsaṃraha 15v

Pañcarakṣā-mahādevyā sādhana-dhāraṇī-saṃkṣipta 160v

\subsection{Editorial policy}

This edition provides a standardized and structured version of the text present in the manuscript. There are some marginal and interlinear corrections or additions, furthermore several small dotted marks above superfluous akșaras to be deleted or numbers above mixed up akșaras to indicate their correct sequence, all perhaps by a second hand. Occasionally minor corrections have been made by the editor to improve readings.

\subsection{Silent standardizations}

Geminations after $r$ have been standardized

Geminations before $r$ have been standardized

112 Cf. Dhīḥ 1988 and No. 62 in Pandey 1994.

113 Cf. http://sanskritdocuments.org/doc_z_misc_navagraha/shanaishcharastotram.itx (accessed March 2020) where it is recorded as a Śanaiścara-stotra composed by Daśaratha. The text does not seem to be an original part of the Skandapurāna and is likely to be a later attribution. 
Often an $r$ is inserted before double consonants: e. g. puruṣorttama, niṣarṇnaḥ, urccārayet - these have been standardized

Missing or superfluous $r$ have been supplied or ignored

Degeminations before a semivowel have been standardized

Sibilants have been given in their standard form

Variations between $a / \bar{a}, \mathrm{i} / \bar{\imath}, u / \bar{u}, n / n, s / k h, b / v / c, t / t, d / d, p / y, j / y, c c h / k s ̦ a$ and $r / l$ have been standardized (some of the non-standard forms are marked in the ms. itself with a small curly line above the relevant akșaras)

Straight and curly mātrā line inconsistencies like $a / e, \bar{a} / o$ have been standardized Variations between $e / a i$ and $o / a u$ have been standardized

Variations between half $t$ and $n$ have been standardized

Final anusvāras before vowels or at the end of sentences have been changed to $m$ Missing or superfluous anusvāras have been supplied or ignored Missing or superfluous visargas have been supplied or ignored Comma-like punctuation marks have not been indicated Homorganic nasals have been changed to anusvāras when needed Initial $c h$ written as $c c h$ have been standardized Sometimes $d$ stands for $r$ - this has been standardized Sometimes $d d h$ stands for $d h$ (boddhavyam for bodhavyam), $d h v$ (ürddha for ürdhva) $d h r$ (gṛddha for gṛdhra) or $d v$ (ddheșa for dveșa) - these have been standardized

Geminations of a final $d$ after a short vowel and before an initial short vowel (kaścidd eva for kaścid eva) have been standardized

The lack of avagrahas has not been indicated

\subsection{Abbreviations}

ac. a reading in the manuscript before alteration (ante correctionem)

pc. a reading in the manuscript as altered (post correctionem)

corr. correction by the editor

om. omission

ms. an original reading in the manuscript 


\subsection{Ms. Add. 1326}

<1v> om namaḥ sarvabuddhabodhisattvebhyaḥ \|

śrīmat-trijagadīśvaram suvimalaṃ sambuddhajātaḥ svayaṃ dīnāddhe magnasattvam uddhṛtakaraṃ kāruṇyasampādakam |

māram vinirjitya sasainyasakalam śastreṇa mantreṇa vai vande tasmai

guṇālayaṃ supuruṣam buddham sadānandakam ||

ādau ratnatrayaṃ natvā likhyate saṃgrahaṃ mayā |

yāṃ smṛtvā prahatāṃ vyādhis tāṃ vidyādhāraṇī ca sā || ||

[1] prathamatalaṃ parvatāraṇyāder abhyuccaśikharaśiropari

mahograsiddhabhūtale sarvopadravavirahite gahvaraguhārāmalayanādiṣu

viviktavijaneșu manorameșu vā vasan | vidhivad buddhādidevatāyā

paț̣apratimāyā agratạ̣ gurumaṇḍalake puṣpābhikīrṇaṃ kṛtvā

sarvabuddhabodhisattvaṃ praṇamya bodhicittam ca samutpādya ātmānaṃ

niryātayet || tatreyaṃ vidyā sarvadhāraṇīmantraḥ prasiddhyarthaṃ

vijitendriyam sahasram japet ||

tadyathā || oṃ namaḥ sarvabuddhabodhisattvānām | amalā malahārakā anantāḥ samu<2r>tāḥ sajinā amī maniṣṭhā varadā mama dentu atyudāravaram agryam samama sarvadā anantạ̣ tatra 'me vajrapadā arara asamasama samatānanta dharma te khaṇa khaṇa mahāvīrācale sama sama amahamahābale kaṇa kaṇa mahāgrike haha haha vajre vajrāhvaye dhara dhara hūṃ hūṃ maṇḍala mama balāgravikrame kuru kuru turu turu sarvathā sarvahi jvala jvala agra agriṇi hūṃ hūṃ phaṭ phaṭ svāhā || tena sarvadhāraṇimantrāṇām lakṣajāpaḥ kṛto bhavati | sarvarakṣādimantrāś cāsya siddhā bhavanti \|

iti mūlavidyā-dhāraṇī samāptaḥ || ||

[2] oṃ namas traiyadhvikānāṃ tathāgatānāṃ sarvatrāpratihatavyāptidharmatāvalīnām | aṃ ạ̣ sama sama samantato 'nantāvāptiśāmani hara 2 smara smaraṇa vigatarāgabuddhadharmate sara sara samavarāgre hasa hasa traya traya gagana sadā lalarakṣaṇe jvala jvalanasāgare svāhā || ity anena sarvapāpakarmāvaraṇakṣayārtham sarvatathāgatahṛdayaśatākṣarayuktadhāraṇīm tenaiva vidhinā

5 śastreṇa mantreṇa] $p c$.; śastreṇa ac. 10 -bhūtale] $p c . ;$-tale $a c . \quad 18$ agryaṃ] corr.; agyram ms. 
aștasahasram paṭhet saddharmadūṣaṇānantaryādikam

sarvapāpakarmāvaraṇam prahīyate \|

iti śatākṣara-sarvatathāgata-hṛdaya-dhāraṇī samāptạ̣ || <2v> ||

oṃ namo buddhāya ||

tṛ̣̣nājihvam asadvikalpaśirasāṃ pradveșacañcatphaṇaṃ kāmakrodhavitarka-

dveșadaśanaṃ rāgapracaṇḍekṣaṇam |

mohāsyaṃ svaśarīrakoțaraśayaṃ cittoragaṃ dāruṇaṃ prajñāmantrabalena yạ̣

śamitavān buddhāya tasmai namaḥ \|

śāśvatākṣobhyaratneśa-amitāmoghasiddhayaḥ |

locanāmāmakīsītā-tārādevī namạ̣ sadā ||

[3] oṃ namo bhagavate vairocanaprabhavaketurājāya tathāgatāyārhate samyaksambuddhāya \|

tadyathā || oṃ sūkṣme sūkṣme | same same | śānte saānte | dānte dānte | asmārope | anālambe | talambe | yaśovati mahāteje | nirākule | nirvāṇe | sarvabuddhādhișțhānādhiṣṭhite svāhā ||

iti vairocanatathāgata-dhāraṇī samāptạ̣ || 1 ||

[4] oṃ namo bhagavate akṣobhyāya tathāgatāyārhate samyaksambuddhāya || tadyathā || oṃ añjaya 2 mahāñjaya añjayavijaye svāhā ||

iti akṣobhyatathāgata-dhāraṇī samāptah || 2 ||

[5] oṃ namo bhagavate ratnaketurājāya tathāgatāyārhate samyaksambuddhāya \| tadyathā || oṃ ratne ratne mahāratne ratnavijaye svāhā ||

iti ratnasambhavatathāgata-dhāraṇī samāptah || 3 ||

[6] oṃ namo bhagavate 'mitābhāya tathāgatā<3r>yārhate samyaksambuddhāya |

oṃ tadyathā | oṃ amite 2 mahāmite amitavijaye svāhā ||

iti amitābhatathāgata-dhāraṇī samāptaḥ || 4 ||

7 -mantrabalena] corr.; -mandabale ms. 23 -sambhava-] pc.; -sambhavadhā- $a c$. 
[7] oṃ namo bhagavate 'moghasiddhaye tathāgatāyārhate samyaksambuddhāya |

tadyathā | oṃ amoghe 2 mahāmoghe amoghavijaye svāhā ||

iti amoghasiddhitathāgata-dhāraṇī samāptaḥ || 5 ||

oṃ āḥ locanāyai lāṃ hūṃ svāhā || agne || oṃ āḥ māmakīyai māṃ hūṃ svāhā || 5 naiṛ̣tye || oṃ âḥ pāṇụarāyai pāṃ hūṃ svāhā || oṃ āḥ vāyavye | oṃ āḥ tārāyai tāṃ hūṃ svāhā || aiśāne |

iti buddhamaṇḍala-dhāraṇīsaṃgrahaḥ saṃkṣiptaḥ samāptaḥ || ||

oṃ namo dharmāya |

yām āsādya gatā buddhā bhavanto pāram uttamam |

dharmaṃ caiva namasyāmi sarvasattvārthasiddhaye ||

yāḥ sarvajñatayā nayaty upaśamaṃ śāntaiṣiṇaḥ śrāvakān yā mārgajñatayā jagaddhitakṛtāl lokārthasampāāikān | sarvākāram idaṃ vadanti munayo viśvamijayāḥ sugatān tasyai śrāvakabuddhabodhisattvaganino buddhasya mātre namạ̣ || prajñāpāramitāgaṇḍavyūho 'tha daśabhūmayaḥ | samādhirāẹ mahāyānaṃ lañkāvatārakaṃ punaḥ || saddharmapuṇụarīkaś ca tathāgataguhyaka tathā| lalita<3v>vistaraḥ svarṇaprabhāsottamakaṃ namạ̣ ||

[8] oṃ namo bhagavate ārya-prajñāpāramitāyai || tadyathā || oṃ munidharma saṃgrahadharma anugrahadharma vimuktidharma sadānugrahadharma vaiśravaṇaparivartitadharma sarvakāryapariprāptidharma samantaparivartitadharma svāhā || oṃ prajñe 2 mahāprajñe śrutismṛtivijaye dhịh dhāranīiye svāhā || anayā dhāraṇyā ārya-śatasahasryāḥ prajñāpāramitāyā vācanāt phalaṃ labhate \|

iti prajñāpāramitā-dhāraṇī samāptaḥ || 1 ||

13 jagaddhita-] corr.; jagaddhihita- ms. 14 sugatān] corr.; sagatān ms. 
[9] om namah sarvabuddhabodhisattvebhyạ \|

tadyathā || oṃ kiṇi 2 tathāgatodbhave varade uttamottame tathāgatodbhave hūm phaṭ svāhā \|

ārya-gaṇụavyūho-nāma-dhāraṇī samāptaḥ || 2 ||

[10] oṃ namaḥ sarvabuddhabodhisattvebhyạ̣ || evaṃ mayā śrutam ekasmin samaye bhagavān aparimitavaśavartiṣu deveșu viharati sma | acirābhisambuddho dvitīye saptāhe vaśavartino devarājasya vimāne maṇimaye ratnagarbhaprāsāde mahatā bodhisattvasaṃhena sārdham || tatra khalu vajragarbho bodhisattvo daśadiśaṃ vyavalokya sarvāvatīparṣadạ̣ vyavalokya dharmadhātuś ca vyavalokayan sarvajñatācittotpādaś ca samvarṇayan bo<4r>dhisattvaviṣayam ādarśayan caryābalaṃ pariśodhayan sarvākārajñatāsaṃgraham anuvyāharan sarvalokamalam upakarṣayan sarvajñajñānam upasaṃharan | acintyajñānaniryūham ādarśayan bodhisattvaguṇān prabhāvayan | evam eva bhūmyarthạ̣ prarūpayamāṇo buddhānubhāvena tasyāṃ velāyām imāṃ gāthām abhāṣatah || śamadamaniratānāṃ sāantadāntāśayānāṃ khagapathasadṛśānām antarīkṣasamānām | khilamalavidhutānāṃ mārgajñāne sthitānāṃ șṛuta baliviśeṣān bodhisattvān aśeșān ||

kuśalaśatasahasraṃ saṃcayā kalpakoṭyā buddhaṃ śatasahasrān pūjayitvā maharṣīn | pratyekajinavaśīn pūjayitvā anantān sarvajagaddhitāya jāyate bodhicittam || vratatapatapitānāṃ kṣāntipāraṃgatānāṃ hiriśiricaritānām puṇyajñānodgatānām | vipulagatimatīnāṃ puṇyajñānāśrayānāṃ daśabalasamatulyaṃ jāyate bodhicittam \| yā ca jina triyadhvā pūjanārthāya yuktān khagapathapariṇāmaṃ śodhayan sarvakșetram | samyaganugatārthe yāvatā sarvadharmān mokșa jagata arthe jāyate bodhicittam \||

pramuditasumatīnāṃ dānadharmāratānāṃ sakalajagihitārthe nityam evodyatānām | jinagu<4v>ṇaniratānām sattvarakṣāvratānāṃ tribhuvanahitakārye jāyate bodhicittam \|

2 tadyathā] $p c$; tathādya $a c . \quad 2$ tathāgatodbhave] $p c$; tathāgadbhave $a c . \quad 10$ vyavalokayan] pc.; vyavalokya $a c .22$ anantān] pc.; antānan $a c .23$ hiri-] corr.; hari- ms. 
akuśalaviratānāṃ śuddhaśīlāvratānāṃ vrataniyamaratānāṃ śāntasaumyendriyāṇām |

jinaśaraṇagatānāạ bodhicaryāśayānāṃ tribhuvanahitasādhye jāyate bodhicittam ||

anugatakuśalānāṃ kṣāntisārasya bhājāṃ viditaguṇarasānāṃ tyaktamānotsavānām |

nihitaśubhamatīnāṃ dāntasaumyāśayānām sakalahitavidhāne jāyate bodhicittam || pracalitaśubhakārye dhīravīryasahāya nikhilajanahitārthe prodyatāmāna siṃhạ̣ |

avirataguṇasādhyā nirjitakleśasaṃhā jhațiti manasi teșāṃ jāyate bodhicittam \| susamavahitacittā dhvastamohāndhakārā vigalitamadamānā tyaktasaṃkliṣțamārgāḥ |

śamasukhaniratā ye tyaktasaṃsārasamgā jhaṭiti manasi teṣām jāyate bodhicittam \| vimalakhasamacittā jñānavijñānavijñā nihatanamucimārā vāntakleśābhimānāḥ | jinapadaśaraṇasthā labdhatattvārthakārye sapadi manasi teșāṃ jāyate bodhicittam \|

tribhuvanaśivasādhyopāyavijñānadhīrāḥ

kalibalaparihāropāyavidyarddhimantạ̣ |

sugataguṇasamūhā ye ca puṇyānurāgā sapadi manasi teṣāṃ jāyate bodhi< $<$ r $>$ cittam \|

tribhuvanahitakāmā bodhisambhārapūryaih praṇihitamanasā ye duṣkare 'pi caranti | avirataśubhakarme prodyatā bodhisattvāḥ sapadi manasi teșāṃ jāyate bodhicittam || daśabalaguṇakāmā bodhicaryānuraktā vijitakalibalaughās tyaktamānānusaṃāh | anugataśubhamārgā labdhadharmārthakāmā jhaṭiti manasi teșām jāyate bodhicittam \|

iti gaṇitaguṇāṃsā bodhicaryāś carantu jinapadapraṇidhānāḥ satsamṛddhiṃ labhantu | tribhuvanapariśuddhā bodhicittam labhantu triśaraṇapariśuddhā bodhisattvā bhavantu \| daśa pāramitāḥ pūryair daśabhūmīśvaro bhavet |

17 -namuci-] pc.; -namumuci- $a c$. 
bhūyo 'pi kathyate hy aitac chruṇutaiva samāsataḥ || bodhicittam yadāsādya sampradānam karoti yạ̣ | tadā pramuditām prāpto jambudvīpeśvaro bhavet || tatrasthah pālayan sattvān yathecchāpratipādanaị̣ | svayaṃ dāne pratiṣthitvā parāṃś cāpi niyojayet || sarvān bodhau pratișthāpya sampūrṇadānapāragaḥ | etaddharmānubhāvena saṃvaraṃ samupācaret | samyakcchīlaṃ samādhāya saṃvarakuśalī bhavet || 1 || tataḥ sa vimalāprāptaś cāturdvīpeśvaro bhavet | tatrasthah pālayan sattvān akuśalam nivāriṇaị̣ || sva<5v>yaṃ śile pratișțitvā parāṃś cāpi niyojayet | sarvān bodhau pratișțhāpya sampūrṇaśīlapāragạ̣ || etaddharmavipākena kṣāntivratam upāśrayet | samyakkṣāntivrataṃ dhṛtvā kṣāntibhṛtkuśalī bhavet || 2 || tatah prabhākarīprāptas trayastrimśāanhipo bhavet | tatrasthaḥ pālayan sattvān kleśamārganivāriṇaị̣ || svayaṃ kṣāntivrate sthitvā parāṃś cāpi niyojayet | sarvān bodhau pratișțhāpya kṣāntipāramgato bhavet || etatpuṇyavipākena vīryavratam upāśrayet | samyagvīryaṃ samādhāya vīryabhṛtkuśalī bhavet || 3 || tataś cārciṣmatīprāptạ̣ suyāmādhipatir bhavet | tatrasthạ pālayan sattvān kudṛșṭisaṃnivāriṇaih || svayaṃ vīryavrate sthitvā parāṃś cāpi niyojayet | samyagdṛștau pratișțhāpya bodhayitvā prayatnatạ̣ || sarvān bodhim samavāpya vīryapāramgato bhavet | etatpuṇyavipākaiś ca dhyānavratam upāśrayet | sarvakleśān vinirjitya samādhau susthito bhavet | samyagdhyānaṃ samādhāya samādhikuśalī bhavet || 4 || tatạ̣ sudurjayāprāptạ̣ saṃstuṣitādhipo bhavet | tatrasthah pālayan sattvāṃs tīrthyamārgān nivāriṇaị̣ || satyadharma pratișțhāpya bo<6r>dhayitvā prayatnatạ̣ | svayaṃ dhyānavrate sthitvā parāṃś cāpi niyojayet || sarvān bodhau pratiṣțhāpya dhyānapāraṃgato bhavet | etatpuṇyavipākaiś ca prajñāvratam upāśrayet \| sarvamārān vinirjitya prajñābhijñasamṛddhimān | samyakprajñām samādhāya svabhijñākuśalī bhavet || 5 ||

11 niyojayet] corr.; niyojan ms. 18 sarvān] pc.; samyakkṣāntivrataṃ dhṛtvān ac. 23 niyojayet] $p c$.; nijayoyet $a c$. 
tataś cābhimukhīprāptaḥ sunirmitādhipo bhavet | tatrasthaḥ pālayan sattvān abhimānanivāriṇaị̣ || śūnyatāsu pratișthāpya bodhayitvā prayatnatạ̣ | svayaṃ prajñāvrate sthitvā parāṃś cāpi niyojayet || sarvān bodhau pratișṭhāpya prajñāpāraṃgato bhavet |

etatpuṇyavipākena samupāyavratam caret || sarvadușțān vinirjitya saddharmakuśalī sudhīḥ | samupāyavidhānena sattvān bodhau niyojayet || 6 || tato dūraṃgamāprāpto vaśavartīśvaro bhavet | tatrasthạ pālayan sattvān abhisamayabodhanaị || bodhisattvaniyāmeșu pratișţhāpya prabodhayet | tatropāye svayaṃ sthitvā parāṃś cāpi niyojayet || sarvān bodhau pratișțhāpya hy upāyapārago bhavet | etatpuṇyānubhāvaiś ca supraṇidhir upāśrayet || mithyādṛștim vinirjitya samyakdṛșțikṛtī budhaḥ | supratihitacittena samyagbodhau pratișțitah || 7 || <6v>tataś cāpy acalāprāptaḥ brahmasāhasrikādhipaḥ| tatrasthạ pālayan sattvān triyānasampraveśanaị || lokadhātau parijñāne pratișthāpya prabodhayet | supraṇidhau svayam sthitvā parāṃś cāpi niyojayet || sarvān bodhau pratiṣthāpya praṇidhipārago bhavet | etatpuṇyānusāraiś ca balavratam upāśrayet || sarvaduṣțān vinirjitya sambodhau kṛtaniścayah | samyaksampannasamutsāhaih sarvā tīrthyān vinirjayet || 8 || tatah sādhumatīprāpto mahābrahmā bhavet kṛtī | tatrasthaḥ pālayan sattvān buddhayānopadarśanaiḥ || sattvāśayaparijñāne samyagbodhau prabodhayan | svayaṃ bale pratișṭhāpya parāṃś cāpi niyojayet || sarvān bodhau pratișţhāpya balapāragato bhavet | etatpuṇyavipākaiś ca jñānavratam upāśrayet || caturmārān vinirjitya bodhisattvo guṇākaraḥ | samyagjñānam samāsādya saddharmakuśalī bhavet || 9 || dharmameghā tatạ prāpto maheśvaro bhavet kṛtī | tatrasthạ pālayan sattvān sarvākārānubodhanaị̣ || sarvākārabale jñāne pratișthāpya prabodhayet | svayaṃ jñāne pratiṣthitvā parāṃś cāpi niyojayet || sarvān bodhau pratișṭhāpya jñānapāraṃgato bhavet |

18 saṃpraveśanaiḥ] corr.; saṃpiveśanaiḥ ms. 
etatpuṇyānubhāvaiś ca daśabhūmīśvaroś ca ji<7r>nah \|

sarvākāraguṇādhāraḥ sarvajñajñānarāḍ bhavet || 10 ||

iti matvā bhuvabhiś ca sambodhipadalabdhayaḥ |

daśapāramitāpūryaiś caritavyạ̣ samāhitah |

tathā bodhim śivām prāpya caturmārān vinirjayet |

sarvān bodhau pratișthāpya nirvṛtim samavāpsyatha ||

etaj jñātvā paricchāya caradhvaṃ bodhisādhane |

nirvighnaṃ bodhim āsādya labhadhvaṃ saugatāṃ gatim ||

etās tāḥ khalu bho jinaputrā daśabodhisattvabhūmayaḥ samāsato nirdișto

sarvākāravaropetasarvajñajñānānugato drașțavyāḥ || tasyāṃ velāyām ayam

trisāhasramahāsāhasralokadhātu ṣaḍvikāram prakampatạ̣ | vividhāṇi ca puṣpāṇi viyato nyapatat | divyamānuṣyakāni ca bhūtāni sampravāditāny abhūvan | anumodanāsaṃgena ca yāvadakanișṭhabhuvanaṃ prajñaptam abhūt |

iti śrī-bodhisattvacaryāprasthāno-daśabhūmīśvaro-nāma-mahāyānasūtraṃ ratnarājam samāptạ || 3 ||

[11] oṃ namo ratnatrayāya \| tadyathā || oṃ dhunu 2 hūṃ hūm phaṭ 2 svāhā || ya imāṃ kaścid dhārayet sa jayo bhavati ||

iti samādhirāja-nāma-dhāraṇī samāptaḥ || 4 ||

[12] oṃ namo ratnatrayāya || namo laṅkāvatārāya || evaṃ mayā śrutam ekasmin samaye bhagavāl lan̉kāpuri samudramalayagiriśikhare viha $<7 \mathrm{v}>$ rati sma || tatra bhagavān mahāmatim etad avocat || udgṛhṇa tvaṃ mahāmate lan̉kāvatāramantrapadāni yāny atītānāgatapratyutpannair buddhair bhagavadbhir bhāṣitāni bhāṣyante bhāṣișyante 'ham apy etarhi bhāṣișye dharmabhāṇakānām parigrahārtham || tadyathā || dhuțte dhuțte | pațte pațte | kațte kațte | amale amale | vimale vimale | nime 2 | hime 2 | vame 2 | kale kale || atțe | mațte | cațte | tuțte | jñaț̣e | sphaț̣e | kaḍdhe | laḍduhe | paḍdhe || hime 2 dime 2 cale 2 pace 2 bandhe 2 muñce 2 || duḍāre | dhuḍāre | paḍāre | arke 2 marke 2 cakre 2 dime 2 hime 2 || țuṭu țuṭu | dhudhu dhudhu | ruru ruru | huhu huhu | svāhā ||

12 -mānuṣyakāni] corr.; -mānuṣāṣyakāni ms. 13 yāvadakanișṭha-] pc.; yāvadanikașṭhaac. 23 mahāmate] $p c$; mahāmatebo $a c$. 
imāni mahāmate mantrapadāni lañkāvatāramahāyānasūtram | yạ̣ kaścin mahāmate kulaputro vā kuladuhitā vā imāni mantrapadāni | udgrahiṣyanti dhārayiṣyanti vācayiṣyanti paryavāpsyanti | tasya na kaścid avatāraṃ lapsyanti || devo vā devī vā | nāgo vā nāgī vā | yakṣo vā yakṣī vā | asuro vā asurī vā | garuḍo vā garuḍi vā | kiṃnaro vā kiṃnarī vā | mahorago vā mahoragī vā | gandharvo vā gandharvī vā | bhūto vā bhūtī vā | kumbhāṇḍo vā kumbhāṇụī vā | piśāco vā piśācī vā | ostārako vā ostārakî <8r> vā | apasmāro vā apasmārī vā | rākṣaso vā rākṣasī vā | ḍāko vā ḍākī vā | ojohāro vā ojohārī vā | kaṭapūtano vā kațapūtanī vā | manuṣyo vā manuṣyī vā | sarve te 'vatāraṃ na lapsyanti || saced viṣamo graho bhaviṣyanti || so 'syāṣțaśatābhimantritena rudanto krandanto ekādiśaṃ gṛhītvā yāsyanti || || punar aparāṇi mahāmate mantrapadāni bhāṣișye || tadyathā || padme padmadeve | hīne hīnahīne | cucule cule cule | hule huluhule | yule yuluyule | ghule ghulaghule | pale palapale | muñce | chinde | bhinde | bhañje | marde | pramarde | dinakare svāhā || imāni mahāmate mantrapadāni yaḥ kaścit kulaputro vā kuladuhitā vā udgrahiṣyanti dhārayiṣyanti vācayiṣyanti paryavāpsyanti | tasya na kasyacid avatāraṃ lapsyanti || devo vā devī vā | nāgo vā nāgī vā | yakṣo vā yakṣī vā | asuro vā asurī vā | garuḍ̣o vā garuḍī vā | kiṃnaro vā kiṃnarī vā | mahorago vā mahoragī vā | gandharvo vā gandharvī vā | bhūto vā bhūtī vā | kumbhāṇḍo vā kumbhāṇḍi vā | piśāco vā piśācī vā | ostārako vā ostārakī vā | apasmāro vā apasmārī vā | rākṣaso vā rākṣasī vā | ḍāko vā ḍākī vā | ojo<8v>hāro vā ojohārī vā | kațapūtano vā kațapūtanī vā | manuṣyo vā manuṣyī vā | sarve te 'vatāram na lapsyanti || yaḥ imāni mantrapadāni paṭhiṣyanti tena sarve te lan̉kāvatārasūtra paṭhitaṃ bhavișyanti || imāni bhagavato mantrapadāni bhāṣitāni rākṣasanivāraṇārtham iti ||

\section{ārya-lanikāvatāra-nāma-dhāraṇī parisamāptaḥ || 5 ||}

[13] om namah sarvabuddhabodhisattvebhyah || tadyathā || anye manye | arau parau | amane mamane | citte carite | same samitāviśānte | mukte makuṭaye | same avisame | samasame | jaye kṣaye | akṣaye akṣiṇe | śānte samīte | dhāraṇi ālokabhāṣe | pratyavekșuṇi | nidhi ruci ciru | abhyantarapāri | śuddhiukule | mukule | aratre paratre | sukānnkși | asamasame | buddhavilokite | dharmaparīkșite | saṃhanirghasani nirghoṣani | bhayaviśodhani |

1 mahāyānasūtram] pc.; mayānasūtram ac. 3 kaścid] corr.; kacid ms. 9 kațapūtanī] corr.; kațapūnī ms. 24 mantrapadāni] $p c$; mahāmantrapadāni $a c .33$ saṃghanirghasani] $p c$;; samphayanirghasani ac. 
mantre mantrākșayate | rutakauśalye | akșaye vanatāye | vakkulavaloke | amanyanatāye || saddharmapuṇḍarīkāyā mantraḥ || || namo ratnatrayāya || tadyathā || iti me iti me iti me iti me iti me || 5 || nime nime nime nime nime || 5 || ruhe ruhe ruhe ruhe ruhe || 5 || strahe strahe strahe strahe stra<9r>he || 5 || svāhā || ||

namo ratnatrayāya || tadyathā || adậ̣̣ādaṇụapati dị̣̣opate nidaṇụakuśale daṇḍasudhāri 2 sudhārayāmi buddhayasyase dhāriṇi āvartasi saṃvartasi saṃghaparīkṣite saṃghanirghātadharmaparīkṣite sarvarute kauśalyānugate siṃhavikrīẹite anuvarte vartani vartani svāhā ||

ārya-saddharmapuṇụarīkāyā dhāraṇī-mantraḥ samāptaḥ || 6 ||

[14] oṃ namaḥ sarvabuddhabodhisattvebhyah || atha bhagavān guhyakādhipatim etad avocat || smarasi tvaṃ guhyakādhipate tāni dharmaguptyārakșaṇapadāni | yāni mayā ratnacandrasya tathāgatasyāntikāc chrutāni saddharmaparigrahāya || āha || smarāmi bhagavan || bhagavān āha || tena hi tvaṃ guhyakādhipate udīraya tāni dharmaguptyārakṣaṇapadāni | iha parșady asya dharmaparyāyasya cirasthitaye evam ayaṃ dharmaparyāyaḥ cirasthitiko bhavișyati || atha vajrapāṇir guhyakādhipatir daśasu dikṣu sarvabuddhān namaskṛtya imāni mantrapadāny udīrayati sma \| jaya | jayamati | jayaśakra āle | amale | aluḍite | name | namayati | nāmasaṃdhi | utte | uttamati | uttaramati | uttaraṇi | āre āramaṇi | āriśamani |<9v> āmule | mūlāvartite | mūlānugate | ange mañge | mañgite | ạḍimāḍite | khuru khuru | khuru saṃdhi | dharmānugate | dharmatakșe | dharmapraveśe | sare sarasare | abhede | bhedasaṃdhi | ehi ehani | enanugate | nigraho mārāṇām | nirghātanaṃ tîrthyānām | mohanaṃ dharmavidveșinām | vidhamanaṃ kleśānām | ujjvālanaṃ dharmanetrīnām | ārakṣākarṣitānām | āveśanaṃ nirvāṇasya | pragraho bodhisattvaparicārakānām | parisaṃsthāpanā parșadaḥ | kāyānupradānaṃ dharmaśravaṇikānām | samanvāharatvaṃ samyaggatānām | avalokanaṃ samyakpratipannānām | āmukhībhāvatvaṃ mantrapadānām | mā praṇaśyantu mantra santi | ajānanatvam udāharaṇajñānam | akșūṇatā | anavamṛdyatā | deśanā | svabhāvatvaṃ samanantaram | parikīrtitāni cemāni mantrapadāni || athāyaṃ trisāhasramahāsāhasro lokadhātuḥ prākampatạ̣ | ye ca trisāhasramahāsāhasre lokadhātau mārās te sabalāḥ saparivārāḥ bhagavantam upasaṃkramyāvanatakāyāḥ prāñjalībhūtā bhagavantam etad avocat || vayaṃ bhagavaṃs tasya dharmabhāṇakasyopasthānaparicaryāṃ kariṣyāmo yasya

10 saddharma-] corr.; saddha- ms. 25 pragraho] corr.; praho ms. 26 bodhisattva-] pc.; bodhisattvasya ac. $\mathbf{3 0}$ svabhāvatvaṃ] $p c$.; svabhātvaṃva $a c$. 
mukhadvārād imāni mantrapadāni niścarișyanti || naiṣāṃ bhaga<10r>van mantrapadānāṃ śrịh śakyā sadevakena lokena sodhum | te vayaṃ bhagavann ātmanā yasya dharmaparyāyasya guptị̣ kariṣyāmaḥ | anyāṃś cāvatāraprekṣiṇo nigrahișyāmaḥ || atha khalu bhagavān samantāc caturdiśam nāgāvalokitena vyavalokya tasyāṃ velāyām imāni mantrapadāni bhāṣate sma ||

jaye durjaye jayamati | same śatrunirghātani | amūle mūlaparicchinne |

mārasainyavitrāsani | mukte mati | śuddhe abhede | bhaye | mohani bhārohani

vante | vidyavidye balottame |

nigraham parivādinām | dharmavādināṃ saṃgraham |

ārakșā dharmagañjasya | vidye buddhaprakāśite |

ame ame | marmacchede | arthe arthanistaraṇe || caturṇām lokapālānām

āveśanamantrapadāni bhāṣitāni || vīre vīramati | gupte | śubhe |

śubhavatīsame | śakrasya devarājasyehāveśana kṛtam | maitre somavati |

kṣāntikṛtsukaruṇodāhute prīti-upekṣasampanne | brahmāpy āveśito iha || arade varade khakha | amūle | mūlaśodhani |

mārasya nigrahārthāya ime mantrāḥ prakalpitāh ||

adhișṭhitam narendreṇa idam sūtram subhāṣitam \|

pracarișyati tatkāle yatra jñātā bhavișyati \|

ime ca bhāṣitā mantrā medanī ca prakampitā ||

samāgatāḥ sarvamārā i<10v>dam vacanam abravīt ||

vayam ārakṣayiṣyāmas tāṃ vijñām dharmabhāṇakām ||

yeșām haste idaṃ sūtram kālaṃ yāsyati paścimam ||

ity ārya-tathāgataguhyakā-nāma-dhāraṇī samāptaḥ || 7 || ||

[15] oṃ namo ratnatrayāya || evaṃ mayā śrutam ekasmin samaye bhagavāñ chrāvastyām viharati sma || jetavane 'nāthapiṇụadasyārāme

mahatā bhikṣusaṃghena sārdham || tatra bhagavān lalitavistaraṃ nāma dharmaparyāyam deśayanti sma || atha tasyāṃ velāyāṃ bhagavān bodhisattvena duṣkarābhyāsakṛte japtamantraṃ bhāṣate sma || om vaṣaṭ svadhāḥ svāhā || atha khalu tathāgatas tasyāṃ velāyāṃ teṣām trapuśabhallikānām vaṇijām imāṃ saṃharṣaṇām akārṣịt || diśāṃ svastikaraṃ divyaṃ māñgalyaṃ cārthasādhakam | arthā vaḥ sāasatā sarve bhavantv āśu pradakṣiṇām || śrīr vo 'stu dakṣiṇe haste śrīr vo vāme pratișțhitāh | śrīr vo 'stu sarvasāngeșu māleva śirasi sthitāḥ ||

7 bhārohani] pc.; bhārohini ac. 29 tathāgatas] corr.; stathāgatas ms. 30 saṃharșaṇām] corr.; saṃrghașaṇām $a c$., saṃrghaṇām $p c . \quad 34$-sāngeșu] corr.; -tongeșu ms. 
enaiṣināạm prayātānāṃ vaṇijāṃ vai diśo daśah | utpadyatām mahālābhās te ca santu sukhodayāḥ || kāryeṇa kenacid yena gacchathạ pūrvikā diśam | nakṣatrāṇi ca pālentu ye tāṃ diśi-m-adhișṭhitām || kṛttikā rohinī caiva mrgaśirārdrā punar vasụ̣ | puṣpā cai<11r>vāthavā śleṣā ity eșām pūrvikām diśām || ity etā saptanakṣatrā lokapālo yaśasvinạ̣ | adhișțhāḥ pūrvadigbhāge te vo rakṣantu sarvataḥ || teșām cādhipatirājā dhṛtarāșțreti viśrutaḥ | gandharvādhipatih sarva sūryeṇa saha rakṣatu | putrā 'pi tasya bahavah eko nāma vicakṣaṇaḥ | aśītidaśa caikaś ca indro nāma mahābalạ̣ || te 'pi vaś cādhipāletu ārogyena śivena ca pūrve 'smin vai diśobhāge așțau devakumārikāḥ \| jayantī vijayantī ca siddhārthāś cāpi 'parājitā | nandottarā nandisenā nandinī nandavardhanī || tā 'pi vaś cādhipāletu ārogyena śivena ca | pūrve 'smin vai diśobhāge cāpālam nāma cetiyam \| avustam jituvijñātam arhanteti ca tāyibhị̣ | te 'pi vaś cādhipāletu ārogyena śivena ca || kṣamāś ca vo diśah santu mā ca vaḥ pāpam āgamaḥ | labdhārthāś ca nivartadhvaṃ sarvadevebhi rakṣitāḥ || 1 || yena kenacit kṛtyena gacchathāṃ dakṣiṇām diśam | nakṣatrāṇi ca pāletu ye tām diśam adhiṣṭhitām || maghā ca dvau ca phālgunyau hastā citrā ca pañcamī| svāti caiva viśākhā ca eteșāṃ dakṣiṇā diśam || ity etāḥ saptanakṣatrā lokapālā yaśasvināḥ | adhișțhā dakṣi<11v>ṇe bhāge te vo rakṣantu sarvaśạ̣ || teșām cādhipatirājā virūọhaka iti smṛtaḥ | kumbhāṇḍāhipatị̣ sarve yamena saha rakṣatu || putrāpi tasya bahava eko nāma vicakṣaṇah | aśītidaśa caikaś ca indro nāma mahābalaḥ \| te 'pi vaś cādhipāletu ārogyena śivena ca | dakṣiṇe 'smin diśobhāge așțau devakumārikāh || śriyāmati yaśomatir yaśaprāptā yaśodharāḥ | su-utthitā suprathamā suprabuddhā sukhābalāh ||

1 prayātānāṃ] $p c$.; prayānāṃtā ac. 3 gacchathaḥ] $p c$; gacchatathaḥ $a c . \quad 15$ siddhārthāś] $p c . ;$ sirthāddhāś $a c . \quad 20$ te 'pi] pc.; te 'piścā $a c . \quad 32$ mahābalaḥ] corr.; hābalaḥ ms. 
te 'pi vaś cādhipāletu ārogyena śivena ca |

dakṣiṇe 'smin diśobhāge padmakam nāma cetiyam ||

nityaṃ jvalitatejena divyaṃ sarvapraveśitam |

te 'pi vaś cādhipāletu ārogyena śivena ca ||

kṣamāś ca vo diśạ̣ santu mā ca vaḥ pāpam āgatạ̣ |

labdhārthāś ca nivartadhvaṃ sarvadevebhi rakṣitāḥ || 2 ||

yena kenacit kṛtyena gacchathāṃ paścimāṃ diśam |

nakṣatrāṇi ca pāletu ye tāṃ diśam adhiṣṭhitām ||

anurāọhā ca jyeșṭhā ca mūlā ca dṛ̣hhavīryatā |

dve cāṣāụhaś cābhijic ca śravaṇaś ceti saptamī ||

ity etāḥ saptanakṣatrā lokapālā yaśasvina |

adhișțhāh paścime bhāge te vo rakṣantu sarvatah ||

teșā cādhipatirājā virūpākṣeti tam vidụ̣ |

sarvanāgādhirājendra varuṇaiḥ saha rakṣatu ||

<12r>putrā 'pi tasya bahava eko nāma vicakṣaṇah |

aśītidaśa caikaś ca indro nāma mahābalạ̣ ||

te 'pi vaś cādhipāletu ārogyena śivena ca |

paścime 'smin diśobhāge așțau devakumārikāḥ ||

alambuśā miśrakeśī puṇụarīkā tathāruṇā|

ekādaśī navamikā sitā kṛ̣ṇā ca draupadī ||

te 'pi vaś cādhipāletu ārogyena śivena ca |

paścime 'smin diśobhāge aṣtāñgā nāma parvatah ||

pratiṣthā candrasūryāṇām aṣtam arthaṃ dadātu vaḥ |

sā 'pi vaś cādhipāletu ārogyena śivena ca ||

kṣamāś ca vo diśaḥ santu mā ca vaḥ pāpam āgamaḥ |

labdhārthāś ca nivartadhvaṃ sarvadevebhi rakṣitāḥ || 3 ||

yena kenacit krtyena gacchathām uttarāṃ diśam |

nakṣatrāṇi ca pāletu ye tāṃ diśam adhiṣṭhitām ||

dhanișțhā śatabhiṣā caiva dve ca pūrvottare pare |

revatī cāśvinī caiva bharaṇī bhavati saptamī ||

ity etāḥ saptanakṣatrā lokapālā yaśasvinaḥ |

adhișṭhā uttare digbhāge te vo rakṣantu sarvatạ ||

teșāṃ cādhipatirājā kuvero naravāhana |

sarvayakṣādhipo māṇibhadreṇa saha rakṣatu ||

putrāpi tasya bahava eko nāma vicakșanaḥ |

aśītidaśa caikaś ca indro nāma mahābalạ̣ ||

1 cādhipāletu] $p c . ;$ cādhipātaletu ac. $\mathbf{8}$ adhișthitām] pc.; adhișțhitāh $a c . \quad 23$ așțam arthaṃ] pc.; aștartham $a c . \quad 23$ vaḥ] $p c . ;$ me vaḥ $a c . \quad 32$ digbhāge] corr.; dibhāge ms. 
te 'pi vaś cādhipāletu ārogyena śivena ca | $<12 \mathrm{v}>$ uttare 'smin diśobhāge așțau devakumārikāh || ilā devī surā devī pṛthvī padmāvatī tathā | upasthitā mahābalā āśā śraddhā hiri śirī || te 'pi vaś cādhipāletu ārogyena śivena ca | uttare 'smin diśobhāge parvato gandhamādana || āvāso yakṣabhūtānām citrakūṭaḥ sudarśanaḥ| te 'pi vaś cādhipāletu ārogyena śivena ca || kṣamāś ca vo diśah santu mā ca vaḥ pāpam āgamạ̣ | labdhārthāś ca nivartadhvam sarvadevebhi rakṣitā || 4 || așțāviṃśatinakṣatrāḥ saptasaptaś caturdiśam | dvātriṃśad devakanyāś ca așțāv așțau caturdiśam || așțau śramaṇā ca brāhmaṇā janapadeșu naigamāḥ | așțau saindrakā devatās te vo rakṣantu sarvatah || svasti vo gacchatām bhontu svasti bhontu nivartatām | svasti paśyan tathājñātā svasti paśyatu jñātayaḥ || sendrā yakṣā mahārājā arhantam anukampitāḥ | sarvatra svasti gacchadhvam prāpsyadhvam amṛtạ̣ śivam || saṃrakșitā brāhmaṇā vā vāsavais saha rakṣatu \| vimuktacittaiś ca anāśravaiś ca nāgaiś ca yakṣaiś ca sadānukampitāḥ | pāletha āyuḥ śaradāśatam ca samapradakṣiṇām dakṣiṇalokanātha || teșām diśaikapratimāṃ vināyakaḥ sahạ̣ pradaśaiṣa vināyakasya | a<13r>nena yūyaṃ kuśalena karmaṇā madhusambhavā nāma jinā bhavișyatha || prathamād idam lokavināyakasya samagrato vyākaraṇaṃ jinasya | paścād anantād bahubodhisattvā ye vyākṛtā bodhani no nivartyāḥ || śrutvā imaṃ vyākaraṇaṃ jinasya udagracittā paramārthaprītyā | tau bhrātarau sārthasahāyakais taih buddhaṃ ca dharmạ̣ ca śaraṇaṃ prapannāh || ||

iti śrī-lalitavistare trapuśabhallikaparivartane datta-kalyāṇavākyaṃ samāptam || 8 ||

[16] oṃ namaḥ sarvabuddhabodhisattvebhyaḥ || oṃ śrutismṛtigativijaye svāhā || evaṃ mayā śrutam ekasmin samaye bhagavān gṛdhrakūṭaparvate tathāgatavihāre dharmadhātau 'tigambhīre buddhagocare bodhisattvasamuccaye viharati sma | anekadevanāgayakṣarākṣasagandhar-

12 ca] $p c . ;$ ca tu $a c . \quad 17$ sendrāyakṣā] pc.; sendrāyahākṣā ac. 29 -vākyaṃ] corr.; -vyākyaṃ ms. 
vāsuragaruḍakiṃnaramahoragamanuṣyāmanuṣyaih sārdham || tatra bhagavān suvarṇaprabhāsottamasūtrendrarājasya bodhisattvānāṃ nāmāni bhāṣate sma || namo bhagavate ratnaśikhi nāma tathāgatasya | namạ̣ suvarṇaratnākaracchatrakūṭas tathāgatasya | namạ̣ suvarṇapuṣpojjvalaraśmiketos tathāgatasya | namaḥ mahāpradīpasya tathāgatasya | ruciraketur nāma bodhisattvah | suvarṇaprabhā<13v>sottamo nāma bodhisattvaḥ | suvarṇagandho nāma bodhisattvah | sadāprarudito nāma bodhisattvaḥ | dharmodgato nāma bodhisattvaḥ | purastimenākșobhyo nāma tathāgataḥ | dakṣiṇena ratnaketur nāma tathāgatạ̣ | paścimenāmitāyur nāma tathāgataḥ | uttareṇa dundubhisvaro nāma tathāgataḥ || suvarṇaprabhāsottamasūtrendrarājasyemāni bodhisattvānāṃ nāmāni ye dhārayanti vācayanti te bodhisattvā nityaṃ jātismarā bhonti ||

iti suvarṇaprabhāsottamasūtrendrarāje sarvabuddhabodhisattvānāṃ-nāmadhāraṇi samāptaḥ || 9 ||

iti dharmamaṇḍalasya dhāraṇīsaṃgrahaḥ saṃkșiptaḥ samāptaḥ || ||

[17] oṃ namaḥ saṃghāya \| buddhaṃ namāmi satataṃ varapadmapāṇim maitryātmakaṃ gaganagañjasamantabhadram | yakṣādhipaṃ parahitodyatamañjughoṣaṃ viṣkambhinaṃ kṣitikhagarbhatanum namāmi bhaktyā \| oṃ namaḥ śrī-āryāvalokiteśvarāya bodhisattvāya mahāsattvāya mahākārunikāya \| tadyathā || oṃ cala 2 cili 2 culu 2 kuru 2 mulu 2 hūṃ hūṃ phaṭ phaṭ svāhā || dine dine pañcavārāṃs trisaṃdhyam uccārayet | gardabho 'pi granthaśatatrayaṃ g̣̣hṇāti ||

iti padmahasta-dhāraṇī samāptaḥ || 1 ||

[18] oṃ namo mai<14r>treyāya bodhisattvāya mahāsattvāya || tadyathā || oṃ maitreyaspharaṇāya maitrībalam vivardhaya 2 hūṃ phaṭ svāhā || iti maitreya-dhāraṇī samāptaḥ || 2 ||

3 tathāgatasya] corr.; stathāgatasya ms. 15 -saṃgrahaḥ] pc.; -saṃhagraḥ $a c$. 
[19] oṃ namo gaganagañjāya bodhisattvāya mahāsattvāya || tadyathā || oṃ gagane gaganavaralocane cintāmaṇibhadraghațādikaṃ pravarṣaya 2 hūṃ phaț svāhā ||

iti gaganagañja-dhāraṇī samāptaḥ || 3 ||

[20] oṃ namaḥ samantabhadrāya bodhisattvāya mahāsattvāya || tadyathā || oṃ samantabhadre sarvottamamahāprāgbhārakalyāṇaṃ samprāpaya 2 hūṃ phaṭ svāhā ||

iti samantabhadra-dhāraṇī samāptaḥ || 4 ||

[21] oṃ namo vajrapāṇaye mahāyakṣasenāpataye bodhisattvāya mahāsattvāya || tadyathā || oṃ vajrapāṇe vajreṇa sarvadușțasattvamārān nipātaya 2 hūṃ phaṭ 10 svāhā ||

iti vajrapāṇi-dhāraṇī samāptam || 5 ||

[22] oṃ namo mañjuśriyāya bodhisattvāya mahāsattvāya || tadyathā || oṃ mañjughoṣe mañjubalaṃ pravardhaya 2 muḥ hūṃ phaṭ svāhā || iti mañjughoṣa-dhāraṇī samāptaḥ || 6 ||

[23] oṃ namaḥ sarvanivaraṇaviṣkambhine bodhisattvāya mahāsattvāya || tadyathā || oṃ sarvanivaraṇaviṣkambhine sarvapāpāvaraṇaṃ viśodhaya 2 hūṃ phat svāhā ||

iti sarvanivaraṇaviṣkambhinī-dhāraṇī samāptaḥ || 7 ||

[24] <14v> oṃ namaḥ kṣitigarbhāya bodhisattvāya mahāsattvāya | tadyathā || oṃ kṣitigarbhe kalpadrumavaradhare sarvāśāṃ paripūraya 2 hūṃ phaṭ svāhā ||

iti kṣitigarbha-dhāraṇī samāptaḥ || 8 ||

19 -vișkambhinī] corr.; -vișka ms. 
[25] oṃ namo khagarbhāya bodhisattvāya mahāsattvāya \| tadyathā || oṃ khagarbhe khe ratnavarṣaṃ pramuñcaya 2 hūṃ phaț svāhā ||

iti khagarbha-dhāraṇī samāptaḥ || 9 ||

iti saṃghamaṇḍalasya saṃkșiptaḥ dhāraṇīsaṃgrahaḥ samāptaḥ || ||

oṃ namaḥ saptabuddhāya tathāgatāyārhate samyaksambuddhāya \|

ādau vipaśyinaṃ vande tadanu śikhijinaṃ viśvabhuvaṃ munīndraṃ

krakucchandaṃ tathā ca kanakamunivibhuṃ kāśyapaḥ śrī-jinendram |

teșāṃ śrī-s̄ākyasiṃhaṃ paramaguṇanidhiṃ buddhanātham praśastam khyātạ̣

śrī-saptabuddhaṃ kalikaluṣaharaṃ bodhilābhāya bhaktyā ||

[26] oṃ namo vipaśyinaye tathāgatāyārhate samyaksambuddhāya || tadyathā || araḍe karaḍe made madavardhane avare śavare | bhure 2 hure 2 śavare parṇaśavare | huci 2 kuci 2 muci 2 svāhā ||

iti vipaśyi-dhāraṇī samāptaḥ $\|1\|$

[27] oṃ namaḥ śikhinaye tathāgatāyārhate samyaksambuddhāya || tadyathā || ițte mitțe khure vikhure | hili 2 mili 2 ketumūle ambare ambarāvati dumbe adumbe | hili $3<15$ r > kuci 3 muci 3 svāhā ||

iti śikhi-dhāraṇī samāptaḥ || 2 ||

[28] oṃ namo viśvabhuvāya tathāgatayārhate samyaksambuddhāya || tadyathā || mori 2 vyavarti maṇditike | hare 2 ghare 2 khare 2 phale 2 phalini dantini dantile śan̉kați makați nakanaț̣ini | śiri śiri śiri śiri śiri śiri 6 svāhā ||

iti viśvabhuvo-dhāraṇī samāptaḥ || 3 ||

[29] oṃ namaḥ krakucchandāya tathāgatayārhate samyaksambuddhāya || tadyathā || hị̣i miḍi kuḍi muḍi tuḍi āde dante dantili sakare cakare thagari kāñcane kāñcanāvati vare dhare dhare dante siddhi svāhā || 
[30] oṃ namaḥ kanakamunaye tathāgatāyārhate samyaksambuddhāya || tadyathā || tattale tatale talatotale vire virajaye vijjudhare araje viraje virajāmasi matimāli nimuṇde śirimuṇde | kale jvale jvale jvale jvale 4 bhadravati siddhi svāhā ||

iti kanakamuni-dhāraṇī samāptạ̣ || 5 ||

[31] oṃ namaḥ kāśyapāya tathāgatāyārhate samyaksambuddhāya || tadyathā || ạ̣ḍare kạ̣ḍare maṇḍare khạ̣̣̣are jambu jambunadi jambuvati matte maṇditike | amare siddhi | paśu paśu paśu <15v> paśupatisiddhi svāhā ||

iti kāśyapa-dhāraṇī samāptaḥ || 6 ||

[32] oṃ namaḥ śākyamunaye tathāgatāyārhate samyaksambuddhāya || tadyathā || hili mili kili mili ilile katale ketubale | aḍamali ḍaphe ḍạ̣aphe | sarake busaț̣e | narakande kāmini kambudaraki rurutare taraṇi prakṛtirașțe militale itihāse | avale tuvale | valinge vațịi vațịike ațantumve vaț̣itumve | varșatu devaḥ samantena daśasu dikșu namo bhagavatạ̣ kumudodakaṃ bhavantu namo bhagavate ilijaye godohikāye bhṛngārikāye aruci maruci | națte 2 vajre vajranaț̣e | udayanapriye ale tāle kuntāle kulatāle | nārāyaṇi pārāyaṇi paśyani sparśani siddhyantu mama drāmiḍā mantrapadāḥ svāhā ||

iti śākyamuni-dhāraṇī samāptạ̣ || 7 ||

iti saṃkṣiptaḥ saptabuddhaḥ dhāraṇīsaṃgrahạ̣ samāptaḥ || ||

oṃ namo ratnatrayāya || namạ̣ saptānāṃ samyaksambuddhakoṭinām ||

tadyathā || om cale cule cunde mahāvidye satyavādini varade kathaya 2 svāhā ||

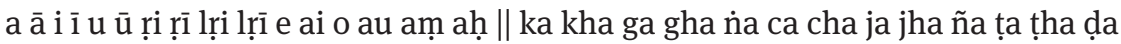
dha ṇa ta tha da dha na pa pha ba bha ma ya ra la va śa șa <16r> sa hạ \|

[33] namaḥ sarvatathāgatānām | oṃ mahācintāmaṇijvalanasāgaragambhīre ākarṣaya 2 āyumdhare 2 saṃdhara 2 kaṇa 2 kiṇi 2 kuṇu 2 sarvatathāgatasamaye tiṣtha 2 mahābhuvanasāgare saṃśodhaya 2 māṃ sarvasattvānāṃ ca bhagavati sarvapāpavimale | jaya 2 jayalabdhe sphațaya 2 vigatāvaraṇabhayaharaṇe hūm 3 mṛtyudạ̣ḍadhare abhayaprade uṣnīṣavyavalokite | samantamukhe samantāvalokite |

2 talatotale] $p c$.; talalatotale $a c . \quad 12$ sarake] $p c$.; sakera $a c . \quad 25$ tathāgata] $p c$; tathāsagata $a c$. 
mahāmāyāmahāmāyonadhare | amoghavimale | ākarṣaya 2 ākațtaya 2 bhara 2 sambhara 2 bhūṣitabhuje | mahāmudrāvilokite | jaya 2 siddhe 2 bodhani 2 sambodhani 2 śodhani 2 saṃ́odhani 2 viśodhani 2 hara 2 mama sarvapāpam | sarvatathāgatakulabhuje | samayaniște prasarantu mama puṇyạ̣ vinaśyatu pāpam | sarvakilbiṣahare maṇiviśuddhe śodhaya vimale vikasitapadme kavacitabhuje | șațpāramitāparipūraṇi | sarvatathāgatoṣnịṣavilokite svāhā || sarvatathāgataguhyādhișțhānādhișthite svāhā || āyurdade svāhā || puṇyaṃdade svāhā || puṇyavilokite svāhā || puṇyāvaropite svāhā || mṛtyudaṇde svāhā || yamadaṇḍe svāhā || yamadūte svāhā || saṃhara<16v>ṇi svāhā || sambharaṇi svāhā || saṃdhāraṇi svāhā || pratisaṃrakṣaṇi svāhā || ojovati svāhā || tejovati svāhā || jayavati svāhā || sarvatathāgatamudrādhișthānādhișṭhite svāhā || oṃ namas traiyadhve sarvatathāgatahṛdayagarbhe | jvala 2 dharmadhātugarbhe | sambhara mamāyuh sambhara śodhaya mama sarvapāpaṃ sarvatathāgatasamantoṣṇișavimalaviśuddhe hūṃ hūṃ hūṃ aṃ vam saṃ jaḥ svāhā || ||

iti cintāmaṇi-nāma-dhāraṇī samāptạ̣ || 1 ||

[34] oṃ namo ratnatrayāya || tadyathā || oṃ namo buddhāya mahākāruṇikabharitahṛdayāya paramātmasamatāgatacittāya traidhātukaikamūrtaye sarvasattvārthaduṣkarakāriṇe sarvasattvāṃś cānuttarāyāṃ samyaksambodhau pratișṭhāpanāya || oṃ āḥ sugatavajratuṣya hoḥ svāhā || ||

iti śrī-buddhabhațțārakasya-nāma-dhāraṇī samāptaḥ || 2 ||

[35] oṃ namo bhagavate ārya-paramagurave mahākāruṇikāya tathāgatāyārhate samyaksambuddhāya \| tadyathā || om mune 2 mahāmunaye svāhā || om vasudhe svāhā || bhūparigraha || oṃ vajrodbhavāya svāhā || bimbavalana || oṃ araje viraje svāhā || tailamrakṣaṇa || oṃ vajragarbhe svāhā || garbhāropaṇa || oṃ vajrakarti cche<17r>daya svāhā || garbhākoțana || oṃ dharmadhātugarbhe svāhā || yașțyāropana || oṃ vajrakoțākoṭe svāhā || bimbākoṭana || oṃ dharmarate svāhā || bimbākarṣaṇa || oṃ supratișṭhitavajre svāhā || āsanādhișṭhāna || om sarvatathāgatamaṇiśatadīpte 2 jvala 2 dharmadhātugarbhe svāhā || pratișṭā || oṃ namạ̣ śākyamunaye tathāgatāyārhate samyaksambuddhāya || tadyathā ||

1 -māyonadhare] $p c$.; -māyonaradhare $a c . \quad 5$ śodhaya] $p c$.; śodhaya $2 a c . \quad 16$ cintāmaṇi] $p c$.; cimantāni $a c .22$ iti] pc.; iti va $a c .26$ bimbavalana] corr.; bimbavartaraṇa ms. 
oṃ mune 2 mahāmunaye svāhā || oṃ mantratathāgatagarbhāya svāhā || oṃ vajradhātugarbhāya svāhā || ||

iti śākyamunīnāṃ viśeșamantra-dhāraṇī samāptah || 3 ||

[36] oṃ namaḥ śrī-śākyamunaye tathāgatāyārhate samyaksambuddhāya || tadyathā || oṃ bhagavati mudrite siddhe sisiddhe śānte dānte mokṣaṇi mukte vimukte mocani amale vimale nirmale dụ̣hacchedani catuhṣașțibuddhakoṭisahasrabhāsite hiraṇye hiraṇyagarbhe || sarvārthasādhani | sarvatrāpratihate svāhā || ya imāṃ dhāraṇịm dhārayel likhel likhāpayed vācayet | yāvad yoniśo manasi bhāvayet sa catuhșaștikalpakoṭisahasrāṇi jātismaro bhaviṣyati | durgatim nābhigacchati | janmani janmani rājā cakravartī bhaviṣyati || asyā dhāraṇyāḥ prabhāvena dine dine jāpāt sumerumātraṃ pāparāśim parikṣa<17v>yaṃ gacchati || || punar api jātismaro-nāma-dhāraṇīm bhāṣate || oṃ namo bhagavate śākyamunaye tathāgatāyārhate samyaksambuddhāya || tadyathā || om śuddhe susiddhe mocani mokṣani mukte vimukte amale vimale aṇdare paṇḍare māngalye hiraṇye hiraṇyagarbhe sarvatrāpratihate svāhā || ya imāṃ dhāraṇị̣̄ dhārayet | yāvad yoniśo manasi cintayet sa caturaśītikalpakoțīsahasrāṇi jātismaro bhaviṣyati | navanavatikalpakoṭīsahasrāṇi rājā cakravartī bhaviṣyati | caturdvīpeśvaraḥ | sarvavyādhinirmuktarūpavāṃś ca bhaviṣyati || ||

iti jātismaro-nāma-dhāraṇī samāptaḥ || 4 ||

[37] oṃ namo bhagavate sarvahutāśanītejorājāya tathāgatāyārhate samyaksambuddhāya \| tadyathā || oṃ hute 2 mahāhute sarvahutāśanateje svāhā || bhojanam bhuktvā yadā imāṃ dhāraṇịm saptadhā-m-āvartya tadā saptabuddhakoțịh sampūjitā bhavanti || ||

iti hutāśanatejorāja-nāma-dhāraṇi samāptạ̣ || 5 ||

6 duḥkhacchedani] corr.; duḥcchedani ms. 9 ya imāṃ] pc.; iyamāṃ ac. • dhāraṇị̣̄] corr.; dhānī ms. 
[38] oṃ namo bhagavate bhaiṣajyavaiḍūryaprabharājāya tathāgatāyārhate samyaksambuddhāya || tadyathā || oṃ bhaișajye 2 mahābhaiṣajye subhaișajye svāhā || ||

iti bhaișajyarā<18r>ja-nāma-dhāraṇī samāptaḥ || 6 ||

[39] oṃ namo bhagavate sarvamañgalatithimukuṭanakṣatrarājāya tathāgatārhate samyaksambuddhāya || tadyathā || oṃ nakșatre 2 sarvamañgalatithimuhūrtanakṣatre sarvārthasādhukāranīi bhavantu svāhā || ||

iti sarvamaṅgala-nāma-dhāraṇi samāptaḥ || 7 ||

[40] oṃ namo bhagavate jihvottararājāya tathāgatāyārhate samyaksambuddhāya \| tadyathā || oṃ vara 2 dhara 2 dhāraṇi 2 sarvaratnāvalokite sarvaratnadhāriṇe sarvaratnapratimaṇụitaśarīre svāhā || ||

iti karṇajāpa-nāma-dhāraṇī samāptaḥ || || 8 ||

[41] oṃ namo bhagavate sarvapāpadahanavajrāya tathāgatāyārhate samyaksambuddhāya \| tadyathā || oṃ vajre 2 mahāvajrinịiye svāhā || ||

iti sarvapāpadahanī-nāma-dhāraṇī samāptaḥ || 9 ||

[42] oṃ namaḥ śrī-guhyendrasamādhivajrāya || asya vajrino guhyanāmāny aștai bhavanti || sucitra suveśa icchāsampatkarī maulī sarvārthasādhakaḥ sarvatathāgatahṛdaya mahāvīrā mahāsamādhivajraś ceti || imāni guhyanāmāni mahāmantrādhipatiḥ prātar utthāya śucaukșasamācāro 'nuvartayan smaret || na tasya sarvamārāḥ sarvavighnāḥ sarvavajravinā<18v>śakāḥ | sarvabhūtayakṣarākṣasapiśācakațapūtanabhūtagrahostārakāḥ| sarvadușțasattvā raudraparaprāṇaharā antarāyaṃ kartum | mantrasiddhiṃ vā kācin nivārayitum || evam ayaṃ mahāvidyārājasamādhivajraṃ guhyottaraṃ paramatantrayantramantrasamprameyaphalaṃ bhavati || ||

iti guhyendrasamādhivajra-nāma-dhāraṇī samāptaḥ || 10 ||

7 -nakșatre] corr.; -nakșatrarāja ac., -nakșatra pc. 11 -buddhāya] pc.; -buddhāyata ac. 21 -samādhi-] corr.; -samādi- ms. 26 -samādhi-] corr.; -samādi- ms. 28 -samādhi-] corr.; -samādi- ms. 


\section{[43] oṃ namo buddhāya ||}

na divi bhuvi vā nāsmilloke na vaiśravaṇālaye na marubhuvane na divyasthāne na dikṣu vidikṣu vā |

caratu vasudhā sphītāṃ kṛtsnāṃ saparvatakānanāṃ puruṣavṛṣabhas tv atulyo 'nyāṃ mahāśramaṇaḥ kutạ̣ || ekagāthā || ||

sarvabuddhān namasyāmi jinān apratipungalān |

śarīrāṇi ca sarveșāṃ sambuddhānāṃ yaśasvinām ||

jāyante yatra sambuddhā bodhiṃ yatra spṛ́santi ca |

pravartanti śivacakram parinirvānty anāsravāh ||

yatra sthitāś can̉kramitā niṣaṇṇās ca tathāgatāḥ |

kalpitāḥ siṃhaśayyāś ca tān deśān praṇamāmy aham ||

ūrdhvaṃ tīryag adhas tāsu diśāsu vidiśāsu ca |

saśarīrāśarīreșu stūpeșu praṇamāmy aham ||

pūrvottare diśobhāge tișthhanti dvipadottamaḥ |

jino duṣprasaho nāma tenemāṃ gātha bhāṣitā ||

ābhiś catasṛbhir gāthāyai stuvanti ta<19r>thāgatān |

kalpakoțīsahasrebhir na te gacchanti durgatim || caturgāthā || ||

buddhe dharme 'vajñākausīdyaṃ tuṣțir alpamātreṇa |

rāgamāne caritakaukṛtyaṃ cānīyata bhedạ̣ |

sattvānām āvaraṇaṃ tatpratikṣo 'grayānasambhāṣā |

sarvāntarāyadoṣaprahāṇam eșām trayā bhavati ||

tadyathā || oṃ vajraprākāravajraprākāre vajradaṃșțrabhayānake | amale vimale nirmale cale cule culuke culuke curu 2 buddhe svāhā \|

yo granthato 'rthato vā gāthādvayadhāraṇīm prayuñjīt || sa hi daśavidham

anuśamśām lạhate | sattvottamān dhīmān kṛtsnāṃ ca dhātupuṣtị̣

prāmodyañ cottamam | maraṇakāle janmaṃ ca yathābhikāmaṃ jātismaraṇatāṃ

ca | sarvatra buddhaiś ca samavadhānaṃ tebhyạ̣ śravaṇaṃ tathāśrayān

asyādhimuktiṃ sahabuddhyādvayamukhatām āśu bodhiṃ ca |

kṣayaṃ hi gacchati mahānidhānaṃ rājāgnicaurodakavipralabdhāḥ |

śrutạ̣ nidhāna hi tathāgatānām vipranāśam bahukalpakotībhị̣ ||

sadā pramodo hy amṛtasya mūlaṃ sattvārthayuktasya ca bodhicittam |

yad yoniśaś caiva vivekacittam parigrahạ sarvasukhasya mūlam || ||

iti gāthādvaya-nāma-dhāraṇī samāptaḥ || 11 ||

7 sambuddhānāṃ] pc. sarvabuddhānāṃ ac. 13 -śarīreșu] pc.; -śarerīṣu ac. 15 duṣprasaho] corr.; duṣpraprabho ms. 20 -sambhāṣā] pc.; -samșābhā ac. 23 culuke] pc.; culuke buddhe ac. 24 granthato] corr.; gratthato ms. 29 -caurodaka-] pc.; -caurodayāka- ac. 
[44] oṃ namo buddhāya || evaṃ mayā śrutam ekasmin samaye bha<19v>gavān śuddhāvāsopari gaganatalapratișțhite saptaratnapravibhaktavicitraratnavyūhe mahāmaṇḍalamāḍe viharati sma || asạ̣khyeyena bodhisattvagaṇena sārdham || tatra khalu bhagavān bodhisattvān āmantrayate sma || udgṛhṇīdhvaṃ yūyạ̣ kulaputrā imāṃ șaṇmukhī-nāma-dhāraṇịm sarvajagaddhitāya || tadyathā || saṃsāre saṃsarato yo me kaścid duḥkhānubhavaḥ san mā bhūt sarvasamatā 'pratisamvidalakṣaṇah | yaś ca me kaścil laukikasampattisukhānubhavah sa bhavatu sarvasattvasādhāraṇaparibhogaḥ | yac ca me kiṃcit pāpakarmākuśalaṃ karmāvaraṇaṃ tan mā bhūd apratideśanayānuttarayā pratideśanayā | yāni ca me mārakarmāṇi tāni mā bhūvann aparijñātāny anuttarayā parijñayā | yac ca me kiṃcit pāramitopasaṃhitaṃ kuśalamūlaṃ laukikalokottaraṃ vā tad bhavatu sarvasattvānām anuttarajñānam | yā ca me vimuktiḥ sā bhavatu sarvasattvavimokṣāya | yā ca me bhūt saṃsāre nirvāṇe pratișțhitatā || tadyathā || oṃ kṣame kṣame | kṣānte kṣānte | dame dame | dānte dānte | bhadre bhadre | subhadre subhadre | candre candre | sucandre sucandre | candrakirane | candravati | tejovati | dhanavati | dharmavati | brahmava<20r>ti | sarvakleśaviśodhani | sarvārthasādhani | sarvānarthapraśamani | paramārthasādhani | kāyaviśodhani || vāgviśodhani | manaḥsaṃśodhani svāhā ||

yaḥ kaścit kulaputro vā kuladuhitā vā imāṃ șaṇmukhī-nāma-dhāraṇị̣̄ triṣkṛtvā rātrau divasasya triṣkṛtvā cānuvartayiṣyati sa sarvakarmāṇi kṣepayitvā kṣipram anuttarām samyaksambodhim abhisambhotsyate || idam avocad bhagavān āttamanās te ca bodhisattvā mahāsattvā bhagavato bhāṣitam abhyanandann iti ||

ārya-ṣaṇmukhī-nāma-dhāranīi samāptaḥ || 12 ||

[45] oṃ namaḥ sarvadurgapatipariśodhanarājāya tathāgatāyārhate samyaksambuddhāya || evaṃ mayā śrutam ekasmin samaye bhagavān sarvadevottamanandavane viharati sma | nānāvividhaih puṣpair upaśobhite nānākalpaṿ̛kșasamalaṃkṛte nānāratnālaṃkāravibhūṣite nānāpakșigaṇasaṃkūjite nānāvādyābhipraṇādite | nānāvidhābhiś ca śakrabrahmādidevāpsarābhir vikrị̄ite | nānāvidhābhir mahābodhisattvakoținiyutaśatasahasraiḥ sārdham || tatra bhagavān mahābrahmāsane niṣaṇnahạ || niṣadya sarvadurgatipariśodhanaṃ nāma samādhị̣ samāpannaḥ samanantaram e<20v>vāpāyatrayasaṃtativimokṣakaṃ

8 bhavatu] $p c$.; vabhatu ac. 9 aprati-] pc.; apratima- ac. 10 -deśanayā] pc.; -deśayāna ac. 13 yā ca] $p c$.; yā $a c . \quad 21$ șaṇmukhī]- corr.; șaṇmu- ms. 21 triṣkṛtvā] pc.; șkṛtritvā ac. 29 -alaṃkṛte] $p c$; -alaṃkrtya $a c .32$ tatra] $p c$.; tatra kha $a c$. 
nāma mahābodhisattvaraśmispharaṇaikamālorṇākosān niścacāra | tena raśminā trisāhasramahāsāhasralokadhātur avabhāsitạ̣ | avabhāsyamātreṇa sarvasattvānāṃ cittakleśabandhanāt parimocitạ̣ | pṛthak pṛthak samprāpakānām antaraṃ tasmin nandanavanaṃ ca samantād avabhāsayitvā || tena ca raśminā bhagavantaṃ nānāpūjāmeghaị̣ pūjayitvā śatasahasraṃ pradakṣiṇīkṛtya śirasā vanditvā bhagavataḥ purastād vimalāsaner upaniṣadyaivam āhụ̣ \| aho buddha aho buddha buddhasya dharmaśodhanam \| asmākaṃ durgatipariśodhana bauddhasya caryāpratișțhāpanaṃ ceti || atha śakro devānām indro bhagavantam śatasahasraṃ pradakṣiṇīḳ̣tya vanditvā bhagavantam etad avocat || bhagavan kena kāraṇena buddharaśmi samantād avabhāsitạ̣ | avabhāsamātreṇa durgatisamantān mocayitvā vimuktimārge pratișțhāpitā || āścarya sugata || bhagavān āha || nedaṃ devendrāścarya buddhānāṃ bhagavatām sūpacitāpramāṇapuṇyasambhārāḥ | aparimitaguṇaratnākarabhūtāḥ | apramāṇopāyapariniṣpannāḥ | apramāṇavineyajanā bhājanībhūtāḥ | asamarddhisamanvāgatāḥ | asamapraṇidhānasamanvāgatāḥ | tasmād devendra <21r> buddhā bhagavanto yathābhājanībhūtāḥ | tathā sattvārthakaraṇaṃ ca bhūtāḥ | yathābhiprāyasattvārthakaraṇaṃ bhavatīti jñātavyaḥ | ity atra saṃ́ayaśańkāvimatir na kartavyāḥ || tathāgatavinayena bhavantīti || atha devendraḥ svakāyạ̣ darśitād utthāya bhagavato vipulām mahatīṃ pūjām kṛtvā vanditvā bhagavantam etad avocat || sarvasattvānāṃ hitakaraṇāya sarvāśāparipūraṇāya bhagavan mama pratibhānam utpādaya sugata mama pratibhānam utpādaya || bhagavan itas trāyatrimśaddevanikāyād vimalamatiprabhānāmno devaputrasya kālagatataptadivasā abhūvan | bhagavan sa kutrotpannāt sukhaduḥhaṃ vānubhaviṣyati | idaṃ bhagavan vyākuru sugato vyākuru || bhagavān āha || devendra prāptakālagatasamayaṃ jñātvā śroṣyasi || devendra āha || bhagavann ayaṃ kālasamaya sugata || bhagavān āha || devendra maṇivimalaprabho nāma devaputra itaś cyutvāvīcau mahānarake utpanno dvādaśavarṣasahasrāṇi tīvraṃ kaṭukāni duḥkhāny anubhaviṣyati | evaṃ punar apy anyonyanarakān narakeșu duhkhaṃ parasparānubhaviṣyati || atha khalu śakrādayaḥ sarve devaputrāḥ śrutvā bhrāntā trastāḥ khinnādhomukhaṃ pati<21v>tāḥ punar utthāyaivam āhuh || kathaṃ bhagavan tasmād dụ̣khạ̣ parasparāto mucyate kenopāyeṇa bhagavan duḥkharāśer etasmān mucyate | paritrāṇaṃ kuru bhagavan paritrāṇam kuru sugata || tatra bhagavāñ chakrabrahmādidevaputrāṇāṃ sarvatathāgatahṛdayena

11 bhagavantam śatasahasraṃ pradakșiṇikṛtya vanditvā bhagavantam] $p c$.; bhagavantaṃm ac. 14 sūpacitā-] corr.; sūpatā- ms. 15 -ratnākara-] corr.; -ratnāka- ms. 22 etad avocat] $p c$; edatavocat $a c$. 
sarvagatyadhiṣthānārtham amoghavajrādhișțhānaṃ samādhim samāpannạ̣ || oṃ vajrādhișṭhānasamaye hūṃ || evaṃ ca samādhisamāpanno 'nabhibhavatīyam vajrādhișthānādhisamayedaṃ sarvadurgatipariśodhanarājạ̣ nāma dhāraṇịm sarvatathāgatahṛdayaṃ niścārayet || oṃ śodhani 2 sarvapāpaviśodhani śuddhe viśuddhe sarvakarmāvaraṇaviśuddhe svāhā || asyā vidyāyā bhāṣaṇāntaram evaṃ sarvasattvānāṃ durgatim vinipātitam | sarvanarakapretatiryaggatim śodhitā | tīvraduḥhāni śāntāni bahavaś ca jātāḥ śucimukhībhutāḥ || punar aparaṃ guhyahṛdayam abhāṣata || oṃ śodhani śodhaya sarvapāpam sarvasattvebhyo hūm || punar aparaṃ devendra idam sarvatathāgatahṛdayam || oṃ sarvāpāyaviśodhani hūṃ phaṭ || punar aparaṃ devendra idaṃ sarvatathāgatahṛdayopahṛdayam || oṃ traṭ || punar aparaṃ devendra sarvadurgatipariśodhanahṛdayam || hūṃ || punar aparam devendra saṃ<22r>kṣepataḥ smaraṇamātreṇāpy apuṇyānāṃ sattvānāṃ sarvadurgatiśāntir anāyāsato vimokṣaṇakaraṇam idạ̣ bhavati || oṃ namo bhagavate sarvadurgatipariśodhanarājāya tathāgatāyārhate samyaksambuddhāya || tadyathā || oṃ śodhane 2 viśodhane 2 sarvapāpaviśodhani śuddhe viśuddhe sarvāvaraṇaviśodhani svāhā || mūlavidyā || oṃ sarvavit sarvāvaraṇāni viśodhaya hana hūṃ phaṭ | oṃ sarvavit hūṃ | oṃ sarvavit hrīm phaṭ | oṃ sarvavit āḥ | oṃ sarvavit trāṃ trạ̣ | oṃ sarvavit om | oṃ sarvavit dhīh | oṃ sarvavit hūṃ || oṃ sarvavit krī traṭ || oṃ sarvavin mahāvajrodbhavadānapāramitāpūjye hūṃ || lāsyā || oṃ sarvavin mahāvajrodbhavaśīlapāramitāpūjye trām || mālā || oṃ sarvavin mahāvajrodbhavakșāntipāramitāpūjye hrīḥ || gītā || oṃ sarvavin mahāvajrodbhavavīryapāramitāpūjye āḥ || nṛtyā || oṃ sarvavit sarvāpāyaviśodhani dhama 2 dhyānapāramitāpūjye hūm hūm phat || dhūpā || om sarvavit sarvadurgatiśodhani kleśopakleśacchedani puṣpavilokini prajñāpāramitāpūjye trāṃ hūṃ phat || puṣpā || oṃ sarvavit sarvāpāyaviśodhani jñānāvalokini praṇidhipāramitāpūjye hrīḥ hūṃ phaṭ || dīpā || oṃ sarvavit sarvāpā<22v>yagandhanāśani vajragandhopāyapāramitāpūjye aḥ hūṃ phaṭ || gandhā || oṃ sarvavit narakagatyākarṣaṇi hūṃ jaḥ phaṭ || vajrāṅkuśa || oṃ sarvavit naraka-uddharaṇi hūṃ hūṃ phat || vajrapāśa || oṃ sarvavit sarvāpāyabandhanamocani hūṃ vaṃ phaṭ || vajrasphoța || oṃ sarvavit sarvāpāyagatigahanaviśodhani hūṃ hoḥ phaṭ || vajrāveśa || oṃ maitrīspharaṇāya svāhā || oṃ amoghe amoghadarśine hūṃ || oṃ sarvāpāyaṃjaha sarvāpāyaviśodhani hūṃ || oṃ sarvaśokatamonirghātanamati hūṃ || oṃ gandhahastine hūṃ || oṃ śūraṃgame hūṃ | oṃ gagane gaganalocane hūṃ || oṃ jñānaketo jñānavati hūṃ || oṃ amṛtaprabhe amṛtavati hūṃ || om candraprabhe candravyavalokini svāhā || oṃ bhadravati bhadrapāle svāhā || oṃ jvālini mahājvālini hūṃ || oṃ vajragarbhe hūṃ || oṃ akṣaye hūṃ hūṃ 
akṣayakarmāvaraṇaviśodhani svāhā || oṃ pratibhānavati pratibhānakūṭe hūṃ || oṃ samantabhadre svāhā ||

ete bhadrakalpikasya bodhisattvasya mantraṃ yathākramam uccārayet || anena yathoktantrānusārānukrameṇa vidhānena pratyahạ̣ prabhātakāle sotpattikrameṇa bhāvayamāno bhāvayed devatāyogasamādhitrayam uttamaṃ yatnatah sarvadurgatipariśodhana<23r>siddhir bhavati || punar aparam devendra sarvadurgatipariśodhanatejorājasya tathāgatasya guhyahṛdayam idam kulaputro vā kuladuhitā vā yaḥ kaścin nāmamātraṃ śṛ̣oti dhārayati vācayati vā | likhitvā ca śirasi śikhāyāṃ bāhau grīiāyāṃ vā baddhvā dhārayati | tasya ihaiva janmany anekāni akālamaraṇāni maraṇasambandhasvapnaprakārāṇi vā durgatinimittāni vā tāni sarvāṇi svapnamātrato nopasarpanti || maṇụalaṃ ca yathāvat praveśyābhiṣiktā hṛdayaṃ japtvā mantraṃ ye kecid bhāvayati | kaḥ punar vādas teșām yāni kānicit pāpāni na nikațā bhavanti | na durgatim gacchanti || puruṣastrīdevanāgayakșarākṣasapretapiśācatiryagnarakādīni yeșām keșāṃcin mṛtakāyeșu maṇḍalam praveśyābhiśikteṣu teṣu narakeșūtpannāḥ samanantara eva vimucyate | devanikāyeșūtpadyante | tatrotpannās santaḥ sarvatathāgatadharmatām abhimukhīkurvanti | avaivartikāś ca bhavanti | saṃtatiś ca niyatā bhavati | sarvatathāgatakule prajātāś ca bhavanti | prahịnāvaraṇaś ca sarvatathāgatakuleṣu vā devakuleṣu vā anyasmin vā sukham anubhavanti | devendra saṃkṣe<23v>pato laukalaukottarasarvahitasukham anubhavantīti || || idam avocad bhagavān āttamanāḥ śakrabrahmādiparṣat sadevamānuṣāsuragandharvaś ca loko yakṣarākṣasādihitasukhāvāpte bhagavato bhāṣitam abhyanandann iti || ||

ārya-sarvadurgatipariśodhana-nāma-dhāraṇī samāptaḥ || 13 ||

[46] oṃ namah sarvabuddhabodhisattvebhyah \| tadyathā || oṃ bodhi 2 sarvabodhi sarvatathāgatagocare dhara 2 hara 2 prahara 2 mahābodhicitte dhara 2 culu 2 raśmisamcodite sarvatathāgatābhișikte guṇagagane śuddhagunāvabhāse mili 2 gaganatalapratișṭite śama 2 praśama 2 sarvapāpapraśamane sarvapāpaviśodhani hulu 2 mahābodhimārgasamprasthite sarvatathāgatamudre svāhā || ||

ārya-vajramaṇḍālaṃkāra-nāma-dhāraṇī samāptạ̣ || 14 ||

3 -kramam] corr.; -kram ms. 11 tāni] pc.; tāni svapna ac. 14 -narakādīni] corr.; -oragādīni ms. 21 -sarvahitasukham] pc.; -sarvasukham ac. 23 -nandann] corr.; -nandan ms. 26 sarvatathāgata-] $p c$; tathāgata- $a c . \quad 31$-kāra] corr.; -kā ms. 
[47] oṃ namo buddhāya || evaṃ mayā śrutam ekasmin samaye bhagavāñ chrāvastyāṃ viharati sma | jetavane 'nāthapiṇḍadasyārāme mahatā bhikṣusamghena sārdham ardhatrayodaśabhir bhikṣuśataị̣ sambahulaiś ca bodhisattvair mahāsattvaị̣ || tatra khalu bhagavān mañjuśriyaṃ kumārabhūtam āmantrayate sma || asti mañjuśrīr uparișțāyām apari<24r>mitagunasaṃcayo nāma lokadhātus tatrāparimitāyurjñānasuviniśs citatejorājo nāma tathāgato 'rhan samyaksambuddha etarhi tiṣthati dhriyate yāpayati sarvasattvānāṃ dharmam deśayati || śṛ̣u mañjuśrīḥ kumārabhūta ime jambudvīpakā manuṣyā alpāyuṣas teșām bahūny akālamaraṇāni nirdișțāni | ye khalu mañjuśrīḥ sattvāsyāparimitāyuṣas tathāgatasya guṇavarṇaparikīrtanam nāma dharmaparyāyaṃ likhiṣyanti likhāpayișyanti nāmadhyeyamātram api śroṣyanti yāvat pustakagatām api kṛtvā gṛhe dhārayiṣyanti vācayișyanti paryavāpsyanti parebhyaś ca vistareṇa samprakāśayiṣyanti puṣpadhūpagandhamālyavilepanacūrṇacīvaracchatradhvajaghaṇțāpatākābhiś ca samantāc ca pūjābhiś ca pūjayiṣyanti | te parikṣiṇāyuṣa punar eva varṣaśatāyuṣo bhavișyanti || ye khalu punar mañjuśrīh sattvās tasyāparimitāyurjñānasuviniścitatejorājasya tathāgatasya nāmāṣțottaraśataṃ śroṣyanti dhārayiṣyanti vācayiṣyanti teșām āyur vivardhayișyanti || ye parikṣin̄āyuṣaḥ sattvā nāmadhyeyam śroṣyanti dhārayiṣyanti vācayișyanti teșām āyur vivardhayiṣyanti || tasmāt tarhi mañjuśrīḥ <24v> dīrghāyuṣkānām prārthayitukāmā kulaputro vā kuladuhitā vā aparimitāyuṣas tathāgatasya nāmāṣtottaraśatam śroṣyanti dhārayiṣyanti vācayiṣyanti teșām ime guṇānuśaṃsā bhaviṣyanti || oṃ namo bhagavate 'parimitāyurjñānasuviniścitatejorājāya tathāgatāyārhate samyaksambuddhāya || tadyathā || oṃ puṇye 2 mahāpuṇe aparimitapuṇye aparimitāyupunye jñānasambhāropacite | om sarvasaṃskārapariśuddhe dharmate gaganasamudgate svabhāvaviśuddhe mahānayaparivāre svāhā || || imāni mañjuśrīs tathāgatanāmāṣțottaraśataṃ ye kecil likhiṣyanti likhāpayiṣyanti pustakalikhitam api kṛtvā gṛhe dhārayiṣyanti vācayiṣyanti te parikṣiṇāyuṣaḥ punar eva varṣaśatāyuṣo bhaviṣyanti || itaś cyutvā aparimitāyuṣas tathāgatasya buddhakṣetre upapadyante || om namo bhagavate aparimitāyurjñānasuviniścitatejorājāya tathāgatāyārhate samyaksambuddhāya || tadyathā || om pụ̣ye 2 mahāpuṇye aparimitapuṇye aparimitāyupuṇye jñānasambhāropacite | oṃ sarvasaṃskārapariśuddhe dharmate gaganasamudgate svabhāvaviśuddhe mahānaya<25r>parivāre svāhā || || tena khalu punaḥ samayena navanavatīnām buddhakoțīnām ekamatenaikasvareṇa idam aparimitāyuhsūtram bhāṣitam || oṃ namo bhagavate aparimitāyurjñāna-

28 dhārayișyanti] corr.; dhārayișya ms. 31 aparimitāyur-] pc.; aparimiyutār-ac. 34 gagana-] $p c$.; gaganate- $a c .36$ aparimitāyur-] corr.; aparimiyur- ms. 
suviniścitatejorājāya tathāgatāyārhate samyaksambuddhāya || tadyathā || oṃ puṇye 2 mahāpuṇye aparimitapuṇye aparimitāyupuṇye jñānasambhāropacite | om sarvasamskārapariśuddhe dharmate gaganasamudgate svabhāvaviśuddhe mahānayaparivāre svāhā || || tena khalu punaḥ samayena caturaśīināṃ buddhakoțīnām ekamatenekasvareṇa idam aparimitāyuhsūtraṃ bhāṣitam || oṃ namo bhagavate aparimitāyurjñānasuviniścitatejorājāya tathāgatāyārhate samyaksambuddhāya || tadyathā || oṃ puṇye 2 mahāpuṇye aparimitapuṇye aparimitāyupuṇye jñānasambhāropacite | oṃ sarvasaṃskārapariśuddhe dharmate gaganasamudgate svabhāvaviśuddhe mahānayaparivāre svāhā || || tena khalu punaḥ samayena saptasaptatīnām buddhakoṭinām ekamatenaikasvareṇa idam aparimitāyuhsūtram bhāṣitam \| oṃ namo bhagavate aparimitāyurjñānasuviniścitate<25v>jorājāya tathāgatāyārhate samyaksambuddhāya || tadyathā || oṃ puṇye 2 mahāpuṇye aparimitapuṇye aparimitāyupuṇye jñānasambhāropacite | oṃ sarvasamskārapariśuddhe dharmate gaganasamudgate svabhāvaviśuddhe mahānayaparivāre svāhā || || tena khalu punaḥ samayena pañcașaștīnām buddhakoțīnām ekamatenaikasvareṇa idam aparimitāyuḥsūtraṃ bhāṣitam || oṃ namo bhagavate aparimitāyurjñānasuviniścitatejorājāya tathāgatāyārhate samyaksambuddhāya || tadyathā || oṃ puṇye 2 mahāpuṇye aparimitapuṇye aparimitāyupuṇye jñānasambhāropacite | oṃ sarvasaṃskārapariśuddhe dharmate gaganasamudgate svabhāvaviśuddhe mahānayaparivāre svāhā || || tena khalu punaḥ samayena pañcapañcāśītīnāṃ buddhakoṭinām ekamatenaikasvareṇa idam aparimitāyuhsūtram bhāṣitam || oṃ namo bhagavate aparimitāyurjñānaśuviniścitatejorājāya tathāgatāyārhate samyaksambuddhāya || tadyathā || om puṇye 2 mahāpuṇye aparimitapuṇye aparimitāyupuṇye jñānasambhāropacite | oṃ sarvasaṃskārapariśuddhe dharmate gaganasamudgate <26r> svabhāvaviśuddhe mahānayaparivāre svāhā || || tena khalu punạ̣ samayena catvāriṃśatīnāṃ buddhakoṭinām ekamanaikasvareṇa idam aparimitāyuhsūtraṃ bhāṣitam || oṃ namo bhagavate aparimitāyurjñānasuviniścitatejorājāya tathāgatāyārhate samyaksambuddhāya 30 || tadyathā || om puṇye 2 mahāpuṇye aparimitapuṇye aparimitāyupuṇye jñānasambhāropacite | oṃ sarvasaṃskārapariśuddhe dharmate gaganasamudgate svabhāvaviśuddhe mahānayaparivāre svāhā || || tena khalu punạ̣ samayena șațtriṃśatīnāṃ buddhakoṭinām ekamatenaikasvareṇa idam aparimitāyuhsūtraṃ bhāṣitam || oṃ namo bhagavate aparimitāyurjñānasuviniścitatejorājāya tathāgatāyārhate samyaksambuddhāya

8 aparimitāyu-] corr.; aparimiyu- ms. 15 svabhāva-] pc.; svabhā- ac. 24 -ārhate] $p c . ;$-ārarhate ac. 35 aparimitāyuḥ-] corr.; aparimiyuḥ- ms. 
|| tadyathā || om puṇye 2 mahāpuṇye aparimitapuṇye aparimitāyupuṇye jñānasambhāropacite | oṃ sarvasaṃskārapariśuddhadharmate gaganasamudgate svabhāvaviśuddhe mahānayaparivāre svāhā || || tena khalu punạ̣ samayena ṣaḍviṃśatīnām buddhakoṭinām ekamatenaikasvareṇa idam aparimitāyuḥsūtram bhāṣitam || oṃ namo bhagavate apa<26v>rimitāyurjñānasuviniścitatejorājāya tathāgatāyārhate samyaksambuddhāya || tadyathā || oṃ puṇye 2 mahāpuṇye aparimitapuṇye aparimitāyupuṇye jñānasambhāropacite | oṃ sarvasaṃskārapariśuddhadharmate gaganasamudgate svabhāvaviśuddhe mahānayaparivāre svāhā || || tena khalu punaḥ samayena pañcaviṃśatīnāṃ buddhakoțīnām ekamatenaikasvareṇa idam aparimitāyuhsūtraṃ bhāṣitam || oṃ namo bhagavate aparimitāyurjñānasuviniścitatejorājāya tathāgatāyārhate samyaksambuddhāya || tadyathā || oṃ puṇye 2 mahāpuṇe aparimitapuṇye aparimitāyupuṇye jñānasambhāropacite | om sarvasaṃskārapariśuddhadharmate gaganasamudgate svabhāvaviśuddhe mahānayaparivāre svāhā || || tena khalu punaḥ samayena daśagañgānadīvālukopamānāṃ buddhakoṭinām ekamatenaikasvareṇa idam aparimitāyuhsūtram bhāṣitam || oṃ namo bhagavate aparimitāyurjñānasuviniścitatejorājāya tathāgatāyārhate samyaksambuddhāya || tadyathā || om puṇye 2 mahāpuṇye aparimitapuṇye aparimitāyupuṇye jñānasambhā<27r>ropacite | oṃ sarvasaṃskārapariśuddhadharmate gaganasamudgate svabhāvaviśuddhe mahānayaparivāre svāhā || 10 || ya idam aparimitāyuhsūtraṃ likhiṣyanti likhāpayiṣyanti sa gatāyu varṣaśatāyuṣo bhaviṣyanti || oṃ namo bhagavate aparimitāyurjñānasuviniścitatejorājāya tathāgatāyārhate samyaksambuddhāya 25 || tadyathā || oṃ pụ̣ye 2 mahāpuṇye aparimitapuṇye aparimitāyupuṇye jñānasambhāropacite | oṃ sarvasamıskārapariśuddhadharmate gaganasamudgate svabhāvaviśuddhe mahānayaparivāre svāhā || 1 || ya idam aparimitāyuḥsūtram likhiṣyanti likhāpayiṣyanti sa na kadācit narakeșūpapadyante | na tiryagyonau na yamaloke na cākṣaṇopapattau na kadācid api pratilapsyante | yatra yatra janmaṇi janmany upapadyante | tatra tatra jātau jātau jātismaro bhavișyanti || oṃ namo bhagavate aparimitāyurjñānasuviniścitatejorājāya tathāgatāyārhate samyaksambuddhāya || tadyathā || om puṇye 2 mahāpuṇye aparimitapuṇe aparimitāyupuṇye jñānasambhāropacite | oṃ sarvasaṃskārapariśuddhadharmate gaganasamudgate svabhāvaviśuddhe ma<27v>hānayaparivāre svāhā

25 -suviniścita-] corr.; -suvinita- ms. 27 om sarva-] pc.; sarva- ac. 28 gagana-] pc.; gaganapariśuddhe $a c$. 
|| 2 || ya idam aparimitāyuḥūtraṃ likhiṣyanti likhāpayiṣyanti | tena caturaśītidharmaskandhasahasrāṇi likhāpitāni bhavanti || oṃ namo bhagavate aparimitāyurjñānasuviniścitatejorājāya tathāgatāyārhate samyaksambuddhāya || tadyathā || om puṇye 2 mahāpuṇye aparimitapuṇye aparimitāyupuṇye jñānasambhāropacite | oṃ sarvasaṃskārapariśuddhadharmate gaganasamudgate svabhāvaviśuddhe mahānayaparivāre svāhā || 3 || ya idam aparimitāyuhsūtram likhiṣyanti likhāpayiṣyanti | tena caturaśītidharmarājikāsahasrāṇi kārāpitāni pratișțhāpitāni bhavanti || oṃ namo bhagavate aparimitāyurjñānasuviniścitatejorājāya tathāgatāyārhate samyaksambuddhāya || tadyathā || oṃ puṇye 2 mahāpuṇye aparimitapuṇye aparimitāyupuṇye jñānasambhāropacite | oṃ sarvasaṃskārapariśuddhadharmate gaganasamudgate svabhāvaviśuddhe mahānayaparivāre svāhā || 4 || ya idam aparimitāyuhsūtraṃ likhiṣyanti likhāpayiṣyanti | tasya pañcānantaryāṇi karmāvaraṇāni prarikṣayaṃ gacchanti || oṃ namo bha<28r>gavate aparimitāyurjñānasuviniścitatejorājāya tathāgatāyārhate samyaksambuddhāya || tadyathā || oṃ puṇye 2 mahāpuṇye aparimitapuṇye aparimitāyupuṇye jñānasambhāropacite | oṃ sarvasaṃskārapariśuddhadharmate gaganasamudgate svabhāvaviśuddhe mahānayaparivāre svāhā || 5 || ya idam aparimitāyuhsūtraṃ likhiṣyati likhāpayiṣyati | tasya na mārā na mārakāyikā na yakṣā na rākṣasā nākālamṛtyur avatāraṃ lapsyante || oṃ namo bhagavate aparimitāyurjñānasuviniścitatejorājāya tathāgatāyārhate samyaksambuddhāya || tadyathā || om pụ̣ye 2 mahāpuṇye aparimitapuṇye aparimitāyupuṇye jñānasambhāropacite | oṃ sarvasaṃskārapariśuddhadharmate gaganasamudgate svabhāvaviśuddhe mahānayaparivāre svāhā || 6 || ya idam aparimitāyuḥūtraṃ likhiṣyati likhāpayiṣyati | tasya maraṇakālasamaye navanavatyo buddhakoțyạ sammukhaṃ darśanaṃ dāsyanti | buddhasahasraṃ hastena hastaṃ tasyopanāmayanti | buddhakṣetrād buddhakṣetram saṃkrāmanti nātra kāṅkṣā vimatir utpādayitavyā || om namo bhagavate aparimitāyu<28v>rjñānasuviniścitatejorājāya tathāgatāyārhate samyaksambuddhāya || tadyathā || oṃ puṇye 2 mahāpuṇye aparimitapuṇye aparimitāyupuṇye jñānasambhāropacite | oṃ sarvasaṃskārapariśuddhadharmate gaganasamudgate svabhāvaviśuddhe mahānayaparivāre svāhā || 7 || ya idam aparimitāyuḥūtram likhiṣyanti likhāpayiṣyanti | tasya catvāro mahārājānaḥ pṛșțhatah pṛșṭhatạ̣

5 -saṃskāra-] $\quad p c$.; -skāsaṃra- $a c . \quad 6$ gaganasamudgate svabhāvaviśuddhe] $p c$; gaganasamudgate ac. 9 -rājāya] corr.; -rāya ms. 35 likhāpayiṣyanti] corr.; likhāyiṣyanti ms. 
samanubaddhāḥ rakṣāvaraṇaguptim kariṣyanti || oṃ namo bhagavate aparimitāyurjñānasuviniścitatejorājāya tathāgatāyārhate samyaksambuddhāya || tadyathā || om pụ̣ye 2 mahāpuṇye aparimitapuṇye aparimitāyupuṇye jñānasambhāropacite | oṃ sarvasaṃskārapariśuddhadharmate gaganasamudgate svabhāvaviśuddhe mahānayaparivāre svāhā || 8 || ya idam aparimitāyuhsūtraṃ likhiṣyanti likhāpayiṣyanti | sa sukhāvatyāṃ lokadhātāv amitābhasya buddhakșetre upapadyante || oṃ namo bhagavate aparimitāyurjñānasuviniścitatejorājāya tathāgatāyārhate samyaksambuddhāya || tadyathā || om puṇye 2 mahāpuṇye aparimitapuṇye aparimitāyupuṇe jñānasambhāropacite | <29r> om sarvasaṃskārapariśuddhadharmate gaganasamudgate svabhāvaviśuddhe mahānayaparivāre svāhā || 9 || yasmin pṛthivīpradeśe idam aparimitāyuḥsūtraṃ likhiṣyanti likhāpayiṣyanti sa pṛthivīpradeśe caityabhūto vandanīyaś ca bhaviṣyanti | yeșām tiryagyonigatānāṃ mrgapakṣidaṃșțiṇāṃ karṇapuṭe nipatiṣyanti teșāṃ sarve 'nuttarām samyaksambodhim abhisambhotsyante || om namo bhagavate aparimitāyurjñānasuviniścitatejorājāya tathāgatāyārhate samyaksambuddhāya || tadyathā || oṃ puṇye 2 mahāpuṇye aparimitapuṇye aparimitāyupuṇye jñānasambhāropacite | oṃ sarvasaṃskārapariśuddhadharmate gaganasamudgate svabhāvaviśuddhe mahānayaparivāre svāhā || 10 || ya idam aparimitāyuhsūtraṃ likhiṣyanti likhāpayiṣyanti | sa strībhāvo na kadācid api pratilapsyante || oṃ namo bhagavate aparimitāyurjñānasuviniścitatejorājāya tathāgatāyārhate samyaksambuddhāya || tadyathā || oṃ puṇye 2 mahāpuṇye aparimitapuṇye aparimitāyupuṇye jñānasambhāropacite | oṃ sarvasaṃskārapariśuddhadharmate gaganasamudgate svabhāvaviśuddhe mahānayaparivāre svāhā || <29v> 11 || ya idam aparimitāyuhsūtraṃ ratnarājaṃ dharmaparyāyam uddiśya ekam api kārṣāpaṇaṃ dānaṃ dāsyati tena trisāhasramahāsāhasralokadhātuh saptaratnamayīparipūrṇaṃ kṛtvā dānaṃ dadyāt tasya puṇyaskandhasya pramāṇaṃ śakyaṃ gaṇayitum | na tv aparimitāyuhsūtrasya puṇyaskandhasya pramāṇaṃ śakyaṃ gaṇayitum || oṃ namo bhagavate aparimitāyurjñānasuviniścitatejorājāya tathāgatāyārhate samyaksambuddhāya || tadyathā || oṃ puṇye 2 mahāpuṇye aparimitapuṇye aparimitāyupuṇye jñānasambhāropacite | oṃ sarvasaṃskārapariśuddhadharmate gaganasamudgate svabhāvaviśuddhe mahānayaparivāre svāhā || 12 || ya idam dharmabhāṇakaṃ pūjayiṣyanti tena sakalasamāptaḥ saddharma pūjitam bhavanti || oṃ namo bhagavate aparimitāyurjñānasuviniścitatejorājāya tathāgatāyārhate samyaksambuddhāya || tadyathā || om puṇye 2 mahāpuṇye aparimitapuṇye aparimitāyupuṇye jñānasambhāropacite | om sarvasaṃskārapariśuddhadharmate gaganasamudgate svabhāvaviśuddhe mahānayaparivāre svāhā || 13 || yathā 
vipaśyiśikhiviśvabhukrakucchandakanakamunikāśyapaśākyamuniprabhṛ<30r>tīnāṃ tathāgatānāṃ samyaksambuddhānām saptaratnamayāḥ pūjāyāḥ kṛtāyā yāvat tasya puṇyaskandhasya pramāṇam śakyaṃ gạ̣ayitum | na tv aparimitāyuḥsūtrasya puṇyaskandhasya pramāṇaṃ śakyaṃ gaṇayitum || oṃ namo bhagavate aparimitāyurjñānasuviniścitatejorājāya tathāgatāyārhate samyaksambuddhāya || tadyathā || oṃ puṇye 2 mahāpuṇye aparimitapuṇye aparimitāyupuṇye jñānasambhāropacite | oṃ sarvasaṃskārapariśuddhadharmate gaganasamudgate svabhāvaviśuddhe mahānayaparivāre svāhā || 14 || yathā sumeroḥ parvatarājasya saptaratnarāśiṃ kṛtvā dānaṃ dadyād yāvat tasya puṇyaskandhasya pramāṇaṃ śakyam gaṇayitum | na tv aparimitāyuh sūtrasya puṇyaskandhasya pramāṇaṃ śakyạ̣ gaṇayitum || oṃ namo bhagavate aparimitāyurjñānasuviniścitatejorājāya tathāgatāyārhate samyaksambuddhāya || tadyathā || oṃ puṇye 2 mahāpuṇye aparimitapuṇye aparimitāyupuṇye jñānasambhāropacite | oṃ sarvasamskārapariśuddhadharmate gaganasamudgate svabhāvaviśuddhe mahānayaparivāre svāhā || 15 || yathā catvāro mahāsamudrā udakaparipūrṇā bhaveyur yāvat tasyodakasyaikaikabindum śakyam <30v> gaṇayitum | na tv aparimitāyuḥūtrasya puṇyaskandhasya pramāṇaṃ śakyaṃ gaṇayitum || oṃ namo bhagavate aparimitāyurjñānasuviniścitatejorājāya tathāgatāyārhate samyaksambuddhāya || tadyathā || oṃ puṇye 2 mahāpuṇye aparimitapuṇye aparimitāyupuṇye jñānasambhāropacite | oṃ sarvasaṃskārapariśuddhadharmate gaganasamudgate svabhāvaviśuddhe mahānayaparivāre svāhā || 16 || ya idam aparimitāyuḥūtraṃ likhiṣyanti likhāpayiṣyanti satkṛtya pūjayișyanti | tena daśasu dikṣu sarvabuddhakṣetreṣu sarvatathāgatān vanditā pūjitāś ca bhavișyanti || oṃ namo bhagavate aparimitāyurjñānasuviniścitatejorājāya tathāgatāyārhate samyaksambuddhāya || tadyathā || oṃ puṇye 2 mahāpuṇye aparimitapuṇye aparimitāyupuṇye jñānasambhāropacite | oṃ sarvasaṃskārapariśuddhadharmate gaganasamudgate svabhāvaviśuddhe mahānayaparivāre svāhā || 17 || dānabalena samudgata buddho dānabalādhigatā narasiṃhoḥ | dānabalasya ca śrūyati śabdạ̣ kāruṇikasya pure praviśantạ̣ || 1 || śillabalena samudgata buddho śilabalādhigatā narasiṃhoḥ | śīlabalasya ca śrūyati śabda<31r> ḥ kāruṇikasya pure praviśantaḥ || 2 || kṣāntibalena samudgata buddho kṣāntibalādhigatā narasiṃhoḥ | kṣāntibalasya ca śrūyati śabdaḥ kāruṇikasya pure praviśantah || 3 ||

1 -viśvabhu-] $p c$.; -viśvabhubhu- $a c . \quad 2$-prabhṛtīnāṃ] pc.; prabhṛnāṃtīnāṃ $a c . \quad 16$ catvāro] corr.; caro ms. 19 -viniścita-] corr.; -viniści- ms. 19 -rājāya] pc.; -rāyajā ac. 25 vanditā pūjitāś] $p c$.; vanditāś $a c$. 
vīryabalena samudgata buddho vïryabalādhigatā narasiṃhoḥ | vīryabalasya ca śrūyati śabdaḥ kārunikasya pure praviśantaḥ || 4 || dhyānabalena samudgata buddho dhyānabalādhigatā narasiṃhoḥ | dhyānabalasya ca śrūyati śabdaḥ kārunikasya pure praviśantaḥ || 5 || prajñābalena samudgata buddho prajñābalādhigatā narasiṃhoḥ | prajñābalasya ca śrūyati śabdaḥ kāruṇikasya pure praviśantaḥ || 6 || oṃ namo bhagavate aparimitāyurjñānasuviniścitatejorājāya tathāgatāyārhate samyaksambuddhāya || tadyathā || oṃ punye 2 mahāpuṇe aparimitapunye aparimitāyupunye jñānasambhāropacite | oṃ sarvasaṃskārapariśuddhadharmate gaganasamudgate svabhāvaviśuddhe mahānayaparivāre svāhā || || idam avocad bhagavān āttamanās te ca bhikṣavas te ca bodhisattvā mahāsattvā sā ca sarvāvatī parșat sadevamānuṣāsuraloko gandharvaś ca bhagavato bhāșitam abhyanandann iti || 15||$<31 v>$

āryāparimitāyur-nāma-mahāyānasūtra-dhāraṇi parisamāptaḥ || ||

[48] oṃ namo bhagavate vajrapāṇaye mahākrodhāya || tatra bhagavān sarvāvaraṇaviśodhanadhāraṇīmantraṃ bhāṣate sma || oṃ sarvapāpadahanavajra hūṃ phaṭ | oṃ sarvapāpaviśodhanavajra hūṃ phaț | oṃ sarvakarmāvaraṇāni bhasmīṃkuru hūṃ phaț || oṃ bhrūṃ vināśāvaraṇāni hūṃ phaț || oṃ drūṃ viśodhayāvaraṇāni hūṃ phaț || oṃ jvala 2 dhaka 2 hana 2 āvaraṇāni hūm phaț || oṃ hūṃ sara 2 prasara 2 āvaraṇāni hūṃ phaț || oṃ hūṃ hana 2 sarvāvaraṇāni hūṃ phaț || oṃ hūṃ phaț sarvāvaraṇāni hūṃ phaț || oṃ sphoțaya 2 sarvapāpāni hūṃ phaṭ || oṃ bhṛta 2 sarvāvaraṇāni hūṃ phaț || oṃ traṭ 2 sarvāvaraṇāni hūṃ phaț || oṃ chinda 2 vidrava 2 sarvapāpāvaraṇāni hūṃ phaț || oṃ daha 2 sarvanarakagatihetum hūṃ phaț || oṃ paca 2 sarvapretagatihetum hūṃ phaț || oṃ matha 2 sarvatiryaggatihetum hūṃ phaț \| tatas teșām upakaraṇāny abhāṣata || oṃ sarvapāpaviśodhani dhama 2 dhūpaya hūṃ phaț || oṃ sarvadurgativiśodhani pușpavilokini hūṃ phaț || oṃ sarvāpāyaviśodhani jñānāvalokakari hūṃ phaț || oṃ sarvāpāyagatināśani gandha hūṃ phaț || oṃ narakagatyākarṣaṇi hūṃ phaṭ || oṃ narakātyuddharaṇi hūṃ phaț || <32r> oṃ sarvāpāyabandhaviśodhani hūṃ phaț || oṃ sarvāpāyagatigahanavināśani hūṃ phaț || etāni mantrāṇi kikaśaṃ suyojitāni saṃtāộya mantraị̣

1 -ādhigatā $p c$;; -ādhitāga $a c . \quad 3$-balena] $p c$;; -baralena $a c . \quad 12$ mahāsattvā] $p c . ;$ sā mahāsattvā ac. 13 abhyanandann] corr.; abhyanandan ms. 19 viśodhayāvaraṇāni] corr.; viśodhanayāvaraṇāni ms. 
sitasarṣapasākṣatena | prakṣālayec ca sugandhikajalena gavyair gandham tathākṣīrasamadyacasāmbukaiś ca \| om śodhane 2 viśodhane 2 sarvapāpaśuddhe viśuddhe sarvakarmāvaraṇaviśuddhe svāhā || udaka || oṃ kan̉kani 2 rocani 2 trocani 2 pratihata hana 2 sarvakarmaparamparāṇi sarvasattvānām svāhā || gavya || oṃ ratne 2 mahāratne ratnasambhave ratnakiraṇe ratnamālāviśuddhe śodhaya sarvapāpān hūṃ phaṭ || oṃ amoghāpratihatasarvāvaraṇāni vināśani hara 2 hūṃ phat || kṣīra || om amite 2 amitodbhave amitasambhave amitavikrāntagāmini sarvakleśakṣayaṃkari svāhā || madya || oṃ puṇye 2 mahāpuṇye aparimitapuṇye aparimitāyupuṇye jñānasambhāropacayakāriṇe svāhā || udakaṃ ca || oṃ padme 2 mahāpadme padmodbhave padmasambhave sukhāvatī gacchantu svāhā || mārgaśodhanaṃ kartavyam || asyā dhāraṇyāṃ bhāṣitamātrāyāḥ sarvadurgatibhyo vinirmuktāḥ svargalokottarabhūmiṣūtpadyante | sarvasiddhayo 'pi siddhyati | samyaksambodhi caivam prā<32v>pyate || 16 ||

iti sarvadurgatipariśodhanavinirgata-anantakalparāja-nāma-dhāraṇī samāptạ̣ || ||

[49] oṃ namo nāgāmbaradharāya vajrapāṇaye mahāyakṣasyenāpataye || tadyathā || oṃ buddhe 2 vibuddhe 2 mahāvaralokapāline | ojohara 2 nāgānām prahara 2 sarvanāgān chinda 2 nāgahṛdayāni sphoṭaya 2 nāganayanāni viśīryante nāgaśarīrāṇi ||

tadyathā || oṃ hūṃ hūṃ phaṭ || nāgavidāraṇāya phaṭ | nāgocchādanāya phaṭ | kālavaśanāya phaṭ || apratihatavaraparākramāya phaṭ | kṛtāntarūpāya phat | lokanāthāya phaṭ | trāsanakarāya phaṭ | kumbhāṇḍasarvacchādanapālāya phaṭ | pretapiśācavināśakāya phaṭ | oṃ hasa 2 māraya 2 nāśaya 2 sarvavighnavināśakāya phaṭ | nīlāmbaradharo vajrapāṇi ājñāpayati svāhā || 17 ||

iti vajrapāṇi-mahārakṣā-nāma-dhāraṇī samāptaḥ || ||

[50] oṃ namah samantabuddhānām || tadyathā || oṃ mahāpratyañgiroṣṇiṣacakravarti sarvayantramantrabandha indrabhuvanabandha vṛkṣadevatābandham dhāraya iha vāsināṃ yena kenacid bhayādikaṃ chinda 2 bhinda 2 ciri 2 giri 2 miri 2 hūm 2 phaṭ 2 svāhā || 18||$<33$ r>

ārya-uṣṇīṣacakravartī-nāma-dhāraṇī samāptaḥ || ||

8 -vikrānta-] pc.; -vikrā- ac. 14 siddhyati] $p c . ;$ ddhyati $a c .19$ sarvanāgān] $p c . ;$ sarvagānān $a c$. 
[51] oṃ namaḥ sarvabuddhabodhisattvebhyah \|| oṃ vajraghaṇța āḥ āḥ || oṃ raṇa 2 praraṇa 2 sampraraṇa 2 sarvabuddhapracārini prajñāpāramitānādasvabhāvena vajrasattvasya hṛdayasaṃtoṣaṇakarāya hūṃ phaț svāhā \| saddharmapāțhārthe ghaṇțān vādayet | tryakșaramantreṇa pușpadhūpadīpagandhanaivedyādikaṃ sarvaṃ yathāvidhinā dadyāt || oṃ āh hūṃ phaț svāhā ||

iti saddharmapāțhe ghaṇțāvādana-nāma-dhāraṇī samāptaḥ || 19 || ||

[52] oṃ namaḥ suvarṇaprabhendrarājāya tathāgatāya || tatra khalu bhagavān buddhamodanaṃ bodhisattvaṃ mahāsattvam etad avocat || kulaputra suvarṇanāmendradhāraṇīm yaḥ kaścit kulaputro vā kuladuhitā vā imāṃ dhāraṇị̣̄ likhitvā kaṇțhe baddhvā dhārayiṣyati | sa iha dhāraṇyā prabhāvena mahāpuṇyasambhāralalitaṃ vivardhayișyanti || oṃ namo daśabhūmipratișțitebhyah sarvabuddhabodhisattvaśrāvakapratyekabuddhebhyah || namạ̣ śrīśākyamunaye | namaḥ suvarṇaprabhendrarājasutāya | namo ratnatrayāya || tadyathā || kuṭi kuțini amitākośani amriri niyiri svāhā || imāni kulaputra dhāraṇimmantrapadāni li<33v>khitvā kaṇțhe baddhvā dhārayitavyam | punyyaskandhair aprameyair vivardhayiṣyanti | anantair buddhaśatair mānanīyo vandanīyah pūjanīyaś ca karișyati | tena paramabuddhabodhiyāne baudhāgriṇiṃ prāpayiṣyati | ya icchate sarvaṃ siddhyati || 20 ||

iti puṇavardhanī-nāma-dhāraṇī samāptaḥ || ||

[53] oṃ namaḥ sarvabuddhabodhisattvebhyaḥ || evaṃ mayā śrutam ekasmin samaye bhagavān rājagṛhe viharati sma | gṛdhrakūțe parvate mahatā bhikṣusaṃghena sarvabuddhabodhisattvagaṇena sārdham || tatra khalu bhagavān ratnavairocanaṃ bodhisattvaṃ mahāsattvam etad avocat | santi kulaputra duḥkhitāḥ sattvā alpāyuṣkās teșāṃ sattvānām arthāya hitāya sukhāya bodhisambhārapūraṇāya | anekakalpanirodham avahitena cittenātināmayitum || iyạ̣ sarvajñatākāradhāraṇīmukhapraveśạ̣ sarvātītānāgatapratyutpannais tathāgatair arhadbhị̣ samyaksambuddhair yauvarājyābhiṣiktānāṃ bodhisattvānāṃ deśitam | tvam apy udg̣̣hya dhāraya

2 sampraraṇa] $p c$.; sampraharaṇa $a c .10$ etad] corr.; ed ms. 16 -rāja-] $p c . ;$-rājāya ac. 21 paramabuddha-] $p c$; parabumaddha- $a c .26$ mahatā bhikṣu-] $p c$; mahabhitākșu- $a c$. 
vācaya deśaya paryavāpnuhi parebhyaś ca vistareṇa samprakāśaya || atha khalu ratnavairocano bodhisattvo mahāsattvaḥ kṛtāñjalipuṭo bhūtvā bhagavantạ̣ praṇamyaitad avocat | deśayasva bha<34r>gavan sarvasattvānām arthāya hitāya sukhāya bodhisambhārapūraṇāya yogapāraprāptāya deśayasva sugata || atha khalu bhagavān sarvāvatīparṣanmaṇụalam avalokyemaṃ sarvajñatākāradhāraṇīmukhapraveśaṃ bhāṣate sma || tadyathā || om namo ratnatrayāya || jali jalini phulke valke sammade mahāsammade | devān aṭi cați țake țhare țharekke ami makasi hili cili tili ruruke mahāruruke | jaye durjaye jayamati śānte śāntanirghoṣani | amūle ale | amūlaparicchinne | mārasainyavitrāsane | mukte muktapariśuddhe | abhīte bhayamocane | bhāra-ojaharaṇadānte vidyāvidyāvarottame | nigrahạ̣ parivādinām | dharmavādinām anugraham | ārakṣā dharmavādinām || caturṇāṃ smṛtyupasthānānāṃ adhimuktipadaprakāśapadam idam || 1 || buddhaprakāśaye amama nimama | avedhi arthe arthanistāraṇe | lokādhimukte | saṃdadhaparibhāvane || caturṇām āryavaṃsānām adhimuktipadaprakāśapadam idam || 2 || bhāṣārthe bhāṣaṇe | dhāre dhārayati | gupte śubhaprabhe | tatphale agraphale niṣphale nileha | amukte amukte nirmukte | atavi tavi muktavati | vila phala ayukta iviti șiviti rati tula <34v> tulamam ahimsāma iti tāva | atvā natvāna sarvaloke | anakali vindha abhūsare | hatamatte | veśagravate | aphala kaphala || trayānām ārakṣitānām adhimuktipadaprakāśapadam idam || 3 || jaḍata aniharava vatavyo idam phala niyāmaphala samudānaya vibhūṣayasya sāmantra | anumatto akumatto | chedāvane | mantrastā daśabalavigrahasthā | isusthita | sunikhama | tīkṣṇāmati | āloko | atitṛ̣ṇā adimati | pratyutpannabuddhapūrvaprahāre || caturṇāṃ samyaksamprahāṇānām adhimuktipadaprakāśapadam idam || 4 || anye manye mane mamane vire virate | śame śamitā viśānte mukte nirakṣame same samasame | kṣaye akṣaye | ajiti śānte samișțe dhāraṇi ālokāvabhāse | ratnavrate | raśmyavate | jñānavate | meruvate | kṣayanidarśane | lokapradīpanidarśane || caturṇāṃ pratisaṃvidānām adhimuktipadaprakāśapadam idam || 5 || cakṣu-ābhāse | nidarśane jñānālokanidarśanaṃ ca | prabhāsane sarvendriyabhūmātikrānte sarvasava vamām | sarve prārthavākṣayaṃkare | gokāhavadane lokānudarśane vibhū || caturṇām ṛddhipādānām adhimuktipadaprakāśapada<35r $>$ m idam || 6 || acale buddhe buddhapracale sattve gṛhṇa siddhi kampati nisiddhi smahițte parakasire | some caṇde datve acala acale | apare vicivare nipare pracacare prasare | anaya abhyāse | kankame prabhāvini | drome nijasograkrame nayate || indriyāṇāṃ balānām

15 caturṇām] $p c$; carṇātum $a c . \quad 20$ ārakșitānām] $p c . ;$ ākșirakṣitānām $a c . \quad 31$-bhūmāṇikrānte] corr.; -bhūmāṇikrānte ms. 
adhimuktipadaprakāśapadam idam || 7 || puṣpe supuṣpe drume parihāre abhayarucire cekaratke akșayamantu | nimile mamale | pañcaśiśire | lokasya vijñāne | nayasaṃgrhīte ca yukte succhandena || saptānāṃ bodhyañgānām adhimuktipadaprakāśapadam idam || 8 || cakravajre maitrasamāpade kānte kete | karuṇarudīkșayī prītirūpe kṣemasampanne arake varate | kharokhare | amūle mūlasādhane || caturṇāṃ vaiśāradyānām adhimuktipadaprakāśapadam idam || 9 || varte cakre cakradhare | varacakre vare prare | hile hile dhale ārupāvate huhure yathābhajribhanganivare | yathāparamcari niśe yathābhayaririśi || satyanirhāra | jalacavila vīryanirhāra | cure mārganirhāra | samādhinirhāra | prajñānirhāra | vimuktinirhāra || vimuktijñānadarśananirhāra | nakṣatranirhāra | candranirhāra | sūryani<35v>rhāra || yadāś caturuttaratathāgatena adbhutām niradbhutām sambuddham abuddham ihabuddham tatrabuddham nihaṃame pare | alaha dalaha pạ̣ḍare paṇḍare | tatrāngalu | mānggagharaṇi pūṭani sampūṭani | gatapraṅga manuniruva | nāśani nāśabandhani | chicchi nicchicchi nidrama | yova hiḍingamā vare mare | hanane bharambhare bhinde bhire bhire ruṣare śaraṇe darạ̣e pravate caranāḍaye vidrambumā varakhumā | brahmacāriṇa indravani dhidhirāyani | maheśvaralalani | mamasume | alamini ekākșarari vañcani | carasthi ābhicaṇḍālasure | sarvasurā āvarasurā punakanitāṃ maṇditām āyinakaṇḍi jabhāme gandhare atra runi makare 'bhirohiṇi siddhamatte vilokamate | buddhādhișțite dhāraṇīmukhe || 33 || daśānām balānām adhimuktipadaprakāśapadam idam || 10 || asmin sarvajñatākāradhāraṇīmukhapraveśabhāṣyamāṇe 'yaṃ trisāhasramahāsāhasralokadhātụ̣ șaḍvikārakampitāh sarvalokadhātavaś cāvabhāsena sphutāḥ | evaṃ cakṣuṣa ābhāsam āgatya sarvalokadhātavaḥ sambodhitā dṛśyante || ye cānyāpi lokadhātuṣu sthitā bodhisattvādidevanāgā ya<36r>kṣāś cāsurā kumbhāṇḍā piśācās te sarve samāgatya bhagavataḥ pādau vanditvā vividhaiḥ pūjāṃ kṛtvā tatraiva niṣeduḥ sarvajñatākāradhāraṇīmukhapraveśaśravaṇārtham || tatra bhagavān punar apy āha || imaṃ kulaputra sarvajñatākāradhāraṇīmukhapraveśaṃ bhāvayamānaś caturaśītidhāraṇīmukhaṃ śatasahasrāṇi pratilabhate | dvāsaptatiś ca dhāraṇīmukhasahasrāṇi | șașți ca samādhimukhasahasrāṇi | mahāmaitrī mahākaruṇā ca saptatriṃśadbodhipakṣāṃ dharmāś ca | sarvajñajñānaṃ ca pratilabhate || iha sakalabaddhe dharmāṇāṃ parigrahạ̣ || imāṃ dhāraṇị̣ buddhvā buddhā bhagavantaḥ sattvānāṃ dharmaṃ deśayanti na cātikṣipram parinirvāyanti || ye cainām śroṣyanti te 'py

2 akșayamantu] pc.; akșamayantu ac. 30 sarvajñatā-] pc.; sarvatājña- ac. 34 pratilabhate] corr.; pratilate ms. 34 sakalabaddhe] $p c$; sakaladdhe $a c$. 
avaivartino bhavanty anuttarāyāṃ samyaksambodhau | likhamānāś cāvirahito bhavanti buddhadarśanena dharmaśravaṇena saṃghopasthānena yāvad anuttareṇa parinirvāṇena | svādhyāyamānāś ca sarvāṇi gāḍhakarmāṇi niravaśeșaṃ kṣapayanti | janmaparivartena ca prathamāṃ bhūmim ākrāmanti | bhāvayamānāś ca pañcānataryāṇi karmāṇi kṣapayanti | yaś ca dharmabhāṇakasya paț̣aṃ badhnāti tasya sarvabuddhāḥ sādhukāraṃ dadanti | vyākariṣya<36v>nty anuttarāyām samyaksambodhau | na cireṇa cāsau bodhisattvaḥ paț̣aparityāgena yauvarājye 'bhișicyate | ekajātipratibaddhaś ca bhavaty anuttarāyām samyaksambodhau || eva yo gandhena pūjayati sạ̣ samyaksambodhigandhasya lābhī bhavati | puṣpeṇa pūjayati jñānapuṣpāṇi pratilabhanti | bhakṣānnapānakạ̣ dattvā tathāgatāhārasya lābhī bhavati | vastreṇācchādya dharmabhāṇakaṃ tathāgatavarṇalābhī bhavati | ratnair ācchādya saptatriṃśatānāṃ bodhipākṣikadharmaratnānāṃ lābhī bhavati | asañgapratibhānatāṃ manāpadharmacatuṣkam ca pratilabhate || || atha khalu maitreyo bodhisattva āha || mayā bhagavan bhūtapūrvaṃ sālendrarājasya tathāgatasya sakāśād iyaṃ dhāraṇimukhaṃ śrutā bhāvanā paripūryādhigatāḥ | evam asaṃkhyeyānāṃ tathāgatānāṃ sakāśe bahūni kuśalamūlāni avaropya puṇyaskandhaḥ parigṛhītāh | tenāhaṃ kuśalamūlena bahubhir buddhasahasrair vyākṛtāḥ kālam avekṣyāhaṃ praṇidhānenaivaṃ ciraṃ saṃsāre saṃsṛtāh | yena me saṃsāre saṃsaratānuttarāṃ samyaksambodhim abhisambuddhāḥ | aham idānīṃ bhagavatā yauvarājyenābhiṣiktāḥ | vimuktipațtaś ca me prajñā śi<37r>rasi baddho 'nuttarāyāṃ samyaksambodhau || atha bhagavān maitreyam bodhisattvam etad avocat || yathaiva te maitrayā paripūrṇaśaktas tvaṃ maitreya śīghram evānuttareṇa jñānena nirvāṇadhātau praveșțum || punar api bhagavān sarvāvatī parṣadam avalokyemāni mantrapadāny abhāṣatạ̣ | tadyathā || dāntabhūmiḥ damathabhūmih smṛtibhūmiḥ prajñābhūmiḥ vaiśāradyabhūmị̣ pratisaṃvidbhūmir anutkṣepabhūmiḥ samatāparikṣayopekṣyabhūmị̣ jātikṣayabhūmir mamuja vinmuja malatmajạ̣ visāgraḥ | daśāvate veśataḥ teraṇa veśalagra | śamuśavatạ̣ vimati vimati yopahira regamata vasisakrama iticoravate | mekhe mudradaharavate prajñākșābubu dahakramita | sadoṣavantaḥ elaya tilaya ahusuḍhā amundhamaṃ arthavati muruvati tehīnadvivā | akanati vakanate samake visābhate | iṭe ițavala atra tatra karuṣaṃ laruṣam | latatha katha sarvantah sarvatarvaḥ aniruddhạ̣ dihașatamvi phalabahuphale śataphalaśișțavate \| eṣu pratītyasamutpādapratisaṃyuktādhimuktipadeṣu prakāśyamāneṣu

12 tathāgata-] corr.; tathāga- ms. • bhavati] pc.; vabhati ac. 16 iyaṃ] pc.; imayam $a c .20$-ānuttarāṃ] $p c$; -ānuttarāyāṃ $a c .23$ atha] $p c$; atha khalu $a c .24$-śaktas] $p c . ;$-śakta ac. 30 teraṇa] $p c$; teṇara $a c$. 
șașțibhir devanayutaiḥ satyadarśanam kṛtam || 1 || tatphalam agraphalaṃ lalaha ala $<37 \mathrm{v}>$ ha nilaṃhare | vacatavyā idaṃ phalaṃ niyāmaphalam | namudaya vibhūkha prajñācakra sunirvṛticakra jñānīcakra || ebhir adhimuktipadair daśānāṃ devakoṭin̄ām anuttarāyāṃ samyaksambodhau cittāny utpāditāni || 2 || paśye momato anumato akumato akumati cchīdatrake mantrasthā daśabalavipravasthāḥ | iśa sthita atimatri tīṣnamati ālokosteri tuṣna || ebhir adhimuktipadaiś catuhṣașțīnāṃ nāgasahasrāṇi-r-anuttarāyāṃ samyaksambodhau cittāny utpāditāni || 3 || aprabhā samadanā ahadyo bhagavandyo karaṇyākṣa middhamati samantakṣau ale bale pitakaro mahābale ojagaro dharaṇe migalakṣa udārakṣa kukākṣa viroyo virūpamukha akṣihastam śaktibala asurovina asuropramardana || ebhir adhimuktipadair dvādaśānāṃ yakṣakoṭinām anuttarāyāṃ samyaksambodhau cittāny utpāditāni || 4 || arthe pilile tinithe saṃtīthe katitene nakeme | nanamaste ubhe rabhe mudame madame matime satihaśūre dhāraṇìya sendrasadevasanāgasayakṣāsuradevānāgā niruktiparivāraniruktarāni smṛtiprajñāparivāram abhipratilābhī <38r> gatidhṛtiparivāragatidhṛtilābhī pūrvakeșu carintavantaḥ abhiskāmantaḥ sūuravantạ̣ ciravīryavantaḥ bhītavantaḥ sitabhāge mārgamudrādiśāpakarṣaṇi kṣaparat | ohāraṇo devaracatu suramudra yakṣamudra rākṣasamudra vedi vedime tape tattape uṣnāname | prakhādye nenavadharaṇiye | āviśadiśāśodhane vākye śuddhe jihvāśuddhe vāciparikarmaprajñābuddhismṛtimatigatidhṛtigaṇanapratisaraṇabuddhị | jayacakre śūnyacakre vyaya || ebhir adhimuktipadaiḥ șaṭpañcās̄īnām asurasahasrāṇām anuttarāyāṃ samyaksambodhau cittāny utpāditāni te sarve 'vaivartikā-r-abhūt || 5 || atha bhagavān vaiśāradyasamavasaraṇaṃ nāma bodhisattvam etad avocat || durlabhaṃ kulaputra tathāgatānām arhatāṃ samyaksambuddhānām loke prādurbhāvo durlabhā ime śīlasamādhiprajñāvimuktivimuktijñānadarśanaparibhāvitā | amī mantrapadāḥ sattvānāṃ hitāya bodhisattvaguṇaniṣpādanārtham śrotavyā udgrahītavyā dhārayitavyā vācayitavyā bhāvayitavyeti | mayā pūrvaṃ bodhisattvacaryā caratā yāvat ṣaṭpāramitā pūritā | daśākuśalakarmāṇi parivarjitāni da<38v>śasukuśamūlāni parisaṃgrhītāni || yenaitarhi mamānuttaraṃ jñānapratilabdham | tat sarvam etasyā dhāraṇyạ̣̄ prabhāveneti bodhavyam || idam avocad bhagavān āttamanā sā ca sarvāvatī parṣad bhagavato bhāṣitam abhyanandann iti || 21 ||

ārya-sarvajñatākāra-dhāraṇimukhapraveśaṃ samāptaḥ || ||

6 mantrasthā] $p c$. ; mantrakesthā ac. 13 katitene] $p c . ;$ katinetene $a c .31$ pūritā] corr.; paritā ms. 34 parșad] corr.; parșado ms. 35 abhyanandann] corr.; abhyanandan ms. 
[54] oṃ namo bhagavatyai ārya-prajñāpāramitāyai || evaṃ mayā śrutam ekasmin samaye bhagavān rājagṛhe viharati sma || gṛdhrakūṭe parvate mahatā bhikṣusaṃghena sārdhaṃ mahatā ca bodhisaṃgheṇa | anekaiś ca śakrabrahmādilokapālaị̣ | devanāgayakṣagandharvāsuragaruḍakiṃnaramahoragaị |

bhikṣubhikṣuṇyupāsakopāsikābhis sārdham || tatra khalu bhagavān āyuṣmantam subhūtim āmantrayate sma || yaḥ kaścit subhūte śrāvakabhūmāv api śikṣitukāmena pratyekabuddhabhūmāv api śikșitukāmena bodhisattvabhūmāv api śikṣitukāmena buddhabhūmāv api śikṣitukāmena | iyam eva prajñāpāramitā śrotavyā udgrahītavyā dhārayitavyā vācayitavyā paryavāptavyā | ihaiva prajñāpāramitāyām upāyakauśalyasamanvāgatena bodhisattvena mahāsattvena sarvadharmasa<39r>mudāgamāya yogaḥ karaṇīya || tat kasya hetoḥ || iha hi prajñāpāramitāyāṃ vistareṇa sarvadharmā nirdișțā yatra bodhisattvena mahāsattvena śikṣitavyam yogam āpadyam iti | anuttarāyāṃ samyaksambodhau śikṣitukāmena | iyam eva prajñāpāramitā śrotavyā udgrahītavyā dhārayitavyā vācayitavyā praryavāptavyā | ihaiva prajñāpāramitāyām upāyakauśalyasamanvāgatena | sarvadharmāḥ samudāgamāya yogạ̣ karạ̣īya || tat kasya hetoḥ || iha hi prajñāpāramitāvistareṇa sarvadharmā nirdișțā | yatra bodhisattvena mahāsattvena śikṣitavyaṃ yogam āpattavyam || ye kecit subhūte kuśaladharmā bodhipakșāḥ | śrāvakadharmā vā pratyekabuddhadharmā vā bodhisattvadharmā vā buddhadharmā vā sarve te prajñāpāramitāyām antargatā anupravișțā saṃgraham samavasarạ̣aṃ gacchanti || subhūtir āha || katame te bhagavan prajñāpāramitāyāṃ yogam āpattavyam iti | śrāvakabhūmāv api śikṣitukāmena pratyekabuddhabhūmāv api śikṣitukāmena bodhisattvabhūmāv api śikșitukāmena buddhabhūmāv api śikșitukāmena | iyam eva prajñāpāramitā śrotavyā udgrahītavyā dhārayitavyā vācayita<39v>vyā paryavāptavyā | buddhadharmā bodhisattvadharmāś ceti kuśaladharmā bodhipakṣāḥ | śrāvakadharmā vā pratyekabuddhadharmā vā bodhisattvadharmā vā buddhadharmā vā ye te prajñāpāramitāyāṃ antargatā anupravișțāḥ saṃgrahasamavasarạ̣aṃ gacchanti || bhagavān āha || tadyathāpi subhūte dānapāramitā śīlapāramitā kṣāntipāramitā vīryapāramitā dhyānapāramitā prajñāpāramitā | adhyātmaśūnyatā bahirdhāśūnyatā adhyātmabahirdhāśūnyatā sūnyatāsūnyatā mahāśūnyatā paramārthaśūnyatā saṃskṛtaśūnyatā asaṃskṛtaśūnyatā atyantaśūnyatā anavarāgraśūnyatā anavakāraśūnyatā

9 śikṣitukāmena] $p c . ;$ kșiśitukāmena $a c .15$ śikṣitukāmena] $p c$.; kāmena śikṣitukāmena ac. 21 pratyekabuddhadharmā] $p c$; pratyekadharmā ac. 23 saṃgrahaṃ] corr.; saṃhagram ms. 31 saṃgraha-] $p c$; saṃhagra- $a c$. • tadyathāpi] $p c$; tadyathāpinā $a c$. 
prakṛtiśūnyatā sarvadharmaśūnyatā svalakṣaṇaśūnyatā anupalambhaśūnyatā abhāvaśūnyatā svabhāvaśūnyatā abhāvasvabhāvaśūnyatā || catvāri smṛtyupasthānāni | catvāri samyakprahāṇāni | catvāri ṛddhipādāḥ | pañcendriyāni pañcabalāni saptabodhyañgāni āryāșțāngamārgah || catvāry āryasatyāni catvāri dhyānāni catvāry apramāṇāni catasra ārūpyasamāpattayạ̣ | 5 așțau vimokṣamukhāḥ | navānupūrvavihārasamāpattayạ̣ | śūnyatānimittāpraṇihitavimokșamu<40r>khāni | pañcābhijñāh | trayaḥ samādhayaḥ | sarvadhāraṇimukhāni || daśatathāgatabalāni | catvāri vaiśāradyāni | catasrạ̣ pratisaṃvidaḥ | mahāmaitrī | mahākaruṇā | aștāalaśāveṇikā buddhadharmāḥ || śrotāpattiphalam | sakṛdāgāmīphalam | anāgāmīphalam | arhattvaphalam || pratyekabuddhadharmatā | sarvajñatā | mārgākārajñatāś ceti || iyam eva subhūte kuśaladharmāḥ bodhipakṣāḥ | śrāvakadharmāḥ pratyekabuddhadharmāḥ bodhisattvadharmāḥ buddhadharmāś ca | ye te prajñāpāramitāyām antargatā anupravișțạ̣̄ saṃgraham samavasaraṇaṃ gacchanti || subhūtir āha || aho aho gambhīrā vateyaṃ bhagavan prājñāpāramitā | yatra hi nāma te kuśaladharmāḥ bodhipakṣāḥ śrāvakadharmāḥ pratyekabuddhadharmāḥ bodhisattvadharmāḥ buddhadharmāś ca | ye te prajñāpāramitāyām antargatānupravișțāḥ saṃgrahasamavasaraṇaṃ gacchanti || bhagavān āha || atyantaviśuddhatvāt subhūte prajñāpāramitā || subhūtir āha || aho aho bhagavan duravagāhā vateyaṃ prajñāpāramitā || bhagavān āha || atyantaviśuddhatvāt subhūte prajñāpāramitā || subhūtir āha || aho aho duravagāhā vateyaṃ bhagavan prajñāpārami<40v>tā || bhagavān āha || atyantaviśuddhatvāt subhūte prajñāpāramitā || subhūtir āha || aho aho ākāśasameyaṃ bhagavan prajñāpāramitā || bhagavān āha || atyantaviśuddhatvāt subhūte prajñāpāramitā || tasmāt tarhi subhūte ākāśopamā prajñāpāramitā || subhūtir āha || aho aho ākāśasameyaṃ bhagavan prajñāpāramitā || bhagavān āha || atyantaviśuddhatvāt subhūte prajñāpāramitā || tasmāt tarhi subhūte ākāśopamā prajñāpāramitā || subhūtir āha || aho aho duravagāhā vateyaṃ bhagavan prajñāpāramitā-m-abhisamyuktena || bhagavān āha || evam etat subhūte evam etat | yathā vadasi duradhimucyā prajñāpāramitā anabhiyuktena | parītakuśalamūlena | durmedhasā anarthikena | aśrutena | pāpamitropastabdhena | pāpamitrasaṃsargabahulena | pāpamitrasampradāyakena | śraddhāmātrakasamādāyakena | ādikarmikena |

2 abhāva] pc.; anubhāva- ac. 3 -prahānāni] pc.; -praprahāṇāni ac. 11 arhattva-] corr.; arhatvams. 12 kuśala-] $p c . ;$ kuśa- $a c .13$ pratyeka-] $p c . ;$ pratyekabubhye- $a c .16$ nāma te] $p c . ;$ nāma ac. 19 saṃgraha-] $p c$; saṃhagra- $a c .20$ duravagāhā] corr.; duragāhā ms. 21 -viśuddhatvāt] $p c$; - viśuddhatvāprat $a c .22$ duravagāhā] $p c$; duragāhā $a c$. 
abhavyarūpena | aparipṛcchakajātīyena | kusīdena | hīnavīryeṇa | hīnasattvena | hīnādhimuktikena | kuśalena parameșu paribhrașțena || tasmāt tarhi subhūte duradhimucyā prajñāpāramitā ucyate || punar aparaṃ subhūte yaḥ kaścit ku<41r>laputro vā kuladuhitā vā imāṃ gambhīrāṃ prajñāpāramitāṃ śroṣyanti dhārayișyanti vācayișyanti paryavāpsyanti | so 'tītānāgatapratyutpannanāṃ bhagavatāṃ bodhiṃ dhārayiṣyanti || tasmāt tarhi subhūte kulaputreṇa vā kuladuhitā vā adhyāśayena kṣipram cānuttarāyāṃ samyaksambodhim abhisambudhyata iti || abhīṣnam ca prajñāpāramitā śrotavyā udgrahītavyā dhārayitavyā vācayitavyā paryavāptavyā kṣipraṃ cānuttarāyāṃ samyaksambodhim abhisambhotsya iti || 22 || idam avocad bhagavān āttamanā āyuṣmāṃś ca subhūtis te ca bhikṣavas te ca bodhisattvā mahāsattvāḥ sā ca sarvāvatī parșat sadevamānuṣāsuragandharvaś ca loko bhagavato bhāṣitam abhyanandann iti || ||

āryārdhaśatikā-prajñāpāramitā samāptaḥ || ||

[55] om namo bhagavatyai ārya-pītavarṇaprajñāpāramitāyai || purvoktavidhānenākāraje candre pītadhīḥāraviśvapadmo pītahaḥkāra makārādiṣoḍaśasvarapariveșṭitam bahị̣kakārādidvātriṃśadvarṇaparivṛtaṃ bhāvayet | tato lāsyā nụtyā gītā puṣpā dhūpā dīpā gandhā | ity așțai yoginī<41v> h | etat sakalapariṇāmena candra udeti | prabhābhāsvaraḥ tadupari prajñāpāramitāpuṣțakam | tadupari dvitīyaṃ candramaṇḍalam | tadupari dvitīyapuṣțakam | sarvam etat pariṇamya bhagavatī prajñāpāramitā pītavarṇā dvibhujaikamukhī pañcatathāgatamakuṭā | vyākhyānamudrāvatī viśvadalapadmacandrāsanāsīnā sarvālaṃkāravastravatī vāmadakṣiṇapārśve utpalasthaprajñāpāramitāpustakadhāriṇi || mantra || oṃ ạ̣ svāhā || pītahūṃkāro lalāṭe śukla-aḥkāra kạ̣ṭhe | pītadhīḥkāro hṛdi kṛ̣̣ṇahūṃkāro nābhāv iti | japakāle catvāry akṣarāṇy anucintayed iti || oṃ dhịḥ śrutismṛtivijaye svāhā 'ti mantram japet || ||

ārya-śrī-pītavarṇa-prajñāpāramitā-dhāraṇī samāptaḥ || ||

2 -muktikena] pc.; -muktinake ac. • paribhrașțena] pc.; paribhratenaște ac. 20 dvitīyaṃ] corr.; dutīyaṃ ms. 26 akṣarāṇy] $p c$.; akșarāṇi $a c$. 
[56] oṃ namo bhagavate ārya-prajñāpāramitāyai || oṃ munidharme saṃgrahadharme anugrahadharme vimuktidharme sadānugrahadharme vaiśravaṇaparikīrtitadharme sarvakāryaparipālanadharme | samanuparivartitadharme svāhā || oṃ prajñe 2 śrutismṛtigativijaye dhīdhāranīye svāhā || anayā dhāritayāșțaśatasāhasrikāprajñāpāramitā dhāritā bhavati || || <42r> 5

ārya-prajñāpāramitā-dhāraṇī samāptaḥ || ||

[57] oṃ namo mañjunāthāya \|

namas te varada vajrāgra bhūtakoṭi namo 'stu te | namas te śūnyatāgarbha buddhabodhi namo 'stu te \| buddharāga namas te 'stu buddhakāya namo namaḥ | buddhaprīti namas tubhyam buddhamoda namo namạ̣ \| buddhasmita namas tubhyaṃ buddhahāsa namo namạ̣ | buddhavāca namas te 'stu buddhabhāva namo namah || abhavodbhava namas te 'stu namas te buddhasambhava | gaganodbhava namas tubhyam namas te jñānasambhava \| māyājāla namas tubhyaṃ namas te buddhanāțaka| namas te sarva sarvebhyo jñānakāya namo 'stu te || yaṃ ca tathāgatastutigāthāḥ pañceti || || oṃ sarvadharmābhāvasvabhāvaviśuddhavajra a āḥ aṃ aḥ prakṛtipariśuddhāḥ sarvadharmā yad uta sarvatathāgatajñānakāyamañjuśrīpariśuddhitām upādāyeti | a āḥ sarvatathāgatahṛdaya hara hara oṃ hūṃ hrīḥ bhagavan jñānamūrtivāgiśvara mahāvāca sarvadharmagaganāmalasupariśuddhadharmadhātujñānagarbha āḥ || || atha vajradharaḥ śrīmān hṛștạ tuṣțaḥ kṛtāñjalị̣ praṇamya nātham sambuddham bhagavantam tathāgatam | anyaiś ca bahuvidhair nāthair guhyendrai<42v>r vajrapāniibhis sa sārdhaṃ krodharājānaih provācoccair idaṃ vacạ̣ | anumodāmahe nātha sādhu sādhu subhāṣita kṛto 'smākaṃ mahānāthah samyaksambuddhaprāpakah | jaganuś cāsya nāthasya vimuktiphalakānikșinah śreyo mārgo viśuddho 'yaṃ māyājālanayoditaḥ | gambhīrodāravaipulya mahārtho jagadarthakṛt buddhānāṃ viṣayo hy eșa sarvasambuddhadeśita iti || ||

3 -parikīrtita-] corr.; -parirtita- ms. $\mathbf{8}$ varada-] pc.; vajrarada- $a c . \quad 15$ namas] $p c . ;$ namas tes ac. 30 vimuktiphala-] $p c$; vimuktināphala- ac. 31 mārgo] corr.; mārno ms. 32 -jagadartha-] $p c . ;$-jagarthada- $a c$. 
ārya-māyājālaṣoḍaśasāhasrikān mahāyogatantrāntaḥpātisamādhijālapaṭalād bhagavattathāgataśākyamunibhāṣitā bhagavato mañjuśrījñānasattvasya paramārthā nāmasaṃīitị parisamāptā || ||

[58] oṃ namo mañjunāthāya || oṃ namo bhagavate mañjuśrīkumārabhūtāya bodhisattvāya mahāsattvāya mahākāruṇikāya ||

tadyathā || om araje viraje śuddhe viśuddhe śodhani viśodhani amale vimale jayavāhani ruru cale hūṃ hūṃ hūm phaṭ phaṭ phaṭ svāhā || imāṃ dhāraṇīm dhārayet vācayet samprakāśayet sa medhāvī bhavanti susuro bhavati saṃskṛtasūtraśāstram pratigṛhṇāmi ekavāroccāritamātreṇa kalpakoțīsamcito 'pi sarvapāpa kṣayam gacchati ekalakṣajāpena pa<43r>ṇdito bhavanti dvitīyalakșajāpena vidyādharo bhavanti tṛtīyalakṣajāpena mañjuśrīrūpaṃ paśyanti pañcānantaryakāriṇo 'pi siddhi syāt yadi siddhati ||

ārya-mañjuśrībhațtāakakasya pratijñā-nāma-dhāraṇī samāptaḥ || ||

[59] oṃ namo șațpāramitāyai ||

oṃ amoghapāśamahādānapāramitāparipūraye hūṃ dara 2 vividhavicitrai sarvasattvā upabhogasarvatathāgatamahādānapūjāmeghapravartaya tara 2 tāraya mahāpadmapāṇi hūṃ phaṭ svāhā || dānapāramitā || 1 || oṃ amoghaśira sambhara 2 bara 2 mahāśuddhasattva padmavibhūṣitabhujadharasamantāvalokite hūṃ phaṭ svāhā || śīlapāramitā || 2 || om mahāvīrya amoghavilokite vara 2 dṛ̣havīryamahābala hūm mahābodhyambarabodhani hūm phaṭ svāhā || kṣāntipāramitā || 3 || oṃ amoghayakṣādhisattvakṣamaṇi hmaṇa 2 mahāmaitrīkāruṇa sarvasattvavatsalamahākāruṇika sarvasattvakṣamị̣i hūṃ phaṭ svāhā || vīryapāramitā || 4 || oṃ sarvatathāgatamahākāruṇadhyānasamādhisarvavimokṣa aprakampaka curu 2 hūṃ phạ svāhā || dhyānapāramitā || 5 || om amoghamahāprajñāvabhāsa spharaṇa<43v>buddhi prasara 2 samantabuddhi-avalokite bhagavān prajñāvalokite cakṣuṣe mahāprajñāvaradapāṇi mahāprajñāpadmadhāriṇabhuje hūm phat svāhā || prajñāpāramitā || 6 ||

oṃ namo dharmakāya sambhogakāya nirmāṇakāya || tadyathā || dānapāramitā šilapāramitā kṣāntipāramitā vīryapāramitā dhyānapāramitā prajñāpāramitā sarvadharmaśūnyatā svāhā ||

4 -bhūtāya] corr.; -bhūtvāya ms. 27 -prajñāvabhāsa] corr.; -prajñā amebhāsa ms. 29 -varadapāṇi] corr.; -padararpāṇi $a c .$, -paradarpāṇi $p c$. 
ārya-ṣaṭpāramitā-hṛdaya-nāma-dhāraṇī samāptaḥ || ||

jinasya mātāṃ vimalāṃ praṇamyaṃ lekhāpanāt puṇyam upārjitayet | tenāstu mātā khila dharmapūrṇaḥ prajñā yathāsaugatadharmapūrṇaḥ || ||

[60] oṃ namaḥ śrī-jambhalāya \|

atasīpuṣpasaṃkāśam lokanāthasureśvaram |

kāmarūpadhara śrīmān kṛ̣̣narāja namas tu te || 1 ||

taptakāñcanavarṇābhā kirīṭamakuṭojjvalā

sarvalakṣaṇasampūrṇa pūrṇabhadra namo 'stu te || 2 ||

raktagauramahāteja cintāmaṇir ivojjvala |

lokaśreșṭha mahāvīra māṇibhadra namo 'stu te || 3 ||

sarojagarbhanirbhāsa ratnābharaṇabhūṣita |

dhaneśvara iti khyāta lokapāla namo 'stu te || 4 ||

śan̉khakundendusaṃkāśam śvetapadmāni bhakṣaṇam |

kalpavṛkșamahākāya amṛto<44r>gha namo 'stu te || 5 ||

āvāhanasuraḥ́reșțha indranīlasamaḥprabha |

ratnahastamahātejah yakṣarāja namo 'stu te || 6 ||

nīlajīmūtasaṃkāśam meghadundubhị̣ niḥsvanạ̣ |

kleśāntakamahābhāga yakṣāntaka namo 'stu te || 7 ||

dvādaśārkamahāteja bhṛtātmakumudaśramaḥ |

arthinām arthadātā ca namas te-v-astu sādhaka || 8 ||

ye tām ca yaḥ paṭhet nityaṃ śraddhācittena mānavạ̣ |

śriyaṃ cālabhate rājā sāgarāntā ca medinī || 9 ||

siṃhāsanasukhāsīnā varabodhisamanvitaḥ|

sattvānāṃ deśayed dharmaṃ sarvasattvahitecchayā || 10 ||

yakṣāṣțakam idam stotram yah paṭhec chrīmato naraḥ |

sarvapāpaviśuddhātmā bodhị̣ cālabhate kramāt || ||

iti yakṣāṣțakaṃ saṃyaksambuddhabhāṣitam samāptaḥ || ||

[61] oṃ namaḥ śrī-jambhalāya || evaṃ mayā śrutam ekasmin samaye bhagavān śrāvastyāṃ viharati sma || jetavane anāthapiṇḍadasyārāme mahatā bhikṣusaṃghena sārdham ardhatrayodaśabhir bhikṣuśataih || atha khalu māṇibhadro mahāyakșasenāpatir yena bhagavān tenopasaṃkrāntopasaṃkramya bhagavanta pādau śirasā vanditvā ekānte 'sthāt

2 praṇamyaṃ] corr.; praṇasmam ms. 4 jambhalāya] ac.; jambhalājāya pc. 16 -hasta] pc.; -hastasa ac. 19 dvādaśārka] pc.; dvādarkaśā- ac. 27 yakșāșțakaṃ] corr.; yakșāșțạ̣ ms. 32 śirasā vanditvā] corr.; śiranditvā ms. 
| ekānte sthito mahāyakṣasenāpatir bha<44v>gavantam etad avocat || idaṃ bhagavan mama hṛdayaṃ yạ̣ kaścit kulaputro vā kuladuhitā vā bhikṣuṇī vā upāsako vā upāsikā vā tadanyo vā dhārayiṣyati tasya sarvakāryāṇi kariṣyāmi rātrau trikṛtvā divasa trikṛtvā dhārayiṣyati vācayiṣyati | tasya hi dhanadhānyahiraṇyasuvarṇabhājanaṃ ca prāpayiṣyāmi ||

oṃ namo ratnatrayāya || oṃ namo māṇibhadrāya mahāyakṣasenāpataye samupasthitam | oṃ hili māṇibhadra hili 2 māṇibhadra kili māṇibhadra kili 2 māṇibhadra śili māṇibhadra śili 2 māṇibhadra | kulu māṇibhadra kulu 2 māṇibhadra | suru māṇibhadra suru 2 māṇibhadra | sarvāsaām paripūraya || tadyathā || surate surakti sumane surathe sayașya hili mili kili keli kāli pūrṇabhadra tili 2 svāhā || ||

ārya-jambhalajalendrasya-nāma-dhāraṇī samāptaḥ || ||

[62] oṃ namo bhagavatyai ārya-śrī-vasudhārāyai ||

kalpoditena vidhinā paripaṭyamānā yā dhāraṇī vividharatnasuvarṇamayyai | pūrṇam karoti bhavanam sahasaiva sarvaṃ tāṃ sarvalokajananīṃ praṇamāmi bhaktyā ||

tvaṃ devī sarvaguṇaratnamahānidhānaṃ sattvārthakāryadhanadhānyasamṛ <45r>ddhahetụ̣ |

hārārdhahāramakuṭā mạ̣ikalpavṛkṣā trailokyanāthavasudhā vasudhāranāmā || utsṛșțarogābhayamṛtyur anekadoṣadāridyraduḥkhavraṇarohaṇam auṣadhīnām |

saubhāgyarūpaguṇapuṣkalagātravarṇaṃ sarvaṃ dadāsi tava pādayugaṃ namāmi \|| yā samyaguktavidhibhị̣ paripaṭhyamānā lakṣmīṃ dadāti vipulāṃ sugatopabhogyām |

tāṃ dhāraṇịm sakalasattvahitaikacitto bhaktyā namāmi satataṃ vasudhārasamijñām \|

yā saṃsmṛtā sucirasuṣṭhutaraṃ pravṛddhaṃ dāridryaduḥkhaduritaṃ satate narāṇām |

tāṃ kalpavṛkṣasadṛśīvasudhārasaṃjñām bhaktyā namāmi śirasā jagato hitāya || 30 ratnākaraṃ ratnanidhānakośāṃ vicitraratnāṃ pratibhāsavarṣām | ratnāvatīṃ ratnamayīm vicitrāṃ namāmi cāryāṃ vasudhāradhārām || yā ratnapāṇisaphalām avabhāsayantī tyāgāvataṃ sadayaśekharam udvahantī | hārārdhahāracalanakuṇụalabhūṣitāṅgīm āryam namāmi satataṃ vasudhārasaṃjñām || ||

15 pūrṇaṃ] $p c . ;$ pūrṇambha $a c . \quad 19$-nāmā] $p c$;-mānāmā $a c . \quad 26$ sakala-] $p c . ;$ saka- $a c$. 
evaṃ mayā śrutam ekasmin samaye bhagavān kauśāmbyāṃ mahānagaryāṃ viharati sma || kaṇṭhakasaṃjñake mahāvanavare ghoṣitārāme mahatā bhikṣusaṃghena sārdhaṃ pañcamātrair bhikṣusaṃhaśa<45v>taih sambahulaiś ca śrāvakair asaṃkhyeyaiś ca bodhisattvair mahāsattvaiḥ \| sarvaguṇasamanvāgataị || tatra khalu bhagavāṃs tasyām eva parṣadi tair eva pariṿ̂tah puraskṛtạ̣ sarvadāridryaduḥhāannavapariśodhanaṃ nāma dharmaparyāyaṃ deśayati sma || ādau kalyāṇaṃ madhye kalyāṇaṃ paryavasāne kalyāṇaṃ svarthaṃ suvyañjanaṃ kevalaṃ paripūrṇaṃ pariśuddham paryavadātam brahmacaryam samprakāśayati sma || tena khalu punạ̣ samayena kauśāmbyāṃ mahānagaryāṃ sucandro nāma gṛhapatih prativasati sma | upaśāntendriyopaśāntamānasā bahuputro bahuduhitaro bahubhṛtyaparijanasampannaḥ śrāddhamahāśrāddhaḥ || tena khalu punaḥ samayena yena bhagavāṃs tenopasaṃkrānta upasaṃkramya bhagavatạ pādau śirasābhivanditvā bhagavantam anekaśatasahasrapradakșiṇīkṛtyaikānte nyașīdat | ekānte niṣaṇṇaḥ sucandro nāma gṛhapatir bhagavantam etad avocat || pṛccheyam ahạ bhagavantam tathāgatạ̣ arhantam samyaksambuddhạ̣ kaścid eva pradeśam sacen me bhagavān avakāśam kuryāt prșțapraśnavyākaraṇāya || evam ukte bhagavān sucandraṃ nāma gṛhapatim etad avocat | pṛccha tvam gṛhapate yad yad evākāṅkṣasyāhaṃ te tatra praśnavyākaraṇena <46r> cittam ārādhayiṣye || evam ukte sucandro nāma gṛhapatị̣ sādhu bhagavann iti | bhagavato vacanam pratiśrutya bhagavantam etad avocat || katham bhagavan kulaputro vā kuladuhitā vā daridro bhūtvā adaridro bhavati | vyādhitaś ca bhūtvā avyādhito bhavati || atha khalu bhagavān jānann eva sucandraṃ gṛhapatim etad avocat || kim iti tvaṃ gṛhapate daridratāyāḥ paripraśnaṃ pṛcchasi || evam ukte sucandro nāma gṛhapatir bhagavantam etad avocat | daridro 'ham bhagavan daridro 'haṃ sugata bahupoṣyo bahuputro bahuduhitṛko bahubhṛtyaparijanasampannạ̣ | tad deśayatu bhagavān dharmaparyāyạ̣ yena daridrasattvā adaridrā bhaveyuh | vyādhitāś ca sattvā avyādhitā bhaveyuḥ | bahudhanadhānyaratnasuvarṇakośakoṣthāgārasampanno bhaveyụ | priyā manāpā paramamanojñāḥ sudarśanīyāś ca bhaveyuh | dānapataye mahādānapatayaś ca akṣiṇyahiraṇyasuvarṇadhanadhānyakośakoṣṭhāgārāś ca bhaveyụ̣ | maṇimuktivajravaidūryaśan̉khaśilāpravāḍajātarūparajatatāmramarakatapadmarāgasamṛddhāś ca bhaveyuḥ |

5 tasyām] $p c$.; tasyāvem $a c . \quad 9$-dātaṃ] corr.; -dānta ms. 12 -parijana-] corr.; -parivājanams. 20 tatra] $p c$.; praśna tatra $a c$. 
supratișțhitagṛhabhāryāputradārakadārikādāsīdāsakarmakarapreṣakaja<46v> nasampannā kuṭumbāś ca bhaveyuh || evam ukte bhagavān sarvāsaāparipūrakeṇa brahmasvareṇa sucandraṃ g̣̣hapatim etad avocat || asti gṛhapate bhūtapūrvam atīte 'dhvany asaṃkhyeyeșu kalpeșu yadāsīt tena kālena tena samayena vajradharasāgaranirghoṣo nāma tathāgato 'rhan samyaksambuddho loka utpādi vidyācaraṇasampannaḥ sugato lokavid anuttaraḥ puruṣadamyasārathị̣ sāātā devānām ca manuṣyāṇām ca buddho bhagavān tasyāntikān mayā kulaputra vasudhārā-nāma-dhāraṇī śrutvā udgṛhītā dhāritā vācitā deśitā paryavāptā anumoditā parebhyaś ca vistareṇa samprakāśitā | aham apy etarhi te kulaputra tāṃ dhārạ̣ị̄ tathā bhāṣiṣye || yathā asyā dhāraṇyāḥ prabhāvena kulaputra mānuṣā na viheṭhayanti | amānuṣā na vihețhayanti | devā na vihețhayanti || nāgā na vihețhayanti || yakṣā na vihețhayanti || asurā na vihețhayanti || rākṣasā na viheṭhayanti || bhūtā na vihețhayanti || pretā na vihețhayanti || piśācā na vihețhayanti || kumbhāṇḍa na vihețhayanti || ostārakā na vihețhayanti || apasmārā na viheṭhayanti || gandharvā na vihețhayanti || kiṃnarā na vihețhayanti || mahoragā na vi<47r>hețhayanti || pūtanā na vihețhayanti | kațapūtanā na vihețhayanti || sarvagrahā na vihețhayanti || sarvadevā na vihețhayanti || kṣutpipāsā na vihețhayanti || sarvāhārā na vihețhayanti || evaṃ yāvat puṣpāhārāḥ || phalāhārāh || khecāhārāḥ | skandhāhārāḥ | mūlāhārāḥ | gandhāhārāḥ | dhūpāhārāḥ | dīpāhārāḥ | mālyāhārāh | āhutyāhārāh | ojohārāḥ | svedāhārāḥ | rasāhārāḥ | raktāhārāḥ | māṃsāhārāḥ | medāhārāḥ | asthyāhārāḥ | majjāhārāḥ | rudhirāhārāḥ | śukrāhārāḥ | jīvitāhārāḥ | sarve na vihețhayanti || evaṃ yāvad vișțāhārāḥ | mūtrāhārāḥ | khețāhārāḥ | singhāṇakāhārāḥ | kledāhārāḥ | klinnāhārāḥ | syandinikāhārāḥ | vāntāhārāḥ | śleṣmāhārāḥ | ucchiștāhārāḥ | anucchișțāhārāḥ | ucchișțāhārāḥ | śasyāhārāḥ | garbhāhārāḥ || sarve na vihețhayanti | sarve ḍākinyo na vihețhayanti | chāyā na vihețhayanti | jātā na vihețhayanti || bhāvanāhārāḥ | rūpāhārāḥ | śabdāhārāḥ | gandhāhārāḥ | rasāhārāḥ | sparśāhārāḥ | āhutyāhārāḥ | nānārūpāhārāḥ | virūpāhārāḥ | anantarūpāhārāḥ | kāmarūpāhārāh | vicitrarūpāhārāh | va<47v>strāhārāḥ | balyāhārāḥ | aśucyāhārāḥ | vicitrāhārāḥ || yāvad ucchișțāhārā na viheṭhayanti | yāvat khecarāḥ | bhūcarāḥ | antarīkṣacarāḥ | pātālacarāḥ | sthalacarāḥ | jalacarāḥ | vanacarāḥ | sarve na viheṭhayanti || eteșāṃ mama sarvasattvānāṃ ca mahāvajrena mūrdhni sphālanāya sphoțanāya praharạ̣āya hūṃ hūṃ phaṭ vajrena sarvaduṣtānām sarvaśatrūṇām māraya 2 śoṣaya 2 stambhaya 2

4 asti] $p c$; ahasti ac. •-āsīt] corr.; -āsī ms. 21 svedāhārāḥ] pc.; svedāhāhārāḥ ac. 26 ucchișțāhārāḥ] corr.; ucchusitāhārāḥ ms. 27 jātā] $p c$. jātāhārā $a c . \quad 30$ ananta-] $p c$;; antana- $a c$. 
bandhaya 2 hana 2 daha 2 paca 2 mara 2 māraya 2 sarvaśatrūn nāśaya 2 hūṃ hūṃ phaṭ svāhā ||

yasya ca kulaputrasya ca kuladihitur vā kulaputra iyaṃ gṛhapate vasudhārā-nāma-dhāraṇī śrāddhasya hṛdayagatā gṛhagatā hastagatā pustakagatā śrutimātragatā | paryavāptā manasā suparicintintā dhāritā vācitā likhitā anumoditā yāvat parebhyaś ca vistareṇa samprakāśitā || tasya kulaputrasya vā kuladuhitur vā dīrgharātram arthāya hitāya sukhāya kṣemāya subhikṣāya yogasambhārāya bhavișyati || yaś cemāṃ vasudhārānāma-dhāraṇị̣̄ tathāgatebhyo 'rhadbhyaḥ saṃyaksambuddhebhyaḥ | udārāṃ pūjāṃ kṛtvā namaskṛtvā āvartayet || sarvatathāgatānāṃ sarvaśrāvakapratye<48r>kabuddhānāṃ sarvabodhisattvānāṃ sarvatathāgatasarvamudrāmantravidyādevatānāṃ tebhyaḥ sarvapūjābhi pūjayet || ardharātre tricaturvārāṇi | tasya devatā āttamanaskāḥ pramuditā prītisaumanasyajātā vācayeyuḥ | tadā bhagavatyā vasudhārayā svayam evāgatya dhanadhānyahiraṇyavṛṣtị̣ pātayiṣyanti || prītyā tathāgataśāsane prītyā buddhaprajñaptyā prītyā dharmaprajñaptyā prītyā saṃhaprajñaptyā prītyā sarvaśrāvakapratyekabuddhaprajñaptyā | prītyā pañcakulā prasthitamudrāmantravidyādevatā prajñaptyā | prītyā dharmabhāṇakasyāśayena || oṃ namo ratnatrayāya || oṃ namo bhagavatyai ārya-śrī-vasudhārāyai || om namo bhagavate śrīvajradharasāgaranirghoṣāya tathāgatāyārhate samyaksambuddhāya || om namo bhagavate 'kṣobhyāya tathāgatāyārhate samyaksambuddhāya || oṃ namaḥ sarvatathāgatāyārhate samyaksambuddhāya || oṃ namạ̣ sarvatathāgatebhyo 'tītānāgatapratyutpannebhyạ̣ || namaḥ kṣamaṃkarasya tathāgatasya | oṃ namo vajradharasāgaragambhīrasya tathāgatasya | agrayugaprāptebhyo vipaśyādibhyaḥ śākyamunibhyo dānapāramitāparipūrṇebhyo bhagavadbhyaḥ | vipaśyinas tejasā ṛddhyā ca <48v> śikhinas tathā | viśvabhuprajñayā caiva krakucchandabalena ca \| kanakamune śikṣāyā kāśyapasya dhutair guṇaị̣ | sākyasiṃhasya vīryeṇa maitreyasya pratijñayā || samṛddhyantu me tathāgatasya ime mantrapadāh | sarvasattvahito vidyā dāridryavyādhiduḥkhavyasanārṇavamocakebhyạ̣ | imāṃ vasudhārā-nāma-dhāraṇīm vidyārahasyaṃ pravakșyāmi || tathāgatabhāṣitasyārthamantrapadānyeșum anusmarāmi || tadyathā || oṃ hūṃ hūṃ dhana 2 dhanaiśvarya śukramāṇe akṣayakośe cintitotpādani sammohani manasi sādhani mano-icchāsādhani śodhanakari |

26 vipaśyādibhyaḥ] corr.; vipadibhyaḥ ms. 32 dāridrya-] pc.; dāridryaduhac. 33 pravakṣyāmi] corr.; pravakșāmi ms. 
koțe 2 koṭāvare koṭiśvarye anantāparyantasarvaratnavastrālaṃkārābharaṇāni dhanadhānyavṛddhiṃkari cintitotpatti sammohani | śukrasya koṣakoṣthāgāradohani bṛhaspate matam apaharaṇi buddhe 2 buddhasatye dharmasatye samghasatye | sarvabuddhabodhisattvasatye | bodhiprāgbhārasatye | sarvaśrāvakapratyekabuddhasatye | brahmasatye | viṣnusatye | rudrasatye | lokapālasatye dhanadasamājñādhari hiraṇyasuvarṇamaṇimuktivajravaiḍūryaśan̉khaśilāpravāọajātarūparajatamarakatapadmarāgaindranīlakarkețanasarvadravyasamṛddhaye | catuh<49r>ṣașțivrīhisahasrāṇām ādhipatyaṃ kārayati | ehy ehi bhagavati vajradharasāgaragambhīrabuddhasatye satyavādini || om cara 2 ciri 2 curu 2 hulu 2 mulu 2 lu lu lu lu lu | le le le le le | iṭi 2 miṭi 2 sara 2 saṃsara 2 visara 2 ihāgacchāgaccha bhagavati vasudhāre mama sarvasattvānāṃ ca gṛhe sādhakānāṃ mano-icchāgamaṃ paripūraya 2 uttișṭ̂a vidyā sarvabuddhā bhagavanta samājñāpayati svāhā || namas traiyadhvikānāṃ sarvatathāgatānām \| tadyathā || oṃ namo ratnatrayāya || oṃ namaś caṇḍavajrapāṇaye | oṃ namo vajrakrodhāya mahādaṃștrotkațabhairavāya | asimusalaparaśupāśagṛhītahastāya || oṃ amṛtakuṇụali kha kha khāhi 2 tiștha 2 bandha 2 hana 2 daha 2 paca 2 mara 2 māraya 2 garja 2 garjaya 2 visphoțaya 2 sarvavighnavināyakānāṃ mahāgaṇapatijivitāndhakārāya hūṃ 2 phaṭ svāhā || oṃ śumbhani 2 hūṃ gṛhṇa 2 hūṃ gṛhṇāpaya 2 hūm ānaya ho bhagavan vidyārāja hūṃ 2 phaṭ svāhā || oṃ vajrayakṣa hana hūṃ phaṭ svāhā || oṃ āharite mahābale hūṃ svāhā || oṃ āḥ hūṃ svāhā || oṃ āḥ sitātapatre hūṃ svāhā || oṃ maṇipadme hūṃ svāhā || oṃ vajradharme hūṃ svāhā || oṃ sarvaviśuddhidharmatā vajrasiddhi hūṃ phaṭ svāhā || <49v> oṃ sarvatathāgatajñānayogīśvari hūṃ svāhā || oṃ śrī-sarvatathāgatabhavāya hūṃ svāhā || oṃ prajñe 2 mahāprajñe śrutismṛtimativijaye svāhā || oṃ cale 2 cunde svāhā ||

tadyathā || oṃ śrī-saumyarūpe svāhā || oṃ śrī-divyarūpe svāhā || oṃ śrīdīptarūpe svāhā || oṃ śrī-bahurūpe svāhā | oṃ śrī-rūpamate svāhā | oṃ śrīrūpaśobhe svāhā || oṃ śrī-rūpamati svāhā || oṃ śrī-suvarṇavapuṣe svāhā || oṃ śrī-jñānarūpe svāhā || oṃ śrī-prajñāpāramite svāhā || oṃ śrī-vajrasattvahṛdaye svāhā || om śrī-bhadre svāhā || oṃ subhadre svāhā || oṃ śrī-bhadramati svāhā || oṃ śrī-subhadramati svāhā || oṃ śrī-mangale svāhā || oṃ śrī-sumañgale svāhā || oṃ śrī-mañgalamati svāhā || oṃ śrī-ālaye svāhā || oṃ śrī-candre svāhā || oṃ sucandre svāhā || oṃ candramati svāhā || oṃ śrī-sucandramati svāhā ||oṃ

1 anantāparyanta-] corr.; anantāparya- ms. 6 -samājñādhari] $p c$.; -samājñānādhari ac. 13 -buddhā] $p c$.; -buddhānā $a c . \quad$ • -jñāpayati] $p c$.; -jñāpatiya $a c .18$ garja] $p c$.; garjaya ac. 25 -tathāgata-] corr.; -tathāta- ms. 
śrī-ale ale svāhā || oṃ śrī-amale svāhā || oṃ śrī-vimale svāhā || oṃ śrī-nirmale svāhā || oṃ śrī-malanāśani svāhā || oṃ śrī-cale 2 svāhā || oṃ śrī-acale svāhā || oṃ śrī-acapale svāhā || oṃ śrī-udghātani svāhā || om śrī-udbhedani svāhā || oṃ śrī-udbhāsani svāhā || oṃ śrī-udghoṣaṇi svāhā || oṃ śrī-priyaṃkari svāhā || oṃ śrī-prītikari svāhā || oṃ śrī-śriyaṃkari svāhā || oṃ śrī-śi<50r>vaṃkari svāhā || oṃ śrī-śubhaṃkari svāhā || oṃ śrī-śrīkari svāhā || oṃ śrī-kīrtikari svāhā || oṃ śrī-lakṣmīkari svāhā || oṃ śrī-satyavati svāhā || oṃ śrī-śasyavati svāhā || oṃ śrī-dhanakari svāhā || oṃ śrī-dhanadhānyavati svāhā || oṃ śrī-dhanavati svāhā || oṃ śrī-dhānyavati svāhā || oṃ śrī-dhana 2 svāhā || oṃ śrī-dhanaiśvarya svāhā || oṃ śrī-śrī-mati svāhā || oṃ śrī-prabhāmati svāhā || oṃ śrī-rurumati svāhā || ọ̣ 10 śrī-surūpamale svāhā || oṃ śrī-vigatamale svāhā || oṃ śrī-vipulagarbhe svāhā || oṃ śrī-akṣayamate svāhā || oṃ śrī-akṣayakośe svāhā || oṃ śrī-dhanadaprade svāhā || oṃ śrī-icchāprade svāhā || oṃ śrī-sarvasukhaprade svāhā || oṃ śrīdhanade dhanadapūjitāya svāhā || oṃ śrī-pūjanīye svāhā || oṃ śrī-arcanīye svāhā || oṃ śrī-arcanāste svāhā || oṃ śrī-ananaste svāhā || oṃ śrī-vinanaste svāhā || oṃ śrī-ananaste vinanaste svāhā || oṃ śrī-dhinanaste svāhā || oṃ śrī-viśvanaste svāhā || oṃ śrī-viśvakeśi svāhā || oṃ śrī-viśvarūpe svāhā || oṃ śrīviśvaṛ̣i svāhā || oṃ śrī-suviśuddharūpe svāhā || oṃ śrī-viśuddhaśīle svāhā || om śrī-viguṇi viguṇiṣe viguṇe svāhā || oṃ śrī-viguṇiṣe svāhā || oṃ śrī-an̉kule svāhā || om śrī-mañkule svāhā || om śrī-prabhaṃ<50v>kule svāhā || om amoghāṅkuśe jaḥ hūṃ vaṃ hoḥ svāhā || oṃ śrī-icchāsiddhipravartani svāhā || oṃ śrī-ākarṣaṇi svāhā || oṃ śrī-āveśani svāhā || oṃ śrī-praveśani svāhā || oṃ śrī-ririme svāhā || oṃ śrī-rurume svāhā || oṃ śrī-dhadhame svāhā || oṃ śrī-dhidhime svāhā || oṃ śrī-dhudhume svāhā || oṃ śrī-khakhame svāhā || oṃ śrī-khukhume svāhā || oṃ śrī tara 2 svāhā || oṃ śrī tare taratare tāra tame tarura virura tāraya 2 om śrī tārayantu māṃ bhagavati vasudhārā-nāma-dhāraṇi mama sarvasattvānāṃ ca icchāgamena svāhā || oṃ śrī-bhagavati oṃ tāre tuttāre ture svāhā || oṃ śrī-bhagavati vasudhārā-nāma-dhāraṇi mama mahārakṣāvaraṇaguptiṃkari svāhā || oṃ śrī-vajre 2 mahāvajre svāhā || oṃ śrī-vajropame svāhā || oṃ śrīmahāvajropame svāhā || oṃ śrī-āvartani svāhā || oṃ śrī-pravartani svāhā || oṃ śrī-niṣpādani svāhā || oṃ śrī-vasudhāre svāhā || oṃ śrī-vasuṃdade svāhā || oṃ śrī-vasudhe kuru 2 svāhā || oṃ śrī-ṭakke 2 svāhā || oṃ śrī-ṭhakke 2 svāhā || oṃ śrī-ḍakke 2 svāhā || oṃ śrī-ukke 2 svāhā || oṃ śrī-tukke 2 svāhā || oṃ śrī-bukke 2 svāhā || oṃ śrī-țaukke 2 svāhā || om śrī-dhakke 2 svāhā || oṃ śrīvarṣaṇi svāhā || oṃ śrī-pravarṣaṇi svāhā || oṃ śrī-utthāpani svāhā || oṃ śrī-va<51r>jradharasāgaragambhīranirghoșatathāgatasatyam anusmara

11 om] pc.; om. ac. 12 akșayamate] pc.; akșamayate ac. 15 vinanaste] pc.; viśvananaste ac. 17 oṃ] $p c$. om vi $a c . \quad 35$-thāpani] corr.; -thāpavi ms. 
svāhā || oṃ śrī-sarvatathāgatasatyam anusmara 3 svāhā || oṃ śrīsarvabuddhasatyam anusmara 3 svāhā || oṃ śrī-sarvadharmasatyam anusmara 3 svāhā || oṃ śrī-sarvasaṃghasatyam anusmara 3 svāhā || oṃ śrī tața 2 mama saparivārasya sarvasattvānāṃ ca sarvāsaāparipūrakeṇa mama sarvasattvānāṃ ca gṛhe ākāśagatạ̣ vā pṛthivīgataṃ vā jalagataṃ vā sthalagataṃ vā antarīkṣagataṃ vā bhūmigatạ̣ vā svargagataṃ vā martyagataṃ vā pātālagatạ̣ vā samudragatạ̣ vā saptadvīpāntagataṃ vā sarvatragataṃ vā parvatāntargataṃ vā bhagavati vasudhāre 'smin gṛhe maṇimuktivajravaiḍūryaśan̉khaśilāpravāọajātarūparajatamarakatamusāragalvakarketanapadmarāgendranīlādyanekaratnāni suvarṇarajatatāmralohadhātumūlajīvādīni

cānekadhanadhānyacatuḥṣaștivrīhisahasrāṇi ca mama sarvasattvānāṃ ca kośakoṣṭhāgārāṇi ca sarvopakaraṇāni bhara 2 bharaṇi svāhā || oṃ śrīsarvāśāparipūraye svāhā || oṃ śrī-śubhamati svāhā || oṃ śrī-śāntamati svāhā || oṃ śrī-mahāśubhamati svāhā || oṃ śrī-mahāmati svāhā || oṃ śrī-puștimati svāhā || oṃ śrī-<51v>mahārthamati svāhā || oṃ śrī-jayamati svāhā || oṃ śrīvijayamati svāhā || om śrī-gurviṇimukhena prasūtani mahātejātejạ̣ hrīḥ svāhā || oṃ śrī-mahāśāntamati svāhā || oṃ śrī-mahāpauṣṭimati svāhā || oṃ śrī-sarvajanavaśaṃkari svāhā || oṃ śrī-sarvadușțanikṛntani svāhā || oṃ śrī-sarvaśatruvināśani hūṃ phaṭ svāhā || oṃ śrī-āgacchāgaccha samayam anusmara svāhā || oṃ śrī-hṛdayam anusmara svāhā || oṃ śrī-upahṛdayam anusmara svāhā || oṃ śrī-āvaraṇam anusmara svāhā || oṃ śrī-ādhāram anusmara svāhā || oṃ śrī-prabhāvam anusmara svāhā || oṃ śrī-svabhāvam anusmara svāhā || oṃ śrī-dhṛtim anusmara svāhā || oṃ śrī-jayam anusmara svāhā || oṃ śrī-vijayam anusmara svāhā || oṃ śrī-sarvasattvasamayam anusmara 25 svāhā || oṃ śrī-sarvatathāgatavinayam anusmara svāhā || oṃ śrī-vasudhāre svāhā || oṃ śrī-vasu svāhā || oṃ śrī-vasudhe svāhā || oṃ śrī-suvasudhe svāhā || oṃ śrī-suvasumukhi svāhā || oṃ śrī-vasuṃdhari svāhā || oṃ śrī-vasumatipriye svāhā || oṃ śrī-vasudhāraṇìye svāhā || oṃ śrī-vasumatiśriye svāhā || oṃ vasudhāre dharạ̣i vasudhāraṇiye svāhā || oṃ śrī-lakṣmīye svāhā || oṃ śrīlakṣmīnivāsanīye svāhā || oṃ śrī-mahālakṣmībhūta<52r>nivāsinīye svāhā || oṃ śrī-vasudhe svāhā || oṃ śriye śrīkari dhanakari brīṃ svāhā || oṃ śrīvasudhāre śrī svāhā || oṃ śrī-vasudhāre dhare dhāraṇi svāhā || oṃ śrī-samaye saumyasamayaṃkari mahāsamaye svāhā || oṃ śrī-dhanadhānyakari samaye śrīkari vasuṃdhari vasudhe svāhā || oṃ śrī-vasudhāre ehy ehi bhagavati samayam anusmara siddhị̣ kuru me hūṃ svāhā || oṃ śrī-vasudhārādhāraṇyai varapradāyai sarvadhanadhānyasarvavastrālaṃkārasarvavrīhyādibhị̣

15 mahāśubhamati] $p c$.; śubhamati $a c .35$ śrī-vasudhāre] $p c$.; vaśrīsudhāre $a c$. 
sarvopakaraṇaị̣ samṛddhị̣ me dehi sarvasattvānāṃ ca dehi śāntiṃ puṣtịm vaśaṃ siddhị̣ ca dadāpaya svāhā || oṃ śrī-dhanadhānyāya vidmahe sarvaratnavastrālaṃkārasarvopakaraṇāni dhīmahe taṃ no śrī-vasudhāraṇī pracodayāyai svāhā || oṃ svāhā || oṃ āḥ svāhā || oṃ svaḥ svāhā || oṃ hrīḥ svāhā || oṃ svāḥ svāhā || oṃ hoḥ svāhā || oṃ yānapātravahe dūragāmini anutpannānāṃ dravyāṇām utpādani-r-utpannānāṃ ca dravyāṇāṃ vṛddhikari țili 2 țeli 2 ita 2 āgaccha 2 bhagavati mā vilamba mama sattvānāṃ ca manorathaṃ paripūraya daśabhyo digbhyo yathodakadhārā paripūrayanti mahīm yathā bhāskaro raśminā vidhamayati tamạ̣ | yathā śītāmśunā jāyati sarvoṣadhịh | yathā mahoșa<52v>dhayạ̣ sarvarogān nāśayanti || dhanado varuṇaś caiva indro vaivasvatas tathā | yathā vahate manonugāminī siddhị̣ cintayantu satataṃ sarvāsaām prayacchadhvaṃ yathākāmaṃ siddhir bhavatu na saṃ́ayaḥ || mantrapadānīha || tadyathā || oṃ khața 2 khiṭi 2 khuṭu 2 prucu 2 muru 2 muruṇ̣̣a 2 tarpari 2 dehi dadāpaya svāhā || oṃ uttișṭha hiraṇyasuvarṇadhāre svāhā || oṃ vastrābharaṇāya svāhā || oṃ annapānāya svāhā || oṃ vasunidhānāya svāhā || oṃ vasudhāre svāhā || oṃ vasudhādhipataye svāhā || oṃ vasudhā svāhā || oṃ gau svāhā || oṃ surabhe svāhā || oṃ indrāya svāhā || oṃ pāñcikebhyạ̣ svāhā || oṃ yamāya svāhā || oṃ varuṇāya svāhā || oṃ vaiśramaṇāya svāhā || om virūc̣hakāya svāhā || oṃ virūpākṣāya svāhā || om dhṛtarāṣṭāya svāhā || oṃ kuberāya svāhā || oṃ agnaye svāhā || oṃ nairṛtyāya svāhā || oṃ vāyuve svāhā || oṃ îsāāāya svāhā || oṃ anantāya svāhā || oṃ kulikāya svāhā || oṃ vāsukāya svāhā || oṃ śan̉khapālāya svāhā || oṃ takṣakāya svāhā || oṃ mahāpadmāya svāhā || oṃ karkoțakāya svāhā || oṃ padmāya svāhā || oṃ așțanāgādhipataye svāhā || oṃ asurādhipataye svāhā || oṃ sūryagrahādhipataye 25 svāhā || <53r> oṃ candranakṣatrādhipataye svāhā || oṃ diśi lokapālāya svāhā || oṃ vidiśi lokapālāya svāhā || oṃ sarvalokapālāya svāhā || oṃ sarvadhanadhānyasuvarṇanidhānāni māṃ dehi dadāpaya svāhā || oṃ vasudhe svāhā || oṃ vasudhādhipataye svāhā || oṃ sarvadevāya namạ̣ svāhā || oṃ sarvanāgāya namaḥ svāhā || oṃ sarvayakṣādhipataye namạ̣ svāhā || oṃ sarvagrahādhipataye namaḥ svāhā || oṃ sarvapiśācādhipataye namaḥ svāhā || om sarvabhūtādhipataye namaḥ svāhā || oṃ sarvapretādhipataye namaḥ svāhā || oṃ sarvamārutādhipataye namaḥ svāhā || oṃ sarvapavanādhipataye namạ̣ svāhā || oṃ sarvamārutādhipataye namaḥ svāhā || oṃ sarvaḍākinībhyo namạ̣

3 sarvopakaraṇāni] pc.; sarvokaparaṇāni ac. 7 āgaccha] pc. ācchaga ac. 10 mahoșadhayaḥ] corr.; mahoșașadhayaḥ ms. • sarvarogān] pc.; sarvarogānan ac. 18 oṃ surabhe svāhā ||] pc.; om. ac. 30 sarvanāgāya] $p c$; sarvanāyagā $a c .34$-ḍākinībhyo] $p c . ;$-ḍākibhyo ac. 
svāhā || oṃ sarvapiśācīnībhyo namạ̣ svāhā || oṃ sarvayakṣiṇibhyo namaḥ svāhā || oṃ sarvamahākālāya namaḥ svāhā || oṃ sarvamātṛbhyo namaḥ svāhā || oṃ sarvabhṛngarībhyo namaḥ svāhā || oṃ sarvabhūtanībhyo namạ̣ svāhā || oṃ eteșāṃ mama sarvasattvānāṃ ca sarvadhanadhānyasuvarṇanidhānāni māṃ dehi dadāpaya svāhā || oṃ śrī-jambhalajalendrāya sarvadravyāni māṃ dehi dadāpaya svāhā || oṃ śrī-āryāvalokiteśvārāya hūṃ svāhā || oṃ maṇipadme hūṃ svāhā || oṃ vajrapāṇe sarvavajradha<53v>rāya hūṃ svāhā || oṃ jambhalajalendrāya jluṃ pluṃ sạ̣ svāhā || oṃ māṇibhadrāya svāhā || oṃ pūrṇabhadrāya svāhā || oṃ dhanadāya svāhā || oṃ vaiśramaṇāya svāhā || oṃ mahādhanadāya svāhā || oṃ nandādevi namaḥ svāhā || om sunandādevi namaḥ 10 svāhā || oṃ bhadrādevi namaḥ svāhā || oṃ subhadrādevi namaḥ svāhā || oṃ civikuṇụale svāhā || oṃ keli mālinīye svāhā || oṃ jambhalamukhendrāya svāhā || oṃ jambhalacalendrāya svāhā || oṃ namaḥ śrī-ārya-jambhalajalendrāya svāhā || oṃ sarvajambhalajalendrāya hūṃ svāhā || oṃ śrī-jambhalajalendrāya svāhā || oṃ phūḥ śańkhapālanāgarājāya svāhā || oṃ śrī-vasudhāre svāhā || oṃ śrīvasudhāraṇiye svāhā || oṃ śrī hūṃ svāhā || oṃ śrī-vasudhāre oṃ śriye śrīkari dhanakari dhānyakari brīm svāhā || oṃ śrī-ilādevyai svāhā || oṃ śrī-labādevyai svāhā || oṃ śrī-vasudhārādevyai svāhā || oṃ śrī-varuṇādevyai svāhā || oṃ śrī-dhanavati svāhā || oṃ śrī-dhānyavati svāhā || oṃ śrī-śrīmati svāhā || oṃ śrī-prabhāvati svāhā || oṃ śrī-candramati svāhā || oṃ śrī-tejomati svāhā || oṃ śrī- 20 sarvaguṇavati svāhā || oṃ śrī-vasudhāre svāhā || oṃ śrī-vasuṃdhari svāhā || oṃ śrī-jambhalajalendrāya svāhā || oṃ śrī jluṃ pluṃ sạ̣ svāhā || oṃ <54r> śrī-guhyaśakațike sarve ākarṣaya 2 jạ̣ svāhā || oṃ āḥ harite mahābale hūṃ svāhā || oṃ śrīguptādevi namaḥ svāhā || oṃ śrī-suguptādevi namạ̣ svāhā || oṃ śrī-sarasvatīdevi namaḥ svāhā || oṃ candrakāntādevi namaḥ svāhā || oṃ śrī-dhanadamahādhanadau svāhā || oṃ śrī-padmamahāpadmakau svāhā || oṃ śrī-civikuṇḍalikelimālinau svāhā || oṃ śrī-pūrṇasupūrṇau svāhā || oṃ mahāratnanidhānapātakau svāhā || oṃ svāhā || jaṃ svāhā || bha svāhā || la svāhā || ja svāhā || le svāhā || ndrā svāhā || ya svāhā || svā svāhā || hā svāhā || oṃ vajrasamāja jạ̣ hūṃ baṃ hoh || oṃ hūṃ svāhā || oṃ śrī svāhā || oṃ kṣīm svāhā || oṃ hrīṃ svāhā || oṃ prajñāśrī svāhā || oṃ āḥ svāhā || oṃ svaḥ svāhā || oṃ sūṃ hūṃ svāhā || oṃ āḥ hūṃ svāhā || eteṣām mama sarvasattvānāṃ ca sarvadhanadhānyasuvarṇanidhānāni māṃ dehi dadāpaya svāhā || oṃ jambhalajalendrāya sarvadravyaṃ māṃ dehi dadāpaya svāhā || oṃ oṃ svāhā || oṃ bhūḥ svāhā || oṃ bhuvaḥ svāhā || oṃ svaḥ svāhā || oṃ bhūr bhuvaḥ sva svāhā || oṃ daśabhyo digbhyaḥ svāhā || utpādayantu me kākiraham aviraham anumodayantu ime mantrapadāḥ siddhyantu || oṃ oṃ oṃ oṃ om | hūṃ hūṃ

35 oṃ bhuvaḥ svāhā ||] pc.; om. ac. 
hūṃ hūṃ hūṃ | hrīṃ hrīṃ hrīṃ hrīṃ hrīm | oṃ hūṃ hrīm | kṣemā<54v>rogyaṃ dhanaṃ dehi dadāpaya svāhā || eșa hṛdayo bhagavatyā mahāpāpakāriṇo 'pi mantrapadāni siddhyanti | kiṃ punạ̣ śraddhādhimuktikasya puruṣapramāṇaṃ mahābhogaṃ dadāti || īpsitaṃ manorathaṃ paripūrayati || oṃ vajre 2 mahāvajre vajropame țakke 2 țhakke 2 hūṃ hūṃ phaṭ svāhā || oṃ śriya śrīkari dhanakari dhānyakari āgaccha 2 brīm svāhā || oṃ śan̉khanidhānāya svāhā || oṃ padmanidhānāya svāhā || oṃ așțau yakṣiṇi sarvapūjā hūṃ svāhā || oṃ yān yāt sarvakāmaduhādyāṃ kāmayati | tāṃs tān sarvān īpsitāṃ paripūrayati | siddhyantu me mantrapadāni ||

tadyathā || oṃ namo ratnatrayāya || oṃ namo devi dhanaduhite vasudhārāṃ pātaya 2 dhaneśvari ratnadehe huru 2 dhaneśvari ratnaṃ me dehi dadāpaya ratnasāgare mahānidhāne nidhānakoṭiśatasahasraparivāre ehy ehi bhagavati | vasudhāre praviśya mama puraṃ mama bhavanaṃ mahānidhānaṃ pātaya 2 turu 2 kuru 2 hūṃ hūṃ phaṭ kailāsanivāsini svāhā || oṃ tiṣtha dhvajāgre māṃ vrīhim pratig̣̣hṇa ratnaśikṣāya svāhā || agnimantra || oṃ suvarṇaretāya svāhā || agnisādhanamantra || oṃ varuṇambhave svāhā || udakamantra || oṃ rasātmake u<55r>tpannadhūme dhūmaśikhe svāhā || oṃ ratnadhare vasuṃdhare ihāgni pratiștha varuṇe varuṇavati pratīccha me cittạ̣ svāhā || udakāhutisarvārtham pratiyacchati || oṃ amṛte țili țilini svāhā || krodhakavaca eṣa mantranayaḥ || iyam hi kulagṛhapate vasudhārā-nāma-dhāraṇī-mantrapadā | asyā dhāraṇyāḥ prabhāvena rogadurbhikṣamaraṇakādayo na prabhavanti | yaṃ tu kulaputra imāni vasudhārā-nāma-dhārạ̣ī-mantrapadāni tathāgatānām arhatāṃ samyaksambuddhānāṃ pūjāṃ kṛtvā ṣạ̣māsān āvartayet | tataḥ siddhā bhavati || yasyāṃ diśi iyaṃ vidyā dhāryate sā dik pūjyamānā bhavati || yasmin sthāne pūjyate pauṣṭikārthaṃ svagṛhe vā paragṛhe vā śraddhayā paramaśraddhayā vasudhārā bhaț̣ārikāyā vā paț̣am vā agrato 'nuprasārya candanena caturasram mạ̣dalaṃ kṛtvā puṣpadhūpadīpagandhamālyavilepanacūrṇacīvaracchatradhvajapatākopaśobhitair balinaivedyavividhopacārair yathāvibhavaṃ pūjām kṛtvā dharmabhāṇakaś cāpi sugandhajalasnātaḥ sugandhāngaḥ śucivastraprāvṛto mayūrāsanopari samupaviśya pratimāpațāāikaṃ sthāpayitvā tam evānusmṛtya sūryodayovelāyāṃ pūjayitvā <55v > pratyaham akhạ̣ḍasamādānato yāvad eva sakalāṃ rātriṃ dhāraṇīm avicchinnam āvartayet || tasya krameṇa sarvasampattir bhavati || tatạ̣ prāktane 'pi

3 śraddhā-] corr.; śraddhyā- ms. 7 -nidhānāya] pc.; -nidhāyanā ac. • yakṣinịi] corr.; yakșaṇī ms. 10 dhana-] $p c$; da dhana- ac. 17 utpanna-] corr.; upanna- ms. 19 pratiyacchati] $p c$.; praticchayati ac. 26 vasudhārā] $p c$; vasuddhādhārā $a c . \quad 28$-dīpa-] corr.; -dī- ms. 33 eva sakalāṃ] corr.; avaśalāṃ ms. 
divase niyamena rātrim atināmayitvā punạ̣ pratyūṣe sugandhajalasnānaḥ śucir amalavastrāvṛto brahmacārī bhūtvā śubhe sthāne sanidānaṃ dhāraṇimm avicchinnam āvartayet || trīṇi vārāṇi tataḥ kulaputro vā kuladuhitā vā mahāpuruṣamātrayā vasudhārayā gṛhaṃ paripūrayati | sarvadhanadhānyahiraṇyasuvarṇaḥ sarvopakaraṇaiś ca | sarvopadravāś ca nāśayati | yad vā tathaiva pratyūṣe sugandhajalena snātạ̣ śucivastrāvṛto madyapānarahito nirāmiṣalavaṇabhojī brahmacārī bhūtvā | pauṣtikārthaṃ svagṛhe vā paragṛhe vā śubhasthāne kośakoșțhāgāre vā candanena caturasramaṇḍalakaṃ kṛtvā bhagavatạ̣ śrīmad-āryāvalokiteśvarasya tathāgatasya sarvaśrāvakapratyekabuddhabodhisattvānāṃ mahāmudrāmantravidyādevatāyāś cāgrato yathāvibhavam udārāṃ pūjāṃ kṛtvā susamāhitas tām eva bhagavatīṃ bhāvayen ekacittotpādo dānapatir hitasukhāśayaḥ śraddhayā paramaśraddhayā sanidānām imāṃ dhāraṇīm ekam ahorātram saptahorātraṃ saptāhorātrāṇi parai<56r $>$ r anālayann avicchinnam āvartayet || ācāryas tathaiva niyamena rātrau trikṛtvā sarvabalyupahāraị̣ pūjayet | tathaiva dānapatir api niyamena sarvam ācaret || pāṭakāle yathāśaktyā suvarṇādidānaṃ dadyāt || tatạ̣ paṭhitasiddho bhavati || tatạ̣ kṣaṇamātrayā gṛhapate vasudhārayā mahāpuruṣamātrayā vasudhārā dānapateḥ gṛhạ̣ paripūrayati | sarvadhanadhānyahiraṇyasuvarṇādibhị̣ sarvopakaraṇaiś ca sarvopadravā nāśayati || tena hi tvaṃ gṛhapate sarvaprayatnenodg̣̣hṇiṣvemāṃ vasudhārā-nāma-dhāraṇịm dhāraya vācaya deśaya grāhaya paryavāpnuhi parebhyaś ca vistareṇa samprakāśayati || tato bhaviṣyati dīrgharātram arthāya hitāya sukhāya bhogāya yogasambhārāya kṣemāya subhikṣāya ceti || tatạ̣ sādhu bhagavann iti pratiśrutya bhagavatạ̣ sucandro nāma gṛhapatir bhagavato 'ntikād imāṃ vasudhārā-nāma-dhāraṇīm śrutvā hṛșțatușța-udagra-āttamanāḥ pramuditaḥ prītisaumanasyajāto bhagavataś caraṇayor nipatya kṛtakarapuṭo bhūtvā bhagavantam etad avocat || udgṛhītā me bhagavann iyaṃ vasudhārā-ṇāma-dhāraṇī prahvīkṛtā dhāritā vācitā paryavāptānumoditā manasā supa<56v>ricintitā parebhyaś ca vistareṇa samprakāśayiṣyāmi || atha tatkṣaṇamātreṇa sucandrasya nāma gṛhapate paripūrṇakośakoșțhāgāro 'bhūt || atha khalu sucandro nāma gṛhapatir bhagavantam anekaśatasahasram pradakṣiṇikṛ̣tya bhagavataḥ pādau śirasābhivandya bhagavantam punạ̣ punar avalokya bhagavato 'ntikā gṛham prakrāntạ̣ || prakramya ca sa gṛhapatir abhyantaraṃ

1 atināmayitvā] corr.; atimayitvā ms. 2 śucir amala-] pc.; śucimala- ac. 3 āvartayet] corr.; ārtayet ms. 5 sarvopadravāś] corr.; sarvopavāś ms. 12 -yen] corr.; -yenn ms. 13 -sukhāśayah] corr.; -sukhāyaḥ ms. 26 āttamanāḥ] corr.; ātmanāḥ ms. 31 nāma] pc.; om. ac. 
praviśyādrākṣīt tatparipūrṇasarvadhanadhānyaratnajātasamṛddhaṃ sarvopakaraṇaiś ca kośakoṣțhāgārāṇi ca paripūrṇāni dṛṣțā ca vismito hṛșțatuṣṭa-udagra-āttamanāḥ pramuditaḥ prītisaumanasyajātaḥ paripūrṇamanorathaḥ | parijụmbhamāṇạ̣ kuśalamūlamṛdusnigdhahṛdayo buddhe bhagavati vasudhārā-nāma-dhāraṇyāṃ ca tīvrapremagurugauravaṃ prasādabahumānacitrīkāraṃ ca bodhicittam utpādayati || atha khalu bhagavann āyuṣmantam ānandam āmantrayate sma || gaccha tvam ānanda sucandrasya gṛhapater agāraṃ paripūrṇasarvadhanadhānyasamṛddhaṃ sarvaratnasuvarṇādibhị̣ sarvopakaraṇaiś ca mahākośakoṣthāgārāṇi paripūrṇāni paśya || atha khalv āyuṣmān ānando bhagavato vacanaṃ prati<57r>śrutya yena kauśāmbīmahānagarī yena sucandrasya gṛhapate niveśas tenopasaṃramyābhyantaram praviśyādrākṣīt | paripūrṇasarvadhanadhānyasamṛddhaṃ ratnasamṛddhaṃ mahākośakoṣṭhāgārāṇi ca paripūrṇāni dṛștvā hṛșțatuṣța-udagra-āttamanāḥ pramuditah prītisaumanasyajāto yena bhagavāms tenopasaṃkrānta upasaṃkramyāyuṣmān ānando vismitah prītisaumanasyajāto bhagavataḥ pādau śirasābhivandya bhagavantam etad avocat || ko bhagavan hetuh kah pratyayo yena sucandro nāma gṛhapatir mahādhano mahābhogo mahākośakoșțhāgāradhanadhānyahiraṇyasuvarṇaratnajātasamṛddhajātạ̣ || bhagavān āha || śrāddhaś cānanda sucandro nāma gṛhapatih paramaśrāddhạ̣ kalyāṇāśrayo dhāritā ca teneyaṃ vasudhārā-nāma-dhāraṇī pravartitā udg̣̣hītā dhāritā vācitā paryavāptā anumoditā parebhyaś ca vistareṇa samprakāśiteti || tenānanda tvam apy udgṛhṇịsvemāṃ vasudhārā-nāma-dhāraṇīṃ dhāraya grāhaya vācaya deśaya paryavāpnuhi parebhyaś ca vistareṇa samprakāśaya bhaviṣyati | bahujanahitāya bahujanasukhāya lokānukampāyai mahato janakāyasyārthāya hitāya su<57v>khāya devānām ca manuṣyāṇāṃ ca | yasya kulaputrasyānandeyaṃ dhāraṇi hastagatā pușțakagatā śrutimātragatā bhavișyati | udgṛhītā hṛdayagatā dhāritā vācitā cintitā gṛhagatā pūjitā ca bhavișyati || tasya kulaputrasya durbhikṣabhayaṃ na bhavișyati | krameṇa tasya vibhavāḥ sambandhante bahujanahitāya bahujanasukhāya lokānukampāyai mahato janakāyasyārthāya hitāya sukhāya devānāṃ ca manuṣyāṇāṃ ca nāham ānanda tạ̣ dharmam samanupaśyāmi || sadevake loke samārake sabrahmake saśramaṇabrāhmaṇikāyāṃ sadevamānuṣāyāṃ ya imāṃ vidyām anyathā kariṣyati | atikramiṣyati vā naitat sthānaṃ vidyate || tat kasya hetoḥ ||

2 -karaṇaiś] corr.; -karaṇyaiś ms. 9 sarvaratna-] corr.; sarvaratnasarvaratna- ms. 12 tenopa-] corr.; teno- ms. 18 yena] pc.; yena bha ac. nāma] corr.; nā ms. 22 parebhyaś] pc.; pabhyareś ac. 24 -prakāśaya] corr.; -prakāśayateta ms. 29 ca bhavișyati] pc.; bhacavișyati ac. 32 -mārake] corr.; -mānake ms. 
abhedyāni hy etāny ānanda vasudhārā-nāma-dhāraṇī-mantrapadāni | na caitāni kṣinnakuśalamūlānāṃ śrutipațham āgamiṣyanti || kaḥ punar vādo yāni pustakagatāni hṛdayagatāni dhārayișyanti vācayiṣyanti paryavāpsyanti || tat kasya hetoḥ || sarvatathāgatānām etad vākyam | sarvatathāgatair ete bhāṣitā adhișthitā dhāritāś ca mudrāyā mudritā prakāśitā samprakāśitā | anumoditā prabhāvitā | praśastā saṃvarṇitā viṿ̛tā uttānī<58r >kṛtā ārocitā ākhyātā daridrāṇāṃ sattvānāṃ nānāsarvavyādhiparipịịitānāṃ sarvaduṣțabhayopadrutānām arthāya hitāya sukhāya sambhogaparibhogāya kṣamāya ceti || ānanda āha || udgṛhītā me bhagavann iyaṃ vasudhārānāma-dhāraṇi dhāritā vācitā paryavāptā anumoditā manasā suparicintitā ca sādhu bhagavann iti || atha khalv āyuṣmān ānanda utthāyāsanād ekāṃśam uttarāsañgam kṛtvā dakṣiṇaṃ jānumaṇḍalaṃ pṛthivyāṃ pratișțhāpya yena bhagavāṃs tenāñjaliṃ praṇamya kṛtakarapuṭo bhūtvā bhagavantam avalokya tasyāṃ velāyām imāṃ gāthām abhāṣatah || acintayo dravyasamṛddhayo sadā anekaratnasusamṛddhakāñcanam | āpūrṇam asmin gṛheșu maṇḍalam namo 'stu te śrīvasudhāraṇī sadā || acintayo bhagavan buddho buddhadharmo 'py acintayā | acintayo 'bhiprasannānām vipākaś cāpy acintayā || sāstā jāneya sarvajña dharmarājaparamparā | pāragāmiphalaprāpto buddhavīra namo 'stu te \| atha khalv āyuṣmān ānanda imaṃ dharmaparyāyam bhagavato 'ntikāc chrutvā hṛșța-udagra-āttamanā pramuditaḥ prītisaumanasyajo bhagavantam etad avocat || ko nāmāyaṃ bhagavan dharmaparyā<58v>yaḥ | kathaṃ bhagavan dhārayāmy enaṃ dharmaparyāyam || bhagavān āha || sucandrasya gṛhapatẹ̣ paripṛcchety api dhāraye | sarvadhanadhānyahiraṇyasuvarṇaratnanidhānam ity api dhārayānanda sarvatathāgatapraśastety api dhāraya | sarvatathāgatādhișțhitā vasudhārādhāraṇīkalpam ity api dhāraye || || idam avocad bhagavān āttamanā āyuṣmān ānandas te ca bhikṣavas te ca bodhisattvā mahāsattvāḥ sā ca sarvāvatī parṣat sadevamānuṣāsuragandharvaś ca loko bhagavato bhāṣitam abhyanandann iti || ||

ārya-śrī-vasudhārā-nāma-dhāraṇī samāptah || ||

3 pustakagatāni] corr.; pustagatāni ms. 22 bhagavantam] corr.; bhagantam ms. 24 dharmaparyāyam] pc.; dharmaryāpayam ac. 25 sarva-] $p c$; sarvahi- $a c$. 
[63] oṃ namaḥ śrī-lokanāthāya || amoghapāśāya bhagavate namạ̣ || evaṃ mayā śrutam ekasmin samaye bhagavān potalake parvate viharati sma \| āryāvalokiteśvarasya bhavane | anekaśālatālatamālacampakāśokātimuktakanānāratnavṛkșasamalaṃkṛte mahatā bhikṣusaṃghena sārdhaṃ așțādaśabhir bhikșusahasrair navanavatibhiś ca bodhisattvakoținniyutaśatasahasraị̣ || anekaiś ca śuddhāvāsakāyikaiś ca devaputrakoțīniyutaśatasahasraih parivṛta puraskṛta îsvaramaheśvarabrahmakāyikā<59r $>n$ devaputrān adhikṛtya dharmaṃ deśayati sma || atha khalv āryāvalokiteśvaro bodhisattvo mahāsattva utthāyāsanād ekāṃsam uttarāsañgaṃ kṛtvā dakșinamạ jānumaṇḍalaṃ pṛthivyāṃ pratișțhāpya yena bhagavāṃs tenāñjaliṃ kṛtvā praṇamya prahasitavadano bhagavantam etad avocat $\|$ asti mama bhagavann amoghapāśarājaṃ nāma hṛdayaṃ yan mayā pūrvam ekanavatikalpavilokitāyāṃ lokadhātau lokendrarājasya tathāgatasya sakāśād udgṛhītaṃ yena bhagavann íśvaradevaputrapramukhāni bahūni śuddhāvāsakāyikadevaputrapramukhāny anekadevaputraśatasahasrāṇi samādāpitāny anuttarāyāṃ samyaksambodhau | asammohajñānavyūhapramukhāni ca mayā daśasamādhiśatasahasrāṇi pratilabdhāni || yasmimsś ca punar bhagavan pṛthivīpradeśe idam amoghapāśahṛdayaṃ pracaret || veditavyaṃ bhagavaṃs tasmin pṛthivīpradeśe īśvaramaheśvarabrahmakāyikapramukhāni dvādaśadevaputraśatasahasrāni rakșāvaraṇaguptaye sthāsyanti || caityasammato bhagavan sa pṛthivīpradeśo bhavișyati | yatredam amoghapāśahṛdayaṃ pracarișyati || anekabuddhakoṭinniyu<59v>taśatasahasrāvaropitakuśalamūlās te bhagavan sattvā bhavișyanti || ya idam amoghapāśahṛdayaṃ śroṣyanti yaḥ kaścid bhagavan kilbiṣakārī syāt sarvapāpāspadaḥ pāpadharmasamācārī || āryāpavādakah saddharmapratikșepakah | avīciparāyanạn sarvabuddhabodhisattvāryaśrāvakapratyekabuddhapratikșepakaḥ | saced vipratisāraṃ gacched āyatyām saṃvaram āpadyate tasyaiva bhagavan ekopavāsakāyenehaiva janmani tat karma viśuddhyati parikṣayaṃ gacchati vāntībhavati | ekāhikeṇa jvareṇa dvyāhikeṇa vā tryāhikena vā caturthikena vā jvareṇaivaṃ saptāhikena jvareṇa | akṣiśūlena vā dantaśūlena vā nāsāśūlena vā dantoșțhaśūlena vā jihvāśūlena vā tāluśūlena vā hṛdayaśūlena vā udaraśūlena vā pārśvaśūlena vā kațiśūlena vā aṅgaśūlena vā an̉gapratyañgaśūlena vā arśagrahaṇiśūlena vā atisāreṇa vā | hastapādadavapārśvaśirorujā vā |

1 lokanāthāya] pc.; lokanāyathāya $a c . \quad 8$ îśvara-] corr.; îśvaro- ms. 11 pratișțhāpya] corr.; papratișțhāpya ms. 20 î́vara-] corr.; íśva- ms. 21 rakșāvaraṇa-] pc.; rakșā- ac. 24 śroṣyanti] pc.; ga śroșyanti ac. 25 syāt] corr.; syā ms. • pāpa-] corr.; pāda- ms. 26 saddharma-] corr.; sadharma- ms. 34 arśa-] corr.; alo- ms. 
balāhakacitrakuṣṭhavicarcikākiṭimabhagaṃdaralohalinggagalagrahavisphoțakāpasmārakākhordair aṇyair vā kṛtyāpakṛtyair vadhabandhanatāḍanatarjaṇabhūtābhyākhyānair vā | sạ̣kșepato bha<60r>gavan kāyapīḍyā vā vākcittapịdayā vā duhsvapnadarśanena vā tat karma parikṣayaṃ gacchati | paryavadānaṃ gacchati || prāg eva śuddhasattvānāṃ śraddhādhimuktikānām | yadi bhagavan catasrạ̣ parșadaś catvāro varṇa māyāśāṭhyenāpi ya idaṃ madīyam amoghapāśahṛdayaṃ śroṣyanti | udgṛhīṣyanti dhārayiṣyanti vācayiṣyanti likhiṣyanti likhāpayiṣyanti paryavāpsyanti anyeșāṃ ca sattvānāṃ śrāvayiṣyanti | antaśa tiryagyonigatānāṃ vā sattvānāṃ karṇapute sthitvā karṇajāpaṃ dāsyanti | imāni ca mantrapadāni cintayișyanti | apratikṣepataḥ | arūpatạ̣ | avikalpatạ̣ | asaṃprabhavatạ̣ | aciraṃgamataḥ | akaraṇataḥ | niḥkleśataḥ | samacintānikṣepataḥ| virahitapañcaskandhạ̣ | anena yogena buddhānusmṛti bhāvayitavyā || tad eșāṃ daśebhyo digbhyo buddhasahasraṃ sammukhaṃ darśanaṃ kārayișyanti | atyayadarśanaṃ ca kariṣyati || peyālam || yāvat puṣțakalikhitaṃ kṛtvā gṛhe sthāpayiṣyanti || kiṃ bahunā bhagavann anyonyaspardhayā vā śroṣyanti | svāmibhayena vā parānuvṛttyā vā uccagghanahetunā vā śroṣyanti | jñātavyaṃ bhagavan paṇḍitenāryāvalokiteśvarasyānu<60v>bhāvena teṣāṃ karṇapuṭe sthitvā sa śabdo nipatiṣyati || tadyathāpi bhagavan kaścid eva puruṣaś candanaṃ vā karpūram vā kastūrikām vā ākruśya paribhāṣya śilāyāṃ vā piṣtvā ātmānaṃ lepayet || na ca tasya candanasya karpūrakasya kastūrikāyāś caivaṃ bhavati || anenāham ākrușța paribhāṣito vā | gandhenātikramișyati | api ca sugandha eva sạ̣ || evam eva bhagavann iyam amoghapāśahṛdayạ̣ yạ̣ kaścid uccagghya ullāpya peyālam | yāvan māyāsaāthyenāpi pūjayet teșām bhagavan khațukasattvānāṃ sa eva kuśalahetur bhaviṣyati | yatra yatropapatsyante avirahitāś ca bhavisyanti || śīlasamādhiprajñāpuṇyasambhāragandhena saugandhikam eva karoti || yah kaścid bhagavan kulaputro vā kuladuhitā vā bhikṣur vā bhikṣuṇī vā upāsako vā upāsikā vā tadanyo vā kaścit sattvā amoghapāśahṛdayam uddiśya śuklāșțamyām upavāsaṃ kuryāt | saptavārān amoghapāśahṛdayam anālāpatah parivartayet || tasya bhagavan dṛșṭa eva dharme viṃśatir anuśaṃsāḥ pratikānikṣitavyāḥ || katame viṃśati yad uta rogāś cāsya kāye notpatsyante | utpannāś cāsya rogāḥ karmavaśena śī<61r>ghraṃ praśamaṃ yāsyanti || snigdhamanojñaślakṣṇagātraś ca bhaviṣyanti ||

1 -kiṭima-] corr.; -ṭikama- ms. 2 kṛtyāpakṛtyair] corr.; kyatāpakṛtyair ms. 4 cittapịdayā vā] pc.; cittapị̄̂avāyā ac. $\mathbf{6}$ bhagavan] corr.; bhavan ms. 7 -sāṭhyenāpi] corr.; -sādhyenāpi ms. - madīyam] corr.; madīm ms. 8 dhārayiṣyanti] pc.; dhārayișyayinti ac. 11 -kṣepataḥ] corr.; -kșipatah ms. 16 -spardhayā] corr.; -syārdhayā ms. 17 -vṛttyā] corr.; -vṛtyā ms. 24 ullāpya] corr.; ullāmyapya ms. 29 upavāsaṃ] corr.; samuvāsaṃ ms. 31 rogāś] corr.; rākāś ms. 
bahujanapriyaś ca bhaviṣyanti | guptendriyo 'rthapratilambhaś cāsya bhavișyati | utpannāś cāsyārthaṃ na caurāḥ pratimoṣyanti | agninā na dahyante nodakena hriyante na rājā śaknoti manasāpy apahartum | karmāntāś cāsya sphītā bhaviṣyanti nāśanir nodakabhayaṃ bhaviṣyati | na vātavṛșțibhayaṃ bhavișyati | saptavārān amoghapāśahṛdayena bhasmodakạ̣ vā parijapya digvidigadha-ūrdhvaṃ ca kṣetrasya bandho dātavyaḥ | sarvopadrava praśamiṣyanti | na caujohārā ojo 'pahartum śaknuvanti | sarvasattvānāṃ ca priyo bhaviṣyati mana-āpaś ca bhaviṣyati | na cāsya śatrubhayaṃ bhavișyanti | utpannaś cāsya śatrubhayaṃ śīghraṃ praśamạ̣ yāsyanti | na cāsya manuṣyabhayaṃ bhaviṣyati | na ca kākhordabhayạ̣ na ca ḍākinībhayaṃ na cāsya tīvrāḥ kleśopakleśā bhaviṣyanti nāgninā na viṣeṇa na śastreṇa kālaṃ kariṣyati | devatāś cāsya satatasamitạ̣ rakṣāvaraṇaguptaye sthāsyanti || yatra yatropapatsyate tatra tatrāvirahitāś ca bhaviṣyati maitrīkaruṇāmuditopekṣayā || ime viṃśatir anuśaṃsāḥ pratikān̉kṣitavyā || aparān așțau dharmān pratilapsyate ka<61v>tamāșțau | maraṇakāle āryāvalokiteśvaro bhikṣurūpeṇa sammukham darśanam dāsyati | sukhena kālaṃ kariṣyati na bhrāntadṛștir bhavișyati na hastavikṣepaṃ kariṣyati na pādavikṣepaṃ noccāraprasrāvan na mañcarūḍhạ̣ kālaṃ kariṣyati sūpasthitasmṛtir bhaviṣyati | nādhomukhạ̣ kālạ̣ kariṣyati maraṇakāle 'kṣayapratibhānam cāsya bhavișyati | yatra cāsya buddhakṣetre praṇidhis tatropapattir bhaviṣyati | avirahitaś ca bhaviṣyati kalyāṇamitraiḥ | trikālaṃ trīn vārān parivartayitavyam || madyamāṃsapalāṇụug̣nñanakalaśunasaṃkārakṛtocchișțạ̣ viśeṣārthino 'py etad varjyāḥ | ayaṃ cāmoghapāśahṛdayo dharmaparyāyạ̣ sarvasattvānāṃ balābalaṃ jñātvā śrāvayitavyaḥ || ācāryamușțir na kartavyāḥ || yasmād vigatamalamātsaryerṣyāpagatā bodhisattvā bhavanti | sattvānām arthakaraṇena bodhị prāpyate bodhisattvānāṃ gaṇanāṃ ca gacchanti || bodhisattva-r-ucyate prajñāsattva upāyaḥ || etau dvau dharmau sattvānām arthakaraṇenaiva prāpyate | sacen me bhagavann anujānīyā yan nv aham imaṃ hṛdayạ̣ tathāgatasya puratạ̣ kīrtaye cataș̣nāṃ parṣadām arthāya hitāya sukhāyānyeșāṃ ca pāpakāriṇām || atha khalu bha<62r>gavān āryāvalokiteśvaraṃ bodhisattvaṃ mahāsattvam etad avocat | bhāṣa tvam śuddhasattva yasyedānīm kālaṃ manyase | anumoditaṃ tathāgatena paścime kāle paścime samaye bodhisattvayānikānāṃ pitṛkāryaṃ karișyati || atha khalv āryāvalokiteśvaro bodhisattvo 'nimișanayano bhūtvā bhagavantam etad avocat || śṛ̣u me bhagavan sarvabodhisattvanamaskṛtam idam

8 sarvasattvānāṃ ca] $p c$; sarvasattvāṃcanā $a c . \quad 14$ ime] $p c$.; iti me $a c .27$ prāpyate] corr.; prāptate ms. 28 etau] pc.; etaudha ac. 29 yan nv] corr.; yanv ms. 34 samaye] corr.; om. ms. 
vimokṣamukhamaṇḍalaṃ bahujanahitāya bahujanasukhāya lokānukampāyai mahato janakāyasyārthāya hitāya sukhāya || || om namo tryadhvānugatapratișțhitebhyạ̣ | namạ̣ sarvabuddhabodhisattvebhyạ̣ | namaḥ pratyekabuddhāryaśrāvakasaṃghebhyo 'tītānāgatapratyutpannebhyạ̣ | namạ̣ samyaggatānām | namaḥ samyakpratyutpannānām | namaḥ śāradvatīputrāya mahāmataye | namah ārya-maitreyapramukhebhyo mahābodhisattvebhyah | namaḥ supratișțhitaśailendrarājapramukhebhyạ̣ tathāgatebhyo 'rhadbhyạ samyaksambuddhebhyạ̣ bhagavadbhyah | namạ̣ suvarṇavarṇaprabhāvinateśvararājāya tathāgatāya || namạ̣ siṃhavikrị̣̄itarājāya tathāgatāya || namaḥ āryāmitābhāya tathāgatāya || namaḥ supratișțhitamaṇikūṭarājāya tathāgatāya || namạ̣ samantaraśmyudga<62v>taśrīkūṭarājāya tathāgatāya || namaḥ vipaśvine tathāgatāya || namaḥ śikhine tathāgatāya || namo viśvabhuve tathāgatāya || namaḥ krakucchandāya tathāgatāya || namạ̣ kanakamunaye tathāgatāya || namaḥ kāśyapāya tathāgatāya || namaḥ śākyamunaye tathāgatāyārhate samyaksambuddhāya ॥

tadyathā || oṃ mune 2 mahāmunaye svāhā || oṃ same 2

mahāsamaye rakṣa 2 māṃ sarvasattvāṃś ca sarvapāpapraśamane svāhā || namaḥ suparikīrtitanāmadhyeyāya tathāgatāya || namaḥ samantāvabhāsavijitasaṃgrāmaśriye tathāgatāya || namaḥ indraketudhvajaśriye tathāgatāya || namo ratnaprabhāseśvararājāya tathāgatāya || namo 'pratihatabhaiṣajyarājāya tathāgatāya || namo vikrāntagāmine tathāgatāya || namo buddhāya namo dharmāya namaḥ saṃghāya || namo 'tītānāgatapratyutpannebhyo buddhebhyo bhagavadbhyạ || tadyathā || smṛtivardhani mativardhani gativardhani dhṛtivardhani prajñāvardhani pratibhānavardhani dhyānavardhani samādhivardhani śamathavardhani | sarvabodhipakṣadharmavardhani sakalabuddhadharmaparipūraṇi svāhā || namo ratnatrayāya || namah āryāvalokite<63r>śvarāya bodhisattvāya mahāsattvāya mahākāruṇikāya || namo mahāsthāmaprāptāya bodhisattvāya mahāsattvāya mahākāruṇikāya ebhyo namaskṛtvā idam āryāvalokiteśvaramukhodgīrṇam amoghapāśarāja-nāma-hṛdayaṃ tathāgatasammukhabhāṣitam mahatparșanmadhye 'ham idānīm āvartayiṣye | sidhyantu me mantrapadāḥ sarvakāryāṇi sarvasattvebhyo mama sarvasattvānāṃ ca rakṣā bhavantu || tadyathā || om cara 2 ciri 2 curu 2 mara 2 miri 2 muru 2 mahākāruṇika svāhā || saṃśodhanamantrah || oṃ

3 tryadhvānugata-] corr.; stryadhvānugata- ms. 7 maitreya] corr.; maitrīya ms. 12 -kūṭarājāya] corr.; -kūrājāya ms. 32 āryāvalokiteśvara-] corr.; āryāvalokiśvara- ms. 
sara 2 siri 2 suru 2 curu 2 ciri 2 viri 2 piri 2 miri 2 mahāpadmahastāya svāhā || vighnotsāraṇamantraḥ || oṃ kara 2 kili 2 kulu 2 mahāśuddhasattvāya svāhā || devatāsaṃsodhanamantraḥ || om budhya 2 bodhaya 2 kaṇa 2 kiṇi 2 kuṇu 2 mahāparamaśuddhasattvāya svāhā || tathāgatamantraḥ || oṃ kara 2 kiri 2 kuru 2 mahāsthāmaprāptāya svāhā || niveśaṇamantraḥ || oṃ cala 2 saṃcala 2 vicala 2 ețața 2 bhara 2 bhiri 2 turu 2 tara 2 tiri 2 turu 2 ehy ehi mahākāruṇika svāhā || ākarṣaṇamantraḥ || oṃ mahāpaśupativeśadhara 2 dhiri 2 dhuru 2 tara 2 sara 2 cara 2 para 2 vara 2 mara 2 lara 2 hara 2 hāhā hīhī $<63 v>$ hūṃ hūṃ | oṃkārabrahmaveśadhara 2 dhiri 2 dhuru 2 tara 2 sara 2 cara 2 para 2 vara 2 hara 2 raśmiśatasahasrapratimaṇḍitaśarīra jvala 2 tapa 2 bhāsa 2 bhrama 2 bhagavan 10 somādityayamavaruṇakuberabrahmendravāyvagnidhanada-ṛsidevagaṇābhyarcitacaraṇāya svāhā || arghāsanasnānamantrādyalaṃkāragandhapuṣpadhūpacchatradhvajapatākābalidīpamantraḥ || suru 2 curu 2 muru 2 ghuru 2 sanatkumārarudravāsavaviṣnudhanadavāyvagni-ṛ̦ināyakabahuvividhaveșadhara || devatālakșaṇamantrạ̣ || dhara 2 dhiri 2 dhuru 2 tara 2 thara 2 ghara 2 para 2 lara 2 hara 2 para 2 sara 2 vara 2 varadāya svāhā || sādhakasya niveśanamantrah || samantāvalokita vilokita lokeśvara maheśvara tribhuvaneśvara sarvagunasamalaṃkṛtāvalokiteśvara muhu 2 muru 2 muya 2 muñca 2 rakṣa 2 māṃ sarvasattvāṃś ca sarvabhayebhyaḥ sarvopadravebhyạ̣ sarvopasargebhyaḥ sarvagrahebhyaḥ sarvavyādhibhyạ̣ sarvavișebhyaḥ sarvajvarebhyaḥ | evaṃ vadhabandhanatāọanatarjanarājataskarāgnyudakaviṣaśastraparimocaka svāhā || kaṇa 2 kiṇi 2 kuṇu 2 cara 2 ciri 2 curu 2 indriyabalabodhyaṅgacaturāryasatyasamprakāśaka | tama 2 rama $2<64 \mathrm{r}>$ sama 2 masa 2 dama 2 dhama 2 mahākāruṇika mahātamondhakāravidhamana ṣaṭpāramitāparipūraka mara 2 mili 2 muru 2 țața 2 țhaha 2 țiṭi 2 ṭhiṭi 2 țuṭu 2 țhuṭu 2 eṇeyacarmakṛtaparikara ehy ehi mahākāruṇika | îsvaramaheśvaramahābhūtagaṇasambhañjaka | kara 2 kiri 2 kuru 2 dhara 2 hara 2 vara 2 sara 2 kara 2 kața 2 kiṭi 2 kuṭu 2 maṭa 2 mahāviśuddhaviṣayanivāsina mahākāruṇika || saptaparivāramantrah || śvetajajñopavītaratnamakuṭamālādhara sarvajñaśirasikṛtajațāmakuṭa mahādbhutakamalālaṃkṛtakaratala dhyānasamādhivimokṣāprakampya bahusattvasaṃtatiparipālaka mahākāruṇika sarvakarmāvaraṇaviśodhaka sarvajñajñānaparipūraka sarvavyādhivimocaka sarvasattvāśāparipūraka sarvasattvasamāśvāsanakara namo 'stu te svāhā || amoghāya svāhā || oṃ amoghapāśāya svāhā || homamantraḥ || ajitāya svāhā || aparājitāya svāhā || amitābhāya svāhā || amitāya svāhā || mārasainyapramardanāya svāhā ||

9 -veśadhara] corr.; -śadhara ms. 27 -ṣațpāramitā-] pc.; -ṣatpāṭpāramitā- ac. 
abhayapradāya svāhā || jayāya svāhā || vijayāya svāhā || jayavijayāya svāhā || varadāya svāhā || varapradā<64v>ya svāhā || akālamṛtyupraśamanāya svāhā || idam ca me karma kuru namo 'stu te svāhā || hṛdayamantraḥ || om raṇa 2 hūm phaṭ svāhā || oṃ jaya hūṃ phaṭ svāhā || oṃ pūji hūṃ phaṭ svāhā || oṃ hūṃ jaya svāhā || oṃ hrīḥ trailokyavijayāmoghapāsaāpratihata hrīḥ hạ̣ hūm phaṭ svāhā || upahṛdayamantraḥ || om vasumati svāhā || oṃ ālolika svāhā || oṃ bahule 2 svāhā || oṃ ālolika hrīḥ hrīḥ hūṃ phaṭ svāhā || niyatāniyatavedanīyāśubhasya me bhagavan karmaṇo 'śeșataḥ | parikṣayaṃ kuru svāhā || oṃ padmahastāya svāhā || oṃ buddhadharmasaṃghāya svāhā || ||

pațhitasiddhasyāsya mantrasya karmāṇi bhavanti | trikālajāpena pañcānantaryāṇi karmāṇi śodhayati | sarvakarmāvaraṇāni viśuddhị̣ ca śodhayati | agarudhūpena sīmābandhaḥ | bhasmodakena sarșapakhadirakīlakādyaiḥ | sarvajvareṣu sūtrakaṃ bandhayitavyam | sarvavyādhiṣu ghṛtatailam udakaṃ vā parijapya dātavyam | kākhordacchedanam śastreṇa rakṣāsūtrakena | udaraśūleṇa lavanodakam | viṣanāśanaṃ mṛttikayā | udakena vā cakṣurogena śvetasūtrakaṃ karṇe bandhayitavyam | dantaśūle karavīradantakāṣtha sīmābandhe pañcaraṅgikasūtram ekaviṃ<65r>śativārān parijapya caturṣu khadirakīlakeșu baddhvā caturdiśaṃ nikhātavyaṃ sīmābandho bhaviṣyati || sarvarakṣāsūtrakenodakena vā bhasmakena vā | sarvagraheșu pañcaran்gikasūtrakaṃ sarvajvareșu śvetasūtrakam | sarpakītalūtalohalinggagalagraheșu madhupippalīyutam | cakșuroge gandhodakam palāśodakaṃ madhuyaștyudakaṃ vā sarvakalikalahavivāde 'bhyākhyāneșūdakaṃ parijapya mukhaṃ prakṣālayitavyam || paraviṣayarājyarāṣṭropadravarakṣāsu pūrṇakalaśam sthāpayitvā śucinā śucivastraprāvṛtena mahatīm pūjām kṛtvā vācayitavyam | mahāśāntir bhavati || tena codakena sektavyaṃ sarvasattvānāṃ rakṣā kṛtā bhavati | sarvetyupadravopasargāḥ praśāmyanti | mudrikāṃ candanatilakaṃ hṛdaye ekaviṃśativārān parijapya kartavyaṃ sarvānantaryāṇi kṣapayanti | satatajāpena gṛhe rakṣā | padmahomena sarvasattvarakṣā | candanahomena sarvagrahabhūtarakṣā | jayā vijayā aparājitā nākulī gandhanākulī | vāruṇī abhayapāṇi indriyapāṇi gandhapriyaṃutagaracakrā mahācakrā viṣnukāntā somarājī sunandā ceti || yathā sambhavato 'ṣtottaraśatavārān parijapya maṇiṃ <65v> kṛtvā śirasi bāhau dhārayitavyam || bālānāṃ gale nārīṇāṃ vilagne svayam parasaubhāgyakaraṇam | alakṣmīpraśamaṇam | putradạ̣ ca | etena

1 amitābhāya] $p c$.; amitāyabhāya $a c . \quad 7$ upahṛdaya-] corr.; upahṛda- ms. 9 'śeșatah] pc.; 'śetaḥ̦a ac. 17 -rogena] pc.; -rogenata ac. 25 mukhaṃ] corr.; mukhaṃvra ms. 34 'șțottaraśata-] $p c$.; 'șțottaśarata- $a c$. 
maṇinā baddhena sarvarakṣā kṛtā bhavati viṣāgni nākramati viṣakṛtaṃ notpadyate || utpannāpi na pị̣̄aṃ janayiṣyanti | śīghraṃ praśamayișyanti | grahā praśamayiṣyanti | vātameghāśanistambhaṇaṃ vāriṇā | karavīralatayā sarvakarmakaram | āryāvalokiteśvarahṛdayam paramasiddhasamādhitam evaitāni karmāṇi kurute || atha sādhayitum icchan vidhim || paṭe 'śeșakai buddhapratimām ālikhyāryāvalokiteśvaro jațāmakuṭadhārī | eṇeyacarmakṛtaparivāsāḥ | paśupativeśadharaḥ sarvālaṃkāravibhūṣitaṃ kṛtvā poṣadhikena citrakareṇa citrāpayitavyạ̣ || tataḥ sādhakena tasyāgrato 'patitagomayena mạ̣ḍalaṃ kṛtvā śvetapuṣpāvakīrṇam | aṣṭau gandhodakapūrṇakumbhāḥ sthāpayitavyāḥ | așțāv upahārāś catuḥṣaṣtịr upakaraṇāni | balimāṃsarudhiravarjitaḥ | agarudhūpaṃ dahatā vidyā aștasahasraṃ jāpayitavyā | ahorātroṣitena vā trirātroṣitena vā triśuklabhojitā vā triṣkālaṃ snāpitā śucivastraprāvṛto bhūtvā <66r> jāpo dātavyaḥ || tataḥ pratimāyā agrata ātmānaṃ jvalitam paśyati | tạ̣ dṛșțā ca prahṛṣyati yāvat svayam evāryāvalokiteśvara āgacchati | sarvāśā paripūrayati | manaḥśilāñjanaṃ vā parijapya akṣiṇy añjayitvā | tato 'ntarhito bhavati | ākāśe krāmati | asammohajñānavyūhaṃ nāma samādhiṃ pratilabhate | yad icchati tat karoty sādhaka iti || || idam avocad bhagavān āttamanā āryāvalokiteśvaro bodhisattvo mahāsattvas te ca bhikṣavas te ca bodhisattvās te ca śuddhāvāsakāyikā devaputrāḥ sadevamānuṣāsuragandharvaś ca loko bhagavato bhāṣitam abhyannandann iti || ||

āryāmoghapāśa-nāma-hṛdayaṃ mahāyānasūtraṃ samāptaḥ || ||

[64] oṃ namaḥ siṃhanādāya || namo ratnatrayāya || namo āryāvalokiteśvarāya bodhisattvāya mahāsattvāya mahākāruṇikāya \|

tadyathā || oṃ akațe vikațe nikațe trikațe kațaṃkațe karoṭe karoṭavīrye svāhā || apatitagomayam abhimantrya așțau maṇḍalakān kuryāt | pratimaṇụalaṃ trayodaśavārān āvartayed dhāraṇịm pratimaṇḍalalekhitaśeṣagomayaṃ dhāraṇīm saptavārābhimantrya <66v > tena vyādhị̣ na pralepayet || saptame divatrayodaśe ekaviṃśati vā pañcānantaryakāriṇo 'pi sidhyati || ||

iti siṃhanādalokeśvarasya vyādhipraśamanī-nāma-dhāraṇī parisamāptaḥ || ||

[65] oṃ namaḥ śrīmad-āryāvalokiteśvarāya bodhisattvāya mahāsattvāya mahākāruṇikāya \|

7 'śeșakai] corr.; 'ślekai ms. 12 -rudhira-] pc.; -rudhirasa- ac. 19 āryāvalokiteśvaro] corr.; āryāvalokiteśva ms. 21 -gandharvaś] corr.; -gandhaś ms. 26 trikațe] $p c$.; trikațeke $a c$. 
tadyathā || oṃ śuddhe viśuddhānge śuddhākși śodhani viśodhani gaganaviśodhani cittaviśodhani āvaraṇaviśodhani karmāvaraṇaviśodhani | hana 2 sarvāvaraṇāni paca 2 pañcānantaryāṇi | padme padmākṣi padmavimale | 5 țața țața haha haha arjale varjale siddhiri svāhā || paṭhitamātreṇa pañcānantaryāṇi karmāvaraṇāni parikṣayaṃ gacchanti || ||

ity āryāvalokiteśvarasya mukhodgīrṇa-siddhinikā-nāma-dhāraṇī samāptaḥ || ||

[66] oṃ namo āryāvalokiteśvarāya || namo ārya-jñānasāgaravairocanavyūharājatathāgatāyārhate samyaksambuddhāya || namaḥ sarvatathāgatebhyo 'rhadbhyạ̣ samyaksambuddhebhyạ̣ | namạ̣ āryāvalokiteśvarāya bodhisattvāya mahāsattvāya mahākāruṇikāya || tadyathā || om dhara 2 dhiri 2 dhuru 2 ețte vațte cala $<67$ r $>2$ pracala 2 kusume kusumacale ili mili cittajvālaṃ apanaya svāhā || ||

[67] oṃ namo lokanāthāya || namo ratnatrayāya || oṃ namo āryāvalokiteśvarāya bodhisattvāya mahāsattvāya mahākāruṇikāya || tadyathā || oṃ maṇipadme hūm || oṃ sarvabandhanacchedanakarāya sarvapāpasamudrocchoṣaṇakarāya | sarvavyādhipraśamanakarāya | sarvetyupadravavināśanakarāya | sarvabhayeșu trāṇāya || tasmai namaskṛtya iti āryāvalokiteśvarasya tava nīlakaṇṭha-nāma-hṛdayam āvartayiṣyāmi sarvārthasādhanaśubhacetanaṃ sarvasattvānāṃ pāpamārgaviśodhakaḥ || tadyathā || avalokitalokamati ehi mahābodhisattva he priyabodhisattva he karuṇikakalpahṛdaya ehy āryāvalokiteśvara paramamaitrīcittakaruṇika kuru 2 karmasādhani vidyāṃ dehi me araṃgame vihaṃgame vigame namạ̣ manasiddhiyogīśvara duhu 2 vīryante mahāvīryadhara 2 dharạ̣īśvara jvala 2 vimalāmalanarta | āryāvalokiteśvara kṛ̣̣nājinajațāmakuṭālaṃkṛtaśarīra pravaramahāsiddhi $\langle 67 \mathrm{v}\rangle$ śuddhādhavaramalamala mahāmala jvala 2 mahājvala kṛṣnavarṇa kṛṣnākṣa ḳ̣pāsana nirvātana he padmahasta jayakeśi niśācareśvara kṛ̣ṇasarpayajñopavīta ehehi varāha tripuradahaneśvara nārāyaṇavararūpaveśadhāri he nīlakaṇṭha he mahāhalāhalaviṣanirjita lokasya rāgaviṣanāśana nṛmokṣaṇa huru 2 muñca 2 muhuru 2 halāhalamahopadrānābha sara 2 siri 2 suru 2 buddhya 2 bodhaya 2 bodhayāmi tava nīlakaṇṭha ehy ehi nīlakạ̣ṭha ehy ehi mām

4 -āvaraṇaviśodhani] corr.; -āvaravidhodhani ms. $\mathbf{8}$ siddhinikā] $\quad$ pc. siddhikāni ac. 22 -sādhana-] pc.; -sādhakana- ac. 23 ehi] corr.; eha ms. 24 ehy] corr.; ehe ms. āryāvalokiteśvara-] $p c$.; āryāvakiloteśvara- $a c$. • -citta-] corr.; -citra- ms. 
asthitasiṃhamukha hasa 2 muñca 2 mahātțātțahāsaninādine ehy ehi bho bho mahāsiddhiyogeśvara bandha 2 vāca sādhaya 2 vidyāṃ smara 2 tvaṃ he bhagavan lokavilokas tvaṃ tathāgata dadāhi me darśanam prasādhaya me svāhā || siddhāya svāhā || varāhamukhāya svāhā || siṃhamukhāya svāhā || mahāsiṃhamukhāya svāhā || siddhavidyādharāya svāhā || padmahastāya svāhā || mahāpadmahastāya svāhā || vajrahastāya svāhā || mahāvajrahastāya svāhā || kṛṣṇasarpakṛtayajñopavītāya svāhā || mahākālamakuṭadharāya svāhā || cakrāyudhadharāya svāhā || śan̉khaśabdaṃ nirnādanakarāya svāhā || baudhanakarāya svāhā || vāmaskandha<68r>deśasthitakṛṣnājināya svāhā || vāmahastavyāghracarmanivāsanāya svāhā || lokeśvarāya svāhā || mahālokeśvarāya svāhā || sarvasiddheśvarāya svāhā || rakṣa 2 māṃ svāhā || kuru 2 rakṣāmūrtināṃ svāhā || namo bhagavate āryāvalokiteśvarāya bodhisattvāya mahāsattvāya mahākāruṇikāya siddhyantu me mantrapadāni svāhā || ||

āryāvalokiteśvarasya-nāma-dhāraṇī samāptạ̣ || ||

[68] oṃ namo āryāvalokiteśvarāya bodhisattvāya mahāsattvāya mahākāruṇikāya || tadyathā || oṃ jaya 2 mahājayavāhini jayottari | kala 2 mala 2 cala 2 hulu 2 chiṇi 2 sarvakarmāvaraṇāni mama bhagavati sahasrāvarti sarvabuddhāvalokite cakṣuhśrrotaghrāṇajihvākāyamanovijñānaviśodhani || tadyathā || om suru 2 prasuru 2 bhara 2 sambhara 2 hara 2 smara 2 oṃ sarvabuddhādhișțhite svāhā || oṃ sarvabuddhāvalokite svāhā || oṃ dharmadhātugarbhe svāhā || oṃ abhāvasvabhāvadharmāvabodhani svāhā || asyā dhāraṇyā ayam upacāraḥ | kalpasahasrasaṃcitaṃ karmāvaraṇaṃ ekavāroccāritena parikṣayaṃ gacchati || buddhasahasrāvaropitaṃ kuśalamūlaṃ bhavati jātiparivartena cakravartirājyaiśvaryam <68v> śatasahasram pratilabhate | maraṇakāle ca buddhasahasraṃ paśyati || pratidinaṃ sahasrāvartam kurvan | ekaviṃśatidivasena bodhisattvasaṃkhyāṃ gacchati | pariśuddheșu buddhakṣetreșūpapadyate trikṛtvā rātrau trikṛtvo divasasya japet | yathepsitāni svapnāni paśyati suvarṇavarṇatathāgataṃ paśyati | aparimitānuśaṃsā bodhisattvasaṃīî̄i śrūyante paśyante | satatasamitaṃ manasi kartavyā || ||

ārya-sahasrāvartā-nāma-dhāraṇī parisamāptạ̣ || ||

3 mahātțātț̣hāsa-] corr.; mahāhnāhnāhāsa- ms. 32 śrūyante] corr.; śrute ms. 
[69] namo lokanāthāya || evaṃ mayā śrutam ekasmin samaye bhagavāñ chrāvastyāṃ viharati sma || jetavane anāthapiṇḍadasyārāme || tatra khalu bhagavān āyuṣmantam ānandam āmantrayate sma || udg̣̣hṇa tvam ānanda imāṃ șaḍakṣarīmahāvidyāṃ dhāraya vācaya paryavāpnuvanti || tat kasya hetoḥ || iyam ānanda șaḍakṣarīmahāvidyā uccehi maharddhikehi mahānubhāvehi bhāṣitā tatra buddhena bhagavatā brahmaṇā sahāpatinā śakreṇa devānām indreṇa dhṛtarāșțreṇa ca mahārājena virūụhakena ca mahārājena virupākṣeṇa ca mahārājeṇa kuvereṇa ca mahārājena virūḍhakeṣu caturṣu tatra mantrapadāni bhavanti \|| tadyathā || patire la<69r>tile daṇḍiki madhumati paṇḍale kāṇụale | yaḥ kaścid ānanda imāṃ șaḍakṣarīmahāvidyām udg̣̣hịsyanti dhārayiṣyanti vācayiṣyanti manasi kariṣyanti paryavāpsyanti akṣarasampuṭe vāpy añjanaṃ bodhim ucyate rājabhayānte caurabhayānte udakabhayānte pratyarthikabhayānte devanāgayakṣagandharvāsuragaruḍakiṃnaramahoragamanuṣyāmanuṣyabhayebhyaḥ siṃhavyāghrādīn ṛkṣamrgahastigaṇḍakamahiṣasarvaduṣtebhyah yah imām mantrapadām vyatikramiṣyati saptadhāsya mūrdhā sphoṭayet || tatra imāni mantrapadāni bhavanti || tadyathā || aṇḍale ukte kokāre saktạ̣ citake smite javanti yasvanti namo buddhāya namo dharmāya namaḥ saṃghāya || bhagavan ya ekāhikajvarasya pratighā tathā ye dvehikajvarasya pratighā tathā ya eva daivasikasya muhūrtikasya śiraśūlasya akșirogasya dantarogasya mukharogasya jihvārogasya galarogasya udaraśūlasya hṛdayaśūlasya arohikasya visucikasya nāham ānanda samanupaśyāmi | sattvā vā sattvanikāyakạ̣ | ya ime hi mantrapadāni || oṃ mājilaṃ kuryāt || oṃ maṇipadme hūṃ || dehe sthāpayitvā || <69v> yatiromavivaro devavarșasaṃkhyātati sukhāvatībhuvane sthāpayet || viśeșe kārttike māse śuklapakṣe manohatam ekam ekapaṭhantiko koṭitulyāni phalaṃ labhete ānanda paurāṇāṃ satyayuge bhāṣitaṃ karmavipākam || || idam avocad bhagavān āyuṣmān ānando bhagavato bhāṣitam abhyanandann iti || ||

[70] oṃ namaḥ śrī-samantabhadrāya || atha khalu samantabhadro bodhisattvo mahāsattva etāny eva lokadhātuparamparānabhilāpyānabhilāpyabuddhakṣetre paramāṇurajaḥsamān kalpān kalpaprasarān abhidyotayamāno bhūyasyā mātrayā gāthābhir gìtena praṇidhānam akārṣit ||

3 udgṛhṇa] corr.; ugṛhṇa ms. 4 șaḍakșarī-] pc. șaḍarīkșa- ac. pary-] corr.; uparyms. 10 paṇḍale] $p c$; paśunḍdale $a c .17$ mūrdhā] corr.; saptā ms. 
yāvat kecid daśadiśi loke sarvatṛyadhvagatā narasiṃhāḥ | tān ahu vandami sarvi aśeșān kāyatu vāca manena prasanna || kṣetrarajopamakāyapraṇāmaiḥ sarvajinān karomi praṇāmam | sarvajinābhimukhe manena bhadracaripraṇidhānabalena || ekarajāgri rajopamabuddhān buddhasugatāna niṣaṇṇaku madhye | evam aśeșata dharmadhātuṃ sarvadhimucyami pūrṇa jinebhị̣ \| teșu ca akṣayavarṇasamudrān sarvasvarā<70r>ñgasamudrarutebhị̣ | sarvajināna guṇān bhạ̣amānas tān sugatā stavamī ahu sarvān || puṣpavarebhi ca mālyavarebhir vādyavilepanacchatravarebhị̣ | dīpavarebhir ca dhūpavarebhị pūjana teșu jināna karomi || vastravarebhir ca gandhavarebhiś cūrṇapuṭebhiś ca merusamebhị̣ | sarvaviśișțaviyūhavarebhị pūjana teșu jināna karomi || yā ca anuttarapūja udārā tān adhimucyami sarvajinānām | bhadracari-adhimuktibalena vandami pūjamī jina sarvān || yac ca kṛtam api pāpa bhaveyā rāgatu dveșatu mohatu vaśena | kāyatu vāca manena tathaiva tam pratideśayamī ahu sarvam || yac ca daśaddiśi puṇya jagasya śaikṣāśaikṣapratyekajinānām | buddhasutān atha sarvajinānāṃ tam anumodayamī ahu sarvam || ye ca daśaddiśi lokapradīpā bodhivibudhya asaṃgataprāptāḥ | tān ahu sarvi adhyeșami nāthāṃś cakra-anuttaravarttanatāyai || ye 'pi ca nirvṛti darśatukāmās tān ahu yācami prāñjalibhūtaḥ | kṣetrarajopamakalpa thihantu sarvajagasya hitāya sukhāya || vandanapūjanadeśanatāya anumodanadhyeșaṇayācanatāya | yac ca śu<70v>bham mayi saṃcita kiṃcit bodhiyi nāmayamī ahu sarvam \| pūjita bhontu atītaku buddhā ye ca dhṛyanti daśaddiśi loke | ye ca anāgata te laghu bhontu pūrṇamanoratha bodhivibuddhāḥ || yāvada keci daśaddiśi kṣetrās te pariśuddhā bhavantu udārāḥ | bodhidrumendragatebhi jinebhi buddhasutebhi ca bhontu prapūrṇāh || yāvata keci daśaddiśi sattvās te sukhitāḥ sada bhontu arogāḥ | sarvajagasya ca dhārmiku artho bhotu pradakṣiṇa ṛdhyatu āsā || bodhicarim ca ahạ̣ caramāṇo bhavi jātismara sarvagatiṣu | sarvasu janmasu cyutyupapattī pravrajito ahu nityu bhaveyā || sarvajinān anuśikṣayamāṇo bhadracariṃ paripūrayamāṇaḥ | śīlacarim vimalā pariśuddhaṃ nityam akhạ̣ḍam acchidra careyam || devarutebhi ca nāgarutebhir yakșakumbhāṇḍamanuṣyarutebhị̣ |

15 yac ca] corr.; yaryya ms. 16 pratideśayamī] pc.; pratideśatuyamī ac. 17 -pratyeka-] corr.; -pratye- ms. 20 tān ahu] corr.; tāhuna ms. 23 -adhyeșaṇa-] corr.; -adheșaṇa- ms. 24 saṃcita] corr.; mamcita ms. 30 ṛdhyatu] $p c . ;$ ṛtudhya $a c$. 
yāni ca sarvarutāni jagasya teșu ruteșv ahu deśayi dharmam || ye khalu pāramitāsv abhiyukto bodhayi citta ma jātu vimuhyet | ye 'pi ca pāpaka ācaraṇīyās teșu parikṣayu bhontu aśeșam || karmatu kleśatu mārapathāto lokagatīṣu vimuktu careyam | padma yathā < 71r> śalilena aliptaḥ sūrya śaśī gagane avasaktạ̣ || sarvi apāyaduḥkhān praśamanto sarvajagaṃ sukhi thāpayamānaḥ | sarvajagasya hitāya careyam yāvada kṣetrapathā diśu tāsu || sattvacari anuvartayamāno bodhicariṃ paripūrayamānaḥ | bhadracariṃ prabhāvayamānạ̣ sarvi anāgatakalpa careyam || ye ca sabhāgata mama caryāye tebhi samāgamu nityu bhaveyā | kāyatu vācatu cetanato vā ekacariṃ praniidhāna careyam || ye 'pi ca mitrā mama hitakāmā bhadracarīya nidarśayitāraḥ | tebhi samāgamu nityu bhaveyā tāś ca ahaṃ na virāgayi jātu || sammukha nityam ahaṃ jina paśye buddhasutebhi parivṛta nāthān | teșu ca pūja kareya udārāḥ sarvi anāgatakalpam akhinnaḥ \| dhārayamānu jināna saddharmaṃ bodhicariṃ paridīpayamānaḥ | bhadracariṃ ca viśodhayamāna sarvi anāgatakalpa careyam || sarvabhaveșu ca saṃsaramāṇaḥ puṇyatu jñānatu akṣayaprāptaḥ | prajñā-upāyasamādhivimokṣaị sarvagunair bhavi akṣayakoṣaḥ \|| ekarajāgri rajopamakṣetrāṃs tatra ca kṣetri acintiya buddhān | buddhasutāna niṣaṇnaku madhye paśyiya bodhicariṃ ca<71v>ramāṇah || evam aśeșata sarvadiśāsu bālapatheșu triyadhvapramāṇān | buddhasamudre 'pi kṣetrasamudrā nottari cārikakalpasamudrān || ekasvarāngasamudraruteșu sarve jināna svarāṅgaviśuddhim | sarvajagasya yathāśayaghoșām buddhasarasvatim ottari nityam || teșu ca akṣayaghoșaruteșu sarvatṛyadhvagatāna jinānām | cakranayaṃ parivartayamāno buddhibalena aham praviśeyam || ekakṣaṇena anāgata sarvān kalpapraveśa ahạ̣ praviśeyam | ye 'pi ca kalpatṛyadhvapramāṇās tāṃ kṣaṇakoțīpravișța careyam || ye ca tṛyadhvagatā narasiṃhās tān ahu paśyiya ekakṣaṇena | teșu ca gocari mātari nityam māyagatena vimokșabalena \| ye ca tṛyadhvasukṣetraviyūhās tān ahu nirhari ekarajāgro | evam aśeșata sarvadiśāsu otari kṣetraviyūha jinānām || ye ca anāgatalokapradīpās teșu vibudhyena cakrapravṛtti | nirvṛttidarśananiṣtha praśāntiṃ tān ahu sarvy upasaṃkrami nāthā || ṛddhibalena samantajavena yānabalena samantamukhena |

4 vimuktu] corr.; vimu ms. 7 sarvajagasya] pc.; sarvagajasya ac. 16 saddharmam] corr.; sadharmaṃ ms. 23 cārika-] corr.; cāri- ms. 
caryabalena samantagunena maitrabalena samantagatena || puṇyabalena samantaśubhena jñānabalena asaṃgagatena | prajñā<72r>upāyasamādhibalena bodhibalaṃ samudānayamānaḥ || karmabalaṃ pariśodhayamānaḥ kalaśabalạ̣ parivartayamānạ̣ | mārabalaṃ abalaṃkaramānạ̣ pūrayi bhadracarībala sarvam || kṣetrasamudra viśodhayamānaḥ praṇidhisamudra prapūrayamāṇaḥ | dharmasamudra vipaśyayamāno jñānasamudra vigāhayamānaḥ || caryasamudra viṣodhayamānaḥ praṇidhisamudra prapūrayamāṇaḥ | buddhasamudra prapūjayamāṇaḥ kalpasamudra careyem akhinnaḥ || ye ca triyadhvagatāna jinānāṃ bodhicariṃ praṇidhānaviśeșāḥ | tān ahu pūriya sarvi aśeșān bhadracarīya vibudhyiya bodhim || jyeșţhaku yaḥ sutu sarvajinānām yasya ca nāma samantabhadrạ̣ | tasya vidusya sabhāgacarīye nāmayamī kuśalam imu sarvān || kāyatu vāca manasya viśuddhiś caryaviśuddhy atha kṣetraviśuddhị̣ | yādṛ́a nāma bhadra vidusya tādṛśa bhotu samam mama tena || bhadracarīya samantaśubhāye mañjuśirīpraṇidhāna careyam | sarvi anāgatakalpam akhinnaḥ pūrayi tām kriya sarvi aśeșām || mā ca pramāṇu bhaveya carīya mā ca pramāṇu bhaveya guṇānām | apramānacariyāpathi hitvā jānayi sarvavikurvitu teșām || yāvata nișțha nabhasya $<72 \mathrm{v}>$ bhaveyā sattva aśeșata niștha tathaiva | karmakleśatu yāvata niṣṭhā tāvata niṣṭha mama praṇidhānam || yac ca daśaddiśi kṣetra anantā ratna-alaṃkṛta dadyu jinānām | divya ca mānuṣa saukhyaviśiștān kṣetrarajopama kalpa dadeyā || yaś ca imaṃ pariṇāmanarājaṃ śrutvā sakṛj janayed adhimuktim | bodhicarām anuprārthayamāno agru višișța bhaved imu puṇyam || varjita tena bhavanti apāyā varjita tena bhavanti kumitrāḥ | kșipru sa paśyati taṃ amitābham paśyamu bhadracariṃ praṇidhānam || lābha sulabdha jīvitu teșām svāgatu te imu mānuṣa janme | yādṛśa so hi samantabhadras te 'pi tathā na cireṇa bhavanti || pāpaku pañca anantariyāṇi yena ajñānavaśena kṛtāni | so imu bhadracariṃ bhaṇamānaḥ kṣipra parikṣayu neti aśeșam || jñānatu rūpatu lakṣaṇataś ca varṇatu gotratu bhotu rupetạ̣ | tīrthikamāragaṇebhir adhṛșyaḥ pūjita bhoti sa sarvatriloke || kṣipru sa gacchati bodhidrumendraṃ gatva niṣīdati sattvahitāya |

8 viṣodhayamānaḥ] corr.; vidhodhayamānah ms. 12 jyeșțhaku] corr.; yeșthaku ms. 18 pramāṇu] corr.; pramāthu ms. 23 ca] pc.; om. ac. 24 sakṛj] corr.; śakṣa ms. 25 agru] corr.; aśru ms. 28 svāgatu] corr.; svāmatu ms. 31 bhadracariṃ] $p c$;; drabhacariṃ $a c$. 
buddhiya bodhi pravartayi cakraṃ dharșayi mārasasainyaku sarvam || yo imu bhadracariṃ praṇidhānaṃ dhārayi vācayi deśayito vā | buddha vijānati <73r> yo 'tra vipāko bodhi viśișța ma kān̉kșa janetha || mañjuśirī yathā jānati śūrạ̣ so ca samantabhadra tathaiva | teșu ahaṃ anuśikṣayamāṇo nāmayamī kuśalam imu sarvam || sarvatriyadhvagatebhi jinebhir yā pariṇāmana varṇitu agrāḥ | tāya aham kuśalam imu sarvam nāmayamī varabhadracarīye || kālakriyāṃ ca ahaṃ karamāṇo avaraṇān vinivartayi sarvān | sammukha paśyiya tam amitābhaṃ taṃ ca sukhāvatikṣetra vrajeyam || tatra gatasya imu praṇidhānam āmukhi sarvi bhaveyu samagrāḥ | tāṃś ca ahaṃ paripūri aśeșān sattvahitaṃ kari yāvata loke \| tahi jinamaṇdali śobhanaramye padmavare rucire upapannạ̣ | vyākaraṇam ahu tatra labheyā sammukhato amitābhajinasya \| vyākaraṇaṃ pratilabhya ca tasmi nirmitakoțiśatebhir anekaiḥ | sattvahitāni bahūny ahu kuryā dikṣu daśasv api buddhibalena || bhadracariṃ praṇidhāna paṭhitvā yat kuśalaṃ mayi saṃcita kiṃcit | ekakṣaṇena samṛdhyatu sarvạ̣ tena jagatasya śubhapraṇidhānam || bhadracarim parināmya yad āptam punyam anantam atīva viśișțam | tena jagadvyasanaughanimagnaṃ yātv amitābhapuriṃ varam eva || ||$\langle 3 \mathrm{v}\rangle$

ārya-bhadracari-mahāpraṇidhānarājaṃ samāptam iti || ||

[71] oṃ namaḥ śrī-āryāvalokiteśvarāya bodhisattvāya mahāsattvāya mahākārunikāya \|

tadyathā || oṃ cara 2 cili 2 culu 2 hulu 2 mulu 2 hūṃ hūṃ hūṃ hūṃ hūṃ phaṭ phaṭ phaț phaț phaț padmahastāya svāhā || ||

iti mokṣapada-nāma-dhāraṇī parisamāptaḥ || ||

[72] oṃ namo ratnatrayāya || namo bhagavate āryāvalokiteśvarāya bodhisattvāya mahāsattvāya mahākāruṇikāya \| tadyathā || oṃ mușți sumuștị cchedani vicchedani nirmale mangale sumañgale sarvabhayamocani sarvapāpabhayebhyo vimocani | oṃ rājabhayāt caurabhayān maraṇabhayāt apasmārabhayāt apaścāībhayāt stambhabhayāt agnibhayād udakabhayāt paracakrabhayāt | senāmadhye gato vā cauramadhye gato vā siṃhamadhye gato vā vyāghramadhye gato vā sarvamadhye gato vā yugamadhye gato vā candramadhye gato vā sūryamadhye gato vā |

1 bodhi] corr.; bo ms. 5 nāmayamī] corr.; nāmayagī ms. 8 avaraṇān] pc.; avaṇāran $a c$. 
kṛṣnasarpamadhye gato vā kālapāśamadhye gato vā nigamamadhye gato vā mañjamadhye gato vā hastimadhye gato vā samudramadhye gato vā | kātumadhye gato vā naramadhye gato vā sarvamadhye gato vā <74r> | sarvopadraveșu mucyate rakṣa 2 māṃ sarvasattvānām āyurārogyaśriyo 'stu āryāvalokiteśvarasya hatyaharityaharyasarvahare sarvapaticchittānāṃ mocani 5 mocasiddhi vini oṃ namạ̣ svāhā || ||

ārya-abhayaṃkarī-nāma-dhāraṇī parisamāptạ̣ || ||

[73] oṃ namo māṇibhadrāya || evaṃ mayā śrutam ekasmin samaye bhagavān śrāvastyām viharati sma || jetavane anāthapiṇḍadasyārāme || atha khalu māṇibhadro mahāyakṣesenāpatih yena bhagavāṃs tenopasaṃkrānta upasaṃkramya bhagavataḥ pādau śirasā vanditvā ekānte sthito māṇibhadro mahāyakṣasenāpatir bhagavantam etad avocat || idaṃ bhadanta mama hṛdayaṃ yaḥ kaścid bhikṣur vā bhikṣuṇī vā upāsako vā upāsikā vā trikṛtvā divase bhaviṣyati || tasyāham satatānubaddho bhaviṣyati sarvakāryāṇi kariṣyāmi | bhojanavastrahiraṇyasuvarṇadhanadhānyarūpyaṃ ca dāsyāmi || sarvārthaṃ cāsya kāryayiṣyāmi | sarvasattvānāṃ ca mānasīkariṣyāmi | sarvacitta cāsya kariṣyāmi | sthāpayitvā maithunopasaṃhitạ̣ sāvadyām || namo ratnatrayāya || namo māṇibhadrāya mahāyakṣasenāpataye hili <74v> māṇibhadra hili 2 māṇibhadra | cili māṇibhadra cili 2 māṇibhadra | culu māṇibhadra culu 2 māṇibhadra | turu māṇibhadra turu 2 māṇibhadra | kuru māṇibhadra kuru 2 māṇibhadra | suru māṇibhadra suru 2 māṇibhadra | sarvārthasādhaye svāhā || tadyathā || pūtane supūtane surūpe susumate surate supuṣpe hilike hili kāli pūrṇasiddhe bhadre hili 2 svāhā || ehi koniske ehi seniske ehi goniske svāhā || saptavārān parijapya siddhir bhavati | asyopacāraḥ śuklapañcadaśyāṃ trikālaṃ śucinā gugguludhūpaṃ dahamānena așțasahasraṃ japet suvarṇaghaṭo labhate || || ārya-māṇibhadra-nāma-dhāraṇī samāptaḥ || ||

16 kāryayiṣyāmi] corr.; nāryayiṣyāmi ms. • mānasī-] corr.; mrāvasī- ms. 17 -saṃhitaṃ] pc.; -saṃhityataṃ ac. 18 hili] pc.; hili 2 ac. 27 guggulu-] corr.; gugulu- ms. 
[74] oṃ namo bhagavate sarvadurgatipariśodhanarājāya tathāgatāyārhate samyaksambuddhāya \| tadyathā || oṃ śodhani 2 sarvapāpaviśodhani śuddhe viśuddhe karmāvaraṇaviśuddhe svāhā || ||

ārya-durgatipariśodhanī-nāma-dhāraṇī samāptaḥ || ||

[75] oṃ padme 2 padmodbhave sukhāvatī gacchatu svāhā || || iti gāthādvayaṃ kālagataśuddhyartham aștotottaraśataṃ japet pāpaśuddho bhavati || || namaḥ sapta<75r>saptatīnāṃ buddhakoținām || tadyathā || oṃ cale cule cunde svāhā \| iti cundābhagavatyāḥ pratidinam aștottaraśataṃ japet pāpaśuddhyartham || ||

iti cundābhagavatī-dhāraṇī-samāptaḥ || ||

[76] oṃ namo bhagavatyai ārya-mahāpratisarāyai || evaṃ mayā śrutam ekasmin samaye bhagavān mahāvajrameruśikhare kūṭāgāre viharati sma || mahatā bhikṣusaṃghena sārdham ardhatrayodaśabhir bhikṣuśataị̣ | sambahulaiś ca bodhisattvair mahāsattvaiḥ || atha khalu bhagavān ūrṇākośāt sarvabuddhadarśanaṃ nāma raśmijālaṃ niścārayitvā dharmaṃ deśitavān sarvāvatīṃ parșadam āmantrayāha || duṣṭagrahavinās̄ārthaṃ bhāṣitā jñānaketubhị̣ | sarvakāmaṃdadā yā ca bhāṣye vidye śṛnotha tām ||

tadyathā || namo buddhāya namo dharmāya namaḥ saṃghāya || namaḥ sarvatathāgatebhyo namaḥ sarvabuddhabodhisattvebhyo 'tītānāgatapratyutpannebhyo namah || oṃ vipulagarbhe vipulavimale vimalagarbhe vimale jayagarbhe vajrajvālāgarbhe gatigahane gaganaviśodhane sarvapāpaviśodhane || om guṇavati gaganavicāriṇi gagariṇi 2 giri 2 giriṇi 2 gabhari gardhabhari | gamari 2 gahari | gaha 2 gargāri 2 gagari $2<75 \mathrm{v}\rangle$ gambhari 2 gabhi 2 gahi 2 gamani 2 gare 2 guha 2 guru 2 guruni bale mucale samucale | guhani 2 guruṇi 2 culu 2 cale 2 mucile jaye vijaye jayavati | aparājite sarvabhayavigate sarvagarbhasaṃrakșaṇi | siri 2 bhiri 2 miri 2 giri 2 ghiri 2 samantākarșaṇi sarvaśatrūn pramathani | rakṣa 2 māṃ sarvasattvāṃś ca 30 sarvadā sarvabhayebhyaḥ sarvopadravebhyaḥ sarvavyādhibhyaḥ | ciri 2 viri 2 dhiri 2 vigatāvaraṇe viśodhani vividhāvaraṇavināśini | muci 2 muri 2 muli 2 vili 2 kili 2 mili 2 kamale vimale jaye vijaye jayāvahe jayavati viśeșavati

7 gāthādvayaṃ] pc.; gādvathādvayaṃ $a c .23$ 'tītānāgata-] $p c . ;$ 'tīnātāgata- $a c$. 
bhagavati ratnamakuṭamālādhari bahuvividhavicitraveśadhāriṇi | bhagavati mahāvidyādevi rakṣa 2 māṃ sarvasattvāṃś ca samantāt sarvatra pāpaviśodhani | hulu 2 mulu 2 rakṣa 2 māṃ sarvasattvāṃś cānāthātrāṇān alayanān aśaraṇān aparāyaṇān parimocaye sarvaduḥhebhyah caṇḍi 4 caṇdini 2 vegavati sarvaduṣțanivāriṇi vijayavāhini | huru 2 muru 2 curu 2 turu 2 āyuḥpālani suravarapramathani sarvadevagaṇapūjite | ciri 2 viri 2 samantāvalokite prabhe 2 suprabhe suprabhaviśuddhe $<76 \mathrm{r}>$ sarvapāpaviśuddhe sarvapāpaviśodhani | dhuru 2 dharaṇidhare dhara 2 sumuja | sumuru 2 ruru cale cālaya sarvadușțān pūraya āśāṃ mattaṅgini śrīvapurdhare jayakamale | kṣiṇi 2 varadānkuśe || om padmaviśuddhe śodhaya 2 śuddhe 2 bhara 2 bhiri 2 bhuru 2 mańgalaviśuddhe | pavitramukhi khaḍgini 2 khara 2 jvalitaśikhare samantāvalokitaprabhe suprabhaviśuddhe samantaprasāritāvabhāsitaviśuddhe jvala 2 sarvadevagaṇasamākarṣaṇi satyavrate || oṃ hrīṃ trīṃ tara 2 tāraya māṃ bhagavati sarvasattvāṃś ca nāgavilokite | laghu 2 lahu 2 hulu 2 hutu 2 turu 2 tuhu 2 kiṇi 2 kṣiṇi 2 sarvagrahabhakṣaṇi pingali 2 mucu 4 sumu 2 suvicare | tara 2 nāgavilokini | tāraya māṃ sarvasattvāmś ca saṃsārārṇavāt bhagavati așțamahādāruṇabhayebhyaḥ | sarvatra samantena diśābandhena vajrapāśabandhane vajrajvālini vajrajvālāviśuddhe | bhuri 2 bhara 2 bhiri 2 bhuru 2 bhagavati garbhavati garbhavate garbhaviśodhani kukșisampūraṇi rakṣaṇi | jvala 2 cala 2 oṃ jvālini varṣantu devah samantena divyodakena amṛtavarṣaṇi devāvatāraṇi | abhiṣi<76v>ñcatu māṃ sugatavaravacanāmṛtavapuṣke rakṣa 2 māṃ sarvasattvāṃś ca sarvatra sarvadā sarvabhayebhyạ̣ sarvopasargebhyạ̣ sarvavyādhibhyạ̣ sarvadușțabhayabhītebhyạ̣ sarvakalikalahavivādasarvabhayaviśodhani duhssvapnadurnimittāmañgalapāpaviśodhani kukșisampūraṇi sarvayakșarākṣasanāgavidāraṇi | bala 2 balavati | jaya 2 vijaya 2 jayatu sarvatra sarvakālaṃ siddhentu me iyam mahāvidyā sādhaya maṇḍalam ghātaya vighnān jaya 2 sidhya 2 budhya 2 pūraya 2 pūraṇi 2 pūraya me āsām vidyodgatamūrte jayottari jayakari jayavati || tiștha 2 bhagavati samayam anupālaya sarvatathāgatahṛdayaviśuddhe vyavalokaya māṃ sarvasattvāṃś ca sarvāśāṃ paripūraya sarvasattvānāṃ ca trāyasva mām așțamahādāruṇabhayebhyạ̣ || sara 2 prasara 2 sarvāvaraṇaviśodhani samantākāramaṇḍalaviśuddhe | vigate 2 vigatamale sarvamalaviśodhani sarvamangalaviśuddhe | sarvāmañgalaviśuddhe | kṣiṇi 2 sarvapāpaviśuddhe | malavigate jayavati tejovati vajravati | vajravati || oṃ trailokyādhiștihite svāhā || sarvatathāgatamūrdhābhișikte svāhā || sarvabuddhabodhisattvā<77r>bhiṣikte svāhā || sarvadevatābhiṣikte svāhā ||

17 -mahādāruṇa-] corr.; -mahāruṇa- ms. 35 oṃ] pc.; om. ac. •-ādhișțhite] pc.; -ādhipașțhite ac. 
sarvatathāgatahṛdayaśuddhe svāhā || sarvatathāgatahṛdayādhișțhitahṛdaye svāhā || sarvatathāgatasamayasiddhe svāhā || indre indravati indravyavalokite svāhā || brahme brahmādhyuṣite svāhā || sarvatathāgatādhișțite svāhā || viṣnunamaskṛtāya svāhā || maheśvaravanditapūjitāyai svāhā || vajradharavajrapāṇibalavīryādhișthite svāhā || dhṛtarāṣtrāya svāhā || virūụhakāya svāhā || virūpākṣāya svāhā || vaiśravaṇāya svāhā || caturmahārājanamaskṛtāya svāhā || yamāya svāhā || yamapūjitanamaskṛtāya svāhā || varuṇāya svāhā || vāruṇāya svāhā || mārutāya svāhā || mahāmārutāya svāhā || agnaye svāhā || vāyave svāhā || nāgavilokitāya svāhā || devagaṇebhyạ̣ svāhā || nāgagaṇebhyaḥ svāhā || yakṣagaṇebhyạ̣ svāhā || rākṣasagaṇebhyạ̣ svāhā || gandharvagaṇebhyaḥ svāhā || apasmāragaṇebhyaḥ svāhā || asuragaṇebhyạ̣ svāhā || garuḍagaṇebhyạ̣ svāhā || kiṃnaragạ̣ebhyaḥ || mahoragagaṇebhyaḥ svāhā || manuṣyagaṇebhyạ̣ svāhā || amanuṣyagaṇebhyạ̣ svāhā || sarvagrahebhyạ̣ svāhā || sarvanakṣatrebhyaḥ svāhā <77v> || sarvabhūtebhyạ̣ svāhā || sarvapretebhyạ̣ svāhā || sarvapiśācebhyaḥ svāhā || sarvāpasmārebhyaḥ svāhā || sarvakumbhāṇdebhyạ̣ svāhā || sarvapūtanebhyạ̣ svāhā || sarvakațapūtanebhyaḥ svāhā || sarvaduṣțapraduṣțebhyaḥ svāhā || oṃ dhuru 2 svāhā || oṃ turu 2 svāhā || oṃ kuru 2 svāhā || oṃ curu 2 svāhā || oṃ muru 2 svāhā || oṃ hana 2 sarvaśatrūn svāhā || oṃ daha 2 sarvaduṣṭān svāhā || paca 2 pratyarthikapratyamitrān svāhā || ye mamāhitaiṣiṇas teșām sarveșām śarīraṃ jvālaya 2 sarvadușțacittānāṃ svāhā || jvalitāya svāhā || prajvalitāya svāhā || dīptajvalitāya svāhā || vajrajvālāya svāhā || samantajvālāya svāhā || maṇibhadrāya svāhā || pūrṇabhadrāya svāhā || samantabhadrāya svāhā || mahāsamantabhadrāya svāhā || kālāya svāhā || mahākālāya svāhā || mātrgaṇāya svāhā || yakṣaṇīnām svāhā || rākṣasīnāṃ svāhā || pretapiśācaḍākinīnāṃ svāhā || 25 ākāśamātṛ̣nāṃ svāhā || samudragāminīnāṃ svāhā || rātricarānāṃ svāhā || divācarāṇām svāhā || trisaṃdhyācarāṇāṃ svāhā || velācarānām svāhā || avelācarānāṃ svāhā || garbhaharebhyaḥ svāhā || garbhadharebhyaḥ svāhā || garbhāhārị̣ibhyạ̣ svāhā || ga<78r>rbhasaṃdhāriṇībhyạ̣ svāhā || culu 2 svāhā || huru 2 svāhā || oṃ svāhā || svaḥ svāhā || bhūḥ svāhā || bhuvaḥ svāhā || bhūr bhuvaḥ svāhā || cili 2 svāhā || viṭi svāhā || dharạ̣i svāhā || dhāraṇī svāhā || agneḥ svāhā || tejovāyu svāhā || cili 2 svāhā || sili 2 svāhā || mili 2 svāhā || budhya 2 svāhā || maṇḍalabandhe svāhā || sīmābandhe svāhā || sarvaśatrūn bhañjaya 2 svāhā || jambhaya 2 svāhā || stambhaya 2 svāhā || chindaya 2 svāhā || bhindaya 2 svāhā || bhañjaya 2 svāhā || bandha 2 svāhā || mohaya 2 svāhā || maṇiviśuddhe svāhā || sūrye sūryaviśuddhe svāhā || śodhani svāhā || viśodhani svāhā || candre 2 pūrṇacandre svāhā || grahebhyaḥ svāhā || nakṣatrebhyaḥ

2 -tathāgata-] corr.; -tathāga- ms. 
svāhā || piśācebhyaḥ svāhā || śivebhyaḥ svāhā || viśvebhyaḥ svāhā || śāntibhyaḥ svāhā || puștịhyaḥ svāhā || svastyayanebhyaḥ svāhā || garbhaharebhyaḥ svāhā || śivaṃkari śāntikari puștikari balavardhani svāhā || śrīkari svāhā || śrīvardhani svāhā || balavardhanakari svāhā || śrījvālini svāhā || muci svāhā || namuci svāhā || maruci svāhā || vegavati svāhā || oṃ svāhā || oṃ sarvatathāgatamūrte pravaravigatabhaye śamayasva me bha $<78 \mathrm{v}>$ gavati sarvapāpa svastir bhavatu mama sarvasattvānām ca svāhā || oṃ muni 2 vimuni 2 dhari 2 cari 2 calane bhagavati bhayaharani 2 bodhi 2 bodhaya | buddhili 2 cumbili 2 svāhā || sarvatathāgatahṛdayajuște svāhā || oṃ maṇi 2 vare abhiṣiñcatu māṃ saparivāram sarvasattvānāṃ ca sarvatathāgatāḥ sarvavidyābhișekair mahākavacamudrāmudritaị̣ sarvatathāgatahṛdayādhișțhitaśuddhe mudre vajre svāhā || samantajvālāmālāviśuddhisphuritacintāmaṇimahāmudrāhṛdayāparājitāmahādhāraniìyam || || punar evam apare mantrāḥ siddhāḥ sarvakarmakarāḥ śubhā || sarvakāmaṃdadā bhadrās tām prabhāṣe śṛ̣otha ca \| tadyathā || oṃ amṛtavare vara pravaraviśuddhe hūṃ 2 phaț 2 svāhā $\|$ oṃ amṛtavilokini garbhasaṃrakṣaṇi ākarșaṇi hūṃ hūṃ phaṭ 2 svāhā || aparājitāhṛdayam ||

oṃ vimale vipule jayavare jayavāhini amṛte viraje hūṃ hūṃ phaṭ 2 svāhā || oṃ bhara 2 sambhara 2 indriyabalaviśodhani hūṃ hūṃ phaṭ ruru cale svāhā || oṃ maṇidhari vajrini mahāpratisare hūṃ hūṃ phaṭ 2 svāhā || upahṛdayavidyā || asyāḥ śravaṇamātreṇa sarvapāpāḥ kṣayaṃgatāḥ | yayā yu<79r>kto vajrakāyo namas tasyai namo namaḥ \| yāṃ smaran rāhulo rakṣan mātaraṃ kukṣisaṃsthitạ̣ | prakșipte 'gnau viṣe nadyāṃ namas tasyai namo namah || yā rakṣed vaniijaḥ putraṃ krūrasarpe vadhodyatam | viṣadāha mumūrṣam ca namas tasyai namo namạ̣ || brahmadatto mahārājo yayā rakṣitamastakaḥ | ripuṃ jitvā virājo 'bhūt namas tasyai namạ̣ sadā || bhikṣur duhş̂̄ilako rogī yayā kaṇṭhe prabandhitah | prāṇamukto yayai svargan namas tasyai namo namạ̣ || samudre potasaṃkșubdhe vāṇijān prāṇarakṣakaḥ | yān smaran sārthavāho 'bhūt namas tasyai namo namaḥ || yayā ca pratibaddhāyāṃ bhāryāyāṃ sutam āptavān | prasāritabhujo rājā namas tasyai namo namạ̣ ||

3 saāntikari] corr.; śāntiri ms. 6 śamayasva] corr.; sva ms. • sarvapāpa] pc.; sarvatapāpa ac. 9 abhișiñcatu] corr.; abhiñcatu ms. 24 rakșan] pc.; rakșa2n ac. 30 bhikșur] corr.; bikșur ms. 
daridrāyāṃ pratismṛtvā dīnāraṃ pradado jine |

rājābhīṣtapradātā 'bhūt namas tasyai namo namaḥ ||

yām prabaddhāsurair yuddhe śakracūḍāmaṇau prabhuh |

labdhavān vijayaṃ vajrī namas tasyai namo namạ̣ ||

yasyām antabalenaiva pūrya pāramitāḥ ṣaṭ |

mārāñ jitvā jinā buddhā namas tasyai namo namạ̣ ||

aparādhī vadhārho 'pi prakṣiptaḥ sarvasaṃkațe |

yāṃ smṛtaḥ parimukto 'bhūt namas tasyai namo namạ̣ ||

yayā bandhitakaṇṭhaś ca mukto 'pāyasaṃkatāt |

nagare nā<79v>yako 'bhūc ca namas tasyai namo namạ̣ ||

yā cāparājitā vidyā sarvabuddhaiś ca dhāritā |

mudritā bhāṣitā nityaṃ paṭhitā paradeśitā ||

likhitā moditā sattvahitāya pūjitā sadā|

smṛtā kāyagatā kṛtvā namas tasyai namo namaḥ ||

yasyāḥ śravaṇamātram ca durlabham bhuvaṇatraye |

pāṭhasvādhyāyanaṃ vāpi namas tasyai namo namạ̣ ||

yā vidyā durlabhā buddhair vyākṛtā sampraśaṃsitā |

mahatī dhāraṇī khyātā sarvapāpakṣayaṃkarī ||

mahābalā mahāvīryā mahātejā mahatprabhā |

mahāguṇavatī vidyā sarvamāravidāriṇī ||

pāpasaṃdhisamudghātī māramadapramocanī |

jananī bodhisattvānāṃ sarvaduṣțavināśinī ||

rakṣiṇi poṣiṇī dhātrī paramantravighātinī |

kākhordaviṣayogānāṃ vidhvaṃsanakarī śivā ||

mahāyānaratānām ca gṛhṇatām likhatām tathā|

pāṭādhyayanakṛtā nityaṃ dadhatāṃ ṣ̣́nvatāṃ tathā ||

parebhyo diśatā caivaṃ nitya manasi bhāvitām |

supustakagatāṃ kṛtvā pūjyamānya namaskṛtām ||

sarvapāpaharī bhadrā bodhisambhārapūraṇī |

namas tasyai namas tasyai namas tasyai namo namạ ॥

yasyā mantraprabhāvena sarve bhaya-upadravāḥ |

duṣtāsurama<80r>nuṣyāś ca daityagandharvarākṣasāḥ ||

grahāḥ skandā apasmārāḥ piśācā yakṣakiṃnarāh |

ḍākinyaḥ śākinīsaṃhāḥ nāgā kākhordavyādhayo ||

jvarāś ca vividharogāḥ parakarmakṛtās tathā|

viṣāgniśastramantrāṇi vidyutạ̣ kālavāyavaḥ ||

3 śakracūḍā-] $p c$.; śacūkraḍā- ac. 7 vadhārho 'pi] corr.; vahaudhāpi ms. • prakșiptaḥ] $p c . ;$ prakșitaptah ac. 35 vividha-] corr.; vivi- ms. 
ativṛștir aṇāvṛṣṭị sarvaśatrubhayāni ca | tathānye 'py upasargā vā vinaśyanti na saṃśayạ̣ || sarvakāryāṇi siddhyanti namas tasyai namo namạ̣ || yaś ca tāṃ dhārayed vidyāṃ kaṇṭhe bāhau ca mastake | nityaṃ rakṣanti devās tạ̣ daityā nāgāś ca mānuṣāḥ || gandharvā kiṃnarā yakṣā bhūtapretapiśācakāḥ | ḍakinya rākṣasā dūtyah kumbhāṇḍạ kațapūtanāḥ || trisaṃdhyam yaḥ pațhen nityaṃ buddhā rakṣanti tam sadā | pratyekā śrāvakāś caivaṃ bodhisattvā maharddhikāḥ || yoginaḥ siddhamantrāś ca mahāvīryā maharṣayaḥ | vajrapāṇiś ca yakṣendraḥ śakraś ca tridaśaiḥ saha || catvāraś ca mahārājā brahmā viṣnur maheśvarāḥ | nandikeśo mahākālaḥ kārttikeyo gaṇeśvarạ̣ || bhairavā mātṛkā durgās tathānye mārakāyikāḥ | vidyādevyā mahāvīryā mahābalaparākramāḥ || māmakī bhṛkuṭī tārā cānnkuśī vajraśṛnkhalā | mahāśvetā mahākālī vajradūtī supāśikā || <80v> vajramālā mahāvidyā suvīryāmṛtakuṇḍalī | vajrāparājitā caṇụī kālakarṇī mahābalā || tathā dhanyā mahābhāgā padmakuṇḍalir eva ca | maṇicū ḍā puṣpadantī svarṇakeśī ca pingalā || ekajațā mahādevī dhanyā vidyutsumālinī | kapālinī ca laṅkeśī buddhā kṣitikanāyikā || hārītī pāñcikaś caiva śan̉khinī kūṭadantinī | śrī sarasvatī lakṣmīh siddheśvarī sadānugāḥ | tam evānye 'pi rakṣanti yasya vidyā kare sthitā || sa bhavet sarvasattvānāṃ mokṣaṇārthaṃ samudyatạ̣ | rājāno vaśagās tasya puṇyarāśi vivardhayet || siddhyante sarvakalpāś ca pravișțo jinamandire | ante bauddhapadam yāyāj jinasya vacanaṃ yathā || yā strī dhārayed vidyāṃ prasūye gurviṇī sukham | aputre labhate putraṃ vyādhimuktā sukhāśinī || dhanadhānyair varair puṣpā mānanīyā priyaṃvadā| susvapnā satyakarī ca jinakșetraṃ samāpnuyāt || || ity avocad bhagavān sā ca sarvāvatī parṣad abhyanandann iti || ||

ārya-mahāpratisarā-mahāvidyā-dhāraṇī samāptā || ||

27 bhavet] $p c$;; vebhat $a c . \quad 28$ vivardhayet] $p c$;; vidhavayet ac. 34 -kșetraṃ] corr.; -kșanatra ms. 
[77] atha vaidyādharakalpaṃ vakṣye sattvānukampayā |

yena rakṣāvidhānena sarvasiddhir bhavișyati ||

yatra rakṣā sthitā ceyaṃ <81r> tatra naśyanti vyādhayạ̣ |

pāpā upagrahārișțā viṣaśatruya dāruṇāḥ ||

buddhāś ca bodhisattvāś ca pratyekāḥ śrāvakās tathā |

devāsuramanuṣyāś ca rakṣāṃ kurvantu tasya vai ||

anayā kṛtarakṣantu vadhārho 'pi vimucyate |

saptāhamṛtako 'py evaṃ vajrīvati na saṃśayạ̣ ||

asyā śravaṇamātreṇa svastir bhavati sarvadā |

devāś caturmahārājā lokapālāś ca rakṣakāḥ \|

atra mantrapadāḥ siddhāḥ samyaksambuddhabhāṣitāḥ ||

tadyathā || namo buddhāya namo dharmāya namạ̣ saṃhāya ||

namo bhagavate sāākyamunaye mahākāruṇikāya tathāgatāyārhate

samyaksambuddhāya || namạ̣ samantebhyạ̣ samyaksambuddhebhyaḥ ||

oṃ giri 2 giriṇi 2 girivati guṇavati ākāśavati ākāśaviśuddhe sarvapāpavigate

ākāśe gaganatale ākāśavicāriṇi maṇidhari vajriṇi jvalitaśikhare

maṇimuktākhacitamaulidhare sukeśe suveșe suvaktre sunetre suvarṇagaure atīte anutpanne anāgate pratyutpanne namaḥ sarvabuddhānāṃ jvalitatejasāṃ buddhe subuddhe bhagavati surakșaṇi akșaye sukșaye sukșame suprabhe sudame sudānte suvrate varade pravare bhagavati bhadravati bhadre subhadre vi<81v>male jayabhadre cạ̣di pracaṇdi caṇde vajracaṇde mahācaṇde ghori gandhāri caṇụāli mātaṅgi varcasi sumati pukkasi sumukhi śabari śābari śaṃkari dramị̣i drāmiḍi drodrị̣i sarvārthasādhani paramārthasādhani hana 2 sarvaśatrūn | daha 2 sarvaduṣțān pretapiśācaḍākinīmanuṣyāmanuṣyāṇām | paca 2 hṛdayam vidhvaṃsaya jīvitam sarvaduṣțagrahāṇām | nāśaya 2 sarvapāpāni me bhagavati rakṣa 2 mama sarvasattvānāṃ ca | sarvatra sarvadā sarvabhayopadravebhyah sarvadușțapradușțānām bandhanaṃ kuru 2 sarvakilbiṣanāśani mārtạ̣ḍe mṛtyudaṇḍe mṛtyudaṇḍanivāriṇi mānande mānini mahāmānini mānadhāriṇi cale vicale vicale vimale viṭi 2 tiṭi 2 niṭi 2 tuṭ̣e ghoriṇi ghariṇi nimiṇi viriṇi vīryaṇi pravare pravarasamare cạ̣ḍali mātañgi rundhasi karasi śarasi varcasi sumati pukkasi śabari śābari śamkari śamani draviḍ̣i drāviḍii hanani dahani pacani pācani mardani śaralaśarale śaralambhe hīnamadhyotkṛșțavidāriṇi | mahili 2 mahāmahili nigaḍe nigaḍabhañje matte 2 mattini mitte dānte cakre cakravākini | jvale 2 jvalini | śabari saābari sarvavyādhiha<82r>riṇi muni 2 cuḍi 2 cuṇdini 2 mahācuṇḍini nimi 2 nimindhari 35 trailokyavardhani trilokajanani trilokālokakari traidhātukavyavalokani

4 dāruṇāḥ] corr.; dāraṇāḥ ms. 20 bhadre] pc.; subhadre ac. 22 sumukhi] corr.; sumakhi ms. 
vajraparaśupāśamudgarakhaḍgacakratriśūlacintāmaṇimakuṭamahāvidyādhāriṇi | rakṣa 2 māṃ sarvasattvāṃś ca sarvatra sarvasthānagatasarvaduṣțabhayebhyaḥ sarvamanuṣyāmanuṣyabhayebhyaḥ sarvavyādhibhyạ̣ vajre 2 vajravati vajradhare vajrapāṇidhare | hiri 2 miri 2 kili 2 cili 2 sili 2 cala 2 vara 2 varade varadāṅkuśe sarvatra jayalabdhe svāhā || sarvapāpavidāriṇiye svāhā || sarvavyādhihariṇi svāhā || garbhasambharaṇi svāhā || sarvatra bhayaharaṇi svāhā || sarvaśatrubhayaharaṇi svāhā || svastir bhavatu mama sarvasattvānāṃ ca svāhā || oṃ bhuvaḥ svāhā || svasti svāhā || sāntị̣ svāhā || puṣṭị svāhā || balavardhani svāhā || om jayatu jaye jayavati jayakamale vimale svāhā || vipule svāhā || sarvatathāgatamūrte svāhā || oṃ bhūri mahāsāante svāhā || oṃ bhūḥ bhūri 2 vajravati sarvatathāgatahṛdayapūraṇi āyuḥsaṃdhāraṇi bale balavati oṃ jayavidye hūṃ hūṃ phaṭ | oṃ maṇidhari vajriṇi hūṃ hūṃ phaṭ 2 svāhā || oṃ maṇivajre hṛdayavajre mārasainyavidrāpaṇe hana 2 sarvaśatrūn vajragarbhe trāsaya 2 sarvabhuvanāni hūṃ hūṃ phaṭ 2 svāhā || yo 'nayā kṛtarakṣāś ca tasyā<82v>yuh samvivardhate | smṛtimān suciraṃjīvī puṇyavāṃś ca sukhī bhavet | samuccāraṇamātreṇa vajrāvamārjanena ca | apamṛtyur mahāvyādhih sarvarogaś ca naśyati || nityaṃ svādhyāyavān prājño pradātā śīlavā kṣamī || vīryapratisampanno balatejạ pratāpavān | buddhāś ca bodhisattvāś ca devāsuram tu guhyakāḥ || yakṣā gandharvarākṣasāś ca sarve te varadāyakāḥ | yeșām tiryaggatānāpi karṇe vidyā nivekṣyati || te 'py avaivartikā bodher bhaviṣyanti na saṃśayah | punaś ca ye 'pare mantrā sarvavighnavidārakāḥ \| sarvasattvahitārthāya tāḥ śṛ̣udhvaṃ vaśaṃvade || tadyathā || namaḥ sarvatathāgatebhyo ye tișțhanti daśasu dikṣu || oṃ maṇivajre hṛdayavajre mārasainyavidāriṇi | hana 2 sarvaśatrūn rakṣa 2 māṃ sarvasattvāṃs ca vajre 2 vajragarbhe trāsaya 2 sarvamārabhavanāni hūṃ hūṃ phat 2 sambhara 2 svāhā || buddhamaitrīsarvatathāgatavajrakalpādhișthite sarvakarmāvaraṇāny apanaya svāhā || tad ahạ̣ sampravakṣāmi roginām yac cikitsitam | caturasraṃ maṇḍalaṃ kuryān mṛdgomayasamanvitam | pañcaraṅgikacūrṇena citrayen maṇḍalaṃ śubham ||

13 -pūraṇi āyuhsaṃdhāraṇi bale balavati oṃ jayavidye hūṃ hūṃ phaṭ | oṃ maṇidhari vajriṇi hūṃ hūṃ phaț 2 svāhā || oṃ maṇivajre hṛdaya-] pc.; om. ac. 17 -mārjanena] corr.; -dārjanena ms. 19 -vān] corr.; -nān ms. 29 vajragarbhe] $p c$.; vagajrarbhe ac. 33 mṛdgomaya-] corr.; mṛgomaya- ms. 
caturaḥ pūrṇakumbhāś ca sthāpayed vidhinā budhaḥ |

pūjāgraih pūjayitvā ca balikarma pracā<83r>rayet | catasraḥ kanyakāḥ sthāpya kṛtvā cāturaṃ śucivṛtam | pūrvāmukhaṃ niṣadyainam etāṃ vidyām udāharet | saptadhā varjayitvāsya rakṣām kuryād vicakṣaṇạ̣ || eva yasya kṛtaṃ brahman nașțāh pāpāś ca sarvata | apamṛtyūpasargāś ca sarvopadravamālikāḥ || sarve devāsurā martyā bhūtayakṣāś ca kiṃnarāḥ | sarvabuddhāś ca rakṣanti kim anye cetare grahāḥ || || ity avocad bhagavān sarvāvatī parṣad abhyanandann iti ||

pratisarāyā kalpa-dhāraṇī samāptaḥ || ||

[78] oṃ namo bhagavatyai ārya-mahāsāhasrapramardanyai || evaṃ mayā śrutam ekasmin samaye bhagavān rājagṛhe viharati sma || gṛdhrakūṭe parvate ratnavṛkṣaprabhāse vanașaṇde mahatā bhikṣusaṃghena sārdham ardhatrayodaśabhir bhikṣuśataị̣ sambahulaiś ca bodhisattvaiḥ mahāsattvaiś ca rājñājātaśatruṇā satkṛto māṇito gurukṛtạ̣ pūjito bhagavāṃs tasmin samaye vaiśālyāṃ mahānagaryāṃ mahopadravaṃ prādurbhūtaṃ dṛṣtvā ṛddhyābhisvareṇa trisāhasraṃ mahāsāhasraṃ lokadhātuṃ vijñāpya sadevāsuraṃ lokaṃ saṃnipātayām āsa || atha brahmā sahāpati brahmakāyikāś ca devāḥ śakraś ca devānām indro devāś ca trayatriṃsāśs ca<83v>tvāraś ca mahārājāḥ saparivārā așțaviṃśatimahāyakṣasenāpatayo dvātrimśanmahāyakṣanagnā hārītī ca saputrā saparivārā upasaṃkrānta bhagavatạ̣ pādau vanditvā caikasvarapadena bhagavantam gāthābhir tuṣțuvuh || dīptakāñcananirbhāsa pūrṇacandraprabhāsvaraḥ | śrī-vaiśravaṇavad vīraratnānām ākaro hy asi || siṃhamāraṇavikrānta mattanāgaparākramaḥ | parvato vā suvarṇasya niṣka jāmbūnadasya ca || candro vā vimale vyomni nakșatrebhi puraskṛtah | madhye śrāvakasaṃhasya lakṣaṇair samalaṃḳ̣tạ̣ ||

lokaḥ sadevako 'py eșa muneḥ śaraṇam āgatạ̣ | manuṣyānāṃ hitārthāya rakṣākāla upasthitah || mahāsāhasrapramardanam sarvabuddhaih prakāśitam | ācakravāḍaparyantạ̣ sīmābandhanam uttamam || namas te puruṣovīra namas te puruṣottamạ̣ |

19 sadevāsuraṃ] pc.; sadevāmāsuraṃ ac. 34 uttamam] corr.; uttam ms. 
kṛtāñjalir namasyāmo dharmarājo mahāmune \| atha bhagavān caturo mahārājān āha || naivaṃ mahārājā yuṣmatparṣadbhir asmatparṣada vihețhavyā || vaiśravạ̣o jinaṃ natvā kṛtāñjalir atho vadet || tatra mantrapadāny asti lokanātha ṣ̣́nohi me \| tadyathā || siddhe susiddhe are araṇe bale jambhe stambhe jațile akhane makhane kha<84r $>$ khane kharațe kharange haripingale timingale timingirini mañgale sidhyantu mantrapadāḥ svāhā || mama saparivārasya sarvasattvānāṃ ca svasty astu vaiśravaṇasya mahārājasya nāmnā balenaiśvaryādhipatena ca svāhā ||

dhṛtarāṣțro muniṃ natvā kṛtāñjalih puro vadet || tatra mantrapadāny asti lokanātha śṛ̣ohi me \| tadyathā || akhe nakhe vinakhe bandhe | varāṇụacapale vakhe vakhane akhine nākhine vahale bhage bhagaṃdare vaśe vartini svāhā || mucyantu mama sarvasattvāṃś ca sarvagrahebhyo dhṛtarāșțramahārājasya nāmnā balenaiśvaryādhipatena ca svāhā || virūụhako muniṃ natvā kṛtāñjalipuṭo vadet || tatra mantrapadāny asti lokanātha śṛ̣ohi me || tadyathā || khakhame khalakhalane kharale khalame khalome khalari khekarakhe khatini kharali karakhi kharamine karaṭe kāli kāmini vicari vividhiye vidheyane samavate śami śamini svāhā || sāmyantu mama sarvasattvānāṃ ca sarvagrahasarvabhayopadravāḥ virūụhakasya mahārājasya nāmnā balenaiśvaryādhipatena ca svāhā || virūpākṣo munim natvā kṛtāñjalih puro vadet | tatra mantrapadā<84v>ny asti lokanātha śṛ̣ohi me \| tadyathā || kragame krakamaṇi krakase krakasame kruśume kruke krukhume kruge agale nagale samagale kuhume hume cakrame aruke amalake kalele kalațake ili mile dhile agaruvati svāhā || svasty astu mama sarvasattvānāṃ ca virūpākṣasya mahārājasya nāmnā balenaiśvaryādhipatena ca svāhā || atha bhagavān siṃhanādaṃ nanāda || daśabalasamanvāgato 'haṃ caturvaiśāradyaviśāradạ̣ | parṣady udāram ārṣasamyaksiṃhanādaṃ nadāmi || brāhmyaṃ cakraṃ pravartayāmi | māro nirjita etena sasainyabalavāhanaḥ | rakṣāyai sarvasattvānāṃ sarve vidyā șṛ̣otha me \| tadyathā || asañge khañgavate balavate balanirghoṣe śūre śūravate vajrasame vajramgame vajradhare stambhe jambhe dṛdhasāre viraje vighase varāgraprāpte arạ̣e araṇye dharmayukte diśi vighuṣṭe svāhā ||

15 sarvasattvāṃś] pc.; sarvasattvānāṃś ac. 
svasty astu līlādevikāyā mama sarvasattvānāṃ ca sarvatathāgatanāmnā

balenaiśvaryādhipatena ca svāhā ||

buddhasya vacanaṃ śrutvā lokapālāh praṇemire |

śeșā bhūtagaṇās trastāḥ palāyanto diśodaśa ||

tad viditvā mahārājās triguptaṃ samudā<85r $>$ haret ||

aho vidyā mahāvidyā mahāsāhasrapamardanī |

yasyā trasanti bhūtāni śrutvā buddhasya bhāṣitam |

yathā prajvalito vahnir asir vā tailapāyitaḥ |

kṣuradhārāsamā vidyā gautamena prakāśitā ||

yo hy etan nābhimanyate buddhavākyaṃ subhāṣitam |

tasyātra brahmaśāpena jyeșțhaputro na bheșyati ||

agnim prajvālayitvā tu gṛhītvā sitasarṣapān |

ghṛtamaṇḍena saṃyuktān prakṣeptavyā hutāśane ||

jyeșthha ūrdhvam caturdikṣu kṣiptvā ca varuṇodakam |

yadi kṣipraṃ na muñceyur idaṃ śrutvā subhāṣitam ||

bhavantu jvalitāḥ sarve yathāgnau ghṛtasarșapāḥ |

kṣemaṃ ca tena lapsyanti yakṣadaṇụena tarjitā ||

teșāṃ vajradharaḥ krūro mūrdhādī sphāțayiṣyati |

rājñā dikṣu sthitānāṃ hi jvalatāṃ tejasā śriyā ||

antarîkṣaṃ tadā śāstā sarvajñā hi samudgatah ||

tato brahmā mahāvijñaḥ prāñjalis tạ̣ namāma ca |

suvarṇaparvatah śrīmān yașțikāñcanasamnnibhạ̣ ||

padmapuṣpavad utphullaḥ śālarājeva puṣpitạ̣ |

pūrṇacandro ravir vāpi nakṣatrair parivāritaḥ ||

suvarṇavarṇakāyena lakșaṇair munir āvṛtaḥ |

evaṃ stutvā muniśreșțhaṃ lokapālān athābravìt ||

na prāptam lokapālānāṃ parṣado nā<85v>nuśāsanam |

itas triratnāni jayante buddhāś ca brāhmaṇārṣabhāḥ ||

alpotsukānāṃ yuṣmākaṃ badhyate mānuṣi prajā|

etac chrutvā lokapālā evaṃ brahmas tathābruvan ||

ete 'pi cānayiṣyāmo ye duștāa bhūtamaṇdalā |

teșāṃ daṇ̣ạ̣ praṇeṣyāmi sūtraṃ brahmaṇā nirmitam ||

atha vaiś ca samānītāvanto dușțamānasāḥ|

vanditāḥ prāñjalisthās te lokanāthaṃ praṇemire ||

namas te puruṣavīra namas te puruṣottamaḥ |

1 Note the inserted donor’s name. 23 śālarājeva] pc.; śālarājyava ac. 25 munir] corr.; manir ms. 34 vanditāḥ] corr.; vandhitāḥ ms. 
prāñjalīkā namasyāmo dharmarāja namo 'stu te || vaiśravaṇo muniṃ natvā prāñjalikā puro 'vadat | cakrākacitracaraṇa yaștikāñcanasaṃnibha || lokapradyotakaraṇa lokanātha mahāmune | ye yakșā hy uttare bhāge pịdayanti tadudbhavāt || teșāṃ daṇụam praṇeșyāmi lokanāthasya sammukham || tadyathā || khaḍge khaḍgagarbhe vicakṣaṇe cakre rājāne candre capale pātāle bhīmaparvate kharāgre kuṭilakarāgre ekākṣi vargavati sārangavati mārgavati gaganavati citravati citrakānti svasty astu mama sarvasattvānāṃ ca uttarasyāṃ diśi svāhā ||

brahmā cāpy atha śakraś ca lokanāthā maheśvarāḥ yakṣādhipatayaḥ sarve hārītī ca saputrikāh | imāṃ puṣpāś ca gandhāś ca pra<86r>tigṛhṇantu mamāhutim | vīryeṇa tejā teșām aiśvaryeṇa baleṇa ca| nihatā sarvarogāś ca svasty astu mama sarvasattvānām ca sarvabhayopadravopasargebhyaḥ svāhā || namas te puruṣovīra namas te puruṣottamah | namasyāmāñjalikarā dharmarāja namo 'stu te || dhṛtarāșțro jinaṃ natvā prāvadat sa kṛtāñjaliḥ | phullarāśir ivotphulla kalavinikarutasvara | morakokilanirghoșa meghadundubhir garjita \| gandharvā diśi ye pūrve pịdayanti tadudbhavān | teșāṃ daṇụam praṇeṣyāmi lokanāthasya sammukham || tadyathā || dharaṇi dhāraṇi pradhvaṃsani bhañjani prabhañjani vidhamaṇi kiṃpuruṣe sakale sārathe sāravati śūradhare śūradhārinii śuddhacaraṇe ghoṣavati sārāgre śānti svasty astu mama saparivāsya sarvasattvānāṃ ca sarvopadravopasargebhyaḥ pūrvasyām diśi svāhā || brahmā cāpy atha śakraś ca lokapālā maheśvarāḥ | yakṣādhipatayah sarve hārīî̄ ca saputrikā || imāṃ puṣpāś ca gandhāś ca pratigṛhṇantu mamāhutim | vīryeṇa tejasā teșām aiśvaryeṇa baleṇa ca \| nihatāḥ sarvarogāś ca svasty astu mama sarvasattvānāṃ ca sarvabhayopadravebhyaḥ $\langle 86 \mathrm{v}\rangle$ svāhā $\|$ namas te puruṣovīra namas te purușottamaḥ | namasyāmo 'ñjalikarā dharmarāja namo 'stu te \| rājā prāha muniṃ natvā virūụhakaḥ kṛtāñjaliḥ | sarvajña sarvadarśī ca sarvavādī pramardaka || sarvasaṃśayacchettā ca sarvalokavināyaka | kumbhāṇ̣̂a ye sthitāyā me pịdayanti tadudbhavān | teșāṃ daṇụam praṇeṣyāmi lokanāthasya sammukham || 
tadyathā || sāanti sāravati kānti kāravati kiṃkasi kiṃrati kiṃraṇḍi kiṃvaḍi

dharaṇi vardhani bhūmidhārạ̣i vibhūmidhāraṇi himavati jyotiścaraṇi mālāgri svasty astu mama sarvasattvānāṃ ca dakṣiṇāyām diśi svāhā ||

brahmā cāpy atha śakraś ca lokapālā maheśvarāh |

yakṣasenāpatayạ̣ sarve hārītī ca saputrikā ||

imāṃ puṣpāś ca gandhāś ca pratigṛhṇantu mamāhutim |

vīryeṇa tejasā teșām aiśvaryeṇa baleṇa ca \|

nihatāḥ sarvarogāś ca svasty astu mama sarvasattvāṃ ca

sarvabhayopadravopasargebhyaḥ svāhā ||

namas te puruṣavīra namas te puruṣottamạ̣ |

namasyāmo 'ñjalikarā dharmarāja namo 'stu te ||

virūpākṣaḥ punaḥ prāha muniṃ natvā kṛtāñjaliḥ |

mahāmegha mahāsiṃha mahāmahamahodadhe ||

mahāvādi mahāśūra mahāsaṃamamardaka |

paści<87r>me ye sthitā nāgāh pịdayanti tadudbhavāt ||

teṣām daṇdam praṇeṣyāmi lokanāthasya sammukham \|

tadyathā || dharmidharāgre balavati balini diśānge vivasi sāgare khari kapile

caṇụāli viriṇi virājane vidhāraṇi vimati varṇavati acale svasty astu mama

sarvasattvānāṃ ca paścimāyāṃ diśi svāhā ||

brahmā cāpy atha śakraś ca lokapālā maheśvarāḥ |

yakṣasenāpatayaḥ sarve hārītī ca saputrikā ||

imāṃ puṣpāṃ ca gandhāṃ ca pratigṛhṇantu mamāhutim |

vīryeṇa tejasā teṣām aiśvaryeṇa baleṇa ca |

nihatāḥ sarvarogāś ca svasty astu mama sarvasattvāṃ ca

sarvabhayopadravopasargebhyaḥ svāhā ||

namas te puruṣavīra namas te puruṣottama |

namasyāmo 'ñjalikarā dharmarāja namo 'stu te ||

atha brahmā muniṃ natvā prāvadat sa kṛtāñjaliḥ |

brāhmaṇa snātaka śuddha sarvavedeșu pāraga |

vaidyarāja janānanda sarvalokacikitsaka \|

ye ca duștāśayā ghorā daśadikṣu vyavasthitāḥ ||

teșām daṇụạ praṇeșyāmo lokanāthasya sammukham \|

tadyathā || brahme brahmaghoṣe brahmasvare vajre vajraghoṣe vajradhare

sthire sāre acale arạ̣e iṣaṇe raṇade rạ̣ide āraṇāde śūravarāgraprāpte sāravati svasty astu mama sarvasattvānām ca sa<87v>rvadigvidigbhyaḥ svāhā ||

brahmā cāpy atha śakraś ca lokapālā maheśvarāḥ |

8 sarvasattvāṃ] corr.; sarvattvāś ms. 32 teșāṃ] corr.; steșāṃ ms. 33 vajraghoṣe] corr.; vajragho $\mathrm{ms}$. 
yakṣasenāpatayaḥ sarve hārītī ca saputrikā || imāṃ puṣpāś ca gandhāś ca pratigṛhṇantu mamāhutim | vīryeṇa tejasā teṣām aiśvaryeṇa baleṇa ca | nihatāḥ sarvarogāś ca svasty astu mama sarvasattvāṃ ca sarvabhayopadravopasargebhyạ̣ svāhā ||

namas te puruṣavīra namas te puruṣottama | namasyāmo 'ñjalikarā dharmarāja namo 'stu te || vātajāḥ pittajāḥ rogā śleṣmajāḥ saṃnipātajāḥ nihatāḥ sarvarogāś ca svasty astu mama sarvasattvānām ca sarvabhayopadravopasargebhyaḥ svāhā || atha śrī-bhagavān buddhaḥ sarvasattvānukampakạ̣ | vaiśālīm nagarīm gatvā tam uvāca jinaḥprajām || mā bhaișța hy āgato 'trāham sarvasattvahitārthikạ̣ | śṛ̣udhvaṃ dharmam atulaṃ yat prabhāṣye hitāya vaḥ || ye kecit paścime kāle sampūjya jinadhātukam | sāhasrapramardanīvidyāṃ sarvagrahapramocanīm | udg̣̣hya dhārayiṣyanti deśayiṣyanti vācakāḥ || teșām hy upadravā sarve upasargā sudāruṇāh || iti kalikalāḥ pāpā vinaśyanti na saṃśayạ̣ || evam ukte mahābrahmā bhagavantam uvāca tam | bhagavan katamā vidyā sā sāhasrapramardanī | baddhā<88r>nām buddhamudrāyā duṣțagrahavimocanī || evam ukte 'tha brahmāṇam bhagavān tam uvāca sa | śṛ̣u brahman mahābhāga bhāṣiṣye 'ham hitārthatạ̣ || tadyathā || acale macale sāramacale prakṛtivarṇe prakṛtinirghoṣe samantamukhe sthire sthāvare vighuṣte vighușțaśabde pragalane sārañgami sāravate sāraṅgavate bale mahābalamahānirbhāse svāhā || tatredam ucyate || kāyagatānusmṛtị̣ śamathavipaśyane trayạ̣ samādhayaḥ catvāra ṛddhipādāś catvāri samyakprahānāni catvāri smṛtyupasthānāni catvāri dhyānāni catvāry āryapramāṇāni catvāry āryasatyāni pañcendriyāni pañcabalāni ṣaḍanusmṛtayaḥ saptabodhyañgāni āryāṣțāngamārga navānupūrvavihārasamāpattayạ̣ | daśatathāgatabalāni ekādaśavimuktyāyatanāni dvādaśāṅgapratītyasamutpādạ̣ | dvādaśākāradharmacakraṃ ṣoḍaśākārā ānāpānānusmṛtị̣ | așțādaśāveṇikā buddhadharmāḥ | dvācatvārimśadakṣarāṇi | iyaṃ sā brahman mahāsāhasrapramardanī vidyā yā tathāgatānāṃ buddhamudrā triratnanirhārạ̣ 35 brahmādisarvalokapālanirhāraḥ satyamārgapratītyasamutpādanirhāraḥ ||

11 -prajām] pc.; -jāṃpra ac. 16 deśayiṣyanti vācakāḥ] pc.; vācakāḥ ac. 27 -smṛtiḥ] pc.; -smsmṛtiḥ $a c$. 
tadyathā || sāle kasini vidhariṇi va<88v>rāgrasāre ākarṣaṇi amoghavate sacane kālīnakāli kāśivatte bharaṇi bhare karkasakhe prasannaprāpte sāraprāpte stambhane stambhaprāpte vajradhare svāhā || atha bhagavān imāṃ gāthā abhāṣata || idam asmin lokeṣu-r-imasmi vā punaḥ svargeṣu vā ratnavarāṇi santi | samo 'sti naiveha tathāgatena devātidevena narottamena | tasmād idam ratnam varam praṇitam etena satyena ihāstu svasti \| kṣayo virāgo hy amṛtam tv asaṃskṛtam ājñāya 'sau sākyamuniprabhāvitaḥ | dharmena tena na samo 'sti kaścid amṛtena sāntena asamskṛtena || tasmād idam ratnavaram praṇītam etena satyena ihāstu svasti || yaḥ śreșṭham ișțam vidhivan prakāśitam śāstānuttarayogavāhakaḥ | samādhinā tena samo na vidyate vajropamādvayamārgadarśinā | tasmād idaṃ ratnavaraṃ praṇītam etena satyena ihāstu svasti || așțau mahāpungala ye praśastāḥ khyātāni catvāri yugāni caiva | te dakṣiṇiyāḥ sugatena gītā maharșiṇā hy apratipungalena | ebhyaḥ pradānaṃ bhavate mahāphalaṃ bījāny astāni yathā sukṣetre | idaṃ praṇitaṃ varasaṃgharatnam etena satyena ihāstu svasti || ye suprasannā < 89r> manasā dṛ̣hena upasaṃkramī gautamaśāsanaṃ hi | te prāptiprāptā amṛtaṃ vigāhya tamonudā nirvṛtim āpnuvanti | idam praṇitam varasaṃgharatnam etena satyena ihāstu svasti || sahaprayogād iha darśanasya trayạ̣ prahīnā yugapat kileśāḥ | satkāyadṛștir vicikitsanā ca śīlaṃ vrataṃ darśanam āryatā ca | idaṃ praṇītam varasaṃgharatnam etena satyena ihāstu svasti || na jātu kuryāt trividhạ̣ hi pāpaṃ kāyena vācā na manasātha vāpi | pracchādanīyaṃ sahasā na kṛtvā tathā na dṛștị grahanena teșām | idaṃ praṇîtạ̣ varasaṃgharatnam etena satyena ihāstu svasti || yathendrakīlaḥ pṛthivīpratișțhitaś caturdiśam vāyubhir aprakampyạ̣ | tathopamāḥ pungalā santi saṃghe ye āryamārgasya vacasya darśakāḥ | idaṃ praṇītam varasaṃgharatnam etena satyena ihāstu svasti || ye āryasatyāni vibhāvayanti gambhīraprajñena sudeśitāni | kāyapradānaṃ ca manasy akṛtvā na te bhayaṃ kașțam avāpnuvanti || idam praṇitam varasaṃgharatnam etena satyena ihāstu svasti || arcir yathā vāyuvaśād vinașțā astaṃgatā naiva upeti saṃkhyām | tathaiva saṃyojanaviprayuktāḥ adarśanaṃ yānti hi bodhiputrāḥ || idam praṇîtạ varasaṃgharatnam etena <89v> satyena ihāstu svasti ||

3 stambhane] pc.; stambhaprāne ac. 4 bhagavān] corr.; bhagan ms. 5 idam] pc.; imad ac. 9 samo] corr.; mo samo ms. 15 maharșināa] corr.; mahaṇā ms. 18 suprasannā] corr.; suprannā ms. 32 etena] $p c$; e $a c$. 
ye jaṅgamā cātra tathaiva sthāvarās te sarvasattvā sukhino bhavantu | śāstāram agryaṃ naradevapūjyaṃ buddhaṃ namasye 'ham ihāstu svasti || ye jaṅgamāś cātra tathaiva sthāvarās te sarvasattvāḥ sukhino bhavantu | śāntam virāgaṃ naradevapūjyaṃ dharmaṃ namasye 'ham ihāstu svasti || ye jaṅgamāś cātra tathaiva sthāvarās te sarvasattvāḥ sukhino bhavantu | gaṇānam agryaṃ naradevapūjyaṃ saṃgham namasye 'ham ihāstu svasti || yānīha bhūtāni samāgatāni sthitāni bhūmāv athavāntarīkṣe | kurvantu maitrī satatam prajāsu divā ca rātrau ca carantu dharmam || yenaiva satyena jino jitāriḥ sa satyavādī ripur asya nāsti | tenaiva satyena ihāstu svasti || mucyantu mama sarvasattvānāṃ ca sarvamahābhayebhyaḥ svāhā || tadyathā || dhire vidhire balanirghoṣe balasāre sāravate prabhūtaprāpte | āradhe varaghoṣe sāravati | acyute balavati śūraprāpte sāraṃame sūryagame sūryanirghoṣe svāhā || iyaṃ brahmạ̣ ca buddhānāṃ buddhamudrā prakīrtitā | sāhasrapramardanī vidyā duṣțagrahapramocanī || yā triratnapadākhyātā lokapālapadā tathā | abhisambuddhair adhișțitā triyāni<90r>kaị̣ || pūjita lokapālāś ca maharṣibhi namaskṛtā| gocarā buddhabodhīnām mārāṇām ca vidāriṇī || tadyathā || khaḍge khaḍge ghoṣe upoṣadhe sārathiprabhe vipulaprabhe saṃkarṣaṇi vikarṣaṇi viśagravati śuddhasādhani varuṇavati vāsave vibhūṣaṇi viśaṃgame paśupati puṣpagarbhe svasty astu mama sarvasattvānāṃ ca sarvabhayopadravopāyāsebhyaḥ svāhā || iyam sā ca mahāvidyā mahāsāhasrapramardanī| buddhamudrā prabuddhānāṃ dușțagrahapramocanī || yayā hi mudritā lokaḥ devāsuramānuṣaḥ | anuttarapadaṃ prāpte bodhisambhārapūrakaḥ \| atha brahmā mahārājāś catvāraś ca sureśvaraḥ | bhagavantam praṇamyocuḥ kṛtāñjalipuṭā mudā || aho vidyā mahārakṣā buddhamudrā mahāmune | mudrāṃ caiva prākāśyāmaḥ sūtraṃ sāhasrapramardane || ye praduṣțāḥ surā daityā sabhūtā jinaśāsane | teșām dạ̣ḍạ praṇeṣyāmi vidyā brahmaṇā nirmitām || śakreṇa dhāritā mūrdhnā lokapālaiś ca mudritā || tadyathā || kalinge hārajudagre jayate siṃhamade sārāgraprāpte haṃsagāmini mālini hule mihule hulime | hahạ̣ hahạ̣ hahaṃ haham ||

3 tathaiva] corr.; stathaiva ms. 5 sarva-] corr.; sarvasarva ms. 25 ca] corr.; ja ms. 
madumudani varāgravati hastine necaramati caṇḍāi calasainya carācare <90v> svāhā ||

tato bhūmir akasmāc ca duṣțaughā vilayaṃ gatāh |

pādayor śirasā natvā mune śaraṇam āgatāḥ |

tatas tasyāṃ nagaryāṃ ca sarvetayaḥ sudāruṇāh |

praśāntāḥ sukhasampannāḥ sattvā āsac chubhānvitāḥ ||

atha caturmahārājā natvā munim avocat |

yo gṛhya dhāraṇāc caināṃ likhitvā dhārayec chucị̣ |

tasyetyupadravāḥ sarve vinaștāḥ syur jayo bhavet |

yatra deśe imāṃ vidyām pravartayec chubhānvitaḥ ||

tasya rakṣām vayaṃ kurma vyādhitaḥ parimocanam |

imām paṭham ca glānasya bhaiṣajyam upanāmayet ||

buddhabodhau tu sambuddhe lokapālaiś caturdiśaḥ |

bhojanāni samānīye catvāri sugatāya vai ||

dattāni nirmitaś caiko muninā bhājanottamaḥ |

gṛhītam pāṇinā śāstā bhaiṣajyam amṛtopamam ||

etena satyavākena amṛtam bhavantu auṣadham |

hārītī ca mahādevī gṛhya paṭyam tathā śubham ||

sāstre dattavatī divyaṃ bhaișajyam amṛtopamam |

etena satyavākyena āturasya rujāpaham ||

sarvām apaharam cāpi bhavatv amṛtam auṣadham |

vipaśvibuddhatejena śikhinaś ca balena ca \|

viśvabhūsatyavākena krakucchandasamādhinā ||

kanakāhvayasya jñānena ṛddhyā vai <91r> kāśyapasya ca |

sāāyasiṃhasya vīryeṇa bhavatv amṛtam oṣadham ||

imāṃ vidyāṃ pațhan dadyā bhaișajyaṃ pūrvasammukhe ||

tadyathā || khațe vikhațe vicale vilambe bale balavati candre caraṇe

amṛtanirghoṣe svāhā || vātajāḥ pittajā rogāḥ śleṣmajāḥ saṃnipātajāḥ nihatạ̣

sarvarogāś ca svasty astu mama sarvasattvānāṃ ca sarvadā sarvabhayebhyaḥ

svāhā ||

buddhāḥ pratyekabuddhāś ca buddhānāṃ śrāvakāś ca ye |

brahmendrau lokapālāś ca yakṣasenāpatîsvarāḥ ||

tathā yakṣā mahānagnā hārītī saputrikā |

vīryeṇa tejasā teșāṃ vetāọakarma cchidyatu ||

bhinatti vajraratnāni vahnir indhanadāhakaḥ|

vātena śoṣitā meghā bhāskareṇa vanaspatiḥ ||

3 akasmāc ca] corr.; akasyarca ms. 6 sattvā āsac] pc.; saātvā sac ac. 21 cāmi] corr.; cāmi ms. 31 śrāvakāś] corr.; śrākāś ms. 34 vetāḍa-] $p c$.; veḍatā- $a c$. 
etena satyavākyena kākhordakarma dahyatām |

nānāgandhais tathā puṣpair vidhūtāḥ sarvapāpakāḥ ||

tadyathā || hume 2 karavati kakhali karali kharale judagre juhkini

juvane jacale galage hariṇi saāvari śānti praśānti svāhā || dhāvani svāhā ||

gandharve svāhā || palañgani svāhā || sarvakākhordakṛtavetāḍacchedani

svāhā || imai mantrapadair līlādevikāyā mama sarvasattvānāṃ ca

sarvakākhordavetāḍauṣadhimantraviṣaprayogāḥ sarvadevai cchedi<91v>tā jitāḥ

parājitāḥ svāhā ||

galagạ̣de viṣe pīte bhadrapīthāsthitạ̣ śucị̣ |

susnātaḥ subhūṣānga imām vidyām udāharet ||

10

tejasā sarvabuddhānāṃ pratyekajinatejasā|

arhatāṃ caiva vīryeṇa hārītyāś ca samṛddhiyā ||

cakṣuṣā cāniruddhasya kāśyapasya dhūtair guṇaị̣ |

kauṇḍinyapūrvaprāptyā ca ānandasya śrutena ca \|

maitryā vai brahmaṇaś caiva svastyaiśvaryeṇa śatakratoḥ |

viṣayair lokapālānāṃ maheśvarabalena ca \|

senāpateś ca śauryeṇa hārītyāś ca samṛddhiyā |

vīryeṇa tejasā teșāṃ viṣam astv aviṣaṃ sadā ||

tatra mantrapadā bhonti nirviṣā viṣadūṣaṇāḥ ||

tadyathā || harikeśi nakile rehire amare aṇdare paṇḍre kaṭake kare keyūre hase

2 ṛse sekharaṃse marugahare svāhā || mukte 2 sumukte svāhā || hile svāhā ||

mile svāhā ||

hatā gaṇḍakilāsāś ca vaisarpāś ca vicarcikāḥ |

pițakā lohalingaśs ca kacchūr bhavati saptamī ||

rāgo dveșaś ca mohaś ca ete loke trayo viṣāḥ |

nirviṣo bhagavān buddho buddhasatyahatạ̣ viṣam ||

rāgo dveșaś ca mohaś ca ete loke trayo viṣāḥ |

nirvișo bhagavān dharma dharmasatyahatạ̣ viṣam ||

rāgo dveșaś ca mohaś ca ete loke trayo viṣāḥ |

ni<92r>rviṣo bhagavān saṃhaḥ saṃhasatyahatam viṣam ||

vișasya pṛthivī mātā vișasya pṛthivī pitā |

etena satyavākyena viṣāh syuh sarvanirviṣāḥ \|

mama sarvasattvānāṃ ca bhūmiṃ saṃkrāmatu viṣaṃ pūrṇaṃ pātre vā

saṃkrāmatu svāhā || kaliśatrum vijetuṃ ca caityạ̣ pūjyaṃ paṭhed imām ||

tadyathā \|

buddhena nirjitā mārā dharmeṇa ca adharmatā |

saṃghena nirjitā tīrthyā indreṇa asurā jitāḥ ||

6 Note the inserted donor's name. 13 dhūtair] corr.; gutair ms. 
asuraiś ca jitāḥ somo vainatyeyena sāgaraḥ |

agninā ca jitāḥ kāșțhā udakenāgniḥ parājitạ̣ ||

vātena nirjitā meghā ratnavajreṇa pādyate |

devāḥ satyena tișțhanti satyena pṛthivī sthitā \|

satyaṃ buddhaṃ ca dharmaś ca satyaṃ bhavatu mā mṛ̣ā $\|$

tadyathā || amṛte agrapuṣpe bahuphale nivāriṇi sarvārthasādhani aparājite dharadharaṇi guhyāvarte gautame guptamate jambhani svāhā || stambhani svāhā || prabhañjani svāhā || balaprabhañjani svāhā || jaye svāhā || vijaye svāhā || jayavijaye svāhā \|

jitāḥ pratyarthikāḥ sarve sarvāpāyāḥ parājitāḥ ||

tatah śāstrātra sarvajña imā gāthā abhāṣata \|

akṣobhyarājo 'valokiteśvaro amitābhanemīratanārcimeruh |

vajrasya co nāma gṛhītvā sarvadā nai<92v>vaṃ bhayaṃ bhonti na

cchambitatvam \|

ya eșa așțān mahādyutīnāṃ nāmāni kīrteya anugrahārtham |

na tasya agnir na viṣam na śastraṃ kramete 'sya kāye kṛtasamparitre ||

sacetane upasthite utkșiptaśastreṇa vadhake ca sammukham |

anusmaranto avalokiteśvaraṃ khaṇḍakhaṇḍaṃ prapateyuḥ śastrā |

saced udg̣̣hītaṃ 'pi bhaveta śastraṃ bhañjitvā pāṇiṃ dharaṇị̣

pateyuh \|

na tasya kāye nipateya kiṃcid anyatra karmaparimena yat kṛtam ||

samagradevā imi gāthā bhāṣișu ||

namo 'stu te buddha anantagocarāya namo 'stu te satyaprakāśakā mune |

satye pratișțhāya prajā mocase sarve ca kāryāḥ saphalā bhavantu ||

tato brahmā vaded buddham mahāvidyā subhāṣitā|

vidyām ahaṃ pravakṣāmi dārakānāṃ hitaṃkarī|

buddhavīram namasyāmi dharmarājam prabhaṃkaram ||

yena prathamato vidyāṃ jambudvīpe prakāśitā |

dharmāya ca viśiștāya saṃghāya ca gaṇottame ||

buddhāḥ pratyekabuddhāś ca buddhānāṃ śrāvakāś ca ye |

ṛṣaye lokapālāś ca yāvanto devatāpi ca \|

ito mānuṣyalokataḥ sarvasattvasamutthitāḥ \|

santīha rākṣasā ghorā garbharakṣā mahāmune |

śakyā na rājabhir draștum nāpi śakyā caturdiśam ||

ye ca trāsanti bhū<93r>tāni bỉjaṃ nāśanti prāṇinām |

teṣạ̣̄ daṇḍaṃ praṇeṣyāmi lokanāthasya sammukham ||

19 saced] corr.; sacī ms. 23 satya-] pc.; satetya- ac. 25 vaded] corr.; vad ms. 33 garbharakșā] corr.; garbhakșā ms. 
tadyathā || añge vange bhage bhavane inandi vinandi murali giri gavari garuṇi saruṇi girigavare locane roṣaṇe rocane rasane alabhe araṇe alaphe talaphe pravarṣaṇi svāhā \|

kṣipraṃ saṃtișțhatā garbhaḥ samyag vardhantu cendriyāḥ | garbhasthā sukhino bhontu mā ca naśyantu jātakāḥ | svasthaḥ saṃtișthatā garbhạ̣ kālena parimucyatām || nānārangāṇi sūtrāṇi akṣatā gaurasarṣapāḥ | eșā rakṣā mayākhyātā ciraṃ jīvantu dārakāḥ || atha śāstā ca sarvajña imāṃ vidyām udāharet | rakșito bhavatu garbhasthaḥ sukhaṃ modantu dārakāh || tadyathā || bodhi 2 mahābodhi bodhānumate phalini phalale bahule bahuphale śikṣe śikṣāsāravate sāgare durāsade durāgame suūre suūraprāpte śūravate bhage bhagābhage bhagini nivāriṇi svāhā || tataḥ sarve grahā natvā procuḥ pañcadaśamunim | nātra bālā marișyanti yatra tișțhe subhāṣitam || anuvṛttyā bhajiṣyāma yathā tava mahāmune \| namo bhagavate buddhāya namo brahmaṇe sidhyantu drāmiḍā mantrapadās tārayantu <93v> imāṃ vidyāṃ brahmā namasyantu svāhā || vaiśravaṇo 'tha sambuddhaṃ natvā prāha kṛtāñjaliḥ | yo 'rcya caityaṃ pațhed vidyāṃ tam bhajema pariṣkaraih \| yatra gehe pațhec caināṃ yasyāgre roginas tathā | tatraivam varṣaparyantam tasya svastyayanaṃ bhavet \| ime caturmahārājā nityaṃ darśanti tanmukham | anubaddhā sadā devā kim anye itare grahā $\|$ athendraḥ prāñjaliṃ natvā dharmarājam samabravīt | vakṣye śubhakariṃ vidyāṃ mantrauṣadhisamāyutām || tadyathā || akrame vikrame ghoṣe bhūtaghoșe bhūtamgame dehini dhadhare 2 dhadhare dadhini nimukhe khakhame khakha khakha sāraṃgame candre capale halihale hāriṇi svāhā || sarvāpāyebhyaḥ svasty astu mama sarvasattvānāṃ ca sarvadigvidigbhyaḥ svāhā || nihatāni sarvapāpāni svāhā || tato brahmā ca śakraś ca lokapālā maheśvarāḥ | yakṣasenāpatayaḥ sarve hārīīi ca saputrikā \| sambuddhaṃ śirasāṃ natvā prāvocan prāñjalīkṛtāḥ | sahasrasūryapradyota pūrṇacandraprabhāsvaraḥ || sadevamānuṣyaloke sadṛśam te na vidyate | acintitā suyuktā ca yakṣarākșasamardanī || rājapramocanī nāma vidyā vairājyapālanī |

16 anuvṛttyā] corr.; anuvṛtyā ms. 24 anye] corr.; anye ms. 37 vairājya-] pc.; vairājajya- $a c$. 
mahāsāhasrake loke <94r> rakṣā vai sūtram uttamam ||

namas te puruṣovīra namas te puruṣottama |

prāñjalisthā namaskṛtvā tatraivāntaradhāyiṣu ||

athāmantrya sa sarvajñah pratyuvāca svaśișyakān |

bhikṣavo dhāryatam nityaṃ pañcarakṣā mahābalā ||

pañcāmiṣe yadi prāpte nirāmiṣaṃ vicintyatām ||

yuṣmābhiś cātmarakṣārthe mā vartemāṃ prabhajyatām ||

tadyathā \|

brahmaṇair vipralabdhena saākyasiṃhasya tāyināḥ |

sa viṣam giriguptena bhojanam upanāmitam ||

sampragṛhya tatạ̣ saāstā nirviṣīkṛtya bhojitam |

etena satyavākyena amṛtam bhotu bhojanam \|

vipaśvino devatāyāḥ śikhino viśvabhuvas tathā|

krakucchandaprasannā ca devatāyā mahābalāh ||

kanakākhyasya devendrāḥ śrīmataḥ kāśyapasya ca |

prasannā śākyasiṃhasya brahmendrās tridaśeśvarāḥ ||

catvāro lokapālāś ca māṇibhadro maheśvarāḥ |

rākṣasī ca mahākālī caṇụā cạ̣ụālinī tathā ||

imāṃ puṣpāś ca gandhāś ca pratigṛhṇantu mamāhutim |

prīṇitāḥ pūjitā bhūtvā ete śodhanti bhojanam ||

pañcāmiṣeṇa samsṛșțam asamsṛșțam karontu me |

apañcāmiṣena saṃș̣̦țam sarvaṃ bhuñjāmi bhojanam ||

sarveșām bījagātrāṇām pratiṣthā pṛthivīrasā |

sarve bhojanasaṃṣ̦țtam asamsṛșțam <94v> bhavantu me |

cchinnam dagdham yathā sūtram tādṛ́sam bhavate punạ̣ ||

tathā bhojanasaṃsṛșțam asaṃș̣̦țam karotu me \|

tadyathā || khakhame khakha khakha khukhume śime śive sihume 2 śimi śime |

svasti svasti svasti svasti || 4 || śānti 2 śarāgrī mama sarvasattvānāṃ ca

pañcāmiṣeṇa saṃș̣̦țam yathāhāraṃ nirāmayam |

yena dagdham yathā sūtram satyam kurvantu tādṛśam ||

tadyathā || kalake kalake kalale kalame balani karuṇālaye kalalale khalume

agnisaṃkrāmaṇi svāhā || vipaśyibuddhaśaraṇam upemi śikhinaṃ ca buddham

sugatạ̣ ca viśvabhuvam | krakucchandabuddhạ̣ kanakamuniṃ ca kāśyapam vis̄āradam śākyamuniṃ ca gautamam \|

eteṣu saptanarottamānāṃ puṣpaiś ca gandhaiś ca śarīrapūjān |

kāyena teṣāṃ manasā ca kṛtvā prasannacittaḥ śaraṇam upemi ||

teșu buddheșu maharddhikeșu yā devatā abhiprasannāḥ |

25 dagdhaṃ] corr.; gagdhaṃ ms. 
tā devatā āttamanā udagrā rakṣantu te māṃ ca śivaṃ karontu || svasty astu līlādevikāyā mama sarvasattvānām ca svāhā || athābravīn mahānando jinaṃ natvā ca bhikṣubhị̣ | evaṃ nātha mahāvidyāṃ praṇamāmi samādadhe || yāṃ śrutvaivaṃ palāyante duștā gandharvarākṣasāḥ | kumbhāṇḍā nāgayakṣāś ca namas tasyai namo namaḥ || yad bālakam <95r> prarakṣanti śișțā gandharvarākșasā | kumbhāṇḍā nāgayakṣāś ca namas tasyai namo namạ̣ || yāṃ pragṛhya paṭhadhārī pūjyamānyasubhāvitạ̣ | bhikṣur vighnam vijetā syān namas tasyai namo namạ̣ || triratnāni caturmudrāḥ pūjyapūjāñgavistaraị̣ | yat pāṭhe rakṣito rāṣțro namas tasyai namo namạ̣ || yasyā mantraprabhāvena vinaśyanti sudāruṇāḥ | kākhordakāś ca vaitāọā namas tasyai namo namaḥ || yasyāḥ śravaṇamātreṇa galagaṇḍādikuṣṭhakāḥ | unmādā garalā nașțā namas tasyai namo namaḥ || yasyāṃ prajalpamānāyāṃ viṣā bhavanti nirviṣāḥ | parayantrāś ca naśyanti namas tasyai namo namaḥ || yāṃ śrutvā prapațhitvāpi daridro dhanavān bhavet | asiddho labhate siddham vidyādharatvam āpnuyāt || aputro labhate putraṃ dușțaḥ śuddhāśayaṃ sukhī | sarvaśastranipāteșu paracakrasamāgame || saṃgrāme sarvakāryeșu svastinā cottariṣyati | vivāde saṃkațe prāpte rājaśatruvivandhite \| yām smṛtvā vimucyeta namas tasyai namo namaḥ| yā sadevāsure loke pūjitā mānitā sadā || śubhaṃkartī mahāvidyā namas tasyai namo namạ̣ | yasyāṃ ca pāṭhamānāyām atiṿ̛știr vinaśyati || anāvṛșți suvṛștịh syān namas tasyai namo namah $\|<95 v>$ durbhikṣapaṭitāyā ca subhikṣaṃ kārayet sadā || upadraveșu māngalyaṃ namas tasyai namo namạ̣ | punar apy āha sambuddha evam kuru mahāratạ | sarvasattvahitārthāya bhajatāṃ samprakāśaya | sarvabuddhaiś ca yā vidyā mahāvidyeti kīrtitā || grhītā dhāritā nityaṃ pāthasvādhyāyanaṃ kṛtā| parebhyo deśitā śuddhā manasā ca vicintitā ||

2 Note the inserted donor's name. 14 namas] corr.; nama ms. 25 vimucyeta] corr.; vimuceta ms. 
bhāvitā pūjitājasraṃ vanditā sevitā sadā |

bhajatāṃ ca bhajetāṃ ca vande tāṃ ca namo śraye ||

jananī bodhisattvānām paravādipramardanī |

sarvamāravihantī yā na me pāpavināśinī || ||

idam avocad bhagavān sā ca sarvāvatī parṣad abhyanandann iti ||

mahāsāhasrapramardanī-nāma-vidyā-dhāraṇī samāptaḥ || ||

[79] oṃ namo bhagavatyai ārya-mahāmāyūryai ||

mṛtasaṃjīvanīm vidyāṃ duṣṭasattvanivāraṇīm |

devīśvarīm mahātmānīm māyūrīm praṇamāmy aham ॥

evaṃ mayā śrutam ekasmin samaye bhagavāñ chrāvastyāṃ viharati sma

| jetavane vihāre mahatā bhikṣusaṃghena sārdham anekair bodhisattvair mahāsattvaị̣ || tasmin samaye svātir bhikṣuḥ kṛṣnasarpena dașțas tad dṛștvānando bhikṣu bhagavantam papraccha | iha bhagavan svātir bhikṣuḥ kṛṣnasarpeṇa dașțam katham pratipadye || e<96r>vam ukte bhagavān ānandam idam āha || gacchānanda tathāgatavacanenānayā mahāmāyūryā vidyārājñyā svāter bhikṣo rakṣāṃ kuru guptiṃ paritrāṇaṃ parigrahaṃ paripālanaṃ śāntim svastyayanaṃ dạ̣ḍaparihāraṃ śastraparihāraṃ viṣadūṣạ̣aṃ viṣanāśanaṃ sīmābandham dharaṇībandham ca kuru sarvopadravebhyo duṣțagrahabhayāt parayantramantrakarmakușthādijvaraśūlarogavișāpasmārebhyaḥ svastyayanaṃ kuru anayā hi |

rātrau svasti divā svasti madhyaṃdine sthite |

svasti sarvam ahorātram sarvabuddhā diśantu vaḥ ||

tadyathā || iḍi viḍi kiḍi miḍi hị̣i piḍi niḍi meḍe dodumvā āḍe nāḍe ghāọe durgāḍe hariṇi caturi harive gāḍi vagự̣i pāṃśu viśācini varṣaṇi ārohini orohaṇi elā melā ele mele keli tili tili tili tili tili mele 2 tili 2 time timile | time tile 2 dume 2 dudume 2 iti miti vișțhaddhe capale vimale hulu 2 aśvamukhi kāli 2 mahākāli kalāli prakīrṇakeśi kulu 2 vahulu 2 kolu 2 hulu 2 vahulu 2 vosā dumbā dodumbā dodumbā dumadumbā golāyā velāyā parivelāyā | piśu 2 hili 2 mili 2 tili 2 bhili 2 | culu culu culu culu <96v > culu culu culu culu culu culu || 10 || muhu muhu muhu muhu muhu muhu muhu muhu muhu muhu || 10 || hulu hulu hulu hulu hulu hulu hulu hulu hulu hulu || 10 || mulu mulu mulu mulu mulu mulu mulu mulu mulu mulu || 10 || hu hu hu hu hu hu hu hu hu hu || 10 || vā vā vā vā vā vā vā vā vā vā || 10 || pā pā pā pā pā pā pā pā pā pā || 10 || jāla jāla jāla jāla jāla jāla jāla jāla jāla jāla || 10 || dama 2 ni tapa 2 ni paca 2 ni jvala 2 ni dundubhi garjani

14 dașțaṃ] $p c$. ; dakșișțam $a c . \quad 15$ vidyārājñyā] corr.; vidyārājñāā ms. 19 -viṣāpasmārebhyaḥ] corr.; -viṣāpmārebhyaḥ ms. 
varṣaṇi sphoțani | tapani tāpani pacani pācani hāriṇi kāriṇi kimini kampani mardani | maṇḍe maṇditike kṣemaṃkari makari śāṃkari śarkari śavari śakari śamkari jvalani | jvala 2 ni | duma 2 ni | dumadumbani | sukusume | golāyā | velāyā parivelāyā varṣantu deva samantena iti kiśi svāhā ||

maitrī me dhṛtarāṣṭreṣu maitrī airāvaṇeșu ca |

virūpākṣeșu me maitrī maitrī kṛṣnagautameṣu ca ||

maṇinā nāgarājñā me maitrī vāsukinā ca me maitrī |

daṇụapādeṣu nāgeṣu pūrṇabhadreșu me sadā |

nandopanandanāmānau varṇavantau yaśasvinau |

devāsurasaṃrāmam anubhavanti maharddhikau ||

etayo<97r >r api me maitrī sarvathā nāganāthayoḥ |

varuṇānavataptābhyāṃ me maitrī mañjulakena ca ||

takṣakena anantena tathā vai sumukhena ca |

aparājitena me maitrī maitrī chitvāsutena ca ||

mahāmanasvinā nityaṃ tathaiva ca manasvinā |

kālako apalālaś ca bhogavāñ chrāvaṇerakaḥ |

dadhimukhe maṇiś caiva puṇụarīko diśāmpati ||

karkoțaka śan̉khapālaḥ kambalāśvatarāv ubhau \|

eteșv api ca me maitrī nāgarājeșu nityaśạ̣ |

sāketakaś ca kumbhīlaḥ sūcīromā tathaiva ca ||

nāgādhipena kālena maitrī me ṛșakena ca |

tathā pūrṇena karṇena maitrī śakațamukhena ca ||

kolakena sunandena vātsīputreṇa me sadā |

elapatreṇa me maitrī maitrī lambulukena ca ||

amānuṣāś ca ye nāgā tathaivottaramānuṣāḥ |

mrrgiraś ca mahānāgo mucilindaś ca viśrutạ ||

pṛthivīcarāś ca ye nāgās tathaiva jalaniśritāh |

antarīkṣacarā ye ca ye ca merusamāśritāḥ ||

ekaśīrṣe duśīișeșu maitrī me teșu nityaśạ̣ |

apādakeșu me maitrī maitrī me dvipadeșu ca ||

catuṣpadeșu me maitrī maitrī bahupadeșu ca |

mā me apādakāḥ himssyu mā me hiṃsyu bahupādakāḥ ||

sarvanāgeșu me maitrī ye nāgā jalaniśritāḥ |

sarvabhūteșu me maitrī <97v> ye kecit pṛthivīsthitāḥ ||

sarvasattveșu me maitrī ye sattvā atra sthāvarāḥ |

sarve prāṇāḥ sarve sattvāḥ sarve bhūtāś ca kevalāḥ ||

20 sāketakaś ca] $p c$.; sāketaścaka ac. 22 pūrṇena] corr.; pūrerṇa ms. 28 -carā] corr.; -tarā ms. 31 maitrī] $p c$.; me maitrī $a c$. 
sarve vai sukhinaḥ santu sarve santu nirāmayāḥ || sarve bhadrāṇi paśyantu mā kaścit pāpam āgamat || maitrīcittaṃ samotthāya karomi viṣadūṣaṇam | rakṣām parigraham caiva svastyaiva paripālanam || namo 'stu buddhāya namo 'stu bodhaye | namo 'stu muktāya namo 'stu muktaye || namo 'stu śāntāya namo 'stu śāntaye | namo 'stu vimuktāya namo 'stu vimuktaye || ye brāhmaṇā vāhitapāpadharmāya ca sthitāḥ sattvahitāya nityam | śuklavratāḥ kṣāntisamādhiyuktās te brāhmaṇās tārayitụ̣ samarthāḥ || teṣāṃ namas te ca mama sarvasattvānāṃ́ ca paripālayantu sarvabhayebhyah sarvopadravopasargajvaravyādhigrahaviṣādibhyo rakṣām kurvantu guptim paritrāṇaṃ parigrahaṃ paripālanaṃ śāntisvastyayanaṃ dạ̣ḍaparihāram śastraparihāraṃ viṣadūṣaṇaṃ viṣanāśanaṃ sīmābandhạ̣ dharaṇībandhaṃ ca kurvantu jīvantu varșaśatam paśyantu śaradāśatam || bhūtapūrvam ānandāham 15 mayūrarājo bhūto mayūrakanyakābhị̣ sārdhaṃ himagirau caran pāśena baddhas tademāṃ vidyānusmaramāṇo mukto 'bhuvan || tadyathā || namo buddhāya namo dharmāya nama<98r>ḥ saṃghāya | namo mahāmāyūryai vidyārājñyaih || hu hu hu hu hu hu || 6 || hulu 3 || nāga le le le | na le le le | dumba le le le | huya 2 vija 2 | thusu 2 gulu 2 | huce jine | jini agalu elā melā ili melā tili melā | ili tili melā ili mitte tili mitte ili tili mitte dumbe dudumbe sudumbe | tosu 2 golā velā celā capalā vimalā iț̣iri bhițtiri rițtiri namo buddhānāṃ cili kisi godohikānāṃ namo 'rhatānāṃ hāla dāla varṣantu devạ̣ samantena daśasu diśāsu namo buddhānāṃ svāhā || atha sa tasmān muktạ̣ svastinā svaviṣayaṃ prāpta | imāny udāharati sma || namo buddhāya namo dharmāya namaḥ saṃghāya | namaḥ suvarṇāvabhāsāya mayūrarājāya || namo mahāmāyūryai vidyārājñyaih || tadyathā || siddhe susuddhe mocani mokṣani mukte vimukte amale vimale nirmale ạ̣ḍare pạ̣ḍare man்gale mangalagarbhe hiraṇye hiraṇyagarbhe ratne ratnagarbhe bhadre subhadre samantabhadre śrībhadre sarvārthasādhani paramārthasādhani sarvānarthaprabādhani sarvamañgalasādhani sarvamañgalasādhani yaśovati manasi mānasi mahāmānasi acyute adbhute siddhe susiddhe mukte vikte mocani mokșani vimokṣani a<98v>raje viraje vimale amṛte amṛtavarṣaṇi amare amaraṇi brahme brahmasvare pūrṇe pūrṇamanorathe amṛte amṛtasaṃjīvaṇi śrībhadre candre candrabhadre sūrye sūryakānte vītabhaye suvarṇe suvarṇaprabhe brahme brahmaghoṣe brahmajușțe sarvatrāpratihate rakṣa 2 mama sarvasattvāṃś ca

4 -pālanam] corr.; -bālanam ms. 10 teșāṃ] corr.; steșāṃ ms. 15 bhūta-] pc.; bhūtatṛac. 25 svaviṣayaṃ] corr.; svaviṣaṃ ms. 36 -sattvāṃś] pc.; -sattvānāṃś $a c$. 
svāhā || namaḥ sarvabuddhānāṃ svastir bhavatu mama sarvasattvānāṃ ca rakṣāṃ kuru guptim paritrāṇaṃ parigrahaṃ paripālanaṃ saāntisvastyayanaṃ daṇḍaparihāram śastraparihāram viṣadūṣaṇam viṣanāśanam sīmābandhạ̣ dharạ̣ībandham ca kurvatu jīvantu varṣaśatam paśyatu saradāśatam || tadyathā || huci guci muci svāhā || namaḥ samantabuddhānāṃ svāhā || etarhy api tasyā hṛdayam anuvyākhyāsyāmi || tadyathā || ili mili itti mitti ilitti limitte iliti limitti tili mitte tili mitte tili mili mili mili mili mili mili | mici limi | miti 3 || sudumbā tumbā suvacā | cili kisiya | bhinna meḍe | namo buddhānāṃ cili kisi ciṃhnāsi prāntamūle | itihāra lohitamūle tumbā ambā sutubā sudumbā kuṭti kunaț̣i kukunaț̣i | tila kuñja naț̣i | aḍakavatyāṃ varṣantu deva samantena navamāsān daśamā<99r>sān iti || ili mili kili mili | keli meli ketumūle dumbe sudumbe | eḍe iḍime sudumoḍe suḍume didalime santuvațte busațte busavaț̣e | vusara 2 dhanamastarake | enamastarake | narkale narkalime khalise narkalike nirmalike narakharimaghoșe | khalamalikhe kharamarakhile | itisarjale tumbe tutumbe anațte națte pranațte aṇa 2 naț̣e aṇamāle aṇamohile varșatu devo navodakena saptakṛtva samantena nārāyạ̣i pārāyaṇi haritāli kuntāli kumbhāṇ̣̣i | ili misti kili misti | kili tili misti | ili me siddhyantu drāmiḍā mantrapadāḥ svāhā || iyam ānanda sarvopadravamadhyagate manasikartavyāni | imāni cānanda mantrapadāni manasikartavyāni || tadyathā || hili mili | vili mili | kili mili | ketumūle susuțte busațte busavațte buddhavaț̣e | busaraṇi 2 budāraṇi | kevatte kevattakamūle | itisarjale | dumbe tutumbe tumbe 2 priyaṃkare āvatțe | parivațte navodakena deva samantena varṣatu namo bhagavate itițāya | indragomisikābhṛngārikāya | āsane pāsane pāpanikūle kapilamitte | ili mitte namo bhagavate buddhāya siddhyantu me <99v> mantrapadāni svāhā || anayānanda mahāmāyūryā mama sarvasattvānāṃ ca rakṣām karotu || nāham ānanda tam paśyāmi sadevāsure loke ya imām anyathā kariṣyati || imāni cātramantrapadāni manasi kartavyāni || tadyathā || ili mili kili mili | kiṃ dugdhe mukte sumukte āḍe nāḍa sunāḍa varṣantu devah param aḍakavatyām | ārā pārā goḍohikā | ili mili bhijjilikā | udukā | kādudukā | okā | daḍākā | ili mili | tili mili samantataḥ kṛtvā hulu 2 hili 2 mili 2 pili 2 kili 2 śīṣeṇa varṣa | culu 2 cili 2 mulu 2 cala 2 viḍi 2 cuḍu 2 viḍi 2 śikhi 2 ițti vițti khikhi khikhi || juhu juhu juhu juhu juhu juhu juhu juhu juhu juhu || 10 || hara 2 haraṇe jambhe prajambhe sarvaduṣṭapradușțānām jambhayāmi stambhayāmi mama sarvasattvānām ca rakṣām karomi guptim paritrāṇam parigraham paripālanaṃ śāntim svastyayanaṃ daṇḍaparihāraṇaṃ śastraparihāraṃ viṣadūṣaṇaṃ viṣanāśanam śāntim svastyayanaṃ dạ̣ḍaparihāraṃ śastraparihāraṃ

8 cili] $p c$.; cili lici ac. 11 -māsān] corr.; -māsin ms. 34 sarvasattvānāṃ] pc.; sarvasarvattvānāṃ ac. 
viṣadūṣaṇam viṣanāśanam sīmābandhạ̣ dharaṇībandham kurvantu jīvantu varṣaśatam paśyatu saradāśatam || tadyathā || citre citramūle citramāle hale halamā<100r>le phale phalamāle guru 2 kharuja | varu 2 ṇe | kharu varuṇe | dhīre vijaye | suru 2 suru eme | arumba garumaruṇe hatạ̣ vișaṃ nihatam viṣam | sarvaduṣțapraduṣțānāṃ damṣțraviṣadūṣaṇam | mūlaviṣam | annaviṣam | 5 pāpaviṣam | sarvabuddhānāṃ tejasām | suru 2 ke | vara 2 ke | varakke | ciri 2 hiri 2 hatam viṣaṃ nihatam viṣaṃ nāsti viṣaṃ saptānāṃ samyaksambuddhānāṃ saśrāvakasaṃghānāṃ tejasā || ela melā ili melā tili melā tili 2 melā | tihā duhā | tilimā timā dumā vimādhu mādhu sukumbhā kumbhā sumbhā sumbā tumbā samatubā | āḍe nāḍe tilakuñjanāḍe | varṣantu devaḥ | ili kisi samantena 10 navamāsān daśamāsān iti | maitrī me sarvasattveșu vusare vusaḍe śavariṇi vudāriṇi vusaț̣e vudāriṇi vadāriṇi 2 kevaț̣e kevaț̣ańkamūle itiśabare | tumbe priyaṃkare āvatte parivaț̣e navodakena varṣantu devaḥ samantena santuṣutte || namo bhagavate indragomisikāya | itițtitāya godohikāya bhṛngārikāya | ate tale kuntale | aț̣e naț̣e aṇaṇațte kunaț̣e | asapāśane pāpanikūle pratikūle | namo buddhānāṃ bhagavatāṃ svāhā ||

aśokam āśritya jino vipaśvi

śikhijinah puṇdarīkasya mū<100v>le |

sālasya mūle upagamya viśvabhūḥ |

śirīṣasya mūle krakucchandabrāhmaṇaḥ |

buddhaś ca konāma kanakamuni udumbare

nyagrodhamūle upagamya kāśyapaḥ |

aśvasthamūle muni śākyapungava |

upetya bodhim samāpya gotamạ̣ |

eteșu buddheșu maharddhikeșu

yā devatāḥ santi abhiprasannās

tā devatā hṛșțamanā udagrāḥ

kurvantu sāntim ca śivaṃ ca nityam ||

tadyathā || ili mili kili cili keli celi | voli udulā sudumoḍe | busara 2 hu hu hu karañja karañjamūle | iti sanatā | iti savatā | kuntali kutāli nārāyani pārāyaṇi

paśyani paśya 2 ni | kapilavastuni | ilivā sidhyantu me drāmiḍā mantrapadāni svāhā ||

imāni punar ānanda mahauṣadhayo brahmendramahārājayakṣasenāpatibhiś ca bhāṣitā ||

tadyathā || kīrtimūle eramūle ekamūle eraṇḍamūle samantamūle naḍe nāḍe āḍenyaḍe aț̣e națte kuśanatțe āḍe nāḍe kuśanāḍe iț̣e mitṭe cāru sutanu araḍe

13 varșantu] $p c$.; rșanvatu $a c$. 
kāmaraḍakā | ilikisā cilikisā ili kili cili godohanā | udvundhu mā bhinnam etā | udvundhu mā kiṃnarā | namo buddhānāṃ svāhā || svasti vo dvipade bhontu svasti vo 'stu catuṣpade | sva<101r>sti vo vrajatāṃ mārge svasti pratyāgateșu ca \| rātrau svasti divā svasti madhyaṃdine sadā | svasti sarvam ahorātram sarvabuddhā diśantu vaḥ || sarvatra svasti vo bhontu mā caișām pāpam āgamat | maitracittaṃ samāsthāya karomi viṣadūṣaṇam || sarve divasakalyānāḥ sarve nakṣatrabhadrakāḥ sarvamaharddhikā buddhāḥ sarve 'rhanto nirāśravāḥ || anena satyevākena svastir bhavatu sarvatah \| anayā mahāmāyūryā mama sarvasattvānāṃ ca rakṣāṃ karotu guptim paritrāṇaṃ parigrahaṃ paripālanaṃ śāntisvastyayanaṃ daṇụaparihāraṃ śastraparihāraṃ viṣadūṣaṇaṃ viṣanāśanaṃ sīmābandhaṃ dharaṇībandhaṃ ca kurvantu jīvantu varșaśatam paśyatu śaradāśatam svāhā ||

ye cānanda mahāyakṣā vasanti jalabhūmiṣu | nagare parvate sarve svasti kurvantu te 'nayā $\|$ tadyathā || hahi 2 hāriṇi | cali 2 ni cālini | tramaṇi trāmaṇi mohani jambhani stambhani svayambhuve svāhā \| pūrvasyāṃ diśi cānanda dhṛtarāșțraḥ sapārșadaḥ | so 'pi mama sarveșām anayā svasti karotu ca || tadyathā || suru suru suru suru suru suru suru suru suru suru || 10 || rumi rumi rumi rumi rumi rumi rumi rumi rumi rumi svāhā || ru ru ru ru ru ru ru ru ru ru svāhā || su su <101v> su su su su su su su su svāhā || ḍa ḍa ḍa suhu 2 svāhā || ānanda dakșiṇasyāṃ ca virūḍhakaḥ sapārṣadaḥ | so 'pi ca mama sarveșāṃ svasti karotu cānayā || tadyathā || veluke 2 amitraghātani varunavati veṇumālini velini veluni putrike cā cū ci cū svāhā|

ānanda paścimāyāṃ ca virūpākṣas sapārṣadah | so 'pi ca mama sarveșāṃ svasti karotu cānayā || tadyathā || veduri 2 veduri 2 veduri 2 | mațitie 2 koṭi 2 vidyumati 2|| hu hu hu hu hu hu hu hu hu hu || 10 || ra ra ra ra ra ra ra ra ra ra || 10 || ru ru ru ru ru ru ru ru ru ru || 10 || cu cu cu cu cu cu cu cu cu cu || 10 || svaḥ svāhā || ānanda cottarasyāṃ tu vaiśravaṇas sapārṣadaḥ | so 'py evaṃ mama sarveșām svasti karotu cānayā ||

12 karotu] corr.; karo ms. 22 tadyathā] pc.; tathādya ac. 36 so 'py evaṃ] corr.; svapyaivaṃ ms. 
tadyathā || sori 2 siri 2 mati | hiri 2 mati | bhiriri | miriri | kiriri | hiriri | ghelu 2 velu 2 pingale | culu 2 bandhamati | hatam viṣaṃ nihatạ̣ vișaṃ bandhumati svāhā || ete caturmahārājā lokapālā sapārṣadāḥ |

te 'pi vai mama sarveșām svasti kurvantu cānayā ||

tadyathā || ele mele | hile hile hile hile me | tilime śile pāśe dumbe

dududmbe varșantu deva samantena hili 2 mili 2 tumbe tutumbe | aț̣e vațte | para $<102$ r $>$ maduvatte varșantu devo guḍu 2 samantena | aḍakavatyām | aṇde nạ̣de taṇde tụ̣de tutuṇ̣̂ bukke 2 iri ḍimi riḍi tiri ḍibhi rị̣i piri ḍimi ḍiti ḍi | hiḍi 2 hiḍi 2 hiri 2 hili 2 hulu 2 tili 2 mili 2 tule 2 tatale svāhā $\|$

yakṣasenāpatiputra saṃjayaś ca sapārṣadah |

so 'py evaṃ mama sarveșāṃ svasti karotu cānayā ||

tadyathā || vale valkale mātañgi caṇụāli | puruṣaṇi | vicilini 2 | gori gandhāri caṇụāli mātan̉gi pukkasi mālini hili 2 mili 2 āgati gati gauri gandhāri koṣtị kācani | vihāri 2 hiri 2 kuṣpe svāhā || maharddhikāś ca ye yakṣā deśe kṣetre vyavasthitāḥ |

te sarve mama sarveșām svasti kurvantu cānayā || tadyathā || akāțte vikațe hariṇi hāriṇi dhāriṇi | hukke 2 cukke 2 vukke 2 | hana hana hana hana hana hana hana hana hana hana hana || 10 || amitrān mama saparivārasya sarvasattvānām ca || daha daha daha daha daha daha daha daha daha daha || 10 || ahitaișiṇo mama sarvasattvānām || paca paca paca paca paca paca paca paca paca paca || 10 || pratyarthikān mama sarvasattvāṇām || cu cu cu cu cu cu cu cu cu cu || 10 || nāśaya mamāhitaișiṇaḥ || jāḍ̂o jāḍo jāḍo jā <102v> ḍo jāḍo jāḍo jāḍo jāḍo jāḍo jāọ̣o || 10 || mama sarvaduṣtān || dhu dhu dhu dhu dhu dhu dhu dhu dhu dhu || 10 || nāśaya sarvaśatrūn mama sarvasattvānāṃ ca || ha ha ha ha ha ha ha ha ha ha || 10 || jiḍi jiḍi jiḍi jiḍi jiḍi jiḍi jiḍi jiḍi jiḍi jiḍi || 10 || nāśaya sarvaśatrūn mama sarvasattvānāṃ ca || jāla jāla jāla jāla jāla jāla jāla jāla jāla jāla || 10 || culu culu culu culu culu culu culu culu culu culu || 10 || hili hili hili hili hili hili hili hili hili hili || 10 || mili mili mili mili mili mili mili mili mili mili || 10 || mihili mihili mihili mihili mihili mihili mihili mihili mihili mihili || 10 || ciḍdi ciḍi ciḍi ciḍi ciḍi ciḍ ciḍi ciḍi ciḍi ciḍi || 10 || viḍi viḍi viḍ̂ viḍi viḍi viḍi vị̣i viḍi viḍi vị̣i || 10 || phuru phuru phuru phuru phuru phuru phuru phuru phuru phuru || 10 || huru 2 nāśaya sarvaśatrūn mama sarvasattvānāṃ ca || hikke mikke cikke cukke 2 śrībhadre mañgalye samantabhadre | hiraṇye hiraṇyagarbhe sarvārthasādhani paramārthasādhani sarvānarthaprabādhani | samantabhadre | amale ka<103r>male vimale candre candravati candraprabhe sūrye sūryaprabhe sūryakānte durvijñeye | dumbe 2 dodumbe priyaṃkare rakṣatha mama sarvasattvānāṃ ca guptim paritrāṇaṃ parigrahaṃ paripālanaṃ

13 pukkasi] corr.; kukkasi ms. 25 ha] pc.; ha ha ac. 
śāntisvastyayanaṃ dạ̣ḍaparihāraṃ śastraparihāraṃ viṣadūṣaṇaṃ viṣanāśanaṃ sīmābandhaṃ dharaṇībandhaṃ ca kurvantu jīvantu varșaśatam paśyatu śaradāśatam svāhā || ye prācyāṃ ye catur yakṣā ye yakṣā yāmyapālakāḥ | vāruṇyāṃ ye ca catvāra uttarāṃ ye ca rakṣakāḥ || vidikṣu ye ca catvāro dharaṇyāṃ ye ca rakṣakāḥ | antarīkșe ca ye yakșā sattvānugrahakārakāh || vaiśravaṇasya ye yakṣā trātaraḥ sainyapālakāḥ | te 'py evaṃ mama sarveșāṃ svasti kurvantu cānayā || yābhị̣ kukṣigato bodhisattvo jātaś ca rakṣitaḥ | dvādaśemāḥ piśācyo me svasti kurvantu cānayā || tadyathā || harare khare khare | male mile mule | madayanti matte timatte maṇditike || hulu hulu hulu hulu hulu hulu hulu hulu hulu hulu || 10 || lulululu || 4 || meḍi meḍi meḍi meḍi || 4 || siddhi siddhi siddhi siddhi || 4 || svasti svasti svasti svasti || 4 || mama sarvasattvānāṃ svāhā || așțamahāpiśācyo yā bodhisattvasya rakṣakāh | tā api mama sattvānām <103v> rakṣām kurvantu cānayā || piśācye saptakāyāś ca bodhisattvaprarakṣakāh | tā api mama sattvānāṃ guptim kurvantu cānayā || rākṣasya pañcamāyāś ca bodhisattvā prapālikāḥ || tā api mama sattvānām trāṇam kurvantu cānayā || așța cānanda rākṣasyo bodhisattvasya guptikāḥ | tā api mama sattvānām anugṛhṇantu cānayā || daśemā yā ca rākṣasyo bodhisattvasurakṣikāḥ \| tā api mama sattvānāṃ sampālayantu cānayā || dvādaśemāś ca rākṣasyo yā bodhisattvapoṣakāḥ | tā api mama sattvānām śāntim kurvantu cānayā || mātṛdvādaśemāś ca yā bodhisattvapālakāḥ | tā api mama sattvānāṃ svasti kurvantu cānayā || ekajațā ca yā raudrī bodhisattvapramodakāḥ | so 'py evaṃ mama sattvānāṃ dạ̣ụād rakṣantu cānayā || rākṣasyo yā mahāvīryā bodhisattvānurakṣakāḥ | tā api mama sattvānāṃ śastrād rakṣantu cānayā || tadyathā || hili 2 mili 2 tatra vatțe cakke | hili hili hili hili hili hili hili hili hili hili || 10 || mili mili mili mili mili mili mili mili mili mili || 10 || taḍe tavade | bukke cukke | pharu 2 huru huru huru huru huru huru huru huru huru huru || 10 || ciṭi

2 vișanāśanaṃ] $p c$; vināśanaṃ $a c . \quad 19$ sattvānāṃ] pc.; sarvatvānāṃ ac. 22 guptikāḥ] corr.; goptikāḥ ms. 25 tā api] $p c$; atāpi $a c .29$ sattvānāṃ] $p c$.; sarvatvānāṃ ac. 
ciṭi ciṭi ciṭi ci<104r>ți ciṭi ciṭi ciṭi ciṭi ciṭi || 10 || hikke mikke cukke | hore 3 dhara 2 hana 2 hara 2 cara 2 curu 2 svāhā $\|$

bhūmicarāś ca rākṣasyo yā bodhisattvarakṣakāh |

rākṣasī pingalāyā ca pañcaputraśatair vṛtā|

hārītī yā ca vikhyātā pañcaputraśatair vṛtā |

yā mātṛ̣āṃ tathā pañcaśataiś ca parivāritā ||

puraskṛtāyā yā nityam pañcabhis tuṣikāśataị |

tā api mama sattvānāṃ svasti kurvantu cānayā ||

tadyathā || namaḥ sarvabuddhānāṃ svāhā || pratyekabuddhānām svāhā

|| arhatāṃ svāhā || maitreyasya bodhisattvasya mahāsattvasya svāhā ||

sarvabodhisattvānāṃ svāhā || anāgāmināṃ svāhā || sakṛdāgāmināṃ svāhā

|| śrotāpannānāṃ svāhā || samyaggatānāṃ svāhā || samyakpratipannānāṃ

svāhā || brahmaṇe svāhā || indrāya svāhā || prajāpataye svāhā || î́ānāya

svāhā || agnaye svāhā || nairṛtyāya svāhā || vāyave svāhā || varuṇāya svāhā ||

kuverāya svāhā || yamāya svāhā || upendrāya svāhā || vaiśravaṇāya svāhā ||

yakṣādhipataye svāhā || dhṛtarāṣțāya svāhā || gandharvādhipataye svāhā || virūụhakāya kumbhāṇḍāhipataye svāhā || virūpākṣāya nāgādhipataye svāhā || devānāṃ svāhā || nāgānāṃ svāhā || asurānāṃ svāhā || marutā<104v>nām svāhā || garuḍānāṃ svāhā || gandharvāṇāṃ svāhā || kiṃnarāṇāṃ svāhā || mahoragānāṃ svāhā || yakṣānām svāhā || rākṣasānāṃ svāhā || pretānāṃ svāhā || piśācānām svāhā || bhūtānāṃ svāhā || kumbhāṇdānām svāhā || pūtanānāṃ svāhā || kațapūtanānāṃ svāhā || skandānāṃ svāhā || unmādānāṃ svāhā || chāyānām svāhā || apasmārāṇām svāhā || ostārakānāṃ svāhā || rudrāṇām svāhā || candrasūryayoḥ svāhā || nakṣatrāṇām svāhā || jyotiṣānām svāhā || grahāṇām svāhā || ṛ̣ịnāṃ svāhā || siddhavratānāṃ svāhā || siddhavidyānāṃ svāhā || gaurīye svāhā || gāndhārīye svāhā || jāngulīye svāhā || mārutāye svāhā || amṛtāyai svāhā || jambhanīye svāhā || stambhanīye svāhā || mātangīye svāhā || cāpețiye svāhā || drāmị̣īye svāhā || śabarīye svāhā || atharvaśabarīye svāhā || cāṇḍāliye svāhā || nāgahṛdayāya svāhā || garuḍahṛdayāya svāhā || manasvinyai svāhā || mahāmanasvinyai svāhā || mānasīye svāhā || mahāmānasīye svāhā || șaḍakṣarīye svāhā || māṇibhadrāya svāhā || pūrṇabhadrāya svāhā || samantabhadrāya svāhā || mahāsamantabhadrāya svāhā || samayāya svāhā || mahāsamayāya svāhā || pratisarāya svāhā || mahā<105r>pratisarāya svāhā || śītavanāya svāhā || mahāŝîtavanāya svāhā || daṇḍadharaṇiye svāhā || mahādaṇḍadharaṇiye svāhā || mucilindāya svāhā || mahāmucilindāya svāhā || jayantīye svāhā || sāntiye svāhā || avyākṛtāya svāhā || aśvakrị̄āya svāhā ||

10 maitreyasya] corr.; maitryeyasya ms. 24 nakṣatrāṇāṃ] pc.; nakṣaṇāṃtrā ac. 25 grahāṇāṃ svāhā] corr.; grahāṇāṃ svāhā || grahāṇāṃ svāhā ms. 28 śabarīye] corr.; khabarīye ms. 
mahādhāraṇīye svāhā || mantrapadebhyaḥ svāhā || mahāmantrapadebhyaḥ svāhā || aparājitāyai svāhā || suvarṇāvabhāsāya svāhā || mahāmayūrarājāya svāhā || mahāmayūrakrāntāya svāhā || mahāmāyūryai svāhā || imāni mantravidyābhị praș̣tābhiś ca sarvataḥ | bhavantu mama sarvasattvānāṃ hatā roga-upadravāḥ || viṣāś ca parakarmāś ca naśyantu mama sarvatạ̣ || rātrau svasti divā svasti svasti madhyaṃdine sthite | svasti sarvam ahorātram sarvabuddhā diśantu vaḥ || namo 'stu buddhāya namo 'stu bodhaye | namo 'stu muktāya namo 'stu muktaye \| namo 'stu sāantāya namo śāntaye | namo 'stu vimuktāya namo 'stu vimuktaye \| ye brāhmaṇā vāhitapāpadharmā ye ca sthitāḥ sattvahitāya nityaṃ śuklavratāḥ kṣāntisamādhiyuktās te brāhmaṇās tārayituṃ samarthāḥ | teșām namo 'stu sarveșāṃ bodhidharmavicāriṇām | te nityaṃ mama sattvānām pālayantu ca sarvadā || svasti mātuḥ svasti pituḥ svasti <105v> garbhagatasya ca | svasti dvipadasattvānāṃ svasti catuṣpadeșu ca || svasty astu mama sattvānāṃ svāter bhikṣos tathā śivam | ye ca nāgā jale bhūmau pātālādricaye sthitā | te mama sarvasattvānāṃ svasti kurvantu cānayā || rātrau svasti divā svasti svasti madhyaṃdine sthite | svasti sarvam ahorātram sarvabuddhā diśantu vaḥ || namo 'stu buddhāya namo 'stu bodhaye | namo 'stu muktāya namo 'stu muktaye \| namo 'stu śāntāya namo śāntaye | namo 'stu vimuktāya namo 'stu vimuktaye || ye brāhmaṇā vāhitapāpadharmā ye ca sthitāḥ | sattvahitāya nityam | śuklavratāḥ kṣāntisamādhiyuktās te brāhmaṇas tārayituṃ samarthāḥ || teșāṃ namo 'stu sarveșāṃ bodhiśikṣāpracāriṇām | te 'pi ca mama sarvasattvānāṃ rakṣantu śaradāṃ śatam || iyaṃ cānanda vidyā vipaśvinā prabhāṣitā | moditā deśitā nityaṃ sarvasattvārthasiddhaye || tadyathā || araḍe karaḍe maḍe maḍamardane | avare śavare ture 2 dhure 2 śavare 2 parṇaśavare | huci huci huci huci huci || 5 || muci muci muci muci || 4 || kuci kuci kuci kuci || 4 || svāhā ||

13 brāhmanā] corr.; brāhma ms. 14 tārayitum] pc.; tāyarayitum $a c .18$ catuṣpadeșu] pc.; catupașpadeșu ac. 20 -caye] corr.; -cakhe ms. 21 te] corr.; ste ms. 31 sarvasattvānāṃ] corr.; sarvatvānāṃ ms. 
iyaṃ cānanda vidyā śrī-śikhinā ca prabhāṣitā |

dhāritā vācitā nityaṃ moditā sattvahetave \|

tadyathā || i<106r>tțe mițte khule viṣule || hili hili hili hili || 4 || mili mili mili mili || 4 || ketumūle ambare ambarāvati danti śabare dumbe dodumbe || hili 2 mili 2 kuci 2 muci 2 svāhā \|

iyaṃ cānanda vidyā śrī-viśvabhuvā prabhāṣitā |

moditā deśitā nityaṃ paṭhitā svastihetave ॥

tadyathā || mori 2 kevaț̣i 2 maṇdi 2 maṇditike | hare 2 khare 2 khuru 2 ghare 2

hare 2 halimi | phale phalini dante dantini dantile sakațti makați naḍe naḍini ||

śiri śiri śiri śiri svāhā ||

iyạ̣ cānanda vidyā śrī-krakucchandena bhāṣitā |

dhāritā moditā nityạ̣ deśitā bhāvitā sadā ||

tadyathā || hiḍi miḍi kuḍi muḍi muritu rituḍi 2 aḍe dante dantili śakari vakari vekari bhakari thagari tagari kāñcane kāñcanāvati | śabare 2 care care care care || 4 || pare pare pare pare || 4 || danti siddhi svāhā ||

iyam cānanda vidyā śrī-kanakamuninā tathā |

bhāṣitā moditā nityaṃ sattvebhyah upadeśitā ||

tadyathā || tatale 2 talete | tale 2 vare 2 vīre vijaye vijavare araje viraje virajāmasi | mati 2 māle mati mālini | muṇḍe śiri muṇḍe || jvale jvale jvale jvale || 4 || <106v> bhadravati siddhi svāhā ||

iyaṃ cānanda vidyā śrī-kāśyapena subhāṣitā |

dhāritā moditā nityaṃ parebhyaś ca upadeśitā ||

tadyathā || aṇḍare pạ̣ḍare kaṇḍale maṇḍle khạ̣ḍle | jambu 2 nadi jambumati matte mạ̣ditike | amale siṃhe | hara hara hara hara || 4 || paśu paśu paśu paśu paśupati || siddhi siddhi siddhi siddhi || svāhā ||

iyaṃ cānanda vidyā śrī-mayāpy etarhi bhāṣitā|

dhāritā moditā caiva sarvasattvahitāya ca \|

tadyathā || hili mili kili mili || ilile katale ketumūle | aḍamale maḍamali amali amale anaḍi daphe daḍaphe | erakahu | anabhiḍaphu | ḍậphu | ruruḍphu | karahu | vusarake vusațte narakande krāmaṇi kāmini kāmarūpiṇi kitiri rocali kekambudarake | taru 2 varuṇi | curu taru varuṇi | taruṇa 2 vati jambare vāsavaraț̣e | tarantarante bharaṇe | ruru tạ̣adharaṇi | ābharaṇi | prakṛtidamșțre mili tale | itihāse avale tuvale jambale kokalike | vaț̣i 2 ke vaț̣i 2 mukule vaț̣e 2 vațțacāce | aḍatambe | tatratambe varṣantu devaḥ śatakṛtvaḥ samantena yathāsukham daśasu diśāṣu namo bhagavatạ̣ kumudodakaṃ bhavantu namo bhagavate | iraṃjaye | ițtițtāye go<107r>dohikāye bhṛngārikāye | aruci nāruci | araje 2 naraji | ațte națte | vajre vajranaț̣e | națe 2 vajre 2

35 kumudodakaṃ] pc.; mukudodakaṃ $a c$. 
națtavajre | udayanapriye | ale tāle kulatāle nārāyaṇi pārāyaṇi paśyani paśyapaśyani saṃsparśani | sidhyantu me drāmiḍā mantrapadāḥ svāhā || iyaṃ cānanda vidyā śrī-maitreyeṇa prabhāṣitā |

dhāritā moditā nityaṃ sarvasattvahitāya ca \| tadyathā || śiri śiri śiri śiri || 4 || bhadre jyotibhadre | hare hariṇi danti śabari śive śūlapālini | bodhi bodhi bodhi bodhi bodhi || 5 || satyabodhiparicāriṇiye svāhā || anayānanda bhikṣo tvaṃ svāteḥ svastyayaṇaṃ kuru | tathaivaṃ sarvasattvānāṃ pālanaṃ viṣanāśanam || iyam cānanda vidyā śrī-brahmaṇāpi prabhāṣitā | moditā dhāritā nityam parebhyo 'py upadeśitā || tadyathā || hili 2 mimi 2 molini | vaṃkari 2 kiri kiri kiri kiri || 4 || kiriṇi | kirikire | brahmāye karạ̣ḍake ratnakaraṇụake vihoḍapusse | dhara 2 sara 2 hara 2 hala 2 phulu phulu phulu phulu || 4 || svāhā || hatạ̣ viṣaṃ nihatam viṣam buddhatejohatam viṣam pratyekabuddhatejohatạ̣ viṣam arhattejohatam viṣam anāgāmitejohatam viṣam 2 sakṛdāgāmitejohatam viṣam śrotāpanna<107v>tejohatam viṣam satyavāditejohatam viṣaṃ brahmadaṇḍatejohatam viṣam indravajratejohatam viṣam viṣnucakratejohatam viṣam agnidāhahataṃ viṣaṃ varuṇapāśahatam viṣam asuramāyāhatam viṣam nāgavidyāhatam viṣaṃ rudraśūlahatạ̣ viṣam skandaśaktihatam viṣam mahāmāyūryā vidyārājñyā hatạ̣ viṣaṃ nihatạ̣ viṣaṃ bhūmyāṃ saṃkrāmatu viṣaṃ svāhā || svasti mama sarvasattvānāṃ ca sarvaviṣebhyạ̣ svāhā || iyạ̣ cānanda vidyā śrī-śakreṇāpi prabhāṣitā| dhāritā moditā nityaṃ parebhyo 'py upadeśitā \| tadyathā || jale jantule mālājantule cāpețijantule mathani ghātani grasani hari śiri dyuti śiri taru taruṇavati hāhā siṃhe dhiti vidhiti || kuru 2 śo varu 2 se | vasare tuțta 2 si | sili 2 mili 2 kapile kapilamūle | hā hī hūṃ sarvadușțapraduṣtānām jambhanam karomi | hastapādāngapratyaṅganigraham karomi | sahatridaśehi devehi drațtigiri surapativarti || vajra vajra vajra vajra vajrapataye svāhā || iyaṃ cānanda vidyā śrī-mahārājaiś ca bhāṣitā | caturbhi dhāritā nityaṃ moditā paradeśitā || tadyathā || jvala 2 na tapa 2 na | dhama 2 na | matha 2 na | sara 2 na | kiṭi 2 kuṭi 2 muṭi 2 miți 2 piți 2 sara 2 mara 2 hara 2 tara 2 ti< 108 r $>$ ri 2 || ța ța ța ța ța || 5 || dā dā dā dā dā dā dā dā dā dā || 10 || vā vā vā vā vā vā vā vā vā vā || 10 || hala hala hala hala hala hala hala hala hala hala || 10 || siddhi siddhi siddhi siddhi

20 skanda-] corr.; svandha- ms. 
siddhi || 5 || svasti svasti svasti svasti svasti || 5 || mama sarvasattvānāṃ ca svāhā ||

sarvapreșyād yamasyaivaṃ dūtāc ca kālayā śataḥ |

brahmādidaṇḍato mṛtyoḥ svasty astu mama sarvatạ̣ \||

yā nadyo bhuvane khyātāḥ tāsu sarvāsu devatāḥ|

yakșādayaś ca bhūtā ye te me kurvantu svasti ca ||

mervādiparvatā ye ca devatās teșu ca sthitāh |

te sarve mama sattvānāṃ svasti kurvantu cānayā ||

aștāvimiśati nakṣatrāḥ grahāḥ sarve mahābalāḥ |

te sarve mama sattvānāṃ svasti kurvantu cānayā ||

tadyathā || hiri 2 khiri 2 miri 2 puri 2 muri 2 hili 2 mili 2 daphu 2 daḍaphu grasani mathani damani dahani ghātani pacani pācani tapani tāpani dahani dāhani tāpani | daha 3 pacani | dara 2 dāraṇi pāṭani mohani stambhani jambhani svayambhū svāhā || ye prajā $<108 \mathrm{v}>$ pataye loke sarvasattvahitaṃkarāḥ |

te sarve mama sattvānāṃ svasti kurvantu cānayā || tadyathā || hari 2 khari 2 mili 2 sili 2 śili 2 mili 2 hili 2 miri 2 śiri 2 daphu ḍaḍaphu grasani mathani ghātani pacani pācani hatini daha 2 dārani pāṭani mohani jambhani stambhanīye svāhā \| ye mahāviṣā ugrā mahāvyādhivināśakāḥ |

te sarve mama sattvānāṃ svasti kurvantu cānayā || tadyathā || aṇ̣arā paṇụarā karaḍa keyūrā bhūtaṃgamā bhūtapati bindupati śiripati tejaḥpati tejograpati yaśaḥpati yaśograpati | araḍa taraḍā taraḍa taraḍā taradūtarā dantā dāhā jehā jelā melā halā 2 phūlā guhā virā rudhirā danturā irikicca kirikicca santurā vipuli nakuli kirimi taranggāriștah | amrāmati jambumati madhumati kamale vimale kuṇ̣ale aḍināḍi ahituhi duhi vakke 2 dūte vatsanābhe mahāgare tulambe dulambe sulambe svāhā || ye ca bhūmau mahāvṛkṣās teșu devāś ca ye sthitāḥ | te sarve mama sattvānāṃ svasti kurvantu cānayā || punaś cānanda vidyeśāṃ gṛhītvemāṃ prakāśaye | svastyayanaṃ mayā khyātaṃ caturṇāṃ parșadāṃ kuru || tadyathā || pañcati dhāvati dharaṇi kuru tu<109r>ru me rakșa 2 māṃ sarvasattvāṃś ca svāhā || rāgadveșaś ca mohaś ca ete loke trayā viṣāh | nirvișo bhagavān buddho buddhasatyaṃ hatam visam | rāgadveșaś ca mohaś ca ete loke trayo vișāh | nirviṣo bhagavān dharma dharmasatyaṃ hatam vișam || rāgo dveșaś ca mohaś ca ete loke trayo viṣāḥ | nirviṣo bhagavān saṃghạ̣ saṃghasatyaṃ hatạ̣ viṣam || yad balaṃ sarvabuddhānām arhatāṃ caiva yad yaśạ̣ | 
tathāgatasya tejena kṛtaṃ svastyayanaṃ mayā | mama sarvasattvānāṃ ca hatạ̣ viṣaṃ nihatạ̣ viṣaṃ mahāmāyūryā vidyārājñyāḥ svasty ānanda svāter bhikṣo bhavatu || tatheti sa pratiśrutya jinaṃ natvā prasāditạ̣ | svāteh svastyayanaṃ kṛtvā tam gṛhya puna cāgatạ || nātha svātir ayaṃ bhikṣur bhavadvidyāprasādatạ̣ | rakṣito he mayā mṛtyor ity ānando 'bravīn munim || athāpi bhagavān āha sarvāvatīṃ ca parṣadaṃ | śṛ̣udhvaṃ sāmpratam bhūtā tadvidhānaṃ mayoditam || gomayāliptake bhūmau sthāpya caityaṃ ca maṇḍale | pūjāgrai pūjayed vidyāṃ pațhitvān pracare balim || tadyathā || oṃ varade hūṃ hariṇi sphațāāiṇi svāhā || kāli kalāli kumbhāṇḍi śan̉khini kamalākṣi hārīti harikeśi śrīmati hari pingale lambe pralambe lambodari kālapāśe kapāladhā<109v>riṇi kalaśodari yamadūti yamarākṣasi bhūtagrasani praticchathemam balim gandham puṣpaṃ dhūpaṃ dīpaṃ ca rakṣata māṃ sarvasattvāṃś ca sarvabhayopadravopasargebhyo rakṣāṃ kuruta guptim paritrāṇam parigraham paripālanaṃ śāntisvastyayaṇaṃ daṇḍaparihāraṃ śastraparihāraṃ viṣadūṣanaṃ viṣanāśanaṃ sīmābandhaṃ dharạ̣ībandham kurvantu jīvantu varșaśatam paśyatu śaradāśatam sidhyantu mantrapadāḥ svāhā \|

mṛtasaṃjīvanī vidyā yā buddhaiś ca prabhāṣitā | māyūrī mahatī khyātā namas tasyai kuru sadā || athānando 'bravīn natvā jinaṃ māraprabhuñjaka | evaṃ nityaṃ mahānātha kariṣye tvatprasādatạ̣ || yasyāḥ prajalpamānāyāṃ sarve duṣțagrahāsurāh | daityā nāgā narā yakṣā vinaśyanti namāmi tām || yasyām prapaṭhamānāyāṃ sarvarogāḥ sudāruṇāḥ | sarvadușțagrahotpannā nașțās tasyai namo namạ̣ || nāśayati ca yā vidyā sarvadravopasargikām | viṣādiparayantrāś ca name tām ca name bhaje || yā vidyā sarvabuddhaiś ca sarvasattvahitārthadaḥ | dhāritā deśitā nityaṃ na me tāgra bhaje śraye || idam avocad bhagavāṃś cānandaḥ sarvāvatī parṣac ca bhagavato bhāṣitam abhyanandann iti || ||<110r>

3 -rājñyāḥ] corr.; -rājñ̄āḥ ms. 21 buddhaiś] corr.; baddhaiś ms. 
[80] oṃ namaḥ śrī-bhagavatyai ārya-mahāśītavatyai || evaṃ mayā śrutam ekasmin samaye bhagavān rājag̣̣he viharati sma || śitavane mahaśmaśāne inghikāyatane || tatra rāhulo bhadrapālaḥ sarvagrahair vihețhamānaḥ bhagavataḥ pādau śirasā vanditvā rudann uvāca \| ihāhaṃ bhagavan sarvadușțagrahair vihețhitạ̣|

duḥkhito durbalas trāta rakṣaṇiyas tvayātra ca || iti śrutvā sa sambuddhạ̣ sugatam prāha rāhulam | gṛhāṇa dhārayemāṃ tvaṃ vidyāṃ śītavatīṃ varām || bhāṣayaṃ tvaṃ sadā svārthe parṣadāṃ ca hitāya te | asyāṃ bhāṣyamānāyāṃ dușțaughā vilayaṃ gatāḥ || tadyathā || añgā kalingā bhangā varanigā saṃsāratarañgā satyadañā bhañgā jesurā | ekacarā aravīrā taravīrā vihețhikā | tara 2 virā | kara vīrā kara 2 vīrā | indrā indrakisarā | haṃsa haṃsakisarā viśācikā cilimālā mahākiccā viheṭhikā | kālucchikā angādarā jayā jayālikhā palā vettoli cili hili kili sumati vasumati | culu națte 2 culu 2 națte culu nāḍi kulu nāḍi hāriț̣aki tarîțțaki kārīṭaki | gauri gandhāri caṇḍāi vetāli mātangi vacīsi dha<110v>raṇi dhāraṇi prajñāmānike taraṇi tāraṇi draștāmālike | kaca kācike | kaca kācice | karaṇāḍike kākalike lalamati rakșamati varāhakule | utpale vālākuli pālākuli manmate utpatte kara vïre kara 2 vïre | tara vīre tara 2 vïre | kuru vïre kuru 2 vïre | curu vīre curu 2 vīre | mahāvīre | ilamati varamati talamati rakșamati sarvārthasādhani paramārthasādhani | apratihate | indro rājā || yamo rājā || varuṇo rājā || kuvero rājā || kumbhāṇ̣̣o rājā || manasvī rājā || vāsukī rājā || yamadagni rājā || daṇụakī rājā || dhṛtarāștro rājā || virūḍhako rājā || virūpākṣo rājā || brahmā sahādhipatī rājā || buddho bhagavān dharmasvāmī rājā || anuttaralokānukampaka mama sarvasattvānāṃ ca rakṣāṃ karotu guptiṃ paritrāṇaṃ parigrahaṃ paripālanaṃ śāntisvastyayanaṃ daṇḍaparihāraṃ śastraparihāraṃ viṣadūṣanaṃ viṣanāśanam sīmābandham dharanībandham ca kurvantu jīvantu varṣaśatam paśyantu śaradāśatam \| tadyathā || ilā milā utpalā iramati varamati balamati kulumati halamati talamati kṣaṇamati rakṣamati 2 arumati ārumati | kuru 2 ma<111r>ti | huru mati | huru 2 phuru 2 dhara 2 khara 2 khuru 2 mati 2 bhūmicanḍe kālike | ahisaṃlāpite sāmalate hūle sthūle sthūlaśile jayasthūle | jaya națī tala nāțî || culu nāḍī vāgbandhani virohani | ālohite | aṇ̣are paṇḍare karālike nare keyūre ketumati bhūtaṃgame bhūtapati dhanye mangalye hiraṇyagarbhe mahābale mahābalābale kitamūle acalacaṇḍe dhurāparā jayalike jayagorohini | curu 2 huru 2 rundha 2 hara 2 khuru 2 khurumati svāhā || dhuraṃdhare | dhare 2 vidhare vimati vișkambhani nāśani vināśani bandhani mokṣaṇi vimokṣaṇi mocani vimocani mohani vimohani bhāvani vibhāvani sādhani śodhani viśodhani saṃkiraṇi sākiraṇi saṃchindani sādhu taramāṇe | tara 2 māṇe | hara 2 bandhumati | hiri 2 śiri 2 huru 2 pingale | 


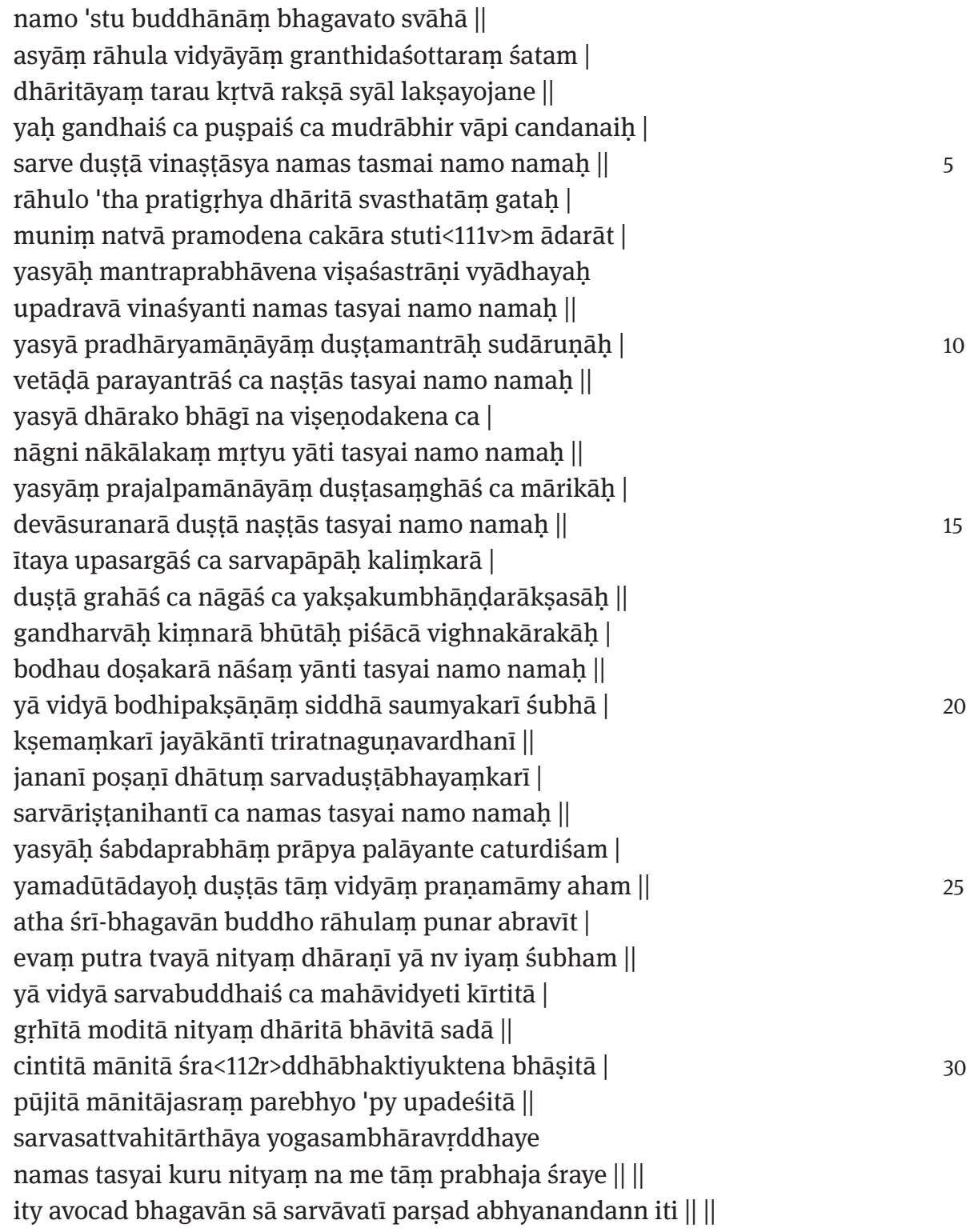


[81] oṃ namaḥ śrī-bhagavatyai ārya-mahāmantrānusāriṇyai || evạ̣ mayā śrutaṃ ekasmin samaye bhagavān vaiśālyāṃ mahānagaryāṃ viharati smāmrapālīvane | tatra bhagavān ānandam etad avocat || gacchānanda vaiśālyām indrakīle pādaṃ sthāpayitvemāni mahāmantrānusāriṇīmantrapadāni bhāṣasvemāṃ gāthāś ca gāthā ||

tadyathā || visarata visarata visarata visarata visarata || 5 || buddho lokānukampaka ājñāpayati | sarvabuddhānumatena | sarvapratyekabuddhānumatena | sarvāhārānumatena | sarvaśaikṣānumatena | sarvaśrāvakānumatena | sarvasatyavākyānumatena | pratyekabrahmānumatena | brahmānumatena | kāmeśvarānumatena | indrānumatena | devānumatena | 10 asurānumatena | asurendrānumatena | sarvāsurānumatena | asurapreșyānumatena | sarvabhūtānumatena || <112v> visarata visarata visarata visarata || 4 || buddho lokānukampaka ājñāpayati || muñcata muñcata muñcata muñcata || 4 || vidyā tiṣthantu iti vyupaśāmyatu | nirgacchata nirgacchata nirgacchata nirgacchata || 4 || buddhah praviśati mahādevo devātidevo devaguruh sendrakāyāś ca devāḥ sabrahmakāḥ saprajāpatayaś catvāraś ca lokapālāḥ praviśanti | anekāni ca devatāśatasahasrāṇi anekāni cāsurendraśatasahasrāṇi anekāni gandharvaśatasahasrāṇi ca pravekṣyanti | bahūni ca bhūtaśatasahasrāṇi bhagavato 'bhiprasannāni pravekṣyanti sarvasattvānām arthāya te vo mānartham kariṣyanti || nirgacchata nirgacchata nirgacchata nirgacchata || 4 || kṣipraṃ palāyata yadi yūyaṃ duṣtacittā na palāyata na paśyate | ye maitracittā narāparāddhukāmā rakṣām cānuvartitukāmās te tișṭhantu matạ̣ ca praviśantu buddho lokānukampaka àjñāpayati || tadyathā || sumu sumu sumu sumu || 4 || suru suru suru suru || 4 || sumuru sumuru sumuru sumuru || 4 || rusumu rusumu rusumu rusumu || 4 || phuru phuru phuru phuru || 4 || mu mu mu mu || 4 || praviśati | rusumu rusu<113r>mu rusumu rusumu || 4 || muru muru muru muru || 4 || miri miri miri miri miri miri miri || 7 || murumiri murumiri murumiri murumiri murumiri murumiri murumiri murumiri murumiri murumiri murumiri murumiri murumiri || 13 || mururīti mururīti mururīti mururīti mururīti mururīti || 6 || murureti murumirīti | riririririri || 6 || rīrīrīrīrīrī || 6 || ritti || miri miri miri miri || 5 || śiri 2 | mirīti 3 | hasi mimi rīti mirīci miri misi praviśati mimi haṃghākāraṃ haṃghārkiṃ karākara karākera kaṭā | kańkarā kańkarā kańkarā kan̉karā kan̉karā kan̉karā kan̉karā kan̉karā || kan̉kare | karīti kurīśe kan̉karī 2 | śati || riririririri || 6 || rīrīrīrī || 4 || rephasārī || phari phari phari phari phari phari phari || 7 || phapharā | anāthānāṃ nāthārithi pūri muci | anāthānāthā nirgacchata ripum nirgacchata palāyata ripum palāyata | yadi yūyaṃ duṣțacittā palāyata naśyata || buddho lokānukampaka evam ājñāpayati praviśati sarvasattvahitādhyā<113v>śayaḥ || maitrīvihārī karuṇāvihārī muditāvihārī upekșāvihārī || 
ete mantrapadāḥ siddhāḥ siddhagāthā jinoditāḥ | sarveșāṃ devatānāṃ hi bhūtānām ca hitaiṣiṇām || jñānenāthottamenādya tathā dharmatayāpi ca | jagatām ītayaḥ sarvā sāmyastv ārogyam astu vah || viśaktikā yasya tṛ̣ṇā vidhvastā viralīkṛtā|

śāntacitto hy anāyāsaḥ sarvaḥ svasti karișyati | yo jagat mokṣamārgesmi niveśayati nāyakaḥ | deśakaḥ sarvadharmāṇāṃ sarva svasti kariṣyati || gatir ya jagatām śāstā kṛtam yena sukhaṃ bahụ̣ | athārya sarvasattvānāṃ sarvaḥ svasti kariṣyati || yena sarvaṃ jagac caitan maitracittena tāyinā | pālitam putravan nityaṃ sarvaḥ svasti kariṣyati || gatir yaḥ sarvasattvānāṃ dvīpaś caiva parāyaṇam | saṃsāre vartamānānāṃ sarvạ̣ svasti kariṣyati || yaḥ sākṣāt sarvadharmāṇām avisaṃvādakaḥ śuci | śucivākyaḥ śuciṃkaraḥ sarvaḥ svasti kariṣyati || yasmiñ jāte mahāvīre samṛddhāḥ sarvasampadāḥ | siddhārthaḥ sarvasambhāraḥ sarvaḥ svasti kariṣyati || yasmiñ jāte mahī sāddhị̣ savaneyaṃ prakampitā | sarvasattvāḥ pramuditāḥ sarva svasti kariṣyati || ṣa ̣̣vikā<114r>ram pracalitā yasya bodhau vasuṃdharā | māraś ca durmanā āsīt sarvaḥ svasti kariṣyati || yaśa āsīn muner yasya dharmacakre pravartite | āryasatyāni vadatạ̣ sarvaḥ svasti karișyati || yena tīrthakarāḥ sarve jitā dharmeṇa tāritāh | vaśīkṛtāḥ sarvagaṇāḥ sarvaḥ svasti kariṣyati || svasti vaḥ kurutām buddhaḥ svasti devāḥ saśakrakāḥ| svasti sarvāṇi bhūtāni sarvakālaṃ diśantu vaḥ || buddhapuṇyānubhāvena devatānāṃ matena ca | yo yo 'rtha samabhipretah sarvārtho 'dya samṛddhyatām | svasti vo dvipade bhotu svasti vo 'stu catuṣpade || svasti vo vrajatām mārge svasti pratyāgateșu ca | svasti rātrau svasti divā svasti madhyaṃdine sthite \| sarvatra svasti vo bhontu mā caiṣām pāpam āgamat | sarve sattvāḥ sarve prāṇāḥ sarve bhūtāś ca kevalāḥ || sarve vai sukhinaḥ santu sarve santu nirāmayāḥ |

1 jinoditāḥ] corr.; jinojitāḥ ms. 3 -ottamenādya] corr.; -otamenādya ms. 7 jagat] pc.; gajat ac. 30 -pretah]] corr.; -prethah ms. 
sarve bhadrāṇi paśyantu mā kaścit pāpam āgamat || yānīha bhūtāni samāgatāni sthitāni bhūmāv athavāntarīkṣe | kurvantu maitrī satatam prajāsu divā ca rātrau ca carantu dharmam || ity ānandaḥ pratiśrutya gataś caivaṃ babhāṣa sạ̣ | tatra mantraprabhāvena śāntāḥ sarve 'pi vetayạ̣ ||

iti dṛṣțā mahānandaḥ pratyakṣaṃ buddhadharmatāṃ <114v> | pratyāgato muniṃ natvā tușțāva tadgunādritạ || bhagavan tvatprabhāvena sarvopadravināśitāḥ | sarvasattvā sukhādyaś ca svasti sarvatra sarvathā || evaṃ mahābalā vidyā yasyā duṣṭopasargitāḥ | vilayaṃ yānti pāpāś ca namas tasyai namo namạ̣ || yasyā mantraprabhāvena duṣțamārāś ca dāruṇạ̣̄ | naśyante ca grahārișțā namas tasyai namo namaḥ || tataḥ sambuddha ity āha mahāvidyeti kīrtitā | bhāṣitā sarvabuddhaiś ca gṛhītā moditā nv iyam || dhāritā vācitā nityaṃ parebhyo 'py upadeśitā | iyaṃ vidyā sadā dhāryā sarvasattvahitāśayaih || || ity avocad bhagavān sarvāvatī parṣad abhyanandann iti || ||

ārya-mahāmantrānusāriṇī-mahāvidyā-nāma-dhāraṇī parisamāptaḥ || ||

[82] oṃ namaḥ śrī-vasudhārāyai || tadyathā || oṃ sarvadușțapradușțānāṃ hūṃ hūṃ phaṭ vajreṇa sarvaduṣṭānāṃ śatrūṇām māraya 2 śoṣaya 2 stambhaya 2 bandhaya 2 hana 2 daha 2 paca 2 sarvaśatrūṇām nāśaya 2 hūm hūṃ phat 2 svāhā || oṃ kṣuṃ hūṃ || oṃ śrīdhane 2 dhanaiśvaryāsukham ānaya akṣayakoṣacintitotpādamanasi sādhani koṭe 2 koṭāvare koṭiśvarya anantāparyantasarvaratnasuvarṇavastrālaṃkārabharaṇe dhana<115r> dhānyavṛ̂ddhiṃkari cintitotpatti samohani śuklasye koṣakoṣṭhāgāradohani brhaspater mantram apaharani || buddhe 2 buddhasatye dharmasatye saṃhasatye sarvabodhisatye bodhiprāgbhārasatye sarvaśrāvakapratyekabuddhasatye brahmasatye viṣnusatye rudrasatye lokapālasatye dhanadasamājñākari hiraṇyasuvarṇamaṇimuktivajravaiḍūryaśan̉khaśilāpravāḍajātarūparajatamarakațapadmarāga-indranīlakarkețanasarvadravyaṃ samṛddhaya || catuḥṣașṭivīhisahasrāṇām ādhipatyaṃ kārayanti || ehy ehi bhagavati vajradharasāgaragambhīrabuddhasatye satyavādini || om cara 2 ciri 2 curu 2 huru 2 muru 2 lululululu | lelelelele || iṭi 2 niṭi 2 samsara 2 visara

23 -aiśvaryasukham] corr.; -aiśvaryāśuklam ms. 32 -sahasrāṇām ādhipatyaṃ] corr.; -sahasrāṇi samādhipatyaṃ ms. 
2 ihāgacchāgaccha bhagavati sādhakānāṃ mano icchāgamanaṃ paripūraya uttișțha vidyāḥ sarvabuddhā bhagavantạ̣ samājñāpayati svāhā| namas triyadhvikānām sarvatathāgatānām țili 2 țoli 2 iṭe 2 āgacchāgaccha bhagavatīye manorathaparipūraye daśabhyo digbhyaḥ yathodakadhārā paripūraya 2 yathā bhāskararaśminā vidhamayati tamạ̣ || yathā siîāmśunā āpyāyati || yathā mahauṣadhinā sarvaro<115v>gā nāśayati || dhanado varuṇaś caiva indro vaivasvatam tathā | manonugāmi cintayantu satatam sarvārtham prayacchadhvam || yathā me kāmā siddhir bhavatu na saṃsayaḥ || khaṭa 2 khiṭi 2 khuṭu 2 muru 2 muruṇụa 2 tarpari 2 dehi me dadāpaya svāhā || oṃ śrī-jambhalajalendrāya sarvadravyaṃ dehi māṃ dadāpaya svāhā || oṃ oṃ oṃ oṃ om | hūṃ hūṃ hūṃ hūṃ hūṃ | hrīṃ hrīṃ hrīṃ hrīṃ hrīm || rakṣa 2 mamārogyadhanaṃ dehi dadāpaya māṃ svāhā || ||

ārya-śrī-vasudhārā-nāma-dhāraṇī parisamāptaḥ || ||

[83] oṃ namaḥ śrī-sarvabuddhabodhisattvebhyaḥ || evaṃ mayā śrutam ekasmin samaye bhagavān deveșu trāyastrimśseṣu viharati sma || sudharmāyāṃ 15 devasabhāyāṃ mahatā bhikṣusamghena mahatā ca bodhisattvasaṃghena śakreṇa ca devānām indreṇa sārdham || tatra khalu bhagavān prajñapta evāsane niṣadya uṣnīṣavyavalokitam nāma samādhị̣ samāpadyate sma || samanantarasamāpannasya bhagavataḥ uṣṇīṣamadhyād imāni mantrapadāni niścaranti sma || namo bhagavate uṣnịịāya śuddhe viraje vimale svāhā || namo bhagavate apratihatoṣnīṣāya || namo buddhāya namo dharmāya namạ̣ saṃghāya || namaḥ saptānāṃ samyaksambuddhakoṭinām | namo <116r> maitreyapramukhānāṃ sarvabuddhabodhisattvānāṃ saśrāvakasaṃghānām || namo loke 'rhatām | namaḥ śrotāpannānām | namạ̣ sakṛdāgāminām | namo 'nāgāminām | namo loke samyaggatānām | namạ̣ samyakpratipannānām | namo devarṣịnām | namaḥ siddhavidyādhararṣiṇām | namạ̣ saāpāyudhānāṃ śāpānugrahasamarthānām | namaḥ sarvavidyādharāṇām | namo devāya brahmaṇe | namaḥ indrāya | namo bhagavate rudrāya umāpatisahitāya | namo varuṇāya | namo bhagavate nārāyaṇāya | mahāpañcamudrānamaskṛtāya | namo bhagavate nandikeśvaramahākālāya tripuranagaravidrāpaṇakarāya | adhimuktikakaśmīramahāśmaśānanivāsitāya | namo mātrgaṇasahitāya | namo bhagavate tathāgatakulasya | namo bhagavate padmakulasya | namo bhagavate vajrakulasya | namo bhagavate manikulasya | namo bhagavate gajakulasya | namo bhagavate karmakulasya | namo bhagavate ratnakulasya | namo bhagavate kumārakulasya | namo bhagavate

12 māṃ] pc.; om. ac. 28 bhagavate] pc.; bhagateva $a c$. 
nāgakulasya | namo bhagavate rāgakulasya | namo bhagavate dṛ̣hhaśūraraṇasenapraharaṇarājāya tathāgatāyārhate samyaksambuddhāya | namo bhagavate amitābhāya tathāgatāyārhate samyaksambu<116v>ddhāya | namo bhagavate akṣobhyāya tathāgatāyārhate samyaksambuddhāya | namo bhagavate vajradharasāgaragarjine tathāgatāyārhate samyaksambuddhāya | namo bhagavate bhaișajyaguruvaiḍūryaprabharājāya tathāgatāyārhate samyaksambuddhāya | namo bhagavate amoghasiddhaye tathāgatāyārhate samyaksambuddhāya | namo bhagavate supuṣpitasālendrarājāya tathāgatāyārhate samyaksambuddhāya | namo bhagavate padmottararājāya tathāgatāyārhate samyaksambuddāya | namo bhagavate vipaśyine tathāgatāyārhate samyaksambuddhāya | namo bhagavate śikhine tathāgatāyārhate samyaksambuddhāya | namo bhagavate viśvabhuve tathāgatāyārhate samyaksambuddhāya | namo bhagavate krakucchandāya tathāgatāyārhate samyaksambuddhāya | namo bhagavate kanakamunaye tathāgatāyārhate samyaksambuddhāya | namo bhagavate kāśyapāya tathāgatāyārhate samyaksambuddhāya | namo bhagavate śākyamunaye tathāgatāyārhate samyaksambuddhāya | namo bhagavate ratnacandrāya tathāgatāyārhate samyaksambuddhāya | namo bhagavate ratnaketurājāya tathāgatāyārhate samyaksambuddhāya | namo bhagavate samantabhadrāya tathāgatāyārhate samyaksambuddhāya $\mid<117$ r > namo bhagavate vairocanāya tathāgatāyārhate samyaksambuddhāya | namo bhagavate vikasitakamalotpalagandhaketurājāya tathāgatāyārhate samyaksambuddhāya || ebhyo namaskṛtvā imāṃ bhagavatīṃ sarvatathāgatoṣnịṣasitātapatrānāmāparājitām pratyaṅgirām pravakṣyāmi || sarvakalikalahavigrahavivādapraśamanīm | sarvabhūtagrahanivāraṇīṃ sarvaparavidyācchedanīm | akālamṛtyuparitrāyaṇīm sarvasattvabandhanamokșaṇīm | sarvadușțaduhsvapnanāśanīṃ yakṣarākṣasagrahāṇāṃ vidhvaṃsanakarīm | caturaśītīnāṃ grahasahasrāṇām vidhvaṃsanakarīm | aṣțāviṃśatīnāṃ nakṣatrāṇāṃ prasādanakarīṃ sarvaśatrunivāraṇīm | aștānām mahāgrahāṇām vidhvaṃsanakarīṃ ghoraduṣṭaduḥsvapnānāṃ ca vināśanīm | viṣaśastrāgnyudakotsāraṇīm | sarvadurgatibhayottāraṇīm | yāvadașțāvakālamaraṇaṃ paritrāṇakarīm | aparājitāṃ mahāghorāṃ mahātejāṃ mahācaṇḍ̄ṃ mahāśvetāṃ mahadīptāṃ̣ mahāmālāṃ mahājvālāṃ mahāpāṇụaravāsinīm \| ārya-tārā bhṛkutị̂́ caiva jayā ca vijayā tathā | sarvamāravihantī ca vajramāleti viśrutā ||

2 -śūraraṇa-] corr.; -śūraṇa- ms. 4 akșobhyāya] corr.; akṣobhyā ms. 30 mahāgrahāṇāṃ] corr.; mahāṇāṃ ms. 
padmā bhāvajacihnā ca mālā caivāparājitā |

vajratuṇ̣̂ī viśālī ca śāntā vaidehapūjitā ||

sau<117v>myarūpā mahāśvetā jvālā pāṇụaravāsinī |

ārya-tārā mahābalā aparā vajraśṛnkhalā caiva \|

vajrakaumārī kulaṃdharī ca vajrahastā vajravidyā kāñcanamālikā ||

kusumbharatnā caiva vairocanakulaprabhā |

tathāgatakuloṣṇīṣa viśrutā vidyumbhamānikā ||

vajrakanakaprabhāsa locanā vajratuṇụī ca |

śvetā ca kamalākṣi ca śrī buddhalocanīti ca \|

tathā vajraprabhā candrā tathā vajradharāpi ca|

vajramālā mahāmāyā devī ca kanakaprabhā ||

sulocanā ca śvetā ca kamalā kamalekṣaṇā |

vinītā śāntacittā ca ātmaguṇajñā śaśiprabhā ||

ityetā mahāmudrāgaṇāḥ samātṛgaṇāś ca sarvān rakṣāṃ kurvantu mama

sarvasattvānām ca || ||

om ṛṣigaṇapraśaste sarvatathāgatoṣnīṣasitātapatre hūṃ hūm hrīṃ șțrom

jambhani || hūṃ hūṃ hrīṃ șțroṃ stambhani | hūṃ hūṃ hrīṃ șțroṃ mohanakari

| hūṃ hūṃ hrīṃ șțrom paravidyāstambhanakari | hūṃ hūṃ hrīm șțroṃ

sarvaduṣțastambhanakari | hūṃ hūṃ hrīṃ șṭroṃ sarvavidyācchedanakari

| hūṃ hūṃ hrīṃ șțrom sarvaduṣṭānāṃ stambhanakari | hūṃ hūṃ hrīṃ

șṭroṃ sarvayakṣarākṣasagrahāṇāṃ vidhvaṃsanakari | hūṃ hūṃ hrīṃ

șṭroṃ caturaśītīnāṃ grahasahasrāṇāṃ vidhvaṃsanakari | hūṃ hūṃ hrīṃ

șṭrom aștāviṃśatīnāṃ nakṣatrāṇāṃ prasādanakari | hūṃ hūṃ hrīṃ șṭrom

aștā<118r>nāṃ mahāgrahāṇāṃ vidhvaṃsanakari | hūṃ hūṃ hrīṃ șțroṃ

rakṣa 2 māṃ sarvasattvāṃś ca || namo bhagavati tathāgatoṣṇīsasitātapatre

mahāpratyañgire mahāsahasrabhuje mahāsahasraśīrṣe koṭiśatasahasranetre

abhedye jvalitațaṃkāri mahāvajrodāre tribhuvanamaṇḍale || om svastir bhavatu

mama sarvasattvānāṃ ca rājabhayāt | caurabhayāt | agnibhayāt | udakabhayāt | viṣaśastrabhayāt | śatrubhayāt | paracakrabhayāt | durbhikṣabhayāt | aribhayāt | aśanibhayāt | akālamṛtyubhayāt | dharaṇīkampabhayāt | ulkāpātabhayāt

| rājadaṇụabhayāt | caṇụamṛabhayāt | nāgabhayāt | vidyudbhayāt |

taptavālukabhayāt | suparṇibhayāt | sarvetyupadravopasargopāyāsabhayāt

| grahabhayāt | devabhayāt | nāgabhayāt | yakṣabhayāt | rākṣasabhayāt

| gandharvabhayāt | asurabhayāt | garuḍabhayāt | kiṃnarabhayāt |

mahoragagrahāt | manuṣyagrahāt | amanuṣyagrahāt | bhūtagrahāt | pretagrahāt | piśācagrahāt | kumbhāṇḍagrahāt | pūtanagrahāt | kațapūtanagrahāt | skandagrahāt | unmādagrahāt | chāyāgrahāt | apasmāragrahāt | ostārakagrahāt

8 -kanaka-] corr.; -kana- ms. 37 skanda-] corr.; skandha- ms. 
| ḍākinīgrahāt | kaṭa<118v>ḍākinīgrahāt | revatīgrahāt | jāmakīgrahāt | śakunīgrahāt | mātṛnandigrahāt | lambikāgrahāt | śamikāgrahāt | ālambanagrahāt | kațavāsinīgrahāt | kațaṃkațakamālinīgrahāt | sarvagrahāt || ojohāriṇyāḥ | garbhāhāriṇyāḥ | rudhirāhāriṇyāḥ | vasāhāriṇyāḥ | māmsāhāriṇyāḥ | medāhāriṇyāḥ | majjāhāriṇyāḥ | jātāhāriṇyāh | jīvitāhāriṇyāḥ 5 | balyāhāriṇyāh | mālyāhāriṇyāḥ | gandhāhāriṇyāḥ | puṣpāhāriṇyāḥ | dhūpāhāriṇyāḥ | phalāhāriṇyāḥ | śasyāhāriṇyāḥ | āhutyāhāriṇyāḥ | pūyāhāriṇyāḥ | viṣțāhāriṇyāḥ | mūtrāhāriṇyāḥ | śleṣmāhāriṇyāḥ | khețāhāriṇyāḥ | siṃghānakāhāriṇyāḥ | vāntāhāriṇyāḥ | viriktāhāriṇyāḥ | aśucyāhāriṇyāḥ | spandanikāhāriṇyāḥ | vittāhāriṇyāh | cintāhāriṇyāḥ || eteṣāṃ sarveṣām sarvavidyāṃ chindayāmy asinā kīlayāmi vajreṇa | parivrājakakṛtāṃ vidyāṃ chindayāmi asinā kīlayāmi vajreṇa | ḍākaḍākinīkṛtāṃ vidyāṃ chindayāmy asinā kīlayāmi vajreṇa | brahmakṛtāṃ vidyāṃ chindayāmy asinā kīlayāmi vajreṇa | śakrakṛtāṃ vidyāṃ chindayāmy asinā kīlayāmi vajreṇa | nārāyaṇakṛtāṃ vidyāṃ <119r> chindayāmy asinā kīlayāmi vajreṇa | mahāpaśupatikṛtāṃ vidyāṃ chindayāmy asinā kīlayāmi vajreṇa | mahākālakṛtāṃ vidyāṃ chindayāmy asinā kīlayāmi vajreṇa | mātṛ̂āgaṇakṛtāṃ vidyāṃ chindayāmy asinā kīlayāmi vajreṇa | kāpālīkṛtāṃ vidyāṃ chindayāmy asinā kīlayāmi vajreṇa | śabarakṛtām vidyāṃ chindayāmy asinā kīlayāmi vajreṇa | pukkasīkṛtāṃ vidyāṃ chindayāmy asinā kīlayāmi vajreṇa | atharvaṇakṛtāṃ vidyāṃ chindayāmy asinā kīlayāmi vajrena | vajrakaumārīkṛtām vidyāṃ chindayāmy asinā kīlayāmi vajreṇa | yamārikṛtāṃ vidyāṃ chindayāmy asinā kīlayāmi vajreṇa | yamadūtakṛtāṃ vidyāṃ chindayāmy asinā kīlayāmi vajreṇa | krūranāgakṛtāṃ vidyāṃ chindayāmy asinā kīlayāmi vajreṇa | agnikarmakṛtām vidyāṃ chindayāmy asinā kīlayāmi vajreṇa | vināyakakṛtāṃ vidyāṃ chindayāmy asinā kīlayāmi vajreṇa | $\quad 25$ kumārakṛtāṃ vidyāṃ chindayāmy asinā kīlayāmi vajreṇa | caturmahārājakṛtāṃ vidyāṃ chindayāmy asinā kīlayāmi vajreṇa | caturbhaginīkṛtāṃ vidyāṃ chindayāmy asinā kīlayāmi vajreṇa | garuḍakṛtāṃ vidyāṃ chindayāmy asinā kīlayāmi vajreṇa | jayakaramadhuka<119v>rasiddhikarasarvārthasādhanakṛtām vidyāṃ chindayāmy asinā kīlayāmi vajreṇa |

bhṛngirīṭinandikeśvarakārttikeyacandrasūryagaṇapatisahāyakṛtāṃ vidyāṃ chindayāmy asinā kīlayāmi vajreṇa | nagnaśramaṇaḳ̂tam vidyāṃ chindayāmy asinā kīlayāmi vajreṇa | arhatkṛtāṃ vidyāṃ chindayāmy asinā kīlayāmi vajreṇa | avalokiteśvarakṛtāṃ vidyāṃ chindayāmy asinā kīlayāmi vajreṇa | vītarāgakṛtāṃ vidyāṃ chindayāmy asinā kīlayāmi vajreṇa |

vajrapāṇiguhyakādhipatikṛtāṃ vidyāṃ chindayāmy asinā kīlayāmi vajreṇa | yatrayatrakṛtām vidyāṃ chindayāmy asinā kīlayāmi vajreṇa | yena kāritā

24 chindayāmy] corr.; vindayāmy ms. 26 chindayāmy] corr.; vindayāmy ms. 
tasya kṛtāṃ vidyāṃ chindayāmy asinā kīlayāmi vajreṇa | muṇụśramaṇakṛtāṃ vidyāṃ chindayāmy asinā kīlayāmi vajreṇa | dūtadūtīcețacețîkṛtāṃ vidyāṃ chindayāmy asinā kīlayāmi vajreṇa | sarvarṣivarakṛtāṃ vidyāṃ chindayāmy asinā kīlayāmi vajreṇa | sarvadevagaṇakṛtāṃ vidyāṃ chindayāmy asinā kīlayāmi vajreṇa | sarvāhitaiṣipatikṛtāṃ vidyāṃ chindayāmy asinā kīlayāmi vajreṇa | oṃ bhagavati rakṣa 2 māṃ sarvasattvāṃś ca | sarvabhayebhyaḥ sarvopadravopasargopāyāsebhyaḥ sarvaduṣțapraduṣțān | sarvapratya<120r>mitrāhitaișiṇo vā tathāgatoṣṇiṣasitātapatre namo 'stu te || sarvabuddhanamaskṛte | asitānalārkaprabhāsphuṭavikasitasitātapatre om jvalala 2 dhaka 2 khāda 2 dara 2 vidara 2 chinda 2 bhinda 2 hūm hūm phaṭ 2 svāhā || sarvadușțān hūṃ hūṃ sarvadurlanghitebhyaḥ phaṭ | sarvadurlikhitebhyaḥ phaṭ | sarvaduśchāyebhyaḥ phaṭ | sarvadigbhyaḥ phaṭ | sarvadurbhuktebhyaḥ phaṭ | sarvaduścharditebhyaḥ phaṭ | sarvāvadhūtebhyạ̣ phaṭ | sarvaduṣkṛtebhyạ̣ phaṭ | sarvaduṣprekșitebhyạ̣ phaṭ | sarvajvalebhyạ̣ phaț | sarvāpasmārebhyaḥ phaṭ | sarvostārakebhyaḥ phaṭ | sarvaḍākinībhyaḥ phaț | sarvarevatībhyạ̣ phaț | sarvakațavāsinībhyaḥ phaṭ | sarvajāmakebhyaḥ phaț | sarvaśakunibhyaḥ phaț | sarvamātṛnandikebhyaḥ phaṭ | sarvagarebhyaḥ phaț | sarvavișebhyạ̣ phaț | sarvayogebhyạ̣ phaț | sarvālambakebhyaḥ phaṭ | sarvabhayebhyạ̣ phaṭ | sarvopadravebhyạ̣ phaṭ | sarvopasargopāyāsebhyạ̣ phaṭ | sarvottrāsebhyaḥ phạ̣ | sarvavyādhibhyạ̣ phaṭ | sarvaśramaṇebhyaḥ phat | sarvagrahebhyah phaț | sarvatīrthikebhyah phaț | sarvapratyarthikebhyah phaț | sarvapātakebhyaḥ phaṭ | sarvonmādebhyaḥ phaṭ | sarvavidyādharebhyạ̣ phaṭ | jayakaramadhukarasarvārthasādhake<120v>bhyaḥ phaṭ | sarvavidyācārebhyaḥ phaṭ | sarvavidyārājebhyaḥ phaṭ | sarvasādhakebhyo vidyācāryebhyạ̣ phaṭ | caturbhyo bhaginībhyaḥ phaṭ | vajrakaumārīye vidyārājñīye phaṭ | sarvavighnavināyakānāṃ phaṭ | paravidrāpaṇakarāya phaț | sarvāsurebhyaḥ phaț | sarvagaruḍebhyaḥ phaț | sarvamahoragebhyaḥ phaṭ | sarvamanuṣyāmanuṣyebhyạ̣ phaṭ | sarvamarutebhyaḥ phaṭ | sarvakumbhāṇḍebhyaḥ phạ̣ | vajraśṛnkhalāya mahāpratyañgirāya phaṭ | sarvopasargebhyạ̣ phaṭ | mahāpratyaṅgirebhyạ̣ phaṭ || chinda 2 phaṭ | bhinda 2 phaṭ | hūm 2 phaṭ | he 2 phaț | ho 2 phaṭ | amoghāya phat | apratihatāya phat | varadāya phaț | asuravidrāpaṇakarāya phaț | sarvadevebhyaḥ phat | sarvanāgebhyạ̣ phaṭ | sarvayakṣebhyaḥ phaṭ | sarvarākṣasebhyạ̣ phaṭ | sarvagandharvebhyạ̣ phaṭ | sarvakiṃnarebhyạ̣ phaṭ | sarvabhūtebhyaḥ phaț | sarvapretebhyaḥ phaț | sarvapiśācebhyaḥ phaṭ | sarvapūtanebhyạ̣ phaṭ | sarvakațapūtanebhyaḥ phat | sarvaskandebhyaḥ phaṭ | vajraśṛnkhalāya

8 -sitātapatre] corr.; -sitāpatre ms. 23 jaya-] $p c . ;$ jayaja- $a c$. 
mahāpratyañgirārājāya phaṭ | kālāya phaṭ | mahākālāya phaṭ | mātrọaṇebhyaḥ phaṭ | mahāmātṛaṇanamaskṛtāya phaṭ | vaiṣnavīye phaṭ | māheśvarīye phaṭ | brahmāṇīye pha<121r>ṭ | agnīye phaṭ | mahākālīye phaṭ | kāladaṇdịye phaṭ | aindrīye phaṭ | raudrīye phaṭ | cāmuṇḍiye phaț | vārāhīye phaṭ | mahāvārāhīye phaṭ | kālarātrīye phaṭ | rātrīye phaṭ | yamadaṇdịye phaṭ | kāpālīye phaṭ | mahākāpālīye phaṭ | kaumārīye phaț | yāmīye phaṭ | vāyavye phaṭ | nairṛtye phaṭ | vāruṇīye phaṭ | mārutīye phaț | saumyeye phaț | aiśānīye phaṭ | pukkasīye phaț | atharvaṇīye phaț | śabarīye phaț | kṛṣnaśabarīye phaṭ | yamadūtīye phaṭ | niśidivācarebhyạ̣ phaṭ | trisaṃdhyācarebhyaḥ phaṭ | dharaṇiye phaṭ | adhimuktikakāśmīramahāśmaśānanivāsinīye phaṭ | ebhyạ̣ sarvabhayebhyạ̣ phaṭ | sarvadoṣebhyaḥ phaṭ | oṃ șțrom bandha 2 dușțān | rakṣa 2 mām sarvasattvān svāhā || ye kecin mama sarvasattvāṃś ca dușțā dușțacittā raudrā raudracittāḥ | pāpāḥ pāpacittāḥ | kupitāḥ kupitacittāḥ | amitrā amitracittāḥ || te ete mama sarvasattvānāṃ ca rakṣām kurvantu jīvantu varṣaśatam paśyantu śaradāśatam | 15 ye kecid yakṣagrahāḥ | ojohārāḥ | garbhāhārā | rudhirāhārā | vasāhārā | māṃsāhārā | medāhārā | majjāhārā | jātāhārā | jīvitāhārā | balyāhārā | mālyāhārā | gandhāhārā | <121v> puṣpāhārā | dhūpāhārā | phalāhārā | āhutyāhārā | vittāhārā | cittāhārā | pūyāhārā | vișțāhārā | mutrāhārā| khețāhārā | śleșmāhārā | siṃhānakāhārā | viriktāhārā | aśucyāhārā | spandanikāhārā | pāpacittā duṣțacittā raudracittā devagrahā | nāgagrahā | yakṣagrahā | rākṣasagrahā | gandharvagrahā | asuragrahā | garuḍagrahā | kiṃnaragrahā | mahoragagrahā | manuṣyagrahā | amanuṣyagrahā | marutagrahā | pretagrahā | pisāācagrahā | bhūtagrahā | kumbhāṇụagrahā | pūtanagrahā | kațapūtanagrahā | skandagrahā | unmādagrahā | chāyāgrahā | apasmāragrahā | ostārakagrahā | ḍākinīgrahā | revatīgrahā | śamikāgrahā | jāmakagrahāḥ | śakunigrahā | mātṛnandigrahā | kambukāminīgrahā | alambanagrahā | kațaḍākinīgrahā | kațakamālinīgrahā | sarvagrahāḥ || jvarā ekāhikā dvaitīyakāḥ traitīyakāḥ cāturthakāḥ saptāhikāḥ ardhamāsikāḥ māsikāḥ dvaimāsikāḥ ardhadaivasikāḥ mauhūrtikāḥ nityajvarāḥ viṣamajvarāḥ bhūtajvarāḥ pretajvarāḥ piśācajvarāḥ mānuṣajvarāḥ amānuṣajvarāḥ vātikāḥ paittikāḥ śleṣmikāḥ sāṃnipātikāḥ śirovartim apanayantu mama sarvasattvā<122r>nām ca ardhāvabhedakam | ārocakam | akșirogaṃ nāsarogaṃ mukharogaṃ kaṇthharogam hṛdrogaṃ galagrahaṃ karṇaśūlaṃ dantaśūlam udaraśūlaṃ hṛdayaśūlam | marmaśūlaṃ pārśvaśūlam pṛșṭhaśūlam udaraśūlaṃ kațiśūlam vastiśūlam guḍasūlam yoniśūlam pradaraśūlam ūruśūlam jañghāśūlaṃ

1 -pratyangirārājāya] pc.; -pratyanggirāyarārājāya ac. 22 asura-] corr.; asuru- ms. 25 skanda-] corr.; skandha- ms. 29 dvai-] corr.; daiva- ms. 
hastaśūlaṃ pādaśūlam aṅgapratyañgaśūlaṃ mama cāpanayantu || bhūtapretavetāọaḍākinījvaradahrakạ̣ḍūkiṭibhakuṣṭhapittakaplīhabhagaṃdaralūtāpāmāvaisarpalohalingāśeșaśvāsatrāsakāsamūrcchāgaraviṣayogāgnyudakamāramārīkalahavairakāntārākālamṛty utryambukatrailāțakavṛścikasarpanakulasiṃhavyāghraṛkṣatarakṣucarmaramakaravṛkataskarājīvakāyikānām apanayantu | anyeșāṃ sarveșām sitātapatrāmahāvajroṣṇiṣamahāpratyaṅgirāvidyānubhāvena yāvad dvādaśayojanābhyantareṇa pañcaśatayojanābhyantareṇa vā vidyābandhanaṃ karomi | tejobandhanaṃ karomi | sarvavidyābandhanaṃ karomi | paravidyābandhanaṃ karomi | sīmābandham karomi dharạ̣ībandham karomi | daśadigbandhaṃ karomi | ākāśabandhanam karomi | parasainyastambhanaṃ karomi || tadyathā || om anale 2 khakhame 2 vīṣade $2<122 \mathrm{v}>$ vīre 2 saumye 2 sānte 2 dānte 2 vajradhare bandhabandhani vajrapāṇe phaṭ || oṃ hūm șțroṃ phat 2 svāhā | oṃ vajrapāśe bandha 2 vajrapāśena sarvadușțavighnavināyakān hūṃ phaṭ 2 rakṣa 2 māṃ sarvasattvāmśs ca svāhā ||

ya imāṃ sarvatathāgatoṣnīṣasitātapatrāṃ nāmāparājitām pratyañgirāṃ mahāvidyārājñīm likhitvā bhūrjapatre vastre vā valkale vā kāyagatạ̣ vā kaṇṭhagataṃ vā kṛtvā dhārayiṣyati vācayișyati | agnyudakaṃ na kramiṣyati | sarvakṛtyakarma na kramiṣyati | na garaṃ na kramiṣyati | yogam na kramișyati | nākālamṛtyunā kālaṃ kramiṣyati | sarvagrahāṇāṃ sarvavighnavināyakānāṃ ca priyo bhaviṣyati mana-āpaś caturaśītikalpakoṭisahasrāṇi jātau jātau jātismaro bhaviṣyati | caturaśītivajrakulakoṭiniyutaśatasahasrāṇi vidyādevatā nityam satatasamitam tasya rakṣāvaraṇaguptiṃ kariṣyanti | caturaśītivajradūtīkiṃkarā nityaṃ paripālayiṣyanti teșām api priyo bhaviṣyati | mana-āpaś ca na kadācid yakṣatvaṃ na rākṣasatvaṃ na bhūtatvaṃ na piśācatvam na pūtanatvaṃ na kațapūtanatvaṃ na manuṣyadāridryaṃ pratyanubhavișyati | gañgānadīvālikāsaṃkhyeyāprameyāṇāṃ buddhānāṃ bhagava<123r>tāṃ puṇyaskandhena samanvāgato bhaviṣyati || imāṃ ca sarvatathāgatoṣṇiṣasitātapatrāṃ nāmāparājitāṃ pratyañgirāṃ mahāvidyārājñīm dhārayamānah | abrahmacārī brahmacārī bhaviṣyati | amaunī maunī bhavișyati | aśuciḥ śucir bhavișyati | anupavāsī upavāsī bhaviṣyati | yo 'pi pañcānantaryakārī syāt so 'pi nirdhūtapāpo bhaviṣyati | pūrvakarmāvaraṇaṃ niravaśeșaṃ parikṣayaṃ gacchanti || yạ̣ kaścin mātṛgrāmaḥ | tathāgatoṣnịṣasitātapatrāṃ nāmāparājitāṃ mahāpratyañgirāṃ mahāvidyārājñīm dhārayamānaḥ | putrārthī putrạ̣ pratilabhate | āyuḥpuṇyabalam pratilabhate | itaś cyutvā sukhāvatyām lokadhātāv upapadyate | sa ca rāgadveșamohamānadarpavigato bhaviṣyati || yaḥ

3 -lūtā-] corr.; -lūtāka- ms. 4 -trailāṭaka-] corr.; -trailāṭuka- ms. 9 para-] pc.; parama- ac. 
kaścin manuṣyamāre gomāre paśumāre sarvetyupadravopasargopāyāse paracakrāgamaneșu tasya bhagavato 'jitasya samyaksambuddhasya sarvatathāgatoṣnīṣasitātapatrāṃ nāmāparājitām dhvajāgrāvaropitāṃ kṛtvā mahatā pūjāsatkāreṇa mahatīm pūjām kṛtvā sarvanagaradvāreṣu praveśayet | vihāre vā grāme vā nagare vā janapade vā nigame vā śmaśāne vā parvate vā araṇyāyata<123v>ne vā || imām aparājitāṃ pratyañgirāṃ vidyārājñīm mahatā satkāreṇa praveśayet | praveśitamātreṇa praśāntiḥ kṛtā bhaviṣyati || sarvetyupadravopasargopāyāsāḥ paracakrāṇi praśāmyanti | ananto nāgarājā śan̉khapālo nāgarājā mahākṛ̣ṇo nāgarājā nandopanandau nāgarājānau | anye ca sarve te nāgarājānaḥ kālena kālaṃ varṣayiṣyanti kālena kālam autsukyam āpatsyante | kālena kālaṃ garjayiṣyati | sarve rogopadravāś copaśamayiṣyanti || oṃ hūṃ șțroṃ bandha 2 sarvaduṣtān rakṣa 2 māṃ sattvāṃś ca svāhā || oṃ hūṃ șțroṃ bandha 2 duṣṭān rakṣa 2 māṃ sarvasattvāṃś ca vajrapāṇe hūṃ phaṭ svāhā || oṃ sarvatathāgatoṣṇiṣa anavalokitamūrdhni tejorāśi | oṃ jvala 2 khāda 2 dhaka 2 dara 2 vidara 2 chinda 2 bhinda 2 hūm 3 phaṭ 2 rakṣa 2 mām sarvasattvāṃś ca svāhā || om sarvatathāgatoṣnịṣasitātapatre hūṃ phaṭ | oṃ rakṣa 2 māṃ sarvasattvāṃś ca hūṃ phaṭ || tadyathā || oṃ anale 2 acale 2 khasame 2 vīre 2 saumye 2 sarvabuddhādhișṭānādhiṣthite sarvatathāgatoṣṇiṣasitātapatre sarvaduṣṭacittān hūṃ phaṭ svāhā || buddhayogena sarvopadraveṣu trijaptā kartavyā | sarvabuddhabodhisattvāś ca sadevamānuṣāsura<124r>garuḍakiṃnaramahoragagandharvaś ca loko bhagavato bhāṣitam abhyanandann iti || ||

ārya-sarvatathāgatoṣṇiṣasitātapatrā-nāmāparājitā-pratyañgirā-mahāvidyārājñīsamāptā || ||

[84] oṃ namo ratnatrayāya \|

tadyathā || oṃ țaki țaki guli gumuli sasa gugu țiṭi viciți huyu huruṭi svāhā || ayam bhagavan nāgaśapathạ̣ paścime kāle paścime samaye duṣțanāgāśaniatiṿ̛ștyanāvṛșțikālavṛșțivātameghāśaniśītavāyuvighnotpātakāle | ayạ̣ vidyādhareṇa uccasare vā parvate vā saptavārān pūrvāmukham uccasvareṇa uccārayitavyam || sarṣapam caturdiśam kṣeptavyaṃ sahakṣiptenoccāritamātreṇa sarvanāgānāṃ śarīrāṇi śatadhā viśīryeyuh vināśayeyur mā bhavanti || tatạ̣ śīghraṃ varṣadhārā-m-utș̣janti | bhagavatoktam ity evaṃ bhujagādhipate dhāraṇīyam iti || ||

iti sapane-vidyā-dhāraṇī samāptaḥ || ||

12 sattvāṃś] pc.; sarvattvāṃś ac. 27 -nāgāśani-] corr.; -nāgāsena ms. 28 ativṛșțy-] corr.; atikașța- ms. 31 viśīryeyuh] corr.; vișṛryeyuh ms. 
[85] oṃ namo bhagavatyai ārya-parṇaśavarītārāyai || namo ratnatrayāya || namo 'mitābhāya tathāgatāyārhate samyaksambuddhāya || namo āryāvalokiteśvarāya bodhisattvāya mahāsattvāya mahākāruṇikāya || namo mahā<124v>sthāmaprāptāya bodhisattvāya mahāsattvāya mahākāruṇikāya || vāmane tvāṃ namasyāmi tvāṃ namasyāmi vāmane || bhagavati piśāci parṇaśavari pāśaparaśudhāriṇi yāni kānicid bhayāny utpadyante | yāni kānicin mahāmāyā yā kācid ìtayā ye kecid upadravā | ye kecid upāyāsā ye kecid adhyātmikā bhayā ye kecid upadravā ye kecid upasargāḥ sambaddhā vā utpadyante | sarvāṇi tāni sarvās tāḥ sarve te bālata evotpadyante | tena paṇditas tad anena satyena satyavacanena satyavākyena | rjjaḥ rjjạ̣ 2 | ebhị̣ pạ̣ḍitādhișțhitair mantrapadaiḥ mama sarvasattvānāṃ ca rakṣāṃ kuru paritrāṇaṃ kuru parigrahaṃ kuru paripālanaṃ kuru 2 śāntisvastyayanaṃ kuru daṇḍaparihāraṃ kuru śastraparihāraṃ kuru viṣadūṣaṇaṃ kuru viṣanāśanaṃ kuru agniparihāraṃ kuru udakaparihāram kuru kākhordacchedanaṃ kuru sīmābandhaṃ kuru dharaṇībandham kuru \| tadyathā || om amṛte 2 amṛtodbhave amṛtasambhave aśvasthe aśvasthāge mā mara 2 mā sara 2 śama praśama upaśama sarvān upaśama sarvākālamṛtyūn upaśama sarvanakṣatradoṣān upaśama sarvadaṃștriṇā copaśama bhagavati piśāci parṇaśavari tunna 2 vi<125r>tunna 2 tunna 2 tumūle svāhā || om gauri gandhāri caṇụāli mātańgi pukkasi svāhā || oṃ an̉kure man̉kure prabhan̉kure parṇaśavari svāhā || oṃ namaḥ sarvaśavarāṇāṃ mahāśavarāṇāṃ bhagavati piśāci parṇaśavari svāhā || oṃ piśāci parṇaśavari hrīḥ hạ̣ hūṃ phaṭ piśāci svāhā || ||

ārya-parṇaśavarī-mahāmārīpraśamanī-nāma-dhāraṇī parisamāptaḥ || ||

[86] oṃ namo 'tītānāgatapratyutpannebhyo 'rhadbhyaḥ samyaksambuddhebhyaḥ || namo 'mitābhāya tathāgatāyārhate samyaksambuddhāya || tadyathā || oṃ mārīci 2 amṛtodbhave | buddhavati | buddhabhāṣite sarvadharmolkāprajvālani | buddhi 2 mahābuddhi | vīre mahāvīravati | vegavati | garuḍavegavati | indravajravegavati | buddhāvalokite | muni 2 namo mahāmuni hūm phaṭ buddhadharmasaṃghabale sarvayakṣarākṣasapiśācakumbhāṇḍapūtanakaṭapūtanasarvagrahavetāọān anyāś ca dușțacittān bandha 2 kara 2 gṛhṇa 2 grasa 2 māra 2 bhañja 2 daha

7 ìtayā] corr.; īnayā ms. 23 haḥ] pc.; hahaḥ ac. 25 nāma] pc.; manā ac. 26 'rhadbhyaḥ] corr.; 'rhabhyah ms. 
2 paca 2 matha 2 sarvabuddhānām balena nāśaya 2 chinda 2 bhinda 2 turu 2 vidrāpaya 2 sarvaśatrūn sarvarākṣasādīnāṃ manuṣyāmanuṣyān vara 2 bandha 2 saṃkoca nikoca | sphoțaya 2 garja 2 tarja $2<125 \mathrm{v}>$ hana 2 sarvaśatrūn sarvaparamantrān sarvaparaprayogān hana 2 sarvarogān rakṣa 2 mama sarvasattvāṃś ca sarvopadravopasargopāyāsebhyaḥ svāhā ||

śikhāṃ vāndhakṛte sarvayakṣarākṣasapiśācādayo yojanaśataṃ prapalāyante | ekavāram apy udāhṛtena saparivārasya rakșām kurute yojanaśatasahasrāṇy api | paṭitamātreṇa sarvayakṣarākṣasādīnām bandhayanti | sarvajanasya priyo bhavati | dine dine śatavārān uccārayet ślokatrayaṃ gṛhṇāti | añjanābhisambhya akṣiṇim añjayet krodhābhibhūto 'pi nayāna paśyati te priyo bhavati | dvilakșajāpena sarvarogān prahīyate | dhāritamātreṇa jātismaro bhavati | tailam ekavāram parijapya śiro mrakṣayet śirovartim apanayati | bahuvidhān bhagaṃdarādīn nāśayati | marīcaguṭikāṃ dvau vārau parijapya nagarādi praviśet yad icchati tal labhate || ||

ārya-hemāṅgā-nāma-dhāraṇī parisamāptaḥ || ||

[87] oṃ namaḥ śrī-bhagavate ārya-maitreyabodhisattvāya || namo bhagavate sākyamunaye tathāgatāyārhate samyaksambuddhāya || namo maitreyāya bodhisattvāya mahāsattvāya mahākāruṇikāya | <126r >

tadyathā || om ajite 2 ajitamjaye | hara 2 mahāmaitrāvalokite | kara 2 mahāsamayasiddhi | bhara 2 mahābodhimaṇụavije | smara 2 asmākaṃ samayasiddhi | bodhi 2 mahābodhi svāhā || oṃ mohi 2 mahāmohi svāhā || mati 2 smare svāhā ||

asyā dhāraṇyāḥ prabhāvena śravaṇamātreṇa

dhāraṇavācanapaṭanasvādhyāyanacintanabhāvanamātreṇa yadā 'sau samyaksambuddhah bodhir abhisambhotsyate || tadāvaśyam mayā sattvā gaveșayitavyā || vyākaraṇaṃ kuryād anuttarāyāṃ samyaksambodhau || ataḥ tiryagyonigatānām api mṛgapakṣigaṇānām karṇapuṭe nipatiṣyati | te 'nuttarāyām samyaksambodhau vyākaraṇam labhyate || asyāḥ śravaṇamātreṇa kadācid apāyagāmino bhavișyanti na cāpāyamalena lipyante || na ca mātụ kukṣāv upapadyante | divyakalpasahasre rājā cakravartir bhavișyati | daśakuśalakarmapathasamanvāgatā bhavișyanti || yathaucitāḥ prārthitā bhogā siddhyanti || na ca mayā bhagavan sarvasattvā vismartavyā | avaśyaṃ mayā

5 -sattvāṃś] $p c$; -sattvāṃnāś ac. 13 parijapya] corr.; parikṣupya ms. 15 hemāngā] pc.; hemāngāthā ac. 17 maitreyāya] corr.; maitrīyāya ms. 25 abhisambhotsyate] corr.; abhisaṃsyāt ms. 30 -sahasre] corr.; -sahas ms. 
bodhimaṇḍaniṣaṇṇena sattvā vyākaraṇa kartavyā || sadbhūyām anuttarāyāṃ samyaksambodhau ceti || ||

ārya-maitreyapratijñā-nāma-dhāraṇī samāptaḥ <126v> || ||

[88] om namo buddhāya \|

yāvatī prathamā koțyaḥ saṃsārasyāntavarjitāḥ |

tāvat sattvahitārthāya cariṣyāmi tāṃ carīm ||

utpādayāmi sambodhau cittaṃ nāthayaśaṃ sukham |

nimantrayeyaṃ jagat sarvam dāridrān mocito 'smi tat ||

vyāpādakhilacittaṃ me īrṣyāmātsaryam eva vā |

nādhyāgreṇa kariṣyāmi bodhi prāpsyāmi yāvatā ||

brahmacaryaṃ cariṣyāmi kāmāṃs tyakṣyāmi pāpakān |

buddhānām anuśikṣiṣyo śīlasaṃvarasaṃyame ||

nāhaṃ tvaritarūpena bodhi prāpnoti notsahe |

aparāntakoṭiṃ sthāsyāmi bodhisattvasya kāraṇā tu \|

kṣetram viśodhayiṣyāmi aprameyam acintayam |

nāmadheyaṃ kariṣyāmi daśadikṣu ca viśrutam ||

kāyavākkarmani cāhaṃ śodhayișyāmi sarvaśạ̣ |

śodhayiṣyam enam karmam kartavye 'smin śubhaṃkaram || ||

iti mañjughoṣakṛti-praṇidhāna-rāja samāptah || ||

[89] oṃ namo bhagavatyai ārya-tārāyai || namo ratnatrayāya || namaḥ śrī-

āryāvalokiteśvarāya bodhisattvāya mahāsattvāya mahākāruṇikāya ||

tadyathā || oṃ tāre tutāre ture svāhā || sarvaduṣțānām mama kṛte jambhaya stambhaya mohaya bandhaya vidhvaṃsaya hūm 3 phaṭ 3 svā<127r $>$ hā ||

sarvaduṣtastambhani tāre svāhā ||

tadyathā || oṃ tāre tāraye hūṃ 3 samayasthite bhara 2 sarvābharaṇavibhūṣite padmani padmamahāpadmāsanasthite hasa 2 trailokyavarade

sarvadevatādānapūjite smarahi bhagavate tāre smarahi bhagavān tathāgatasya purata samayam dhara 2 mahāsattvāvalokite maṇikanakavicitrābharạ̣e oṃ vilokaya bhagavati tāre hrīṃ hrīṃ hrīṃ phaṭ svāhā || ||

ārya-tārāpratijñā-nāma-dhāraṇī samāptaḥ || ||

11 kāmāṃs] corr.; kāyāt ms. • tyakṣyāmi] corr.; svabhyașyāmi ms. 26 -mahāpadmāsanasthite] corr.; -mapadmāsanisthite ms. 27 -pūjite] corr.; -pūji ms. 
[90] oṃ namah śrī-sarvabuddhabodhisattvebhyah || namo bhagavate sasarvamārabalapramathanāya tathāgatāyārhate samyaksambuddhāya || namo bhagavatyai ārya-dhvajāgrakeyūrāyai || evaṃ mayā śrutam ekasmin samaye bhagavān deveșu trāyastriṃśeșu viharati sma || pāṇ ḍakambalaśilāyām || atha khalu śakro devānām indro vemacitreṇāsurendreṇa jitaḥ satvaraṃ tvaramāṇo yena bhagavāṃs tenopasaṃkrāntopasaṃkramya bhagavantam idam avocat || ihāhaṃ bhagavan vemacitreṇāsurendreṇa jitah parājito devās trāyastrimśáś ca jitāḥ parājitās tatrāsmābhir bhagavan kathaṃ pratipattavyam || bhagavān āha || udgṛhāṇa devendra dhvajāgrakeyūrāṃ nāma dhā<127v>raṇīm aparājitām || mayā pūrvaṃ bodhisattvabhūtenāparājitadhvajasya tathāgatasyāntikād udg̣̣hya parebhyo vistareṇa samprakāśitā | tato nābhijānāmi vāgbhayavāksambhavā | romaharṣaṇanimittaṃ vā || antaśas tatkṣaṇikām asti kāyapị̣̂ā vā || tat katamā sā bhagavan || bhagavān dhvajāgrakeyūrāṃ nāma dhāraṇīm aparājitā hṛdayaṃ bhāṣante sma || || tadyathā || oṃ namo ratnatrayāya || oṃ namo dhvajāgrakeyūre jaya 2 vijaya 2 jayavāhani śaṃkari prabhaṃkari prabhañjani bhañjaya 2 stambhaya 2 mohaya 2 bhagavati jayavāhani jayottari matha 2 pramatha 2 hasa 2 grasa 2 hūm 2 he 2 laghu 2 lambodari trinetre caturvaktre caturdaṃțtre asimusalacakratriśūlavajrakavacamudrādhāraṇi rakṣa 2 māṃ sarvasattvāṃś ca bhagavati sarvopadravopasargebhyah \|| om bhagavati hana 2 daha 2 paca 2 matha 2 pramatha 2 dhana 2 vidhuna 2 hūm 2 phat 2 sphoțaya 2 bhañjaya 2 vidhvaṃsaya 2 mama sarvaśatrūn kruța 2 tṛța 2 ulkāmukhi ulkādhāriṇi trailokyamathani vidhvaṃsaya 2 mama śatrūṇāṃ sainyān | rakṣa 2 māṃ sarvasattvāṃś ca sarvopadravebhyah | cala 2 cili 2 curu 2 kala 2 kili 2 kulu 2 muñca 2 aț̣atț̣a $<128 \mathrm{r}>$ hāsa vidhvaṃsaya mama śatrusainyān trāsaya 2 bhrāmaya 2 buddhasatyena dharmasatyena saṃghasatyena satyavādisatyena satyavādi nitya mātikramatha buddhadharmasaṃghasatya mātikramatha satyavādisatya mātikramatha | lambodari kuṭa 2 kuțāpaya 2 rudram ānaya 2 viṣnum ānaya 2 candrasūryam ānaya 2 trailokyādhipatim ānaya 2 sarvadevām ānaya 2 sarvayakṣarākṣasakumbhāṇdamahoragādīn ānaya 2 vidhvaṃsaya 2 mama sarvaśatrusainyān | māṃ sarvasattvāṃś ca rakṣa 2 rakṣāpaya 2 ran̉ga 2 rañgāpaya 2 kulu 2 culu 2 puṣpamālini rundha 2 rṭi 2 ciṭi 2 viṭi 2 bhṛkuțīmukhaparasainyakulonmādanakari hala 2 hili 2 hulu 2 dhvaṃ 2 he 2 riṇa 2 mati jambudhvaje buddhavilokite rakṣa 2 māṃ sarvasattvāṃś cemaṃ sthānaṃ ca sarvatathāgatāvalokite svāhā || guṇarājaprabhāsottame svāhā || candrārkavimale svāhā || sarvagrahanakṣatre dhyāmīkaraṇi svāhā || rakṣa 2 māṃ sarvasattvāṃś cemaṃ sthānaṃ sarvabhayebhyaḥ svāhā ||

11 nābhijānāmi] $p c$; bhinājānāmi $a c .12$-nimittaṃ] $p c$.; -minittaṃ $a c$. 
iyaṃ sā devendra dhvajāgrakeyūrā-nāma-dhāriṇī aparājitā | yatra kvacid yuddhe vā kalahe vā vivāde vā vigrahe vā yena paṭhișyate sa sarvatra jayo bhaviṣyati | dhva<128v>jāgre vā kaṇṭhe vā baddhvā dhārayitavyā | manuṣyarājaśūrapuruṣāṇāṃ sarveșāṃ rakṣām karoti | strīrūpadhāriṇī bhūtvā purataḥ sthitvā 'bhayaṃ dadāti | śatrusainyaṃ vidrāpayati māñgalyaṃ

pavitram pāpanāśanam śrī-lakṣmī samsthāpitā bhaviṣyati || || idam avocad bhagavān āttamanās te śakro devendraḥ sarvāvatī parṣad bhagavato bhāṣitam abhyanandann iti || ||

ārya-dhvajāgrakeyūrā-nāma-dhāraṇī parisamāptāḥ || ||

[91] oṃ namo bhagavatyai ārya-mahāmāyāvijayavāhinyai || evaṃ mayā śrutam ekasmin samaye bhagavān vaiśravaṇapuryāṃ suvarṇaśṛnge parvataśikhare viharati sma || anekaiś ca devanāgayakṣagandharvāsuragaruḍakiṃnaramahoragavidyādharāpsarādibhị̣ stūyamāno dharmālokamukhaṃ nāma dharmaparyāyạ̣ deśayām āsa || atha nārāyaṇo 'surair jitaḥ parājitaḥ satrastạ̣ tejobalahīno yena bhagavāṃs tenopasaṃkāntạ̣ | upasaṃkramya bhagavatạ̣ pādau śirasābhivandyaikānte niṣaṇṇạ̣ san evam āha || sarvajño 'si bhagavan sarvadarśī sarvasattvānukampakaḥ tad deśayatu bhagavān dharmaparyāyam | yena devā nāgā yakṣā rākṣasādayo manuṣyā vā mahati śa<129r>strasampāte saṃgāme vā upadravena vā vivāde vā sarvavijayino bhaviṣyanti || bhagavān āha || kim atra nārāyaṇo bhīto 'si māyādharas tvaṃ nārāyaṇa māyāvī tvaṃ mahābalo 'si | anekamāyājālena sattvān vihețhayasi | saṃgrāme vijayapraśnaṃ paripṛcchasi || nārāyaṇa evam āha || iha bhagavan kāmāsurendreṇāsuramāyājito 'hạ̣ mṛtāś ca devāḥ kecit palāyitāḥ | kecid vidhvaṃsitāḥ tad deśayatu bhagavān dharmaparyāyam | yena sattvā saṃrāme vijayino bhaviṣyati || asurān parājayișyati hīyamāno darpā asurā bhavișyati || bhagavān āha || bhūtapūrvaṃ nārāyaṇa atīte 'dhvani magadhārohirake parvate ratnaśrīr nāma rājā babhūva | tena kālena tena samayena viśveśvaro nāma tathāgato 'rhan samyaksambuddho vidyācaraṇasampannạ̣ sugato lokavid anuttaraḥ puruṣadamyasārathị̣ śāstā devānāṃ ca manuṣyānāṃ ca buddho bhagavān babhūva || tasya bhagavato viśveśvarasya sakāśāt | mayā imāni mahāmāyāvijayavāhiṇī-nāmavidyāmantrapadāni udg̣̣hītāni dhāritāni vācitāni paryavāptāni anumoditāni parebhyaś ca vistareṇa samprakāśitāni || asyā dhāraṇyā <129v> prabhāvena

3 dhārayitavyā] corr.; rayitavyā ms. 7 parșad] corr.; parșa ms. • bhagavato] pc.; bhagatova ac. 19 śastrasampāte] corr.; śastrampāte ms. 24 vidhvaṃsitāḥ] corr.; vidhvaṃsitāḥtāḥ ms. 
nārayaṇa na kvacic chatrubhayaṃ na vinipātabhayaṃ na caurabhayaṃ cotpannaṃ bhavati | varșaśatasahasrāṇi dharmeṇa rājyạ̣ kārayitvā paścāt sukhena nagarān nagarāntaram udyānayātrām iva dhāraṇyāḥ prabhāvena yāti | jātiparivṛtye māndhātā nāma bodhisattvaś cakravartī rājā babhūva | saptaratnasamanvāgatạ̣ | ājñāyā sakalatrailokyam ājñāpitavān || pūrvaṃ dānapāramitānisyandena sarvasattvān yathābhilașitenopakaraṇena vasudhārām yāti bhagavān | sarvasattvāḥ sukhinạ̣ sarvopakaraṇasamṛddhā babhūva || tadyathā nārāyaṇa asyā dhāraṇyāḥ prabhāvenānekakalpaśatāni dānapāramitāsambhāra paripūritavān || ye ca devanāgayakṣagandharvāsuragaruḍakiṃnaramahoragavidyādharamanuṣyāmanuṣyājñākarās tișṭhanti | na ca te pratipakṣam udvahanti catuḥ̣așțikalpasahasrāṇi prāviṣkṛtya paśyad vainateyabhayān nāgān mukhe sthāpayitvā ekajanmani anuttarāṃ samyaksambuddho 'haṃ loke 'nuttaro devaguru sambhūtaḥ | te nārāyaṇa gṛhṇatāṃ mahāmāyāvijayavāhinī-nāma-dhāraṇīmantrapadāni || || tadyathā || namas tryadhvānugatapratișțhitebhyạ̣ <130r> sarvabuddhabodhisattvebhyaḥ sarvamudrāmantrapadebhyah || om māye mahāmāye mahāmāyādhāraṇi iyaṃ sā mahāmāyātantreṇa mahāmāyārūpeṇa bhrama 2 mama sarvasattvānāṃ ca ye virūpakạ̣ cintayanti sarvaduṣțasattvās tān bhrāmaya 2 mohaya 2 mūrcchāpaya 2 māraya 2 vidhvaṃsaya 2 mara 2 mahāmāye alalalale mahāmāyāsahasramukhi sahasraśire sahasrabhuje jvalitanetre sarvatathāgatahṛdayagarbhe asidhanuḥparaśupāśatomarakanayaśaktinụmuṇ̣̣haste mudgaracakrahaste | ehehi bhagavati sarvatathāgatasatyena devarșigaṇasatyena mahāmāyāvijayavāhini smara 2 sarvatathāgatajñānarūpeṇāgaccha 2 sarvāvaraṇakṣayaṃkari parasainyavidrāvaṇi mohaya 2 mama sarvasattvānāṃ ca sarvaduṣtān rakṣa 2 māṃ sarvasattvāgre sarvabhayopadravebhyah svāhā || mahāmāyādhāraṇiye svāhā || oṃ mahāmaṇḍalādhișṭhānādhiṣthite svāhā || oṃ vajradharavanditapūjitāye svāhā || oṃ padmapāṇipriyāya svāhā || oṃ sarvadevanamaskṛte svāhā | oṃ mātṛanạavanditapūjitāye namạ̣ svāhā || oṃ jaye svāhā || oṃ vijaye svāhā || oṃ svāhā || oṃ avidhite svāhā || oṃ aparājite svāhā || oṃ mohanīye svāhā || oṃ jambhanīye svāhā || oṃ ja<130v>yantīye svāhā || om bhramaṇiye svāhā || om bhrāmaṇīye svāhā || oṃ sarvāsuradamanìye svāhā || oṃ mahākālavanditapūjitāye svāhā || oṃ kāmarūpiṇiye svāhā || oṃ māyārākṣasīye svāhā || oṃ ra 2 svāhā || oṃ ru 2 hūṃ 2 phaṭ he jarśaye māyābhagavati mahāmāyāvijayavāhini mā vilambasva mama sarvasattvānāṃ ca sarvakāryaṃ kuru 2 hūṃ 2 phaṭ 2 svāhā || ||

1 na vinipātabhayaṃ] corr.; na vinipātabhayaṃ na vinipātabhayaṃ ms. 22 nụmuṇ̣ii-] corr.; nuṣuṇịī- ms. 25 parasainya-] corr.; paramairanyai- ms. 30 aparājite] pc.; a-aparājite $a c$. 
imāni nārāyaṇa mahāmāyāvijayavāhinī-nāma-dhāraṇīmantrapadāni dhāraya vācaya parebhyaś ca vistareṇa samprakāśayati || ||

iti śrī-mahāmāyāvijayavāhinī-nāma-dhāraṇī parisamāptaḥ || ||

[92] om namo ratnatrayāya \|

tadyathā || oṃ ili mitte tili mitte ili tili mitte dumbe dumbālīye dusme dusmālìye 5 tarkāraṇe marme marmaraṇe kaśmīre kaśmīramukte aghe aghane aghanāghane ili milīye askāpiye appāpiye śvete śvetatuṇḍe anantarakṣe svāhā || oṃ asijihve śūlajihve vajrakāyāgrama 2 jvala 2 mahājvāle mahāyogeśvari hūṃ phaṭ svāhā || || om namo mārīcyai \||

sattvaparyañkato dhīmān ālambitamahākṛtaḥ|

prātạ̣ sāyaṃ ca hṛccandra sitauṃkāreṇa bhāvayet ||

vairocanākhyām ātmā<131r>naṃ tatkaraiḥ sarvatạ̣ sitam |

prākāraṃ vartulaṃ caitya bhūṣitordhva jvalatprabhā ||

rakṣārtham puratah paścāt savyavāme 'tha mūrdhani |

kramān mātrādisādi mārādisasutādi ca ||

pratimāpețakalyāṇamitrapustādisambhavāt |

tato hṛccandragāṃ pītam āmaśokacchaṭodbhavām ||

cintayed ārya-mārīcīm sūcīsūtradharārūộhām |

utthānābhinayī savya nāsārandhreṇa tām purạ̣ ||

saṃsthāpya syūtanetrāsya duṣțān prākārato bahị̣ |

kurvāṇām asakṛnnaddha bodhyañgīdhārạ̣ị̣ paṭhet ||

tata oṃ ādi mārīcyai svāhā mantro yathābalaṃ |

japyo 'tha mantravid vāmarandhrena tām hṛdi ||

praveśyāśokakāntā syād raśmijaiḥ pītaśūkaraị̣ |

bahị sampișța taddușțaih kurvāṇo sīmabandhanam ||

hemābhaśūkarārūụhāṃ taptakāñcanabhāsurām |

līlayordhvasthitām candre viśvāmbhoruhasaṃśraye ||

aśokavṛkṣaśākhāgra vilagnāṃ vāmapāṇinā |

bibhratīṃ varadākāram dakṣiṇaṃ karapallavām |

dīptaratnopaśobhena maulināṃ buddhaśekharām |

śvetavastrāṃ namasyāmi mārīcīm abhayapradām || ||

ārya-mārīcī-nāma-dhāraṇī samāptah || ||

14 mūrdhani] corr.; mūrdhnani ms. 19 nāsā-] corr.; nāraso- ms. 21 -dhāraṇīṃ] corr.; -ddhāraṇịm ms. 24 praveśyāśokakāntā] corr.; braveśyāśokakāntā ms. 25 kurvāṇo] corr.; kuvāmā ms. 27 līlayordhva-] corr.; līlayoddha- ms. 
[93] om namo bhagavatyai vajrasarasvatyai || caturvajrakrameṇa sādhanaṃ likhyate || pūrvavat || aṃkāraṃ <131v> dhyātvā hṛccandre pāpadeśanādiśūnyatābodhiparyantaṃ paṃkārajaśvetābjendau | abījāt spharaṇādinā sambhūtāṃ sitavarṇāṃ manoramām | dakṣiṇe raktāmbujadhāriṇīm | vāmena prajñāpāramitāpustakadhāriṇīm | vajrasamājamudrayā || oṃ vajrasamāja jạ̣ jaḥ jñānasattvapraveśādipūrvakaṃ prajñāpāramitāṃ vajraparyañkasamāsīnāṃ bhāvayet | tasyā hṛdaye candrastham akāraṃ dhyātvā spharạ̣asaṃharaṇakrameṇa mantrạ̣ japet || oṃ picu 2 prajñāvardhani | jvala 2 medhāvardhani | dhiri 2 buddhivardhani svāhā || pradīpapañktim iva jvalantīm mukhān nirgatya nābhimaṇụalam praviśantīm vicintya || evam anyeșām drașțavyam | tathā coktam || prathamaṃ śūnyatāṃ bauddhị̣ dvitīyaṃ bījasaṃyutam | tṛtīyaṃ bimbaniṣpattim caturthaṃ māsam akṣaram || ||

ārya-vajrasarasvatī-sādhanaṃ parisamāptaḥ || ||

[94] oṃ namaḥ śrī-mahāsarasvatyai || pūrvoktavidhānena śūnyatāṃ yāvad abhimukhīkṛtyādhișṭhāya vā sitakamalasaptahastapramāṇaṃ tadupari śaśimaṇḍalaṃ tanmadhye hrīḥāraṃ śuklaṃ tena sitakamalaṃ svabījagarbham bhāvayet | tena ca bhagavatīm mahāsarasvatīm anucintayet | śaradindukalākārām sitakamalopari candramaṇḍalasthām | dakṣiṇakare va<132r>radām | vāmena sanālasitasarojadharām | smeramukhīm atikaruṇāmayām śvetacandanakusumavasanadharām | muktāhāropaśobhitahṛdayām | nānāratnālaṃkāravatīm | dvādaśavarṣākṛtị̣ muditakucamukuladanturorastațīm | spharadanantagabhastivyūhāvabhāsitalokatrayām | tatas tatpurato bhagavatīṃ prajñām | dakṣiṇato medhām | paścimato matim | vāmataḥ smṛtim | etāḥ svanāyikāsamānavarṇādikāḥ | sammukham avasthitāś cintanīyāḥ | tatạ̣ svanābhipradeśe candramaṇḍale sitam āṃkāram dhyātvā tato niścarantīm aśeṣavāṅmayamālāvacchinnapravāhāṃ vicintayan mantram āvartayet || tatrāyaṃ mantraḥ | oṃ hrịḥ̣ mahāmāyāngamahāsarasvatyai namạ̣ || evaṃ poṣadhiko bhūtvā maunād avatiṣthan | nirantaraṃ devatāhaṃkāram udvahan mantram apy āvartayann ananyakarmā māsena sārasvatīṃ vāṇīm labhate | māsatrayeṇa brahmaghnāpi sidhyatīti ||

12 dvitīyaṃ] corr.; dvitīyayam ms. 15 mahā-] pc.; vajramahā- ac. 17 -madhye] corr.; -madhyadhya ms. 23 -danturorastațīm] corr.; -dantarorastațīm ms. -ananta-] corr.; -antams. 28 -cchinnapravāhāṃ] corr.; -schinnapravāhāṃ ms 29 -sarasvatyai] corr.; -svarasvatyai ms. 
atha bhaișajyam ucyate \| ajākṣirābhayāvyoṣapāṭhogrāsigrusaindhavaiḥ | siddham sārasvataṃ sarpị̣ pacet saptābhimantritam || caturguṇe ajākṣīre ghṛtasthaṃ pipācayet | auṣadhaiḥ palikāmātraiḥ śanair mṛdvagninā sudhīḥ || māsamātraṃ prayuñjīta vāṇịm prāpnoty anuttarām | șaṇmāsopayogena sākṣād vāgî́saro <132v> bhavet || mattakokilanirghoṣo jāyate madhurasvaraḥ | saṃśayā neha kartavyā vicitrā bhāvaśaktayaḥ || ||

iti mahāsarasvatī-dhāraṇī samāptā || ||

[95] oṃ namo ratnatrayāya || namaḥ sarvabuddhabodhisattvebhyạ̣ | namo mahābhayapungalāya | namạ̣ saptebhyah samyaksambuddhebhyạ̣ || tadyathā || oṃ hrīḥ hrīḥ hrịḥ sarvanāgānām anantakulānāṃ vāsukīkulānāṃ takṣakakulānām śańkhapālakulānāṃ karkoṭakakulānāṃ padmakulānām mahāpadmakulānāṃ kulikakulānāṃ valāhakulānāṃ puṇụarīkakulānāṃ ghanakulānāṃ meghakulānāṃ jaladharakulānāṃ jīmūtakulānāṃ vasantakulānām airāvatakulānāṃ kumudakulānāṃ kuhlārakulānāṃ saugandhikulānām hana 2 śareṇa bandha 2 cāpena tāḍaya 2 utpalena bhītānām abhayaṃ dehi pralayakāla iva vajradharam avatāraya varṣantān nāgān vaśīkuru phuḥ kuru 2 phụ̣ kāraya 2 phuḥ phu oṃ kurukulle hrīḥ hūṃ phaṭ svāhā || ||

ārya-kurukullā-nāma-dhāraṇī samāptaḥ || ||

[96] oṃ namaḥ śrī-bhagavatyai vajravairocanyai ||

devi tvam eva girijā kamalā tvam eva padmāvatī tvam asi tāraṇī vedamātā | vyāptā tvam eva tu vane jagadekarūpā tubhyam nama 'stu <133r> manasā vapuṣā girānah ||

yānatrayeṣu daśapāramiteti gītā vistīrṇayānagajanākulaśūnyateti | prajñāprasaṅgacaturamṛtapūrṇapātrī tubhyaṃ namo 'stu manasā vapuṣā girānah \|| ānandanandavirame sahajasvabhāvā cakratrayāntaḥparivartitaviśvamātā | vidyutprabhātapanabhāsvarajñānagamyā tubhyaṃ namo 'stu manasā vapuṣā girānaḥ \| kim atra bahunā māta vajravairocanīśvarī | yad yad āvāñchitaṃ siddhidātrī tubhyaṃ namo 'stu te || ||

iti śrī-vajravairocanī-stava samāptaḥ || || 
[97] oṃ namo bhagavatyai ārya-śrī-vasudhārāyai || divyarūpī surūpī ca saumyarūpī varapradā | vasudharī vasudhārā ca vasuśrī śrīkarī varā || dharaṇi dhāraṇi dhātā śaraṇyā bhaktivatsalā | prajñāpāramitā devī prajñāśrī buddhibaddhanī || vidyādharī śivā sūkṣmā saāntā sarvatra mātṛā | tarunị tāraṇī devī vidyādāneśvareśvarī || bhūṣitā bhūtamātā ca sarvābharaṇabhūṣaṇī | durdāntatrāsanī bhīmā ugrā ugraparākramā || dānapāramitā devī varṣaṇi divyarūpinịi | nidhānī sarvamāñgalyā kīrtilakṣmī yaśaḥśubhā || dahanī māranīi caṇ̣̂ī śabarī sarvamātṛ̂ā | kṛtāntatrāsanī bhīmā kaumārī viśvarū $<133 \mathrm{v}>$ piṇī || vīryapāramitā devī jagadānandarocanī| tāpasī ugrarūpī ca ṛddhisiddhibalapradā || dānapuṇyamahābhāgā arjitā jitavikramā| jagadaikahito vidyā saṃgrāme tāraṇī subhā || kṣāntipāramitā devī śālinī dhyānadhyāyanī | padmanī padmadhārī ca padmam āsanam āsanī \| śūddharūpī mahātejā hemavarṇā prabhākarī| cintāmaṇidharī devī prajñāpustakadhārinīi || nidhānakūṭam ārūọhā dhānyāgāradhanapriyā | traidhātukamahā ādī divyābharaṇabhūṣinīi || mātarī sarvabuddhānāṃ ratnadhātveśvarîśvarī| śūnyatābhāvanī devī bhāvābhāvavivarjanī || vaināyakī vinetā ca dīpinī kleśacchedanī | bhindinī sarvamārānāmm saptapātālakṣobhanī || brahmanī vedamātā ca guhyarādguhyavāsinī | sarasvatī viśālākṣī caturbrahmavihāriṇi || tathāgatī mahāramyā vajinin̄ dharmadhāraṇī| karmadhāteśvarī vidyā viśvajvālāgramaṇḍali || bodhanī sarvamārāṇāṃ bodhyañgakṛtaśekharī| dhyānādimuktisampannā advayadvayabhāvinī || sarvārthasādhanī bhadrā trirūpāmitavikramā| darśanī buddhamārgāṇām nașțamārgapradarśanī || vāgîśvarī mahāśānti gotrī dhyātrī dhanaṃdadā| trirūpadhāriṇī siddhā yoginī yogi<134r>nîśvarī ||

20 mahātejā] $p c . ;$ majāhātejā $a c . \quad 22$-dhanapriyā] corr.; -dhapriyā ms. 
manoharī mahākāntī śubhagopriyadarśinī | sārthavāhakṛpāvṛșți sarvatathāgatātmakī || namas te 'stu mahādevī sarvasattvārthadāyanī | namas te divyarūpī ca vasudhārā namo 'stu te || || aṣtottaraśatam nāma trikālaṃ yạ̣ paṭhed imām | prāpnoti niyatam siddhim īpsitārthamanoratham || yad ajñānāt kṛtam pāpam anantaryāna sudāruṇam | tat sarvā kṣapayiṣyanti smaraṇān nāmabhadrakam || athavā śīlasampannaḥ sa ca jātismaro bhavet | priyaś cādeyavākyaṃ ca rūpavān priyadarśanạ̣ || viprakṣatriyakuleșu āśrayam upajāyate | ante bhūmīśvaraṃ prāptạ̣ paścāt prāptā sukhāvatī || ||

iti śrī-ārya-vasudhārā-nāmāṣṭottaraśata-nāma-buddhabhāṣita parisamāptaḥ || ||

[98] om namo bhagavatyai ārya-śrī-vajravidāraṇyai || evaṃ mayā śrutam ekasmin samaye bhagavān vajreșu viharati sma || sarvaśarīram vajramayam adhișthāya | vajrakrodhabhayaṃ vajrasārapadā bhāṣante sma || acchedyam abhedyam satyaṃ dṛ̣haṃ sthiraṃ sarvatrāpratihatạ̣ sarvatrāparājitam | sarvasattvavidrāpaṇakaraṃ sarvasattvonmādanakarạ̣ sarvavidyācchedanakaraṃ sarvavidyāstambhanakaraṃ sarvavidyākarmavidhvaṃsanaka parakarmavidrāpaṇa<134v>karaṃ sarvagrahonmādanakaraṃ sarvagrahavimokṣaṇakaram | sarvabhūtāpakarṣaṇakaraṃ sarvavidyāmantrakarmaparāyaṇakaram | asiddhānāṃ siddhanakaram | siddhānāṃ ca vināśanakaraṃ sarvakarmapadam | sarvasattvān rakṣakaṃ śāntikaṃ pauṣtikam | sarvasattvānāṃ stambhanakaraṃ sarvasattvānāṃ mohanakaram | idaṃ mantramahābalam buddhānubhāvo yakṣendro vajrapāṇiḥ pratyabhāṣata || || om namo ratnatrayāya || tadyathā || om traṭa 2 trāṭaya 2 sphuṭa 2 sphoțaya 2 ghurṇa 2 ghurṇāpaya 2 sarvasattvāni bodhaya 2 sambodhaya 2 trasaya 2 trāsaya 2 bhrama 2 bhrāmaya 2 sarvabhūtāni kuṭa 2 saṃkuṭaya 2 sarvaśatrūn 2 ghaṭa 2 saṃghațaya 2 sarvaśatrūn ghața 2 saṃghațaya 2 sarvavidyāvajra 2 sphoṭaya vajra 2 kațavajra 2 matavajra 2 vajrāțthāsanīlavajrasuvajrāya svāhā || oṃ he he phullani saphullaghunaphullani phulla kuru 2 vajravijayāya svāhā || oṃ vajrakilikilāya svāhā || om kața 2 maṭa 2 rața 2 māțanapramāṭanāya svāhā || om cala 2 nicala 2 hara 2 mara 2 māraya 2 vajravidāraṇāya svāhā || om chinda 2 bhinda 2 mahāvajrakilikilāya svāhā || oṃ bandha 2 krodha mahākilikilāya svāhā 35

30 sarvaśatrūn] $p c . ;$ sarvaviśatrūn $a c$. 
|| oṃ curu 2 candrakilikilāya svāhā || oṃ trāsaya 2 vajrakilikilā<135r>ya svāhā || oṃ hara 2 vajradharāya svāhā || oṃ prahara 2 vajraprabhañjanāya svāhā || oṃ matisthiravajra śrutisthiravajra mahāvajra apratihatavajra ehy ehi vajra śighram vajrāya svāhā || oṃ dhara 2 viri 2 dhuru 2 sarvavajrakulam āvartaya svāhā || mama sarvaśatrum māraya oṃ hūṃ phạ svāhā || om namaḥ samantavajrāṇām $\quad 5$ sarvabalam āvartaya mahābale kațare tatale acale mạ̣ḍalamāye ativajra mahāvimalana ajite jvala 2 țiti țiṭi pingale | daha 2 tejavati tini 2 bandha 2 mahābale vajrāṅkuśajvalāya svāhā || oṃ namo ratnatrayāya || namaś caṇḍavajrapāṇaye mahāyakṣasenāpataye || oṃ hara 2 vajra | matha 2 vajra | dhana 2 vajra | hara 2 vajra | paca 2 vajra | dhara 2 vajra | dhāraye 2 vajra | dāruṇa 10 2 vajra | chinda 2 vajra | bhinda 2 vajra | hūm phaṭ || namaś caṇḍavajrapāṇaye mahāvajrakrodhāya | oṃ huru 2 tiștha 2 bandha 2 hana 2 amṛte hūṃ hūṃ phaṭ || || hṛdayopahṛdayam mūlamantra || || sarvapāpakṣayaṃ kṛtvā sarvadụ̣khavināśanam | manobhị̣ sarvamantrāṇāṃ sarvaśrīsamalaṃkṛtạ̣ ||

upaśāntendriyo bhūtvā nașțāśrayahatāyuṣaḥ |

lakṣmīr api vinașțā ca revateś ca parāṅmukhāḥ ||

kāntāpriyajane duṣṭā kudravaś ca upadrutāḥ |

nāsvayaṃ ca samarthāṇāṃ bhūyah < 135v> vyasanam eva ca ||

grahanakṣatrapīḍa vā kākhordadāruṇā grahāh |

pāpakam paśyate svapne śokāyāsasamucchritam ||

te ca susnātaśucinā śrotavyaṃ sūtram uttamam |

śṛ̣vantu me idam sūtram gambhīram buddhagocaram ||

prasannacittasumano śucivastrair alaṃkṛtā|

te ca sarve ca duṣtātmā upasargā sudāruṇāḥ ||

tejāsya ca praśāmyate samantā sarvam āpnutām |

āyuś ca vardhate puṇyaṃ sarvapāpair vimokṣitam ||

maṇisarṣapadūrvābhir ratnākṣatasacandanaiḥ |

vajragranthite puṣpair jalām āyurjakāñcanam ||

ghaṭam tu rajataś cāpi śucivastreṇa veștitam |

ekaviṃśativāraṃ vā vārān aṣṭottaraṃ śatam \|

japed vajravidāraṇyām mantraṃ snāpya pārthivaḥ sadā | evaṃ nityajapāt pụ̣yam sarvaṃ sampadyate śubham || || idam avocad bhagavān vajrapāṇi bhāṣitam abhyanandann iti || ||

ārya-vajravidāraṇa-hṛdaya-mantra-nāma-dhārạ̣ī samāptā || ||

17 revateś] $p c . ;$ revatecaś $a c$. 
[99] oṃ namaḥ śrī-bhagavate ārya-gaṇapatihṛdayāyai || evaṃ mayā śrutam ekasmin samaye bhagavān rājagṛhe viharati sma || gṛdhrakūțe parvate mahatā bhikṣusamghena sārdham ardhatrayodaśabhir bhikșuśataih sambahulaiś ca bodhisattvaih tena khalu punah samayena bhagavān ānandam āmantrayate sma || yaḥ kaścid ānanda imāni gaṇapatihṛ<136r>dayāni dhārayiṣyanti vācayișyati paryavāpsyanti || tasya ca sarvakāryāṇi siddhāni bhaviṣyanti || tadyathā || || oṃ namo 'stu te mahāganapataye || oṃ gaḥ gaḥ gah gaḥ gaḥ gaḥ gaḥ gaḥ oṃ gaṇapataye svāhā || oṃ gaṇādhipataye svāhā || oṃ gaṇeśvarāya svāhā || oṃ gaṇapatipūjitāya svāhā || oṃ kața 2 mața 2 dara 2 vidara 2 hana 2 gṛhṇa 2 dhāva 2 jambha 2 stambha 2 moha 2 dehi 2 dāpaya 2 dhanādisiddhi me prayaccha || oṃ namo 'stu te mahārudravacanāya svāhā || oṃ amṛtabindukșubhitacitta mahāhāsam āgacchati | mahābhaya mahāparākrama mahāhastidakșinịiprabho dadāpaya svāhā || oṃ namo 'stu te mahāgaṇapataye || oṃ gaḥ gaḥ gaḥ gaḥ gaḥ gaḥ gaḥ gah | oṃ gaṇapataye svāhā || oṃ gaṇādhipataye svāhā || oṃ gaṇeśvarāya svāhā || oṃ gaṇapatipūjitāya svāhā || oṃ kuru 2 svāhā || oṃ suru 2 svāhā || oṃ muru 2 svāhā || oṃ turu 2 svāhā || oṃ namo namạ̣ svāhā || || idam ānanda ganapatihṛdayam yah kaścit kulaputro vā kuladuhitā vā bhikṣu vā bhikṣunīi vā upāsako vā upāsikā vā | yaḥ kaścit kāryam ārabhya | mantrasādhanaṃ vā triratnapūjāṃ vā rājakulagamanaṃ vā deśāntaragamanaṃ vā antardhānaṃ vā tena buddhānāṃ bhagavataḥ pūjāṃ kṛtvā ārya<136v>gaṇapatihṛdayaṃ saptavārān uccārayitavyam || tasya kāryāṇi siddhyante nātra saṃśayaḥ || sarvakāryāṇi sakalikalahadivyaḍambaravigrahavivādeșu nityaṃ smārayitavyam sarvaḥ praśamaṃ gacchati dine 2 kālam upasthāpya saptavārān uccārayitavyam | mahāsaubhāgyo bhavati || rājakule mahāprasādo bhavișyanti | śrutidharo bhavișyanti | na cāsya kasyacit avatāraṃ gavekṣī avatāraṃ pratilapsyati | nacāsya bodhicittāntarāyo bhaviṣyati || jātau jātau jātismaro bhaviṣyati || idam avocad bhagavān àttamanās te ca bhikṣavo te ca bodhisattvā sā ca sarvāvatī parṣat sadevamānuṣāsuragaruḍakiṃnaragandharvaś ca loko bhagavato bhāṣitam abhyanandann iti || ||

ārya-śrī-gaṇapatihṛdayo-nāma-dhāraṇī samāptaḥ || ||

12 -kṣubhitacitta] corr.; -bhikṣutacitta ms. • mahāhāsam] corr.; mahāsam ms. 24 smārayitavyaṃ] corr.; samārayitavyaṃ ms. 25 rājakule] $p c . ;$ rāgajakule ac. 29 āttamanās] corr.; ātmanās ms. • te] corr.; ste ms. 
[100] oṃ namo bhagavatyai ārya-uṣṇịsavijayāyai || evaṃ mayā śrutam ekasmin samaye bhagavān sukhāvatyāṃ dharmasaṃgītimahāguhyaprāsāde viharati sma || sukho pratișṭhito bhagavān āmitāyus tathāgato āryāvalokiteśvaraṃ bodhisattvaṃ mahāsattvam āmantraye sma || santi kulaputra duḥkhitān sattvān nānāvyādhiparipīḍitān alpāyuṣkās teșām arthāya hitāya sukhāya imāṃ sarvatathā<137r>gatoṣnīṣavijayā-nāma-dhāraṇị̣ dhārayet | vācayet deśayet paryavāpnuyāt parebhyaś ca vistareṇa samprakāśayet | dīrghāyuṣkānām upādāyeti || atha khalv āryāvalokiteśvaro bodhisattvo mahāsattva utthāyāsanād ekāṃsam uttarāsaṅgạ̣ kṛtvā kṛtāñjalipuṭo bhūtvā bhagavantam etad avocat || deśayatu bhagavan sarvatathāgatoṣnịṣavijayā-nāmadhāraṇị̣ deśayatu sugata | atha khalu bhagavān sarvāvatīparṣanmaṇḍalam avalokya samantāvalokitapriyā-nāma-samādhisamāpanna-r-imāṃ sarvatathāgatoṣṇīsavijayā-nāma-dhāraṇīm bhāṣante sma || || oṃ namo bhagavatyai sarvatrailokyaprativiśișțāya buddhāya te namah || tadyathā || oṃ bhrūṃ bhrūṃ bhrūṃ śodhaya 2 viśodhaya 2 asamasamantāvabhāsaspharaṇagatigagane svabhāvaviśuddhe | uṣṇīsavijayāpariśuddhe | abhiṣiñcatu māṃ sarvatathāgatāḥ sugatavaravacanāmṛtābhiṣekair mahāmudrāmantrapadaiḥ || oṃ āhara 2 āyusaṃdhāraṇi śodhaya 2 viśodhaya 2 gaganasvabhāvaviśuddhe | uṣnīṣavijayāpariśuddhe | sahasraraśmisamcodite sarvatathāgatāvalokini șaṭpāramitāparipūraṇi | sarvatathāgatamātre daśabhūmipratișțite | sarvatathāgatahṛdayādhișțhānādhișṭite | oṃ mu<137v>dre mudre | mahāmudre | vajrakāyasaṃhatanapariśuddhe | sarvakarmāvaraṇaviśuddhe | pratinivartanāya viśuddhe | sarvatathāgatasamayādhiṣṭhānādhiṣthite || oṃ muni 2 mahāmuni | vimuni 2 mahāvimuni | mati 2 mahāmati | mamati | sumati | tathatābhūtakoṭipariśuddhe visphuṭabuddhaśuddhe | oṃ he he | jaya 2 | vijaya 2 smara 2 sphara 2 sphāraya 2 | sarvabuddhādhișțhānādhișțhite | om suddhe 2 buddhe 2 vajre 2 mahāvajre | vajragarbhe | jayagarbhe | vijayagarbhe | vajrajvalāgarbhe | vajrodbhave | vajrasambhave | vajre vajrị̣i vajraṃ sambhavatu mama śarīram sarvasattvānāṃ ca | kāyapariśuddhir bhavatu 30 mama sarvagatipariśuddhiś ca sarvatathāgatahṛdayādhișṭhānādhișțite | sarvatathāgatāś ca samāśvāsayantu | oṃ budhya 2 sidhya 2 bodhaya 2 vibodhaya 2 mocaya 2 vimocaya 2 śodhaya 2 viśodhaya 2 samantān mocaya 2 samantaraśmipariśuddhe | sarvatathāgatahṛdayādhișṭhānādhișṭhite | oṃ mudre 2 mahāmudre mahāmudrāmantrapadaiḥ svāhā || iyam sā kulaputra sarvatathāgatoṣṇiṣavijayā-nāma-dhāraṇī mahāmṛtyudaṇḍanivāraṇi pavitrā-m-aghanāśanī likhitā bhūrjapatre anyatre vā

31 -pariśuddhiś] pc.; -pariśuriddhiś ac. 34 tathāgata] pc.; tatagathāta $a c$. 
kvacic caityamadhye kumbham āśritya samsthāpya || mạ̣ḍalam udārāṃ pūjām kṛtvā pradakṣiṇam <138r> sahasraṃ kartavyam | yathāvibhavānurūpatạ̣ suvarṇapatre nāma likhitvā dharmadhātugarbhe saṃsthāpya sampūjya dharmadhātucodane vā | ārdramṛttikā vā kārayitvā saptaikaviṃśati catvāriṃśat śatavārāṃ sahasraṃ vā sampūjya cchattrapatākāpuṣpadhūpadīpagandhanaivedyādikạ̣ sarvapūjābhị̣ pūjayet || imāṃ sarvatathāgatoṣnịṣavijayā-nāma-dhāraṇīm vācayet || ante dūrvākṣatena caityamūrdhni arcayet | yasyaivaṃ kṛte 'paramitāyumedhāvino bhavișyanti || dānaṃ dātavyam | saptadināyụ̣ saptamāsāyụ̣ pratyāgamiṣyati | saptamāsāyụ̣ saptavarṣāṇi jīvati | saptavarṣāyuh saptativarṣāṇi jīvati | paramāyuhśatam jīvati 10 | smṛtimān bhavati | mahārogoparimukto bhavati | śrīrāyurarthasampannaś ca bhavati || ||

ārya-uṣṇịsavijayā-nāma-dhāraṇī samāptaḥ || ||

[101] oṃ namo bhagavatyai ārya-prajñāpāramitāyai || evaṃ mayā śrutam ekasmin samaye bhagavān rājagṛhe viharati sma || gṛdhrakūṭe parvate mahatā bhikṣusaṃghena sārdhaṃ mahatā ca bodhisattvasaṃghena | tena khalu punạ̣ samayena bhagavān gambhīrāvabhāsanāmasamādhisamāpannạ̣ | tasmin samaye āryāvalokiteśvaro bodhisattvo mahāsattvaḥ gambhīrāyām prajñāpāramitāyāṃ caryām evaṃ <138v > vyavalokayati sma pañcaskandhāna svabhāvaśūnyāna vyavalokayati sma || athāyuṣmāñ chāriputro buddhānubhāvena āryāvalokiteśvaraṃ bodhisattvaṃ mahāsattvam etad avocat || ihāryāvalokiteśvara kulaputreṇa vā kuladuhitā vā gambhīrāyāṃ prajñāpāramitāyāṃ caryāṃ cartukāmena kathạ̣ vyavalokayitavyam || avalokiteśvara āha || yaḥ khalu kulaputro vā kuladuhitā vā gambhīrāyāṃ prajñāpāramitāyāṃ caryāṃ cartukāmena tenaivaṃ vyavalokayitavyam | rūpaṃ śūnyaṃ śūnyataiva rūpaṃ rūpā na pṛthak śūnyatāyā na pṛthak śūnyam || evaṃ vedanāsaṃskāravijñānāni śūnyatāni || evaṃ śāriputra sarvadharmā śūnyāḥ svalakṣaṇāḥ anutpannāḥ aniruddhāḥ acalāḥ vimalāḥ acyutāh anūnāḥ asampūrṇāḥ | tasmāt tarhi śāriputra śūnyatā yāvan na rūpaṃ na vedanā na saṃjñā na saṃskārā na vijñānam na cakṣuḥ na śrotraṃ na ghrāṇam na jihvā na kāyo na mano na rūpo na śabdo na gandho na raso na sprașțavyam | na dharmaḥ na cakṣurdhātuḥ evaṃ yāvanta dharmadhātuh yāvantā vidyākṣayo yāvanta jarāmaraṇakṣayo | na duḥkhaṃ na samudayo na nirodhaḥ na mārgo na jñānaṃ na prāpti nāprāptiḥ tasmāt tarhi sāriputra aprāptitvāt | bodhisattvo prajñāpā<139r>ramitām āśritya viharati | taccittālambanamātratvād

28 anūnāḥ] corr.; anyānāḥ ms. 
anuttarāyāṃ samyaksambodhau paryāsātikrāntā niṣthā nirvāṇaprāptās tryaadhvavyavasthitāḥ | sarvabuddhair api prajñāpāramitām āśritya anuttarāṃ samyaksambodhim abhisambuddhā | tasmāt tarhi jñātavyam || prajñāpāramitā yukto mantraḥ anuttaro mantrạ̣ asamasamo mantrạ̣ sarvaduḥkhapraśamano mantraḥ satyam amithyatvāt || ||

tadyathā || oṃ gate gate pāraṃgate pārasaṃgate bodhi svāhā || || evaṃ saāriputra gambhīrāyām prajñāpāramitāyām śikṣitavyaṃ bodhisattvena mahāsattvena || atha khalu bhagavān samādher vyutthāya | āryāvalokiteśvareṇa bodhisattvena mahāsattvena sādhukāram adāt | sādhu sādhu kulaputra evam etat | gambhīrāyāṃ prajñāpāramitāyāṃ nirdiṣțam || tad anumodyạ̣ sarvatathāgatair iti || || idam avocad bhagavān āttamanā āyuṣmāñ chāriputra āryāvalokiteśvaraś ca bodhisattvo mahāsattvaḥ sā ca sarvāvatī parṣat sadevamānuṣāsuragandharvaś ca loko bhagavato bhāṣitam abhyanandann iti || ||

ārya-śrī-pañcaviṃśatikā-prajñāpāramitā-nāma-dhāraṇī samāptaḥ || ||

[102] oṃ namaḥ śrī-bhagavatyai ārya-mārīcyai || evaṃ mayā śru<139v>tam ekasmin samaye bhagavāñ chrāvastyāṃ viharati sma || jetavane 'nāthapiṇụadasyārāme mahatā bhikṣusaṃghena sārdham ardhatrayodaśabhir bhikṣuśataiḥ sambahulaiś ca bodhisattvair mahāsattvaih || tatra khalu bhagavān bhikṣūn āmantrayate sma || asti bhikṣavo mārīcī nāma devatā sā sūryacandramasoḥ purato 'nugacchati | sā na dṛśyate na guhyate na badhyate na virudhyate na muṣyate na muhyate na dậ̣̣yate na muṇ̣̂tyate na dahyate na śastrā tam upagacchati || yo 'pi tasyāḥ bhikṣavo mārīcī nāma devatāyā nāmaṃ jānāti so 'pi na dṛśyate na gṛhyate na badhyate na nirudhyate na muṣyate na muhyate na dahyate na dạ̣ḍyate na śastrām upagacchati | so 'hạ̣ bhikṣavo mārīcīdevatāyā nāma jānāmi || aham api na dṛśye na gṛhye na vadhye na muṣye na muhye na dạ̣ḍye na dahye na śastrām upagacchāmi | imāni mantrapadāni bhavanti || tadyathā || oṃ padākarmasi parākramasi udayamasi vairamasi arkamasi markamasi urmamasi vanamasi gulmamasi cīvaramasi māhācīvaramasi antardhānamasi svāhā || oṃ mārīcīdevate pathe māṃ gopaya utpathe mām gopaya | rājakulato māṃ <140r> gopaya | adhvajanapadato māṃ gopaya | hastibhayān māṃ gopaya | caurabhayān māṃ gopaya | agnibhayān māṃ

2 tṛyadhva] corr.; tyadhva ms. 4 asamasamo] pc.; anusamasamo ac. $\mathbf{5}$ amithyatvāt] corr.; amadhyātvāt ms. 11 āttamanā] corr.; ātmanā ms. 16 bhagavāñ] pc.; bhavāgañ ac. 26 upagacchāmi |] pc.; upagacchāmi | so 'haṃ bhikṣavo mārīci devatāyā nāma jānāmi || aham api na dṛśye na $a c$. 
gopaya | udakabhayān māṃ gopaya | sarvapratyarthikapratyamitrabhayān māṃ gopaya | ākuleṣu anākuleṣu mūrchiteșu amūrchiteșu | siṃhato me rakṣa vyāghrato me rakṣa nāgato me rakṣa sarpato me rakṣa || tadyathā || om ālo tālo macchalā sattvamūrdhitira rakṣa rakṣa mama saparivārasya sarvasattvāṃś ca sarvabhayopadravebhyah svāhā || ||

oṃ namo ratnatrayāya || namo bhagavatyai ārya-mārīcīdevatāyai || tasyā hṛdayam āvartayișyāmi ||tadyathā || oṃ vartari balāri varāhamukhi sarvaduṣțapraduṣțānāṃ cakṣur mukhaṃ bandha 2 svāhā || oṃ mārīci svāhā || om vanale vartāli vadari 2 varāri varāhamukhi sarvaduṣțānāṃ cakṣur mukhaṃ bandha 2 svāhā || ||

idam avocad bhagavān āttamanā āyuṣmantas te ca bhikṣavo sā ca sarvāvatī parṣat sadevamānuṣāsuragaruḍamahoragakiṃnaragandharvaś ca loko bhagavato bhāṣitam abhyanandann iti || ||

\section{ārya-śrī-mārīcī-nāma-dhāraṇī parisamāptā || ||}

[103] oṃ namo bhagavatyai ārya-grahamātṛkāyai || namo ratnatrayāya || namo buddhāya namo dharmāya <140v> namaḥ saṃghāya || vajradharāya namaḥ || padmadharāya namạ̣ || kumārāya namạ̣ || namạ̣ sarvagrahāṇāṃ sarvāsaāparipūrakānāṃ namo nakṣatrāṇām | namo dvādaśarāśīnām | namaḥ sarvopadravānām || tadyathā || om buddhe 2 vajre 2 padme 2 sara 2 prasara 2 smara 2 krīḍa 2 krịḍya 2 mara 2 māraya 2 mardaya 2 ghātaya 2 mama sarvasattvānāṃ ca sarvavighnān chinda 2 bhinda 2 sarvavighnān nāśanaṃ kuru mama saparivārasya sarvasattvānāṃ ca kāryaṃ kṣepaya 2 sarvapāpāni saparivārasya sānte 2 dānte 2 dāmaya 2 dāpaya 2 drutaṃ darśayātmānam bhagavati rakṣa 2 sarvasattvānāṃ ca sarvanakṣatragrahapīdā nivāraya 2 bhagavati śreyaṃ kuru mahāmāyā prasādhaya 2 sarvaduștān nāśaya 2 sarvapāpāni mama saparivārasya candre 2 caṇḍani 2 turu 2 cande 2 muru 2 mumu 2 paca 2 havāhave bhavābhave ugrā-ugre tapātape pūraya 2 bhagavati manorathạ̣ mama saparivārasya sarvasattvānām ca sarvatathāgatādhișṭhānādhișthite samaye svāhā || oṃ svāhā || hūṃ svāhā || hrīḥ svāhā || dhūḥ svāhā || dhīḥ svāhā || om ạdityāya svāhā || oṃ somāya svāhā || 30 oṃ añgārāya svāhā || oṃ buddhāya svāhā || oṃ bṛhaspataye svāhā || oṃ śukrāya svāhā || oṃ śanaiścarāya svāhā || oṃ rāhave svāhā || oṃ ke<141r>tave svāhā || oṃ vajradharāya svāhā || oṃ padmadharāya svāhā || oṃ kumārāya svāhā || oṃ sarvagrahāṇāṃ svāhā || oṃ sarvanakṣatrāṇāṃ svāhā || oṃ sarvopadravānāṃ

1 sarvapratyarthikapratya-] corr.; sarvātpārthikapratyeka- ms. 11 āttamanā] corr.; ātmanā ms. 
svāhā || oṃ dvādaśarāśīnāṃ svāhā || oṃ sarvavidyai hūṃ hūṃ phaṭ phaṭ svāhā \| $\|$

imāni vajrapāṇi grahamātṛkā-nāma-dhāraṇīmantrapadāni kārttikamāse śuklapakṣe saptamīm ārabhya poṣadhiko bhūtvā yāvac caturdaśī grahanakṣatrā maṇḍalamadhye pūjayitvā dine dine saptavārān uccārayitavyā tatạ̣

pūrṇamāsyām ahorātraṃ vācayitvā ahorātraṃ pūjayet | tasya navanavati varṣāṇi mṛtyubhayam na bhaviṣyati || ulkāpātagrahanakṣatrapīdābhayaṃ na bhaviṣyati || jātau jātau jātismaro bhaviṣyati || devaputrasadṛśo bhavati || sarve grahā pūjitāś ca bhaviṣyati sarve grahā īpsitaṃ varaṃ dāsyati || || atha te sarve grahā sādhu bhagavann iti kṛtvā praṇamyāntarhito 'bhavann iti || || idam avocad 10 bhagavān āttamanās te ca bhikṣavaḥ bodhisattvā mahāsattvā sā ca sarvāvatī parṣat sadevamānuṣāsuragaruḍagandharvaś ca loko bhagavato bhāṣitam abhyanandann iti || ||

ārya-grahamātṛkā-nāma-dhāraṇī samāptaḥ || || <141v>

[104] oṃ namo bhagavatyai ārya-vajragandhāryai ||

anekaśatasahasraraśmiprajvalite dīptatejāya ugrabhīṣmabhayānakāya

|| raudradarśanāya | vikarālāya | vikarāya | pravalāya | yogīśvarāya | bhīṣmabhayānakāyai | șaṇmukhāyai | dvādaśabhujāyai | dvādaśanetrāyai | vikīrṇakeśāyai | anekarūpavirūpavicitraveśadhāraṇīyai | ehehi bhagavati āryamahāvajragandhārī trayānāṃ ratnānāṃ satyena ||

tadyathā || oṃ ākaḍhye 2 baladevaṃ maheśvaram | garuḍaviṣnuụ kumāraṃ brahmam indram candram ādityayakṣarākṣasabrahmarākṣasa-

gandharvabhūtapretapiśācakumbhāṇḍayonijaṃ

karmajam | sthāvaram | jaṅgamam | asuram | agnim

yamavaruṇavāyukuveravirūọhakavirūpākṣavaiśravaṇasan̉kukarṇavikarṇam |

sarvajvarān ekasya sarvajvaraș̣takeṇa saptagranthaya kartavyāḥ |

saptajaptodakena saptābhimantritena mukhādiśodhanapānabhojanaṃ ceti ||

namo ratnatrayāya || tadyathā || oṃ kara 2 jambhani 2 stambhani 2

sarvarogapraśamani svāhā || ||

anena mantreṇa pūrvābhimukhaṃ sthitvā saptavārān samarcya || rājakule praviśet | kruddho 'pi prasīdati || ||

iti hayagrīvakalpe vajragandhārī-nāma-dhāraṇī samāpta || || <142r>

10 'bhavann] $p c$.; bhagavann ac. 11 āttamanās] corr.; āttatmanās ac., ātmanās pc. 32 vajragandhārī] corr.; vajragandhā ms. 
[105] om namo ratnatrayāya || namo bhagavatyai

ārya-buddhaḍākinīvajravārāhyai ||

yā śrī bhagavatī vidyā mahāvīryaguṇaprabhā |

athāto bhagavatīnāṃ guhyeśvarīnāṃ sadevatīnāṃ mahādhiyānāṃ

mahāmantraṃ mahāguhyạ̣ mahāmāyā maheśvarī ||

trailokyaṃ saṃhare teșām trailokyaṃ sṛjate punạ̣|

guhyakānām iyaṃ mātā mahāmāyeti viśrutā ||

trailokyạ̣ trāsanī vidyāṃ prapadyeyaṃ maheśvarī |

yayā vijñātamātrayā vidyayā sādhakeśvaraḥ ||

sadevagandharvagaṇān sayakṣāsuramānuṣān |

10

vidyādharapiśācāś ca rākṣasoragakiṃnarān ||

vaśamānayati bhūtāni jalajasthalajāni ca |

mahāścaryakarī vidyā indrajālakarī tathā ||

mohanam stambhanaś caiva vidveṣoccāțanādikam |

vaśyākarṣaṇajambham cānekavidhāṃ kutūhalām ||

paṭhitā kurute vidyām vācā siddhiṃ ca sādhake |

na japaṃ na vratạ̣ tasyā nopavāso vidhīyate ॥

akleśatā bhavet siddhir devī satyaṃ vadāmy aham |

mantra tava mahāmāye sarvatrailokyasādhike \|

pravakṣyāmi mahāyogī divyair akṣarapañktibhiḥ || ||

oṃ namo bhagavati vajravārāhyai āryāparājite trailokyamāte mahāvidye sarvabhūtabhayāvahe | mahāvajre mahāsane ajite aparājite pa<142v>śyakari netrabhrāmaṇi viṣaśodhani krodhani karāliṇi saṃtrāsani māriṇi suprabhedani parājaya vijaya jambhani stambhani mohani vajravārāhi mahāyogini kāmeśvari khage || tadyathā || protaṅge 2 hana 2 prāṇān kikiṇi | khikhini | dhuna 2 vajraste | śoṣaya 2 khaṭvāngakapāladhāriṇi | mahāpiśitamāṃsāśani mānuṣāntaprāvṛte | sārdhanaraśiromālān granthitadhāriṇi sumbhanisumbhe | hana 2 prāṇān sarvapāpasattvānām sarvapaśūnāṃ māṃsacchedani krodhamūrte daṃșțākarālini mahāmudre śrī-herukadevasyāgramahiṣi sahasraśire sahasrabāhave śatasahasrānane jvalitatejase jvālāmukhi pingalalocane vajraśarīre vajrāsani | mili 2 timili 2 he 2 hūṃ 2 kha 2 dhu 2 dhuru 2 muru 2 advaite mahāyogini pațitasiddhe drem dreṃ drem drem graṃ graṃhe 2 ha 2 bhīmeha sahasravīre hā 2 ho 2 hūṃ trailokyavināśini śatasaharakoțītathāgataparivārite hūm phaṭ siṃharūpe khạ̣ gajarūpe gạ̣ trailokyādare mahāsamudralekhane grasa 2 hūṃ hūm phaṭ vīrādvaite hūṃ hūm 35 hā hā mahāṣaṇḍammohani yogeśvari tvaṃ ḍākini lokānāṃ bandhani sadyaḥ pratyayakāriṇi hūṃ phaṭ bhūtatrāsani ma<143r>hāvīre paramasiddhe vidyeśvari hūṃ phaț hūṃ hūṃ phaț hūṃ hūṃ phaț svāhā || eșā bhagavatī mahāmāyā pațhitasiddhā | asyāḥ sādhanaṃ bhavati | somagrahe sūryagrahe vā graham paśyan | ekaviṃśativārān pravartayet || tatạ̣ siddho 
bhavati | yāvad āvartayati tāvan strīsahasrair anugamyate | sakṛduccārite nākarṣayati mārayati | kruddhacetasā uccāṭanavidveșaṇastambhanaṃ ca kurute icchāvaśāt | kusumaṃ sakṛtparijapyākāśe kṣipet | brahmādīnāṃ darśayati | śmaśānāngāram sakṛjjaptam gehe grāme nagare vā kṣiped dāhaṃ darśayati | mayūrapicchakạ̣ sakṛjjaptam ākāśe bhrāmayet | punar upaśamayati | śarkarāsakṛjjaptāṃ caturdiśaṃ kṣipec caturan̉gabalaṃ darśayati | mayūrapicchakạ̣ viparītạ̣ bhrāmayet | pratyānayanaṃ kṛtạ̣ bhavati || ||

ārya-mahāmāyāvajravārāhī-nāma-dhāraṇī samāptah || ||

[106] adhunā mahāmāyāśmaśānāny ucyate || pūrvadigbhāge maṇḍalasya sādhakānugrahaṃ nāma śmaśānam || uttare vādvaitakaram | paścime krodhānanam | dakṣiṇe ghorāndhakāram | āgneye mahāpralayam | nairṛtye mahāmelāpakayogabahulam | vāyavye siṃhanāgamahāphetkāram | aišāne sarojabīja nāma <143v> śmaśānam || eṣu yathāyogam gandhāṅga-khāṇḍatāngaardhakhaṇditāngga-vibhīṣaṇākāra-bhayaṃkarāḥ śūlabhinnodbaddhaśavāḥ | pāțalākan̉kelicūḍaśirīṣodumbaravațāśvatthanāgakesarapādapāḥ | yathākrameṇa mahiṣamārjārabhalluvyāghrāśvagṛddhaśūkarapiśācamukhā maharddhikā yakṣāḥ | samantataś ca śmaśānāșțake śrgālagṛddholūkavāyasaśvanavetāḍabhūtādayaś veti || ||

iti mahāmāyādevyāḥ śmaśānam || ||

[107] namas te vajravārāhī caturmāravināśinī |

sarvasiddhipradātā ca buddhaḍākinī namaḥ sadā ||

namas te vidyādharīdevī raktavarṇasamojjvalā |

kuliśapātradharī devī sarvasiddhipradāyanī ||

namas te 'stu mahādevī mahāmāyāmaheśvarī |

sarvaśatrunikṛntā ca jaganmātā namo 'stu te || ||

iti vidyādharī-svalpa-stuti samāptaḥ || ||

20 caturmāra-] corr.; caturmā- ms. 22 -samojjvalā] corr.; -samojvalajjvalam ac., -samojjvalalam pc. 
[108] oṃ namo bhagavate mahābhairavāya || oṃ paraśupāśahastāya oṃ amṛtakuṇụali kha 2 khāhi 2 tișțha 2 bandha 2 hana 2 daha 2 paca 2 matha 2 hūṃ phaț svāhā || ||

iti mahābhairavasya-nāma-dhāraṇī samāptaḥ || ||

[109] oṃ namaḥ straiyadhve sarvatathāgatahṛdayagarbhe jvala jva<144r>la dharmadhātugarbhe saṃhara mamāyuḥ sambhara saṃśodhaya mama sarvapāpaṃ sarvatathāgatasamantoṣnịiṣavimalaviśuddhe hūṃ hūṃ hūṃ aṃ vaṃ saṃ jaḥ svāhā || ||

iti cintāmaṇi-nāma-dhāraṇī samāptaḥ || ||

[110] oṃ namaḥ saptānāṃ samyaksambuddhakoținnām || tadyathā || oṃ cale cule cunde svāhā || mahāvīrya apratihataśāsane | mahābalaparākrame | asimusaladharaparaśupāśag̣̣hītahaste mahākrodhakrodheśvara ugrarūpini anantamukhasahasrabhuje ajite aparājite | amoghadurgamasahasrākși sarvatathāgatādhișthānādhișțite sarvadevānāṃ vanditapūjite suprasādhite | vajraghoșaṇe vajravajrāvahe | vajrāyudhavajrakātyāyini vajronmīlitākṣi akṣaye aghore ghorarūpiṇi vikṛtadarśane vajravaidūryālaṃkṛtaśarīre oṃ bhagavati cunde krum kruṃ hūṃ hūṃ śruṃ śruṃ śroṃ śroṃ ruṃ ruṃ g̣̣hṇa 2 āveśaya 2 g̣̣hṇāpaya 2 hana 2 sara 2 māraya 2 bhuñja 2 hana 2 daha 2 paca 2 gṛhṇa 2 mamedaṃ duștagraham jvaram ekāhikaṃ dvyāhikạ̣ tryāhikaṃ cāturthakaṃ saptāhikam ardhamāsikaṃ māsikaṃ daivasikam ardhadaivasikaṃ 20 mauhūrtikam | vātikaṃ paittikaṃ śleșmanikaṃ sāṃnipātikaṃ grahabhūtạ̣ vetāḍaṃ yakṣarākṣasaṃ kumbhāṇḍam yonijam <144v> karmajaṃ sthāvaraṃ jañgamaṃ ye māṃ himsanti kecid duștās tān sarvān sādhaya 2 mardaya 2 tāpaya 2 śoṣaya 2 utsādaya 2 hana 2 vajreṇa | sara 2 daṇḍena | māra 2 khaḍgena | oṃ bhagavati cunde hūṃ hūṃ hūṃ cuṃ cuṃ cuṃ draṃ draṃ draṃ ruṃ ruṃ rum añcale cule cunde svāhā || ||

iti cundābhațțārikāyā rakṣāmantra samāptaḥ || ||

1 mahābhairavāya] pc.; mahārabhairavāya ac. 4 iti] pc.; iti bhai ac. 21 paittikaṃ] corr.; paitikaṃ ms. 
[111] oṃ namaḥ śrī-sūryāya || ādityạ prathame nāmaṃ dvitīya ravir ucyate | gabhastis tṛtiya nāma caturthe bindur eva ca \| pañcame savitā nāma șașțame ca divākara | dharmārthah saptame nāma așțame tapanas tathā || navame bhāskaro vidyāt daśame sahasrāṃśakaḥ | tuṣṭir ekādaśe nāma dvādaśe sūrya eva ca || dvādaśaitāni nāmāni yaḥ paṭhed ravisaṃnidhau | dvādaśaṃ harate vyādhị̣ kuṣțapātakanāśanam || sarvatīrtheșu yat snānam phalaṃ prāpnoti cepsitam | mucyate sarvapāpebhyo rakṣa māṃ sūryadevatā ||

iti ādityadvādaśa-nāma samāptaḥ || ||

[112] oṃ namaḥ śrī-pūrṇacandrāya \| namas te paramadeva namas te sāgarodbhava | namas te kalādhāri pūrṇacandra namas tu te \| kundendutuṣārasaṃkalpaṃ phalaprākārajīvinam | haṃsavāhanasamprasthaṃ niśākaraṃ namāmy aham ||

iti niśākara-nāma samāptaḥ || ||

[113] <145r> || om namaḥ śrī-bhagavatyai ārya-ugratārāyai || ekajațādevyai || namo buddhadharmasaṃhebhyạ̣ | namạ̣ sarvaśrāvakapratyekabuddhabodhisattvakrodharājebhyah || namo bhagavate paramagurave mahākāruṇikāya sāânamunaye tathāgatāyārhate samyaksambuddhāya || tadyathā || oṃ ugre 2 mahogre ugrarūpe ugratāre oṃ hrī hūṃ ekajaṭe pingalograikajațe ūrdhvajațe candrakhaṇụānkitajaṭe vyomavajrodbhāsitamakuṭe naraśiromuṇụamālābharaṇe damșțākarālograbhịṣaṇadarśane bhṛkuṭīmukhi mahāmukhi hasa 2 mada 2 madanotsuke madanātapatre kuleśvari kulasundari kulamātali kulakelini rama 2 surate suratotsuke surateśvari vikṛtadamșțre mahānāsye bālendukoṭisaṃkāśadamane vidyurjihve lolarasane saṃtrāsitabhuvane vikarāli saṃkāli mahākańkāli kālānale kāle rohani kālakañkālavidhamani vajramahākālarūpadhāraṇi mahākāli kālīsadamani vetāli vajravetāli padmavetāli vetālotthāpani vetālakalipriye mahāśmaśānavāsini mahākāpālini mahākālakapāladhāriṇi māṃsaśoṇitamedovasāramyate

16 kundendu-] corr.; kundu- ms. 
mānuṣāntraprāvṛtaśarīre naraśiromuṇụamālāvalambitadehe śavāsane <145v> kṛtāntāsane kṛtāntakāriṇi kṛtāntamathani kṛtāntadaṃṣtre mahākāli kālīśadhamani kālamohane mahākālakañkālavidhamani vajramahākālarūpadhāriṇi hāhā hīhī hūṃ hūṃ hehe haha trața 2 truṭa 2 khaṭa 2 ghața 2 vighața 2 tața 2 rața 2 cețaya 2 mețaya 2 vetālamadhyavartini jvalite jvalite jvalitaśikhe prajvalitamūrteje prajvalitahutavahanayane jvala 2 jvālaya 2 vajre 2 vajragarbhe vajrajvālānalaprabhe vajrajvālāgarbhe vajrajvālāmaṇḍale nābhikośamadhyagate vajrajvālāvabhāsitaśarīre vajradaṇḍe vajraveśe vajravārāhi tṛṣnāvidveșayacchali mahākālîśadamani | daha 2 bhasmīkuru sarvavighnān | vajrakhaḍge mānicande ajite aparājite amite aparamite aparimitapuṇyajñānasambhāropacite asame asamantake grasa 2 marda 2 matha 2 pramatheśvari apratihatamahāvidye madhyavartini akale niṣkale catuṣkale kalanātīte amṛte amṛtodbhave amṛtarūpiṇi vajrāmṛte amṛtavarṣaṇi amṛtaplave kuṇụalini avadhūte avadhūtanivāsini avadhūte bhakșiṇi bindunādadhamani dhamma 2 raṇa 2 bhaṇa 2 rāya 2 kana 2 kvana 2 dhara 2 daradānte mahā<146r>nāde meghanirghoṣanāde meghanāde meghanādamahānādapriye meghanādoccāriṇi hūṃkārarūpe ghorātțahāsasaṃtrāsitabhuvane tribhuvaneśvari dhaka 2 dhuku 2 dhuna 2 vidhuna 2 dama 2 gmā 2 dhum 2 ghum 2 hūṃ 2 mu 2 muñca 2 mocaya 2 jaya 2 mahākāruṇike parameśvari viśveśvari vīreśvari krodheśvari mahākrodharājeśvari pītheśvari samayeśvari samaye mahāsamayāsamaye samaye samayānupālini samayavartini cakravartini samayaśodhani samayāvatāriṇi | smara 2 samaye samayajñe vīranāyaki vajranāyaki pịthanāyaki kāmeśvari kāmarūpe viśvarūpe mahogre ghorarūpe bahuvividhavicitrarūpadhāriṇi mahāvikṛtarūpasahasraparivartini mārāri darpadalani mahāvighnaughaghātani | tarjaya 2 sarvamārān | śoṣaya 2 saptasāgarān | ghātaya 2 sarvadușțapradușțān | kīlaya 2 sarvagrahān | mohaya 2 sarvabhūtān | trāsaya 2 sarvayakṣarākṣasān | bhagavati mahākāruṇikakrodheśvari rakṣa 2 māṃ saparivāraṃ sarvasattvāṃś ca || oṃ maṇi 2 mahāmaṇi cintāmaṇi maṇidhari maṇipadme padmamaṇibande vajramaṇi vajrakartari vajraḍākini hṛdayonmūlini mahocchuṣme kin̉ki<146v>ni khinkhini vyāghracarmāchāditajaghane mahākrodharāje mudrābhūṣitacaraṇayugale goṇāsābharaṇe nāgāṣțakaphạ̣imaṇirañjitaśarīre bhūṣaṇālaṃkṛtavigrahe he 3 si 3 śatasahasrātirekaprabhāvabhāsite traidhātuke suraśatamakuṭamaṇimālāvalicumbitapādapīthe viśvamātre brahmendrarudrākarṣaṇi hūṃkārapūraṇi traidhātukavaśaṃkari trailokyākarṣaṇi sarvatathāgataguhyahṛdaye mahāmudrādhiṣṭite mahopāye

28 mahākāruṇika] corr.; mahāruṇika ms. 29 maṇipadme] pc.; ṇimapadme $a c$. 
mahāmāye māyāvimohani māyājālanaye | cara 2 vicala 2 samcara 2 traidhātukanamaskṛte raviśaśihutavahanayane mahākalpāgnisaṃnibhe vīre 2 vīreśavallabhe vīreśanamite paramaṇḍalamudrābhañjani jạ̣ hūṃ vaṃ hoḥ | vajrāṅkuśadhāriṇi pāśāsphoțani priye vajrapadmamahāmukhe mahāvajradharasvarūpiṇi dharmadhātujñānagarbhe rama 2

sarvayogini maṇḍalapūjite kāruṇyāmṛtanirbhare caṇḍāmśumālini viśvagarbhe viśvākragarbhanilaye candre 2 candrāvaguṇṭite mastake candramaṇdalamadhyagarbhagate araṇe arunodayasamnibhe araṇamaṇụalārūọhe jvalitānalatejase kālarātri sarvavighnavidhvaṃsani bhoḥ bhoḥ aśeșavidyāgarbhamahāsarvamaṇḍalapūji<147r>te mahākāruṇike bhaktānuvatsale mahāmantrānusāriṇi mahāmantragarbhasarvamantramudrāvighātasvārthasaṃjanani catustattvopadeśakāriṇi mahāmantrodgate sahasrākṣe sahasrabhuje śatasahasrākși mohaya 2 nāśaya 2 ghātaya 2 stambhaya 2 māraya 2 tāraya 2 bhañjaya 2 vidhvaṃsaya 2 utsādaya 2 sarvadușțapraduṣțān | bhagavati ghorāgraikajaṭe hūm 3 phat 3 namo 'stu te svāhā || vīreśapūjite svāhā || yoginīgaṇavandite svāhā || sarvatathāgatasamabhișțute svāhā || sarvatathāgatādhișțite svāhā || apratihatavidye svāhā || apratihataprabhāve svāhā || trailokyākarṣaṇi svāhā || oṃ hrīṃ svāhā || oṃ hūṃ svāhā || oṃ trīṃ svāhā || tricakravartini svāhā || catuścakramaṇḍale svāhā || rūpiṇi svāhā || arūpiṇi svāhā || bhṛkuṭimukhi svāhā || varāhamukhi svāhā || kṛtāntamathani svāhā || mātṛgaṇavandite svāhā || mātṛphaṭāravartite svāhā || śmaśānavāsini svāhā || mahākili 2 priye svāhā || mohani svāhā || vimohani svāhā || śodhani svāhā || viśodhani svāhā || ekavīrye svāhā || mahāvīrye svāhā || śvetavīrye svāhā || jñānaḍākini svāhā || jñānāmṛtasamudgate svāhā || dharmadhātu<147v>garbhe svāhā || mahābodhicittavajre svāhā || mahāsamaye svāhā || trailokyadhamani svāhā || mahāsāhasrapramardani svāhā || bhūḥ svāhā || bhuvaḥ svāhā || svaḥ svāhā || bhūrbhuvaḥsvaḥ svāhā || vajravārāhi svāhā || vajratāre svāhā || sarvamaṇḍalavidyādhipate svāhā || pañcarakṣāyai svāhā || samāśvāsakari svāhā || abhayaprade svāhā || rakṣa 2 māṃ sarvasattvāṃ́ ca sarvabhūtapretapiśācaḍākaḍākinyapasmārabhayebhyạ̣ sarvatra sarvadā mama sarvasattvānāṃ ca śāntiṃ kuru puṣțim kuru rakṣāṃ kuru bhagavati pingalograikajaṭe hūṃ 3 phaṭ 3 namo 'stu te svāhā || oṃ āḥ hrīṃ hūṃ hạ̣ hah || ||

1 mahāmāye] $p c$; mahāpāmāye $a c . \quad 8$ araṇe] $p c$; amṛraṇe $a c . \quad 32$ śāntiṃ] $p c$.; śāntiṃ pușțị̣ $a c$. 
[114] oṃ namaḥ śrī-daśakrodhāya mahābhairavāya || yamāntakaprajñāntakapadmāntakavighnāntakatakkirājanīladaṇụamahābala-acalasarvakrodhebhyạ̣ sarvaduștapradușțān māraya 2 kāraya 2 garjaya 2 visphoțaya 2 hūṃ hūṃ hūṃ phaț phaț phaț svāhā || ||

[115] oṃ namaḥ ālị̄hā mahāsaṃvaraṃ devī śrī-herukạ̣ mahāvīraṃ sahajānandarūpīdevī śrī-mahāsaṃvaraṃ namo 'stu te || || <148r> sayogāmbaraṃ devī sarvajñena pramodakavīrā māravidhvaṃsanī devī praṇamāmi śrīyogāmbaraṃ namo 'stu te || || hevajradūtī dehi premavadanāni hasitaānandādidevī sukhasundarīdevī śrī-hevajrayogato phaladāyanī devadevī namo 'stu te || || namo 'stu śrī-kālacakradevī nīlavadanā ānandadvaya ālingganapremā namo 'stu siddhi-ālị̣̄hadevī namāmi śrī-kālacakraṃ namo 'stu te || || oṃ namaḥ śrī-mañjunāthāya || oṃ sarvadharmābhāvasvabhāvaviśuddha a āḥ aṃ a | prakṛtipariśuddhāḥ sarvadharmā yad uta sarvatathāgatajñānakāya mañjuśrīpariśuddhitām upādāyati a āḥ sarvatathāgatahṛdaya hara hara oṃ hūṃ hrīḥ bhagavan jñānamūrti vāgiśvaramahā ca sarvadharmagaganāmalasupariśuddhadharmadhātujñānagarbha āḥ || iti mantreṇādimadhyāvasānādhișthānapūrvakaṃ nāmasaṃgītibhațțārikāṃ pratyahaṃ pratisaṃdhya tridhārān ekavāraṃ vā paryañkam abhivandanasamāhitaḥ san paṭhed evaṃ tāvan nimittāni na paśyati || tadanantaraṃ yathātantraṃ siddhirūpā svam anutișțhed iti || ||

ārya-nāmasaṃgīti-dhāraṇī parisamāptaḥ || || <148v>

[116] oṃ namaḥ śrī-āryāvalokiteśvarāya bodhisattvāya mahāsattvāya mahākārunikāya \| tadyathā || oṃ śuddhe viśuddhānge śuddhākṣi śodhani viśodhani gaganaviśodhani cittaviśodhani āvaraṇaviśodhani karmāvaraṇaviśodhani | hana 2 sarvāvaraṇāni pañcānantaryāni padme padmākși | padmavimale | țaṭa țața || 4 || haha haha || 4 || arjale varjale | siddhili svāhā || paṭhitamātreṇa pañcānantaryāni karmāvaraṇāni parikṣayaṃ gacchanti || ||

iti āryāvalokiteśvarasya mukhodgīrnāā siddhinikā-nāma-dhāraṇī samāptaḥ || ||

11 namo] corr.; na ms. • namo 'stu] corr.; namastu ms. 12 namāmi śrī-] pc.; namāśrīmi ac. 26 āvaraṇa] corr.; āvaṇa ms. 30 mukhodgīrṇā] corr.; mukhaṃgīrṇo ms. 
[117] oṃ namo mañjunāthāya || namaś caṇụavajrakrodhāya vajrakrodhāya || oṃ tadyathā || oṃ bhara 2 kuru 2 tișțha 2 vana 2 hana 2 amṛte hūṃ 3 phaṭ svāhā ||

asyopacārah prātar utthāya saptābhimantritam udakābhiṣekaṃ ca | yat kiṃcit tathājyam abhimantreṇa bhakṣayet || șaṇmāsopabhogena rasāyanaṃ bhavati || śrutidharo bhavati candano gīre japet | candanāt parimucyate | puṣpagandhaphalaṃ vāsasya dāyate sarvaśo bhaviṣyati \|

amṛtabhakṣā-nāma-dhāraṇī samāptā || ||

[118] om namo ratnatrayāya || oṃ namo tārāyai || tadyathā || <149r> dhare 2 dhāre 2 dhāraṇi rạ̣akețai abhayākalpe jalpani gaṇi anantakalpa-

amṛtakalpahutāśane anantamukhe anantacakṣusamudgate ubhaye svāhā || namaḥ sarvavidyā siddhyantu me mantrapadā svāhā || ||

iti așțamahābhayaharaṇatārā-nāma-dhāraṇī samāptā || ||

[119] oṃ namo ratnatrayāya || tadyathā || oṃ namo buddhāya mahākāruṇikāya bharikṛtahṛdayāya || paramātmasamatāgatacittāya traidhātukamūrtaye sattvārthaduḥkarakāriṇe sarvasattvāṃś cānuttarāyāṃ samyaksambodhau pratișțhāpaya oṃ āḥ sugatavajratuṣya hoḥ svāhā || ||

iti buddhabhaț̣āakakasya dhāraṇī samāptạ̣ || ||

[120] oṃ namaḥ śrī-yogāmbarāya || oṃ tadyathā || oṃ hūṃ hạ̣ svāhā | oṃ ā ah om sum | oṃ kṣum | oṃ yum | om hūm | oṃ smrum | oṃ hmrum | oṃ ymrum 20 | oṃ kṣmrum | oṃ hūṃ || oṃ phram | oṃ phrom | oṃ phrim || oṃ ha ho hri hrī 3 ọ̣ ghrī ghra | oṃ kuru 2 oṃ vartari 2 oṃ hūṃ | oṃ supriyagandhe hūṃ | oṃ hūṃ hoh | oṃ śrim | oṃ hūṃ hūṃ hūṃ | oṃ kum | oṃ sunṛtye hūṃ | oṃ kṣum | oṃ kṣaśa | oṃ oṃ om | oṃ hūṃ ga | oṃ sumu | oṃ imu | oṃ dhanāgre | oṃ khātani | om bhūrbhuvaḥ || || oṃ kuṃ a | khum ā | gum i | ghum î | cum u | chum 25

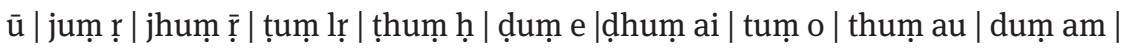
$<149 v>$ dhum ạ || ||

iti śrī-yogāmbarasya karmarāja-nāma-dhārạ̣ī samāptaḥ || || 
[121] oṃ namo lokanāthāya bodhisattvāya mahāsattvāya mahākāruṇikāya || tadyathā || oṃ devāsuranarayakṣarākṣasādibhị̣ vanditapādapadmāya aśeșanārakasattvoddhāraṇatarpaṇāya mahākāruṇikāya | sarvasattvāṃś ca narakādiduḥkhottāraṇāya 2 uddhara 2 samuddhara 2 buddhasatyena dharmasatyena saṃghạ̣satyena satyavādisatyena oṃ ạ̣̄ hūṃ phaṭ svāhā || ||

iti sarvalokeśvara-dhāraṇī-parisamāptạ̣ || ||

[122] oṃ namaḥ śrī-khasarpaṇāya || trailokyadarpanāya ekāgracittāya sakalarogavināśanāya sarvasattvānāṃ ca sāntiṃ kuru puștị̣ kuru rakṣāṃ kuru siddhiṃ kuru oṃ āḥ hrīṃ hūṃ phaṭ svāhā || ||

iti khasarpaṇa-nāma-dhāraṇī samāptạ̣ || ||

[123] oṃ namaḥ śrī-mañjunāthāya || oṃ namạ̣ arapacanāya kumatidahanadakṣāya mañjubuddhipradāya candrakāntimaṇibuddhipradāya khaḍgapustakavyagrahastāya mañjuvāṇīvarapradāya sarvasattvānāṃ ca sāntị̣ kuru puṣṭiṃ kuru rakṣāṃ kuru 2 oṃ āḥ dhīḥ hūṃ phaṭ svāhā || ||

iti arapacanamañjuśrī-nāma-dhāraṇī samāptạ̣ || || <150r>

[124] oṃ namo maitreyanāthāya || bhāvi vidyācaraṇasampannaḥ samyaksambuddhāya sarvasattvārthadravitacittāya puṣpaṃ dhūpaṃ dīpaṃ gandhaṃ saṃsāraduḥkhoddhṛtyānuttarāyām samyaksambodhau pratișṭāpaya oṃ āḥ maitreyanāthāya hūṃ phaṭ svāhā || ||

iti śrī-maitreya-nāma-dhāraṇī samāptạ̣ || ||

[125] om namaḥ saddharmapuṇụarīkāya \| oṃ vajraghaṇța āh 3 oṃ raṇa 2 praraṇa 2 sampraraṇa sarvabuddhapracāriṇi prajñāpāramitānādasvabhāvena vajrasattvahṛdayasaṃtoṣanakarāya hūm phat svāhā ||

3 -tarpaṇāya] corr.; -tarparāya ms. 12 -nāthāya] corr.; -nāya ms. 17 -vidyā-] corr.; -vidyāś- ms. 18 sarvasattvārtha-] $p c$; sarvasathattvārtha- ac. 20 maitreya-] corr.; maitrīya- ms. 21 maitreya] corr.; maitrīya ms. 23 sampraraṇa] pc.; sampraraṇa 2 ac. 24 -nādasvabhāvena] corr.; -svabhāvenāda ms. 
saddharmapāṭhārthe ghaṇțāvādanasampannaḥ mantreṇa dadyāt | puṣpam dhūpaṃ dīpaṃ gandhaṃ yathāvidhinā sarvaṃ dadyāt oṃ āḥ hūṃ phaṭ svāhā || ||

iti saddharmapāṭha-dhāraṇī-samāptā || ||

[126] oṃ namas tārāyai || oṃ tāre sarvavighnahare sarvabhayaśāntikare pratibhāse mama kṛte sarvadușțān stambhaya 2 jambhaya 2 mohaya 2 hūṃ phaṭ sarvadușțapradușțastambhani svāhā || ||

iti vajratārā-nāma-dhāraṇī samāptaḥ || ||

[127] oṃ ugratārāyai namaḥ || oṃ tāraṇi

sarvaduḥkhabhayahāriṇi caturmāranivāraṇi

sarvadevāsuranaragandharvakiṃnaramahoragopadravapramardani bhūtapretapiśācayakṣa<150v>rākṣasān ḍākaḍākinībhayavidhvaṃsani paramakṛtayantramantraprayogavināśini bhagavati durgottaraṇi āgacchāgaccha bhagavati eșāṃ vidyāṃ sarvatathāgatānāṃ vākyaṃ sarvaśatrūṇām hana 2 daha 2 paca 2 matha 2 cheda 2 bheda 2 truta 2 sarvasattvānāṃ ca śāntiṃ kuru puștịị kuru rakșāṃ kuru hrị̣̣ hạ̣ hūṃ phaț svāhā || ||

iti ugratārā-nāma-dhāraṇī samāptaḥ || ||

[128] oṃ namaḥ daśakrodhāya || oṃ yamāntaka | prajñāntaka | padmāntaka | vighnāntaka | acala | țakkirāja | nīladaṇụa | mahābala | uṣṇiṣacakra | sumbharāja | saparivāraṃ sampannikebhyaḥ sarvasattvānāṃ ca sarvavighnavināyakānāṃ kāyavākcittaṃ kīlaya 2 vidhvaṃsaya 2 sarvamārān mārakāyikān yakṣān rākṣasān mahoragān bhūtān piśācān devān mānuṣān asurān kiṃnarān kumbhāṇḍebhyah sarvaśatrūṇām hana 2 daha 2 paca 2 matha 2 vighnavināyakaṃ kuru 2 hūṃ phaṭ svāhā || ||

iti daśakrodhānāṃ dhāraṇī parisamāptaḥ || ||

1 -pāțhārthe] corr.; -pāṭhadhe ms. 5 -vighna-] corr.; -vighni- ms. 12 -yakșa-] pc.; -yakșasān ac. 23 mahoragān] corr.; mahogān ms. 25 -vināyakaṃ] corr.; -vināyanaṃ ms. 
[129] oṃ namaś caturdaśalokapālāya \| oṃ indrayamajalayakșabhūtavahnivāyurākșasabrahmasūryacandraasurapṛthivīnāgānāṃ mama rakṣāṃ kuru śāntiṃ kuru puṣṭiṃ kuru rakșāṃ kuru sarva <151r>devebhyaḥ puṣpaṃ dhūpaṃ dīpaṃ gandham ca śarkarādisahitaṃ rakṣa 2 svāhā || ||

iti lokapālasya nāmānāṃ dhāraṇī samāptā || ||

[130] oṃ namaḥ śrī-gaganākṣepavajrayoginyai || oṃ vajrayoginyai hrīṃ 2 ru 2 khaṃ 3 phem 3 aṃ 3 mama sarvasattvānāṃ ca śāntiṃ kuru 2 puștịm kuru 2 rakṣāṃ kuru oṃ sarvatathāgatasamayam anusmara 2 hūṃ phaṭ svāhā || ||

iti gaganākṣepavajrayoginī-nāma-dhāraṇī samāptaḥ || ||

[131] oṃ namo raktayamārīye || tadyathā || oṃ raktamakuțāya raktajațāya raktamukhāya raktaśarīrāya raktabhujāya raktahārāvalīmālāya raktarathasamārūḍhāya raktābharaṇabhūṣitāya mama sarvavighnān hara 2 caturmārān nivāraya 2 trāsaya 2 bhrāmaya 2 chinda 2 bhinda 2 nāśa 2 tāpa 2 śoṣa 2 cheda 2 bheda 2 truta 2 hūm 2 phat 2 svāhā $\|$ oṃ indrāya surādhipataye namaḥ svāhā || oṃ hrīḥ yamāya pretādhipataye namaḥ svāhā || ștrị̣̄ varuṇāya nāgādhipataye namaḥ svāhā || vaṃ kuverāya yakṣādhipataye namaḥ svāhā || hūṃ î́varāya bhūtādhipataye namaḥ svāhā || raṃ agne tejādhipataye namaḥ svāhā || aṃ nairṛtye rākṣasādhipataye namạ̣ svāhā || naṃ vāyavye pavanādhipataye namaḥ svā<151v>hā || aṃ candrāya nakșatrādhipataye namaḥ svāhā || hūṃ ā sūryāya grahādhipataye namaḥ svāhā || hūṃ brahmaṇe lokādhipataye namaḥ svāhā || vaṃ vasudhārāya sarvamātṛhbyo namaḥ svāhā || phem vemacitrāya asurādhipataye namaḥ svāhā || svāhā sarvanāgebhyo jalādhipataye namaḥ svāhā || sarvabhūtebhyo namaḥ svāhā || haṃ hāṃ hị̣ hrīṃ hūṃ 2 phaṭ svāhā || ||

iti raktayamāri-nāma-dhāraṇī samāptā || ||

[132] oṃ namaḥ prasannatārāyai || prasannatāre amṛtamukhi amṛtalocane sarvārthasādhani paramārthasādhani sarvasattvavaśaṃkari śāntiṃ puștịm dhṛtiṃ rakṣāṃ kuru oṃ āḥ hūṃ hrīṃ hūṃ phaṭ svāhā || ||

iti prasannatārā-nāma-dhāraṇī samāptaḥ || ||

3 -asura-] pc.; -asuramṛ- ac. 17 namaḥ svāhā] $p c . ;$ svāhā $a c$. 
[133] oṃ namaḥ śrī-mahābhairavāya || oṃ namo daṃșțrotkațabhairavāya asimusalaparaśupāśagṛhītahastāya oṃ amṛtakuṇụaline kha 2

khāhi 2 tișṭha 2 bandha 2 hana 2 daha 2 paca 2 matha 2 sarvayakṣarākṣasabhūtapretapiśācāpasmārān sarvasattvānāṃ ca rakṣāṃ kuru hūṃ phaṭ svāhā || ||

iti śrī-mahābhairavasya dhāraṇī samāptaḥ || ||

[134] oṃ namaḥ śrī-vighneśvarāya || oṃ namaḥ vighnāntakṛtmahākrodha mahābalaparākrama imaṃ mantraṃ sarvatathāgatā<152r>nāṃ bhāṣitam mama sarvavighnavināyakānāṃ kāyavākcittaṃ kīlaya oṃ amṛtakuṇụaline sarvavighnān cheda 2 bheda 2 truta 2 daha 2 paca 2 matha 2 oṃ ā vighnāntakṛt 10 hūṃ phaṭ svāhā || ||

iti śrī-siddhivighneśvara-dhāraṇī samāptā || ||

[135] oṃ namaḥ śrī-mahākālāya || śāsanopakāriṇe yadi prajñāsamarasi kāli kalāli vetāli caṇḍāli siddhi yogini akṣobhyaśirasidhāriṇi sarvasattvānāṃ pracchopaya 2 gṛhṇa 2 sarvaśatrūṇām māraya 2 kāraya 2 bandha 2 cheda 2 bheda 2 truta 2 mama sarvasattvānāṃ ca rakṣa 2 hūm phaṭ svāhā || ||

iti śrī-mahākālasya dhāraṇī samāptaḥ || ||

[136] om namaḥ śrī-gaṇeśāya ||

sumukhaś caikadantaś ca kapilo gajakarṇakaḥ |

lambodaraś ca vikaṭo vighnarājo vināyakạ̣ ||

dhūmraketur gaṇādhyakṣo bhālacandro gajānanạ̣ |

vakratuṇ̣ạ̣ śūrpakarṇo herambas skandapūrvajạ̣ \||

ṣoḍaśaitāni nāmāni yaḥ paṭhec chṛnuyād api ||

vidyārambhe vivāhe ca praveśe nirgame tathā |

saṃgrāme saṃkațe caiva vighnaṃ tasya na vidyate || ||

iti śrī-gạ̣eśasya ṣoḍaśanāma samāptā || ||

19 -kaḥ] corr.; -kam ms. 21 dhūmra-] corr.; dhruma- ms. gaṇādhyakșo] corr.; gaṇādhikṣo ms. --naḥ] corr.; -nam ms. 22 śūrpakarṇo] corr.; sulparṇo ms. - -bas] corr.; -ba ms. -jah]] corr.; -jam ms. 
[137] oṃ namo bhagavatyai ārya-śrī-vasudhārāyai || vasudhārāyā pațasya pra<152v>timāyā vāgrataś candanena caturasraṃ maṇḍalakạ̣ kṛtvā | tatra bhagavatīm manasāropya pūjayitvā candanāliptapāṇih | vasudhārādhāraṇīpustakasūtrāvabaddhakusumamālāṃ puratạ̣ sthāpitodakabhājane nikṣipya sarvasattveșu mahāmaitrīcittam ālambyābhimatasiddhau hṛdayam ādhāya vasudhārādhāraṇiṃ paṭhet || pațhaṃś ca svāhānvitamantrāṇāṃ svāhāśabdoccārayet || sitapuṣpadūrvāsahitākhaṇḍataṇụulāny udakabhājanena dadyāt || șaṇmāsaṃ yāvat pāṭhāvasāne ca śucibhūmau pradeśe tad udakaṃ visarjayed iti || ||

iti śrī-vasudhārā-dhāraṇy-upadeśa samāptā || ||

[138] oṃ namạ̣ suvarṇaprabhā-indrarājāya || tadyathā || buddhamodanaṃ bodhisattvam mahāsattvaṃ bhagavantam etad avocat || kulaputra suvarṇanāmendrarājadhāraṇị̣ kadācid kulaputro vā kuladuhitā vā imu dhāraṇị̣̄ dhārayișyanti | kaṇțhe baddhvā dhārayitavyā iha dhāraṇīdhāreṇa punyasambhāramahālalitam vivardhayiṣyanti || namo daśabhūmisarvabuddhabodhisattvaśrāvakapratyekabuddhebhyaḥ namaḥ śākyamunaye | namaḥ catustathāgatasuvarṇaprabhā-indrarājasutāya | sarvabuddhabodhisattvebhyah || atha imāni dhāraṇī bhāṣante sma <153r> || namo ratnatrayāya || tadyathā || kuṭi kuṭini amitākośani amriri niyiri svāhā || || imāni dhāraṇi dhārayiṣyanti kaṇṭhe baddhvā dhārayitavyā || puṇyaskandhaaprameyaih vivardhayiṣyanti anantaiḥ buddhamānanīyaś ca pūjanīyaś ca stotrayiṣyanti || tena paramabuddhabodhiyāne vivāṃgriliṃ dadāpayiṣyanti yo yah icchate sarvaṃ siddhyanti || ||

iti punyyavivardhana-nāma-dhāraṇī samāptā || ||

[139] oṃ namo buddhāya || evaṃ mayā śrutam ekasmin samaye bhagavāñ chrāvastyāṃ viharati sma || jetavane vihāre || tadānandasyākarṣaṇārthaṃ prakṛter mātaṅgadārikāyā mātā madhye gṛhānganasya gomayenopaliptvā darbhān saṃstîryāgniṃ prajvālyāṣțaśatam arkapuṣpāṇām mantreṇāvartyaikaikaṃ puṣpam agnau pratikṣipanti sma | tatreyam mantrah || amale vimale kusume sumane | yena baddhāsi vidyut icchayā devo varṣati vidyotati garjati vismayaṃ mahārājasya

12 bodhisattvam] $p c$; bodhisasattvam ac. 13 kula-]pc; kutala- $a c .16$-pratyekabuddhebhyah] corr.; -pratyekaddhebhyaḥ ms. 21 -aprameyaiḥ] corr.; -apramāyaih ms. 27 -dārikāyā] corr.; -dāriyā ms. 30 baddhāsi] corr.; buddhosi ms. 
samabhivardhayitum devebhyo manuṣyebhyo gandharvebhyạ̣ śikhigrahā devā viśikhigrahā devā ānandasyāgamanāya saṃkramaṇāya grahaṇāya juhomi svāhā ||

iti kṛte ānandaś caṇḍālagṛhaṃ gataḥ cittākṣiptaḥ || prārudann āha || <153v> vyasanaprāpto 'ham asmi na ca me bhagavān samanvāharati || atha bhagavān ānandaṃ samanvāgatya caṇḍālamantrāt pratihṛtavān anayā vidyayā || tadyathā ||

sthitir acyutir anīti svasti sarvaprāṇibhyạ̣| saraḥ prasannaṃ nirdoṣaṃ praśāntam sarvato 'bhayaṃ | ìtayo yatra śāmyanti bhayāni calitāni ca | taṃ vai devā namasyanti sarve siddhāś ca yoginạ̣ | etena satyavākyena svasty ānandasya bhikṣave \| athānandas tata smṛtimān svaṃ vihāraṃ gatạ | bhagavantạ̣ natvaikānte sthitaḥ || atha bhagavān ānandam evam āha || udg̣̣hṇa tvam ānanda imāṃ șaḍakṣarīm vidyāṃ dhāraya vācaya paryavāpnuhi | ātmano hitāya sukhāya bhikṣūṇām bhikṣuṇīnām upāsakānām upāsikānāṃ hitāya sukhāya || iyam ānanda șaḍakṣarī vidyā șaḍbhị̣ samyaksambuddhair bhāṣitā caturbhiś ca mahārājaị śakreṇa brahmaṇā ca dhāritā || mayā caitarhi bhāṣitā | tvam apy etarhi | ānanda tām dhāraya vācaya paryavāpnuhi yaduta || tadyathā || aṇḍare pạ̣ḍare karaḍe keyūre arcihaste kharagrīve bandhumati viḍamati dhara vidha cili mili viloḍe viśāni loke viśa cala cala golamati kaṇḍavilā cile mile sātini nimne yathāsaṃvibhakte gālayati bhaṇḍavilā svāhā || yasya kasyaci<154r>d ānanda șaḍakṣaryā vidyayā paritrāṇạ̣ svastyayanaṃ kuryāt || sa yadi vadhyārho bhaved daṇḍena mucyate dậ̣̣arhaḥ prahāreṇa prahārārhaḥ paribhāṣaṇayā paribhāṣyārho romaharṣaneṇa romaharṣaṇārhạ̣ punar eva mucyate || nāham ānanda taṃ samanupaśyāmi sadevake loke samārake sabrāhmaṇake saśramaṇabrāhmaṇikāyāṃ prajāyāṃ sadevamānuṣāsurāyām || yasyānanda șaḍakṣaryā vidyayā rakṣāṃ parigraheṇa kṛtāyāṃ paritrāṇe parigrahe paripālane sūtreṇa baddhena svastyayanena kṛtena syād anyathābhāvaṃ varjayitvā paurāṇaṃ karmavipākam || || idam avocad bhagavān āttamanā sā ca sarvāvatī parșan ānandādibodhisattvāś ca bhagavato bhāṣitam abhyanandann iti || ||

ārya-ṣaḍakṣarī-dhāraṇī samāptaḥ || ||

2 juhomi] corr.; jahomi ms. $\mathbf{6}$ samanvāgatya] corr.; samanvādgatya ms. 20 kharagrīve] corr.; saragrīve ms. 32 bhagavato] $p c$.; bhagatovato $a c$. 
[140] oṃ namo lokanāthāya || evaṃ mayā śrutam ekasmin samaye bhagavān āryāvalokiteśvarasya bhavane potalake parvataśikhare ramye nānāvṛkșasahasrāvakīrṇe jāmbunandasuvarṇakāñcanāvabhāse nānāratnamayavimānabhūmipradeśe viharati sma || anekair devanāgayakṣāsuragaruḍakiṃnaramahoragamanuṣyāmanuṣyakoținiyutaśatasahasraị̣ sārdhaṃ tatra bhagavān puraskṛtaḥ <154v> satkṛto gurukṛto mānitaḥ pūjito 'rcito apacāyitah parivṛtaḥ dharmaṃ deśayati sma || ādau kalyāṇam madhye kalyāṇaṃ paryavasāne kalyāṇaṃ svartham suvyajanaṃ kevalaparipūrṇaṃ pariśuddhaṃ paryavadātaṃ brahmacaryaṃ samprakāśayati sma \|| atha khalu brahmādyā devā āryāvalokiteśvaraṃ saṃstuvanti sma || he bhagavan kṛtakṛtyaḥ kṛtakaranīyaḥ apahṛtabhārah | anuprāptasvakārthah parikṣiṇabhavasamyojanaḥ samyagājñāsuvimuktacittaḥ | suvimuktaprajñaḥ | ājāneyo mahānāgaḥ sarvacetovaśiparamapāramitāprāptaḥ | paripūrṇapuṇyajñānasambhāraḥ | uttīrṇabhavakāntāraḥ | parahitayatnaḥ mahākarunāābaddhahṛdayaḥ | prajāparamasattvavatsalạ̣ sukhapradạ̣ snehaprasūtayaśāḥ || anantasattvottaraṇaḥ kuśalakṛtapratijñaḥ sugatātmajas tribhuvanaikabāndhavaḥ vigatarāgo vigatadveșo vigatamohaḥ | trimalaprahīṇaḥ | traividyāpāragaḥ | șaḍabhijñāprāptah | nyagrodhaparimaṇḍalaḥ | dvātrimsśanmahāpuruṣalakṣaṇadharaḥ | aśîtyanuvyañjanālaṃkṛtagātraśobhạ̣ | suvarṇavarṇaḥ ratnacchaviḥ | pāṇḍarāvadātamūrtị̣ | navanāgakesarāruṇajațādharah | jațākalāpopa<155r>gūḍhamūrdhị̣ | amitābhajinamakuțaraśmijvalitavyomaprabhạ̣ | kāñcanādriprathitayaśah | suvipulatejaḥ udayodgīrṇadinakaroṣnịșạ | prajvalitamaṇikanakayajñopavītārdhakāyaḥ | daśabhūmipratișțhitạ̣ | daśapāramitābharaṇaḥ | akhaṇ dịtaśîlaḥ | acchidrašîlaḥ | siṃhavikrāntoraḥsthaḥ gambhīranādaḥ siṃhanādaḥ snigdhanādaḥ | komalalalitagātrah | vṛṣabhekṣanagatị | dakșināavartasunābhih gambhīranābhị̣ | ardhacandrālaṃkṛtatilakaḥ | vistīrṇalalāto bimboșțhạ̣ pralambabāhuh nirantarabhrūḥ | uttunganāsa kalaśākṛtigrīvaḥ | dīrghānguliparvāṇi mṛdutāmranakhạ̣ | jālāvanaddhahastaḥ | cakrālaṃkṛtapāṇipādatalaḥ | śaratkamalanibhaḥ | sūkșmo pavitragātraḥ | brahmagambhīrasvaraḥ hṛdayaṃgamaḥ | priyaṃgamạ̣ | premaṇiyo darśanīyaḥ | jāmbunadakāñcanavarṇaḥ | ramaṇīyaḥ kamalākṣaḥ | kamalodbhavạ̣ kamalasambhavạ̣ kamalāsanạ̣ kamalamukhạ̣ kamalạ̣ kamalahastạ̣

4 -pradeśe] corr.; -pradeśo ms. 16 sugatātmajas] pc.; pratisugatātmajas ac. 23 -yaśaḥ] corr.; -śāḥ ms. 26 -nādaḥ] corr.; -nāpaḥ ms. 30 -parvāṇi] corr.; -paṇarviṇị ms. • -nakhaḥ] corr.; -naḥkha ac., -khanaḥ pc. 31 -pādatalaḥ] pc.; -pāṇidatalaḥ ac. • śaratkamala-] corr.; plaratkșamala- ms. 
kamaṇḍaluvyagrahastaḥ | kṛ̣ṇājinadharạ̣ | kṛpānidhidharaḥ tridaṇḍadharạ̣ akṣadharaḥ | padmadharaḥ | pūtaḥ pavitrāmaraḥ | pūrvābhilāṣi amṛtavarṣaḥ | cintāmaṇikalpah sudarśanaka<155v>lpavṛkṣaḥ sarvasattvadhṛtikarah | sarvavyādhipraśamanaḥ prītikaraḥ sarvasattvopajīvyaḥ buddhanirmāṇakāyaḥ | sugataveśadharaḥ | sugatadhātudharaḥ | ekaikaromakūpasarvasattvasārạ̣ kṛtapunyaḥ kṛtakṛtyạ̣ kṛtakaraṇīyaḥ kṛtakuśalạ̣ kṛtaniścayạ̣ uttaptavīryaḥ saṃsārānikrāntaḥ saddharmayauvarājyābhiṣekaḥ tārānugatacaraṇaḥ bhṛkuṭikṛtajñaḥ jayavanto nayavantaḥ smṛtivanto mahāprajñāvantaḥ | mahāvikramavantạ̣ guṇavanto maitrīmantaḥ śīlavantaḥ śāntavantạ̣ stutivantaḥ bhāgyavantaḥ | arthavantaḥ | arthānāṃ dātāraḥ | saṃśayānāṃ chetārạ̣ dharmāṇāṃ pravaktāraḥ lokānāṃ sāātārah | paripūrṇacandramaṇḍalamukhạ̣ sarvaratnakhacitanitambapradeśạ suvarṇayūpasthāyī sūryasahasrātirekatejạ̣ | ruciraśarīraḥ | brahmendrādinamaskṛta iti || || yaḥ kaścid āryāvalokiteśvarasya nāmāṣțottaraśatena stotrāpahāraṃ kuryāt || tasya pañcānantaryāṇi karmāvaraṇāni parikṣayam gacchanti | sarvamaṇḍalapraviṣțo bhavati | sarve ca mantrās tasya sidhyanti | anekakalpakoṭiniyutaśatasahasrāṇi durgatiṃ nābhijānāti | avīciṃ na praviśati || prātar utthāya yaḥ paṭhed vā<156r>cayed vā tasya kāye kuṣthavicarcikākāsaśvāsasarvavyādhivinirmukto bhavati | janmani janmani jātismaro bhavati | devaputrasadṛśo bhavati tasya ca maraṇakālasamaye sukhāvatyāṃ lokadhātāv upapadyate | jātau jātau āryāvalokiteśvareṇāvirahito bhavati | satatajāpena medhāvī bhavati | śūraḥ surūpạ̣ susvarạ̣ sarvaśāstraviśārada ādeyavākyo bhavati || anena stotropahāraṃ kuryāt | dvāṣaștigañgānadīvālikāsamā buddhā bhagavantaḥ pūjitā bhavanti samo vipāko nāsti viśeṣaḥ || ||

iti sarvajñajinadhāturatnakaraṇḍaka-nāma bhagavata āryāvalokiteśvarastotram samāptā || ||

[141] oṃ namaḥ vajragandhārī kṛṣnā șaṇmukhī dvādaśabhujā ūrdhvapingalakeśī pratyālị̣̄hapadā dạ̣șțrākarālavadanā | pratimukham trinayanā dakṣiṇaṣaḍbhujeṣu yathākramaṃ vajravajraghạ̣țākhaḍgatriśūlabāṇacakrāṇi | vāmaṣaḍbhujeṣu khaṭvāngāṅkuśadhanuḥ paraśupāśahṛttarjanyaḥ | prathamamukhaṃ kṛṣnạ̣

2 pavitrāmaraḥ] corr.; paritramaraḥ ms. 6 -niścayaḥ] corr.; -niścaḥ ms. 19 paṭhed vā] corr.; dvāțhe $a c$., țhed vā pc. 21 maraṇa-] pc.; ramaṇa- ac. 27 sarvajña-] pc.; sarvajñatāac. 30 ūrdhva-] corr.; ūrdva- ms. 32 -bāṇa-] corr.; -bāṇavāra- ms. 
aparāṇi mukhāni pañcavarṇāni | viśvapadmasūryāsanā ceti | atra ca bhagavatī dhāraṇi ||

namo ratnatrayāya || namaś caṇḍavajrapāṇaye mahāyakṣasenāpataye namo bhagavati <156v> mahāvajragandhāri anekaśatasahasraprajvalitadīptatejāyai | ugrabhīṣmabhayānakāyai | yoginīya bhīșmabhaginīye dvādaśabhujāyai vikīrṇakeśāyai | anekarūpavividhaveśadhāriṇiye ehy ehi bhagavati vajragāndhāri trayāṇām ratnānāṃ satyena ākaḍhya 2 baladevādikaṃ ye cānyasamayena tiṣthanti tān āvartayiṣyāmi | śīghram gṛhṇa 2 oṃ ala 4 hulu 2 suru 2 curu 2 dharma 2 ranga 2 rañgāpaya 2 pūraya 2 āviśa 2 bhagavati mahāvajragāndhāri siddhacaṇḍavajrapāṇir ājñāpayati hrīḥ hạ̣ hūṃ phat svāhā || asyā karmaprasaro 'nekavidha iti || ||

ārya-śrī-vajragāndhārī-nāma-dhāraṇī samāptā || ||

[142] om namo kālacakrāya || akacațatapayasaśabde ālikālim nītārtheṇoktā || ālikālikālijāpena trailokyaṃ kṣobhayen mantrī | lakṣajāpeṇa kiṃ punar ekamātram iti || ādikādi ucyate ||

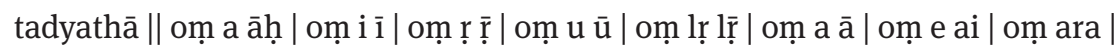
oṃ āra | oṃ o au | oṃ ala | oṃ āla | oṃ ha hā | oṃ pa pā | oṃ ra rā | oṃ va vā | oṃ la lā \|

iti sṛṣṭikrameṇālijāpaḥ śvāsapraveśena | śvāsanirgameṇa kāliḥ | oṃ ka kā | oṃ kha khā |<157r> oṃ ga gā | oṃ gha ghā | oṃ ṅa nāā oṃ ca cā | oṃ cha chā $\mid$ oṃ ja jā $\mid$ oṃ jha jhā | oṃ ña ñā | oṃ ța țā | oṃ țha țhā | oṃ ḍa ḍā $\mid$ oṃ ḍha ḍ̂ā | om ṇa ṇā | om pa pā | oṃ pha phā | oṃ ba bā | oṃ bha bhā | oṃ ma mā | om ta tā $\mid$ om tha thā | oṃ da dā | oṃ dha dhā | oṃ na nā | oṃ sa sā | oṃ hya hyā | om șa șā | oṃ śa śā | oṃ hva hvā iti ādau oṃkāram dattvā kṣobhạ̣e | akṛșțavarṇo vauṣaṭpadeyam || evạ̣ purakṣobhamantrah || ||

iti kālacakranibaddha-dhāraṇī samāptạ̣ || ||

[143] oṃ namo hevajranāthāya \| praṇamya nāthaṃ hevajraṃ sarvadharmaikasaṃvaram | saṃgṛhyate yathāmnāyaṃ bāhyapūjāvidhir mayā || tatra śrī-hevajrayogavān mantrī pratyūṣe yathāvasaraṃ vā kṛtasamārjanādike bhūbhāge hastam dattvā | oṃ rakṣa 2 hūm 2 phat svāheti bhūmim adhișṭāya || tatra pañcāmṛtasugandhādivațikayā | tat tadbhūmyavimokṣapūrvakam |

13 -ṇoktā] corr.; -loktā ms. 14 lakṣajāpeṇa] pc.; lakṣapājāpeṇa $a c$. 
pīṭhopapīṭha kṣetropakṣetra cchandohopacchandoha melāpakopamelāpaka pīlavopapilava śmaśānopaśmaśāna ity uccārayet | caturasraṃ maṇḍalam upalipya | oṃ vajrarakṣe hūṃ ity ebhir mantrair hṛdbījakiraṇākṛștạ̣ bhagavantaṃ samaṇḍalạ̣ sarvavīravīreśvarīṃ saṃkṣeparūpaṃ tatrāropya arghapādyādidānapūrvakam așțamātṛbhị̣ sampūjya hūṃkārajaṃ tadabhi<157v>mantritapuṣpādikaṃ tasmai dadyāt || tatra tryakṣarahṛdayopahṛdayamantrair bhagavatyai svamantrābhyāṃ bhagavatyai || oṃ gauri hūṃ 3 phaṭ svāhā || oṃ cauri hūṃ 3 phaṭ svāhā || oṃ vetāli hūṃ 3 phaṭ svāhā || oṃ ghasmari 3 phaṭ svāhā || oṃ pakvasi hūṃ 3 phaṭ svāhā || oṃ śabari hūṃ 3 phaṭ svāhā || oṃ caṇḍāi hūṃ 3 phaṭ svāhā || oṃ dombi hūm 3 phaṭ svāhā || iti mantrair yathāsthānam gauryādīnām | tato bāhyādisarvapūjādibhị̣ sampūjya tryakșaragarbhitapuṣpadāmena mantraiḥ || oṃ aștānanāya hūṃ 3 phaṭ svāhā || oṃ pingārdhakeśavarmaṇe hūṃ 3 phaṭ svāhā || oṃ caturvimśatinetrāya hūṃ 3 phaṭ svāhā || oṃ ṣoḍaśabhujāya hūṃ 3 phaṭ svāhā || oṃ kṛṣnajīmūtavapuṣe hūm 3 phaṭ svāhā || oṃ kapālamālānekadhārinyai hūm 3 phaṭ svāhā || oṃ ādhmātakrūracittāya hūm 3 phaṭ svāhā || oṃ ardhendudaṃsțriṇe hūṃ 3 phaṭ svāhā || iti mantraiś ca saṃstutya yathāyogam anyatstutipraṇidhānādikaṃ ca kṛtvā śatākṣaramantreṇa dṛ̣̂hī kuryāt || mantrạ̣ || oṃ vajrasattva samayam anupālaya vajrasattva tenopatișthita dṛḍho me bhava sutoṣyo me bhava hṛdaye me bhava anurakto me bhava sarvasiddhim me prayaccha sarvakarmasu karmacittạ̣ śreyaḥ kuru hūm ha ha ha ha hoḥ bhagavan <158r > sarvatathāgatavajra mā me muñca vajrībhava mahāsamayasattva āḥ || iti || tataḥ kṛto vaḥ sarvasattvārthaṃ siddhị̣ dattvā yathānugā gacchadhvaṃ buddhaviṣayapunarāgamanāya ca mur iti visarjyatam cakram ātmany antabhāvā rekhālopādikaṃ kuryāt || nairātmyapūjām api || tathaiva maṇụalakam upari 'py āropya ca maṇdalacakraṃ tryakșaraṃ svahṛnmālāmantreṇa nāyikāyai || anyāsāṃ praṇavasvāhāvidarbhitasvabījamantraị pūjādikaṃ yathāsthānaṃ dattvā tryakṣararahitapuṣpadānamantraiḥ stutiṃ ca kuryāt śeșaṃ pūrvavad iti | bāhyapūjāvidhị̣ | smṛtyai saṃgrahād yan mayārjitam | puṇyạ̣ tenāstu loko yaṃ satpūjābhājanaṃ rasam || ||

iti śrī-hevajradhāraṇapūjāvidhi-saṃgrahạ̣ samāptā || ||

2 pīlavopapīlava] corr.; pīlacopapīlavaupapīlava ms. • uccārayet] corr.; uccāryarayen ms. 3 kiraṇākṛșțam]] corr.; kaṇākṛștam ms. 7 hṛdayopahṛdaya-] pc.; hṛyodapahṛdayaac. $\mathbf{8}$ vetāli] $p c$.; vetāli 3 ac. 16 -dhāriṇyai] corr.; -dhāriṇyaika ms. ādhmāta-] corr.; ādhyāta- ms. 19 anupālaya] corr.; anupāla ms. 24 yathā-] $p c . ;$ yatvāthā- $a c$. 
[144] oṃ namaḥ śrī-herukāya || kroḍhapingalalocanāya sahasratejase dhara 2 jvala 2 prajvala 2 triśūlavyagrahaste sara 2 prasara 2 hasa 2 gṛhṇa 2 gṛhṇāpaya 2 trāsaya 2 sarvaduștasattvānāṃ nāgarājānām sarpānāṃ mukhaṃ kīlaya 2 śūlaṃ nāśaya 2 gulmaṃ nāśaya 2 plīhaṃ nāśaya 2 aśmarīṃ nāśaya 2 evaṃ sarvān rogān nāśaya 2 ekāhikaṃ dvyāhikaṃ tryāhikaṃ cāturthakaṃ sarvajvaraṃ sāṃnipātikam jvaraṃ dușțjvaraṃ māhendrajvaraṃ vātikaṃ paitti<158v>kaṃ śleṣmikaṃ sāṃnipātikaṃ māsārdhamāsikam sāṃvatsarikaṃ evaṃ sarvān rogān nāśaya 2 vināśaya 2 hūṃ śrī-heruka sarvasattvānāṃ ca mama saparivārasya śāntiṃ svasti kuru svāhā || ||

iti śrī-herukasya-nāma-dhāraṇī samāptaḥ || ||

[145] oṃ namo bhagavatyai ārya-mahāpratisarāyai || pūrvoktavidhānena śūnyatābhāvanānantaram akārajendumaṇḍale pītapaṃkārākṛtavividharaśmiparārthaṃ pariṇamya bhagavatīm mahāpratisarāṃ jhațity ātmānaṃ nișpādayet | pītāṃ caturmukhāṃ trinetrāṃ așțabhujām | prathamamukhaṃ pītạ̣ dakṣiṇaṃ sitam | paścimaṃ nīlaṃ vāmaṃ raktam | dakṣiṇabhujaiḥ khaḍgacakratriśūlaśaradharām | vāmabhujaị paraśucāpapāśavajradharām | viśvapadmacandrāsane lalitākṣepasaṃsthitāṃ raktaprabhāmaṇḍalām | sarvābharaṇabhūṣitām | vicitravastravasanāṃ pațạạ̣śukottarīyām | nānāratnamakuțām evaṃ vicintya | tataḥ kāyavākcittacandreșu | oṃ āḥ hūṃ sitapītanīlatryakṣarāṇi cintayet | tatas tān antare candrasthaprakāraṃ vicintya nānāvidhadevatībhir ātmānaṃ pūjitaṃ dṛșțā tāvad bhāvayed yāvat khedo na jāyate | khede sati svahṛccandre muktāhāropamam mantraṃ paśyañ japet || oṃ maṇidhari vajiriṇi mahāprati<159r>sare hūṃ hūṃ phaṭ phaṭ svāhā || ||

ārya-mahāpratisarāyā dhāraṇī samāptaḥ || ||

[146] oṃ namo bhagavatyai ārya-mahāpratisarāyai || prathamaṃ yogī samāhitacitto bhūtvā hṛdi paṃkārapariṇataṃ viśvapadmam | tatropari akārapariṇatam candramaṇụalaṃ tatra pìtapakāraṃ vinyasya tadvinirgataraśmibhir gurubuddhabodhisattvān saṃcodyānīyāgrato vicitrāsanopavișțān | vandanāpūjanāpāpadeśanāpuṇyānumodanātriśaraṇagamaṇabodhicittotpādapunyaparināmanākṣamāpanāḥ kuryāt | tato

5 rogān] pc.; rokāgān ac. • dvyāhikaṃ] corr.; dvyāddhikaṃ ms. • tryāhikaṃ] corr.; tryātrikaṃ ms. 6 paittikaṃ] corr.; pītikam ms. 18 lalitākṣepa-] corr.; lalikșepams. 23 muktāhāropamam] corr.; muktāhārāpasam ms. 31 -āpanāḥ] corr.; -āpannāḥ ms. 
maitrīkaruṇāmuditopekṣābhāvanā || oṃ śūnyatājñānavajrasvabhāvātmako 'ham | ity uccārya śūnyam vibhāvya tatah svacitte jhaṭiti candrasthapītapaṃkāraṃ vibhāvya tatpariṇāmena pratisarāṃ supītāṃ ratnamakuṭinīm pītaśuklanīlaraktacaturmukhīm | trinetrām așțabhujāṃ dakṣiṇabhujaiḥ khaḍgacakratriśūlaśaradhāriṇīm | vāmabhujaị̣ pāśaparaśucāpavajradhāriṇīm | padmacandrāsane lalitākṣepasaṃsthitām | nānāratnābharaṇabhūṣitāṃ vibhāvya śiraḥkaṇṭhahṛdayopahṛdayeșu | candrasthaśuklaraktapītakṛṣnān || oṃ āḥ praṃ hūṃkārān vinyasya | etan mantroccāreṇainam ātmānaṃ devīrūpam adhitișṭhet <159v> || tataḥ svahṛdayān nirgataraśmibhir akṣobhyādīn saṃcodyānīyābhiṣekaṃ gṛhītvā mukuṭe adhipatim akṣobhyaṃś cintayet || tatạ̣ svahṛdayāt pūjādevīḥ saṃsphārya pūrayitvā tu kṛtvā śatākṣaramantram āvartya ca tāvad bhāvayed yāvat khedo na jāyet | khinnacitte sati mantraṃ japet || oṃ maṇidhari vajriṇi mahāpratisare hūṃ hūṃ phaṭ phaṭ svāhā || hūṃ hūṃ phaṭ rahito 'pi mantraḥ || ||

ārya-mahāpratisarāyā sādhana samāptaḥ || ||

[147] oṃ namo bhagavatyai ārya-mahāmāyūryai || pūrvoktavidhānena viśvapadmacandre haritamaṃkārajām mahāmāyūrīṃ haritavarṇāṃ trimukhāṃ ṣaḍbhujām pratimukhaṃ trinetrāṃ kṛṣnaśukladakṣiṇetaravadanām | dakṣiṇatrihasteșu yathākramaṃ mayūrapicchabāṇavaradamudrām | tathā vāmatrihasteșu ratnacchațācāpotsaṅgasthakalaśām | vicitrābharaṇāṃ śrnngārarasām navayauvanām | candrāsanacandraprabhāvatīm ardhaparyan̉kiṇim amoghasiddhimukuṭām bhāvayed ātmānam || tato 'syāḥ śi raḥkaṇthhahṛdayanābhisthacandreșu yathākramam || oṃ āḥ maṃ hūm || ity akṣaracatuṣțayam vibhāvya spharaṇaṃ saṃharạ̣aṃ kurvìt | tato mantram japet || oṃ mahāmāyūrīvidyārājñ̄i hūṃ hūṃ phaṭ svāhā || || <160r>

ārya-mahāmāyūrī-dhāraṇī samāptạ̣ || ||

5 -triśūla-] pc.; -śūtrila- ac. 9 devīrūpam] corr.; devīrūm ms. 10 saṃcodyānīyābhișekaṃ] corr.; saṃcodyāyābhișekaṃ ms. 11 akṣobhyaṃś] corr.; akșobhyaṃ ms. •-devīḥ] corr.; -dravīḥ ms. 13 khinnacitte] corr.; khinnavittasavitta ms. 
[148] oṃ namo bhagavatyai ārya-mahāsāhasrapramardanyai || pūrvoktavidhānena viśvapadmacandre bụ̣kārodbhavāṃ mahāsāhasrapramardanīm ātmānaṃ dhyāyāt || śuklām ekamukhīṃ șaḍbhujāṃ dakṣiṇatribhujeșu khaḍgabāṇavaradamudrāḥ | vāmatribhujeșu dhanuspāśaparaśuvaḥ | vicitrālaṃkāradharām | rūpayauvanaśrñgāravatīṃ vairocanakirịtiyuktām | padmacandrāsanaprabhām || ||

ārya-mahāsāhasrapramardanī-sādhanam iti || ||

[149] oṃ namo bhagavatyai ārya-mahāmantrānusāriṇyai || pūrvoktavidhānena mahāmantrānusāriṇī caturbhujaikaimukhī kṛ̣ṇā | dakșiṇabhujadvayena vajravaradavatī | vāmabhujadvayena paraśupāśavatī | hūṃkārabīiā | akṣobhyakirīịinī sūryāsanaprabhā ceti || ||

ārya-mahāmantrānusāraṇī-sādhanam iti || ||

[150] oṃ namo bhagavatyai ārya-mahāśītavatyai || pūrvoktavidhānena mahāśītavatī caturbhujaikamukhī raktā dakșinabhujadvaye akṣasūtravaradavatī | vāmabhujadvaye vajrāñkuśahṛtpradeśasthapustakavatī | jīmbījā amitābhamakuṭā | ardhaparyan̉kasthitā nānālaṃkāravatī sūryāsanaprabhā ceti || ||

ārya-<160v>mahāsiītavatī-sādhana-nāma-dhāraṇī samāptāḥ || ||

iti pañcarakṣā-mahādevyā sādhana-dhāraṇi-saṃkṣipta samāptah || ||

[151] oṃ namo bhagavatyai ārya-pratisarāyai | prathamaṃ tāvan mantrī mukhaśaucādikaṃ kṛtvā manonukūle sthāne sukhāsane upaviśya || oṃ āḥ rakṣa 2 hūṃ phaṭ svāhā || iti sthānātmayogarakṣām adhitișțhet | tataḥ svahṛdaya akārajam candramaṇḍalam | tasyopari paṃkāraraśmivinirgatān | gurubuddhabodhisattvān avabhāsya | purato dṛ̦țvā mahāpratisarāḥ pratisarāpramukhān sagaṇaparivārān pūjayet | puṣpadhūpadīpagandhabalinaivedyādīn ḍhaukayitvā pāpaṃ pratideśayet | triratnaśaraṇaṃ gacchet | bodhicittotpādayet | kuśalaṃ pariṇamya kṣamāpayet | tataś caturbrahmavihārān bhāvayet | tadduḥkhoddharaṇā karuṇā | sukhapratișthāpanā maitrī | sthirasukhatvena muditā | tathārūpatvenopekṣā | tataḥ sarvadharmān manasāvalambya nirvikalpakaṃ

7 sādhanam] $p c$; sādhanasam $a c .21$ manonukūle] $p c$; manorūnukule $a c$. 
vicintya | oṃ śūnyatājñānavajrasvabhāvātmako 'ham | tato hūṃkāreṇa viśvavajramayībhūmīm adhitișthet | tenaiva ca vajreṇa vajrapañjaram | vajraprākāram | vajravitānaṃ ca vicintya | tanmadhye suṃkārapariṇa<161r>taṃ sumeruṃ parvatam | mahāmokṣapurabhavanam | nānākusumābhikīrṇam | tasyopari hūṃkāreṇa viśvavajram | praṃkārapariṇatạ̣ viśvapadmaṃ karṇikākesarānvitam | tasyopari candramaṇḍalaṃ madhye praṃkāraraśmim saṃsphārya | taiḥ pañcajñānātmakam ākṛṣya | sarvatathāgataih sadevīkṛtya | dravībhūtabījapariṇāmeṇa vakṣyamāṇavarṇākṛtị̣ | mahāpratisarā gauravarṇā dvirașțavarṣākṛtị̣ | caityālaṃkṛtamūrdhacandrāsanasthā sūryamaṇụalālīụhā vajraparyan̉kiṇi trinetrā | așțabhujā calatkuṇụalaśobhitā hāranūpurabhūṣitā | kațakakeyūramaṇditamekhalā | sarvālaṃkāradhāriṇī | tasyā bhagavatyāḥ prathamamukhạ̣ gauravarṇam | dakṣiṇaṃ kṛ̣̣̣am | pṛșthe pītam | vāme raktam | dakșiṇaprathamabhuje cakram | dvitīye vajram | tṛtiye śaraḥ | caturthe khaḍgaḥ | vāmaprathamabhuje vajrapāśạ̣ | dvitīye triśūlam | tṛtīye dhanụ̣ | caturthe paraśụ̣ | bodhivṛkṣopaśobhā | nānāpuṣpaphalādyalaṃkṛtā | brahmāviṣnumaheśvaranandikeśvarādibhị̣ saṃstutā | devanāgayakṣagandharvadakṣiṇapārśve satkaraṇīyā | indrayamavaruṇavaiśravaṇāsuragaruḍakiṃnaramahoragādibhị̣ devaiḥ stutā || rāgadveșamohavāsanānusaṃdhipāśacchedanakarī | para<161v>mantramudrāviṣakākhordacūrṇaprayogavidveṣaṇābhicārakāṇāṃ ca duṣṭacittānāṃ vidhvaṃsanakarī | sarvabuddhabodhisattvāryagaṇavarapūjābhiratānāṃ paripālanakarī | mahāyānodgrahaṇalikhanapaṭhanavācanasvādhyāyanaśravaṇadhāraṇābhiyuktānāṃ parirakṣaṇakarī | evambhūtā bhagavatī spharaṇasaṃharaṇayogena sādaranirantarābhyāsenāvalambya || tasyāḥ jāpamantraḥ || oṃ maṇidhari vajriṇi mahāpratisare hūṃ hūṃ phaṭ svāhā || tasyā mahāpratisarāyāḥ pūrvasyām diśi | tathaiva pūrvayogam adhikṛtya viśvapadmamadhye hūṃkāreṇa bījacihnapariṇāmena mahāsāhasrapramardanī kṛ̣̣navarṇā pingalordhvakeśā | narakapālālaṃkṛtā | bhrūbhṛkuṭìaṃștrākarālavadanā sphuratsūryamaṇḍalāsanā | lalitākṣepena mahābhūtamahāyakṣam ākramyamāṇā | kațakakeyūramaṇḍitā | hāranūpurabhūṣitā | tasyā dakșiṇaprathamabhuje varadavajram | dvitīye an̉kuśah | tṛtīye śarah | caturthe khaḍgaḥ || vāmaprathamabhuje tarjanīpāśạ̣ | dvitīye paraśuḥ | tṛtīye dhanuh | caturthe padmopariṣaḍaṃsaratnam | tasyā mūlamukham kṛṣnam | dakṣiṇe śvetam | pṛșthe pītam | vāme haritam | sarvaṃ trinetram |

17 -saṃstutā] corr.; -saṃstușțyā ms. 18 mahoragādibhiḥ] corr.; mahoradibhị̣ ms. 29 -ālaṃkṛtā] corr.; -ābhyaṃkṛtā ms. 34 mūlamukhaṃ] corr.; mūlamuṃ ms. 
nānāratnādyalaṃkṛtaśarīram | mahābalaparā<162r>kramam | raudraveśā | vațavṛ̣̣̂opaśobhitā | saptamātrādidevatāsaṃtrāsanakarī | revatyādigrahāṇām saṃtrāsitamanāḥ | vāsukyādyașțanāgasaṃtrāsanakarī | vātapittaśleṣmādiśodhanakarī | raudratamo 'ndhakārameghasphāṭanakarī | sarvāpamṛtyunivāraṇakarī | tasyā jāpa || oṃ amṛtavare vara vara pravaraviśuddhe hūṃ hūṃ phaṭ svāhā || tato mahāpratisarāyā dakṣiṇadigmukhe viśvapadmopari candramaṇdalamadhye māṃkārabījapariṇāmeṇa jhațiti mahāmāyūrī pītavarṇā sūryamaṇụalālịḍā sattvaparyan̉kiṇī | trimukhā trinetrā așțabhujā | ratnamakuṭin̄i sarvābharaṇabhūṣitā | tasyā dakṣiṇaprathamabhuje varadạ̣ | dvitīye ratnaghațadharā | tṛtīye cakram | caturthe khaḍgạ̣ || vāmaprathamabhuje pātropari bhikṣuh | dvitīye mayūrapicchah | tṛtīye ghațopari viśvavajram | caturthe ratnadhvajam | tasyā mūlamukhaṃ pītaṃ dakṣiṇe kṛ̣̣nam | vāme raktam | aśokavṛkṣopaśobhitam | tatpārśvasthitasaptaviṣaị̣ saṃcchādanakarī | saraudrakapilādirākṣasīvidhvaṃsanakarī | samastanāgādīnāṃ saṃtrāsanakarī | devanāgayakșagandharvaiḥ namaskaraṇīyā | sasaptaviṃśatinakṣatrābhinavagrahādibhị sevanīyā | sasthāvajraṃgamavi<162v>șavimocanīyā | sadaivadaityāsurasammodanakarī || tasyā bhagavatyā jāpaḥ || oṃ amṛtavilokini garbhasaṃrakṣaṇi ākarṣaṇi hūṃ hūṃ phạ svāhā || tasyāḥ pratisarāyāḥ paścimadiśi viśvapadmopari candramaṇḍalamadhye maṃkārabījapariṇāmajām mahāmantrānusāriṇīm vibhāvayet | śuklavarṇām dvādaśabhujāṃ trimukhāṃ trinetrām | spharatsūryamaṇḍalālị̣hāṃ ratnamakuṭinīm | sarvālaṃkāraśobhinīm | navayauvanopetāṃ hāranūpurakuṇụalālaṃkārām | śirịṣavṛkṣopaśobhitām | tasyāḥ prathamabhujābhyāṃ dharmacakramudrā | dvitīyabhujābhyāṃ samādhimudrā | tṛtīye varadạ̣ | caturthe abhayaḥ | pañcame vajram | șașțhe śarah | tṛtīye tarjanīpāśah | caturthe dhanuh | pañcame ratnacchațā ṣașṭhame padmāñkitaḥ kamalạ̣ || mūlamukham śuklaṃ dakṣiṇe kṛṣnạ̣ vāme raktam | nānākusumāvakīrṇam | sāșțalokapālādidaivaiḥ sampūjanīyā | sacaturmahārājikādevasaṃghaiḥ saṃstutā | samālāvidyādharair arcitā | tasyā jāpạ̣ || oṃ vimale vipule jayavare amṛte viraje hūṃ hūṃ phaṭ svāhā || tato mahāpratisarāyā uttarasyāṃ diši viśvapadmopari candramaṇḍalamadhye trāmbījapariṇāmajā mahāśī<163r>tavatī haritavarṇā | sūryamaṇḍalālị̣hā trimukhā trinetrā ṣaḍbhujā | tathāgatamakuṭinī | sarvābharạ̣ālaṃkṛtā divyavastropacchādinī | tasyāḥ prathamabhuje abhayạ̣ | dvitīye vajram | tṛtīye śarah || vāmaprathamabhuje tarjanīpāśaḥ | dvitīye dhanuḥ | tṛtīye

3 -manāh] corr.; -sanāḥ ms. 12 ghațopari] pc.; țoghapari ac. 18 -vajraṃgama-] pc.; -vajrammaga- $a c . \quad 20$ tasyāḥ] $p c$; te tasyāḥ ac. 27 tarjanī] $p c$; jatarnī $a c$. 
ratnadhvajam || mūlamukhaṃ haritam | dakṣiṇe śuklaṃ vāme raktam | campakavṛkṣopaśobhitam | sakāmadevādipramukhaị̣ sampūjya stutā | sahārītyādiyakṣayakṣaṇividhvaṃsanakarī | kākolūkagṛdhraśyenakapotādividrāvaṇakarī | sarvabhūtapretapiśācavetāḍarākṣasādisammohanakarī | asyā jāpaḥ || oṃ bhara 2 sambhara 2 indriyabalaviśodhani hūṃ hūṃ phaṭ svāhā || evaṃ yathānirdiṣțam maṇḍalaṃ vibhāvya | tasyā raśmisamūhavyāptāt svasvabījāt raśmiṃ niścārya tāś ca raśmayaḥ samastatraidhātukam abhivyāpya | tatraivākșare praveśayet | punar gaganakuhare sphārayitvā jñānacakram ākṛșya saṃstutya cānīya svasamayacakre praveśayet | tato hṛdyam ekalolībhūtam vibhāvya | tasyā raśmibhis sarvatathāgatān ākṛṣya sampūjya prārthayed abhiṣekam | sicyamānam ātmānaṃ paśyet | pūjāstutyamṛtāsvādapūrvakaṃ bhāvayed vicakṣa<163v>ṇaḥ || cakṣuṣo mohavajrī mahāpratisarā śrotayor dveșavajrī mahāsāhasrapramardanī | ghrāṇe mātsaryavajrī mahāmāyūrī | vaktre rāgavajrī mahāmantrānusāraṇī | sparśe īrṣyāvajrī mahāŝītavatī || evaṃ rūpavedanāsaṃjñāsamskāravijñānaskandhadhātvāyatanasvabhāvā | evaṃ devatāviśuddhito jñātavyaṃ viśeșatah | tatraiva samayī bhūtvā mantraṃ japed anena vidhinā | yāny eva mantrākṣarāṇy uccāryante | tāni devatāyogena sādhyanāmavidarbhitena śāntamānasena | avacchinnaṃ japet || jvare śare tathā roge saṃgrāme ca tathaiva ca | ḍākinībhūtocchuṣmanadīśatruprapị̄ite \| aśanividyunmeghānāṃ parvate vanamārgayoḥ | tasmān mantraṃ smaran nityaṃ sarvaśan̉kānisūdanam || tatraiva kramah \| sarvasattvahitārthāya sarvasattvahitodayam | yena kenacid adhyeșyam āyuṣo vṛddhihetutạ || pañcarakṣāvidhānena likhya svastyayanaṃ mayā| sattvānāṃ ca hitārthāya vartayen maṇḍalam śubham || śucibhūmau śubhe ramye gomayenopalepite | vitāne vitate caiva nānāvastrapralambite \| samantālliptagandhena candanena viśeșatah | vimśāṣțakam anguliṃ kṛtvā maṇḍalaṃ vartayet tataḥ \|| śvetena rajacūrṇena śāntikarma praśa<164r>syate | padmasyāṣṭadalam kuryāt karṇikākesarānvitam || kalaśān pañca saṃsthāpya sragdāmavastraśobhitam |

5 -piśāca-] $p c$.; -piśāraca- ac. • -vetāḍa-] pc.; -veḍātā- ac. 14 mātsarya-] corr.; māccharyams. 16 -saṃskāra-] pc.; -saṃjñaskāra- ac. 19 -mānasena] corr.; -mānaset ms. 23 mantraṃ] corr.; ma ms. 
chatraṃ patākasaṃyuktam pallavena tu cchāditam || pustakaṃ dharmadhātuṃ ca pațaṃ cāvalambitam | puṣpaṃ dhūpaṃ ca gandham ca balinaivedyaḍhaukitam \| dūrvākundasamāyuktaṃ śuklaṃ puṣpaṃ viśeșatạ̣ | digvidikșu devānāṃ pūjayec ca yathāvidhim || guḍabhaktaśuklapuṣpaṃ pāyasaṃ ca viśeșatah | gandharvānāmm balim dattvā pūrvasthāne tu sthāpayet || tilakṛ̣ṇasurāpūrṇamatsyamāṃsapalāṇḍakaị̣ | kumbhāṇụānāṃ baliṃ dadyād dakṣiṇe diśi sthāpayet || pāyasaṃ dadhikṣiraṃ ca sarjaram ca viśeșatah | 10 paścimāyāṃ dadhiṃ sthāpya nāgānāṃ tu mahābalim || māṣamungakulutthānāṃ jāmbuḍīisìdhum eva ca | uttarasyāṃ diśi sthāpya yakṣāṇāṃ tu baliṃ dadet || îsānīm diśím ārabhya yāvad vā savyagocare | śuklaraktaṃ ca haritaṃ sragdāmaṃ ca pralambitam || madhye śvetasragdāmaṃ nānāpuṣpaṃ viśeșataḥ | kṣīrarudhiraśavāṇāṃ sarjaraṃ gandham eva ca || tattadvastvaśeșānām tu arghaṃ dattvā yathārthataḥ | phalāphalī yathāprāpta laḍḍumodakaśaṣkulị̣ || piștịādi yathāprokta khaṇḍakṣīravi<164v>śeșataḥ | dakṣine baliṃ saṃsthāpya așțacihnena śobhitam || tathā dharmabhāṇakācāryaḥ karmavajī̄ tathaiva ca| snānaṃ kṛtvā śucivastram āsanaṃ ca śucimatam || pūrvābhimukhaṃ tișthayet pāțhayen mauninaṃ sadā| piṇụapātikabhikṣūnāṃ śuciśīlaṃ praśasyate || ācāryāngulinā kaścit pāṭhayet pariśuddhitaḥ | ekavārādikārambhaikavimiśādi pravartayet || nyūnādhikavidhau pāṭhah samyaksiddhir na jāyate | dhairyavīryeṇa sampannaḥ karuṇām sattvārtham udyamān || tena svastyayanaṃ kuryāt pūrvabuddhena bhāṣitam | śuklabhojanabhuktānāṃ āmișaṃ ca vivarjayet || sarvanirāmiṣaṃ kṛtvā sarvaśāstre tu sammatāḥ | uttarābhimukhācāryas tatra karma samārabhet || bhāvayet pūrvam uddișțaṃ devatālambanaṃ prati | stutipūjāsamāyukta ghaṇṭhāvādanatatparaḥ \|| namo 'stu buddhāya anantagocare namo 'stu te satyaprakāśakamune |

12 jāmbudịi-] corr.; jambuṃkṣī- ms. 28 nyūnādhika-] corr.; punādika- ms. 
satye pratișțhāya prajāya mocase sarve ca kāmāḥ saphalā bhavantu ||

namas te puruṣavīra namas te 'stu tathāgatāḥ |

namas te devatā sarve dharmadhātu namo 'stu te ॥

dūrvākundasamāyuktaṃ mantraṃ nāma vidarbhitam |

arcayed devatāmūrdhni dharmadhātuṃ tathaiva ca \|

sakṛd uccārya mantreṇa sakṛd yogena arca $<165 r>$ yet |

ayutena tu karmeṇa āyur vardhati sarvatah ॥

yena kenacid adhyeșyan tasyā maṇḍalaṃ vartayet |

rājyaṃ rāșțraṃ tathā grāmaṃ goșțham udyānam eva ca ||

amanuṣyāvatārarogātmakadurbhikṣaṃ naśyati |

tena karmeṇa rakṣante śuṣkadārūṇy api svayam |

acintyakarmaduhkhāni yadarthaṃ kartum icchati |

tato rakṣāvidhānena rakṣā bhavati niścitam ||

vātajāḥ pittajā rogāḥ śleșmajāḥ sāṃnipātajāḥ |

nihatāḥ sarvarogāś ca svastir bhavati sarvadā ||

pāṭhasvādhyāyayogena nirvighno bhavati khaluh || ||

iti śrī-pañcarakṣā-mahādevyā sādhana samāptah || ||

[152] oṃ namaḥ śrī-cakrasaṃvarāya ||

praṇamya vajravārāhīṃ yoginīcakranāyakam |

saṃgṛhyate yathāmnāyaṃ hastapūjāvidhir mayā \|

tatra gaṇamaṇḍalādau śrī-cakrasaṃvarayogavān svavāmakarayogavān

svavāmakarasthān pṛthivyaptejovāyvākāśadhātūn | pātanī-

māraṇīākarṣaṇī-narteśvarī-padmajālinī-svabhāvān adhimucya

vṛddhā-tarjanī-madhyamānāmikā-kanișțhān nakheșu

vajrasattvavairocanāmitābhākṣobhyaratnasambhavāmoghasiddhisvabhāvān

yathākramaṃ śuklapītaraktakṛ̣ṇaharitavarṇān || oṃ hạ namaḥ hrīḥ svāhā hūṃ <165v> vașaṭ he hūṃ hūṃ hoḥ phaț 2 haṃkāraṃ vinyasyet | karatale jhațiti niṣpannaraktapañcadalakamalaṃ dhyātvā tatpūrvādidigdaleșu vāmāvartena yathākramam | yāminī-mohinī-saṃcālinī-saṃtrāsinī-caṇḍikā-svarūpāṇīti nīlaśvetapītaharitadhūmravarṇāni || hāṃ yoṃ hrīṃ moṃ hreṃ hrīṃ hūṃ hūṃ phaṭ phaț || iti bỉjākșarāṇi paśyet || karṇikāyāṃ ca vajravārāhīsvabhāvaṃ raktavarṇam | oṃ vaṃ iti bỉjam etatpratibimbaṃ cakratrayaṃ vā adhạ̣

1 satye] corr.; pratye ms. 9 goșțham udyānam] corr.; goṣṭhopadyānam ms. 10 amanuṣyāvatārarogātmakadurbhikṣaṃ] corr.; amanuṣyāvatāḍogātmakādurbhikṣam ms. 22 -vāyv-] corr.; -vāhy- ms. 23 padmajālinī] corr.; pajālinī ms. 24 vịddhā-] corr.; vṛddhyā- ms. •-kanișthān] pc.; -kanișțhānn ac. 32 cakratrayaṃ vā] corr.; cakrayāmva ms. 
karapṛșthe 'pi sphuṭaṃ paśyet | tatas tatkaragatāni bījākṣarāṇi dravadravyena mrakṣayitvā tatạ̣ karatalaṃ sarvavīrayoginyadhișṭitatrivajrasvabhāvam adhimucya | tatra dravādidravyatryakṣaramantreṇa așțapadamantreṇa vā dadyāt | tataḥ sampūjya nyūnādhikavidhipūraṇārthaṃ śatākṣaramantraṃ paṭhitvā cakrādyadhișțhānādyartham adhyeșya taddravyam aparasmin dravye anyatra vā sthāpayitvā hastalagnena dravyeṇa vāmanāsikāgṛhītena hṛjjihvāśirasi hūṃ āḥ oṃkāroccāraṇapūrvakaṃ mrakṣayet taddevatāvṛndam ātmani pravișțam adhimuñced iti || likhito hastamayāsya saṃcāratantre svāhā || ||

iti hastapūjā-vidhāna samāptaḥ || ||

[153] <166r> oṃ namaḥ śrī-nairātmādevyai || pūrvoktavidhānena śūnyatānantaraṃ candramaṇụale nīla-aṃkārabījavartīṃ spharaṇādipūrvakaṃ parinamya śavahṛccandrasthārdhaparyañkanātyasthitām nairātmyāṃ kṛ̣ṇām ekamukhām ūrdhvapingalakeśām akṣobhyamakuṭinīm damșțrākarālalalajjihvāṃ dakṣiṇena kartidhāraṇyam | vāmena kapālakhațvāngadhāriṇīm | raktavartulatrinetrāṃ pañcamudrāvibhūṣaṇām | tacchiraḥkaṇṭhahṛdayeșu oṃ āḥ hūṃkārān | hṛccandramuṣticandre aṃkāraṃ dṛștvā imam mantram japet || om a ā i i u u ụ ṛ ̣̣ lṛ l⿳̣ e ai o au aṃ aḥ svāhā || ||

iti śrī-nairātmā-sādhana-dhāraṇī samāptaḥ || ||

[154] oṃ namaḥ śrī-vajrabhairavāya || pūrvoktavidhānena khadhāturephaje sūrye hūṃkārajvaladbhāsvaram | kalpānalam ivātyugraṃ kṛ̣̣̣avarṇaṃ mahādyutim || tadutpannam mahāraudraṃ vajrahūṃkārasaṃjñakam | aț̣ahāsamahāraudraṃ kṣapayantam tridhātukam || ghaṇțāvajraprayogeṇa mudrābandhakaradvayam | pratyālīẹhapadenaiva bhairavākrāntabhīkaram || hṛtkaṇțhamastake nyasya oṃ āḥ hūṃ akṣaratrayam | abhișekavidhānena cittavajreṇa mudrayet || jāpaḥ || oṃ hūṃ 2 phaṭ 2 svāhā || ||

4 nyūnādhika-] corr.; nyūnyādhika- ms. 5 cakrādyadhișțhānādy-] pc.; cakrādhidyașțhānādyac. 8 saṃcāratantre] corr.; saṃcataratantu ac., saṃcataratantusa pc. 22 -ugraṃ] corr.; -agram ms. 
[155] oṃ namaḥ śrī-hayagrīvabhairavāya || pūrvoktavidhānena viśvakamalamadhye sūrye raktahaṃkārajñānaniṣpannam āryahayagrīvaṃ raktavarṇatrimukham așțabhujaṃ pratimukham trinetram | nīlasitadakṣiṇetaravadanaṃ sarpābharaṇaṃ lalitākṣepapadanyāsaṃ krodhadṛșținirīkṣyamāṇam prathamamukhaṃ smeram | lalitajihvaṃ dakṣiṇamukham | daṃștrāvașțabdhauṣṭhaṃ vāmamukham | vyāghracarmanivasanam | vajradaṇḍakaraṇamudrāśarodyatadakṣiṇakaracatușțayam | tarjanīkāsvakucagrahapadmadhanurudyatavāmakaracatuṣțayam | akṣobhyamaulinaṃ dhyāyād iti paramāśvajñānavajro nāma samādhị̣ || oṃ hūṃ hayagrīva svāhā || ||

iti hayagrīva-dhāraṇī samāptạ̣ || ||

[156] ihādyanutpannān avasthitạ̣ sarvasvabhāva iti saugatamatam viditvā tatah samair upașțāsamsṛ̣sțaratnamayam tatra madhye sahasrayojanapramāṇam sumerukam tatropaviśya ratnatrayaśaraṇagamādipuraḥsaram kāyavākcittam adhiṣṭ̂āya tenaivākāśavyāpisūryamaṇḍalam abhinirmāya tenaiva hūṃkāraṃ jvaladbhāsurākāram vicintya | tato namaḥ samantakāyavākcittava<167r>jrāṇām || oṃ āḥ hūṃ ity anena daśadiganantāparyantalokadhātuvyavasthitān sarvabuddhabodhisattvān ānīya jñānākāreṇa praveśya punar dvitīyahūṃkāreṇa hayakandharaṃ saṃcodyānīya praveśya tṛtīyahūṃkāreṇāham eva hayagrīvavajrasvabhāvātmako 'haṃ raktavarṇaṃ mahābhayānakaṃ trinetraṃ kapilaśmaśrum raudrabṛhaduraṃ daṃștrākarālinam | dantauṣṭhakapālamālinaṃ jațāmakuṭinam | amitābhaśiraskaṃ dvitīyamukhaṃ nīlaṃ hayānanaṃ hīhīkāranādinaṃ brahmāṇḍaśikharākrāntạ̣ dvitīyena bhavāgraparyantam | așțanāgopetam | kharvavāmanākāram | vyāghracarmanivasanaṃ sarvālaṃkārabhūṣitam | sakaladevāsuram tarpayantam | gṛhītavajradaṇḍam | nānāvarṇāś ca raśmayạ̣ spharaṇasaṃharaṇapūrvakaṃ vicintayed iti | asya bhagavataḥ prabhāvā cintāmaṇibhadraghațakalpatarurasarasāyanādisiddhisādhanāni abhimukhībhavantīty uktam saptaśatikakalpe | kiṃcid bhagavato lakșatrayajāpāt | ubhayacakravartirājyam āmukhībhavati | anekābhir apsarobhị parișkṛtah puraskṛto vidyādharasthāne bahalasukham anubhavann avatișțhati || devendraḥ cchattradhāro bhavati | brahmāś ca mantrī | vemacitrī sainyapa<167v>tiḥ | hariḥ pratīhāraḥ | samastadevatāvalaganti |

6 daṃșțāvașțabdhaușțhaṃ] corr.; drașțrāvapūrvauṣu ms. 14 tatropaviśya] corr.; tatroviśya ms. 28 -saṃharaṇa-] corr.; -saṃhaṇa- ms. 29 -kalpataru-] corr.; -kalpayatara- ms. 
nagnācāryaḥ śan̉karaḥ samastaguṇān upadarśayati | yāvad bhagavān maitreyo nābhisambudhyati tāvat tișțhati | abhisambuddher anuttarāyāṃ samyaksambodhau vyākriyata iti || saptaśatikakalpoktam || ||

iti śrī-hayagrīvabhairavasya dhāraṇī samāptā || ||

[157] oṃ namah śrī-bhūtaḍāmarasaṃvarāya ||

śakrabrahmakuverādimadavidhvaṃsakovidam |

śrīmat ḍāmaraṃ natvā likhyate tasya sādhanam ||

saṃkṣiptāmnāyasaṃśuddham saṃkṣiptarucirañjanam |

yakṣayakṣādisaṃsiddhikautukaikahṛdā mayā ||

prathamaṃ tāvan mantrī svahṛdīndau viśvavikāsitaraśmisamākulakalevaraṃ raktarambījam vicintayet | tatas tadviniḥsṛtāńkuśākārākṛ̣̣ya purato ḍāmaram abhisampūjya saptavidhānuttarapūjābhị̣ śūnyatāṃ bhāvayet | tatạ̣ kuṇụābhanirmalavikāśinirākarārdhaṃ śan̉khābhahūṃkṛtikṛtāspadabindumadhye | dedīpyamānam akhilam pariṇamya samyak viśvāșțakomaladalaṃ kamalaṃ praveśyat || tatạ̣ tanmadhya akārapariṇatauṣadhīśopari hūṃkāragarbham hūṃkārapariṇatanīlajvālāvajraṃ vibhāvya paśyet tatparị̣atam | jhatiti <168r> vikațalīlaṃ bhūtasaṃtrāsanīŝilaṃ jagadupakṛti kartavyāpi raktaikaha iti | hariharaśarajanmādya 'gramāraikavīram vikațadaśanam īṣadvispharakrodhajālam \| nīlapingordhvabaddhakeśam nīlavastrāvṛtatanum | dakșiṇe vajradharaṃ vāme pāśatarjanīdharam | pañcakapālamakuṭam vāme triśūlakapāladharam | dakṣiṇe ḍamarukartikādharam | kapilajaṭāmakuṭinaṃ trinetraṃ vyāghracarmāmbaraṃ sitaṃ mahābhūtādhipāparājitaṃ pratyālịḍhapadākrāntaṃ hastadvayasamābaddhamudram śrī-bhūtaḍāmaram | tatreyạ̣ mudrā anāmikādvayaṃ veșța kuñcayet tarjanīdvayam | kanișthāmadhyamāṃ caiva jyeșṭhāñguṣṭhena cākramet ||

2 nābhi-] corr.; nāmābhi- ms. 3 -śatika-] corr.; -śati- ms. 5 -ḍāmara-] corr.; -dāmbarams. 7 ḍāmaram] corr.; ḍāmbaraṃ ms. 9 -kautukaika-] corr.; -kautukai- ms. 10 -vikāsita-] pc.; -vikāsitāta- ac. • -kalevaraṃ] corr.; -kavelevalaṃ ms. 13 -nirmala-] corr.; -nirmaladms. 14 -kṛtāspada-] corr.; -kṛtāsyadra- ms. 15 dedīpyamānam] corr.; devīpyamānam ms. 20 jagad-] corr.; jagatad- ms. 23 nīla-] corr.; -nīlaṃnīla- ms. 28 -ḍāmaram] corr.; -ḍāmbaram ms. 
așțanāgopaśobhitam | tatra śiroveșțanaṃ karkoṭako nīlạ̣ | grīvābharaṇạ̣ takṣako raktah | nandopanandau karṇakuṇḍalau pītāv eka eva | brahmasūtram anantaḥ sitaḥ | kaṭisūtram vā vāsukiḥ śuklaḥ | mudrābhujayoḥ keyūrakulikaḥ pārāvatavarṇaḥ | itarabhujayos tathā śan̉khapālo dhavalạ̣ | nūpuro padmamahāpadmo raktāv eka eva \|

raktacakṣur dvayaṃ caiva bhūtaṃ śrī-bhūtaḍāmaram |

cintayed atisaṃkruddhaṃ jagadarthaikatatparạ \|

hṛtkaṇṭhorṇāmūrdhānaṃ satatam rakṣārthaṃ mudrayā spṛ́et |

dhyānāt khi<168v>nno japen mantraṃ vajravācā krodhavācā |

mantrah || hūm vajra phaṭ || ity

abhyarthito 'smi guṇino khalu sajjanena

kenāpi tena likhitaṃ kim api sphuṭam me |

vairocanena yad avāptam itaḥ śubhaṃ tat

trailokyalokakaluṣāpaharaṃ śamantu || ||

iti śrī-bhūtaḍāmara-saṃkṣipta-dhāraṇī samāptah || ||

[158] oṃ namo bhagavatyai ārya-vajravārāhyai || prathamaṃ tāvan mantrī śmaśānādau bījān pradeśe sthitvā evaṃkāramadhye vaṃśuklaṃ tanmadhye paṃkārapariṇāmena viśvapadmavaraṭakamadhye raṃkārapariṇatasūryamaṇḍale śuklavarṇavajravārāhīm bhāvayet || tatah pariṇāmena bhagavatīṃ vibhāvayet | śuklām ugrakiraṇām ūrdhvapādasthitāṃ śakrabrahmākrāntām | adhạ̣ pādena bhairavakālarātrīsamākrāntāṃ dvibhujāṃ ekānanāṃ muktakeśīm nagnāṃ nirābharaṇāṃ pīnonnatapayodharām raktavartulatrinetrām [a blank space of four akṣaras left out]yanāṃ sabhrūbhangabhṛkuṭinīm | daṃșțākarālavadanāṃ vāme khaṭvāngakaroțadharāṃ dakṣiṇe vajrakartikādharām atibhīmarūpāṃ vibhāvayet bhāvanākhinno yogī jāpaṃ mantrạ̣ tatrāyaṃ mantrarājạ̣ || om sarvabuddhaḍākinīye vajravarṇanīye vajravairocanīye hūm 3 phaṭ svāhā || iti hṛdayam || oṃ vajra<169r>yoginī hrīḥ hūṃ phaṭ svāhā || upahṛdaya || atha balimantrạ̣ || oṃ vajrayogini idaṃ baliṃ gṛhṇa 2 ruru mama siddhị̣ prayaccha hūṃ phaṭ | așțamyāṃ caturdaśyāṃ niyatam kāmabaliṃ dattvā bhāvayen muhur muhụ̣ || bhagavatyāhaṃkāreṇa viharet bhagavatyānugrahaṃ kurvanti sādhakasya ca yadi śubhāśayagurubhakto 'nujñāto yogīnadīsrotapravāhena bhāvayet pañcāśānigulikāṃ mukhe prakṣipya dhūpaṃ dattvā śmaśānāngāreṇa niśāyāvaharet japed bhāvayet | na vikalendriyā

6 -ḍāmaram] corr.; -ḍāmbaram ms. 8 spṛśet] corr.; spaśyet ms. 12 sphuṭaṃ] corr.; sphațam ms. 13 tat] corr.; ta ms. 14 trailokyaloka-] corr.; trailoka- ms. - śamantu] corr.; samastu ms. 15 -ḍāmara-] corr.; -ḍāmbara- ms. 23 pīnonnata-] corr.; pīnonnatu- ms. 
bhavet | tasya șaḍvīreṇāñcitasiddhir bhavati nānyathā || atha homavidhir bhavet trikoṇakuṇụakṛtvāni māṃsaṃ surām ālodya vāmahastena homayet buddho 'pi ca sameti kiṃ punaḥ kṣudramānuṣāh | rajasvaro raktanabhuktamuñgī tu bhojanaṃ māṃsasammuktamānuṣaiḥ sadyam ākarṣaṇaṃ dhruvam | svakāya-udgīrṇaṃ vā tata svakeśair homayed budhạ̣ nimbakāșțhāgnim prajvālya sadya vidveșaṇaṃ paraṃ kākapakṣaị̣ kṛto homaḥ dhūrturāgnau susamāhitaiḥ kațutailavișam āloḍya sadyoccāțanaṃ māraṇaṃ jāgratah suptakṛto tiṣṭha bhuñjamānoḥ maithune pibā sadākālaṃ japen mantraṃ māraṃ tasya na vidyate || hoti naraḥ samyakjambukenāhutiśataṃ tasya māsatra<169v>yād ūrdhvaṃ sadyaṃ naśyate kulāt | mahāmāṃsena yaḥ kaścit homayet sadyasaṃutam śatam așțottaraṃ yāvat trisaṃdhyaṃ sādhakottamah | bhuñjate medinīṃ vidyāṃ ṣaṇmāsena jagadvaśam ānayet || rājyạ̣ tasya prayacchati prītyā ḍākinyā na saṃśayaḥ || ||

iti śrī-gaganātmajaśuklavarṇavajravārāhī-nāma-dhāraṇī samāptaḥ || ||

[159] oṃ namaḥ śrī-vajrayoginyai || prathamam evaṃkāramadhye paṃkārajaviśvadalapadmavarațake raktavaṃkārapariṇatasūryamaṇụalopari raktahūṃkārapariṇatam ātmānaṃ bhagavatīṃ vajrayoginīm ugrakiraṇāṃ nagnāṃ pratyālị̣hapadasthitām | dvibhujāṃ pīnonnatapayodharām | raktavarṇām mahārāgasvabhāvām | calatpracaṇụavartulatrinayanām | sabhrūbhañgabhṛkuṭinīm | daṃșțrākarālavadanām | lalajjihvām ūrdhvapingalakeśām | śavārūụhāṃ navayauvanabhāgyām | hārārdhahārakin̉kiṇiśabdaghughuraravavicitrāṃ ratnālaṃkṛtanūpuraravām | pañcamudropetām | vāme kapālaṃ devāsurarudhirapūritam | dakșiṇakare kartitarjanīdharām | atibhīmarūpiṇị̣ śmaśānādau bhāvayet || bhāvanākhinno mantrī mantraṃ japet || tatrāyam mantraḥ || om sarvabuddhaḍākinīye oṃ vajravarṇanìye oṃ va<170r>jravairocanìye hūṃ 3 phaṭ 3 svāhā || mūlavidyā || oṃ vajraḍākinìye hrīṃ hūṃ phaṭ svāhā || așțamyāṃ caturdaśyām pañcamyāṃ balipūjādikaṃ śmaśāne kartavyạ̣ vajrayoginīm || oṃ śrī-vajrayoginī sarvabhūtapretapiśācādīn sādhaya 2 hana 2 daha 2 grasa 2 sarvasiddhisādhanāni prayaccha sarvāśāṃ paripūraya svāhā || oṃ śrī-vajrayogini sarvasiddhị̣ kuru 2 sarvavighnavināyakān hana 2 samyaksambodhāya mama baliṃ gṛhṇa 2 hūṃ 3 phaṭ 3 svāhā || ||

iti śrī-vajrayoginī-nāma-dhāraṇī samāptah || ||

1 -vīreṇāñcita-] corr.; -vīsenañcita- ms. • bhavet] corr.; bhava ms. 3 sameti] corr.; samāti ms. 5 udgīrṇam] corr.; añgīrṇaṃ ms. 7 kațutailavișam] corr.; kațutailasam ms. 9 -āhuti-] corr.; -āngatī- ms. 18 pīnonnata-] corr.; pīnonmanna- $a c$. pīnonna- $p c$. 
[160] oṃ namo vajraśṛnkhalāyai || pūrvoktavidhānena hṛdi candramaṇḍale haritahūṃkārajñānanișpannāṃ vajraśṛnnkhalāṃ trimukhāṃ șaḍbhujām | nīlaśukladakșinetaramukhīm | trinetrāṃ vajraśṇnikhalāṃ śaravaddakṣiṇakaratrayām | tarjanīpāśacāpavad vāmakaratrayām | haritaśyāmavarṇām ịṣaddhasitamukhīṃ sarvālaṃkārāṃ dușțasattvaniṣūdanīm 5 ātmānaṃ dhyātvā mudrāṃ bandhayet | hastadvena pṛthak pṛthak vajramuștịm kṛtvā kanīyasīṃ tarjanīṃ ca śṛnikhalākāreṇa bandhayet || oṃ vajraśṛnikhale hūṃ phaț svāhā || iti jāpamantraḥ || pūrvoktavidhānena śūnyatābhāvanānantaram | viśvakamalasūryasthaharitaśyāmahūṃkārajām | $<170 \mathrm{v}>$ prathamamukhīṣaddhāsarasam | dakṣiṇaṃ kapilaṃ kapilarocanaṃ vāme raktam | bhṛkuṭīdaṃșțrākarālam | dakșiṇeșu catuṣkareșu abhayavajraśṛnkhalaśaradharām | vāme catuṣkarai rudhirapūrṇakapālatarjanīpāśacāpadharām || lalitākṣepāsanasthāṃ mārjāracarmottarīyām | amoghasiddhibhūṣitordhvapingalakeśāṃ vicintya || oṃ vajraśṛnkhhale hūṃ phaṭ svāhā || iti mantraṃ japet || ||

ārya-vajraśṛnkhalā-dhāraṇī samāptā || ||

[161] oṃ namaḥ śrī-herukāya \|

śrī-herukaṃ jagannātho bhūtvā sarvārthasampadaḥ | kuryāj jagaddhitārthāyety evam ādau vibhāvayet || trāṇadharmodayāntasya kūṭāgārodārāśrayam | viśvavarṇābjasaccandra vajrāsanaśaśiprabham || sphațikendugramūlāsya nīlasavyāruṇetaram | svābhaprajñāśleșikaṇṭhaṃ vajrāsimaṇipadminam || vajrasattvaṃ vibhāvyaivaṃ svacittatryakșarīkṛtam | tadvaktreṇābjasaṃvișțaṃ sarvarāgāgninā drutam || locanādisvasaṃiityā durdṛștyārthāpacoditam | pralayāgnimahājvālā vajrahīḥārasambhavam || tadudbhavaṃ kṛpākrodhaṃ mahābhairavadāmakam | bhrūbhaṅgordhvajvalatkeśaṃ nīlaṃ daṃșțrānvitaṃ sitam || cakșusavyatarāraktaṃ bhasmoddhūlitavigraham | svābhāṅganā dvijaih śleși raudrādișaḍrasānvi<171r>tam || kṛ̣ṇavajrāsikhațvāngamaṇirājakaragraham |

4 -pāśa-] pc.; -pāśata- ac. 5 -niṣūdanīm] pc.; -niṣūnīdam ac. 9 -haritaśyāma-] pc.; -hataśyāma- ac. 23 -śleșikaṇṭhaṃ] corr.; -śniṣi ms. 26 durdṛṣtyārthāpacoditam] corr.; duddhṛșyārthāpacoditam ms. 30 bhasmoddhūlita-] corr.; bhasmodhūlita- ms. 32 -rājakara-] $p c$; - -rājaraka- $a c$. 
nṛkaran̉kaśiromāla sadvastrābharaṇapriyam || dakṣinānighritalākrāntam vāmorutalapịḍanam | raudrāsanam samāsthāya herukaṃ svaṃ prabhāvayet | sambuddhendriyasadyogaṃ kāyavākcittatryakṣaram | hṛjjñānasattvam akṣobhyamaulinam ratnaśālinam || paramānandasukhāsvādaṃ spharatsaṃhārarūpiṇam | saṃcintya jñānasaundaryaṃ yogī yogaṃ samāpnuyāt || śmaśānāșțakamadhyastho niḥsañgo hṛștamānasaḥ | prajñopāyavidhānena candrasūryaprayogatạ̣ || ālikālisamāyogād bhāvayet sūryamaṇḍalam | tatra hūṃkārasambhūtaṃ vajrasūcisamanvitam || śavastham ardhaparyañkam naracarmasavāsanam | bhasmoddhūlitagātram ca spharadvajram ca dakșiṇam || calatpatākakhatvāngam vāmaraktakaroṭakam | śatārdhamuṇụamālābhị̣ kṛtahāramanoharam || īṣaddaṃșṭakarālāsyam raktanetravilāsinam | pingordhvakeśam akṣobhyamukuṭam karṇakuṇḍalam || asthyābharaṇaśobhaṃ tu śiraḥpañcakapālakam | buddhatvadāyikạ̣ dhyāyāt jagan māranivāraṇam || mantrajāpaḥ || oṃ hūm phaṭ svāhā || ||

iti saṃkṣipta-dvibhujaherukasya-nāma-dhāraṇī samāptaḥ || ||

[162] <171v> om namo bhagavate ārya-pītavarṇaprajñāpāramitāyai || pūrvoktavidhānenākārajacandre pītadhīḥkārajaviśvapadme pītahaḥkāramakārādiṣoụaśasvarapariveșṭitạ̣ bahiḥkakārādidvātriṃśadvarṇaparivṛtaṃ bhāvayet || tato lāsyā mālyā nṛtyā gītā puṣpā dhūpā dīpā gandhā | ity așțau yoginị̣ || etat sakalapariṇāmena jñānacandra udeti | prabhābhāsvaraḥ | tadupari padmam | tadupari prajñāpāramitāpustakam | tadupari dvitīyaṃ candramaṇḍalam | tadupari dvitīyapustakam | sarvam etat pariṇamya bhagavatī prajñāpāramitā pītavarṇā dvibhujaikamukhī pañcatathāgatamakuṭā | vyākhyānamudrāvatī | viśvadalapadmacandrāsanāsīnā | sarvālaṃkāravastravatī | vāmadakṣiṇapārśve utpalasthaprajñāpāramitāpustakadhāriṇi || mantrạ̣ || oṃ ạ̣ dhịḥ hūṃ svāhā || pīta-oṃkāro lalāṭe śukla-aḥkāraḥ kaṇṭhe | pītadhịḥkāro hṛdi kṛ̣̣nahūṃkāro

1 -karańka-] corr.; -karañga- ms. $\mathbf{3}$ herukaṃ svaṃ] pc.; herukaṃ ac. $\mathbf{5}$ ratnaśālinam] corr.; śālinaṃ ratna ms. 10 ālikāli-] corr.; ālikā- ms. 18 asthyābharaṇa-] corr.; astyābharaṇams. 29 bhagavatī] pc.; bhagavaītī ac. 30 -mukhī] corr.; -makhī ms. 33 pīta-oṃkāro] pc.; pītakāro $a c$. 
nābhāv iti || jāpakāle catvāry akṣarāṇi 'nucintayed iti || oṃ dhīḥ śrutismṛtivijaye svāhā || iti mantram japet || ||

iti śrī-pītavarṇa-prajñāpāramitā-nāma-dhārạ̣ī samāptạ̣ || ||

[163] <172r> oṃ namo bhagavatyai ārya-prajñāpāramitāyai || evạ̣ mayā śrutam ekasmin samaye bhagavān śrāvastyāṃ viharati sma || jetavane 'nāthapiṇụadasyārāme mahatā bhikṣusaṃghena sārdhaṃ paripūrṇenārhadbhikṣusahasreṇa bodhisattvānāṃ ca mahāsattvānāṃ mahāsaṃnāhasaṃnaddhānāṃ paripūrṇair daśabhir bodhisattvaśatasahasraị̣ sārdhaṃ sarvair avinivartanīyair anuttarāyāḥ samyaksambodheh | tadyathā || mañjuśriyā ca kumārabhūtena | maitreyeṇa ca asañgapratibhānena ca | anikṣiptadhureṇa ca || evampramukhair daśabhir bodhisattvaśatasahasraị̣ || atha khalu mañjuśrīkumārabhūto 'ruṇodgatagamanakālasamaye svakād vihārān niṣkramya yena tathāgatavihāras tenopasaṃkrāmed upasaṃkramya bahirdhā vihārasya dvāre sthito 'bhūt tathāgatasya darśanāya vandanāyai paryupāsanāya || athāyuṣmān api śāradvatīputraḥ svakā vihārān niṣkramya yena tathāgatavihāras tenopasaṃkrānto bhagavato darśanāya vandanāyai paryupāsanāya || athāyuṣmān api pūrṇo maitrāyaṇīputrạ̣ | āyuṣmān api mahāmaudgalyāyanaḥ | āyuṣmān api mahākāśyapaḥ | āyuṣmān api mahākātyāyanaḥ | āyuṣmān api mahākaușthilaḥ | sarvatra cāññe ca mahāśrāvakāḥ || svakasvake<172v>bhyo vihārebhyo nișkramya yena bhagavato vihāras tenopasaṃkrāntā upasaṃkramya ekānte tasthụ̣ || atha khalu bhagavān abhikrāntābhikrāntaṃ mahāśrāvakasaṃnipātaṃ viditvā svakād vihārān niṣkramya bahirdhā vihārasyaikānte prajñapta evāsane nyaṣīdat | niṣadya ca bhagavān jānann evāyuṣmantam śāradvatīputram āmantrayate sma || kutra tvaṃ śāradvatīputra kalyam evāgatya tathāgatavihāradvāre sthitaḥ || evam ukte āyuṣmāñ cāradvatīputro bhagavantam etad avocat | sarvatra prathamataram bhagavan mañjuśrīḥ kumārabhūtas tathāgatavihāradvāre sthitaḥ || paścād vayam bhagavantạ̣ draștukāmāḥ || atha khalu bhagavān jānann eva mañjuśriyaṃ kumārabhūtam āmantrayate sma | satyaṃ kila tvaṃ mañjuśrīh sarvaprathamataram tathāgatavihāradvāre sthitạ̣ | tathāgatasya darśanāya vandanāyai paryupāsanāya || evam ukte mañjuśrīḥ kumārabhūto bhagavantam etad avocat || evam etad bhagavann evam etat sugata sarvaprathamataram asmy

3 dhāraṇī] pc.; dhārasaṇi ac. 7 ca] pc.; ca sa ac. 13 niṣkramya] corr.; nikramya ms. 15 āyuṣmān] corr.; āyuṣmānn ms. 17 āyuṣmān] corr.; āyuṣmānn ms. 18 -kāśyapah] corr.; -kāśyapenaḥ ms. 19 cāññe] corr.; cānne ms. 21 -kramya ekānte] corr.; -krāme ms. bhagavān] corr.; bhagavānn ms. 23 nyașīdat] corr.; nyapīdat ms. 25 tvaṃ] corr.; stvam ms. 
āgataḥ svakād vihārān niṣkramya yena tathāgatavihāras tenopasaṃkrānta upasaṃkramyaikānte sthito bhagavato darśanāya vandanāyai paryupāsanāya || tat kasmād dhetos tathā hi bhagavann aṭ̣pto 'hạ̣ tathāgatasya darśanāya vandanāya paryupā<173r>sanena ca | yad apy ahaṃ bhagavaṃs tathāgatam upasaṃkramāmi darśanāya vandanāyai paryupāsanāya | tat sarvasattvānām arthāya saced bhagavaṃs tathāgato drașțavyo vanditavyaḥ | paryupāsitavyaḥ | evaṃ drașțavyạ̣ | evaṃ vanditavyaḥ | paryupāsitavyo yathāhaṃ paśyāmi | yathāhaṃ vande | yathāhaṃ paryupāse | evaṃ tathāgata dṛșto bhavati | vanditaḥ paryupāsitaś ca | ahạ̣ ca bhagavan sarvasattvānāṃ kṛtaśa tathāgatam paśyāmi || bhagavān āha || kathaṃ tathāgato mañjuśrīḥ draștavyo yāvat paryupāsitavyaḥ || mañjuśrīr āha || tathāgatākāreṇa tathāgatạ̣ paśyāmy avikalpākāreṇānupalambhayogena || evam anutpādākāreṇa tathāgatam paśyāmi | yāvad abhrākāreṇa tathāgatam paśyāmi | na ca tathāgata samudāgacchati evaṃ tathāgatam paśyāmi na tathatā bhavati | evam tathāgatam paśyāmi | na tathatā deśasthā na pradeśasthā evaṃ tathāgatam paśyāmi | na tathatā atītā nāgatapratyutpannānāṃ evaṃ tathāgatạ̣ paśyāmi | na tathatā dvayaprabhāvitā nādvayaprabhāvitā | evaṃ tathāgatạ̣ paśyāmi na tathāgatā saṃkliśyate | na vyavadāyate | evaṃ tathāgatạ̣ paśyāmi | na tathatā utpadyate na nirudhyate | evaṃ tathāgatam paśyāmi | evaṃ ca tathāgato dṛșto bhavati | vandi<173v>taḥ paryupāsitaś ca | evam ukte bhagavān mañjuśriyam kumārabūtam etad avocat || evaṃ paśyaṃs tvaṃ mañjuśrīh kị̣ paśyasi || mañjuśrīr āha || evaṃ na paśyan nāhaṃ bhagavan na kiṃcit paśyāmi | evam ahạ̣ bhagavan paśyan na kasyacid dharmasyotpādaṃ paśyāmi | na nirodhaṃ paśyāmi || athāyuṣmāñ chāradvatīputro mañjuśriyaṃ kumārabhūtam etad avocat || duṣkarakārakas tvaṃ mañjuśrīr yas tvaṃ tathāgatam evaṃ paśyasi | evaṃ paryupāse | yasya ca te sarvasattvānām antike mahāmaitrī pratyupasthitā na ca te kāci sattvopalabdhị̣ sattvābhiniveśo vā sarvasattvānāṃ parinirvāṇāya cāsi pratipanno na ca te kaścit sattvābhiniveśạ̣ saṃnāhạ̣ saṃnaddhạ̣ sa cānupalambhayogena yāvad abhāvayogena || evam ukte mañjuśrīḥ kumārabhūta āyuṣmantam śāradvatīputram etad avocat || evam etad bhadanta śāradvatīputra yathā kathayasi sarvasattvaparinirvāṇāya saṃnāhaś caiṣa saṃnaddho na ca me kācit sattvopalabdhir vā sattvābhiniveśo vā | nāyạ̣ bhadanta śāradvatīputra saṃnāha evaṃ saṃnaddhạ̣ | katham ahạ̣ sattvadhātor ūnatvaṃ vā kuryāṃ pūrṇatvaṃ vā saced bhadanta sāaradvatīputra parikalpam upādāya ekaikasmin buddhakṣatre gañgānadīvālukāsamā buddhā

1 tathāgata] corr.; stathāgata-ms. 3 kasmād] $p c . ;$ kasmahed $a c . \quad 15$ tathāgataṃ] $p c . ;$ tagathātaṃ ac. 17 paśyāmi] pc.; papaśyāmi ac. 25 paśyasi] corr.; paśyāmi ms. 26 pratyupasthitā] corr.; pratyapasthitā ms. 
bhagavanto bhaveyur e<174r>kaikaś ca tathāgato gañgānadīvālikāsamān kalpāṃs tiṣṭhet sa rātrim divaṃ ca dharmaṃ deśayamāna ekaikayā dharmadeśanayā yāvanto gañgānadīvālukāyā samair buddhair bhagavadbhị̣ sattvā vinītās tāvataḥ sattvā naikaikas tathāgata ekaikayā dharmadeśanayā vinayet | evam api kṛtvā naiva sattvadhātor ūnatvaṃ vā pūrṇatvaṃ vā prajñāyate | tat kasmād dhetoḥ sattvaviviktatvā sattvāt saced bhadanta sāradvatīputra sattvadhātor naivonatvaṃ vā pūrṇatvaṃ vā prajñāyate || evam ukte āyuṣmān śāradvatīputro mañjuśriyaṃ kumārabhūtam etad avocat || yadi mañjuśrīḥ sattvaviviktatvāt sattvadhātor naivonatvam na pūrṇatvaṃ vā prajñāyate | tat kasyedānīm bodhim abhisambudhya dharmạ̣ deśayiṣyasi || evam ukte mañjuśrīḥ kumārabhūta āyuṣmantạ̣ sāaradvatīputram etad avocat | yadā tāvad bhadanta śāradvatīputra atyantatayā sattvānupalabdhis tat ko 'trābhisambhotsyate kasya vā dharmaṃ deśayișyate || tat kasmād dhetos tathā hi bhadanta śāradvatīputra atyantatayā sarvadharmānupalabdhị̣ || atha khalu bhagavān mañjuśriyaṃ kumārabhūtam etad avocat || yadā tāvan mañjuśrīr atyantatayā sarvadharmānupalabdhị̣ | tat kim idānīṃ sattvam api prajñāpayișyasi | api ca sace tvāṃ mañjuśrī ka<174v>ścid eva pṛcchet kiyantaḥ sattvā iti kiṃ tasya tvaṃ vade || mañjuśrīr āha || tasyāhaṃ bhagavann evam pṛșta evaṃ vadeyaṃ yāvanta eva buddhadharmā iti saced bhagavat punar api prcchet | kiṃcit pramāṇaḥ sattvadhātur iti || tasyāham bhagavann evam pṛcche | evaṃ vadeyaṃ yatpramāṇo buddhaviṣayah || bhagavān āha || sacet punar api te mañjuśrīḥ kaścid evaṃ pṛcchet | kim paryāpannaḥ sattvadhātur iti | kị̣ tasya tvaṃ vade || mañjuśrīr āha || tasyāhaṃ bhagavann evaṃ pṛșta evaṃ vadeyạ̣ yat paryāpannānutpādācintyatā || bhagavān āha || sacet punar api te mañjuśrīḥ kaścid evaṃ pṛcchet kiṃ pratișthitaḥ sattvadhātur iti || kiṃ tasya tvaṃ vadeh || mañjuśrīr āha || tasyāhaṃ bhagavann evaṃ pṛ̦ța evaṃ vadeyaṃ yatpratișṭhito 'nutpādadhātus tatpratișțitah sattvadhātur iti || bhagavān āha || yasmin samaye tvaṃ mañjuśrīh prajñāpāramitāṃ bhāvayasi tadā kutra pratișṭhām prajñāpāramitām bhāvayasi || mañjuśrīr āha || yasminn ahaṃ bhagavann aham samaye prajñāpāramitām bhāvayāmi | apratișṭhito 'yaṃ tasmin samaye prajñāpāramitāṃ bhāvayāmi || bhagavān āha || apratișțhitasya te mañjuśrīḥ prajñāpāramitābhāvanā || mañjuśrīr āha || saiva bhagavan prajñāpāramitābhāvanā <175r> yaṃ na kvacit pratișțhānam || bhagavān āha || yasmin samaye tvaṃ mañjuśrīh prajñāpāramitām bhāvayasi kataratte kuśalamūlaṃ tasmin samaye upacayam gacchaty apacayạ̣ vā || mañjuśrīr

6 bhadanta] corr.; bhagadanta ms. 14 atyantatayā] corr.; atyantayā ms. 15 mañjuśrīr] corr.; mañjur ms. 33 bhagavan prajñā-] corr; bhagavann aprajñā- ms. 35 gacchaty] corr.; ty ms. 
āha || na me bhagavan tasmin samaye kiṃcit kuśalamūlam upacayạ̣ gacchaty apacayaṃ vā || nāsau bhagavān prajñāpāramitāṃ bhāvayati | yasya kasyacid dharmasyopacayo vā apacayo vā bhavati || na sā bhavagan prajñāpāramitābhāvanā veditavyā | yā kasyacid dharmasyopacayāya vā apacayāya vā pratyupasthitā | sā bhagavan prajñāpāramitābhāvanā naiva pṛthagjanadharmān upādatte || tat kasmād dhetos tathā hi bhagavan prajñāpāramitābhāvanā na kasyacid dharmasyopalambhena pratyupasthitā yaṃ dharmaṃ prajahyādupādadīta vā | sā bhagavān bhāvanā yā naiva saṃsāradoṣān upayāti na nirvāṇaguṇān || tat kasmād dhetos tathā hi bhagavan saṃsāram eva tāvan na samanupaśyāmi kaḥ punar vādaḥ | saṃsāradoṣā nirvāṇam eva tāvan nopalabhe kaḥ punar vādo nirvāṇagunān drakṣyāmi sā bhagavan prajñāpāramitābhāvanā yaṃ na kasyacid dharmasyādānaṃ vā grahaṇaṃ vā niḥsaraṇaṃ vā | sā bhagavan prajñāpāramitābhāvanā yā na kasyacid dharmasya $<175 \mathrm{v}>$ hānir vā vṛddhir vopalabhyate || tat kasmād dheto na hi bhagavann anutpādo hīyate vā vardhate vā yaivaṃ bhagavan bhāvanā sā prajñāpāramitābhāvanā | sā bhagavan prajñāpāramitābhāvanā yā na kaścid dharmam utpādayati vā nirodhayati vā || sā bhagavan prajñāpāramitābhāvanā yā na kasyacid dharmasyonatvaṃ vā pūrṇatvaṃ vā karoti yā bhagavann evaṃ bhāvanā saivaṃ bhagavan prajñāpāramitābhāvanā || punar aparaṃ bhagavan prajñāpāramitābhāvanā yā naivācintyān dharmān prārthayate na prādeśikān api tu khalu punar bhagavams tad api na samvidyate yat prārthyate yena prāpyate yatra prārthyate evaṃ bhāvanā bhagavan prajñāpāramitābhāvanā bhagavan prajñāpāramitābhāvanā evaṃ pratyupasthitā ime dharmāgrā ime dharmā hīnā iti | nāpi tān dharmān upalabhate | yeșāṃ dharmāṇām agratā vā hīnatā vā syāt | evaṃ prajñāpāramitābhāvanāyogānuyuktạ̣ kulaputra sarvadharmān nopalabhate | na bhagavan prajñāpāramitābhāvanā kaścid dharmam agraṃ vā hīnaṃ vā kalpayati || tat kasmād dheto na bhagavann anutpādasya | kaścid agraṃ vā hīnaṃ vā nāpi tathatāyā bhūtakoṭā yāvat sarvadharmāṇāṃ kiṃcid agraṃ vā hīnaṃ vā evaṃ bhāvanā bhagavan prajñāpāramitābhāvanā <176r> || evam ukte bhagavān mañjuśriyaṃ kumārabhūtam etad avocat | na punar mañjuśrīr agrā buddhadharmāh || mañjuśrīr āha || agrāhyatvād bhagavann agrā buddhadharmāh || tat kiṃ punar bhagavan sarvadharmāḥ śunyā iti tathāgatenābhisambuddhāḥ || bhagavān āha || evam etan mañjuśrīḥ śūnyāḥ sarvadharmā tathāgatenābhisambuddhāḥ || mañjuśrīr āha || tat kị̣ punar bhagavan śūnyatāyā agratā vā hīnatā vā prajñāyate || bhagavān āha || sādhu sādhu mañjuśrīr evam etan mañjuśrī yathā

5 -bhāvanā] corr.; -mābhāvanā ms. 8 prajahyād-] pc.; pravajahyād- $a c .14$ kasyacid] pc.; kva kasyacid $a c .18$ bhagavann] pc.; vagann $a c .32$ bhagavann] corr.; gavann ms. 
kathayasi na punar mañjuśrīr anuttarā buddhadharmāh || mañjuśrīr āha || evam etad bhagavann anuttarā buddhadharmāḥ || tat kasmād dhetos tathā hi bhagavaṃs teșv ante-r-api dharmo na saṃvidyate nopalabhyate na te anuttarā buddhadharmāḥ || punar aparaṃ bhagavan sā prajñāpāramitābhāvanā yā buddhadharmāṇām ārādhananāyai saṃvartate na p̣̣thagjanadharmāṇāṃ prahāṇāya saṃvartate na buddhadharmāṇāṃ janayitrī evaṃ bhāvanā bhagavan prajñāpāramitābhāvanā || punar aparaṃ sā bhagavan prajñāpāramitābhāvanā drașțavyā yā na kaścid dharmaṃ cintayate na vijānīte || bhagavān āha || na tvaṃ mañjuśrī buddhadharmāṃś cintayasi || mañjuśrīr āha || no bhagavaṃś cintayeyam aham bhagavan buddhadharmā saced ahaṃ buddhadharmānāṃ pari<176v>niṣpattim paśyeyaṃ na bhagavan prajñāpāramitābhāvanā kasyacid dharmasya vikalpena pratyupasthitā | ime pṛthagjanadharmā ime śrāvakadharmā ime pratyekadharmā ime samyaksambuddhadharmā iti || tat kasmād dhetos tam eva bhagavan dharmaṃ prajñāpāramitābhāvanāyogam anuyuktaḥ kulaputra nopalabhate yasyaitān dharmāṇām pṛthagjanadharmān vā nirdiśet śaikșadharmān vā nirdiśed aśaikșadharmān vā nirdiśet | samyaksambuddhadharmān vā nirdiśet | tam atyantayā dharmān na samanupaśyāmi || evaṃ bhāvanā bhagavan prajñāpāramitābhāvanā | na bhagavan prajñāpāramitābhāvanāyogam anuyuktasya kulaputrasyaivaṃ bhavati | ayaṃ kāmadhātur ayaṃ rūpadhātur ayam ārūpyadhātur yāvad ayạ̣ nirodhadhātur iti || tat kasmād dhetos tathā hi sa bhagavan na kaścid dharmā yo nirodhadharmaṃ samanupaśyati || evaṃ bhagavan prajñāpāramitābhāvanā veditavyā || punar aparaṃ bhagavann eșā sā prajñāpāramitābhāvanā yā na kasyacid dharmasyopakāraṃ vā apakāraṃ vā karoti | na hi bhagavan prajñāpāramitābhāvanā buddhadharmāṇāṃ dātrī na pṛthagjanadharmāṇām āgacchatrī | eșaiva sā bhagavan prajñāpāramitābhāvanā || yo naiva pṛthagjanadharmā<177r>ṇām nirodho na buddhadharmāṇām pratilambhaḥ || evam ukte bhagavān mañjuśriyaṃ kumārabhūtam etad avocat || sādhu sādhu mañjuśrī yas tvam imam evaṃrūpaṃ gambhīraṃ dharmạ̣ deśayasi | sthāpitā te mañjuśrīyam mudrā bodhisattvānām mahāsattvānām ābhimānikānāṃ ca śrāvakāṇām aupalambhikānāṃ ca bodhisattvayānikānāṃ yathābhūtaṃ prativedhāya na te mañjuśrīḥ kulaputrā vā kuladuhitaro vā ekabuddhaparyupāsitā bhaviṣyanti | naikabuddhāvaropitakuśalamūlā ya imaṃ gambhīraṃ prajñāpāramitānirdeśaṃ śrutvā nottrasiṣyanti na saṃtrasiṣyanti na saṃtrāsam āpatsyante | api tu khalu punar mañjuśrīr atikramya te buddhasahasrāvaropitakuśalamūlā bhavișyanti || ya imaṃ gambhīraṃ

10 saced ahaṃ] pc.; sacehaṃda ac. 16 nirdiśed] corr.; nirdiśetd ms. 28 mañjuśriyaṃ] corr.; mañjuśrīriyaṃ ms. 
prajñāpāramitānirdeśaṃ śrutvādhimokṣanti na uttrasiṣyanti na saṃtrasiṣyanti na saṃtrāsam āpatsyante || evam ukte mañjuśrīḥ kumārabhūto bhagavantam etad avocat || pratibhāti me bhagavan bhūyasyā mātrayā prajñāpāramitānirdeśạ̣ | pratibhātu te mañjuśrīr iti bhagavann asyāvocat || mañjuśrīr āha || eșā sā bhagavan prajñāpāramitābhāvanā | yā na kasyaci dharmasya sthitim upalabhate nāsthitim || tat kasmād dhetor asthitatvāt sarvadharmāṇām nopa<177v >lambhate || eșaiva sā bhagavan prajñāpāramitābhāvanā veditavyā | yā na kasyacid dharmasyādhyālambanāya pratyupasthitā || tat kasmād dhetos tathā hi bhagavan nirālambanāḥ sarvadharmā evaṃ bhāvanā bhagavan prajñāpāramitābhāvanā || punar aparam bhagavan sā prajñāpāramitābhāvanā drașțavyā | yatra buddhadharmā api nāmukhībhavanti | kutạ̣ punaḥ pratyekabuddhadharmāḥ | nāpi śrāvakadharmāṇām āmukhībhāvo bhavati | kaḥ punar vādạ̣ pṛthagjanadharmāṇām || punar aparaṃ bhagavan prajñāpāramitābhāvanā yām āgamyācintyān api buddhadharmān acintyā buddhadharmā ceti na vikalpam āpadyata iti || seyaṃ bhagavan prajñāpāramitābhāvanā bodhisattvānām mahāsattvānāṃ sarvakarmākalpāya drașțavyā || punar aparaṃ bhagavan sā prajñāpāramitābhāvanā bhāvanāyām āgamya sarvadharmān buddhadharmān paśyati | sarvadharmān acintyadharmān paśyati asamanupaśyantayā bahubuddhaśatasahasraparyupāsitās te bhagavan kulaputrāḥ kuladuhitaraś ca bhavisyati | ya imaṃ prajñāpāramitānirdeśaṃ śrutvā adhimokṣante nottrasiṣyanti na saṃtrasiṣyanti na saṃtrāsam āpatsyante || punar aparam bhagavan sā prajñāpāramitābhāvanā yāṃ na kaścid dharmaṃ sạ̣kliśyantạ̣ vā vyavadāyanta<178r>ṃ vā samanupaśyati || evaṃ bhāvanā bhagavan prajñāpāramitābhāvanā | sā caișā bhagavan prajñāpāramitābhāvanā || yā naiva pṛthagjananānātvaṃ karoti na śrāvakanānātvaṃ na pratyekabuddhanānātvaṃ yāvat samyaksambuddhanānātvaṃ ca karoti || eșā sā bhagavan prajñāpāramitābhāvanā || atha khalu bhagavān mañjuśriyaṃ kumārabhūtam āmantrayate sma | kiyantas tvayā mañjuśrīs tathāgatāḥ paryupāsitāḥ || mañjuśrīr āha || yāvanto bhagavan māyāpuruṣasya cittacaitasikā niruddhāh | iyanto mayā bhagavan tathāgatāḥ paryupāsitāḥ || bhagavān āha || na tvaṃ mañjuśrīr buddhadharmasamsthitāḥ || mañjuśrīr āha || kaścit punar bhagavan sa dharma upalabhyate yo na buddhadharmasaṃsthitạ̣ || bhagavān āha ||

1 na] $p c . ;$ sa na $a c . ; 3$ bhagavan] corr.; bhagava ms. 6 asthitatvāt] $p c . ;$ asthitatvā ac. 7 bhagavan] corr.; bhagan ms. 9 bhagavan] corr.; bhagava ms. 15 ceti] corr.; cātri ms. 20 bhagavan] corr.; bhagavavan ms. • kulaputrāḥ] corr.; kulapatrāh ms. 21 -duhitaraś ca] $p c . ;$-duhitaścara $a c .22$ saṃtrāsam] $p c . ;$ saṃtrāsapām ac. 24 bhagavan] corr.; bhagan ms. 
kasya punar mañjuśrīr ete buddhadharmāḥ || mañjuśrīr āha || bhagavan tava tāvad ete buddhadharmā iti nāma na saṃvidyante | nopalabhyante | kutaḥ punar anyeșāṃ bhaviṣyanti || bhagavān āha || prāptā te mañjuśrīr asaṃgatā || mañjuśrīr āha || tad yadā tāvad ahaṃ bhagavan saṃgataiva tat kiṃ bhūyo 'ham asaṃgatām anuprāpsyāmi || bhagavān āha || tat kiṃ niṣaṇṇo 'si mañjuśrīr bodhimaṇ̣̣e || mañjuśrīr āha || bhagavān eva tāvad bodhimaṇḍe na niṣaṇṇạ̣ katham punar ahaṃ niṣatsyāmi bhūtakoțim pramāṇīkṛtya || bhagavān āha || <178v> bhūtakoțir iti mañjuśrīh kasyaitad api vacanam || mañjuśrīr āha || bhūtakoțir iti bhagavan satkāyasyaitad adhivacanam || bhagavān āha || kiṃ saṃdhāya mañjuśrīr evaṃ vadasi || mañjuśrīr āha || asann eṣa bhagavan kāyo na satkāyaḥ naiṣa saṃkrāmati tenaiṣa kāyo asatkāyaḥ || atha khalv āyuṣmān sāradvatīputro bhagavantam etad avocat || niyatās te bhagavan bodhisattvā mahāsattvā bhaviṣyanti bodhaye ya imaṃ prajñāpāramitānirdeśaṃ śrutvādhimokṣyante nottrasiṣyanti na saṃtrasiṣyanti na saṃtrāsasam āpatsyante || atha khalu maitreyo bodhisattvo mahāsattvo bhagavantam etad avocat | āsannībhūtās te bhagavān bodhisattvā mahāsattvā bhaviṣyanti bodhaye ya imaṃ prajñāpāramitānirdeśaṃ śrutvā adhimokṣyante nottrasiṣyanti na saṃtrasiṣyanti na saṃtrāsam āpatsyante || tat kasmād dhetor eșaiva bhagavan paramā bodhi yaiṣāṃ dharmāṇām anubodhanā || atha khalu mañjuśrīkumārabhūto bhagavantam etad avocat || buddhā eva te bhagavan bodhisattvā mahāsattvā drașțavyā ya imāṃ prajñāpāramitānirdeśaṃ śrutvādhimokṣyante nottrasiṣyanti na saṃtrasiṣyanti na sạ̣trāsam āpatsyante || tat kasmād dhetor buddha iti bhagavan paramārthato 'nutpādasyaitad adhivacanam || atha khalu nirālambā bhaginī bhagavanta<179r $>$ m etad avocat | na te bhagavan bodhisattvā mahāsattvāḥ pṛthagjanadharmān śrāvakadharmān pratyekabuddhadharmān samyaksambuddhadharmān adhyālambiṣyante ya imāṃ prajñāpāramitānirdeśaṃ śrutvādhimokșyante nottrasiṣyanti na saṃtrasiṣyanti na saṃtrāsam āpatsyante || tat kasmād dhetos tathā hi bhagavan nirālambāḥ sarvadharmāḥ asaṃvidyamānatvāt tenaiṣām ālambanaṃ na saṃvidyate || atha khalu bhagavān āyuṣmantam āmantrayate sma || evam etac chāriputraivam etat | niyatās te kulaputrāḥ kuladuhitaraś ca bhavișyanti bodhaye ya imāṃ prajñāpāramitānirdeśaṃ śrutvādhimokṣyante nottrasiṣyanti na saṃtrasiṣyanti na saṃtrāsam āpatsyante | avinivartanīyau bhūmau tvạ̣ sāradvatīputra pratișṭhitās tān kulaputra saced bhadanta sāaradvatīputra bhagavatā dharmadhātur abhisambuddhạ̣ syāt tad yo 'sāv anutpādadhātuḥ sa 35 niruddho bhavet || api tu sāaradvatīputra sa eva dharmadhātur bodhị || tat

9 bhagavān āha] $p c$.; bhaganāvāha ac. 24 khalu] corr.; khala ms. 31 -duhitaraś ca] pc.; -duhitaścara $a c$. 
kasmād dhetor niḥsattvo hi dharmadhātur abhāvāḥ sarvadharmā iti bodher adhimuñcanam etad yo 'sau dharmadhātur iti saṃkhyāṃ gacchanti || tat kasmād dhetoḥ sarvadharmā hy anānātvā buddhaviṣayataḥ | anānātvam iti bhadanta śāradvatīputra | avijñaptikapadam etad avijñaptikam iti | <179v> bhadanta śāradvatīputra na tac chakyam vijñāpayitụ̣ saṃskṛtatvena vā yāvad 5 asaṃskṛtatvena vā na tatra kācid vijñaptis tena tad avijñaptikam | sarvadharmā hi bhadanta saāradvatīputrāvijñaptikā || tat kasmād dhetos tathā hi sarvadharmāṇām prādurbhāvo nāsti | yasmin sthitvā vijñāpyeran | ye 'py amī ānantaryaprasṛtā acintyaprasṛtās te ye cācintyapraș̣tā bhūtaprasṛtās te || tat kasmād dhetor na hy acintyam iti bhadanta sāaradvatīputra abhedapadam etat | ye 'py acintyasamanvāgato naiva te svargagāmino nāpāyagāmino na parinirvāṇagāminaḥ || tat kasmād dhetor na hy acintyạ̣ gamanāgamanena pratyupasthitam | yāvanta parinirvāṇam gamanāgamanena pratyupasthito | ye 'pi bhadanta śāradvatīputra cataș̣ṣu mūlāpattiṣu vyavasthitāḥ | amūle te vyasthitāḥ || tat kasmād dhetor na hi bhadanta śāradvatīputrānutpādasya mūlam agram veșyate || amūle bhikṣur ity apratișțitasya bhikṣor etad adhivacanam | utpannam adhivacanam karaṇam ity adhikasamāropyasyaitad adhivacanam adhikasamāropye bhadanta śāradvatīputra caran loke dakṣinịyo bhavati || tat kasmād dhetos tathā viśamạ̣ so 'dhikasamāropạ̣ | śrāddho bhadanta śāradvatīputra bhikṣur nārhati śraddhādeyam pari<180r>bhoktam | aśrāddho śāradvatīputra bhikṣur arhati śraddhādeyạ̣ paribhoktam | kalpiko bhadanta saāradvatīputra bhikṣur nārhati śraddhādeyaṃ paribhoktam | akalpiko bhadanta śāradvatīputra bhikṣur arhati śraddhādeyaṃ paribhoktam | asamupahatanetrīko bhikṣur arhat kṣiṇāsrava ity ucyate || śāradvatīputra-r-āha || kiṃ saṃdhāya mañjuśrīr evaṃ vadasi || mañjuśrīr āha || na samatā samupahatā yā samatā saiva sā netrī idaṃ saṃdhāya bhadanta śāradvatīputra evaṃ vadāmy asamupahatanetrikā bhikṣur arhann akṣinnāsrava ity ucyate | anuttīrṇabhaya iti bhadanta śāradvatīputrārhatạ̣ kṣiṇāśravasyaitad adhivacanam || śāradvatīputra-r-āha || kiṃ punaḥ saṃdhāya mañjuśrīr evaṃ vadasi || mañjuśrīr āha || aṇūny api tasya bhayāni na samvidyante tat kim uttariṣyati || idaṃ saṃdhāya bhadanta śāradvatīputraivaṃ vadāmy anuttīrṇabhaya ity arhataḥ kṣịnāsravasyaitad adhivacanam iti || || śāradvatīputra āha || || anutpannakșānti mañjuśrīh kasyaitad adhivacanam || mañjuśrīr āha || yena bhadanta śāradvatīputra aṇur api dharmo notpāditạ̣ sa

4 bhadanta] $p c$.; śāra bhadanta ac. $\mathbf{6}$ tena tad] corr.; tenad ms. 16 agraṃ] corr.; dagram ms. 17 adhivacanaṃ karaṇam] pc.; adhivacakanaṃraṇam ac. 18 adhikasamāropye] corr.; adhikamāropye ms. 20 bhadanta] pc.; bhagadanta ac. 21 śāradvatīputra] corr.; śāratīputra ms. 24 śāradvatīi-] pc.; śāratīdvatī- ac. 25 saṃdhāya] corr.; saṃdhāyasa ms. 31 vadāmy] corr.; vadāsy ms. 
ucyate anutpannakṣāntika iti || || sāaradvatīputra āha || avinīto bhikṣur iti mañjuśrīḥ <180v> kasyaitad adhivacanam || mañjuśrīr āha || avinīto bhikșur iti bhadanta saāradvatīputrārhataḥ kṣīnāsravasyaitad adhivacanam || tatra kasmād dhetor avinayo hi vinīto na vinayo vinītah || || kasyaitad adhivacanam buddha iti yo samudāgato notpanno na nirotsyate | yena kenacid dharmeṇa samanvāgato 5 nāpy atra kiṃcit padam apadasyaitad bhadanta śāradvatīputrādhivacana yad uta buddha iti || tathāgataṃ bhadanta sāaradvatīputra paryeșitukāmena ātmā paryoșitavya ātmeti bhadanta saāradvatīputra buddhasyaitad adhivacanaṃ yathā ātmā atyantatayā na saṃvidyate nopalabhyate | tathā buddho 'py atyantatayā na saṃvidyate nopalabhyate | yathā ātmā na kenacid dharmeṇa vacanīyas tathā buddho 'pi kenacid dharmeṇa vacanīyo yatra na kācit saṃkhyā sūcyate buddha iti || nacaitad bhadanta sāaradvatīputra sukaram ājñām ātmeti yad adhivacanam evam etad bhadanta śāradvatīputra na sukaram ājñātum buddha iti yad adhivacanam || atha khalv āyuṣmān śāradvatīputro bhagavantam etad avocat || nāyaṃ bhagavan mañjuśrīḥ kumārabhūtas tathā deśayati | yathā 15 ādikarmikā bodhisattvā ājānīyuh || evam ukte mañjuśrīḥ kumārabhūta āyuṣma<181r>ntaṃ śāradvatīputram etad avocat || nāhaṃ bhagavac chāradvatīputra tathā deśayāmi yathā kṛtāvino 'py arhanta ājñāsyanti nāpy arhan tathā deśayāmi | yathā kaścid vijñāsyati tat kasmād dhetor na bodhị̣ | kecid vijñātā nāpi sambuddhān dṛștvā na śrutā na smṛtā notpāditā na nirodhitā noddișțā nopadeśitā | etāvad etad bhadanta śāradvatīputra yāvatā bodhị sā ca bodhir na bhāvo nāpy abhāvạ̣ || tat kasmād dhetor na bodhyā kiṃcid abhisamboddhavyaṃ nāpi bodhim abhisambudhyate || śāriputra āha || na mañjuśrīr bhagavatā dharmadhātur abhisambuddhạ̣ || mañjuśrīr āha || na bhadanta śāradvatīputra bhagavatā dharmadhātur abhisabuddhaḥ || tat kasmād dhetos tathā hi bhadanta sāaradvatīputra dharmadhātur eva bhagavān sakulaputrān kuladuhitṛ́ ca jānīyur ya imāṃ paramāṃ prajñāpāramitānirdeśaṃ śrutvādhimokṣante nottrasiṣyanti na saṃtrasiṣyanti na saṃtrāsam āpatsyante | mūrdhā ca pratigrahiṣyanti te te saāradvatīputra paramadānapatayo bhaviṣyanti || mahādānapatayo viśișțadānapatayas te te sāradvatīputra śîlasampannā bhavișyanti | paramaśīlasamāpannāḥ paramaviśișțaśīlāḥ śīlaguṇapathaprāptāya imāṃ prajñāpārami<181v>tānirdeśaṃ śrutvādhimokṣante nottrasiṣyanti na saṃtrasiṣyanti na saṃtrāsam āpatsyante || te te śāradvatīputra paramayā

10 atyantatayā] $p c$.; atyantayāta ac. 13 -vacanam evam] $p c . ;$-vacanam $a c . \quad$ • àjñātuṃ] corr.; ājñatta ms. 18 nāpy] pc.; nāāpy ac. 24 mañjuśrīr] corr.; mañjuśrīd ms. 27 paramāṃ] corr.; pramāṃ ms. 28 śrutvādhimokșante] corr.; śrudhimodhikșante ms. 
kṣāntyā parameṇa vīryeṇa paramair dhyānaih paramayā 'pratisamayā prajñayā samanvāgatā bhaviṣyanti || te te śāradvatīputra bodhisattvā mahāsattvā yāvat sarvākāravaropetena sarvajñajñānena samanvāgatā bhaviṣyanti || ya imāṃ prajñāpāramitānirdeśaṃ śrutvā adhimokṣante nottrasiṣyanti na saṃtrasiṣyanti na saṃtrāsam āpatsyante || punar aparaṃ bhagavan mañjuśriyaṃ kumārabhūtam etad avocat || kiṃ punas tvaṃ mañjuśrīr arthavaśaṃ sampannecchasy anuttarām samyaksambodhim abhisamboddhum || mañjuśrīr āha || saced ahaṃ bhagavan bodhīyaṃ samprati svayam evam aham iccheyam abhisamboddhuṃ bhagavan bodhim prārthayāmi || tataḥ kasmād dheto bodhisattvā-r-evaișā yo 'yaṃ mañjuśrīḥ kumārabhūtah || evam ukte bhagavān mañjuśriyaṃ kumārabhūtam etad avocat | sādhu sādhu mañjuśrīr yas tvam imāny evaṃrūpāṇi gambhīragambhīrāṇi sthānāni cecchasi || yathāpi nāma tvaṃ pūrvajinakṛtādhikāro 'nupalambhacaritabrahmacaryaḥ || mañjuśrīr āha || labdhaṃ bhagavan dharmaḥ syād yady aham anupalambhacārī syām || evam ukte bhagavān mañjuśriyaṃ kumārabhūtam e<182r>tad avocat | paśyasi tvaṃ mañjuśrīr imāṃ mama śrāvakopasampadam || mañjuśrīr āha || paśyāmi bhagavan || bhagavān āha || kathaṃ paśyāmi || mañjuśrīr āha || tathāhaṃ bhagavan paśyāmi yathā naiva pṛthagjanān paśyāmi naiva śaikṣān paśyāmi naivāśaikṣānya paśyāmi naiva paśyāmi eva paśyāmi yạ̣ naiva bahunya paśyāmi nāpy alpakān paśyāmīyam naiva vinītān paśyāmi || atha khalv āyuṣmāñ chāradvatīputro mañjuśriyaṃ kumārabhūtam etad avocat || yas tvaṃ mañjuśrīḥ śrāvakayānikān evaṃ paśyasi samyaksambuddhayānikān punas tvaṃ kathạ̣ paśyasi || mañjuśrīr āha || bodhisattva iti bhadanta śāradvatīputra nāmaṃ na samanupaśyāmi abhisambudhyata iti nāma dharmaṃ na samanupaśyāmi || evaṃ bhadanta śāradvatīputra samyaksambuddhayānikān paśyāmi || śāriputra āha || tathāgatas tvaṃ mañjuśrīḥ kathaṃ paśyasi || mañjuśrīr āha || tiṣthhantu bhadanta śāradvatīputra mahānāgo sā mahānāgam ghaț̣aye || evam ukte āyuṣmān śāradvatīputro mañjuśriyaṃ kumārabhūtam etad avocat || buddha iti mañjuśrīḥ kasyaitad adhivacanam || mañjuśrīr āha || yatra punar bhadanta || śāriputra āha || anutpādasyaitan mañjuśrīr adhivacanam | yad utātmeti || mañjuśrīr āha || e<182v>vam etad bhadanta śāradvatīputra yasyaitad adhivacanam ātmeti tasyaitad adhivacanam buddha iti | api tu bhadanta śāradvatīputra apadādhivacanam etat yad idam ucyate buddha iti na hy etad bhadanta sāaradvatīputra sukaraṃ vācābhir vijñāpayitum buddha iti || vāg api bhadanta śāradvatīputra na sukarā nirūpayitum iyaṃ vāg atikutra bhadanta śāradvatīputra yad evaṃ vadasi | idạ̣ saṃdhāya bhadanta

1 paramair] corr.; paramamair ms. $\mathbf{6}$ arthavaśam] corr.; ava ms. 11 etad] pc.; deta ac. 12 imāny] corr.; imānn ms. 28 ghațtaye] corr.; gharttaye ms. 
sāaradvatīputraivaṃ vadāmy avinīto bhikṣur ity arhataḥ kṣīṇāsravasyaitad adhivacanam || śāradvatīputra āha || adhicitte caratīti mañjuśrīḥ kasyaitad adhivacanam || mañjuśrīr āha || adhicitte caratīti bhadanta śāradvatīputra pṛthagjanasyaitad adhivacanam || śāradvatīputra āha || kiṃ saṃdhāya mañjuśrīr evaṃ vadasi || mañjuśrīr āha || tathā hi bhadanta śāradvatīputra bodhi karoti || evam ukte āyuṣmān sāaradvatīputro mañjuśriyaṃ kumārabhūtam etad avocat || sādhu sādhu mañjuśrīḥ yas tvaṃ yathārhan kṣinnāsravas tathā kathayasi || mañjuśrīr āha || evam etad bhadanta śāradvatīputra yathā vadasi || kṣiṇāsravo 'smi na cārhan tat kasmād dhetos tathā bhadanta śāradvatīputra kṣiṇā me āsravāḥ | śrāvakabhūmau vā pratyekabhūmau vā anena bhadanta śā<183r>radvatīputra paryāyeṇa kṣīṇāsravo na cāsmy arhan || atha khalu bhagavān mañjuśriyaṃ kumārabhūtam etad avocat || syān mañjuśrīḥ paryāyo yad bodhisattvo mahāsattvo bodhimaṇụe niṣaṇṇo 'bhavyo syād anuttarāyāṃ samyaksambodhim abhisamboddhum || mañjuśrīr āha || syād bhagavan paryāyo yad bodhisattvo mahāsattvo bodhimaṇụe niṣaṇno 'bhavyo 'nuttarām samyaksambodhim abhisamboddhum || tat kasmād dhetos tathā hi bodhāv aṇur api dharmo na saṃvidyate nopalabhyate tenocyate anuttarā samyaksambodhir iti sā ca bodhir anutpannā tatra na kaścid dharmạ̣ samvidyante nopalabhyante yo bodhimaṇḍe niṣīdet yo vā bodhim abhisambuddhyat || yena vā bodhim abhisambudhyata | yạ̣ vā bodhim abhisambudhyat | yo vā bodhimaṇụād uttișțhati | anena bhagavan paryāyeṇābhavyo bodhisattvo mahāsattvo bodhimaṇḍe niṣaṇnānuttarām samyaksambodhim abhisamboddhum || evam ukte bhagavān mañjuśriyaṃ kumārabhūtam etad avocat | bodhir iti mañjuśrīḥ kasyaitad adhivacanam || mañjuśrīr āha || bodhir iti bhagavan pañcānām ānantaryām etad adhivacanaṃ tat kasmād dhetos tathā hi bodhiprakṛtikāny eva tāni pañcānantaryāṇy etāvattvāt tenaiṣā bodhir āntaryaprakṛti<183v>kā ānantaryānām abhisambudhyamānā bodhiṃ na ca pratyakṣībhāvanā sarvadharmeșu bodhị \|| tat kasmād dhetoḥ sarvadharmā hy atyantatayāpratyakṣās te na kenacid abhisambuddhā na dṛștā na jñātā yāvan na viditā evam eșā bodhi || api tu khalu punar bhagavann ābhimānikaiḥ sthāpitāny etāni abhisambuddhāni yāvat pratyakṣīkṛtāni || evam ukte bhagavān mañjuśriyaṃ kumārabhūtam etad avocat || kiṃ te mañjuśrīr mamāntike || evaṃ bhavati tathāgato me tathāgata iti || mañjuśrīr āha || no hīdaṃ bhagavan tat kasmād dheto na me bhagavan naiva bhavet tathāgato me tathāgata iti || tat kasmād dhetos tathā caivaṃ tathatā caivam tathatā ca yathā ca tathatā tathā caiṣa tathāgatas tathā hi bhagavan na

6 saāradvatīputro] corr.; śāradvatītro ms. 10 vā pratyeka] $p c . ;$ pravātyeka ac. 20 abhisambuddhyat] $p c$;; abhisambuvyaddhyat ac. 23 bhagavān] corr.; bhagavā ms. 
tathatā tathāgata vijñāpayati || nāpi tathāgatas tathatāṃ vijñāpayati || tat kasmād dhetos tathā hi bhagavan paramārthato abhāvā tathatā | abhāvas tathāgatas tasmāt tarhi bhagavan na me evaṃ bhavati tathāgato me tathāgata iti | api tu tathāgata iti | bhagavān nāmadhyeyamātram etat || tat katarāsau tathāgato yatra me evaṃ bhaviṣyati | tathāgato me tathāgata iti || bhagavān āha 5 || saṃśayas te mañjuśrīs tathāgatạ̣ || mañjuśrīr āha || <184r> no hīdaṃ bhagavan saṃśayah sacet kācit tathāgatapariniṣpattị syāt tathāgatotpattir vā tathāgataparinirvāṇaṃ vā || evam ukte bhagavān mañjuśriyaṃ kumārabhūtam etad avocat || na tava mañjuśrīr evaṃ bhavati utpannas tathāgata iti || mañjuśrīr āha || syān me bhagavann utpanna tathāgata iti saced dharmadhātor utpattị̣ syāt || bhagavān āha || nādhimucyase tvaṃ mañjuśrīr gañgānadivālukopamā buddhā bhagavantaḥ parinirvṛtā iti || mañjuśrīr āha || kaccit punar bhagavann ekaviṣayā buddhā bhagavanto yad idam acintyavișayāḥ || bhagavān āha || evam etan mañjuśrīr ekavișayā buddhā bhagavanto yad idam acintyaviṣayāḥ || mañjuśrīr āha || kaścit punar bhagavan etarhi tișthati || bhagavān āha || evam etan mañjuśrīr āha || tena hi bhagavann ete gañgānadivālukopamā buddhā bhagavanto parinirvịtāḥ || tat kasmād dhetos tathā hi bhagavan ekavișayā buddhā bhagavanto yad idam acintyaviṣayāḥ | na cācintyatā utpadyate vā nirudhyate vā| tasmād bhagavan evābhisambuddhena ye 'pi te anāgate 'dhvani tathagatā 'rhantas samyaksambuddhā bhavișyanti abhisambuddhā eva te || tat kasmād dheto na hy acintatā atītā vā anāgatā vā pratyutpannā vā | <184v> tasmād bhagavan vibhramas teșām lokasamniveśah | prapañcayanti te bhagavan loke saṃniveśaṃ yeșām evaṃ bhavati | utpannas tathāgato yāvat parinirvāsyati veti || evam ukte bhagavān mañjuśriyaṃ kumārabhūtam etad avocat || tena hi tvaṃ mañjuśrīr idam tathāgatācintyaniścintyam acintya tathāgatasya vāgrata udāharann udāharer avaivartikasya bodhisattvasya mahāsattvasya vārhato vā kṣiṇāsravasya || tat kasmād dhetos tathā hi te śrutvā naivānujñāsyanti | naiva pratikrokṣyanti | tat kasmād dhetos tathā hi tac cintyam acintya niścintyam || mañjuśrīr āha || acintyānāṃ niścintyānām bhagavan na sarvadharmāṇām ko 'trānujñāsyati vā | pratikrokṣyanti vā || bhagavān āha || yathaiva mañjuśrīs tathāgato niścintyas tathaiva pṛthagjanā api niścintyāh || mañjuśrīr āha || pṛthagjanā api bhagavaṃs tathaiva niścintyāḥ || bhagavān āha || evam etan mañjuśrīḥ tat kasmād dhetos tathā hi sarvāṇi cintyā

2 bhagavan] corr.; bhagava ms. $\mathbf{6}$ saṃśayas te] pc.; saṃsasteya ac. 7 -niṣpattih] corr.; -niṣpatih ms. 11 utpanna] corr.; etyanna ms. • dharmadhātor] corr.; urmavātor ms. 13 iti] corr.; i ms. 22 tat kasmād] pc.; tasmātkad $a c$. • atītā] corr.; atītāvānā $a c$., atītānā $p c$. • pratyutpannā] $p c$.; pratyutpanānnā $a c$. 
niścintyā || mañjuśrīr āha || tat kasmād bhagavān evam āha || yathaiva tathāgato niścintyaḥ || evaṃ pṛthagjanā api niścintyā iti || nanu bhagavan pṛthagjanatvam api niścintyam || tat kasmād dhetoḥ niścintyā hi bhagavan sarvadharmāḥ | ye kecid bhagavan parinirvāṇāya prasthi<185r>tā vihariṣyante te bhagavaṃs tat kasmād dheto yaiva niścintyatā tad eva parinirvāṇaṃ tasmāt tarhi bhagavān nāsti niścintyatāyā nānātvaṃ ye 'pi te bhagavann evam āhur ime pṛthagjanadharmā ime āryadharmā iti | ta idaṃ vacanīyāḥ kalyāṇamitrāṇi tāvat paryupāsadhvam || tataḥ paścātjñāsyatha ime pṛthagjanadharmā ime āryadharmā iti || evam ukte bhagavān mañjuśriyaṃ kumārabhūtam etad avocat || icchasi tvaṃ mañjuśrịḥ tathāgatam sarvasattvānām agryam | mañjuśrīr āha || iccheyam ahaṃ bhagavaṃs tathāgatạ̣ sarvasattvānām agryaṃ saced iha kācit sattvapariniṣpattị̣ || bhagavān āha || icchasi tvaṃ mañjuśrīḥ tathāgatam acintyadharmasamanvāgatam || mañjuśrīr āha || iccheyam ahaṃ bhagavan tathāgatam acintyadharmasamanvāgatam | sacet kaṃcid acintyadharmasamanvāgataḥ syāt || bhagavān āha || icchasi punas tvam 15 mañjuśrīr evam ime śrāvakās tathāgatena vinītā iti || mañjuśrīr āha || iccheyam ahaṃ bhagavann evam ime śrāvakās tathāgatena vinītā iti | sacet kaścid acintyadhātuvinayaṃ gacchen na bhagavan buddhotpādaḥ kasyacid upakāreṇa vā apakāreṇa vā pratyupasthitāḥ || tat kasmād dheto tathā hi sthita eva dhātur asaṃkīrṇa eșa dhātu yad utācintyadhātus tasmiṃś ca dhā<185v>tau na śrāvakanānātvaṃ yāvan na pṛthagjananānātvam upalabhyate || bhagavān āha || na tvam mañjuśrīr evam icchasi anuttarapuṇyakṣetram tathāgata iti || mañjuśrīr āha || abhāvatvād bhagavan puṇyakṣetraṃ tathāgatas tenaiva tad anuttarapuṇyakṣetram naitad anuttarapuṇyakṣetram nākṣetram naitad anuttaram punyakṣetram || api tu khalu punar bhagavan nātra kaścid dharmạ̣ samudāgacchati na kṣīyate evaṃ tatra puṇyakṣetram | tatra ca bījaṃ prakṣiptam na vivardhate na parihīyate || bhagavān āha || kiṃ saṃdhāya mañjuśrīr evạ̣ vadasi | tatra kṣetre bỉjam avaropitam na vivardhate na parihīyate iti || mañjuśrīr āha || tathā hi bhagavann acintyaṃ tat kṣetram | etat pụ̣yakṣetram || atha khalu tasyām velāyām buddhānubhāvena șaḍvikāraṃ mahāp̣̣thivīcālo 'bhūt | șoḍaśānām ca bhikṣusahasrāṇām anupādāyāsravebhya cittāni vimuktāni saptānāṃ ca bhikṣuṇîsatānāṃ trayāṇām copāsakaśatānāṃ catvāriṃśataś copāsikāsahasrāṇām | șaște ca kāmāvacarāṇāṃ devakoṭiniyutaśatānāṃ virajo vigatamalam dharmeṣu ca dharmacakṣur utpannam || atha khalv āyuṣmān ānanda utthāyāsanād ekāṃśam cīvaram prāvṛtya dakṣiṇaṃ jānumaṇḍalaṃ

2 -janatvam] corr.; -janāsyatvam ms. 4 viharișyante] corr.; vihante ms. 7 ta idaṃ] pc.; itadam ac. 24 naitad] corr.; naitadd ms. 29 tathā] corr.; stathā ms. • tat kșetram] corr.; tatakșetram ms. 32 copāsaka-] corr.; copāyaka- ms. 34 āyușmān] corr.; āyuṣmānn ms. 
pṛthivyāṃ pratiṣṭhāpya yena bhagavāṃs tenāñja<186r>liṃ praṇamya bhagavantam etad avocat | ko bhagavan hetụ̣ kaḥ pratyayāsya mahatạ̣ prthivīcālasya loke prādurbhāvāya || evam ukte bhagavān āyuṣmantam ānandam etad avocat | ayam ānanda puṇyakṣetranirdeśo nāma dharmaparyāyạ pūrvakair api buddhair bhagavadbhir asminn eva pṛthivīpradeśe bhāṣitạ̣ || ayam ānanda hetur ayạ̣ pratyayāsya mahataḥ pṛthivīcālasya loke prādurbhāvāya || atha khalv āyuṣmāñ chāradvatīputro bhagavantam etad avocat || acintyaśrīr eșa bhagavan mañjuśrīh || tat kasmād dhetos tathā hy asya yad yad eva pratibhāti | tad acintyam evaṃ pratibhāti atha khalu bhagavān mañjuśriyaṃ kumārabhūtam āmantrayate sma || evam etan mañjuśrīr yathā sāaradvatīputro bhikșur vācaṃ bhāṣate | yad yad eva mañjuśriyaḥ kumārabhūtasya pratibhāti sarvaṃ tad acintyam eva pratibhāti || evam ukte mañjuśrīḥ kumārabhūto bhagavantam etad avocat | na hi bhagavann acintyaṃ pratibhāti cintyam eva bhavet saced acintyaṃ pratibhāyāt | api tu na tat kiṃcid yan nācintya sarvaḥ śabdo bhagavann acintyạ̣ na cācintyatāśabdo nāśabdo na cāśabdaḥ śakyo nirdeșțam || bhagavān āha || samāpadyase punas tvaṃ mañjuśrīr acintyaṃ samādhim || mañjuśrīr āha || no hī<186v>daṃ bhagavann acintyaṃ samādhim samāpadye || tat kasmād dhetos tathā hi bhagavann aham evācintyaḥ samādhị̣ | samāpadye 'haṃ bhagavann acintyaṃ samādhị̣ saced aham cintyaḥ || syāṃ samādhir iti bhagavan niścintyācintyam etat | tat katham acintyaṃ samādhim samāpatsye api tu khalu punar bhagavann abhūn me pūrvam ādikarmikasyaiva samudācāram acintyaḥ samādhị̣ | samāpattavya iti na me bhagavann etarhi bhūyo 'tra samudācāraḥ samudācarati acintyaṃ samādhiṃ samāpadye 'ham iti || tadyathāpi nāma bhagavann idyastācāryasya pūrvam ādikarmikabhūmau śikṣamāṇasya evaṃ samudācāro bhavati gokīlāny eva vidhyeyam iti | sa yadā vālavedhe niṣpanno bhavati tadā na tasya punar eva samudācāra utpadyate | kim ahaṃ bhūyo gokīlāny eva vidheyam iti | yad idam vālavedhe suśikșitatvāt || atha ca punar ya vākāńkṣati vālavedhanāya tadā tad ayatnenaiva vidhyati || evam eva bhagavann abhūn me pūrvam eva samudācāro 'cintyaṃ samādhim samāpadye 'ham iti || tadāham evaṃ samādhị̣ samāpanno 'nena samādhinā viharāmi || tadā na mamātra bhūya evaṃ bhavati | anena samādhinā viharāmi bhavyam iti || tat kasmād dhetor yadā yadā anena samādhinā vi<187r $>$ harāmi | tadā tadā eșa samādhir aprajñaptikaḥ || atha khalv āyuṣmān śāradvatīputro bhagavantam etad avocat || atra hi bhagavan mañjuśrīkumārabhūto na viśvasīti || anenācintyena

6 mahatah] $p c$; ha mahatah ac. 7 khalv] pc.; khalulvac. 9 tad] corr.; tadd ms. 14 acintyam] pc.; antyamci $a c .20$ bhagavan] corr.; bhagan ms. 32 viharāmi] corr.; vihar ms. 
samādhinā viharan | asti punar bhagavann asmād acintyāt samādher anyạ̣ śāntataraḥ samādhir iti || atha khalu mañjuśrīḥ kumārabhūta āyuṣmantaṃ sāradvatīputram etad avocat | kathạ̣ tvad anya śāradvatīputra jānīṣe śānta eṣo acintyaḥ samādhir iti | yadāpy āyuṣmān sāaradvatīputra evam āha || asty asmād acintyāt samādher anyạ̣ śāntataraḥ samādhir iti || saced bhadanta

śāradvatīputra eșo 'cintyaḥ samādhiḥ sa vidyetad upalabhyete syād asmād acintyā samādher anyaḥ śāntataraḥ samādhih | sāaradvatīputra āha || eșa hi mañjuśrīr acintyaḥ samādhị na sa vidyate nopalabhyate || mañjuśrīr āha || tathā hy eșa bhadanta saāradvatīputra acintyaḥ samādhis tenaiṣo 'cintyạ̣ samādhir na saṃvidyate nopalabhyate || api tu bhadanta sāadradvatīputra kaścinn 10 acintyasya samādher lābhī | sarvasattvā api bhadanta sāaradvatīputra acintyasya samādher lābhinaḥ || tat kasmād dhetọ̣ || sarvam hi cintyam acintyạ̣ yā yā cintyatā ayam acintyaḥ samādhi tasmā<187v >t sarvasattvā apy acintyasya samādher lābhinạ̣ \|

atha khalu bhagavān mañjuśriyam kumārabhūtam āmatrayate

sma || sādhu sādhu mañjuśrīr yas tvaṃ sarvāṇīmāny evaṃūpāṇi gambhīrāṇi sthānāni nirdiśasi yathāpi nāma tvaṃ pūrvajinakṛtādhikāro 'nupalambhaciracaritabrahmacaryas tat kiṃ te mañjuśrīr eva bhavati prajñāpāramitā yā sthitvā evam āha || mañjuśrīr āha || sacen me bhagavan syāt | prajñāpāramitāyām sthitvā evam āha || evam api syād upalambhe sthitvā evam āha || ātmasaṃjñāyāṃ sthitvā evam āha || yāvad bhāvasaṃjñāyāṃ sthitvā evam āha || tasmān na prajñāpāramitāyāṃ sthitvā evam āha || tat kasmād dhetọ̣ || sacen me bhagavan prajñāpāramitāyāṃ sthānaṃ syād athavā asthānaṃ na prajñāpāramitā syāt || api tu khalu punar bhagavann ātmasthānaṃ prajñāpāramitāsthānam asthānasamutthanam anavakāśạ̣ notthānam | evaṃ sthānam acintyaṃ sthānaṃ na kasyacid dharmasya sthānam | tenaitat sthānaṃ prajñāpāramitāsthaṃ na prajñāpāramiteti bhagavan yo 'nutpādạ̣ sarvadharmāṇām iyaṃ prajñāpāramitā | acintyadhātor etad adhivacanaṃ yad uta prajñāpāramitā nāma yaś cācintyadhātụ so 'nutpādadhātur yaś cānutpādadhātuḥ sarvadharmadhātuḥ ya<188r>ś ca dharmadhātuḥ sa niḥsamudācāradhātuḥ | yaś ca nị̣samudācāradhātuh | so 'cintyadhātuh | yaś cācintyadhātuḥ sa ātmadhātuḥ yaś cātmādhātuḥ sa prajñāpāramitādhātur iti hi prajñāpāramitādhātuś cātmadhātuś cādvayam etad advaidhīkāram tenaiṣo 'cintyadhātur yenaiṣo 'cintyadhātur anutpādadhātur yenaiṣo 'nutpādadhātus tenaiṣa dharmadhātur yenaiṣa dharmadhātus tenaiṣa niḥsamudācāradhātur yenaiṣa niḥsamudācāradhātur yenaiṣo 'cintyadhātur yenaiṣo 'cintyadhātur yenaiṣa ātmadhātur yenaișa ātmadhātus tenaișa prajñāpāramitādhātur yenaișa

17 tvaṃ] corr.; stvam ms. 18 'nupalambha-] pc.; 'nupabhalaṃ- ac. 21 sthitvā] corr.; sthi ms. 
prajñāpāramitādhātus tenaiṣo 'cintyadhātur yenaiṣo 'cintyadhātus tenaiṣa na samudāgacchati yo na samudāgacchati sa na saṃvidyate | yo na saṃvidyate na vinaśyati yo na vinaśyati | tad acintyam iti hi tathāgatadhātuś cātmadhātuś cādvayam etad advaidhīkāram | yad apy etad bhagavān āha || ātmabhāvanā prajñāpāramitābhāvaneti || tat kasmād dhetoh prajñāpāramiteti | bhagavān ātmadhātor etad adhivacanam | tat kasmād dhetor yo bhagavann ātmadhātuṃ jānīyāt so 'saṃgatā jānīyād yo 'saṃgatā jānīyāt sa na kacid dharmaṃ jānīyāt tat kasmād dhetos tathā hy acintyaṃ jñānaṃ buddhajñānaṃ <188v > na kasyacid dharmasya jñānaṃ buddhajñānaṃ tat kasmād dhetor na hi tat jñānam paramārthena vidyate yạ̣ paramārthena vidyate | tat kathaṃ dharmacakram pravartayiṣyati || yadā ca tat jñānaṃ paramārthena na vidyate | tadā tat jñānam asañgam yadā ca tat jñānam asaṃgạ̣ tadā tat jñānam abhāvaḥ || yadā tat jñānam abhāvas tadā tat jñānam avișayaṃ yadā tat jñānam aviṣayạ̣ | tadā tat jñānam aniśritam yadā tat jñānam anāśritam tadā tat jñānam apratișthitam tadā tat jñānam apratișṭhitaṃ tadā tat jñānaṃ notpāditann apratilabdhaṃ nāpy utpatsyate | tat kasmād dhetor na hi tat jñānam guṇasaṃskṛtam vā aguṇasaṃskṛtạ̣ vā || tat kasmād dhetos tathā hi tat jñānaṃ niścintyaṃ tena guṇā vā aguṇā vā kathaṃ nirdiśyeyuh yasmān niścintyaṃ tat jñānaṃ tena tat jñānam acintyaṃ yad evaṃ jñānam tat buddhajñānam anupalambhayogena nāpi te jñānena kaścid dharmo 'bhisambuddho jñāno vā nāpi tat jñānaṃ pūrvāntato vā aparāntato vā āgatam nāpi tat jñānam anutpannapūrvaṃ nāpi tat jñānam anutpannapūrvaṃ nāpi tat jñānam anutpannapūrvam anutpannatvād yaṃ notpannaṃ tạ̣ nāntardhāsyati notpatsyete | nāpi tasya jñānasya kiṃcid anyajñānam sadṛśam tena tat jñānam aci<189r>ntyam asadṛśam nāpi tasya jñānasya ādimadhyaparyavasānam upalabhyate na tad jñānam ākāśasamam nāpi tasya jñānasya samaṃ vā vișamaṃ vopalabhyate | tena tad jñānam asamasamam nāpi tasya jñānasyānyat jñānam pratirūpakam apy upalabhyate | tena tad jñānam apratirūpam || atha khalu bhagavān mañjuśriyaṃ kumārabhūtam etad avocat | na punar etan mañjuśrīr jñānam akupyam || mañjuśrīr āha || akṛtam etad bhagavan jñānaṃ tenaitenaitad akupyam || tadyathāpi nāma syād bhagavann anārhatạ̣ kārṣāpaṇo na kupyo nāpy akupya iti saṃkhyāṃ gacchati || evam etad bhagavann evam etat jñānam akṛtam asamudānītam ajanitam anutpāditam anirodhitạ̣ tenaitad akupyạ̣ || atha khalu bhagavān mañjuśriyaṃ kumārabhūtam āmantrayate sma | ka imam mañjuśrīs tathāgatajñānanirdeśam evaṃ nirdișțam adhimokșyante || mañjuśrīr āha || ye bhagavann saṃsāradharmāṇo bhavișyanti | na parinirvāṇadharmāṇas te 'dhimokṣyante | ye

13 yadā tat jñānam] corr.; yadā tat jñānaṃ yadā tat jñānam ms. 36 ye] $p c$. yena $a c$. 
satkāyā na caritā yeșām rāgadveșamohā na kṣịnās tat kasmād dhetor na hy akṣayaḥ kṣiyate parikṣayaṃ vā gacchati ye saṃsārān na samatikrāntā na saṃsāre saṃkhyāṃ gacchati yenaiva mārgeṇa virahitā na mārgasaṃjñām apy utpādayanti te 'sya bhāṣitasyārtham ājñāsyanti || <189v> evam ukte bhagavān mañjuśriyaṃ kumārabhūtam etad avocat | sādhu sādhu mañjuśrīḥ subhāṣitā te 5 iyaṃ vāk || atha khalu tasyāṃ velāyām āyuṣmān mahākāśyapo bhagavantam etad avocat | bhaviṣyanty anāgate 'dhvani bhagavan kvacid asya gambhīrasya dharmavinayasyāsyāś ca gambhīrāyāḥ prajñāpāramitāyāḥ saśrotāro adhimoktāraḥ | ājñātāraḥ pratigrahitāro vā || evam ukte bhagavān āyuṣmantạ̣ mahākāśyapam etad avocat || ihaiva te kāśyapa parṣadi

bhikṣubhikṣuṇyupāsakopāsikā ye 'nāgate 'dhvani asya gambhīrasya dharmavinayasyāsyāś ca gambhīrāyāḥ prajñāpāramitāyāḥ śrotāro bhaviṣyanty adhimoktārạ̣ ājñātāraḥ pratigrahitāro vā bhaviṣyanti || tadyathāpi nāma kāśyapa gṛhapatir vā g̣̣hapatiputro vā śatasahasramūlyena maṇiratnena naștẹna dụ̂khito durmanā nāttamanā bhavet sa tenaiva pratilabdhena sukhitạ̣ | saumanasyajāto bhavet vigataparyavasthānamanasikārạ̣ | evam eva kāśyapa tāsāṃ bhikṣubhikṣuṇyupāsakopāsikānām imāṃ gambhīrāṃ prajñāpāramitām ajātām anutpannām prakṛtiparinirvṛtām yāvadabhāvām aśṛ̣vatām evaṃ bhaviṣyati || kathaṃ vayaṃ nāma imām evaṃrūpāṃ gambhīrāṃ prajñāpā<190r>ramitām ajātām anutpannāṃ prakṛtiparinirvṛtāṃ yāvadabhāvāṃ na śṛ̣umas te cāpareṇa kāreṇa śrutvā āttamanaso bhaviṣyanti sumanaso vigataparyavasthānamasikārā evaṃ ca vācaṃ bhāṣișyante | adya no buddhadarśanam abhūt tathāgataparyupāsanaṃ ca yatra hi nāmāsmābhir iyam gambhīrā prajñāpāramitā yāvad ajātānutpannā yāvad abhāvā śrutā || tadyathāpi nāma kāśyapa devās trayastriṃśā āttamanaso bhavantyā nanditā pārijātaṃ kovidāraṃ tañgībhūtaṃ dṛṣțā na cireṇa vatāyaṃ pārijātạ̣ kovidārạ̣ | sarvaparisphullo bhavișyatīti || evam eva kāśyapa tā bhikṣubhikṣuṇyupāsakopāsikā imāṃ gambhīrāṃ prajñāpāramitām ajātānutpannāṃ yāvad abhāvāṃ śrutvā āttamanasa ānandino bhaviṣyati || ye ca te āttamanasa ānandino bhaviṣyanty anāgate 'dhvani | imāṃ gambhīrām prajñāpāramitām ajātānutpannāṃ yāvad abhāvāṃ śrutvā niṣṭhāṃ tvaṃ tatra kāśyapa gaccha ihaiva te parṣadi mamābhūvan ye te āttamanasa ānandino bhaviṣyanty anāgate 'dhvani teșāṃ tayā āttamanaskatayā cānanditayā ca na cireṇa putri kān̉kṣitavya sarvapariphullatām gamiṣyanti yad uta sarvabuddhadharmapari<190v>phullatayā yad apīyam kāśyapa gambhīrā

4 utpādayanti] corr.; atpādayanti ms. 12 -vinayasyāsyāś] corr.; -vinayasyāś ms. 16 manasi-] pc.; masina- ac. 26 tanigībhūtaṃ] corr.; staṅgībhūtam ms. 28 -bhikṣuṇy-] corr.; -bhiṇyms. 34 cireṇa] corr.; vireṇa ms. 35 -buddha-] corr.; -ddha- ms. 
prajñāpāramitā yāvad ajātābhāvānutpannā tathāgatasyātyayena sthāsyati pracarișyati | anāgate 'dhvani tad api kāśyapa buddhādhișțhānena buddhānubhāvena jñātavyam || tasmāt tarhi kāśyapa ya imāṃ prajñāpāramitām yāvad ajātām abhāvām anutpannāṃ śroṣyanti nāyaṃ teșāṃ prathamakạ̣ śravaḥ || tadyathāpi nāma kāśyapa maṇikāro mạ̣iratnaṃ paśyan yadā āttamanā bhavati | nișțhā tatra gantavyā nāsya maṇiratnasya prathamakaṃ darśanam pūrvānupūrvadṛșțam anena maṇikāreṇedam maṇiratnam evam eva kāśyapa ya imāṃ gambhīrām prajñāpāramitām yāvad ajātām abhāvām anutpannāṃ śrutvā āttamanasa ānandino bhavișyanti udagrāḥ prītisaumanasyajātā nāyam kāśyapa teșām prathamakaḥ śravaḥ | ye te kāśyapa evaṃ vācam bhāṣiṣyante etad eva tāvad bhasasvayam idam mañjuśriyaḥ kumārabhūtasya prajñāpāramitānirdeśaṃ yāvad abhāvājātānutpannām iti pūrveṇa pūrvaṃ tair mañjuśrīḥ kumārabhūtaḥ paryupāsito bhaviṣyati || tadyathāpi nāma kāśyapa kaścid eva puruṣo 'nyatarạ̣ grāmạ̣ vā nagaranigamaṃ vā janapadaṃ vā kenacid eva kāryeṇa gato bhave<191r>t || athāpareṇa kāreṇa tasya kaścid eva puruṣa upasaṃramya tasya nagarasya varṇaṃ bhāṣet | teṣāṃ cārāmarāmaṇīyakānāṃ janapadarāmaṇīyakānāṃ puṣkiriṇyā rāmaṇīyakānām udyānarāmaṇīyakānām utsahradataḍāgarāmaṇīyakānāṃ puṣpaphalarāmaṇīyakānāṃ ca varṇaṃ bhāṣet | sa ca tac chrutvā tuṣṭị vindet | saumanasyajātah punah punar adhyeșayet || etad eva tāvad bhoḥ puruṣa parikīrtayasveti sa puruṣa eva niṣțhāṃ gato bhaved anubhūta pūrvamanena puruṣeṇa tạ̣ nagaraṃ tāni cārāmaramaṇiyakāni janapadarāmaṇīyakāni puṣkariṇīāmaṇīyakāni udyānarāmaṇīyakāni utsahradataḍāgarāmaṇiyakāni puṣpaphalarāmaṇiyakāni tat kasmād dhetos tathā hi sa tac chrutvā tuṣța āttamano bhavanty udagraḥ prītisaumanasyajātah || evam eva kāśyapa yair mañjuśrīkumārabhūtaḥ paryupāsito bhavișyaty abhijñam copasaṃkānto bhavișyati paripușțaś ca teșām imāṃ gambhīrāṃ prajñāpāramitāṃ yāvad ajātābhāvānutpannām śrutvā udāraprītiprāmodyaṃ bhaviṣyati udāraṃ prītiprāmodyam utpatsyate evạ̣ vācaṃ bhāṣiṣyante | etad eva tāvac chṛ̣uyāma yad uta mamaiva prajñāpāramitānirdeśaṃ yāvad ajā<191v>tābhāvān utpannam iti | evam ukte āyuṣmān mahākāśyapo bhagavantam etad avocat || imāni teșām bhagavan śrāddhānām kulaputrāṇāṃ kuladuhitṛnām cānāgate 'dhvani ākāralingāni nimittāni bhaviṣyati yānīmāni bhagavatā nirdṛșțāni || bhagavān āha || evam etat kāśyapa yathāvācam bhāṣase imāni teșām anāgate 'dhvani śrāddhānām kulaputrāṇāṃ kuladuhiṭ̣nāṃ̣ ca

10 prathamakaḥ] corr.; prathakamakah ms. 13 kumāra-] corr.; kumā- ms. 15 -nigamaṃ] corr.; -nigam ms. 19 utsa-] corr.; utsada- ms. 24 utsa-] corr.; utsada- ms. -hrada-] corr.; -hradas- ms. 
ākāralinganimittāni bhaviṣyanti | yānīmāni mayaitarhi nirdișțāni || atha khalu mañjuśrīkumārabhūto bhagavantam etad avocat || anākārasya tasya bhagavan dharma-alingagasyānākārāyāś ca bhagavan prajñāpāramitā yāvad animittāyā ākārālinganimittaṃ vā kathaṃ bhavișyati | yā ca bhagavato dharmadeśanā sā anākārā alingā yāvad animittā tat kathaṃ bhagavann anākārasyāling gasya yāvad 5 animittasya nirdeśo bhaviṣyati || evam ukte bhagavān mañjuśriyaṃ kumārabhūtam etad avocat || etāny eva teșām mañjuśrīḥ kulaputrāṇām kuladuhitṛnāṃ ca ākāralinganimittāni bhaviṣyanti imāṃ gambhīrāṃ prajñāpāramitām yāvad atyantabhāvām anutpannādeśyamānām adhimokṣyante yāvat paryvāpsyanti yatra hi mañjuśrīḥ pra<192r>jñāpāramitā paridīpanā | tatra sarvabuddhadharmaparidīpanā drașțavyā | tatrācintyatā paridīpanā drașțavyā | yāni mañjuśrīḥ pūrvabodhisattvacārikāṃ caratāṃ kuśalamūlāni samudānītāni yair kuśalamūlair iyam anuttarā samyaksambodhir abhisambuddhā tāni kuśalamūlāni samudānetukāmena kulaputreṇa vā kuladuhitā vā iyam eva prajñāpāramitā śrotavyā adhimoktavyā likhitavyā dhārayitavyā vācayitavyā upadeșțavyā svādhyātavyā pravartayitavyā paryavāptavyā yoniśo manasikartavyā bhāvayitavyā | yāvat puṣpadhūpagandhamālyavilepanacūrṇacīvaracchatradhvajaghaṇțāpaṭākāvaijayantībhir deyapradānaprabhṛtibhiś ca pūjābhir yathāśaktyā yathābalaṃ pūjayitavyā satkartavyā | sarvaśrāvakapratyekabuddhabhūmim atikramitukāmena kulaputreṇa vā kuladuhitā vā iyam eva prajñāpāramitā śrotavyā yāvat satkartavyā || || yathā mañjuśrīr avaivartikabhūmyavakrānti bhavati | evaṃ śrotukāmena kulaputreṇa vā kuladuhitā vā iyam eva prajñāpāramitā śrotavyā yāvat satkartavyā | ye mañjuśrīḥ kecid dharmās tān sarvān anutpādasamatayādhimoktukāmena kulaputreṇa vā kuladuhi<192v>trā vā ime prajñāpāramitā śrotavyā | yāvat satkartavyā | sarvadharmā api mañjuśrīr nābhisambuddhās tathāgatenetīmam nirdeśam adhimoktukāmena kulaputreṇa vā kuladuhitrā vā ime prajñāpāramitā śrotavyā yāvat satkartavyā || tat kasmād dhetor na hi sa kaścid dharmah samvidyate upalabhyate | yo 'bhisambudhyeta yena vā abhisambudhyeta yạ̣ vā bodhị̣ sambudhyeta evam evārthagatim adhimoktukāmena kulaputreṇa vā kuladuhitrā vā iyam eva prajñāpāramitā śrotavyā yāvat satkartavyā | na hi kaścid dharmo yo na bodhir ity evam adhimoktukāmena kulaputreṇa vā kuladuhitrā vā iyam eva prajñāpāramitā śrotavyā yāvat satkartavyā | sarvadharmā na vikalpayitukāmena kulaputreṇa vā kuladuhitrā vā iyam eva prajñāpāramitā śrotavyā yāvat satkartavyā || tat kasmād 35 dhetor tarhi prajñāpāramitā kasyacid dharmasya pariniṣpattijanayatrī

7 etāny] corr.; etānn ms. 13 anuttarā] pc.; anuttarāyā ac. 19 deya-] corr.; dīyams. 34 satkartavyā] $p c$.; katsartavyā $a c$. 
vyavasthāpayati darśayati vā sarvadharmā na saṃkliśyante na vyavadāyanta ityam evam avatartukāmena kulaputreṇa vā kuladuhitrā vā iyam eva prajñāpāramitā śrotavyā yāvat satkartavyā | sarvadharmā nātītā nānāgatā na pratyutpannā ity evam adhimoktukāmena kula<193r>putreṇa vā kuladuhitrā vā imām eva prajñāpāramitā śrotavyā yāvat satkartavyā || tat kasmād dhetor na hi mañjuśrīr anutpādo 'tītānāgato na pratyutpannạ̣ | tat kasmād dhetor anutpādasameva śaraṇāhi mañjuśrīḥ sarvadharmāḥ || evaṃrūpeșu sarvadharmeșu niḥsaṃśayatāṃ gantukāmena kulaputreṇa vā kuladuhitrā vā iyam eva prajñāpāramitā śrotavyā yāvat satkartavyā | yathā mañjuśrīḥ triparivartasya dvādaśākārasya dharmacakrasya pravartanām bhavati | tacchrotukāmena tatpratipattukāmena tatrādhimoktukāmena kulaputreṇa vā kuladuhitrā vā iyam eva prajñāpāramitā śrotavyā yāvat satkartavyā | sarvasattvān maitryā spharitukāmena sattvasaṃjñāyām vā sthātukāmena sarvalokena sārdham avivaditukāmena sarvalokān upalabdhị̣ cāvabodhukāmena kulaputreṇa vā kuladuhitrā vā iyam eva prajñāpāramitā śrotavyā yāvat satkartavyā | yāvat sarvadharmān utpādam avabodhukāmena kulaputreṇa vā kuladuhitrā vā ihaiva prajñāpāramitāyāṃ śikṣitavyam anupalambhayogena || atha khalu mañjuśrīh kumārabhūto bhagavantam etad avocat | nirguṇāyā bhagavan prajñāpāramitāyāḥ ke gu<193v>ṇāḥ ke 'nuśaṃsāḥ akiṃcitsamarthāyā bhagavan prajñāpāramitāyā asamam utthāpikāyā avināśikāyā na kasyacid dharmasyāyūhikāyā niryūhikāyā niścetāyā yā nirvyāpārāyāḥ svabhāvam ajānamānāyā adṛștvāyāḥ svabhāvam apaśyamānāyā kasyacid dharmasya dāyikāyā na kasyacid dharmasya hāyikāyāḥ sarvadharmāvirodhikāyāḥ sarvadharmāṇām anānātvakaraṇiyā yā akaraṇìāḥ sarvadharmāṇām anekatvakārikāyāḥ sarvadharmānām anānātvakārikāyā akṛtāyā akṣayāyā avināśikāyāḥ | pṛthagjanadharmāṇām arhaddharmāṇāṃ pratyekabuddhadharmāṇām bodhisattvadharmāṇām api ca na dātrikāyāḥ na jñātṛkāyāḥ aduḥkṛtikāyā na hārikāyā na saṃsārasyāyūhikāyā na nirvāṇasya niryūhikāyā na buddhadharmāṇāṃ dāyikāyā na vināśikāyāḥ | na cintyāyā na kārị̣yā na vikāriṇyāḥ sarvadharmāṇāṃ notpādikāyā na nirodhikāyā nocchedikāyā na śāśvatikāyā nāgamikāyā na nirgamikāyā na viviktakārikāyā nāviviktakārikāyā na dvayakārikāyā nādvayakārikāyā yāvad abhāvāyā bhagavan prajñāpāramitā<194r>yāḥ | ke guṇāḥ ke 'nuśaṃsāḥ || evam ukte bhagavān mañjuśriyaṃ kumārabhūtam etad avocat | evam evāsyāṃ mañjuśrīr guṇāḥ prajñāpāramitāyāṃ veditavyā yāvad abhāvā niśceșțāh || api tu khalu punar mañjuśrī bodhisattvena mahāsattvena bodhisattvasamādhau śikṣitukāmena

6 'tìtānāgato] corr.; 'tītānāmāgato ms. 24 anānātva-] corr.; anānātma- ms. 26 avināśikāyāḥ] $p c$; avinākāśikāyāḥ $a c .31$ nirgamikāyā] $p c$; nikārgamikāyā $a c$. 
bodhisattvasamādhim niṣpādayitukāmena yatra samādhau sthitvā sarve buddhā bhagavanto dṛ́syante teșām ca buddhakṣetrāṇi drașțukāmena teṣāṃ ca nāmadhyeyāni jñātukāmena teșāṃ buddhānāṃ ca bhagavatām anuttarāṃ pūjāṃ kartukāmena teșāṃ ca dharmadeśanāyām āvartukāmenādhimoktukāmena ihaiva prajñāpāramitāyāṃ śikṣitavyaṃ śikṣāyogena || atha khalu mañjuśrīḥ kumārabhūto bhagavantam etad avocat | kenaiṣā bhagavan kāraṇena prajñāpāramitā || bhagavān āha || anutpannāniruddhatvān mañjuśrīḥ prajñāpāramitety ucyate | yad idam ādiśāntatvāt | aniḥśaraṇatvāt | akarạ̣iyatvāt | yāvad abhāvatvāt | paścādbhāvạ̣ sā prajñāpāramitā | anena kāraṇena mañjuśrīḥ prajñāpāramitābhāvanā bodhisattvānāṃ mahāsattvānāṃ pratikān̉kșitavyā || eṣa ca bodhisattvānāṃ mahāsattvānāṃ gocaraḥ yaḥ sarvadharmeṣv agocarạ̣ <194v> atra caramāṇo mañjuśrīr bodhisattvo mahāsattvo gocaraprasuta ity ucyate || evam eva gocaro yad uta gocaraḥ sarvayānikas tat kasmād dhetor akṛto hy eșa gocaras tenaiṣa ucyate agocara iti || punar aparam mañjuśrīh kumārabhūto bhagavantam etad avocat || kutra caramāṇo bhagavan bodhisattvo mahāsattvaḥ kṣipram anuttarām samyaksambodhim abhisambhotsyate || evam ukte bhagavān mañjuśriyaṃ kumārabhūtam etad avocat || prajñāpāramitāyāṃ caraṇo mañjuśrī bodhisattvo mahāsattvo kṣipram anuttarāṃ samyaksambodhim abhisambhotsyate | asti mañjuśrīr ekavyūho nāma samādhir yatra samādhau caramāṇo bodhisattvo mahāsattvaḥ kṣipram anuttarām samyaksambodhim abhisambhotsyate || evam ukte mañjuśrịh kumārabhūto bhagavantam etad avocat || katham bhagavann ekavyūhaḥ samādhir bodhisattvena mahāsattvenāvatartavyaḥ kena kāraṇenaikavyūhaḥ samādhir ity ucyate ॥ bhagavān āha || ekavyūha iti mañjuśrīr anutpādasyaitad adhivacanam | ekavyūhaṃ samādhim avatartukāmena kulaputreṇa vā kuladuhitā vā pūrvam eva prajñāpāramitā pariprașțavyā || tataḥ paścād ekavyūhaṃ samādhim avatarișyati || tat kasmād dhetor a<195r>kopyo hi mañjuśrīr anutpādaḥ | apratikupyaḥ | akopanīyaḥ | acintyaḥ anuścintyanīyaḥ | niścintya ekavyūham samādhim avatartukāmena mañjuśrīḥ kulaputreṇa vā kuladuhitā vā viviktāni śayanāsanāni kartavyāni | asaṃsargārāmeṇa ca bhavitavyạ̣ sarvanimittamanasikāreṇa paryan̉kaṃ baddhvā niṣīditavyạ̣ tatraikas tathāgato manasikartavyạ̣ | sarvadharmāś ca manasikartavyāḥ || anupalambhayogenāyaṃ ca tathāgatam manasi kuryāt tasya nāmadheyaṃ grahītavyam | tac ca nāmadheyaṃ śrutvāpalabhya yasyām diśi sa tathāgatas tāṃ diśam āmukhīkṛtya niṣīditavyam | tam eva tathāgatạ̣ manasi kurvatām |

14 kasmād] corr.; smād ms. 26 avatartu-] corr.; avattartu- ms. 33 -kartavyāḥ] pc.; -rtakavyāḥ ac. 
tena manasikṛtenātītānāgatapratyutpannā buddhā bhagavanto manasikṛtā bhaviṣyanti || tat kasmād dhetor ekam idaṃ tathāgatatvaṃ yathā mañjuśrīr ekasya tathāgatasyāprameyā buddhaguṇā aprameyaṃ pratibhānaṃ evam eva mañjuśrīr ekavyūhasamādhim samāgamya ekasyānutpādasyāprameyā dharmaparyāyaviśeșāḥ pratikāṅkṣitavyā yesya pravasyante | ye ca tathāgatair arhadbhih samyaksambuddhair bhāṣitāh || yāvanta khalu punar ānandena dhāritās tāvantāsya dharmaparyāyāḥ pratibhāṣyanti || iyaṃ khalu punar ekavyūhāṃ samādhim niṣpādya yāvad a<195v>syāyuḥpramāṇaṃ syān tāvad avatișțheta sanidānaṃ dharmadeśayamānaḥ || yeșāṃ khalu punaḥ mañjuśrīḥ keșāṃcid bodhisattvayānikānām evaṃ bhavati | katara eṣa ekavyūhaḥ samādhir 10 iti ta evaṃ vacanīyā yeyam acintyagụ̣aparikīrtanā parikīrtitā imām tāvad acintyaguṇaparikīrtanatāṃ samādāya vartadhvam | yathā yathaināṃ samādāya vartiṣyadhve tathā tathāsya samādher guṇān drakṣyatha yathopadișțena ca vidhinā niṣīdișyatha || sa khalu punar eșa samādhir na śakyaḥ pariniṣpādayitum apalambhe dṛștiko vastudṛștikair yāvad bhāvadṛștikaih | syād 15 yathāpi nāma mañjuśrīḥ kasyacit puruṣasya maṇiratnam anargheyam anavadāpitam bhavet tam enaṃ kaścid evaṃ vadet || kim etad yad bhoḥ puruṣa maṇiratnam ko vāsya maṇiratnasya guṇa iti tam enam evam vadeta yat khalu bhoḥ puruṣa jānīyā aprameyā evāsya maṇiratnasya guṇạ̣̄ || atha khalu sa puruṣas tasya puruṣasya tạ̣ maṇiratnaṃ dadyād avadāpanārtham | avadāpasva tāvad bhoḥ puruṣa idaṃ maṇiratnaṃ tato jñāsyasi || atha khalu sa puruṣa tam mạ̣iratnaṃ gṛhītvā avadāpan nopakaraṇair avadāpayet || evạ̣ tạ̣ mạ̣iratnam avadāpyamānam apratimūlyam bhavet | yathā yathā tam maṇiratnam avadāpayet | tathā <196r> tathāsya maṇiratnasya guṇān paśyet || evạ̣ mañjuśrīr yadā yadā sa kulaputro vā kuladuhitā vā evaṃ samādhiṃ samāpatsyate | avatariṣyati | tadā tadāsya samādher gunān drakṣyati || tadyathāpi nāma mañjuśrīḥ sūryamaṇḍalasya na kaścin mạ̣ḍalaparyanto yo na raśmibhị̣ sphuṭaḥ || evam eva mañjuśrīr ekavyūhaṃ samādhim āgamyāvatīrya pratilabhya na sā kācid dharmadeśanā yā na prajñāpāramitādeśanā evam eva gāheta nāsau kạ̣cid dharmam ajātāniruddhaṃ paśyet || tadyathāpi nāma mañjuśrīś catasṛṣu dikṣu mahāsamudrasya catvāraḥ puruṣā udakam abhyutkṣipeyụ̣ sarvaṃ tad ekarasam evotkșipeyur yad uta lavaṇarasam | evam eva mañjuśrīr yā kacid dharmadeśanā mayā deśitā sarvā sā ekarasā yad utānutpādarasā abhāvarasā virāgarasā vimuktirasā nirodharasā yo 'pi mañjuśrīḥ kulaputra iha samādhau sthito yaṃ yam eva dharmam deśayiṣyati || tat sarvam ekarasām eva deśayiṣyati

1 -ātītānāgata-] corr.; -ātīnāgata- ms. 10 bhavati] corr.; bhagavati ms. 18 vadeta] corr.; vadheta ms. 27 samādher] corr.; samādhyer ms. 
| yad utānutpādarasam evābhāvarasam eva virāgarasam eva vimuktirasam eva nirodharasam eva imaṃ mañjuśrīḥ samādhim āgamya yạ̣ kaścin mayā dharmo deśitas taṃ sa kulaputra ākāṅkṣamāṇo bhāṣet nirdiśed upadiśet || evaṃ hi mañjuśrīḥ sa kulaputra <196v> imaṃ samādhim āgamya yā kācid deśanā sarvāntām ajātām anutpannābhāvām eva deśayiṣyaty anupalambhayogena || punar aparaṃ mañjuśrīr imaṃ samādhim āgamya bodhisattvo mahāsattvaḥ kṣipraṃ bodhipākṣikān dharmān paripūrya kṣipram evānuttarāṃ samyaksambodhim abhisambhotsyate || punar aparạ̣ mañjuśrīr yadā bodhisattvo mahāsattvo nātmadhātor yāvan na dharmadhātor utpādaṃ paśyati | na nirodham naikatvaṃ na nānātvam | evaṃ kṣāntiko 'pi mañjuśrīr bodhisattvo mahāsattvaḥ kṣipram anuttarāṃ samyaksambodhim abhisambhotsyate | yo vā na cintayed anuttarāṃ samyaksambodhị̣ tasyāpi kulaputrasyaiṣā kṣāntir bodhisattvadharmāṇāṃ buddhadharmāṇāṃ ca pratilambhāya na ca bodhim buddhatvāya samprārthayiṣyati || evam imāṃ mañjuśrīḥ kṣāntiṃ tasya kulaputrasya kṣipraṃ vadāmy anuttarāyāṃ samyaksambodhau | avirahitaś ca sarvabuddhadharmair vaktavyah yasyātra kulaputrasya vā kuladuhitur vā imaṃ nirdeśaṃ śrutvā na syād dhanvāyitatvaṃ vākāṅkṣāyitatvaṃ vā || evam ukte mañjuśrīḥ kumārabhūto bhagavantam etad avocat || kiṃ hetur nirjātā bhagavann uttarā samyaksambodhị̣ || bhagavān āha || no hīdam mañjuśrīḥ naivānuttarā samyaksambodhihetur na hetur nirjātā || ta<197r>t kasmād dhetor na hy anutpādo 'bhāvo vā hetur hetuniryāto vā | tat kasmād dhetor ajānatvāt sarvadharmāṇām || tasmāt tarhi mañjuśrīr yasyātra kulaputrasya vā kuladuhitur vā imaṃ nirdeśam śrutvā na saṃsīdanā bhavet | tam apy aham avaivartikam iti vadāmy anuttarāṃ samyaksambodhau || tasmāt tarhi mañjuśrīr ya iha gambhīrāyām prajñāpāramitāyām nirdiśyamānāyāṃ bhikṣavo bhikṣuṇyopāsako vopāsikā vā nāvalīyiṣyanti | yāvan na saṃlīyiṣyanti te te mama śaraṇaṃ gatās te mamātra pravrajitās teșām cāham śāstā | yo mañjuśrīḥ kulaputro vā kuladuhitā vā iha gambhīrāyāṃ prajñāpāramitāyāṃ na śikṣitenāsau bodhisattvaśikṣāyāṃ śikṣate || tadyathāpi nāma mañjuśrīḥ ye kecid bhūtagrāmā bījagrāmā tṛnagulmauṣadhivanaspatayo virohanti sarve te mahāpṛthivīm niśritya evam eva mañjuśrīr ye kecid bodhisattvānāṃ mahāsattvānāṃ kuśaladharmāḥ sarve te prajñāpāramitāparigṛītā vṛddhị̣ virūḍhiṃ vaipulyatām āpadyante na visaṃvādayanty anuttarāṃ samyaksambodhim || evam ukte mañjuśrīh kumārabhūto bhagavantam etad avocat | yo 'yaṃ bhagavan prajñāpāramitānirdeśo deśitaḥ | asya bhagavan prajñā<197v>pāramitānirdeśasya kecid iha jambudvīpe grāmeṣu vā nagareșu vā

28 -pāramitāyāṃ] corr.; -ramitāyāṃ ms. 30 kecid bhūtagrāmā] corr.; kecidd abhūtagrāmā ms. 35 deśitaḥ] corr.; dehitaḥ ms. 
janapadeṣu vā sampratigrahītāro bhaviṣyanti yāvad deśayitāro bhaviṣyanti || evam ukte bhagavān mañjuśriyaṃ kumārabhūtam etad avocat | yair mañjuśrīr iyaṃ prajñāpāramitānirdeśa eva tarhi śrutvā ca praṇidhir utpāditaḥ | imam evaṃ vayaṃ jātivyativṛttāḥ prajñāpāramitānirdeśaṃ śṛ̣uyāma iti te śroṣyanti yāvad vistareṇa bhāvayiṣyanti | abhāvanatayān ārhatān mañjuśrīr mṛdukuśalamūlān vadāmi ye te imām prajñāpāramitām śroṣyanti śrutvā codāram prītiprāmodyaṃ pratilapsyante | yas tvaṃ mañjuśrīr imaṃ prajñāpāramitānirdeśaṃ śrotukāmo bhavet | sa evaṃ vacanīyaḥ | kiṃ tava kulaputraitena śrutamātre śrutvā aśraddadhataḥ saṃsīdanam abhūd iti || tat kasmād dhetor na hi kasyacid dharmasya pariniṣpattir nirdișțā na pṛthagjanadharmāṇām anutpādo vā vināśo vā pratilambho vā nirdișțah | na śaikṣadharmāṇām nāśaikṣadharmāṇām na pratyekabuddhadharmāṇām na buddhadharmāṇām utpādo vā vināśo vā pratilambho vā nirdișțạ̣ || evam ukte mañjuśrīḥ kumārabhūto bhagavantam etad avocat | yo me bhagavan bhikṣur vā bhikṣuṇi vā upāsako vā upāsikā <198r> vā evaṃ vadet | katamādya tathāgatasya 15 dharmakathā pravṛttābhūt || tasyāham bhagavann evaṃ pṛ̣ța evaṃ vadeyaṃ sarvadharmāviruddhā kathā || tat kasmād dhetos tathā hi na kācit sattvopalabdhị̣ | utpādena viruddhaḥ | nāpi sā kathyạ̣ kenacit sattvena sukaram ājñātam || tat kasmād dhetos tathā hi na kācit sattvopalabdhị̣ || punar aparaṃ bhagavann aham tasyaivaṃ vadeyam anutpattir nāma sā dharmadeśanābhūt || tat kasmād dhetos tathā hi bhagavann anutpādasamāḥ | sarvadharmās tasyāṃ ca kathāyām nārhatām uttary adhigamo nirdișțạ̣ arhaddharmaiś ca te pṛthag ayaṃ na dharmā yathā na vināśitāḥ || punar aparaṃ tasyāhaṃ bhagavann evaṃ vadeyạ̣ neha dharmadeśanāyāṃ kaścit saḥ parinirvṛtaḥ parinirvāti parinirvāsyati vā || tat kasmād dhetos tathā hi bhagavann atyantatayānupalabdhitvāt sattvasya | evam ahạ̣ bhagavan prṣțah samāna evaṃ vadeyam || punar aparaṃ bhagavan yo mamāntikād imāṃ gambhīrāṃ prajñāpāramitām śrotukāmạ̣ | paripṛccheta kātavādya bhagavatā sārdhaṃ kathā pravṛttābhūd iti tasyāham evaṃ vadeyaṃ sace tvam icchasi tāṃ kathāṃ śrotum tan mā ca na samākṣepaya śroṣyāmīti mā ca cittam utpādaya śroṣyāmīti | yādṛśî bhoḥ puruṣa māyāpuruṣasya prajñā tādṛ́sīm prajñām utpādya <198v> evam iyam dharmadeśanā śakyā ajñātum sacet tvam bhoḥ puruṣa icchasīmāṃ dharmadeśanāṃ śrotum tad evaṃ tiṣtha || tadyathāpi nāmākāśe śakunipadam | evam iyam śakyā dharmadeśanām śrotum sacet tvam bhoḥ puruṣa icchasīmām dharmādeśanāṃ śrotuṃ tan mādvayam ālambasva-m- 35 advayam || tat kasmād dhetor na hi kācid iha dvayaparikīrtanā parikīrtitā |

9 abhūd] corr.; abhūdd ms. 15 upāsako] corr.; upāko ms. 29 iti] corr.; ati ms. 
advayaparikīrtanā vā | saced icchasīmāṃ dharmadeśanām śrotuṃ tan mā ātmasamiñāṃ ca vināśaya dṛșțikṛtāni ca mā samakramabuddhadharmāś ca mādhyālambasva pṛthagjanadharmebhyaś ca mā caleti yo me bhagavan śrotukāmaḥ pṛcchet tam aham evaṃ vadeyam evam anuśāseyam anupratișthāpayeyaṃ sacet kulaputro vā kuladuhitā vā paripṛcchaka eva tișṭhe 5 nirviśetu tat tasya asyā pratibhānaṃ mudrāyām pratișṭitasya paścād uttarīmāṃ gambhīrām prajñāpāramitām yāvad ajātābhāvānutpannāṃ deśayeyam || evam ukte bhagavān mañjuśriyaṃ kumārabhūtam etad avocat || sādhu sādhu mañjuśrīḥ subhāṣitā te iyaṃ vāk | eva cottare vadet tasya kulaputrasya vā kuladuhitur vā tathāgatadraștukāmena yam eva prajñāpāramitā bhāvayitavyā abhāvanāyogena | tathāgataṃ paryupāsitukāmena kulapu<199r>treṇa vā kuladuhitā vā ihaiva prajñāpāramitāyāṃ śikṣitavyam anupalambhayogena | tathāgatomeśās te 'ti vyapadestvakāmena kulaputreṇa vā kuladuhitā vā ihaiva prajñāpāramitāyāṃ śikṣitavyam anutpādayogena | anuttarāyām samyaksambodhim abhisamboddhukāmena kulaputreṇa vā kuladuhitā vā ihaiva prajñāpāramitāyām śikṣitavyam anabhisaṃskārayogena | sarvasamādhikauśalyaniṣpādayitukāmena kulaputreṇa vā kuladuhitā vā ihaiva prajñāpāramitāyāṃ śikṣitavyaṃ prajñāpāramitāyogena | yāvat sarvākārevaropetaṃ sarvajñajñānaṃ parinișpādayitukāmena kulaputreṇa vā kuladuhitā vā ihaiva prajñāpāramitāyām șikṣitavyam abhāvayogena || tat kasmād dhetos tathā hi yāvat sarvākāravaropetạ̣ sarvajñajñānam akṛtam anutpannam abhāvaṃ sarvadharmāḥ saniḥsaraṇā na sa kaścid dharmo yo na saniḥsaraṇaḥ sa evam anugantukāmena kulaputreṇa vā kuladuhitā vā ihaiva prajñāpāramitāyāṃ śikṣitavyaṃ yāvad abhāvayogena | sarvadharmā aniḥsaraṇā na sa kaścid dharmo yaḥ saniḥsaraṇaḥ || tat kasmād dhetor anutpannatvāt sarvadharmāṇām evam ājñātukāmena kulaputreṇa vā kuladuhi<199v>tā vā ihaiva prajñāpāramitāyām śikṣitavyaṃ yāvad abhāvayogena sarvasattvā bodhāya caranti | na kaścit sā yo na bodhāya caranti atrāsaṃsīditukāmena kulaputreṇa vā kuladuhitā vā ihaiva prajñāpāramitāyāṃ śikṣitavyaṃ yāvad abhāvayogena || tat kasmād dhetos tathā hi sarvadharmā bodhisamā yathā hi | sarvadharmā bodhisamās tathā bodhi yathā ca bodhis tathā sarvasattvā yathā ca sarvasattvās tathā carị̣ | avidyamānatvāt sarvācariracāriṇi | sā ca bodhiyā ca bodhir anutpādo 'pi sạ̣ | ajātir api sātrāsaṃsīditukāmena eva rūpeṣu sarvadharmeșu tena kulaputreṇa vā kuladuhitā vā ihaiva prajñāpāramitāyāṃ śikṣitavyaṃ yāvad abhāvānutpādayogena || yad api mañjuśrīs

1 icchasīmāṃ] corr.; icchasimācan ms. 12 śikșitavyam] corr.; śikṣatavyam ms. 16 kuladuhitā] corr.; kulahitā ms. • ihaiva] corr.; ihai ms. 29 -pāramitāyāṃ] corr.; -pāramiyāṃ ms. 
tathāgatavikurvitaṃ yāvat tathāgatavikrīẹitaṃ tad api prajñāpāramito darśitam || tat kasmād dhetor nidarśanā adarśayitrī prajñāpāramitā avaivartikāṃs tān ahaṃ mañjuśrīr vadāmi ye bhikṣavo vā bhikṣuṇyo vā upāsako vā upāsikā vā ita prajñāpāramitātaḥ catuṣpadagāthāṃ pramāṇamātrapramāṇam apy udgrahiṣyanti paryavāpsyanti dhārayiṣyanti vācayiṣyanti yāvat samprakāśayișyanti kah punar vādo ye tathatvā<200r>ya pratipatsyante | niyatās te kulaputrāḥ kuladuhitaraś ca bodhāya veditavya | buddhavișaye sthita ya imāṃ gambhīrāṃ prajñāpāramitāṃ yāvad abhāvājātābhāvānutpannāṃ śrutvā nottrasiṣyanti na saṃtrasiṣyanti na saṃtrāsam āpatsyante || uttari cādhimokṣyante niyatās te bhaviṣyanti sarvabuddhadharmeșu imām apy ahạ̣ mañjuśrīr mudrāṃ sthāpayāmi | buddhānujñātāṃ tathāgatavijñātāṃ sarvair arhadbhị̣ sampratīcchatām imāṃ mudrāṃ sthāpayāmi | samatā ca buddhānām iyam asaṃgatā paridīpanā yāvat sarvabuddhadharmeșu nirdișțā anayā ca mañjuśrīr mudrayā mudrito bodhisattvayānikaḥ kulaputro vā kuladuhitā vā 'bhavyo bhavaty apāyagamanāya abhavyaśrāvakabhūmau pratyekabuddhabhūmau vā gantum avakramaṇāya vā | atha khalu tasyām velāyāṃ śakro devānām indraṃ trāyastriṃśāś ca devaputrā divyena candanacūrṇena divyaiś ca māndāravaih puṣpair divyaiś ca gandhair divyaiś cotpalakumudapuṇụarīkair divyaiś ca vādyair imāṃ prajñāpāramitāṃ pūjayamānā bhagavantam mañjuśriyaṃ kumārabhūtam abhyavākirann abhiprākirann evaṃ cāvocat || idaṃ kuśalamūlam asyaivānuttarasya dharmaratnasya pūjāyai punaḥ punạ̣ śravaṇāya ca teṣām tavameye anayā mudrayā mudri<200v>tāḥ || evaṃ ca śakro devānām indro vācam abhāṣata vayam api bhagavan tadyogam āpaśyāmahe | asyā gambhīrāyāḥ prajñāpāramitāyā yāvad anutpannāyā iha jambudvīpe teṣām tathāgatarūpāṇāṃ kulaputrāṇāṃ kuladuhiț̣nām ca śrotāvabhāsam āgamanāya yāvat teșām eva sarvabuddhadharmapariniṣpādanāya yeșām khalu punar bhagavan kulaputrāṇāṃ kuladuhitṛnāṃ cāyam prajñāpāramitānirdeśo alpakṛcchreṇa śrotāvabhāsam āgamiṣyati śrutvā ca vimokṣya adhimuktāś codgrahịsyanti paryavāpsyanti yāvad vācayiṣyanti niṣthā taị̣ kulaputraị̣ kuladuhitṛbhiś ca gantavyā devatopasaṃhāra evāyam asmākam iti || evam ukte bhagavān śakraṃ devānām indram etad avocat || evam etat kauśika sarvabuddhadharmapariniṣpattis teșāṃ kulaputrāṇāṃ kuladuhiț̣nāṃ ca drașțavyāni yatāś ca te pratikānikṣitavyā anuttarāyāḥ samyaksambodhe || atha khalu mañjuśrīḥ kumārabhūto bhagavantam etad avocat | adhitișțatu bhagavann adhitișṭhatu sugata | imaṃ gambhīraṃ prajñāpāramitānirdeśaṃ

1 prajñā-] $p c$;; jñāpra- $a c .11$ mudrāṃ] corr.; madrāṃ ms. 18 divyaiś] corr.; diś ms. 19 -puṇ̣araikkair] corr.; -puṇ̣akair ms. 
teśām kulaputrāṇāṃ kuladuhiṭ̣nāṃ cārthāya samanantarabhāṣitā ceyaṃ vāk || atha khalu tasyāṃ velāyāṃ buddhānubhāvena ṣạ̣vikāraṃ mahāpṛthi<201r>vīcālo abhūt | samanantarapracalitāyāṃ ca mahāp̣̣thivyām || atha khalu bhagavāṃs tasyāṃ velāyāṃ smitam akarot | samantaraprāviṣkṛte ca bhagavatā smite 'tha khalu tasyāṃ velāyāṃ trisāhasramahāsāhasralokadhātur mahatāvabhāsena sphuṭo 'bhūd imaṃ prajñāpāramitānirdeśam tathāgatasyādhitișțhatah || atha khalu mañjuśrīḥ kumārabhūto bhagavantam etad avocat || imāni bhagavan pūrvanimittāni tathāgatasyemaṃ prajñāpāramitānirdeśam adhitișțhatạ̣ || bhagavān āha || evam etan mañjuśrīr asya prajñāpāramitānirdeśasyādhitișțhatah | imāni pūrvanimittāni ebhị pūrvanimittair jñātavyam adhitișțhato 'yaṃ prajñāpāramitānirdeśa iti || te te mañjuśrīr anayā mudrayā mudritā jñātavyā ye tena kaścid dharmaṃ pratikroṣyanti abhyanujñāsyanti vā | tat kasya hetor upalambhasya hi mañjuśrīḥ sa tah pratikrośanā bhavaty anujñā vā tasmāt tarhi mañjuśrīr ye te anayā mudrayā mudritās teșām kṛtaśa iyaṃ mudrā mayā sthāpitā | athāhitena kaṃcid dharmam deśayiṣyanti na vikalpayiṣyanti || tat kasmād dhetoḥ paramārthato 'nutpannatvān mañjuśrīh sarvadharmāṇām || || idam avocad bhagavān āttamano mañjuśrīś ca kumārabhūtas te ca mahābodhisattvās te ca mahāśrā<201v>vakāḥ sā ca sarvāvatī parṣat sadevamānuṣāsuragaruḍagandharvaś ca loko bhagavato bhāṣitam abhyanandann iti || ||

ārya-saptaśatikā-prajñāpāramitā parisamāptạ̣ || ||

[164] namo bhagavatyai ārya-prajñāpāramitāyai || evaṃ mayā śrutam ekasmin samaye bhagavān rājagṛhe viharati sma || gṛdhrakūṭe parvate mahatā bhikṣusaṃghena sārdham ardhatryodaśabhir bhikṣuśatair anekaiś ca bodhisattvakoținiyutaśatasahasraiḥ śakrabrahmalokapālapramukhair anekaiś ca devakoṭiniyutaśatasahasraiḥ parivṛtah puraskṛto bhagavān śrīratnagarbhasiṃhāsane niṣaṇno dharmaṃ deśayati sma || ādau kalyāṇaṃ madhye kalyāṇaṃ paryavasāne kalyāṇaṃ svarthaṃ suvyañjanaṃ kevalaṃ paripūrṇaṃ pariśuddhaṃ paryavadātaṃ brahmacaryaṃ samprakāśayati sma || atha khalv āryāvalokiteśvaro bodhisattvo mahāsattva utthāyāsanād ekāṃśam uttarāsañgam kṛtvā dakṣiṇaṃ jānumaṇḍalaṃ pṛthivyāṃ pratișțhāpya yena bhagavāṃs tenāñjalim praṇamya prahasitavadano bhūtvā bhagavantam etad avocat || deśayatu me bhagavān prajñāpāramitāṃ svalpākṣarāṃ mahāpuṇyāṃ

3 samanantara-] pc.; samantanara- ac. 25 anekaiś] pc.; anekaivāś ac. 31 khalv] pc.; khalu ac. 
yasyāḥ śravaṇamātreṇa sarvasattvāḥ sarvakarmā<202r>varaṇāni kṣapayiṣyanti niyatạ̣ ca bodhiparāyaṇā bhaviṣyanti ye ca sattvā mantrasādhane udyuktās teșām cāvighnena mantrā siddherantīti || atha khalu bhagavān āryāvalokiteśvarāya bodhisattvāya mahāsattvāya mahākāruṇikāya sādhukāram adāt sādhu sādhu kulaputra yas tvaṃ sarvasattvahitāya sukhāya pratipannạ̣ sarvasattvārtham dīrgharātram abhiyuktas tena hi tvaṃ kulaputra śṛ̣u sādhu ca suṣthu ca manasi kuru bhāṣișye 'ham te prajñāpāramitām svalpākṣarāṃ mahāpuṇyām yasyāḥ śravaṇamātreṇa sarvasattvāḥ sarvakarmāvaraṇāni kṣapayiṣyanti niyatam ca bodhiparāyaṇā bhaviṣyanti || ye ca sattvā mantrasādhane udyuktās teșām cāvighnena mantrā siddheranti || || athāryāvalokiteśvaro bodhisattvo mahāsattvo bhagavantam etad avocat || tena hi sugato bhāṣatu sarvasattvahitāya sukhāya ca || || atha khalu bhagavāṃs tasyāṃ velāyāṃ sarvasattvapramocanīṃ nāma samādhim samāpadyate sma yayā samāhitayā ūrṇākośād bhrūvivarād anekāni raśmikoṭiniyutaśatasahasrāṇi niścaranti sma || taiś ca raśmibhị̣ sarvabuddhakṣetrāṇi sphuțāny abhūvan ||<202v> ye ca sattvās tayā prabhayā sprștāạ te sarve niyatābhūvann anuttarāyām samyaksambodhau yāvan nārakāḥ sattvāḥ sarvasukhasamarpitā abhūvan | sarvāṇi ca buddhakṣetrāṇi ṣaḍvikāram pravicelur divyāni candanacūrṇatathāgatapādamūle prāvarṣat || || atha khalu bhagavāṃs tasyāṃ velāyām imām prajñāpāramitām bhāṣate sma || tadyathā bodhisattvena mahāsattvena sarvasattveșu samacittena bhavitavyam || maitracittena bhavitavyam | kṛtajñena bhavitavyam | kṛțavedinā ca bhavitavyam | sarvapāpaviratacittena bhavitavyam | idaṃ ca prajñāpāramitāhṛdayam āvartayitavyam || ||

namo ratnatrayāya || namạ̣ śākyamunaye tathāgatāyārhate samyaksambuddhāya tadyathā || oṃ mune mune mahāmunaye svāhā || asyāḥ prajñāpāramitāyā lābhān mayānuttarā samyaksambodhir anuprāptā sarvabuddhāś cāto niryātās tvayāpīyam eva prajñāpāramitā śrutā || mahāsaākyamunes tathāgatasākṣāt || tena hi tvam sarvabuddhabodhisattvānām agrato buddhatve ca vyākṛto bhavișyasi tvaṃ māṇavakānāgate 'dhvani samantaraśmyudgataśrīkūṭarājo nāma tathāgato 'rhan samya<203r>ksambuddho vidyācaraṇasampannaḥ sugato lokavid anuttaraḥ puruṣadamyasārathị̣ śāstā devānāṃ ca manuṣyāṇām ca buddho bhagavāṃs tvadīyam api ya idaṃ nāmadheyaṃ śroṣyanti likhiṣyanti likhāpayiṣyanti dhārayiṣyanti vācayiṣyanti paryavāpsyanti parebhyaś ca vistareṇa samprakāśayiṣyanti pustakalikhitam api kṛtvā gụhe dhārayiṣyanti te

5 adāt] corr.; udāt ms. $\mathbf{8}$-mātreṇa] corr.; -mātre ms. 11 etad] $p c$. ; et $a c .14$ samāhitayā] $p c$; samādahitayā ac. 17 yāvan] pc.; yāvantāran $a c . \quad 29$-pāramitā] corr.; -pārami ms. 
sarve tathāgatā bhavișyanty anāgate 'dhvani || tadyathā || oṃ jaye jaye padmābhe avame sarasaraṇi dhiri dhiri dhirādhiri khiri khiri khirākhiri devatānupālini buddhottāraṇi pūraya pūraya bhagavati sarvāsām mama sarvasattvānām ca sarvakarmāvaraṇāni viśodhaya sarvabuddhādhișthitena svāhā || ya imā paramārthā prajñāpāramitā sarvabuddhānāṃ jananī bodhisattvamātā sadyạ̣ pāpaharī bodhisattvanāyikā sarvabuddhair api na śakyate anuśaṃsā vaktụ̣ kalpakoțīśatair api anayā pațitamātrayā sarvamaṇḍalābhișikto bhavati || sarve ca mantrā abhimukhā bhavanti || || atha khalv āryāvalokiteśvaro bodhisattvo mahāsattvo bhagavantam etad avocat || kena kāraṇena bhagavann iyaṃ prajñāpāramitā saṃ<203v>kșiptā || || atha bhagavān āha || alpopāyatvāt ye 'pi sattvā mandotsāhās te 'pīmāṃ prajñāpāramitāṃ svalpākṣarāṃ dhārayișyanti vācayiṣyanti likhișyanti likhāpayișyanti || te sarve alpopāyena bodhiparāyaṇā bhaviṣyanti || anena kāraṇena kulaputra sạ̣kṣiptā prajñāpāramiteti || evam ukte āryāvalokiteśvaro bodhisattvo mahāsattvo bhagavantam etad avocat || || āścaryaṃ bhagavan paramāścaryam sugata yāvad eva bhagavatā sarvasattvahitāya sukhāya ca dharmaparyāyo deśito mandapuṇyānāṃ ca sattvānām arthāya hitāya sukhāya ceti || || idam avocad bhagavān āttamanā āryāvalokiteśvaro bodhisattvo mahāsattvo te ca mahāśrāvakās te ca bodhisattvā mahāsattvāḥ sā ca sarvāvatī parṣat sadevamānuṣāsuragandharvaś ca loko bhagavato bhāṣitam abhyanandann iti || ||

ārya-svalpākṣarā-prajñāpāramitā samāptā || || ārya-nāgārjunapādaiḥ pātālād uddhṛteti || ||

[165] <204r> oṃ namaḥ śrī-vasudhārāyai || pūrvavac chūnyatāparyantaṃ vibhāvya jhatiti jambhalarūpam ātmānam dhyātvā svahṛdaye candramaṇḍale madhyavaṃkārabījaniryātāṃ vasudhārāṃ bhagavatịm dhyāyāt | kanakavarṇām 25 sarvālaṃkāravatīṃ dvirașțavarṣākṛtim | dakṣiṇakareṇa varadāṃ vāmakeṇa dhānyamañjarīdharām | akṣobhyamakuṭadhāriṇīm | purato bhagavatīm vasudhārām | dakṣiṇato vasuśriyam | paścimato śrī-vasumukhīm | vāmato vasumatiśrīm | etāś cādyakṣarabījāḥ svanāyikāsamānarūpāḥ cintanīyāḥ || evaṃ vibhāvya mantram āvartayet || om vasudhāriṇi svāhā || oṃ śrī-vasu svāhā || oṃ vasuśriye svāhā || oṃ śrī-vasumukhi svāhā || oṃ śrī-vasumatiśriye svāhā || pratyaham gomayena dvihastapramāṇaṃ caturasraṃ maṇḍalakaṃ kṛtvā trisaṃdhyam sugandhikusumair abhyarcya sahasracatușțayaṃ

2 devatānupālini] $p c$; devatānāpālini $a c . \quad 6$ śakyate] $p c$.; śakṛtekya $a c . \quad 9$ etad] $p c$.; edatad ac. 14 -lokiteśvaro] pc.; -lokiśateśvaro ac. 19 te] corr.; ste ms. 20 -gandharvaś] corr.; -gandhaś ms. 
japatāṃ ṣaṇmāsān manorathaṃ paripūrayati || yathālabdhakusumānāṃ caturlakṣam āhutị̣ kṛtvā mahatī śrīr bhavati || vasudhārādhāraṇīṃ dhārayet || || tatra bhagavatīm manasāropya pūjayitvā candanāliptapāṇiḥ | vasudhārādhāraṇīpustakasūtrāvabaddhakusumamālāṃ puratạ̣ sthāpitodakabhājane 'ti nikṣipya <204v> sarvasattveșu mahāmaitrīcittam ālambyābhimatasiddhau hṛdayam ādhāya vasudhārādhārạ̣ị̣ paṭhet | paṭhaṃś ca svāhānvitamantrānām svāhāśabdoccārayet sitapuṣpadūrvāsahitākhaṇḍataṇdulāny udakabhājanena dadyāt | ṣaṇmāsaṃ yāvat pāṭhāvasāne ca śucipradeśe tad udakaṃ visarjayed iti || ||

iti vasudhārā-dhāraṇī samāptaḥ \|

[166] oṃ namaḥ ratnatrayāya || pūrvoktavidhānena hṛdi candramaṇḍale sita-oṃkārajāṃ sitātapatrāparājitāṃ bhagavatīṃ trimukhāṃ ṣaḍbhujām pratimukhāṃ trinayanāṃ śuklāṃ nīlāruṇadakṣiṇavāmamukhīm | cakrāṅkuśadhanurdharadakṣiṇakarām | sitavajraśarapāśatarjanīdharavāmakarām | sukrodhadṛștikāṃ sarvagrahavidhvaṃsanīṃ divyālaṃkāravastravatīm | vairocananāyakāṃ dhyātvā mudrāṃ bandhayet | dakṣiṇahastamuṣtitarjanīṃ hṛdi saṃsthāpya | vāmahastamuṣṭim utthāpayet || jāpamantraḥ || oṃ sitātapatrāparājite sarvagrahān trāsaya 2 hana 2 hūṃ 2 hūṃ 2 phat 2 svāhā || ||

ity ārya-sitātapatrāparājitā-nāma-dhāraṇī samāptā || ||

[167] oṃ namaḥ śrī-vajracarcikāya || pūrvoktavidhānena śūnyatābhāvanānantaram așțadalaka<205r>maloparisthahūmkārajavajraṃ vaṃkārādhișthitavarațakaṃ dhyātvā tatpariṇatāṃ vajracarcikāṃ trinetrām ekamukhīm ardhaparyañkatāṇḍavām | mṛtakāsanasthāṃ kṛ̣āṅgīm damṣțrotkațabhairavām | naraśiramālāvibhūṣitakaṇṭhadeśām asthyābharaṇabhūṣitām | pañcamudrādhāriṇīm akṣobhyamakuṭinīm | vyāghracarmanivasanām | muktakeśīm șaḍbhujāṃ dakṣiṇe vajrakhaḍ̣acakradhāriṇīm | vāme kapālamaṇikamaladharām | raktavarṇāṃ karmānurūpatạ̣ śuklādivarṇayuktāṃ ca dhyātvā | svahṛccakārakarānītajñānacakraṃ puraḥ saṃsthāpya pūjādikaṃ nivartya praveśayet || tato japet oṃ vajracarcike hūṃ svāhā || ||

iti śrī-vajracarcikā-nāma-dhāraṇī samāptaḥ || ||

4 -kusuma-] corr.; -kusu- ms. 13 -dakșiṇa-] corr.; -dahiṇa- ms. 18 -parājite] corr.; -parājitāṃ ms. 22 -stha-] corr.; -șrstha- ms. 
[168] oṃ namaḥ śrī-dhvajāgrakeyūrāyai || natvā dhvajāgrakeyūrāṃ sarvāpāyabhayāpahām | tasyāḥ sādhanasiddhir likhyate śraddhayā mayā || ādau tāvan mantrī mukhaśaucādikaṃ kṛtvā manonukūlasthāne sukhāsanopavișțaḥ san || maitryādimanasaḥ śuddho dānapāramitāparaḥ |

bhāvayen māravidhvaṃsakāriṇīm tāriṇīm raṇaị̣ || oṃ candrārkavimale svāheti mantram uccārya svahṛdi tyaṃkārapariṇatacandrasūryasampuṭopari dhvaṃkārapītaraśmibhir ākāśa<205v>deśe buddhabodhisattvān dṛșțā manomayapuṣpādibhị̣ sampūjya triśaraṇagāthām paṭet | tadanantaram oṃ svabhāvaśuddhāḥ sarvadharmāḥ svabhāvaśuddho 'ham iti mantram uccārya muhūrtam śūnyaṃ bhāvayet || tataḥ oṃ śūnyatājñānavajrasvabhāvātmako 'ham ity ahaṃkāram utpādya sattvābhyuddharaṇāśayạ̣ | pratibimbasaṃnibhạ̣ candrasūryasampuṭopari dhvaṃkārapītaraśmibhir anantasattvān buddhabodhisattvarūpeṇālaṃkṛtya taddhṛdi praviśya punar āgatya raśmisamudbhavaṃ bījeșu viṃśatam bhāvayet || tat sarvaṃ pariṇamya saṃgāmatāraṇīm devīm pītavarṇāṃ manoramām | caturvaktrabhujāṃ kruddhāṃ pratyālị̣hāṃ lambodarīm | śubhāṃ raktavartulatrinetrām sunīlāvaraṇadhāriṇām | asitacakrasavyahastām | vāmābhyāṃ tarjanīpāśakṛṣnavajrān̉kitaśvetamusaladharāṃ vāmāñgāśliṣțatriśūlam | prathamam pītānanāṃ vāme raktāntarasitām | ūrdhvavikṛtadhūmābhāṃ raktapingordhvajațābaddhāṃ kapālapañcaśobhanām | padmasūryamadhyasthām ātmānaṃ bhāvayet sthitam | evaṃ samayasattvaṃ niṣpādya sūryasthabījaraśminā jñānasattvam ānīya sampūjya || jaḥ hūṃ vaṃ hor ebhir akṣaraị̣ ākṛṣya praveśya baddhvā vaśam nayet || tatas tathāgatān yācayet | abhiṣiñcatu māṃ sarvatathāga<206r>tāḥ || tato 'kṣobhyādibhị̣ tathāgataih svahṛdayād visphāritapañcāmṛtaparipūritakanakakalaśahastair abhișicyamānam ātmānaṃ bhāvayet | tatreyam abhiṣekagāthā | abhiṣekamahāvajraṃ traidhātukaṃ namaskṛtam | dadāmi sarvabuddhānāṃ triguhyālayasambhavam \| oṃ sarvatathāgatābhiṣekasamayaśriya āḥ hūṃ svāhā || tato pariśișțapānīyaṃ pariṇamya mukuțe akṣobhyo jāyate | mantram āvartayen nityaṃ satyavādī dayāparah || oṃ bhagavati dhvajāgrakeyūre parasainyavidhvaṃsanakari svasainyaparipālani | ulkāmukhi kha 2 khāhi 2 parasainyavidhvaṃsani anantamukhena anantabhujena prahara 2 hūm hūm phaṭ 2 svāhā || hṛdayamantraḥ || oṃ

10 -gāthā paṭhet] pc.; -gāpathāṭhet $a c .15$ raśmi-] corr.; raśi- ms. 23 -bīja-] corr.; -jams. 26 -paripūrita-] corr.; -paripūrikanakapūrita- ms. 34 -vidhvaṃsani] $p c . ;$-vidhvaṃ ac. - anantamukhena] corr.; anantamukhena anantamukhena ms. 
sarvagrahanakṣatradhyāmīkaraṇi svāhā || upahṛdayamantraḥ || mālāmantras tu dhāraṇyāṃ drașțavya utthānakāle \| kṛto vaḥ sarvasattvārthaḥ siddhị̣ dattvā yathānugā | gacchadhvaṃ buddhaviṣayaṃ punar āgamanāya ca || ity anena mantreṇa visarjayitvā vihared iti || ||

iti dhvajāgrakeyūrā-sādhana-dhāranīi samāptah || ||

[169] oṃ namo bhagavatyai āryoṣnịịavijayāyai || prathamaṃ tāvan mantrī mukhaśaucādikaṃ kṛtvā sukhāsanoparistha caturbrahmavihārā<206v>n bhāvayet || tadanantaram svahṛdy akāraparinatam candramaṇụalaṃ dhyātvā tadupari sitabhrūṃkāraṃ dṛșțā tadvinirgataraśmisamūhair jagad avabhāsya purataḥ sarvabuddhabodhisattvān vicintya pūjāpāpadeśanādikaṃ kuryāt || tataḥ oṃ śūnyatājñānavajrasvabhāvātmako 'ham || tatạ̣ punar api svahṛdindau paṃkārajaviśvadalakamalaṃ dhyātvā tadupari candrabimbamadhyagam sitabhrūṃkāraṃ dṛșțā tatpariṇatām uṣnịṣavijayāṃ caityaguhāntaḥsthāṃ pītavarṇāṃ trimukhāṃ trinetrām așțabhujāṃ sarvālaṃkārabhūṣitāṃ viśvadalakamalacandrasthāṃ vajraparyan̉kām || prathamaṃ sitavadanāṃ dakṣine pītamukhāṃ vāme nīlamukhāṃ damșțrāpuṭāvașțabdhaușthām | dakṣiṇacaturbhujeșu viśvavajrāṃ raktāravindastha-amitābhajinaśaravaradahastām | vāmacaturbhujeșu dhanuhtarjanīpāśa-abhayabhadraghațahastām | vairocanamakuținịm divyavasanaparidhānottarīyām | nānālaṃkārabhūṣitāṃ sitaprabhāmālinīm paśyet || tasyā dakșine lokeśvaro vāmena padmadhārī dakșine cāmarahastạ̣ || vāme vajrapāṇiḥ kuvaladalaśyāmaḥ vāme kuvalayasthavajradhārī dakșine cāmarahastaḥ | etau niṣaṇṇau cintanīyau || tataḥ pūrvadakșiṇapaścimo ttare<207r>ṣu | acalațakkirājanīladaṇdamahāvarāh | sarve nīlā dvibhujā ekamukhāḥ trinetrāḥ pratyāliḍhāḥ vyāghracarmāmbarāḥ ūrdhvakeśā aștanāgābharaṇāḥ | viśvadalakamalasūryākrāntāḥ | tarjanīpāśahastā | dakṣiṇe khaḍga-an̉kuśavajradaṇḍahastā bhāvanīyāḥ | upari śuddhāvāsakāyikau devaputrau cintanīyau | pūrṇakumbhabhūtāmṛtau pravarșamāṇau || evaṃ saparivārāṃ bhagavatīṃ dhyātvā satkuryāt || oṃ śirasi āḥ kaṇțhe hūṃ hṛdaye trāṃ lalāțe hrịḥ nābhau ạ̣ ạ̣ pādayoḥ || tato mudrāṃ bandhayet | sampuṭāñjaliṃ kṛtvā tarjanyau saṃkocya jyeșṭhāngușțhābhyāṃ sādhukāraṃ dattvā oṃkāratrayasahitām dhāraṇīm ekavāram āvartya paścād vinā mudrayā āvartayet || oṃ bhruṃ svāhā || hṛdaya || oṃ amṛtāyurdade svāhā || upahṛdayamantraḥ || oṃ amite amitodbhave amitavikrānte amitagātre

2 dhāraṇyāṃ] corr.; dhānāṃ ms. 35 amitodbhāve] pc.; amidbhave $a c$. 
amitagāmini amitāyurdade gaganakīrtikari sarvakleśakṣayaṃkarīye svāhā || iti mālāmantraḥ || ||

āryoṣṇịṣavijayā-sādhana-dhāraṇī samāptạ̣ || ||

[170] oṃ namaḥ śrī-mahāmāyādevyai || tathaiva ṣaḍdevatācakrạ̣ yogī nābhikamalakarṇikāvasthitaravisomasampuṭagarbhe ciraṃ vici<207v>ntya || tathaiva tadraśmirekhayā varṇāvalītrayaṃ grathitayā veșțatrayasaṃyate sampuṭe mantraṃ japet | iha tantre tryakṣarā mantrāḥ tatra bhagavato mantraḥ || oṃ hūṃ hūṃ buddhaḍākinyādīnāṃ yathākramạ̣ || oṃ oṃ hūṃ oṃ hūṃ hūṃ || oṃ svā hūṃ | oṃ āḥ hūṃ | oṃ hā hūṃ || kathaṃ japet sampuṭe garbhe japyaṃ bījākṣaraṃ vinyasya tacchīrṣe vīram utthāpya oṃkāram uccārayan vīrād raśmirekhām ucchvāsavāyunā sahotthāpya tayāvabhāsya jagad buddhamayīm kuryāt bījākṣaram uccārayan | teṣu sarvabuddheșu svadevatāsvabhāvatām adhimuñcet | antahūṃkāram uccārayet | niśvāsavāyunā samākṛṣya tadbuddhamayạ̣ jagat vīre saṃharet || evạ̣ punah punah kurvīta yāvata khedo na bhavati | sati khede viśramā sarvam idam kuśalam anuttarāyai samyaksambodhaye 'bhimataphalasiddhi yeva pariṇamayya pūrvavat pūjāṃ kṛtvā svahṛ̂bījākṣare mạ̣ḍalam antarbhāvya tata utthāya svadevatāni vāmātmānam adhimucya sarvaṃ kurvīta | sarvaṃ ca bhojyaṃ pañcabhir bījaih pañcajñānāmṛtamayam kṛtvā svahṛdaye ca devatācakram adhimucya vicintya ca tajjihvāsu tadamṛtaṃ juhuyāt || snānam kurvan devatābhișekavidhim dhyāyāt | madhyāhnasāyāhnasaṃdhyayos tu maṇḍalagṛ<208r>ham praviśya svahṛdbījaraśmibhir ādhāramaṇụalam nirmāya tata eva bījāc catasrā yoginị̣̄ krameṇa saṃsthāpya yathāsthānaṃ niveśya pūrvavad abhiṣekādikam sarvam vidhim anuṣthāpya mạ̣ḍalamantraṃ bhāvya | tata utthāya pūrvavat samāhitayogaṃ kuryāt | ardharātrasaṃdhyāyāṃ tv ayaṃ viṣayaḥ | sampūjyārghaṃ dattvā oṃ vajra mur iti | jñānamaṇḍalam anutș̣jya jñānabījasamaṇḍalam antarbhāvya nirābhāsaṃ sambodhicittam adhimucya supyāt | evaṃ dināntareṣv api devīsaṃgīticodanotthāpitạ̣ sarvaṃ pūrvavat kuryāt | evaṃ pratyahaṃ yāvat siddhinimittāni labhate | tatra maṇḍaleśvarasya mantro lakṣajāpena sidhyati | śeșānām ayutajāpena mālāmantrāś ca tantrāntarādare netavyāḥ | tān svahṛtsūryahṛccandre vā yathāyogaṃ

4 șaḍdevatā-] corr.; yadavatā- ms. 5 ciraṃ] corr.; vīra ms. $\mathbf{6}$ grathitayā] corr.; gratthitayā ms. - -samyate] corr.; -sayadyate ms. 7 try-] corr.; nty- ms. 14 tadbuddha-] pc.; dbutaddhaac. 22 nirmāya] corr.; niryāya ms. 24 -șțhāpya] corr.; -șțhāpaya ms. 28 pūrvavat] corr.; pūvat ms. 
maṇḍalīkṛtya pradīpamālāvajjvalataśvetasābhilikhya manasā vācayann iva japed iti \|

dhruvataivaṃ mahāmāyāsādhanaṃ yan mayopārjitam |

kuśalaṃ tena buddhạ̣ syāt vaśī viśvārthasādhane || ||

iti mahāmāyā-nāma-dhāraṇī samāptạ̣ || ||

[171] oṃ namaḥ śrī-vajrajvālānalārkāyai || tathaiva śūnyatānantaraṃ sūryanīlahūṃkārapariṇatavajrajvālārkaṃ nīlavarṇaṃ jvālāmālākulaprabhạ̣ caturmukha<208v>m aștabhujam ṣṇngāravīrabībhatsakaruṇārasānvitacaturmukhaṃ caturbhir dakṣiṇakarair vajrakhaḍgacakrabāṇadharam | caturvāmakarair ghaṇṭācāpapāśakhaṭāngāsaktavicitrapatākadharam | jvaladanalakapilaśikhākalāpam | atibhīṣaṇamahāhivalayakan̉kaṇakațisūtranūpurakaṇṭhikākuṇḍalamukuṭābharaṇam | mahāmāyācakracaraṇacaturasrapatnikaṃ viṣnum ālị̣hapadenākramyāvasthitaṃ bhāvayed iti || tato mudrāṃ bandhayet || karavajrabandhāṅgulijvālāgarbhamadhye-m-āṅguṣthadvayam utthitam kṛtvā mantraṃ japet || ||

iti vajrajvālānalārka-dhāraṇī samāptạ̣ || ||

[172] oṃ namaḥ śrī-cạ̣ḍamahāroṣaṇāya || om hrāṃ hrāṃ hrīm cạ̣ḍarūpeṇa cațe 2 pracațe 2 kaha 2 prasphura 2 prasphāraya 2 hana 2 grasa 2 bandha 2 jambhaya 2 stambhaya 2 mohaya 2 sarvaśatrūṇām mukhabandhanam kuru 2 sarvaḍākinīnāṃ grahabhūtapiśācavyāghrayakṣāṇām trāsaya 2 mara 2 māraya 2 ruru caṇḍa ruku rakṣa 2 hūm caṇḍamahāroṣaṇam ājñāpayati oṃ caṇḍamahāroṣaṇa hūṃ phaṭ svāhā || bali || oṃ namo bhagavate śrī-caṇḍamahāroṣaṇāya | devāsuranarasaṃtrāsanakarāya sakalamārasaṃtrāsanakarāya sugandhikusumavapuṣe akṣobhyakṛtaśekharāya <209r> idam balim gṛhṇa 2 mama sarvavighnān hana 2 caturmārān nivāraya 2 trāsa 2 trāsaya 2 chinda 2 bhinda 2 nāśa 2 trāsa 2 cheda 2 bheda 2 sarvadușțasattvān mama virūọhacittakān bhasmīkuru hūṃ phaṭ svāhā || ||

iti śrī-caṇụamahāroṣaṇa-dhāraṇī samāptạ̣ || ||

9 -mukhaṃ] corr.; -makham ms. 10 -khațvāñgāsakta-] corr.; -khațvāngasakums. 13 -āvasthitaṃ] pc.; -āvasthitaṃ va ac. 21 -roṣaṇam] corr.; -syeṇam ms. 24 sugandhi-] corr.; ataśi- ms. 26 trāsaya] corr.; trāmaya ms. 
[173] oṃ namaḥ śrī-mahāsaṃvarāya \| pūrvavat jhațiti śūnyatānantaram hūṃkārodbhavaṃ yoginīgaṇanāyakam || bhairavaṃ kālarātriṇaṃ ca karṇikāsūryāgnaupari | tāṇḍavaṃ tu mahākāyaṃ kṛ̣̣nārdhaharitārdhakam || șațsaptatibhujāsāsyaṃ saptadaśatrilocanam | jațāmakuṭadharaṃ vīraṃ viśvavajrārdhacandrakam || mahādaṃstrāākarāāāsyam savyāvasavyataḥ sadā | nīlapītaraktaharit kramec cheșā ca bhṛngavat || mahāraudrāț̣ahāsaṃ ca bhairavānvitabhīṣaṇāḥ || savyāvasavyata jñeyā abjavṛtaṃ yathākramāt | danticarmadvihastānikāt yonimudrā tathāparāt | vajrāsikuntatriśūlaṃ dakṣiṇena yathākramam || paraśukartribāṇaṃ ca śūlabhinnaṃ tu mudgaram | cakraḍamarukṣikșiīināgadabhindipālakam || śan̉khakāhāradaṇdikā mayūrapicchikā tathā| kākapakṣakuñcikāra agnikuṇdạm tu parvavat || lagukā darpaṇā vīnā gulphapāṇiṃ tu <209v> phusphusam | antarāhunigadam ca haḍībhujanakālikā | kabandhajālātailaṃ ca bhairavaṃ rūpatạ̣ kramāt || || vāme ghaṇțākhețadaṇ̣aṃ musalaṃ pāśapātrakam | dhanukhațvāngapustakaṃ pițțāni tarjanī tathā || ghurghurā mālāśṛnkhalā śirā śmaśānadhūrikā | bhokandrakādacarmaṃ ca lavatakacatolikā || codanācitikāșțhī ca gaḍāphalī tu mastakam | kaṃkāra kālikātriṃ ca netrabukka guṇavartikā || śanaiścarakīlakam ca bījapūrakaputrakam | śūcī tu kāyacarmaṃ ca meghavṛkṣāṅkuśas tathā || evaṃ kramato vijñeyā dvāsaptatikarās tathā| pañcamudrākṛtābharaṇaṃ șaṇmudropetabhūṣaṇam || śatamuṇdamālikāś caiva keyūranūpurādayā | vyāghracarmanivasanā romāvalī ca gātragāḥ || || tasyāgrato mahādevī vajravārāhīm īdṛsáḥ | dvibhujā savyakartiṃ ca vāme kapāladhāri ca || jan̉ghābhyāṃ bhagavatālingya mahārāgānurāgiṇī | ekavaktrā muktakeśā nagnā ca raktavarṇikā ||

7 savyāvasavyataḥ] pc.; savyāvyavasavyataḥ ac. 20 -kheța-] corr.; -pheța- ms. 32 -vārāhīm] $p c$; -vārāhītim $a c$. 
muṇụamālāśritā grīvā śṛngārābharaṇojjvalā | śirasi kapālamālā ca divyagandhānurāgiṇī || nūpurakeyūrādiś ca divyaśragdāmabhūṣiṇī| șaṇmudrābharaṇair yuktā ratnābharaṇatrinetrajā || pralayādisamādīpti <210r> mahātejaprabhāsvaram | prajñopāyasukhādaṃ ca sarvasaṃdhiṣu vigrahā || mahāherukajvālaiś ca visphurantam vibhāvayet | evaṃ rūpatu mahāvajraṃ herukaṃ tu vibhāvayet || sarvasaukhyasamāyuktam mokṣasiddhị̣ ca dehi me \| tato jāpamantraḥ || oṃ āḥ kāyavākcittavajra hūṃ phaṭ hāḥ || oṃ vajravārāhi mahādevi hūṃ phaṭ hāḥ || mūlavidyā || ||

iti mahāsaṃvarasya karmarājaviśuddhi-nāma-dhāraṇī samāptạ̣ || ||

[174] oṃ namaḥ śrī-hevajrāya || tato pūrvavat śūnyatānantaram dharmodayāyām kūṭāgāramadhye viśvābjakarṇikopari niṣpannahiraṇyagarbhahariharapuraṃdarabrahmācatuṣțayahṛdayasthasūryacatuṣcaraṇo nagno navanāṭarasai padābjakrāntaḥ ardhaparyañkanāparābhyām ālị̣̄hapadena nụtyaṃ viśvavajrāṅkajvaladūrdhvakapilakuntalo lalāṭopari śuṣkapañcamuṇditam pañcabuddhamakuṭị kṛṣnavarṇaṣoḍaśabhujāḥ aț̣ahāsyapratimukhaṃ raktavartulanetrā mūlamukhaṃ kṛ̣̣naṃ savyāni sitakṛṣnāni vāmāni raktakṛṣnanīlāni ūrdhvadhūmravarṇāḥ vikṛtāni sarvamukhāni sabhrūbhaṅgabhṛkuṭīkāni daṃștrākulakulāni savyāșțakapāleṣu hastyaśvakhara<210v>gāvoșțramanujaśarabholūkakākataḥ | vāmāṣțakakapāleṣu pṛthivīvaruṇavāyutejacandrasūryayamadhanada | cakrīkụ̣ḍalakaṇṭhirucakamekhalabhasmāni | sārdhapacāsanaraśiraśreniikeyūranūpurāṇi ca bhūṣaṇāni || tasyāgrato devī nairātmā nagnā kṛ̣̣nā kartikapāladhāriṇi sarve vāmāṣṭabhujābhyāṃ bhagavantạ̣ gāọham ālingya pratyālị̣̂ha nụtyanti pañcamudrādimudritam raktavartulanetrā damșțrākarāla ekamukhā jvaladūrdhvapingalakeśī lalāțasthapañcamudrāgaṇāvalambitaśuṣkamuṇḍamālānūpurāṇi vibhūṣaṇāni sa prajñāntam bhagavantam bhāvayet || || tato jāpaṃ kuryāt || oṃ devapicuvajre 30 hūṃ phaṭ svāhā || mūla || oṃ nairātmye hūṃ phaṭ svāhā || oṃ gaurīye hūṃ phaṭ svāhā || oṃ caurīye svāhā || oṃ vetālīye svāhā || oṃ ghasmarīye svāhā || om pukkasīye svāhā || oṃ śabarīye svāhā || om caṇụālīye svāhā || om ḍ̣mbīye

4 -trinetrajā] pc.; -tritranetrajāac. 14 -karṇikopari] corr.; -karṇekopari ms. 15 hṛdayastha] pc.; hṛdasthaya ac. 22 -śarabholūkakākataḥ] corr.; -śarabhontukākataḥ ms. 29 -gaṇāvalambita-] corr.; -galāvalambita- ms. 33 pukkasīye] corr.; pakkasīye ms. • ḍombīye] corr.; dvambīye ms. 
svāhā || || bali || oṃ akāromukhasarvadharmānām ādyanutpannatvā hūṃ phaṭ || śatākṣarapaṭhaṃ kuryād iti || ||

iti śrī-hevajra-nāma-dhāraṇī samāptaḥ || ||

[175] oṃ namaḥ śrī-trailokyavijayāyai || pūrvoktavidhānena sūrye nīlahūṃkārajatrailokyavijayabhațțārakam | nīlaṃ ca<211r>turmukham așțabhujaṃ prathamamukhaṃ krodhaśṛngāram | dakṣiṇaṃ raudram | vāmaṃ bhībhatsam | pṛșṭhaṃ vīrarasạ̣ dvābhyāṃ ghaṇțānvitahastābhyāṃ hṛdi vajrahūṃkāramudrādharam | dakṣiṇatrikaraị̣ khaḍgānnkuśabāṇadharam | vāmatrikaraiś cāpapāśavajradharam | pratyālị̣̄hena vāmapādākrāntamaheśvaramastakam | dakṣiṇapādāvașțabdhagaurīstanayugalam | baddhasragdāmamālādivicitrāmbarābharaṇam ātmānaṃ vicintya mudrāṃ bandhayet | tatra muṣțidvayaṃ pṛșțhalagnaṃ kṛtvā kanīyasīdvayaṃ śrn̉khalākāram yojayed iti \|

mantrah || om śumbha niśumbha hūṃ gṛhṇa 2 hūṃ gṛhnāpaya 2 hūṃ ānaya hāḥ bhagavan vidyārāja hūṃ phaṭ svāhā || ||

iti śrī-trailokyavijayā-nāma-dhāraṇī samāptaḥ || ||

[176] oṃ namo buddhāya ||

lokātīta namas tubhyaṃ viviktajñānavedine | yas tvaṃ jagaddhitāyaiva khinnaḥ karuṇayā ciram \| skandhamātravinirmukto na sattvo 'stīti te matam | sattvārtham ca parikhedam agamas tvam mahāmune || te 'pi skandhās tvayā dhīman dhīmadbhyaḥ samprakāśitāḥ | māyāmarīcigandharvanagarasvapnasaṃnibhāḥ || hetutạ̣ sambhavo yeșāṃ tadabhāvān na santi ye | kathaṃ nāma tatas spașțạ̣ pratibimbasamā matāḥ \| bhūtāny acakṣurgrāhyāṇi tanmayam cakṣuṣaṃ katham | rūpaṃ tvayaivaṃ bruvatā rūpagrāho nivāritạ $\|<211 v>$ vedanīyạ̣ vinā nāsti vedanāto nirātmikā | tac ca vedyaṃ svabhāvena nāstīty abhimataṃ tava \| saṃjñārthayor ananyatve mukham dahyeta vahninā | 30 anyatve 'dhigamābhāvas tayoktaṃ bhūtavādinā ||

4 trailokya-] corr.; strailokya- ms. $\mathbf{8}$-trikaraih] pc.; -trākaraị̣ ac. 10 -āvașțabdha-] corr.; -āvașțacca- ms. 16 trailokya-] corr.; strailokya- ms. 23 -svapna-] pc.; -svasnapna- $a c$. 
kartā svatantraḥ karmāpi tvayoktam vyavahārataḥ | parasparāpekșikī tu siddhis te 'bhimatānayoh || na kartāsti na bhoktāsti puṇyāpuṇyam pratītyajam | yat pratītya na taj jātaṃ proktam vācaspate tvayā || ajñāyamānaṃ na jñeyaṃ vijñānaṃ tad vinā na ca | tasmāt svabhāvato na sto jñānajñeye tvam ūcivān || lakṣyāl lakṣaṇam anyac cet syāt tal lakṣyam alakṣaṇam | tayor abhāvo 'nanyatve vispașțam kathitaṃ tvayā || lakṣyalakṣaṇanirmuktaṃ vāgudāhāravarjitam | śāntam jagad idam dṛșțam bhavatā jñānacakṣuṣā || na sann utpadyate bhāvo nāpy asan sadasan na ca | na svato nāpi parato na dvābhyām jāyate katham || na satạ sthitiyuktasya vināśa upapadyate | nāsvato 'śvavișāṇena samasya śamatā katham || bhāvanārthāntaranāśo nāpy anarthāntaraṃ matam | arthāntare bhaven nityo nāpy anarthāntare bhavet || ekatve hi ca bhāvasya vināśa upapadyate | pṛthaktve na hi bhāvasya vināśa upapadyate \| vinașțāt kāraṇāt tāvat kāryotpattir na yujyate | na vā vinaștāt svapnena tulyotpatti<212r>r matā tava || niruddhād vā no ruddhād vā bījād an̉kurasambhavaḥ | māyotpādavad utpādaḥ sarva evaṃ tvayocyate || atas tvayā jagad idam parikalpasamudbhavam | parijñātam asadbhūtam anutpannam na naśyati || nityasya saṃsṛtir nāsti naivānityasya saṃș̣tị | svapnavat saṃsṛtị proktā tvayā tattvavidāṃ vara || svayaṃkṛtaparakṛtam dvābhyām kṛtam ahetukam | tārkikair iṣyate duḥkhạ̣ tvayā tūktam pratītyajam || yaḥ pratītyasamutpādah śūnyatā saiva te matā | bhāvah svatantro nāstīti siṃhanādas tavātulạ̣ || sarvasaṃkalpahānāya śūnyatāmṛtadeśanā | yasya tasyām api grāhas tvayāsāv avasāditaḥ || nirīhā vaśikā śūnyā māyāvat pratyayodbhavāḥ | sarvadharmās tvayā nātha niḥsvabhāvāḥ prakāśitāḥ || na tvayotpāditam kiṃcit na ca kimcin nirodhitam | yathā pūrvaṃ tathā paścāt tathatā buddhavān asi || āryaniṣevitāṃ matām anāgamyā hi bhāvanā|

8 'nanyatve] corr.; 'nyatve ms. 9 -nirmuktam] corr.; -nirmaktaṃ ms. 
nānimittam hi vijñānaṃ bhavatīha kathaṃ cana ||

animittam anāgamya mokṣo nāsti tvam uktavān |

atas tvayā mahāyāna tat sākalyena deśitam \|

yad avāptaṃ mayā puṇyaṃ stutvā tvāṃ stutibhājanam |

nimitte bandhanāyaitad bhūyāt tenākhilaṃ yagat ||

iti lokātīta-stavaḥ samāptaḥ || || <212v>

[177] oṃ namaḥ śrī-grahamātṛkāyai || evaṃ mayā śrutam ekasmin samaye bhagavān aḍakavatyāṃ mahānagaryām anekadevanāgayakṣagandharvāsuragaruḍakiṃnaramahoragāpsarādityasomāñgārabudhabṛhaspatiśukraśanaiścararāhuketubhir așțāviṃśatinakṣatrādibhih stūyamāno mahāvajrasamayālaṃkāravyūhādhișțhānādhișṭhite siṃhāsane viharati sma || anekair bodhisattvaiḥ śatasahasraiḥ sārdham || tadyathā || vajramatinā ca nāma bodhisattvena mahāsattvena || vajracandreṇa ca nāma bodhisattvena mahāsattvena || vajravegena ca nāma bodhisattvena mahāsattvena || vajrasenena ca nāma bodhisattvena mahāsattvena || vajravināyakena ca nāma bodhisattvena mahāsattvena || vajracāpahastena ca nāma bodhisattvena mahāsattvena || vajravikurvitena ca nāma bodhisattvena mahāsattvena || vajrādhipena ca nāma bodhisattvena mahāsattvena || vajrālaṃkāreṇa ca nāma bodhisattvena mahāsattvena || vajravikrameṇa ca nāma bodhisattvena mahāsattvena || jyotivajreṇa ca nāma bodhisattvena mahāsattvena || avalokiteśvareṇa ca nāma bodhisattvena mahāsattvena || samantabhadrena ca nāma bodhisattvena mahāsattvena || samantāvalokiteśvareṇa ca nāma bodhisattvena mahāsattvena || lokaśriyā ca nāma bodhi<213r>sattvena mahāsattvena || padmaketunā ca nāma bodhisattvena mahāsattvena || ratnaketunā ca nāma bodhisattvena mahāsattvena || vikasitavaktreṇa ca nāma bodhisattvena mahāsattvena || padmagarbheṇa ca nāma bodhisattvena mahāsattvena || padmanetreṇa ca nāma bodhisattvena mahāsattvena || mañjuśriyā ca nāma bodhisattvena mahāsattvena || maitreyeṇa ca nāma bodhisattvena mahāsattvena || evampramukhair bodhisattvasaṃghaị̣ śatasahasraih sārdham parivṛtaḥ puraskṛto bhagavān dharmaṃ deśayati sma || ādau kalyāṇaṃ madhye kalyāṇaṃ paryavasāne kalyāṇạ̣ svarthaṃ suvyañjanaṃ kevalaṃ paripūrṇam pariśuddham paryavadātạ̣ brahmacaryaṃ prakāśayati sma || cintāmaṇimahāvyūhālaṃkāraṃ nāma dharmaparyāyaṃ deśayati sma || atha khalu vajrapāṇir bodhisattvo mahāsattvas

3 sākalyena] $p c$; sākanalye $a c . \quad 24$-ketunā] $p c . ;$-ketunāma $a c . \quad 26$-sattvena] $p c . ;$-sattvesana ac. 
tatparṣanmạ̣ḍalam avalokyāsanād utthāya svaṛddhyādhiṣṭhānena bhagavantam anekaśatasahasrapradakṣiṇīkṛtya praṇamya purato niṣadya sagarveṇa paryañkam āyujya līlayā tatparșanmaṇụalam avalokya vajrāñjalim svahṛdaye pratișṭhāpya bhagavantam etad avocat || grahāś ca bhagavann ugrānugrarūpāś ca raudrāraudrarūpāś ca krūrākrūrarūpāś ca te sattvān vihețhayanti | keșāṃcit prāṇam apaharanti | keșāṃcid upadravāś ca kurvanti | keșā<213v>ṃcid ojohārāś ca kurvanti | keșāmcid dravyam apaharanti keșāṃcid dīrghāyuṣkasattvānām alpāyuṣaṃ kurvanti | evaṃ sarvasattvān upadraveṇa vāhayanti tad deśayatu bhagavān dharmaparyāyạ̣ yena sarvasattvā sarvopadravebhyo rakṣā bhavișyanti || bhagavān āha || sādhu sādhu vajrapāṇe yas tvaṃ sarvasattvānām arthāya hitāya sukhāya kụpācittam utpādya mahāguhyātiguhyataraṃ tathāgatam samyaksambuddham paripṛcchasi || tac chṛ̣u sādhu ca suṣṭhu manasi kuru bhāṣiṣye 'haṃ te grahāṇām ugrarūpāṇāṃ krūrātibhīṣaṇamukhānāṃ mahāguhyātiguhyataraṃ divyapūjām ca jāpyaṃ ca yathānukramavarṇabhedena sarveșām yathā tuṣyanti te grahāḥ | pūjitā pratipūjyante nirdahanty apamānitā || devāpy asurāś caiva kiṃnarāś ca mahoragāḥ || yakṣāś ca rākṣasāś caiva mānuṣāś caivāmānuṣāḥ || śamayanti ca kruddhāś ca mahānugrahatejasā || pūjām teṣām pravakṣyāmi mantrāś cāpi yathākramam || atha khalu bhagavāñ chākyamunir bhagavān arhan samyaksambuddhạ̣ || svahṛdayāt karuṇāvikrīẹitaṃ nāma raśmijālaṃ niścārya grahāṇāṃ mūrdhni praveśayati sma || atha tatkṣaṇād eva te sarve grahā ādityādayotthāya bhagavantam sākyamunim tathāgatam arhantam samyaksambuddham sarvābhị divyapūjābhị pūjayitvā <214r> praṇamya jānubhị̣ nipatya kṛtāñjalipuṭo bhūtvā bhagavantam etad avocat | anugṛhītā vayaṃ bhagavatā tathāgatenārhatā samyaksambuddhena || tad deśayatu bhagavān tādṛ́sạ̣ dharmaparyāyaṃ yena vayaṃ sāmagrībhūtvā tasya dharmabhāṇakasya rakṣāṃ kuryāmaḥ | guptị̣ paritrāṇaṃ parigrahaṃ paripālanaṃ śāntisvastyayanaṃ daṇḍaparihāram śastraparihāram viṣadūṣaṇam viṣanāśanam sīmābandhaṃ dharaṇībandhaṃ ca kuryāmah || atha khalu bhagavān śākyamunis tathāgato 'rhan samyaksambuddho grahāṇām mantrapūjāmśs ca bhāṣante sma || oṃ megholkāya svāhā || oṃ śītāṃśave svāhā || oṃ raktāngakumārāya svāhā || oṃ buddhāya svāhā || oṃ bhogāspadāya svāhā || oṃ asurottamāya svāhā || oṃ kṛ̣̣navarṇāya svāhā || oṃ rāhave svāhā || om jyotiketave svāhā || || oṃ yathānukramavarṇabhedena diśā ca gandhamaṇḍalakam padmamadhye dvādaśāṅgulapramāṇam ca caturasraṃ caturdvāraṃ catustoraṇaśobhitam

3 sagarveṇa] corr.; sagarbhena ms. 
kūṭāgāracakrasamanvitam kartavyam || tanmadhye sitakamalopari kun̉kumagandhamaṇḍalakaṃ citrayed eva bhāskaraṃ tāpasarūpadharaṃ bhujābhyāṃ sitakamaladharaṃ raktavarṇasahasrasūryakoṭīsamatejomālinaṃ vigraham | asya deyaṃ kṣīrabhojanaṃ kundurudhūpam || oṃ megholkāya <214v> svāhā || || pūrvasyāṃ diśi raktakamalopari priyaṅgugandhamaṇḍalake somo brāhmaṇa iti jñeyaṃ sitavarṇaṃ jațāmakuṭadharaṃ bhujadvayenākṣasūtrakamaṇḍaludharaṃ kumudapuṣpāvasaktam | bhojanaṃ ghṛtodanaṃ śrīvāsadhūpạ̣ || oṃ candrāmṛtavikramāya śītāṃśave svāhā || || dakṣiṇasyāṃ diśi śuklakamalopari candanagandhamaṇḍalake bhikṣuman்gala coktam raktavarṇo ratnamakuṭi śaktidharạ | varadahastạ̣ | bhojanamatsya deyam | bhaktaguḍodanaṃ vā | gugguludhūpạ̣ | oṃ raktāṅgārasojjvalakumārāya svāhā || || paścimāyāṃ diśi raktapadmopari kṛṣnāgarugandhamaṇḍalake brahmacārī budhạ̣ syāt sitavarṇaḥ | raktaśmaśrụ̣ | akṣasūtrakamaṇḍaludharạ̣ | bhojanaṃ mungamāṣakṛsaraḥ | dhūpo gandharasaḥ | rājaputraḥ || oṃ pītavarṇāya namạ̣ buddhāya svāhā || || uttarasyāṃ diśi sitakamalopari devadārugandhamaṇḍalake guruh parivrājakaguruś caiva taptakāñcanavarṇābho raktaśmaśruh | akṣasūtrakamaṇḍaludharạ̣ | asya deyaṃ dadhibhaktodanakṣīraṃ vā madhughṛtadhūpạ̣ || oṃ lohitavarṇanirgamāya oṃ bhogāsyapadāya svāhā || || āgneyām diši raktapadmopari candanagandhamạ̣ḍa<215r>lake śukraḥ pāśupatadhārī gokṣīravarṇadhavalāmbho jațāmakuṭākṣasūtrakamaṇḍaludharaḥ | asya deyaṃ kṣīrabhojanam | karpūradhūpạ̣ || oṃ namaḥ śukrādhipataye asurottamāya śuddhe virahe svāhā || || nairṛtyāṃ diśi sitapan̉kajopari nīlacandanagandhamaṇḍalake śanaiścarạ̣ kṛṣnavarṇaḥ phaṇabhṛtìyạ̣ pītajațāmakuṭaśmaśruh | akṣasūtrakșikșirikādharaḥ | bhojanaṃ matsyamāṣabhaktakṛsaraḥ | dhūpo gandharasaḥ || oṃ śanaiścarāya sukṛ̣̣nāya kṛ̣ṇabhuk svāhā || vāyavyāṃ diši raktāmbhojopari tagarapādigandhamaṇḍalake kāpāliko rāhuh | rājāvartavarṇanibho 'rdhadeho ravirathabhayānakalocanayuge | daṃștrākarālabhṛkuṭìkṛtalocanapañcavarṇameghataralabhujābhyāṃ candrasūryakamaṇḍalābhinayasthitaḥ | asya deyaṃ māṣāmiṣabhojanaṃ tilakṛsaro vā vivarṇadhūpaḥ || oṃ vikṛtavadane rudhirāsane rāho bhṛngāñjanasaṃnibhāya amṛtapriyāya svāhā || || aiśānyāṃ diśi raktasaroruhopari pṛkkāgandhamaṇḍale cāṇụāle ketur bhavet || dhūmravarṇakṛtāñjalināgākṛtisvapucchabhṛtạ̣ | asya deyaṃ bhojanam ghṛtapūrakam sarjarasadhūpaḥ || oṃ namaḥ dhūmrābhasaṃnibhāya jyotiketave 35 namaḥ svāhā || ||

4 megholkāya] corr.; megholkālāya ms. 12 -sojjvala-] corr.; -sojvala- ms. 13 kṛṣnāgaru-] corr.; kṛṣnāguru- ms. 21 pāśupata-] corr.; pāṇụupata- ms. 24 nīla-] corr.; nī- ms. 28 -locanayuge] corr.; -locayuge ms. 29 -tarala-] corr.; -taralala- ms. 
<215v> mạ̣ḍalapūrvadvāre buddho bhagavān | dakṣiṇadvāre vajrapāṇiḥ paścimadvāre lokanāthạ̣ | uttaradvāre mañjuśrīkumārạ̣ | pūrvottarakoṇe sarve grahāḥ | pūrvadakṣiṇakoṇe sarvanakṣatrāḥ | dakṣiṇapaścimakoṇe sarvopadravāḥ | paścimottarakoṇe bhațāāikā mahādevyā śvetanīlāruṇatrimukhā hastadvayena vyākhyānamudrā dakṣiṇe ratnacchațā vāme pāśaśaktidharā | ratnamakuṭinī vajraparyan̉koparișțhā candrāsanasamāsīnā șoḍaśavarșākārā sarvālaṃkārabhūṣitā || pūrvadvāre bāhye dhṛtarāștrasya dadhibhaktaḥ || dakṣiṇe virūḍhakasya dadhimāṣabhaktạ̣ || paścime virūpākṣasya kṣirabhaktạ̣ || uttare kuverasya dadhimāṣabhaktah || sindhurasameta || yathānukramavarṇabhedena pațākā deyā tathānukramavarṇabhedena puṣpādipūjā kartavyā pratyekaṃ dīpo deyo ghṛtamadhubhyāṃ śankhaṃ pūrayitvā pañcaratnam prakṣipyārgho deyaḥ| sarveșāṃ mukhapaṭo deyam iti || evaṃ varṇabhujāsanamudrācihnāni bhavanti || oṃ namaḥ sarvatathāgatebhyaḥ sarvāśāparipūrakebhyạ̣ sarvathābhaktine svāhā || ratnatrayasya mantram || evam pratyekaṃ japet || saptasaptāșțaśatam mantram ekaikaśatah || evaṃ pūjitāḥ sarve grahā vividharūpiṇaḥ | dadā<216r>ti vipulān bhogān saubhāgyān janayanty api || imāni vajrapāṇe navagrahāṇāṃ hṛdayāni pathitasiddhāni yathānukramavarṇabhedena gandhamaṇḍalakam kṛtvā dvādaśāñgulimadhye pūjayitavyāni tāmramṛnmayarūpyādibhājanena arghaṃ dattvā așțottaraśatavārān mantram japet | ekaikaśạ̣ || paścāt punaḥ vajrapāṇe grahamātṛkā-nāma-dhāraṇi-mantrapadāni saptavārān uccārayitavyāni || tatas te sarve grahā ādityādayo rakṣāvaraṇaguptiṃ kariṣyanti || sarve grahāḥ sarve dāridrān mocayișyanti | gatāyuṣo dīrghāyur kariṣyanti || yac ca khalu punar vajrapāṇe bhikṣubhikṣuṇyupāsakopāsikā anye vā sattvajātīyā yeșām karṇapuṭe nipatiṣyanti na te 'kālamṛtyunā kālaṃ kariṣyanti || yac ca khalu punar vajrapāṇe grahān mạ̣ḍalamadhye pūjayitvā dine dine saptavārān uccārayiṣyanti || tatas tasya dharmabhāṇakasya sarve grahāḥ sarveṇa sarvāśām paripūrayiṣyanti | tatkulād api dāridrān nāśayiṣyati || atha khalu bhagavāñ chākyamuni tathāgatạ̣ punar api grahamātṛkā-nāma-dhāraṇī-mantrapadāni bhāṣante sma \|| om namo ratnatrayāya || namo buddhāya namo dharmāya namaḥ saṃghāya || vajradharāya namaḥ | padmadharāya namạ̣ | <216v> kumārāya namaḥ | namaḥ sarvagrahāṇāṃ sarvāśāparipūrakāṇām | namo nakṣatrāṇāṃ namo dvādaśarāśīnām namạ̣ sarvopadravāṇām || tadyathā || oṃ buddhe 2 vajre 2 padme 2 sara 2 prasara 2 smara 2 krī ḍa 2 krīḍaya 2 mara 2 māraya 2 marda 2 ghātaya 2 mama sarvavighnānām ca sarvavighnān chinda 2 bhinda 2 sarvavighnān nāśanaṃ kuru 2 mama saparivārasya sarvasattvāṃś ca kāryaṃ

14 sarvathā-] pc.; sarvatathā- ac. 37 -sattvāṃś] corr.; -sattvāṃ ms. 
kṣepaya 2 mama sarvasattvānāṃ ca sarvanakṣatragrahapị̣āṃ nivāraya 2 bhagavati śreyaṃ kuru mahāmāyāṃ prasādhaya sarvaduṣțān nāśaya sarvapāpāni mama saparivārasya sarvasattvānāṃ ca canda 2 candani 2 turu 2 muru 2 muyu 2 mumu 2 muñca 2 havāhave bhavābhave ugre ugrapratāpe pūraya 2 bhagavati manorathaṃ mama saparivārasya sarvasattvānāṃ ca sarvatathāgatādhișṭhānādhișțhite svāhā || || oṃ svāhā || hūṃ svāhā || hrīḥ svāhā || oṃ dhūḥ svāhā || oṃ ādityāya svāhā || oṃ somāya svāhā || oṃ dharaṇīsutāya svāhā || oṃ buddhāya svāhā || oṃ bṛhaspataye svāhā || oṃ śukrāya svāhā || oṃ śanaiścarāya svāhā || oṃ rāhave svāhā || oṃ ketave svāhā || oṃ buddhāya svāhā || oṃ vajrapāṇaye svāhā || oṃ padmadharāya svāhā || oṃ kumārāya svāhā || oṃ sarvagrahāṇām svāhā || oṃ sarvanakṣatrāṇām svā<217r>hā || oṃ sarvopadravāṇām svāhā || oṃ dvādaśarāśīnāṃ svāhā || oṃ sarvavidye hūṃ hūm phaṭ 2 svāhā || ||

imāni vajrapāṇe grahamātṛkā-nāma-dhāraṇī-mantrapadāni kārttikamāse śuklapakșe saptamīm ārabhya poșadhiko bhūtvā yāvac caturdaśī grahanakṣatrān madhye pūjayitvā dine dine saptavārān uccārayitavyāḥ || tatah pūrṇamāsyām ahorātraṃ vācayet || tasya navanavativarṣāṇi mṛtyubhayaṃ na bhavișyati || jātau jātau jātismarāś ca bhavișyati || sarve grahā īpsitavaraṃ dāsyanti | atha te sarve grahāḥ sādhu bhagavann iti kṛtvā praṇamyāntarhitābhūvann iti || || idam avocad bhagavān āttamanās te ca bhikṣavas te ca bodhisattvā mahāsattvā sā ca sarvāvatī parṣat sadevamānuṣāsuragaruḍagandharvaś ca loko bhagavato bhāṣitam abhyanandann iti \||

ārya-grahamātṛkā-nāma-dhāraṇī parisamāptaḥ || ||

[178] oṃ namaḥ śrī-caṇ̣ikāyai \||

brahmā protanarūpā bahuvividhivā caṇḍacaṇụā ca raudrī kaumārī kṛttikāmātā pibanti madhumadyam vaiṣnavī gāyamānā| vārāhī vādayantī paṭutarapațahān nụtyamānā tathaindrī cāmuṇụā cāpi lakṣmī haragạ̣asahitā mātaro vaḥ punantu || || <217v> gaṇapatiś ca heramba vighnarājo vināyakaḥ| devaputra mahāvīrya mahābalaparākramam || mahodara mahākāyaṃ ekadaṃștrā gajānanam | śvetavarṇa mahādīpti trinetram gaṇanāyaka || akṣamālā svadantaṃ ca dakṣiṇe karasaṃsthitā |

15 ārabhya] $p c$; ābharabhya $a c . \quad 16$ pūjayitvā] pc.; pājayitvā $a c .20$ āttamanās] corr.; ātmanās ms. 27 -mātā pibanti] $p c . ;$-māpitābanti $a c .28$ cāpi] corr.; cāpa ms. 


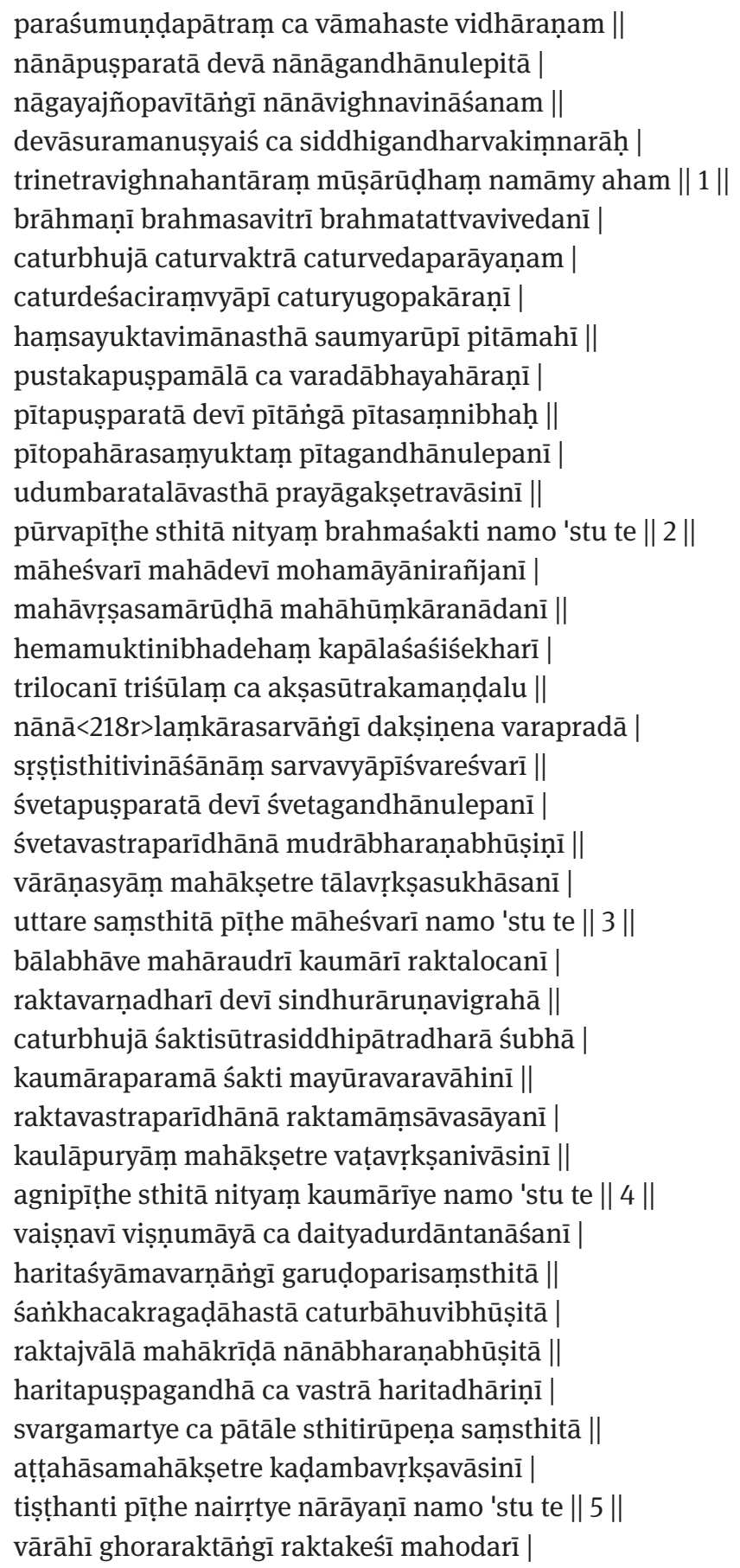




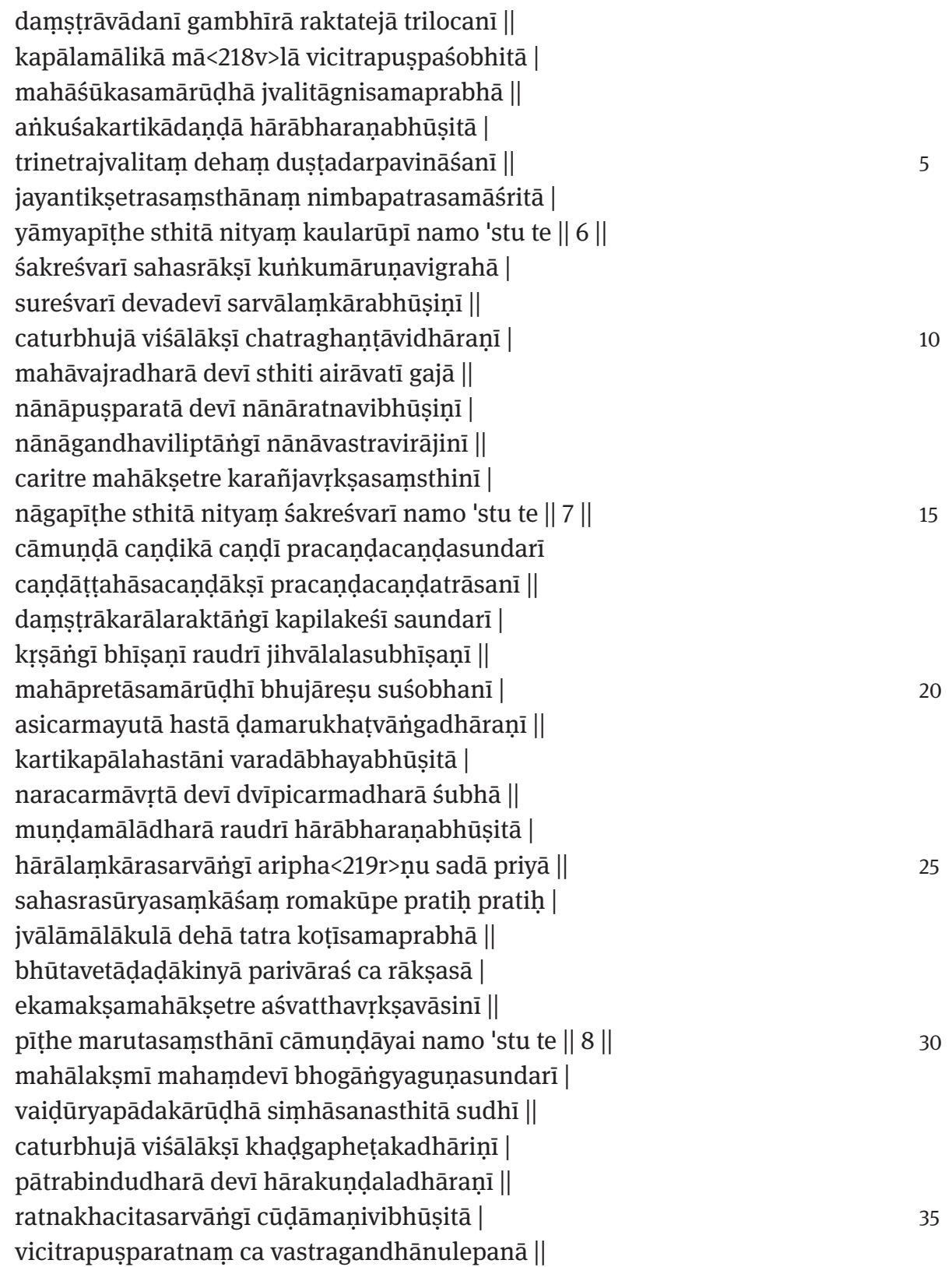

3 jvalitāgni-] corr.; jvalitā- ms. 19 -lala-] corr.; -lalla- ms. 30 cāmuṇ̣̣āyai] corr.; cāmuṇụāyanaya ms. 34 hāra-] corr.; hārkayū- ms. 
trailokyavyāpinī devī sarvasthasacarācaram | siddhigandharvanamitā vidyādharasurārcitam || devīkoțamahākṣetre plakṣavṛkṣasamssthā varā | îsānapīthe saṃsthānaṃ mahālakṣmī namo 'stu te || 9 || așțakṣetrasthitā devī așțaṿ̣kṣanivāsinī | așțabhairavasamyuktam așțamātṛ namo 'stu te || jananī sarvabhūtānām sarvasattvopakāraṇī| sarvadoṣaharā devī saṃsārapāśacchedanī || tvam eva sarvamātṛstham tvam eva yogarūpiṇī| tvam eva ș̣ṣtisaṃhārī tvam eva sthitirūpiṇī || tvam eva sarvarūpāṇi tvam eva viśvarūpiṇi | pītheśvaro mahādeva devadeva mahātmanā || bhairavabhịṣa<219v>ṇaṃ raudrạ̣ ghoragambhīrarūpiṇam | nirañjananibham deham sarvakāmamahotsavam || nānābhujasamākīrṇā nānāvaktradharā śubhā | trilocanamahātejā agnisūryasamaprabhā || babhrur āddhā śiroruhā dāvāgnisamatejasā | triśūlamuṇ̣akhațvāngam ḍamarutarjanīdhvajam || prajātakatsukānāṃ ca khaḍgacarmadharā śubhām | pāśāṅkuśadharaṃ devaṃ vajrasūcīmahādharam || kapālakartikaṃ cakraṃ gajacarmāvaguṇṭhitam | daṃștrākarālavadanaṃ vyāghracarmakațivṛtam || sālaṃkāreṇa sarvāngaṃ narāsthipuṣpaśobhitā| śīrșamālādharā devā kāpālikottama śubha || cūọāmaṇimahātejaṃ kapālacandrabhūṣitam | mahāpretāsanaṃ nityaṃ nityamānā sadā priyam || sahasūryasamaṃ tejam chatrabindutasaṃnibham | catuṣpịṭhasthitā nityam așțakṣetranivāsinī || așțamūrtisthitā devam așțakayoginīpriyā | bhadrapiṭ̂he sthitā nityaṃ bhadrakālī samāvṛtā || bhadrakāraṇakartāram vīrabhadraṃ namo 'stu te || || asitāngaruruś caiva caṇdo 'tha krodhabhairavam | unmattabhairavaṃś caiva kapālī bhīṣaṇas tathā || saṃhārabhairavaṃ cāșțam bhairavāya namo 'stu te || || svasthānasvādhikārāś ca svasvarūpā svavīrakā |

3 -vṛkṣa-] corr.; -vṛ- ms. 21 -guṇṭitam] corr.; -gutthinam ms. 25 cūḍā-] corr.; coḍāms. 29 așțaka-] corr.; așțoka- ms. 33 kapālī-] corr.; kapīla- ms. 35 svasvarūpā] corr.; sasvarūpā ms. svavīrakā] corr.; svavīpara ms. 
svasva 'ṣțavṛtānāṃ ca divyākṣaṃ ca bhūmigatāh || daśadikkṣetra<220r>pālaṃ ca kṣetrāś caiva caturdaśa | pañcāśakṣetrapālāṃś ca kṣetrapāla namo 'stu te || || nātha nātha mahānātha ādinātha mahātmane | śrīnātha siddhinātha ca mīnanātha namo 'stu te || || kṣetranātha ca pīṭha ca dvīpanātha mahātmane | pretanātha ca bhūta ca vațanātha namo 'stu te || || trināthanavanātham ca ṣoḍaśanātham uttamam | saptaviṃśati pañcāśa caturaśîti namo 'stu te || || sarveșām nāthasiddhānāṃ samantam ca kuladvayam | yogasadya tathā vīra tatas sarvaṃ namo 'stu te || || ekakālā dvikālām vā trikālaṃ yaḥ paṭhen naraḥ | śatam āvartayed yena prāpnoti śṛ̣u-m-uttamam || nāśayet śokacittāni nāśayed vighnadevatā | nāśayet kalahaṃ rogān nāśayed duḥhadușțaram || naśayed bhayadāridram nāśayed ripujam bhayam | nāśayed agnicaurādīn nāśayed rājakrodhajam || nāśayed vigrahaṃ ghoram nās̄ābhicāraṇaṃ kṛtam | nāśayed rāgadveșāṇi nāśayet sarvapātakam || āyur ārogyam aiśvaryaṃ dhanadhānyavivardhanam | dharmārthakāmamokṣānāṃ yaśasaubhāgyam uttamam || ṛddhisiddhiśriyam lakṣmịm vidyājñānasutānibham | buddhiprajñāsumitram ca vardhate ca dine dine \| nākāle maraṇaṃ yo 'sau utpātaṃ nāśayet sadā | sarvarogam praśāmyanti dī<220v>rghāyuś ca pralabhyate || ||

iti śrī-pīṭhā-stava-stotraṃ samāptah || ||

[179] oṃ namaḥ śrī-bhīmasenāya ||

śrī-skanda uvāca || devadeva mahādeva sarvalokahiteśvara | girīśa lokanātheśa dīno 'haṃ dīnavatsara || tvaṃ rudraḥ sarvabhūtānāṃ nāśāya ca guṇatrayaḥ || tvatpraśādān mahādeva kathām ekām vadasva me | tārako 'pi mahāśūras trailokyaparameśvarah ||

1 bhūmigatāḥ] corr.; bhamigagāḥ ms. 3 -pālāṃś] corr.; -pālāṃ ms. 9 caturaśīit] corr.; caurāśîti ms. 16 ripujaṃ] corr.; vipaṛd ms. 23 vardhate] corr.; buddhate ms. 
tadvadhaṃ ca kariṣyāmi tan me brūhi vṛṣadhvaja | śrī-mahādevovāca ||

śṛ̣u vatsa pravakṣyāmi tārakānāṃ vadhasya ca | trailokyasya hitārthāya mantras tatra sthite purā || guṇatrayeṇa jānanti jagaty asmiṃś carācare |

ekārṇave hi śayanaḥ kalpānte bhagavān prabhuh || ș̣̣țināśaṃ yadā jātaṃ mahaccintāṃ karomy aham | kị̣ vā bhūtadattamāne kim ante kiṃ bhaviṣyati || mahaccintā mayā vatsa svapnānte maruttātmajạ̣ | mantrastotraṃ mayā prāptam trailokyeṇa prakāśitam || tārakạ̣ vāgbhavaṃ caiva lakṣmīś ca kāmarājakam | bhīmāya ca tataḥ paścād vahnijāyā tato manuh | an̉kākṣaraṃ mahāmantraṃ trailokyaṃ cāpi durlabham || sakṛt smaraṇamātreṇa jarāmarạ̣avarjitam || || dhyānaṃ tasya pravakṣyāmi sarvaśāstreșu <221r> gauravam | bhīmaṃ bhītinam rūpam ca dvibhujaṃ ca gadāvaram || sauvarṇaṃ pītavāsaṃ ca sitayajñopavītinam | nānābharaṇaśobhāọhyaṃ smitavaktramanoharam | praphullakamalābhāsaṃ sucāruyugmanetrakam || iti dhyātvā svayaṃ caiva samāsthāpyārghyapātrakam || śrī-bhīmātmānaṃ bhāvayet || || bālārkāyutatejasaṃdhṛtajațāyutendukhaṇḍojvalaṃ nāgendraiḥ kṛtabhūṣạ̣aṃ japavaṭị̄ śūlaṃ kapālakaraị̣ | khațvāngadadhatam trinetravilasatpañcānanaṃ sundaraṃ vyāghratvakparidhānam abjanilayaṃ śrī-bhīmasenam bhaje || ||

iti śrī-bhimasena-dhyāna-svalpa-stuti samāptaḥ || ||

[180] om namaḥ śanaiścarāya \| praṇamya devadeveśam sarvagrahanivāraṇam | śanaiścarasya śāntyarthaṃ cintayām āsa pārthivaḥ || raghuvamsśeșu vikhyāta rājā daśarathạ̣ purā| cakravartī sa vijñeyaḥ saptadvīpādhipo bhavet || kṛttikānte śaniṃ jñātvā devajñair jñāpito hi sạ̣ | rohị̣ịm bhedayitvā tu śanir yāsyati sāmpratam || śākațam bhedam ity uktạ̣ surāsurabhayaṃkaram | dvādaśābdaṃ tu durbhikṣaṃ bhaviṣyati sudāruṇam ||

3 -vakșyāmi] corr.; -vakṣāmi ms. 12 -jāyā tato] pc.; jātayāto $a c$. 
etac chrutvā tato vākyaṃ mantribhị saha pārthivaḥ | deśāś ca nagare grāmā bhayabhītāḥ samantatạ̣ || bru<221v>vanti sarvalokāś ca kṣayam etat samāgatam | ākulaṃ tu jagad dṛṣțā paurajānapadādikam || papraccha praṇato rājā vasișțhapramukhān dvijān | samādhānaṃ kim atrāsti brūhi māṃ dvijasattamaḥ || || vasișțha uvāca \| prajānāṃ pratirakṣeyaṃ tasmin bhinne kutaḥ prajāḥ | idaṃ yogam asādhyaṃ tu brahmaśakrādibhị̣ saha || tadā saṃcintya manasā sahasaṃ paramaṃ mahat | samādhāya dhanur divyaṃ divyāyudhasamanvitạ̣ || ratham āruhya vegena gato nakṣatramaṇḍalam | sapādayojanaṃ lakṣaṃ sturyannotāparisthitam || || rohiṇịprșṭham āsthāya rājā daśarathas tadā | rathe tu kāñcane divye maṇiratnavibhūṣite \| hamsavaṛnahayair yukta mahāketusamucchrite | dīptamāno mahāratnaih kirịțamukuṭojjvalaih || babhrāja sa tad ākāśe dvitīya iva bhāskaraḥ | ākarṇapūritaṃ cāpaṃ saṃhārātra niyojitam || kṛttikānte śani sthitvā prāviśat kila rohiṇim |

dṛṣtvā daśaratham cāgre tasthau sabhṛkuṭimukham || saṃhārāstram śanir dṛștvā surāsuravimardanam | hasitvā tadbhayāc chaurir idam vacanam abravīt || || śanaiścarovāca \| pauruṣam tava rājendra pararipubhayaṃkaram | devāsuramanuṣyāś ca siddhavi<222r>dyādharoragāḥ || mayāvalokitā rājan bhasma cāśu vrajanti te | tuṣṭo 'haṃ tava rājendra tapasā pauruṣena ca \| varaṃ brūhi dāsyāmi manasā yad abhīpsitam || || daśaratha uvāca ||

rohị̣ī bhedayitvā tu na gantavyaṃ tvayā śane | saritaḥ sāgarā yāvad yāvac candrārkamedinī || yācitạ̣ tan mayā saure nānyam icchāmi te varam | evam astu śaniḥ prāha varam dattvā tu sāávatam || punar evābravìt tuṣțā varaṃ varaya suvrata || 20 || samprāpya tadvaraṃ rājā kṛtakṛtyo bhavet tadā|

3 kșayam etat] $p c$.; kșameyatat ac. 4 jagad] corr.; ja ms. 10 manasā] corr.; mavasā ms. 16 mahā-] corr.; nehā- ms. 21 sa] corr.; ma ms. 
prārthayām āsa hṛṣṭātmā varamantraṃ śaniṃ tadā || || śanir uvāca \|

dvādaśābdam tu durbhikṣaṃ bhaviṣyanti kadācana

kīrtir eșā madīyā tu trailokya 'pi bhaviṣyati ||

evaṃ varaṃ tu samprāpya hṛșțaromā ca pārthivaḥ |

rathopari dhanu sthāpya bhūtvā caiva kṛtāñjalih ||

dhyātvā sarasvatīm devīm gaṇanātham vināyakam |

rājā daśarathaḥ stotraṃ saurer idam athākarot ||

oṃ namạ̣ kṛ̣̣nāya nīlāya śikhikaṇṭhanibhāya ca |

namo nīlamayūkhāya nīlotpalanibhāya ca ||

namo nirmāsadehāya dīrghamaṃśujațāya ca ||

namo viśālanetrāya śuṣkodarabhayāya ca ||

namaḥ puruṣagātrāya sthūlaromāya vai namạ̣ |

namo <222v> dīrghāya śuklāya kālapṛșthe namo 'stu te ||

namas te kroḍharājāya durnirīkṣāya vai namạ̣ |

namo ghorāya raudrāya bhīṣaṇāya karāline \|

namas te sarvasūkṣmyāya valīmukha namo 'stu te | namo mandagate nityam nistriṃsāya namo namaḥ || atṛptāya namo tubhyaṃ bhasmāñgāya namo 'stu te | sūryaputra namas te tu bhāskare bhayadāya ca || 30 || adhodṛști namas te tu samvvartaka namo namạ̣ || namaḥ kālāgnirudrāya kṛtāntāya ca vai namaḥ || namo mandakṛte tubhyam śanaiścarāya vai namaḥ| tapasā dagdhadehāya nityaṃ yogaratāya ca || jñānacakṣu namas te tu kāśyapātmajamunaye | tuṣṭo dadāsi rājyaṃ ca duṣṭo vai harasi kṣaṇāt || devāsuramanuṣyāś ca paśupakṣis tathodbhidạ̣ | tvayāvalokitā sarve nāśayanti samantatạ̣ || brahmaśakramanuṣyāś ca ṛșayaḥ saptatārakāḥ | rājyam bhrașțā patantīha bhavadduṣțāvalokitạ̣ || deśāś ca nagaram grāmā dvīpāś caiva drumas tathā | tvayāvalokitās te 'pi nāśayanti samantatạ̣ || prasādaṃ kuru me saure varārtho 'haṃ tava sthitaḥ | evaṃ stutvā tadā sauri graharājo mahābalạ̣ || abravīd īdṛsam vākyaṃ hṛșțaromā ca bhāskariḥ || || śanir uvāca || tuṣto 'ham tava rājendra stavenā<223r>nena suvrata | varaṃ brūhi pradāsyāmi svecchayā laghunandana || || daśaratha uvāca \| adya prabhṛti te saure pị̄̂a kāryā na kasyacit | 
devāsuramanuṣyāṇāṃ paśupakṣisarīṣ̣pāḥ ||

śanaiścarovāca \|

grahārthaṃ tu grahājñayā grahāḥ pịḍākarāh smṛtāḥ |

adeyo 'yaṃ varam tubhyam tuṣṭo 'ham tu dadāmi te || 40 ||

tvayā proktam tu me stotram ye pațiṣyanti mānavaḥ |

ekakālāṃ dvikālāṃ vā pīḍām muñcāmi tasya vai ||

devāsuramanuṣyānāṃ siddhividyādharoragāḥ |

mṛtyusthānasthitā vāpi janmapị̣ākarās tu ye ||

yaḥ punạ̣ śraddhayā yuktaḥ śucisthāne samāhitaḥ|

samīpattraiḥ samāpadya pratimāṃ lohajāṃ mama ||

maddine tu viśeșeṇa stotranāmnā pūjabhṛt |

pūjayitvā mama stotraṃ bhūtvā caiva kṛtāñjalih ||

tasya pị̄̂ā na caivāhaṃ kariṣyāmi kadācana |

gocareṇa magnena vā daśāśvanta daśāsu ca ||

tyajāmi satatam tasya pịḍā cānye grahasya ca |

anena ye prakāreṇa pị̄̂āmuktạ̣ jagad bhavet ||

varadvayaṃ tu samprāpya rājā daśarathas tadā |

śanair kṛtvātha māsana namaskṛtvā śanaiścaram ||

śaninā cābhyanujñāna svanagaragamas tadā|

svasthānaṃ tato gatvā prāptakā svabhavaṃ tadā ||

nāladhakauśikā cai<223v>va pingalākṣo mahāmuni |

śanaiścarakṛtā doṣā mocatyaśāntakāśayah || ||

iti skandapurāṇe śanaiścara-stava-sto<224r>tra samāptaḥ || ||

iti dhāraṇīsaṃgrahaḥ saṃkṣiptạ̣ parisamāptạ̣ || ||

ye dharmā hetuprabhavā hetum teșām tathāgato |

hy avadat teșām ca yo nirodha evamvāiei mahāśramaṇaḥ || ||

deyadharmo 'yaṃ pravaramahāyānayāyinaḥ paramopāsaka-paramadhārmikadharmātmā-śrī-trailokara-strī-pūrṇāvatī-dvayo-pramukhādisagaṇaparivārāṇām yat puṇyaṃ tad bhavatv ācāryopādhyāyamātāpitṛpūrvagamanaṃ kṛtvā sakalasattvarāśe 'nuttarasamyaksambodhipadaṃ prāptayo 'stu || || svasti || śrīmat-paśupati-caraṇakamala-dhūlidhūsaritaśiroruha-śrīmanmāneśvarīṣṭadevatāvara-labdhaprasāda-dedīpyamānamānonnataravi-

11 maddine] corr.; madina ms. 19 -gamas-] corr.; -mas- ms. 23 śanaiścara] corr.; śaniśca ms. 25 tathāgato] corr.; tagato ms. 29 bhavatv] corr.; bhavat ms. 
kulatilaka-hanumantadhvaja-nepāleśvara-mahārājādhirāja-rājarājendrasakalarāja-cakrādhīśvara-gajapati-śrī-śrī-jayamahīndrasiṃhamalladevaparamabhațtāakadevānāṃ sadāsamaravijayinām

prabhuthākurasya vijayarājye || || ||

dānapati-śrī-kāntipuri-mahānagare śrī-bhāskaradeva<224v>saṃskārita-sata-

śrī-keśavacandrakṛta-pārāvata-mahāvihārādhișthita-kasmirapaṭo-nāmahnuracchebho \|

mārgasya pūrvapārśve sthita gṛhādhivāsina-dharmātmā-śākyabhikṣu-śrītrailokara || tasya bhāryā pūrṇavatī-lakșmī || trailokarasya prathamabhāryāyāḥ prathamaputra sāākyabhikṣu-śrī-dharmātmā-dharmacandra || tasya kāntā viṣnumatī || trailokarasya dvitīyabhāryāyāḥ prathamaputra puṇyātmāśākyabhikṣu-śrī-buddhaśaraṇa || dvitīyaputra guṇātmā-s̄ākyabhikṣu-śrīkaruṇāmaya || dharmacandrakasyātmaja-bālakumāra-śrī-dharmaśaraṇa || trailokarasya putrī kanyāpradāna-puṇyavatī-lakṣmī || dvitīyaputrī cakravatīlakșmī saheti || ||

ete sahānumatena idam bhagavatī śrī 3 dhāraṇīsaṃgrahapustaka pițakāgatapatre karjarākṣareṇa likhitạ̣ kṛtvā gṛhe sthāpitā bhavanti || || atha deśabhāṣā dānapati-śrī-trailokarasya bhāryā pūrṇāvatī yāmanasa atipunyacitta utpatijusyam vayāva thva bhagavatī śrī-śrī-śrī-dhāraṇīsaṃgrahapustaka-navagrahādi-samasta-māra-vighna-roga-bhaya-harañayāya <225r> nimittina dhāraṇīsadhākvapunyaphalarāyakāmanāna thva pustakarocakam dayakāva śrī 3 kuladevatā prītinadohorapājuro || || etat puṇyānubhāvena yajamānasya sagaṇaparivārāṇām āyur-ārogya-janadhana-saṃtāna-navaratnādi-catuḥ̣așți-vrīhy-ādi-lakṣmīvṛddhir astu || || śreyo 'stu || saṃvat 839 bhādravapadamāse śuklapakṣe pañcamyāyāṃ tithau | cittānakṣatre śuddhiyogye yathākarṇamuhūrte ādityavāsare siṃharāśigate savite kanyarāśigate candramasi || etaddine likhitasampūrṇam iti || || lekhakasya kāṣṭhamaṇḍapa-mahānagare tarumūla-mahāvihāre khạ̣ḍacūkamahāpuṣkariṇyāṃ pūrvadiśasthita vajradevyā caraṇāmbuja-śevita mahāpātrakula-śrī-vajrācārya-śrī-patidevena likhitasampūrṇaṃ karomi || || yathā dṛșțam tathā likhitam lekhako nāsti doṣaṇam | yadi śuddham aśuddham vā śodhanīyam mahadbudhaị̣ || || bhagnapṛștha-kaṭigrivā stabdhadṛțțir adhomukha | kaștena likhi<225v>tam śāstraṃ putravat pratipālayet

1 -rājādhirāja] corr.; -rājādhija ms. 3 -bhațāāraka] pc.; -bhabhațāāraka ac. 5 bhāskara-] corr; bhāska ms. 7 Words in italics indicate vernacular parts in the colophon. 10 -putra] pc.; -putraputra ac. 26 yathākarṇamuhūrte] pc.; om. ac. 29 pūrvadiśasthita] $p c . ;$ pūrvadigaśasthita $a c . \quad 31$ dṛștam] ac.; dṛșțam paratrakāle samyaksambodhipadaṃ prāptā bhavanti $p c$. 
bhākhā thva puștaka sunānaṃ phayakāyādo | robhayātasā senakarasā pañcamahāpāparākajaro || gvahnanaṃ robhamayāse nidāna || || yātasā lakṣāhuti yajñayānōaphalarākajaro || ||

śubhamañgalaṃ bhavantu sarvadā || || 
